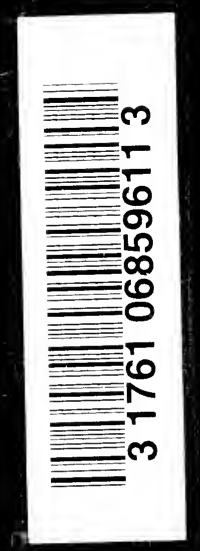




$$
\text { - }
$$




BOOKS BY THOMAS C. HALL, D.D. PUBLISHED BY CHARLES SCRIBNER'S SONS

History of Ethics Within Organized Christianity. 8vo .... net $\$ 3.00$ The Social Meaning of Modern Religious Movements in England. $12 \mathrm{mo} \$ 1.50$ The Messages of Jesus According to the Synoptists. Sq. $16 \mathrm{mo}$. . net $\$ 1.25$ 


\section{HISTORY OF ETHICS WITHIN ORGANIZED CHRISTIANITY}





\section{HISTORY OF ETHICS}

\section{WITHIN ORGANIZED CHRISTIANITY}

BY

THOMAS CUMING HALL, D.D.

PROFESSOR OF CHRISTIAN ETHICS IN UNION THEOLOGICAL SEMINARY.

AUTHOR OF "THE SOCIAL MEANING OF MODERN RELIGIOUS

MOVEMENTS IN ENGLAND," "THE MESSAGES OF JESUS

ACCORDING TO THE SYNOPTISTS," ETC.

NEW YORK

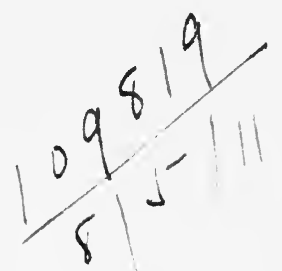

CHARLES SCRIBNER'S SONS 
COPYRIGHT, 1910, BY

CHARLES SCRIBNER'S SONS

Published September, 1910

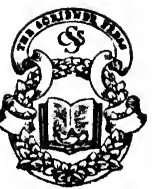




\section{Jn $\mathfrak{g e m o r i a m}$}

TO THE LOVING MEMORY OF

Cornelius Eupler $\mathcal{C u p l e r}$

TO WHOM THE AUTHOR'S HEART WAS KNIT

IN TENDEREST TIES OF LIFE-LONG FRIEND-

SHIP, AND BY WHOSE LOVE HIS LIFE WAS

ALWAYS QUICKENED AND REFRESHED-THIS

BOOK IS MOST AFFECTIONATELY DEDICATED

May, 1910 



\section{PREFACE}

IN sending out this history, which has been the labor of several years, the author turns back in memory to the many who have aided him. It is impossible to thank all those by name to whom the author is deeply indebted. But a special word of thanks is due to my friend and colleague Dr. Marvin R. Vincent, who has read the whole volume in proof, and out of his ripe and broad scholarship offered many invaluable suggestions and corrections. Professor Charles A. Briggs made most helpful suggestions in the inception of the work, both as regards system and method. Indeed to each and all of my colleagues I return heartfelt thanks for most valuable suggestions and inspirations as I worked in a field that, of necessity, trenched on all the theological disciplines. To those in charge of the libraries which I have used I wish also to return thanks for uniform kindness and courtesy. Whether in Berlin or Oxford, in New York or London, I have found everywhere most self-sacrificing eagerness to aid me in getting the books I needed. But a special word of thanks I owe to Professor and Geheimrat Dr. Pietschmann of Göttingen for unnumbered signs of special interest in this volume, and great courtesy in granting me special facilities in the splendid library he so ably directs.

This book, if properly done, should prove exceedingly valuable, but as to whether it is well done others beside the author must judge. He can only claim that he has gone directly and critically to the sources, and sought at first hand to understand the work of those whom he reviews. He has sought to estimate the ethical progress of the past as objectively and fairly as possible. That blunders have been made, that errors have crept in, that partial views have been taken is inevitable. For all cor- 
rections the author will be frankly grateful, and should the book find favor he will try to embody any such corrections in future editions.

One main purpose has sustained the writer throughout much weary plodding, and that was to understand and help others understand the essential message of Our Lord and Master Jesus Christ. One of the painful truths brought home to us by any study of history is the fact that the simplicity of Jesus' teachings has been obscured and overlaid by intruding elements. The simple things for which the Master stond, and which can be tried out in life we have deemed "impracticable," because "you can't change human nature." So ecclesiastical tradition has substituted theologies which cannot be tested in life, for ethics which may be. It has demanded belief in doubtfully true speculative and intellectual propositions, and called such assent "faith," where the Master demanded loving and trustful acceptance of simple canons of conduct, and identified such acceptance with loyalty to his purpose. The study of the history of ethics may lead, it is to be hoped, a chosen band to really resolutely insist upon putting in the foreground what Jesus put in the foreground, and relegating even true traditions to the background if they are of secondary importance for his purpose. We must as good Protestants complete the work of the Reformation and strip from historical organized Christianity the encumbering graveclothes in which her life has been stifled. With good heart and hope the author puts forth his history of ethics within organized Christianity, knowing well that the prayers of the ages are yet to be answered and God's kingdom will come and his will will be done on earth even as in heaven.

700 Park Ave., New York, May, I910. 


\section{CONTENTS}

PAGE

INTRODUCTION . . . . . . . . . . . . . . . . 3

CHAPTER

I. The Preparation for Christianity. . . . to

Note of Introduction . . . . . . . . . . 10

I. The Grecian (Classic) Contribution . . . . II

II. The Hellenistic Preparation. . . . . . . 18

III. The Roman Preparation . . . . . . . 30

IV. The Old Testament Preparation . . . . 32

II. New Testament Ethics . . . . . . . . . . 48

Introduction . . . . . . . . . . . . . 48

I. The Ethics of Jesus . . . . . . . . . . . 49

II. The Ethics of Paul . . . . . . . . . . 69

III. The Ethics of the Johannine Interpretation of Jesus . . . . . . . . . . . 87

IV. The Ethics of the Other Canonical Writings 93

III. The Ethics of the Early Church. . . . . . 105 Introduction . . . . . . . . . . . . . 105

I. The Ethics of Unorganized Christianity . . . Iro

II. The Struggle for Individualization . . . . 124

III. The Intellectual Formulation of Christianity I43

IV. The Ethics of Ecclesiastical Organization . . 167

V. The Ethical Forces of Christianity . . . . I77 
CHAPTER

IV. The Old Catholic or Bishop's Church and ITs EтHICS . . . . . . . . . . . 187

Note of Introduction . . . . . . . . . . 187

I. Athanasius and Monasticism . . . . . . 193

II. The Message of the Great Preachers . . . 202

III. The Monastery and Asceticism . . . . . 215

IV. The Bishop's Church and Culture . . . . 221

V. The Bishop's Church and the Cult and Its Ethics . . . . . . . . $23 \mathrm{I}$

VI. The Church and Her Theology . . . . 235

VII. The Ethics of the Councils . . . . 25 I

V. The Militant Papacy and Its Ethics . . . . 258

I. The Separation of the East from the West . . $25^{8}$

II. The Relation of Church and State . . . $26 \mathrm{I}$

III. The Missionary Movement and the Monasterv

VI. Scholasticism ANd Its Ethics . . . . . . 282

I. The Ethics of Scholasticism . . . . . . . 282

II. Constructive Scholasticism . . . . . . . 294

III. Critical Scholasticism . . . . . . . 333

IV. Mystical Scholasticism . . . . . . $34 \mathrm{I}$

ViI. The English Reformation and Its Ethics . . 365 Note of General Introduction . . . . . . 365

I. The Ethics of the Forerunners of the Reformation-Wyclif, the Lollards, Tyndale, Hooper . . . . . . . . . 378

II. The Ethics of the Lollards . . . . . . . 386

III. The Ethics of Puritanism-Thomas Cartwright, Travis, John Knox . . . . 396 
CHAPTER

IV. The Ethics of Anglo-Catholicism. . . . 4IO

V. The Ethics of Independency . . . . . . 424

VI. The Ethics of Philosophical Protestantism . 438

VIII. The Continental Reformation and Its Ethics . 468

I. The Ethics of Luther . . . . . . . . . 468

II. The Ethics of Melanchthon . . . . . . . 496

III. The Anabaptist Movement and Its Ethics . 505

IV. The Ethics of the Reformed Churches. . . 509

V. The Ethics of John Calvin . . . . . . ${ }_{5}^{\mathrm{I} 8}$

VI. The Ethics of the Creeds of the Continental Reformation . . . . . . . . 533

VII. The Epigones of the Sixteenth and Seventeenth Centuries. . . . . . . . 535

VIII. The New Protestant Casuistry . . . . . 540

IX. The Ethics of Pietism in the Continental Churches . . . . . . . . . 544

$\mathrm{X}$. The Ethics of Post-Tridentine Roman $\mathrm{Ca}$ tholicism . . . . . . . . . . . 554

XI. The Ethics of Philosophical Protestantism on the Continent. . . . . . . . 563

IX. The Merging of Churchly with Philosophical Ethics-A Summary . . . . . . . 576 Introductory Note . . . . . . . . 576

INDEX . . . . . . . . . . . 599 



\section{HISTORY OF ETHICS WITHIN ORGANIZED CHRISTIANITY}





\section{HISTORY OF ETHICS WITHIN ORGANIZED CHRISTIANITY}

\section{INTRODUCTION}

I. However difficult it may be to define scientifically the great historic force in the world's history which men call Christianity, one note it has which separates it from all kindred movements: it is linked in the traditions of all its professed followers with the message of the man Jesus Christ.

This Jesus appears, however, in history, primarily as a new inspiration and vital force. We have no detailed and exhaustive account of his activity and no exact summary of his actual doctrine. For a biography of him we must depend upon the imperfect memories of loving interpreters, whose materials are given in such a way as to preclude accurate chronological rearrangement. At best such reordering is hypothetical, however attractive. Honest and devout men and women gave their explanations of what Jesus had taught, and interpreted him to the eager numbers who, after his death, became his followers. These questions they answered with a large freedom, so that it is now often quite impossible to say how far we have the words of Jesus and how far the commentary of the disciple. ${ }^{1}$ In some cases, as in the case of Paul, the claim was advanced for inward spiritual authority to speak in the name of Jesus even after his death.

Yet, in spite of the meagre records, the significance of this life has been simply overwhelming. No matter what men may yet

${ }^{1} C f$. especially the discourses of John's Gospel. For the literature that deals with the question whether Jesus was an historical personage at all, see under the heading, "The Ethics of Jesus," the literature there noticed, p. 49. 
believe of Jesus, he has left immeasurable results for all the succeeding ages. This life is connected with a great upward movement. The religious feelings of men received new inspiration and direction. The standards of human conduct and judgment were purified and changed. That life still exercises its wonderful power, and is still the centre of a great, though incomplete, movement aiming at divine perfection. It is the ethics of this movement in its various phases that we set ourselves to study.

Jesus did not, as far as we can see, give himself distinctly to the organization of a new community, or to the reconstruction of society, or to the development of a new religious philosophy. As has well been said, "He (Jesus) gathered about him a little circle of disciples. With them he ate and drank, and during his short activity they constantly accompanied him. They saw how he associated with men and heard what he said to them. He did not teach, he worked and felt before their eyes and inspired them to so work and feel. He did not consciously place his person in the foreground, he did not talk about the significance of his life and sufferings. In fact, however, the impression of his person went far beyond his teaching. He was more than a prophet: in Him the Word was made flesh." 1

The influence of that person continues to be felt. No communal life can ever now escape that influence, and no philosophy can fail to take account of the teachings which rose up at once in response to that great personality.

It is true that no community has completely embodied the inspirations of Jesus, and that all so-called Christian systems of thought exhibit manifest weaknesses. So that a history of the ethics of our common Christianity is a history of approaches to a goal. Indeed this is the greatness of Jesus that his name is linked with a divine ideal so high that no church and no state can claim, with any pretence to truth, to have really incorporated that ideal.

'Wellhausen, J.: "Israelitische und jüdische Geschichte," $4^{\text {th }}$ ed., Berlin, rgor, p. $3^{88 .}$ 
If we simply seek to isolate the philosophic and ethical postulates of Jesus and his early disciples, and thus identify Christianity with these, we might well ask with Ziegler," "Are we still Christian?" But this very question implies the common misconception of the significance of Jesus and Christianity which makes Ziegler's history often utterly misleading in spite of its attractiveness and ability. This misconception is, alas, all too common on the part of both friend and foe. Jesus did not bring primarily either a new philosophy or a new ethics. He brought a new ideal of life. And the transforming power of that ideal is no longer a matter of humble faith, but of historic experience. Indeed the history of the ethics of Christianity is the history of the influence of that great personality and the ideals which he brought, upon the most diverse philosophies and the most widely differing social structures.

II. Two fields of inquiry open up before us. On the one hand, the history of the ethics of Christianity might lead us to an attempted history of the morality of communities calling themselves Christian. Or, on the other hand, we might concern ourselves wholly with the theoretical approach to the definition of certain norms of conduct as distinctively Christian. It is this latter field to which we must turn; but at the same time realizing that the unfolding ideals of the Christian life are not matters of pure thought, but are born of the experience of the Christian thinker struggling to incarnate his ideals. It would be fortunate if we could always use the words "morality" and "ethics" to cover, the one the more especially objective and the other the theoretical aspects of our field, in some such way as Otto Ritschl ${ }^{2}$ has suggested, but unfortunately that is not yet possible. Theories of conduct are not the product of our morality any more than morality is the product of pure theory. Theory and practice go hand in hand. To weigh these several factors is

'Ziegler, Theobald: “Geschichte der christlichen Ethik," 2d ed., Strasburg, 1892, p. 593 .

2Ritschl, Otto: "Wissenschaftliche Ethik und moralische Gesetzgebung," Tübingen, rg03, p. Ir. 
not always possible. To ignore either of them is fatal to all sound thought. We can no more separate permanently theories of ethics from the practice of morality than we can separate, save in thought, the mind from the body.

The history of the objective morality of historic communities is exceedingly difficult, and belongs more particularly to the field of the history of civilization. It is with the ethical theory and the ethical ideals we have in these pages to concern ourselves.

III. A very serious question is raised for the historian of the ethics of Christianity by the confessedly relative character of all Protestant moral standards. Any thorough-going Protestantism must surrender all claim to the possession of a body of infallible rules of conduct whose explication is simply a matter of sincerity and shrewd candor. The actual rules of conduct must grow out of experience. What is right and what is wrong cannot be resolved into a matter of enactment, and legally formulated. Where, then, it may be asked, is there any difference between philosophical or speculative ethics and a modern Protestant-Christian ethics? To this the only possible reply is that we maintain the reality of the Christian experience, and that out of Christian experience we may expect a body of conduct distinctly bearing the marks of its origin. No speculative system of ethics can therefore satisfy the Christian heart and conscience, when it takes no account of what to the Christian believer is the supreme reality of his experience. The Christian has seen God in Christ Jesus, and from thenceforth Jesus has for him the value of God. His experience of forgiveness of $\sin$ is attested by the outcome in appropriate conduct and in his fellowship with a brotherhood in forgiveness. The basis for a Christian ethics is therefore the forgiven life working itself out in a transformation of all ideals, a revaluation of all values, to accept the challenge of our fiercest critic, Friedrich Nietzsche. And the goal is distinctly set forth in the revelation of God in all human life. There is, therefore, no complete system of Christian ethics, nor can there be any such until human experience is completely under the sway of the Christian ideal. At the same 
time we hope to show that there are steady approaches to the ideal set before us as a formal principle, and that our task is the history of these approaches.

IV. Strangely enough, the history of Christian ethics has had no adequate treatment by an English-writing student. The two volumes by F. D. Maurice on "Moral and Metaphysical Philosophy," although abounding in learning and suggestion, re too diffuse and too unhistorical in method to be of the highest value as history. The historical volume of Wuttke's "Christian Ethics" is translated from the German into English (Edinburgh, 1873; New York, 1875), but the original is defective in method and the translation is harsh. The translation (Clark's Foreign Theological Library) of Luthardt's "History of Christian Ethics," in two volumes, is well done, but Luthardt's pronounced Lutheran dogmaticism gives the whole history a bias that robs an otherwise valuable work of its greatest usefulness. In Germany the history of Christian ethics has always received more attention than with us. Staüdlin's (C. F.) "Geschichte der Sittenlehre Jesus" (4 vols., I799-I823) is indeed out of date, but contains a great mass of material from which all subsequent historians have borrowed. The same may be said of Marheinecke's (Ph.) "Allgemeine Geschichte der christlichen Moral in der deutschen Reformation vorangehenden Zeiten" (Sulzbach, I806). Nor is the volume of Wuttke, already mentioned as translated, of much present value. A. Neander's "Vorlesungen über Geschichte der christlichen Ethik, herausgegeben von David Erdmann" (Berlin, I864) marks a distinct advance in historical method. And W. M. L. de Wette's "Lehrbuch der christlichen Sittenlehre" (Berlin, I833) has much material, treated, however, from the distinctly philosophical stand-point of de Wette. The most recent works, apart from Luthardt's volumes, already mentioned as being translated, are Bestmann's "Geschichte der christlichen Sitte (2 vols., 1880-1885), which is full of most valuable detailed research, but is lacking in central organizing view-points. Gass's "Geschichte der christlichen Ethik" (3 vols., I88I-I887), which remain beyond doubt the most valuable modern history, is especially good in the treatment 
of the Middle Ages and the early history. Ziegler's "Geschichte der christlichen Ethik" ( 2 d ed., I892) fails to always bring out the fundamental meaning of Christianity, and is often too lacking in sympathy with the movements described to do them full justice. At the same time the book has high merit, and is always brilliant if often hasty in judgment and somewhat superficial in its estimates, and leaves upon the theological specialist the impression that a competent authority in another field felt he had to fill out his work by dealing with a subject for which he had no special qualification. Apart from histories of distinctly Christian ethics, there are sketches of the history of ethics as a speculative science of marked value. Among these is the admirable little sketch by Sidgwick, "Outlines of the History of Ethics for English Readers" (4th ed., 1896). In Wundt's "Ethik" there is also a brief but interesting history of ethics. In 1845 , Fr. Ehrenfeuchter published his "Entwickelungsgeschichte der Menschheit, besonders in ethischer Beziehung" (Heidelberg), and it is a great pity that more work along the lines he then laid down, but with the greater abundance of accurate references to savage life now accessible, is not being attempted. Emil Feuerlein's "Die philosophische Sittenlehre in ihren geschichtlichen Hauptformen" (2 vols., Tübingen, I856I859) contains valuable historical material. The most notable historical work along the ethical line has been done by Jodl (Friedr.), whose "Geschichte der Ethik der neueren Philosophie" (2 vols., Stuttgart, 1882-1889, and a new ed. of vol. I in I906) is by all means the fullest and most satisfactory exposition known to the writer. But the chapter on "Christian Ethics" is sadly wanting. Karl Köstlin has written on the "Geschichte der Ethik des klassischen Alterthums" (vol. I., "Die griechische Ethik bis Plato," I887). Upon this Luthardt has also written in his "Die antike Ethik in ihrer geschichtlichen Entwickelung" (Leipsic, I887). An older work by C. Meiners, "Allgemeine kritische Geschichte der Ethik (älteren und neueren) oder Lebenswissenschaft" (Göttingen, r800-180r, 2 vols.), has largely lost its value. Martineau's "Types of Ethical Theory" (2d ed., r886) is largely valuable for its brilliant though too 
ornate style. The analysis of the historic systems is lacking in historical objectivity and their classification cumbersome and defective. Some historical examination is found in the pages of James Mackintosh's "Dissertation upon the Progress of Ethical Knowledge" (edited by Whewell, 3d. ed., Edinburgh, I862), but on the whole it is not now serviceable.

V. The field is so vast that it is impossible to attempt even a fairly complete bibliography of the primary and secondary sources. The range covers the fields of philosophy, dogmatics, and general history. Indeed, some of the most useful ethical literature carries no real indication of its character in the assigned purpose of the book. For the early canonical period we have only the canon itself, and for the early church we must depend upon literature given up in the main to polemic or dogmatic exposition. Even the Old Catholic or Bishop's church was so insistent upon doctrine as the basis of life, that formal ethics has but a secondary place. The ethics of the militant church, educating the north of Europe and intrenching itself in the places of political power, is to be found mingled with canon law and with ecclesiastical institutionalism. Even when the scholastic period is reached it is still the dogmatic and cosmological interest that dominates, and the ethics of an Anselm or Dun Scotus must be reconstructed by the historian from materials gathered for dogmatic exposition. It is therefore impossible in such a history to do more than gather from the literature such typical forms as may illustrate the steady progress of the Christian conception of God in Christ Jesus and the region of thought about conduct. After the critiques of Kant we find ethics no longer possible as an authoritative system. From his day on, philosophical ethics and the ethics of organized Christianity cannot be separated, and the content of ethics is based both within and without organized Christianity upon experience. Hence, as we shall see, our history really terminates with the new Protestantism made necessary by the critical philosophy, and the last chapter of our book is therefore only a summary of the situation thus produced. 


\section{CHAPTER I}

\section{THE PREPARATION FOR CHRISTIANITY}

Note of Introduction.-I. The Grecian (Classic) Contribution-II. The Hellenistic Preparation-III. The Roman Preparation-IV. The Old Testament Preparation: Propheticism; The Early and Later Priestly Development; The Deuteronomic Synthesis; The Contribution of Hellenized Judaism.

\section{NOTE OF INTRODUCTION}

That the ethics of Christianity represent a synthesis into which elements entered from the most various quarters can no longer be seriously denied. A certain type of Judaism had succeeded in keeping itself relatively untouched by the changes going on in thought all about it. So that the early New Testament literature, although written in Greek, is yet thoroughly Jewish in thought and fundamental feeling. At the same time even within the period of the New Testament writings-say 45 to I25-the whole world was profoundly affected by elements that appear in the pages of the later writings of the canon, and we cannot understand the canonical writings without some understanding of the ranges of thought amid which they had their origin. In the beginning the Christian church had its following from among the most extreme types of Jewish thought and feeling, namely, the zealots of Galilee and the middle class thinking of Jerusalem. It was Paul who introduced it to the larger world of aristocratic Judaism and the cultivated circles of Hellenism. In this Hellenism Christianity found too much that was congenial to pass it by. We must then rapidly review the various elements that affected Christianity, and deal with them as they affected her. These elements were classic Greek speculation, the Hellenized world of thought, the Roman Empire, and more particularly the Old Testament in its various phases. 


\section{THE GRECIAN (CLASSIC) CONTRIBUTION}

Strictly speaking, it was Hellenism rather than the classic Greek philosophy (Democritus, Plato, Aristotle) that supplied the intellectual forms for the use of early Christianity. The unorganized character of the Jewish intellectual and artistic life made it inevitable that the early church should seek elsewhere than in the Old Testament for the means of systematic expression of her life and purpose. Judaism itself felt the lack and turned in the same way to Greece for help. Josephus and Philo show how inevitably the thoughtful turned to the classic models.

The books of the Old Testament could supply content and inspiration for the apologetic preaching of the early church, but for dialectic and rhetorical method, for training in systematic and logical thinking, the early defenders of the faith had to look to the Greek and Roman schools.

It is impossible at this point to do more than very briefly point to some of the main elements of that classic thought which at once gave form to the ethical thinking of the early church.

Plato rather than Aristotle has been chiefly influential in most periods of the church's life. Even when; as in the Middle Ages,

Literature.-Schmidt, L.: "Die Ethik der alten Griechen"; 2 vols.; Berlin, r882.-Zeller, Eduard: "Die Philosophie der Griechen"; 5 vols. (in various editions); Leipsic, 1889-1903.-Windelband, W.: "Lehrbuch der Geschichte der Philosophie"; I vol., 4th ed., Tübingen, I907; pp. 20-218; English translation, New York, I90I; pp. 23-262.-Grote, George: "History of Greece"; Io vols.; London, I888 (especially vol. VIII).-Weber, A.: "History of Philosophy"; translated by Thilly; New York, Scribner's, I903; pp. 17-53.-Ueberweg-Heinze: "Grundriss der Geschichte der Philosophie"; roth ed.; 4 vols.; Berlin, I90I-1906 (especially full citations of literature).Ziegler, Theobald: "Die Ethik der Griechen und Römer"; Bonn, r88I (vol. I of his "Geschichte der Ethik).—Köstlin, Karl: "Die Ethik des klassischen Altertums (I. Die griechische Ethik bis Plato)"; Leipsic, I887 ("Geschichte der Ethik," vol. I).-Luthardt, C. E.: "Die antike Ethik in ihrer geschichtlichen Entwickelung"; Leipsic, I887.-Rohde, Erwin: "Psyche, Seelenkult und Unsterblichkeitsglaube der Griechen"; 2 vols.; 4th ed.; Tübingen, 1907.Mahaffy, J. P.: "History of Classical Greek Literature"; 3 vols.; 2d ed.; London, I883, 1889.-Jowett, B.: "Dialogues of Plato," with notes; 5 vols.; 3d ed.; New York and London, 1892.-Schaubach, E.: "Das Verhältniss der 
Aristotle was the avowed master of all minds, the religious character of the Platonic philosophy was indirectly, in mysticism, in devotional books, and in a thousand phrases and terms of thought, even more influential than the Organum. Of course Plato's works were only very uncritically known. Some of his leading doctrines are to this day confounded with conceptions entirely strange to his thinking. He was used to support an intellectual dogmatism that would have been wholly opposed to his artistic longing for intellectual freedom. And yet a dogmatic teaching church found in the Socratic identification of wisdom with goodness and knowledge with salvation, as Plato developed it, a great source of strength and comfort. The church came revealing, and, "If a man know all good and evil, and how they exist, and have existed, and will be brought forth, would he not be complete and wanting in no virtue, whether justice or self-control or holiness? He would possess them all, and he would know those (situations) which were dangerous and which were not, and would guard against them whether they were supernatural or natural." 1 The Platonic thinking lent itself to an appeal to supernatural enlightenment. The "de-

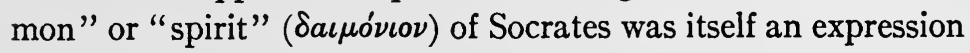
of highest ethical faith. "You have heard me speak of an

Moral des classischen Alterthums zur christlichen in Theologische Studien und Kritiken"; 1851; vol. XXIV, pp. 59-121.-Neander, A.: “Ueber das Verhältniss der hellenischen Ethik zur christlichen"; pp. 140-214; in his "Wissenschaftliche Abhandlungen"; edited by J. L. Jacobi; Berlin, 1851.-Caird, E.: "The Evolution of Theology in the Greek Philosophers" (Gifford Lectures, 1900-1901, 1901-1902; 2 vols.; Glasgow, 1904.-Hatch, Edwin: "The Organization of the Early Christian Churches" (Bampton Lectures, 1880); London, 188r; and "The Influence of Greek Ideas and Usages upon the Christian Church"; edited by A. M. Fairbairn; 2d ed.; London, 1891 (Hibbert Lectures, 1888).Friedländer, L.: "Darstellungen aus der Sittengeschichte Roms in der Zeit von August bis zum Ausgang der Antonine"; 7th ed.; Leipsic, r9or.-Siebeck, Herm. : "Plato's Lehre von der Materie," in his "Untersuchungen"; 2d ed.; Freiburg, 1888.-Harnack, A.: "Lehrbuch der Dogmengeschichte"; vol. I.; 2d ed.; Introduction; Freiburg, i. B., 1888; English translation.

${ }^{2}$ Laches $199 \mathrm{~L}$. The translations here and elsewhere are in the main those of Jowett, with only a few departures for special reasons in favor of a more literal even if more clumsy rendering. 
oracle or sign which comes to me, and is the divinity which Meletus ridicules in the accusation. This sign I have had ever since I was a child," says Socrates. "The sign is a voice which comes to me, and always forbids me to do something which I was going to do, but never commands to me do anything." 1

The development of this conception of an immediate intuitional inhibition by Plato into the doctrine of immediate vision and ethical insight is most interesting, and gives at once room for a religious interpretation of common ethical experience. ${ }^{2}$ The cult and the mystery have more in common with Plato than with Aristotle, and the religiously ethical character of the speculative insight becomes more and more prominent in his teaching. ${ }^{3}$ So that we may say that the ethics of Christianity has been profoundly and directly influenced by several elements in Plato's philosophy. The Platonic doctrine of the immaterial immortal character of the soul, with its contact on the one side with the Eternal and unchanging Being in the vision of ideas, and on the other with the changing life of action and suffering, is wholly foreign to the ranges of thought out of which Christianity came, but was at once in crude outline accepted, and remains to-day as the basis of nearly all Christian eschatology. Any one has only to try and fit the early Christian teaching of the resurrection of the body, which was the fundamental postulate of the Jewish eschatology, into the Platonic framework to see how distinctly the conception of the soul as it is taught in the Phædrus differed from the Jewish faith. But as between the two notions it is Plato that has triumphed. Although, again, it must ve remembered that Plato's doctrine has also received serious modifications. Ethically Plato's doctrine of the soul laid emphasis upon the immediate and individual judgment at death. Communal and national judgment, such as Prophetism and the

\footnotetext{
${ }^{1}$ Apology 3I. Cf. also Xenophon Memor. IV, 8 and I, 4, 15, and the Phædrus $246 \mathrm{ff}$.

${ }^{2}$ Cf. Windelband, W.: "Lehrbuch der Geschichte der Philosophie," 4th ed., Tübingen, r907, p. ror; English translation, New York, rgor, p. I23.

Cf. Phædrus, 250.
} 
Apocalyptic books had proclaimed, gives way, even in the New Testament, to individual and immediate decision. ${ }^{1}$ The transposition of the emphasis from the national and communal to the individual responsibility for guilt cannot, of course, be traced entirely to Plato, but his doctrine of the immortal soul lent itself in a peculiar way to the new personal ethics of the Christian community.

The Platonic teaching of the idea was directly connected with his ethical interest. Indeed its development was designed to secure a permanent and unchanging foundation for conduct amid the confessedly changing circumstances of the sensible existence. ${ }^{2}$

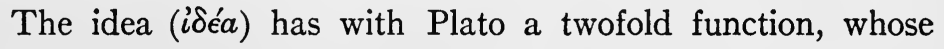
connection it is not always easy to trace. On the one hand it is the unchanging essence, the eternal type of the temporal and the changing including in this the psychical and non-corporeal. ${ }^{3}$ On the other hand the idea is conceived of as possessing a dynamic character, so that the idea of the "good" is not only the type of goodness, but is the creator of all good things in so far as they are good." Plato's ideas are not simply spirit as over against material things. The distinction is not, as in the later and corrupted thought, that of body and soul. The idea expresses the highest being apart from all body, a reality only known in conception, giving unity to the manifold.

Both these conceptions appear again and again in the ethical constructions of Christianity and in all shades of comprehension. More particularly in the orthodox thought of God do we find attempts to express the incommunicable nature of his transcendental holiness in terms that recall Plato's teaching, and in the "Logos" doctrine the Platonic idea as a dynamic force appears in all shades of Hellenistic and Neoplatonic corruption.

${ }^{1}$ Cf. Luke r6 : r9-3r and $23: 43$; cf. the "Republic," book X.

${ }^{2}$ Cf. Wundt: "Ethik," r886, p. 239, and Windelband: "Lehrbuch der Geschichte der Philosophie," 4th ed., r907, p. 95. English translation, New York, r9or, p. rir8.

${ }^{3}$ Phædo, 78-80; Parm., r35; "Republic," VI, 507-510; Timæus, 28 (placed on the lips of Timæus).

"Phædo, 97-ror; "Republic," VI, 507 ff. 
We shall also have occasion to notice the distinctly metaphysical interest that attaches itself to the relative monotheism of Plato as contrasted with the purely ethical interest of Old Testament monotheism. Here again it is hard to escape the conviction that Plato has outweighed the prophets. The way in which as, for instance, in the Timæus, the metaphysical and ethical interests are linked with cosmological speculations, ${ }^{1}$ suggests the method of all early Christian theology. The cosmogony of Genesis has little or no metaphysical interest. 'Its message is religious and ethical. For Plato the metaphysical was in the last analysis the only guarantee of the ethical. The value of God is that he is the foundation for all being, including of course as chiefly important the ethical verities. This intellectualism is fundamental to classical Greek ethics. ${ }^{2}$ It has most profoundly influenced all Christian thought. Our estimate of this influence may be that of Professor Harnack ${ }^{3}$ or that of Professor Pfleiderer, ${ }^{4}$ but the facts are quite beyond dispute. The origin of metaphysical monotheism is to be sought, not in the prophets or even in Paul, much less in Jesus, but in Plato.

On another field Platonic teaching has mingled with the ethics of the Old Testament and given a distinct color to the doctrines of Christianity. This is the important region of human guilt. The estimate of matter as changing, and in itself lower and evil and something to be escaped from, is wholly foreign to the older Jewish thought, whose God creates all things and all very good. ${ }^{5}$ A despondent view of life appears, however, very plainly in Plato, ${ }^{6}$ and very soon began to deeply mark the thinking of Christianity in the Hellenic world. Even in Paul we see the shadows of a despondent estimate of human life falling on

${ }^{1}$ Timæus, 30-48.

2 Cf. Interesting discussion of "Motives" by Schmidt: "Ethik der alten Griechen," Berlin, I88I, vol. I, pp. I56-165 and 253-256.

"Cf. "Dogmengeschichte," $2 \mathrm{~d}$ ed., I888, vol. I, pp. IOI-I Io.

"Cf. "Die Entwicklung des Christentums," I907, p. 7.

- Genesis I : 31 .

' $C f$. Phædo, 66, 67, with the further development in Philo's "De Mundi officio," $\$ \$ 57-60$. 
his pages, although he had probably no direct knowledge of the sources whence they came.

In the later stages of Plato's philosophy these elements of world-flight and asceticism seem even more pronounced. ${ }^{1} \mathrm{He}$ was perhaps influenced by his own political failures. ${ }^{2} \mathrm{He}$ himself regarded the "Republic" as only a council of perfection, and Plato had so low an estimate of Athens that he was himself strongly under the conviction that Athens at least could never really learn. ${ }^{3}$ The life of philosophy was to be a life of retirement and contemplation far from the phenomenal confusions of the market and the street. In fact the philosopher of the "Republic" is very nearly the picture of the statesman and monk of the great Papal state at its best. It is impossible to overlook the influence exercised by Plato upon the whole conception of life born of the monastic ideal. In conjunction with the oriental and Egyptian notes, which appear also in Plato and are more and more apparent in Neoplatonism, we find the temper of the age from which Christianity sprang despondent as it looks out on human nature, and the doctrine of total depravity has its roots far more in Hellenistic than in Semitic soil. ${ }^{4}$ In the teaching of Plato not only was the body a limitation upon pure knowledge, but even the psychic process so far as it dealt with particulars. Mystic salvation in its escape from particulars into the immediate revelation of the vision exactly corresponds to one phase of Plato's hope. So that more than once we face an estimate of life with its manifoldness that calls itself Christian, but whose real roots are in the soil of Greece.

On the formal side of the ethical thinking of the church, both Aristotle and Plato exercised a great and beneficent influence. All attempts to classify the virtues and to reduce to systematic form the moral life and its demands go back at once to either

${ }^{1}$ Cf. Timæus, 69-7r.

${ }^{2} C f$. Steinhart, Karl: "Platon's Leben," Leipsic, I873.

${ }^{3}$ Apology 3I, 32.

"Cf. Schultz, H.: "Alttestamentliche Theologie," 5th ed., pp. 493-5×2. English translation, 2 vols., Edinburgh, 1892; vol. II, p. 24I-280. 
Plato or Aristotle or to both. ${ }^{1}$ In the early chapters Aristotle cannot always be distinctly traced, and again it is Plato with his fourfold division of the virtues ${ }^{2}$ that dominates the early thought. In the attempt, indeed, to fit the ethical ideals of Christianity into these classic forms violence has often to be done either to the contents or to the forms. Indeed it is in following up this effort that the strong contrast between the classic and the Christian ideals comes into view. ${ }^{3}$ At the same time it was from Greek and Roman models that early Christianity learnt what it knew of systematic co-ordinated thinking, and the strength of its teaching was due in large measure to contact with the flower of Greek culture in the works of Plato and Aristotle.

However much we may regret the confusions that arose and that still persist between the classic and the Christian interests, we should never cease to be grateful for the intellectual schooling given the early church by contact with Grecian dialectics.

The ethics of Plato were developed in the midst of a society commonly called democratic, but which was in truth a small slave-holding and highly aristocratically governed community. Plato himself belonged to the most highly privileged class in the state. This state itself was rapidly going to pieces under the burden of these privileged classes and under the strain of external political complications. This decay was patent to all the thoughtful elements in the community. The "Republic" of Plato and the "Laws," so far as they are from his hand, represent an earnest and wonderfully inspiring attempt to suggest a new social construction to arrest the decay. On its purely formal side the work of Plato had enormous influence upon the social dreaming of Augustine, and through him moulded, in larger measure than is perhaps generally recognized, the great Priest-

\footnotetext{
${ }^{1}$ As in Thomas Aquinas.

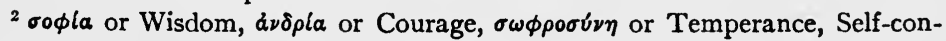
trol, and $\delta \iota x a \iota \sigma o u ́ \eta \eta$ or Justice.

${ }^{3}$ Cf. Schaubach: "Das Verhältniss der Moral des klassischen Alterthums zur christlichen Theologie. Theologische Studien und Kritiken," r851, pp. 59-1 2 I.
} 
state of the Middle Ages. Plato was, however, far from democratic in either his temper or his hope. At the same time he wished for an aristocracy of the noblest and an aristocracy trained for its work of self-sacrifice and duty by sacrifice and service. The Roman Catholic hierarchy was a bold attempt on a large and most impressive scale to realize this ideal. The relative success of the experiment was due to the fact that it was linked with that religious enthusiasm which Plato sought to infuse into Athenian life. ${ }^{1}$ And the history of the attempt goes far to justify the real insight of the great philosopher.

At the same time the weaknesses of Plato's ideals were born of the very social organization he wished to redeem. The aristocratic type of thought and feeling so prominent in the small, closely organized Greek cities reappears in the priestly reconstruction of the Middle Ages, and did so in part, at least, under the influence of the Platonic conceptions carried over by Augustine. The "Republic" reflects the caste spirit which played such havoc with the political and religious ideals of the Old Catholic church, and which, amid all semblance of democracy, even to this day give to the ethics of the Roman Communion an aristocratic character.

\section{THE HELLENISTIC PREPARATION}

The Grecian life that is most plainly reflected in our earliest Christian sources is not that of either the Ionic or Attic periods, but that which since Droysen has been called Hellenism. ${ }^{2}$

LITERATURE (in addition to list on page $7 f$. and of the standard histories of Greece).-Droysen, J. G.: "Geschichte des Hellenismus"; 2d ed.; 3 vols.; Gotha, 1877-1878.-Mahaffy, J. P.: "The Silver Age of the Greek World"; Chicago, 1906.-Hatch, Edwin: "The Influence of Greek Ideas and Usages upon the Christian Church"; 3d ed.; by A. M. Fairbairn (Hibbert Lectures for r888) ; London, I89r.-Zeller, E.: "Die Philosophie der Griechen"; vol. III.,

${ }^{1} C f$. Windelband, W.: "Lehrbuch der Geschichte der Philosophie," 4th ed., I907, p. 105. English translation, "History of Philosophy," New York, I90I, p. 127 .

${ }^{2}$ Droysen, J. G.: "Geschichte des Hellenismus," 3 vols., Gotha, I877. See Von Wilamowitz-Moellendorff: "Griechische Literatur des Altertums" (Kultur der Gegenwart, I, viii, 1907), p. 84. 
Greece became the world's teacher when her culture was scattered over all known lands and was forced upon the unwilling Orient by the conquests of Macedonia. Aristotle was Alexander's teacher, but the pupil had greater insight into the actual possibilities of empire than even his teacher. He saw that a really world-wide empire could not be built upon the basis of the intellectual aristocracy of the Greek city. ${ }^{1}$ According to Plutarch, Aristotle advised Alexander to treat the Greeks as friends and relations and the barbarians as plants and animals. ${ }^{2}$ It was quite as impossible to build empire on such organization as Athens possessed as it would have been to build up a kingdom in the Middle Ages on the basis of the free city. Athens had in 309 B. C. a population of 21,000 free citizens, I0,000 "strangers" ( $\left.\xi^{\prime} v o \iota\right)$, free but not citizens, and 400,000 slaves. ${ }^{3}$ The result of such a city organization was the intense particularism and the haughty patrician pride which marked the free cities of the Middle Ages. Such a spirit is as far removed from democracy as the east is from the west. The intellectual conquest of the world was effected only when this organization was broken down, and Grecian culture like Jewish religion had become relatively homeless. Moreover, this conquest was effected, like

part I; Leipsic, I903.-Rohde, E.: "Kleine Schriften"; Tübingen, I902 (especially "Die Religion der Griechen"); in 2d vol., pp. 335-336.-Siebeck, H.: "Untersuchungen zur Philosophie der Griechen"; 2d ed.; Freiburg, r888.Wendland, P.: "Christentum und Hellenismus in ihren litterarischen Beziehungen"; Leipsic, 1902; and "Die hellenistisch-römische Kultur in ihren Beziehungen zu Judentum und Christentum"; Tübingen, r907.-v. Wilamowitz-Moellendorff: "Geschichte der griechischen Literatur (in der Kultur der Gegenwart"); Teil I, Abteilung VIII, pp. 3-238; 2d ed.; Berlin, r907.Cumont, Fr.: "Les Religions orientales dans le paganisme romain"; Paris, 1906.-Deissmann, G. A.: "Licht vom Osten”; 2d ed.; Tübingen, I9०9.

${ }^{1}$ Droysen, vol. II, pp. 15-17.

2Aristot. apud Plut. de fort. Alexander I, 6. See also Aristotle, "Politics," I, I, quoted by Droysen.

3 Boeckh's "Staatshaushaltung der Athener," 4 Bücher mit Inschriften, Berlin (Ist ed., I8r7; 3d ed., by Max Fraenkel, I886), vol. I, p. 38, based on disputed census figures, which, however, Droysen accepts as accurate. $C f$. vol. I, § III, p. 429 of ist ed., I836. (Translated by Sir G. C. Lewis, London. 2 vols., 1828, 2 d ed., 1842 . Translated by A. Lamb, Boston, 1857,2 vols.) 
the political conquests of Alexander, by skilful use of the forces of the antagonists. The result was that with Alexander began that cosmopolitanism which fitted Greek thought to the conditions out of which came the still greater world-empire of Rome. Indeed the history of Hellenism stretches on into the intellectual life of Rome under the Cæsars. Cicero founded an empire of thought which was based on Hellenism, and which contested with the Cæsars for the dominion over men's minds, ${ }^{1}$ and men sought in it consolation for lost national freedom. The historians before Droysen have underestimated the achievements of this period, when science and speculation became the possession of an enlarging world. Alexander founded over seventy cities or trading colonies, and thus Hellenism became the mother of the modern city-development and taught Rome a lesson in the organization of an awakening world.

This cosmopolitanism was not gained without sacrifice. Greece lost her liberty, and the world of Hellenism is overshadowed by the greatness of this loss. The unity of her thought gave way to a unity based on a synthesis of many elements, and at every point the student of Hellenic art or literature marks concessions to the synthetic character of the whole movement. Into this synthesis enter three elements that have especial bearing upon the ethics of Christianity. It is a period of philosophic adaptation that is often rather conglomerate than an organized philosophic whole. During this time is born a popular religious philosophy with many elements drawn from oriental cults, and it is during this era that an oriental mysticism brings forth its full fruit, and is itself ennobled and purified by Hellenistic thought. This philosophic synthesis involved all possible combinations drawn from the teachings of the Academy, the Peripatetics, the Stoa, and from Epicurus as well as from the scepticism of the Middle Academy and the mysticism of Neoplatonism. The Stoicism which conquered Rome and became the religion of Epictetus, Seneca, and Marcus Aurelius, was

${ }^{1} C f$. Cicero's own statement of his ambition in "De Divinatione," liber II, $\$ \$ \mathbf{I}, 2$. 
mingled with the popular teaching of the Cynics ${ }^{1}$ and the scepticism of Carneades. Panætius the Rhodian ${ }^{2}$ (II2 B. C.) Stoic rejected astrological prophecies, and the Middle Academy permanently influenced the stoic doctrine of causation. ${ }^{3}$ Into this synthesis entered also elements drawn from oriental dualism with its fundamentally pessimistic outlook upon life. Thus we find already in Hellenism the struggle between a metaphysical monotheism and an ethical dualism which torments Christian thinking to this day." This dualism marked the Stoicism which became the religion of the intelligent and which undermined the vulgar polytheism, not by attacking it as did the Epicureans, but by explaining it away.

The drift of this synthesis was toward pantheistic monotheism. Rohde has, indeed, vigorously denied that the Greek mind had a tendency to monotheism, ${ }^{5}$ but in the intellectual struggles of the various schools metaphysical speculation led inevitably to monism. Indeed it became only a matter of the degree of culture in the various individuals how they combined this metaphysical monotheism with the popular polytheism. It was Stoicism that most skilfully wove together the ethical with the philosophical and religious interests, and thus became, as we shall see, even in Christian history, a substitute for an ethics based on the inspirations of the New Testament. In spite of its wide hold on cultivated minds, Epicureanism was from the beginning unsympathetic to Christian feeling. It was more distinctly antireligious in the sense of conscious insistence upon mental illumination as over against vulgar religious forms. ${ }^{\circ}$ Whereas Christian feeling at its best never placed the emphasis upon in-

${ }^{1} C f$. Wendland, P.: "Die hellenistisch-römische Kultur." Tübingen, pp. $39-50$.

2 See Cicero's "De Divinatione," Liber II, \$ 42.

"Cf. Windelband: "Lehrbuch der Geschichte der Philosophie." Tübingen, 1907, pp. 163-173. English translation, New York, 1901, pp. 197-209.

"Cf. Windelband: "Lehrbuch der Geschichte der Philosophie." Tübingen, 1907, p. 158. English translation, New York, 1901, p. I90.

" "Kleine Schriften," vol. II, p. 320.

- Cf. Windelband: "Lehrbuch der Geschichte der Philosophie," 4th ed., 1907, pp. 141, 142. English translation, New York, rgor, pp. I70, I7 I. 
tellectual illumination. It was also more readily misunderstood in its hedonism. For although it was in essence no more hedonistic than Stoicism, yet its definition of pleasure was more openly sensuous and more deliberately æsthetic than was compatible with the sterner puritanism of early Christianity. Its very attempt to rescue human responsibility by detaching conduct from a central power was not fitted to appeal to the aroused religious hope. ${ }^{1}$

The Cynic-Stoic movement appealed most directly to the life that needed hope, consolation, and direction as, under the storms of war, old institutions, old faiths, and old altars went down.

At the same time this very factor in the history of stoic ethics accounts in part for the extreme individualism that often limited its influence. Both Cynic and Stoic placed the individual in the centre of ethical interest. No considerations of either state or religious community could interfere with individual enlightened man doing that which advanced his own peace. Virtue was the satisfaction of the individual soul's longing for happiness. Cynicism went often the full length, ${ }^{2}$ but Stoicism also, like Epicureanism, had ever "happiness" conceived of as the peace of the individual in the foreground.

It is not accurate to say that it was Christianity that discovered the individual. Individualism came with cosmopolitanism; and Stoicism rather than Christianity formulated it for all ages. But, on the other hand, Hellenistic Stoicism was distinctly aristocratic-and not even the popular preaching of the Cynics ever raised Hellenistic thought to the point of ascribing to every individual as such inherent value. The "wise" were those who fought their way into subjection of the world by trained indifference to the lower delights. But this way was only open to the few. Literary Stoicism as we know it retained to the last this aristocratic character, even in the Christian edition of it by

${ }^{1}$ Cf. Schmidt, L.: "Die Ethik der alten Griechen," vol. I, pp. $287,288$. Where, however, he warns against the superficial treatment of Epicurus's doctrine in the classic passages "Diogenes Laertius," 10, 133, and "Cicero de Fato," 9, 18; 10, 23, and "De Natura Deorum," 1, 25, 69.

${ }^{2} C f$. Schmidt, L.: "Die Ethik der alten Griechen," vol. II, pp. 448-451. 
Ambrose of Milan. The slave Epictetus, whose teaching savors less than the others of this intellectual aristocracy, yet addressed himself to the ruling caste as we see from his complaints of the luxury and idleness of his hearers. ${ }^{1}$ In Panxtius, in Cicero, in Marcus Aurelius, and Seneca the ethics are those of men separated deliberately from the crowd, seeking consolation amidst the disappointments in life in the consciousness of lonely victory over the world. So that a distinctly pharisaic element enters easily into its spirit.

At the same time literary Stoicism did not constitute the whole of the movement. It could not have had as a philosophy any great influence over the average life. Literary Stoicism reveals almost no contact with the moral difficulties and struggles of the small trader or the petty agriculturist, who after all formed the great bulk of the population. There was, however, a popular as well as a literary Stoicism, and to understand its influence we must go to the Stoic-Cynic propaganda in sermon and tract, and must remember how wide was the scope of Greek education. ${ }^{2}$

This popular Stoicism was a combination made from elements taken from all the schools of Grecian thought, and such a combination was made the more easily because, marked as were the differences in the metaphysical constructions, they had on the ethical field distinct characteristics common to them all. They were all hedonistic. The resolute attainment of the highest happiness was the goal for the Academy and the Stoa, for the Epicurean and the Lyceum. They were all highly individualistic. The communal interests of Plato and Aristotle wellnigh disappear as the Greek city-state gave way to oriental empire. They were all deeply intellectualistic. Any redemption must come with knowledge, and however differently this knowledge was conceived, whether as magic illumination or scientific insight, it was the sine qua non of all ethical living. They all

'Epictetus: "Enchiridion," cap. I, 6.

${ }^{2} C f$. Wendland, P., in loc. cit., and Ussing, J. L.: "Erziehung und Jugendunterricht bei den Griechen und Römern," new ed., Berlin, 1885 . 
saw in proud resistance to evil the mark of the ethical life

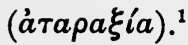

It is easy both to overestimate and underestimate the ethics of this popular Stoicism. Its weakness was primarily that it taught resignation in the midst of evils where resignation is not in place. Its goal was individual extrication rather than a kingdom of righteous conditions. Its conception of law was high, but was legal and mechanical, and like all attempts to build an ethics upon pantheism, its code was rigid and cold, lacking alike in contact with the longings of the heart and the hopes of the mind. It gave the world seekers after God, but inspired to resignation rather than transforming faith, and rather drew men out of the world than flung them upon the world for its transformation.

Into this popular Stoicism came also other than intellectual elements. Wilamowitz has pointed out ${ }^{2}$ that the Hellenistic period was one of scientific triumph, compared to which the time of the Roman emperors was one of decay. No less must we insist that it was a time of great moral uplift and religious revival.

As in all religious revivals, many strange elements entered into the movement. The very force and freshness of religious inspiration resents intellectual analysis, and so is apt to admit uncritically the most foreign elements. ${ }^{3}$

The fierce invective of Christian apology has blinded men too easily to the real good in the age. Hatch says: "It is questionable whether the average morality of civilized ages has largely varied .... and it is probable on $a$ priori grounds and from the nature of the evidence which remains, that there was in ancient Rome, as there is in modern London, a preponderating mass of those who loved their children and their homes, who were

'Cf. Windelband: "Lehrbuch der Geschichte der Philosophie," 4th ed., 1907, p. 136. English translation, New York, I901, p. I65.

2 "Die griechische Literatur des Altertums" ("Kultur der Gegenwart," I, viii), 2d ed., r907, p. 84.

'Cf. Cumont, F.: "Les religions orientales," 1906, pp. 197-235. 
good neighbors and faithful friends." 1 This revived ethical and religious interest sought satisfaction in the strange and ancient cults of the Orient.

Philosophy had to become a teaching of redemption, and in making the change from the cool seclusion of the schools to the heats of the street, oriental mystic rites and the authority of hoary antiquity had no small part in the transformation. Even in "men like Seneca, Epictetus, and Marcus Aurelius the Stoic teaching had become completely a philosophy of redemption." 2 Much more do we find the Hellenistic-Roman world overrun by all sorts of religions proclaiming redemption.

The age was, of course, a curious mingling of gross superstition and highly modern types of thought. ${ }^{3}$ But the age sought redemption. The immediate experience of evil, of a world to be overcome, of misery and dissatisfaction, called for explanation and relief. The simplest explanation is that matter is evil and spirit is good. This never was a Greek conception. But the religions to which it gave birth soon affected Greek thought.

Into the Hellenistic world had come in early days the foreign ungrecian cult of Dionysus, with its dances, mystery, ecstasy, its uplift to divine life even if only in the single moment of rapt enthusiasm. Thrace also gave the Orphic cult with its mystic redemption, and in their inception, like all mysticism when pure and logical, these cults were non-ethical. The redemption was conceived of as physical and psychical uplift into the very being of God. But these were only forerunners of the mystic cults that made the Hellenistic world a strange conglomerate of Grecian philosophy and oriental religion. The great advance was the ethical transformation of these cults, and then ennobling

\footnotetext{
'Hatch, Edwin: "The Influence of Greek Ideas and Usages upon the Christian Church," 3 d ed., London, 189r, pp. I39, 140. Cf. also Friedländer, "Darstellungen aus der Sittengeschichte Roms, vol. III, pp. $676 f f$., $c f .5^{\text {th }}$ ed.

2 Windelband: "Lehrbuch der Geschichte der Philosophie," 4th ed.; 1907, p. 176. English translation, New York, I901, p. 2 13.

- $C f$. the scepticism of the Middle Academy, and the modern spirit of the second part of Cicero's "De Divinatione," Liber II, $\$ \S 3,4,5,59$, etc.
} 
of them by making them schools for self-restraint and entrances into the life of avowed fidelity to duty. ${ }^{1} \quad$ The Greek mind could not be content with a non-intellectual transformation of life. The Stoicism of the Hellenistic period clung to the overcoming of the world by knowledge, but added to it the asceticism characteristic of oriental dualism. Yet even the asceticism of Hellenism had an intellectual character. One of the most valuable lessons it taught as a preparation for the higher ethics of Christianity was the intellectual honesty which insisted upon rationalizing even the rites and mysteries given primarily on authority (Neoplatonism).

The longing for immortality fixed upon these rites and mysteries and united with them the philosophical speculations of the earlier period. ${ }^{2}$ It was this period which formulated and intrenched in human thought many of the most lasting conceptions of immortality, last judgments, and heaven and hell. ${ }^{3}$

From Persia came the cult that, profoundly modified, no doubt, by its contact with Hellenism, was yet as the Mithras cult to give the Roman soldier his religion, ${ }^{4}$ and many rites and superstitions to the Christian church (see page I90).

It was, perhaps, the fundamental weakness of Greek and Roman paganism that its mythology, and its physical and metaphysical character hindered the development of a religion essen-

${ }^{1}$ Cf. Rohde: "Die Religion der Griechen," p. 334, vol. II, of "Kleine Schriften," IgO2.

'Cf. Rohde, Erwin: "Psyche; Seelenkult und Unsterblichkeitsglaube der Griechen," 4th ed., 2 vols., Tübingen, 1907.

"In Plato's description of last judgment in the "Republic," book X, 614-62I (Steph. ed.).

- Cf. Cumont, Fr.: “Texte et Monuments figurés relatifs aux Mystéres de Mithra." Bruxelles, $1896,1899,2$ vols. (especially the introduction). Also Cumont's article in Roscher's "Lexikon der griechischen und römischen $\mathrm{My}$ thologie," vol. 2 (1894-1897), and his "Religions Orientales," Paris, 1907 (in "Annales du Musée Guimet"). Lajarde, "Recherches sur le cult public et les mystéres de Mithra en Orient et en Occident," r867. Donsbach, "Die räumliche Verbreitung und zeitliche Begrenzung des Mithrasdienstes im römischen Reich," Brünn, 1897. See a condensed account in Dill, S.: "Roman Society from Nero to Marcus Aurelius," London, 1904, pp. 547-626. Dieterich, A.: "Eine Mithrasliturgie," Leipsic, 1903. 
tially ethical in character, ${ }^{1}$ by constantly putting the emphasis on other factors. How could cults that culminated in the worship of the Emperor give to the national life a religion primarily ethical? The mystery became, however, a rite of purification whose origin indeed was magic separation of the divine from the human and whose purification was thought of as physical. But as it is seen in the Hellenistic-Roman world it has an ethical character. And that feature of it seems to have undergone a rapid and wholesome development. Especially the Mithras cult seems to have placed the emphasis upon a really ethical purification, and so become an ethical religion of high value in the Hellenistic-Roman world. Cumont thinks Renan's judgment extreme, that if the triumph of Christianity had not come the world would have been "Mithradized." 2 At all events, it is certain that the cult centred about a struggle for the higher life by virtuous living and brave purification of the soul from baser elements. That in the later Roman world it was a serious, perhaps the most serious, rival which Christianity had is certain, and it was in so many ways so like Christianity that, oblivious to the fact that it was much older than the Christian church, the Christian apologists regarded it as a base imitation by the help of the devil. ${ }^{3}$ This cult was only one of the forms under which the Orient influenced both the outward rite and the inward life of the period." The real groundwork of orientalism, as thus seen, is dualistic, and as Rohde says, "the unmutilated (unentstellte) pantheism of the Stoic . . . knows no mystic and no

${ }^{1} C f$. Tzschirner, H. G.: “Der Fall des Heidenthums," ed. by C. W. Niedner, 1829, pp. 13-164. Döllinger: "Heidenthum und Judenthum, Vorhalle zur Geschichte des Christenthums," Regensburg, 1857. Schürer, E.: “Geschichte des jüdischen Volkes," 3 vols., I 901, I898. For full literature, see vol. III (I898), p. 109. English translation.

2 "On peut dire que, si le Christianisme eût été arrêté dans sa croissance par quelque maladie mortelle, le monde eût été mithriaste," Renan, "Marc-Aurèle, et la fin du monde antique," 3 d ed., Paris, I882, p. 579.

"Tertullian, "De Corona," I 5. "De Præscriptione Hæret," 40. " Justin Martyr Apol.," I, 66.

"For an eloquent presentation of the influence, see Cumont's "Les religions orientales," pp. I-23 and 237-254. 
redemption, ${ }^{1}$ but such contradictions exist in every age, and have never seriously hindered the most striking combinations. So in the Hellenistic-Roman world pantheism and dualism play each a part and live in relative peace with each other. Compromises of the most startling character were common. ${ }^{2}$ So that in the popular religious cults differences, even of a farreaching character, if only confined to the philosophical groundwork, exerted little divisive force.

It is most unfortunate that we have so little trustworthy information about these religions of the humble. The evidence of extensive guild and trade combinations under the guise of religious associations, and of the economic character of many of these cults is overwhelming. One need not go as far as Osborne Ward in his utterly uncritical treatment, ${ }^{3}$ yet the proletarian character of these religious mysteries explains on the one hand the few remains of any literary character, and on the other the tremendous hold they exercised upon the starved imagination of the poor.

For the wealthy and intelligent class Stoicism became "a religion raised upon the ruins of popular polytheism," "and for the humble and unlearned the oriental cult or the Hellenic mystery furnished food for the religious and ethical life, the ethical elements being largely borrowed from philosophy. ${ }^{5}$

In a later chapter (page I29) we shall have occasion to deal more fully with Neoplatonism in connection with the struggle in the church against Gnosticism. It will be sufficient here to

1 " Kleine Schriften," vol. II, p. 335.

2 Cicero says: "And the habits of reverence for, and the discipline and rights of, the augurs, and the authority of the college, are still retained for the sake of their influence on the minds of the common people." "De Divinatione," Lib. II, § 33. Mueller's ed., IV, vol. II, p. 222.

3 Ward, C. Osborne: “The Ancient Lowly," 2 vols., reprint by Kerr, Chicago, 1907.

- Quotation from the admirable sketch in Weber's "History of Philosophy," pp. $140-148$ of the English translation, New York, 1903.

${ }^{3}$ It is only fitting to call attention to the work of Deissmann, of Berlin, upon the relation of inscriptions to the life of the lowly. In his "Licht vom Osten," ז909. 
point out the history of those elements that so seriously affected pagan thinking, and which most definitely marked its ethics in the teachings of Neoplatonism.

Plato, as we have seen (page 13), never completely separated between soul and body in the sense common to early Christianity. The relation also of Plato to matter, although touched by the Pythagoreanism that influenced his later thought, never really leaves the Greek ground.

Neopythagoreanism, however, fully taught the distinctively oriental dualism of mind and matter, and insisted upon the essential evil of the $\breve{v} \lambda \eta$ as over against the principle of spirit as good. ${ }^{1}$ In this attitude toward matter Stoicism itself was influenced by the oriental intrusion and the optimism of the older Stoics in the matter of the attainment of the ideal gave way in the later Stoicism to the despondent view of the inherent evil of all men because still in the body. ${ }^{2}$ The attitude toward matter became in Neopythagoreanism and Neoplatonism that of hostility as the seat of evil, and redemption was almost grossly conceived of as separation of soul and body; but in connection with the doctrine of the transmigration of souls, mere death was not redemption. The psyche had to be trained for its non-material life. ${ }^{3}$ In various degrees this training was thought of ethically or physically. And thus there grew up those Neoplatonic systems which deeply impressed even into our own day the Christian church's teaching with regard to soul and body.

1 Cf. interesting discussion of Plato as mystic in Wundt, Max: "Geschichte der griechischen Ethik," pp. 450-494, and especially 454-462, Leipsic, I908.

2 Windelband: "Geschichte der Philosophie," 1907, p. 192 and note. English translation, New York, I90r, p. 23I and note 2.

The beautiful work of Rohde in this field has already been often quoted and used. 


\section{THE ROMAN PREPARATION}

It is impossible to separate between the Roman world of thought and that of Hellenism so far as these worlds are intellectual systems. Rome simply accepted the teaching of Greece and from the point of view of thought added little or nothing.

At the same time the adaptation of Hellenistic cosmopolitanism to the needs of a proud world-imperialism could not leave the systems of ethics founded upon this cosmopolitanism untouched. Cicero's "De Officiis" may be little more than a translation from the Greek, but the actual ethics of Cicero show plainly, even in the confusions, how the world of imperial ambitions amidst which he lived deeply influenced his ethical thinking. It was not unnatural that Cicero should give, through Ambrose's adaptation, an ethics to the young ecclesiastical empire.

The Roman contribution to the ethics of Christianity was therefore rather in giving the preparation for a world-wide claim and in bridging the gulf between law and ethics.

In Roman life the "munia" or duties of citizenship lay at the basis of the whole ethical development." The ethics were pronouncedly communal, and morals were organized life. If this led easily to legalism and externalism, it also gave fibre and strength to the whole social structure, and as the early church became the heir to Rome's imperial inheritance, she also took over a good share of Rome's legal ethics and her overestimate of external conformity to a given order. ${ }^{2}$ Rome spared the

Literature.-Mommsen, Theodor: "Römische Geschichte" (especially vol. I).-Cicero, M. T.: Complete works; edited by Müller; Leipsic, I905 (especially $4^{\text {th }}$ section, vols. I, II, and III).-Dill, S.: "Roman Society from the Time of Nero to Marcus Aurelius"; London, I905.-Juvenal: "The Satires."Renan, Ernest: "Marc-Auréle et la fin du monde antique"; 3 d ed.; Paris, 1882.-Ferrero, G.: "The Rise and Decline of the Roman Empire"; 5 vols.; English translation by Zimmern; New York, x907-r909.-v. Jhering, R.: "Der Geist des römischen Rechts auf den verschiedenen Stufen seiner Entwickelung"; Leipsic, r89r; 5 th ed.

${ }^{1}$ Kuhn, Emil: "Die stätische und bürgerliche Verfassung des römischen Reichs bis auf die Zeiten Justinians," Leipsic, $r 864,1865,2$ vols., part r, pp. $7 f f$.

'Cf. Mommsen, Theodor: "Römische Geschichte," vol. V, pp. 570-576. 
internal legal arrangements of conquered states as much as was possible. But the process by which she reduced to fundamental uniformity the various provinces was an exhibition of consummate instinctive governing power. ${ }^{1}$ This process, however, involved changes in her own constitution and life. Her religion suffered most drearily under the constantly increasing complication of her superstitions, ${ }^{2}$ and became more and more distinct from her ethics and social order.

Upon the ethics of ecclesiastical Christianity, however, Rome left the stamp of her institutionalism. To this day duty to the organization, and the obligation of conformity even against the personal judgment, is at once an institutional and political strength and a religious and ethical weakness of the communion which still bears the name of Rome.

The ethics underlying Roman law was never Christian and remains substantially Stoic up to its very last formulation in the code of Napoleon. Even when it passes for Christian law it soon appears to the really Christian student that he is dealing with the exalted conceptions of Stoicism, but not with the Sermon on the Mount. ${ }^{3}$ The eclecticism characteristic of all Roman thought, and particularly of Cicero, enabled the later Roman men to take up Christian elements into their thinking, and thus to make a body of conceptions, often really hostile to Christian thinking, seemingly acceptable. No one could be more pronouncedly pagan than was Cicero, but Ambrose's edition of his ethics passes for Christian into our own age.

And on the side of Rome's organization the influence upon Christian ethics was simply overwhelming. The Roman Catholic church became the heir of Rome's imperial policy and imperial ideals. Rome ruled by a judicious assertion of authority, stern and relentless where her sway seemed in any way involved, with the largest and most amazing concessions to in-

${ }^{1}$ Cf. Marquardt, I.: "Römische Staatsverwaltung," 2 d ed., vol. I, pp. 497-567.

${ }^{2}$ Cf. Marquardt, I.: "Römische Staatsverwaltung," $2 \mathrm{~d}$ ed. (revised by Georg Wissowa), Leipsic, I88I-I885, vol. III, pp. I-480.

"Cf. von Jhering: "Geist des Römischen Rechts," vol. I. 
dividual differences where her authority was taken for granted. This has marked the temper of historical Christianity ever since, and even in modern Protestantism (as in the state churches of England and Germany) still gives the model for imitation, often unconsciously.

Nor is it a matter of indifference that Rome supplied the sacred language in which Christian ecclesiasticism was to do its thinking. More than once in the course of our history we shall have occasion to mark the fact that the use of Latin has a distinct and interesting influence upon the development of the ethics of Christianity.

\section{THE OLD TESTAMENT PREPARATION}

What gives the ethics of the Old Testament its peculiar character and universal significance is not simply its "desire to keep the flame of a pure service of God alight," " nor yet its monotheism, but its linking its ethics with its conception of God, and making the communal life the field for the exhibition of the qualities of the God the community worshipped.

Just so soon as God was conceived of as final righteousness, even if the type of that righteousness was often poor and low,

Literature.-See the literature given in Driver, S. R.: "An Introduction to the Literature of the Old Testament"; 8th ed., r9o9.-Smith, H. P.: "Old Testament History"; New York, I903 (see literature in the Preface).-Wade, G. W.: "Old Testament History"; London, rgor; pp. x-xii.-Kent, C. F.: "The Student's Old Testament"; New York; 4 vols. so far published, I904, 1905, 1907, 1910; classified bibliography in appendices to each volume.-Wellhausen, Julius: "Israelitische und jüdische Geschichte"; Berlin, r901.Winckler, Hugo: "Geschichte Israels"; Berlin, 1895-1900; 2 vols.-Cornill, C. H.: "Der Israelitische Prophetismus"; five lectures; Strasburg, 1900.The articles in Cheyne's "Encyclopædia Biblica" and Hastings's "Bible Dictionary," as well as the standard commentaries on the various books, good lists of which are given by Kent in the volumes mentioned. A good introduction to modern Bible study is Briggs, C. A.: "General Introduction to the Study of Holy Scripture"; New York, 1899.-Schultz, H.: "Alttestamentliche Theologie"; 5th ed.; Tübingen, 1896; English translation, Edinburgh, 1892; 2 vols.Duff, A.: "The Theology and Ethics of the Hebrews"; New York, 1902.

'Curtius: "Gesammelte Reden," Berlin, I882, vol. II, pp. 2 and 9, quoted by Ziegler: "Geschichte der christlichen Ethik," 2 d ed., Strasburg, 1892, p. 14. 
and the demand was made that the community should show its fidelity to its divinity by conforming to that type of righteousness, the way was at last open for a boundlessly fruitful ethical development.

In all religions God is linked to his people by some bond. In Judaism at last this bond was interpreted in terms of the ethical life and in prophetism at its best in terms exclusively ethical. ${ }^{1}$ Thus at last the communal life was given not merely a political or legal, but an ethical content, and it was more and more clearly realized that the communal life was conditioned upon fulfilling righteousness. On the lowest plane this righteousness might be thought of as simply ritual correctness, a type of magic cleanness, but this never held the whole field of even the most priestly Jewish vision. It might be true that a ritual development gave a certain character to the ethics of Israel, but it never wholly dominated them.

The ethical development cannot be traced as a simple matter of chronology, for the documents only permit of tentative reconstructions of the history, and these reconstructions show that various developments were going on side by side.

Two main lines of development may be called the prophetic and the priestly. The school of the Deuteronomists sought to make a synthesis of these two main types, and later the Greek influence gave a still further "wisdom" type. In all the developments, even in the "wisdom" documents, may be traced the slow ethical acquirements gained in the long process from the nomadic pastoral life of the early border tribes to the commercial trading life of the diaspora. The virtues of a gracious primitive hospitality and the shrewd thrift of a later commercial period jostle one another in the latest writings of the Greek period. ${ }^{2}$ The nation became, in part at least, a trading community. Tradition ascribed the transition period to the reign of Solomon, but the semi-nomadic "shepherds," like Amos of Tekoa, who

\footnotetext{
${ }^{1}$ Micah $6:$ I-8; Amos $5:$ I-27; Ezekiel $18:$ I-9.

${ }^{2}$ Proverbs $3: 27$ and $22: 7$.
} 
travelled up and down the trade routes with their flocks and herds, may have long before Solomon's traditional date become Oriental merchants as one still sees them in the bazaars of Cairo and Constantinople.

In the valleys of Palestine there persisted memories of all the economic stages through which the tribes of Israel passed. Shepherds watched their flocks and drove them from pasture to pasture as in the days of Jacob and Abraham. The vine dresser and small peasant farmers clustered about the foothills and made the richer soil of the valley yield up its fruit. The fisherman plied his trade on the inland lakes, while a more prosperous "diaspora" bound together Rome, Alexandria, and the cities of Asia Minor in an elaborate and most profitable system of money exchange.

The impress of all these economic phases is upon the religion and morals of that Judaism whose chief records are the canonical books.

Prophetism.-The Ethics of Prophetism in the seventh and eighth centuries before Christ mark the turning-point in the history of Israel. Material prosperity seems to have come in the life of the northern kingdom. ${ }^{1}$ Probably the developed trade routes and the relative safety of both northern and southern kingdoms as vassal states, playing off Egypt against the great rising northern powers, gave commerce and industry large rewards. Luxury became rife. Now to the stern, hardy seminomadic prophetism of the desert, represented by such faithful followers of Jehovah, or Jahwe, as Amos, the shepherd-merchant, this self-indulgence, and conformity to the religious cults of more advanced peoples amidst the pleasure-seeking of the town was a direct betrayal of the national God. If criticism be right in its conjectural excisions, ${ }^{2}$ the message of the older prophets was almost wholly a demand to return to the relative simplicity of

\footnotetext{
${ }^{1}$ Amos 6 : I-6; Hosea I $2: 7-8$.

${ }^{2} \mathrm{Cf}$. articles in "Encyclopædia Biblica" (Cheyne) and in Hastings's "Bible Dictionary," on Amos, Micah, Hosea, and Isaiah.
} 
the older semi-nomadic period. The virtues praised and the vices denounced are those in the foreground of a relatively simple pastoral life. The new trading life, with its oppression of the debtor class, its private ownership of land and speculation in its increasing values, its violence and robbery under legal forms, with corruption of courts and perversion of justice, seemed to the nomad shepherd utterly abhorrent and destructive. As he sweeps the political horizon, made familiar to him, no doubt, as he travelled with his flocks and herds from north to south and south to north, he sees Damascus, Gaza, Ammon, and Moab judged for cruelty, slave-hunting, slaughter of women and children, sacrilege, and commercial greed; and realizes that these are more and more becoming the sins of the Hebrew tribes as they fall heirs to the life of the valleys.

The remedy, however, is only a return to the simpler life. Moreover, the semi-nomadic prophetism never could evolve elaborate stated places of worship or complicated sacrificial ritual. ${ }^{1} \quad$ The emphasis was put upon the strong righteousness of Jahwe, the firm protection of the poor and the oppressed. ${ }^{2}$ Commercial competition is the great destroyer of tribal and family bonds built up on the simple communism of the family group. Amos therefore fiercely denounces what, to him, was destructive of all the values he set store by.

The negative denunciatory message of Amos is, however, supplemented by the utterances of the priestly Hosea, whose view of life is softer and more constructive. Jahwe is pictured as the forgiving husband, and one of the most fruitful religioethical conceptions of history is thus introduced. The relations of the nation to God as the Father of the nation is further expanded in the Isaian anthology, for Jahwe is thought of as at least the prospective Father of all nations. ${ }^{3}$ The prophetic conception of righteousness is high, and the communal life is the proper field for the moral man to prove his loyalty to Jahwe. The ritual elements are not wholly ignored, but they are distinctly put in the secondary place." And "to do justly and love

\footnotetext{
${ }^{1}$ Amos $5: 21-27 . \quad{ }^{2}$ Amos $8:$ I-10. 'Isaiah $56: 1-8$. 'Micah $6: 8$.
} 
mercy and to walk humbly with God" forms the ethical content of loyalty to Jahwe.

Moreover, Jahwe is a redeeming God ${ }^{1}$ and to become the Redeemer of the whole earth. ${ }^{2}$ This redemption is ethical in character. ${ }^{3}$ God is the one God of righteousness and other gods are either nothing or are evil. To worship them is the sin of adultery, for the relationship between Jahwe and his people is thought of again in terms of the marriage relationship. This involved a constant idealization of the "covenant" between God and his people. Even the legal elements that inhere in the conception of a covenant are swallowed up in the deeper thought of love as the very being of that covenant, and mutual loyalty as its chiefest crown. Thus the foundation was laid for a fairer ethical temple. The prophetic movement had, naturally, various levels, and its upward movement was not a steady onward progress. The prophets of the second temple period (Haggai and Zechariah, about $5^{2 I}$ ) are far more concerned with the outward and visible signs of the nation's allegiance than with the inner quality of the service. Nor are we to define too sharply the prophetic movement. It stretched from the eighth century up to John the Baptist, in various degrees protesting against types of declension and disloyalty, and in various ways proclaiming a return to an idealized simple worship of Jahwe, often linked with longings for the old nomadism (Essenes, John the Baptist in the wilderness), and identifying its ideals with a past impossible to recall. But the glory of Israel is its prophetism; from the early prophets of action (Elijah, Nahum, Micah) who left no writing, to John the Baptist, a long succession of noble spirits strove for a splendid ethical monotheism and a theocratic democracy. Other and weaker elements mingled with this teaching, but these things alone lift the prophetic writings and services of Old Testament history up amid God's providential care of the race as his chiefest gifts to our ethical and religious life.

${ }^{1}$ Micah $6: 4$.

${ }^{2}$ Isaian anthology.

${ }^{3}$ Isaiah $62:$ I-5 and many passages. 
The Early and Later Priestly Development.-As prophetism bore to the end the marks of its nomadic origin, so both the early and later priestly developments reveal constantly their close connection with sacred places which grew in stability and importance as the population became greater and more settled. That this transition period from nomadism to semi-agrarian conditions has always been linked with a great leader and law-giver called Moses is a presumption in favor of his historical character, although with the present data we may despair of defining exactly either his real place in the history or even of meeting all the objections and difficulties critical study has suggested. Yet it seems impossible not to believe that the whole period was dominated by one of those great constructive minds whose memory remains as a priceless treasure to his nation and the world.

It is impossible to separate clearly the priestly elements of Israel's history from the prophetic. Yet the emphasis was so different that, from time to time, the ideals did sharply conflict. Nor was the priesthood any more at constant peace with the growing monarchy than prophetism. At the same time they had more in common with each other. Prophetism was not in its nature institutional; both the monarchy and the priesthood were. Prophetism was essentially radical, and even under the guise of a return to primitive piety it was essentially an unfolding of new and higher ethical ideals. Neither a monarchy nor a priesthood can escape conservatism. Indeed that is for both a large part of their social function. Prophetism was often critical and denunciatory to the point of destructiveness. The prophets' words were "too heavy, the land could not bear them." The monarchy and priesthood stood for things as they substantially were, and wished only to purge the nation from the grosser sins.

The legal development has an exceedingly early origin. The first "ten words" (Exodus 34) have already agricultural additions to what was possibly in the beginning a purely pastoral 
and nomadic code, ${ }^{1}$ and the association of the name of Moses with the earliest codes as well as the carrying on of the codification by legal fiction in his name points to a beginning of a written law when first the people began to settle down about sacred places like Bethel and Gilgal and to make them centres of political life.

The legal development as such does not rise to very great ethical heights. The recently discovered code of Hammurabi reflects a more homogeneous social condition and a more consistent legal aim. The old primitive lex talionis was firmly imbedded and never overcome. Polygamy and divorce were contemplated as constant social factors. Slavery is retained, but in a merciful form, and the ceremonial and external forms are hopelessly mingled with the moral and the inward. Even gross superstitions (Leviticus $16: 8$-10) are sanctioned, and through-

${ }^{1}$ Exodus $34: 14^{-28}$.

Make no covenant with the inhabitants of the land.

Thou shalt worship no other Gods. II

III

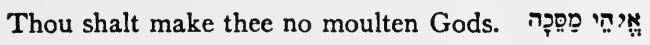

IV

Thou shalt keep the feast of unleavened bread.

All the first-born are mine.

v

VI

All the first-born of thy sons shalt thou redeem.

VII

On the seventh day thou shalt rest.

VIII

Three times a year thou shalt appear before Jahwe.

IX

Thou shalt not offer the blood with unleavened bread.

$\mathrm{X}$

Thou shalt not seethe a kid in its mother's milk.

[This is simply leaving out the agricultural words, some of which seem on their face to be later additions.] 
out a utilitarian and superficial view of the nature of rewards and punishments appears. The whole ethics ranges within the present life, and even threatens that life by its mass of minute regulation, some of which had once sanitary justification but much of which had become merely meaningless routine.

Yet, making all these concessions, it must be recognized that it was a great step forward when the rude and often fanatical nomad entered upon an ordered social state with its own legal character. It is at least open to question whether the legislation in its final form was ever more than a priestly dream and ideal born during the later exilic days; but whether this be so or not, the evidences multiply that the laws of Leviticus were never the actual working laws of a Jewish state. They bore the marks of an increasingly centralized worship and a narrowing life. Yet while this is true, at the same time really lofty conceptions of Jahwe as a righteous God are never absent. Law conserves and crystallizes the ethical gains of communal experience and aids in carrying them over into new social organizations. An examination of the primitive Hebrew law-giving reveals the tribal communism in which the care of the poor and feeble is as natural as the care of members of a family one of the other. The commercial trading spirit was endangering, evidently, this community of feeling (Micah and early Isaiah), and the legal development faithfully attempted to stem this tide. The forbidding of all interest in such a social state was, of course, impossible of exact enforcement; but it was attempted, and the laws of mortgage and debt collection, if unpractical and unenforceable in a trading community, yet showed the survival of ideals borrowed from the past.

In one important respect the Torah began to have deep ethical significance. Amid a corrupt and corrupting civilization settled the little bands of pious Jews, who came trickling back from Babylon and Egypt that they might once more worship Jahwe on the sacred soil. To guard themselves and their children from the depravity and vice of the mixed populations amid which they lived, the "Holy Community" fenced the life of the 
individual and family by ceremonial regulations resulting in, and intended to result in, the isolation and seclusion of the religious Jew. That this later priestly development was a hardening and formalizing process none can deny, but it is equally impossible to blind ourselves to the fact that the process alone, so far as we can see, saved for us the Old Testament writings, and a community built upon the foundation of ethical monotheism. Far from thinking of the Jew as naturally exclusive and prone to separation, the tendency seems to have been altogether on the other side. Only the severest ceremonial discipline and the most fanatical faith could save the Jew to his mission as he became a trader and a wanderer upon the face of the earth. The ethical significance of this ceremonial exclusiveness was simply tremendous. It resulted in a constant sifting process. Thousands of Jews in all ages have rationalized their faith and have as promptly been lost to Judaism. From the Christian point of view this may not be a great misfortune now, it would have been a world-calamity if the Jewish community as such had thus been lost, as the northern kingdom was lost, before its achievements on the religious and ethical fields had become the property of humanity. The preservation of these ethical conquests are not due to the nation as such, but to the Holy Community, the "Brotherhood of the Synagogue," whose faith and zeal kept the Torah from being lost amid the wrecks of the national life, as the waves of Assyrian, Neo-Babylonian, Persian, and Greek conquest overflowed the world. This Brotherhood of the Synagogue kept its character only by the increasing attention to the externals of the legal system. How really dear that law became to the devout heart may be seen in the Irgth Psalm and the hymns of the second temple. Its significance as the only real preservative of the faith and morals of the community was an experience to which generation after generation of scribes could bear their witness. The ethics of the priestly set of documents, like its theology, is abstract and stiff, legal and external. The way of thinking is hard and narrow, yet it is exceedingly doubtful whether we would know 
anything about a prophetic ethics had it not been conserved for us in the midst of this very legalism.

The Deuteronomic Synthesis. - The prophetic and priestly emphasis were happily never wholly separated, and early in the history of the nation arose a school of legal interpretation seeking to combine the ethical and religious quality of propheticism while conserving the Mosaic ceremonial and the ritual devoutly believed to have had its origin at Sinai. The lofty ethical and religious character of the Deuteronomic writers ${ }^{1}$ is seen not only in the book from which is taken the name for the school, but also in the prophetic interpretation of the history. The priestly interpretation overemphasizes the element of ritual correctness, the Deuteronomic writers find the essence of the relationship between God and his people in the loving righteousness which constitutes God's character (Deut. I I : I326 and many other passages). The monotheism is exclusive and even stern (Deut. I2 : 2-4), the ritual demands are heavy and exacting, the place of ceremonial is large and burdensome, yet the emphasis is not on these things. These regulations, in fact, fit naturally into the life of obedience to moral regulation and religious exaltation.

This type of thinking must not be confined to one revival period under Josiah. It is to be found all down the history, and the teachings of Jesus may be called the natural flowering of this synthetic process. The theme of the Deuteronomic school is the loving redemption of Jahwe, and the literature breathes the atmosphere of confident faith, even while it threatens wrongdoing and scourges all declension from the national religion. The appeal is throughout to Moses as the great prophet as well as law-giver, and the separation in the tradition between Moses the prophet and Aaron the priest gives great force to the ethical interpretation of the ritual law. The national significance of a pure worship and a high morality form the constant burden of the Deuteronomic school (Deut. 32: I-43; Judges $2:$ II-23;

${ }^{1}$ Among these are to be counted editors of historic books as Judges, Samuel, and Kings. 
and many other passages). With the priestly writers these Deuteronomic writers see in the following after "strange" gods a principal cause of Israel's discomfiture.

A centralized worship and elaborate sacrificial life is, moreover, equally with the priestly interpretation of the history, thrown back into a time when we see from the documents the school has itself preserved for us that the worship was scattered among many "high places" without any sense of wrong-doing on the part of the most developed religious life, and when every head of a family was by that fact a priest and offered sacrifices freely. ${ }^{1}$ Happily the older traditions were already regarded as sacred, and seem little altered, and the school of writers in the Deuteronomic spirit content themselves with homiletic and ethical interpretation. These ethical advances are constantly along the line of spiritualized worship and social righteousness and humanity.

The ethics are sometimes crudely eudæmonistic, but the eudæmonism is of national character and therefore of a far loftier type than sometimes appears in the lower ranges of the nation's thought. Jahwe is always represented in the twofold aspect as a loving redeemer to a faithful and repentant Israel, and a stern judge and avenger when Israel wanders from the path of true worship and moral purity. Indeed the highest rhetoric of the school is expended in enforcing these two conceptions (Deut. 27 and 28, etc., etc.), and the picture of God as a God of vital righteousness and loving grace is of epoch-making beauty in the religious literature of the world.

NotE.-Literary criticism has not finished the work of historical analysis, and many positions now accepted generally may yet be given up; but one point has been gained for all schools and for all time. We see in the Old Testament the gradual revelation of God in the midst of human conditions, and realize that the revelation is constantly conditioned by the human life in which God reveals himself. The difficulty of exact historical

${ }^{1}$ Judges $6: \mathrm{I} 1-22$, etc., etc. 
reconstruction may be admitted. Many most attractive hypotheses-may yet have to be altered or rejected. A reasonable agnosticism is a wholesome historical grace. It may be quite vain to attempt, for instance, to separate Isaiah into a first, a second, and a third writer, because probably we are dealing with the songs of a special religious and literary movement, with a common inspiration, but extending over a long period of time from the monarchy of Hezekiah to the joyful return of little bands of wanderers under Persian protection. So also the Deuteronomic "writer" is more likely a particular school of thought, again having a distinct historic origin in the religious movement of Josiah's time, but extending its literary activity, particularly its editorial work, far down into the exilic period. The sharp lines of the fashionable reconstruction may have to be softened, but the main outlines are fairly assured, and for religious and practical purposes we have now an outline of the Old Testament history far more fruitful than the impossible traditional and uncritical misunderstanding. It remains as a thing greatly to be desired that the devotional literature of the Old Testament, especially the Psalms, be made to give up their contribution to the wonderful ethical advances of the "Brotherhood of the Synagogue" from which that literature, no doubt, sprang.

The Contribution of Hellenized Judaism.-The power of the Jew to assimilate and be assimilated is generally underestimated because of the exclusive character of those who resist the process. Thousands of Jews must have been lost amid the civilization of Babylon. Egypt swallowed up, no doubt, many more, and all down history the capacity of the Jew for adaptation to foreign life and foreign thought has been just as remarkable as the persistence of that minority which conserves the exclusive life and thought. The Jew no more succeeded in withstanding the influence of Greek culture than he has withstood the various types of European culture. Educated Judaism evidently sought to withstand the inroads of foreign thought by interpreta- 
tions in the spirit of ethical monotheism of the materials given from without. Thus both the priestly and the prophetic cosmogonies may best be understood as an apologetic reinterpretation of a Babylonian or some older cosmogony which had in it and behind it the dangers of an attractive but religiously destructive polytheism.

So also the literary activity of Judaism flung itself upon the reproduction of a history that would inspire the world with respect, and properly represent their ideals to the nations. Along exactly this line we have the "wisdom literature" and the works of Philo and Josephus. The moment we comprehend the aims of Philo and Josephus we see that in their day and in their own way they were trying honestly and sincerely to do what the priestly and prophetic writers had done in their time. There is no need to suppose intentional twisting or accommodation on the part of any of the writers, at the same time the trustworthy character of the history and the philosophical interpretation is effected by the undoubted attitude of special pleading.

From the time of the Exile on we have a distinct ethical development which culminates in the New Testament. In that process all stages of resistance to foreign ideals and all kinds of skilful compromise may be traced. From Persia came the development of a crude dualism. Satan relieved Jahwe, as Wellhausen remarks, of many of the unethical characteristics still clinging to the old desert war-god. At the same time the monism of Judaism was too firmly rooted to give way wholly to dualism. The Exile had indeed raised many questions which the teachers of the period of the second temple had failed to answer. Dualism was a simple answer to some of these doubts, but it, too, seriously challenged the fundamental faith of the Holy Community to be really accepted in all its consequences.

The most serious question that pressed for an answer was, "Why do the righteous suffer?" This doubt could no longer be ignored, and the ethical thought in the canonical books of this period largely centres about various answers to this searching 
question. Of course from the priestly and organization point of view the obvious although superficial answer was that a temple to Jahwe had not yet been built and that the ritual obligations had never yet been fully met (Zechariah, Haggai). The most serious and thorough discussion was that of Job. In its original form, however, the conclusion was too agnostic and unsatisfactory for the average mind, and so we have the closing chapter and perhaps the speeches of Elihu added as a contribution to the solution of the problem.

The most hopeful and religiously influential answer was that of the closing period of the anthology of Isaiah, where the final purpose of all suffering is found in the glory of a new heaven and new earth wherein dwelleth righteousness.

In none of the answers does a future life play a large part. But in Isaiah, as in Daniel, there dawns the hope of a new era, in which all religious and ethical aspirations will be met and satisfied by the revelation of Jahwe in a community of peace and happiness. In this new communal life all the awful doubts and difficulties raised by the failures and sufferings of the Holy Community were to be set at rest forever.

The firmer and higher the faith in Jahwe was, by so much greater and more terrible seemed the desertion of the little company of the faithful. The tragedy of the situation was in the fact that Jahwe was not only thought of as almighty ruler, but as loving father. ${ }^{1}$ A merely almighty ruler could do what he liked. But a loving father in covenant relation with his children cannot be unethical. And even though the conception of fatherhood is oriental, and hence deeply tinged by despotism, ${ }^{2}$ nevertheless the relationship is not simply that of creator and creation, but of love and affection.

Hence it happened that the more loving and intimate the relation between Jahwe and Israel was conceived of as existing, by so much the more was the poor heart of the faithful follower torn; and the stranger and more inexplicable becomes the oppression and the defeat of the chosen child.

${ }^{1}$ Isaiah $63: 16 ; 64: 8$. Jeremiah $31: 9$.

${ }^{2}$ Isaiah $64: 8$. 
The vision of a redemption was thus more and more thrust into the foreground. It was no new thought. The traditions of a flight from Egypt still haunted the imaginations of Israel. The redemption was to come in catastrophic world-changes. The fall of Babylon, and wreck of the Persian supremacy were basal images upon which the Jewish apocalyptical literature fastened, and in Daniel, the Book of Enoch, etc., we have the developed solution of the nation's pain in great judgments and future deliverances so dramatic and so overwhelming that room for doubt as regards either the power or the righteousness of Jahwe could have no place.

Yet this solution could not meet all needs. The rather crude ethics of this literature and its failure along the lines of any unifying philosophy gave rise to a rationalization more thoroughgoing. The "wisdom" of the later Jewish writings was the starting-point. The method of procedure was, however, to remove God as such from the scene of the temporary trial and disaster, and to fill up the place thus made vacant by lesser and intermediary beings. Thus Philo and the Alexandrian Jews translated Plato's teaching. Wisdom becomes the Logos mediating in creation and providence between a transcendent God and the created world. Man is sharply divided into body and soul, and the metaphysical dualism of Platonic thought is religiously developed and exploited. Into Philo's synthesis come all the elements of world-flight, contemplative life, ${ }^{1}$ despondency, a doctrine of a final judgment and exaltation of the transcendent which mark Plato's later period. ${ }^{2}$ Combined with this is the distinctly Jewish hope of a great consummation and a final vision of God. This is reached not by asceticism, but in prophetic ecstasy.

The final form of government is the theocratic democracy borrowed from the Old Testament prophets. ${ }^{3}$ The main emphasis is upon God as the final good and knowledge of God as

${ }^{1}$ This quite apart from the writing which can scarcely be defended as by Philo: "De vita contemplativa." Cf. "Legis Allegor," II, § I8.

${ }^{2}$ Contra Ziegler.

${ }^{3}$ Not from Stoics as Zeller argues. 
the goal of all life. Philo uses many phrases in an Old Testament sense, which he has borrowed from Greek philosophy, but which lead to misinterpretation of Philo, if his Jewish use of them is forgotten. His ethics is distinctly Hebrew rather than Greek, democratic rather than aristocratic, and this in spite of the hierarchy which he took over from the Platonic speculation.

Note.-In the somewhat dreary rationalization of the Old Testament by Philo some things stand out clearly as characteristic probably of Judaism over wide sweeps, and not especially Alexandrian. First the real aim is to express Judaism in Greek phrases rather than to hellenize Judaism. Secondly, the chief interest always remains religious and ethical. Thirdly, the dominant character of certain Greek positions made it seem inevitable to find some harmony if the Old Testament was to be still retained. Hence, just as misguided Christian apologetics has always attempted to make the Old Testament teach the latest lesson of science, so the Jewish apologist rewrote his history to conform to what seemed assured historical data. As Josephus in the time of Roman supremacy, or the prophetic historian in the time of Babylonian ascendancy, so the Jewish philosopher Philo in Alexandria sought in the day of Greek philosophical dominance to rewrite his nation's wisdom in the language of the day. ${ }^{1}$

'Side lights on this process may be gained in R. H. Charles's admirable "Critical History of the Doctrine of the Future Life in Israel, in Judaism, and in Christianity." The Jowett Lectures, I898-1899. Cf. also Professor Deissmann's "Licht vom Osten," already mentioned. 


\section{CHAPTER II}

\section{NEW TESTAMENT ETHICS}

Introduction.-I. The Ethics of Jesus-II. The Ethics of Paul-III. The Johannine Interpretation-IV. The Ethics of the other Canonical Writers: Hebrews; James; The Revelation to John; The Ecclesiastical Literature.

\section{INTRODUCTION}

The unity of life is a postulate of our faith, but its understanding demands our breaking it up into many elements and viewing it from many standing places. The canonical interpretations of Jesus cannot be forced into any mechanical and absolute harmony, and to rightly weigh the ethical teachings of the canonical books we must reckon with the distinct differences in interest and outlook on the world manifest to the candid student of the New Testament writings.

Jesus has become historically the central figure ${ }^{1}$ in the struggle of humanity upward to the redeemed life. The "Christian Era" has become the important factor in the life-history of India, China, Japan, and the far-off island-continents then unknown.

${ }^{1}$ The critical question as to the historical character of Jesus and Paul has produced a large literature. After a survey of its arguments the writer is more convinced than ever of the historicity of Jesus and Paul, but for the ethical student it is sufficient to say that no single fact is indispensable to the ideal which has power over us. The main works on the negative side are: Robertson, John M.: "Pagan Christs" (studies in comparative hierology), London, I 903; Robertson, John M.: "Christianity and Mythology, London, I900; Drews, Arthur: "Die Christus mythe," Jena, I909; Burnouf, Emile: "La Science des Religions," 4th ed., I 885 (English translation by J. Liebe, London, I888); Kalthoff, A.: "Das Christus-Problem," 2d ed., Leipsic, 1903; Kalthoff, A.: "Was wissen wir von Jesus?" Berlin, 1904; Smith, Wm. B.: "Der vorchristliche Jesus," Giessen, I906; Jensen, P.: "Moses, Jesus, Paulus, drei Varianten des babylonischen Gottmenschen Gilgamesch," Frankfort-on-Main, 1909. 
This place in history no theological changes, no readjustment of values can now disturb. Whatever civilizations may come after ours, they can only come on the basis of that which rose on the wrecks of Grecian culture and Roman imperialism. The churchly reconstruction of life, the Christianized barbarism of the north, the entire reinterpretation of the ideals of existence, date from the life, death, and teachings of a lonely figure whose scattered phrases are given us in the pages of the New Testament. What were the ethics of Jesus, is a serious question. In various degrees the interpretations of those teachings drift apart from one another and from the original central instruction.

The world-forces that culminate in the churchly society of the Middle Ages may be variously estimated and judged. For some the light went out when the cross rose above the palaces of Rome and Constantinople. But all must admit that the triumph of that cross was the outcome of the profound impression made in the midst of men by a Jewish peasant workman in the course of a public life extending over hardly more than three years at the most. The reasons for the rapid rise of the churchly society that called itself Christian do not belong here; we have, however, to enter upon the work of discovering the ideals and hopes which, centring about Jesus, gave us the canonical books, the ecclesiastical societies east and west, and the modern civilization we call by courtesy Christian.

\section{THE ETHICS OF JESUS}

Our one interest is to ask the question: What was the organizing ethical ideal of Jesus, as a man, working, struggling, and teaching? What did he actually proclaim as the ethical ideal upon which he would have men organize all life?

Literature.-Briggs, Charles A.: "The Ethical Teaching of Jesus"; New York, 1904.-Weiss, Bernhard: "Lehrbuch der biblischen Theologie"; Berlin, 7 th ed., I903; translation of 3 d ed., Edinburgh, 1882; 2 vols.-Wette, Wilhelm M. de: "Biblische Dogmatik des Alt, und Neuen Testaments"; 3d ed.; Berlin, 1831.-Neander, Augustus: "Geschichte der Pflanzung und Leitung der christlichen Kirche durch die Apostel"; 5th ed.; 1862; translated by J. S. 
We have not now to do with the unfolding of these ideals, however legitimate such inferential unfolding may be, either in any personal interpretation of Jesus or in historical Christianity. With the outcome of his teaching, however inevitable, we are not immediately concerned. We wish simply to know, what did Jesus the Galilean rabbi teach as the ethical foundation of human life?

At the very beginning of our inquiry we must remember the distinctly Jewish character of all we know of Jesus Christ. The Jewish mind dealt with concrete problems and with things here on earth. The dualism of good and evil was forced upon him. But his faith in God compelled him to believe that that dualism was only temporary. God was sure to at last disclose himself as not only triumphant over all evil, but as ruler of this world and all its fortunes.

Ryland, revised by Edw. Robinson, New York, I865.-Toy, C. H.: “Judaism and Christianity"; Boston, I890.-Rogge, Christian: "Der irdische Besitz im neuen Testament"; Göttingen, 1897.-Cone, Orello: "Rich and Poor in the New Testament"; New York, 1902.-Stevens, G. B.: "The Theology of the New Testament"; New York, 1899 (International Theological Library).Beyschlag, W.: "Neutestamentliche Theologie"; 2d ed.; Halle, 1896; 2 vols.; also an English translation by Neil Buchanan, New York, 2d ed., I395; in 2 vols.-Holtzmann, H. J.: "Lehrbuch der neutestamentlichen Tneologie"; Freiburg, I897; 2 vols.-Pfleiderer, Otto: "Das Urchristentum, seine Schriften und Lehren"; 2d ed.; Berlin, 1902.-Wernle, Paul: "Die Anfänge unserer Religion"; 2d ed.; Tübingen, I904; also an English translation by G. A. Bienemann, New York; Putnam, 1903-1904; in 2 vols.-Gould, E. P.: "The Biblical Theology of the New Testament"; New York, rgoo.-Wendt, H. H.: "Die Lehre Jesu"; 2d ed.; Göttingen, rgor; also an English translation by John Wilson, New York, 1892; 2 vols.-Mathews, Shailer: "The Social Teaching of Jesus"; New York, 1897.-Peabody, F. G.: "Jesus Christ and the Social Question"; New York, rgor.-Weiss, Johannes: "Die Predigt Jesu vom Reich Gottes"; 2d ed.; Göttingen, r900.-Lütgert, W.: “Das Reich Gottes nach den synoptischen Evangelien"; Gütersloh, r895.-Bousset, W.: "Jesu Predigt in ihrem Gegensatz zum Judentum"; Göttingen, I892.Jülicher, Adolf: "Die Gleichnisreden Jesu"; Tübingen, I899; 2 vols.Weinel, H.: "Die Gleichnisse Jesu"; 2d ed.; Leipsic, r904.-Jacoby, Her_ mann: "Neutestamentliche Ethik"; Konigsberg, I899.-Weiss, Johannes: "The Ethics of Jesus in Hastings's Bible Dictionary of Christ and the Gospels"; New York and Edinburgh, 1906; vol. I.; pp. 543-547.-Rau, Albrecht: "Die Ethik Jesu"; Giessen, I899. 
Later interpretations of Jesus introduce elements we must gravely suspect as foreign to the thought and world of Jesus. We want to know simply and solely, so far as our materials enable us to know it, what did Jesus himself believe and teach?

In consequence of our aim we must exclude the interpretation of Jesus by Paul. Without in the least questioning the high value of this interpretation, or in any way doubting that it is a legitimate development of the spiritual meaning of Jesus for human life, we must clearly understand that Paul did not himself pretend to base his teaching on the historical Jesus. For him the risen Christ and a living present revelation formed the foundation of his "gospel." Even if all the sayings gathered by Resch from Paul's writing as possible fragments of the teachings of Jesus are to be so considered, the ethical significance of actual quotations from the words of Jesus remains small and inconsiderable. ${ }^{1}$

In like manner we must exclude the Fourth Gospel. It also is a wonderful interpretation of the heart and spirit of Jesus. Yet at the present state of our scholarship it is quite impossible to separate finally between the elements that embody objective accounts of Jesus as teacher and worker and the subjective elements so prominent in the discourses. We may believe in many such elements. Even the history of the synoptic Gospels may have to be corrected from pages of the Fourth Gospel, ${ }^{2}$ yet it would be both uncandid and unwise to treat the Fourth Gospel as a whole as though it were an objective history of the life and sayings of Jesus. In fact its religious value is not in that direction.

We are reduced, then, to the three first Gospels. Here again elements must be treated with extreme care. Earnest and intellectually sincere scholarship can hardly now accept the "ecclesia" passages in Matthew (I6 : I8 and I8: 17 ) as undoubted

${ }^{1}$ Cf. "Agrapha," by Alfred Resch, 1889, in "Texte und Untersuchungen," vol. V, r889.

${ }^{2}$ Cf. "Das Johannes Evangelium," H. H. Wendt, Göttingen, I900, pp. 45, 233 . 
reports of the words of Jesus. The best working hypothesis proposed as a solution of the synoptic problem accepts as a basis two documents, one of which is Mark almost as we have the Gospel, and the other a collection of "sayings" of Jesus. Luke and Matthew have woven these two together, mingling, however, material peculiar to themselves, and rearranging the "sayings," although keeping the order of Mark almost exactly. The additions of Matthew and Luke must then be treated cautiously, and upon the narrative of Mark, and the "sayings" as found in both Matthew and Luke, we must be content to base our first impression of Jesus as an ethical teacher. Side lights we may gain from later sources. The interpretation of Jesus of every age has had its own peculiar religious value; at the same time objective historical study cannot afford to confuse its conclusions with such interpretations no matter how valuable or how sound.

In order to measure Jesus as an ethical teacher and to grasp surely the organized ideals that underlay his ethics, we must form some idea of the environment in which he taught and the style of his teaching. Although literary Rabbinism is for the most part much later than Jesus, ${ }^{1}$ yet Rabbinism as a system of religious instruction and as a religious tendency existed long before him. Just as the Platonic ethics were profoundly influenced by the opposition to the Sophists, so the ethics of Jesus grew up in opposition to and yet deeply influenced by the Rabbinical ideals.

The style of Jesus bears witness to the influence upon him of the eschatological teaching of his day. Yet deeper still was the influence of the literature, sacred in the eyes of his religious world, in which he found an ethical basis for his opposition to the legalism and formality under which the religious and ethical life of his time groaned. The ethical precepts of that literature

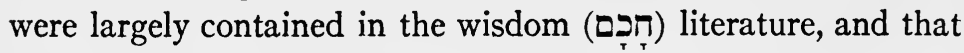
type of ethical teaching finds its place in the original sayings of Jesus. We possess, it is true, only Greek renderings of the

${ }^{1} C f$. Ency. Brit., American Reprint, art. "Mishnah," XVI, 527. 
northern Galilean dialect in which Jesus probably spoke and taught. But it requires only a little care and attention to mark under the Greek dress the literary character of the original saying. Now no one in ordinary life would interpret poetry and proverb by the same rules we apply in the construction of legal documents or philosophical lore. Instinctively we are guided by the style of the saying to the method of its interpretation. The same thing is true of the teachings of Jesus. We must pass on the character of the particular saying, and in our interpretation we must be guided by the feeling for the literary class to which it belongs.

Three great literary types influenced deeply the thought and style of Jesus. The exalted religious style of the prophetical poetry finds frequent reflection in his longer sayings; the somewhat artificial epigram of the wisdom literature has also its counterpart; and the eschatological dreaming and vivid word painting of the latter Jewish period has its corresponding imagery in his latter work. ${ }^{1}$

In considering, then, the ethical scheme of Jesus, we must take into consideration the purpose and inspiration of each saying. It is of great importance to discover how far he was deliberately standing upon the ethical ground he found prepared in the past history of his people, and how far he was transcending or consciously opposing the conclusions of his religious and ethical environment.

Jesus' ethics, like the ethics of Spinoza, was intensely "Godconscious." When he uses the term "Abba" he implies no such distinction as the Greek gives us between "Our" father and "my" father; this is reflected in Luke's version of the Lord's Prayer. ${ }^{2}$ For him God was all in all and absolutely sovereign. ${ }^{3}$ The heaven is his throne, the earth his foot-stool; he marks the sparrow's fall ${ }^{4}$ and numbers the hairs on our head; he clothes the lily of the field, ${ }^{6}$ and his will was to be done on earth

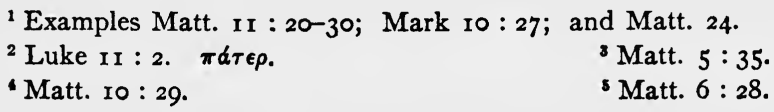


as completely as it is thought of being done in heaven. ${ }^{1}$ Unity with the purpose of God rather than love to God is the basis of the thought of Jesus. In the original Mark Gospel the only mention of love to God is in a quotation from Deuteronomy. ${ }^{2}$ This impression of Jesus' teaching is well represented in the late literature, as in the prayer of Jesus in the $I 7$ th of John. The ethical ideal of Jesus was "to do the will of God." 3 To love God was self-understood. The impression made by the original teaching of Jesus is that ethics was thelemic (to coin a much-needed word

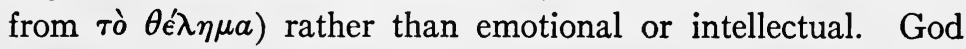
was accepted as intellectually apprehended. Love to God proceeded from right relation to him, rather than forming the basis for those relations. The basis of life and the world was the will of God. He who worked with this will had all things made possible to him. ${ }^{4}$ Faith was this acceptance of God and his will as the ultimate basis of all life. Later Greek speculation sought to interpret this ethical sense of unity with God into a unique metaphysical relationship. Perhaps the beginning of the process is seen in the Fourth Gospel, but it certainly is not justified by Jesus' own words, nor does the essentially Jewish thinking of Paul give it any foundation. The consciousness of a unique relationship to God was ethical and not metaphysical. ${ }^{5}$ As the later Gospel put it: "His meat and drink was to do the will of him that sent him and to finish his work." 6

Moreover, the conception of this divine will was spiritual as well as ethical. The differentiation of God as an ethical God from the conceptions of him as simply a triumphant national war-hero had gone far during the captivity and in the later prophetic literature of the Old Testament. At the same time, the popular mind had no more grasped the difference then than it has now; and even the religious world of Jesus' time was caught in lower and false notions of the national relationship to Jahwe. ${ }^{7}$ Jesus carried on the work of the later prophets in

\footnotetext{
${ }^{1}$ Matt. $6:$ Io.

'Mark II : 22-24.

${ }^{2}$ Mark I $2: 30$.

3 Mark $3: 35$.

5 Mark 12 : $1-9$.

- John $4: 34$.

${ }^{7}$ Cf. John the Baptist's message, Matt. 3:9, where these notions are condemned.
} 
emphasizing the ethical rather than the national relationship to God. But he went further than the prophets in making this the sole basis of relationship. ${ }^{1}$

As Schultz points out: ${ }^{2}$ "That in the olden days more value was placed upon the blameless carrying out of the religious popular customs; and that the prophets on this account had unwearyingly to emphasize the fact that the great principles of morality formed the fundamentals of righteousness, we see in all the older prophets." Yet even in the prophets the basis of any possible morality was the fulfilment of ritual requirements; just as to-day many fairly intellectual Protestants cannot think any man a really "good" or "godly" man who does not keep one day in the week for observances they prize, or who cannot repeat "formulæ" they think ritually necessary. The failure is, of course, in the conception of God as ethical. Jesus had so completely seen God as ethical that for him ritual requirement took its normal place as expedient and helpful, or hurtful and a hindrance in accordance with the changing requirements of man's life. ${ }^{3}$

The vast ethical advance thus described was due to Jesus' conception of the kind of righteousness God required and the character of the holiness ascribed to God. The perfection of God $^{4}$ is not based on simple power, but upon an essential righteousness. Jesus drew the logical ethical consequence of the vision of God as given in Exodus 34:6 and developed more fully by the Deuteronomist; but in doing so realized that attachment to custom and ritual was accidental and not essential. His saying, "Destroy the temple and in three days I will build it again," was naturally misunderstood by even his friends. He expressed there his sense of the true relationship between the inward and the outward. For him the temple was but an out-

${ }^{1}$ Matt. $5: 20 ; 7: 21-22$.

2 "Alttestamentliche Theologie," XXI, p. 293, 2d ed., or English translation, vol. II, p. 923 .

${ }^{3}$ Mark $2: 25-28$, "David and show-bread and Sabbath made for man," and in Mark $7:{ }_{15}$, "That which proceedeth out of a man that defileth."

Matt. $5: 48$. 
ward expression that would in an indefinitely short period be easily rebuilt, if the essential ethical unity with God was not destroyed. It was in this sense also that he felt his presence made many otherwise perhaps useful ritual requirements, such as fasting, washing, etc., ${ }^{1}$ unnecessary for his disciples so long as he was with them.

The assumption by Jesus of an absolutely ethical God he never established by argument, nor would he have claimed for it originality. He would have, indeed did point back to Deuteronomy and the Psalms as setting it forth. What was original in his teaching was the separating that conception from national and ritual entanglements and making it the sole foundation upon which he built up his moral system.

Jesus assumed in consequence of his consciousness of God as righteousness, and as demanding from us only righteousness, the freedom and moral personality of every human being. The centurion reveals a faith not found in Israel. ${ }^{2}$ Yet the life of Jesus was too short and the material actually from his lips too scanty to assert that he either fully realized or fully exploited the logic of this position. The universalism of Luke may be as late a product as that of Paul; both are, however, legitimate outcomes of Jesus' conception of an ethical God as over against a national and unethical thought of him. The parables of Luke are certainly genuine, and that of the Good Samaritan reflects the logic that broke down so largely (for of course other elements entered into the case) the national boundaries of the proclamation of Jesus.

The definite "Good news" that Jesus proclaimed had, then, as presuppositions a sovereign ethical God in some moral relationship to man, and logically to all men. That relationship Jesus taught his disciples to describe with the term "Abba," or father. The will of God which was for Jesus the moral foundation of life, was the will of a just and kindly father. ${ }^{3}$ The

1 Mark 2 : 18; Matt. 9 : 14.

2 Luke $7: 9$.

3 Parable of Prodigal Son. Luke I 5 : I I-32; Matt. $6: 8$, "Your Father knoweth what things ye have need of "; Matt. $7:$ I I, "Ye being evil-good gifts," etc. 
fatherhood of God in relation to the nation of Israel was a fairly familiar figure, although probably the false terror before Jahwe as judge which made his name unpronounceable (יהו) also prevented the full content of even this prophetical phrase being realized. The good news that men were in personal relationship with God, independently of the nation's sins, and that personal repentance could establish relationships that even national judgments could not shake, was new religious teaching and exalted the conception of manhood at once. This teaching was in close connection with God's Kingdom as proclaimed by Jesus. What was this Kingdom?

Johannes Weiss, of Marburg, has given the most recent and the most careful answer to this important question, ${ }^{1}$ and his answer has found wide acceptance among the younger New Testament scholars. ${ }^{2}$ In accordance with Dalman's theory, he asserts that the idea of Jesus is wholly eschatological. For Jesus the reign of God is always ("stets") an eschatological quantity about which a "presence" can only be alleged in so far as it is a fact that the "end" is already in process of beginning." ${ }^{3}$ This is not the place to critically analyze the positions taken; sufficient it is to say that so far as the method of introduction of this "reign of God" 1 is concerned, this school is undoubtedly right. Although Jesus distinctly denies any knowledge of the time of the coming of the kingdom, ${ }^{5}$ he undoubtedly expected it sharply, swiftly, and with catastrophe, and as an "eschatological quantity." But it is one-sided criticism of his words to fix attention solely on the method of the Kingdom's ultimate triumph. What was the essence of the Reign of God? is the serious question. Here little light is given by the eschatological dreaming of such a literature as that to which Daniel belongs, and that side of Jesus' teaching does not concern us now at all. Happily we have abundant material at hand for

1 "Die Predigt Jesu vom Reiche Gottes," I 900.

${ }^{2}$ Cf. "Theologische Litteraturzeitung," Oct. I 2, I90I (No. 21, coll. 563-568), article by Bousset in review.

${ }^{3}$ Dalman quoted by Weiss, Joh., p. 17 of "Predigt Jesu vom Reiche Gottes"

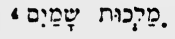

${ }^{3}$ Matt. $24: 36$. 
examination of the ethical content which Jesus ascribed to the Reign of God.

The organic basis of the teaching of Jesus was his placing of the emphasis upon the ethical factors in this Reign of God. In this he followed in the footsteps of Isaiah, Amos, and Hosea, but with greater clearness and precision and with greater powers of personal moral impression. He strongly insisted upon this religio-ethical basis for the Reign of God, and he emphasized this religio-ethical factor as a condition for the personal participation in the glories of that reign. This we see in the fundamental teachings gathered from the "sayings-collection" in what we know as the Sermon on the Mount. The arrangement of this "Sermon" is, of course, the work of Matthew, but the contents as we have them in Luke and Matthew reflect the intensely ethical conception Jesus had of the Kingdom of God. The Kingdom was thought of as coming in the apocalyptic visions of catastrophe, judgment, and change; but the nature of the Kingdom when it came was not the material triumph of Judaism, but the triumph of Righteousness. No saying is more undoubtedly that of Jesus than that of Matthew $6: 33$, "Seek ye first the

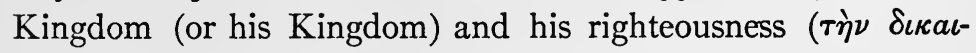

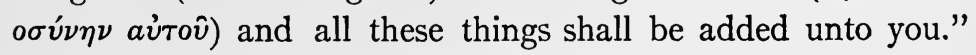

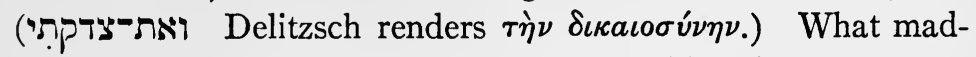
dened institutional religion, then, as it maddens it now, was to be told that the essence consisted not in a ritual or credal correctness, but in an inner ethical character which it did not then, as it does not now, fully exemplify. The bitter hostility to Jesus was aroused by the fact that he went into details, and the class of professional religious teachers felt that their influence and teaching were the objects of his attack.

That the organic basis of Jesus' proclamation was a national ethical reformation-to be completed only in the midst of cataclysmal changes -is seen in the fact that his proclamation was misunderstood. He was made a Galilean hero. "The common people heard him gladly." 1 A national redemption

${ }^{1}$ Mark I $2: 37$. 
from poverty and oppression as the result of Jesus' teaching was no doubt their crude hope. According to Jesus the rich were shut out from the Kingdom by their riches, and the poor were welcomed for their poverty. This was acceptable teaching to the humble but restless fishermen of northern Galilee, until he went on to emphasize the ethical change needed in them also to gain entrance to that Kingdom, when they also fell away.

This national factor in the teaching of Jesus is often forgotten in the recognition of Christian universalism. Yet nothing is clearer than that not only did Jesus begin as a strictly national teacher, but that he himself only realized with sorrow, so far as he fully realized it, the hopeless character of his national work. Here also Jesus only filled out the dream of the exilic Isaiah. His desire was, indeed, a world-wide redemption, but the "suffering servant" was to be an ethically reformed Judaism. Repentance and good works were to save the nation, or a remnant of the nation, in the midst of coming catastrophies, and the redeemed Israel was to teach righteousness to the world. The good news was to be proclaimed among all nations ${ }^{1}$ and the "elect" would partake in the ethical change, and then the tribulation would destroy the wicked, and the Son of Man would come to a completed and triumphant Kingdom.

This emphasis upon the ethical rather than upon the political and economic character of the Kingdom is not only seen in the Sermon on the Mount (so called) but in the material which Matthew gathers into the long discourse to the disciples. ${ }^{2}$ This material, however, is to be probably divided into two separate periods of the teaching of Jesus.

The historical order of Mark may be provisionally accepted as the oldest and most correct one. That order practically divides the ministry of Jesus into two periods. The first was full of success, of hope, and of large personal expectation. Then came the coldness in Galilee and his final deposition from the place of a popular idol and coming national leader. From that time on the Mark material is intensely personal. The message is no

${ }^{1}$ Mark 13 : 10.

${ }^{2}$ Matt. $9: 37-10: 42$. 
more to the nation but to the chosen group. They are to be made ready to do the work of Kingdom proclaimers, which the nation would not, was not, in fact, ethically fit to do.

This division is not found in Matthew nor in John, although in Luke traces of it are to be distinctly seen. Yet it is a striking fact that Matthew in mixing sayings of the two periods in the sermon he constructs ${ }^{1}$ involves Jesus in confusions from which Mark alone saves him, and in which Luke does not involve him. ${ }^{2}$ Mark distributes this material, and without question correctly. As long as Jesus had hope for the ethical reformation of Judaism he confined his message to it. He hoped it would then do the world work. When he considered a national change in so short a time as no longer possible, he turned to a small chosen group. The ideal became a redeemed spiritual community. The "ecclesia" passages of Matthew are, no doubt, a later addition. Jesus never probably used any word of Hebrew or Aramaic

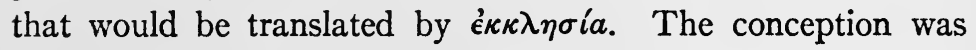
simply a spiritually minded following, ethically fitted to be proclaimers and forerunners of the coming ethical transformation. This then brings us to consider what Jesus looked upon as the ideal of personal ethics for such a spiritual community.

Jesus never was a systematic teacher, as the contrast between him and the scribes goes to show. "They were astonished at his teaching, for he taught them as having authority and not as the scribes." 3 He declared what seemed to him obvious and does not seem to have argued. His teaching was inspirational and not analytical. Hence it is impossible to arrange his teachings without doing a measure of injustice to them. Moreover, his personal ethical teaching was so interwoven with his religious faith that it is wellnigh impossible to separate it from the theological groundwork. The particular feature, however, of his teaching we may perhaps bring out under several heads.

${ }^{1}$ Chapters $9: 38-10: 42$.

${ }^{2}$ Compare Matt. $10: 5^{-15}$, where the messengers are to stay in Israel and preach only to their nation, with $10: 16-23$, where they are "messengers to the nations."

3 Mark I : 22. 
I. Morality was for Jesus not outward conduct but inner motive. The man who looks after the woman with lustful eye has committed adultery with her in his heart. ${ }^{1}$ This was not new, but it was a neglected and forgotten truth in the fatal transformation of the law to simple statutory requirements. In Job's defence (chapter XXXI) the hero of the drama is made to emphasize the inward spirit; even secretly he has not rejoiced at an enemy's misfortune, nor "has his heart been enticed" even "secretly" to worship moon or sun. Jesus, however, presses the logic home. All ritual and legal requirement is but symbolic of the real demand made upon the moral man for an inward purity of thought and hope. "Not that which entereth into the mouth defileth the man, but that which proceedeth out of the mouth, this defileth the man." 2 "For out of the heart come forth evil thoughts, murders, adulteries, fornications, thefts, false witness, railings: these are the things which defile a man." 3 To eat with unwashed hands did not, therefore, defile a man. This logic made Jesus the radical destroyer of the existing moralities, which were as intimately bound up with outward things as much Protestant morality is bound up with "Sabbath keeping," "church going" and "Bible reading," no matter how mechanical. How sweeping the judgment was in the time of Jesus it is hard for us now to realize. No doubt Jesus' condemnation of all "judging" was the outcome of the

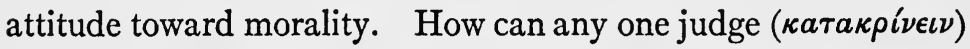
another without reading the heart? Hence to the woman taken in adultery (a scarcely doubtful tradition of Jesus) Jesus himself refuses condemnation. This is not to allege that he had any clear-cut philosophy on the relation of the state to the individual, or that he himself withheld all condemnation when he felt himself in a position to weigh motives. He puts his dictum forth in poetical form. The version in Luke gives us a clew to the arrangement of the material:

"Judge not and ye shall not be judged.

Condemn not and ye shall not be condemned.

With what judgment ye judge
${ }^{1}$ Matt. $5: 28$.
${ }^{2}$ Matt. I5 : 1 r.
${ }^{3}$ Matt. 15 : 19-20. 
Ye shall be judged.

With what measure ye mete

Ye shall be measured.

"Why look at the mote in your brother's eye

And regard not the beam in your own?

Or how say to your brother, lo here!

Let me cast out the mote from your eye,

And you see not the beam in your own!

Hypocrite, cast out the beam from your eye

And see clearly to cast out the mote from your brother's."

This inward character of ethics had its basis in the spiritual experiences of the Old Testament as reflected in such literature as the 5 Ist Psalm:

"Create a clean heart in me, O God;

Renew a right spirit within me."

And as in that Psalm, offerings and sacrifices began to take their place in the teachings of Jesus as non-essential.

II. This led to the proclamation by Jesus of the supreme importance of morality as thus defined. The identification of morality with ritual in his day had confused the issue before human life much as that issue is now confused by the identification of morality with opinion. The solemn scene of the Judgment poem $^{1}$ is based upon this sense of conduct as the criterion of life. Not every one that says "Lord, Lord," but only the man who "does the will" of his Father shall enter into the Kingdom of Heaven. ${ }^{2}$ Those even who have conjured with the name of Jesus and done in his name "mighty works," but whose life "worked iniquity," cannot be saved by their ritual correctness. Conduct springing from a good will is for Jesus the supreme test. "By their fruits ye shall know them." 3 Conduct is the outcome of the character. In a little poem given by Luke ${ }^{4}$ Jesus emphasizes this inwardness of morality at the same time that he asserts its supremacy:

"It is not a good tree giving bad fruit:

It is not a bad tree giving good fruit:

For each tree by its fruit can be known.

Matt. $25: 31-46 . \quad{ }^{2}$ Matt. $7: 2$ I. $\quad{ }^{3}$ Matt. $7: 20 . \quad$ Luke $6: 43$. 
Not of thorns do men gather their figs:

Not of brambles gather men grapes.

The good man from good stores of his heart does his good:

The bad man from bad stores of his heart does his bad:

From the stores of the heart speaks the mouth."

The supremacy of righteousness is the motive put always before the disciples. "Ye shall be perfect, even as your heavenly Father is perfect." 1

III. This righteousness is not only ethical as over against ritual correctness, and inwardness as over against simple conformity to rule, but the character of it is deeply compassionate. This is not only seen in the exclusively Lucan parables ("The Good Samaritan," “The Lost Sheep," etc.), and in Jesus' own conduct as with the woman taken in adultery, or in the works of mercy recorded by Mark, but Jesus emphasizes it as belonging to any real righteousness. "It is not the will of your Father which is in heaven that one of these little ones should perish." 2 That the will of the Father is compassionate is the whole teaching of the parable of the Prodigal Son, and as our morality is to do this will our morality must be tender and compassionate. This made another point of strain between the teachings of Jesus and the popular ritual conception of righteousness. Again Jesus here consciously elaborates what he found, no doubt, in the prophetical books. Matthew, for instance, cites Hosea $6: 6$ as a parallel to Jesus' reply to those who objected to his eating with publicans and sinners, ${ }^{3}$ where the prophet says, "I desire mercy and not sacrifice." He makes the compassionate will of a father the basis for a personally compassionate morality. It is this in the ethical teaching of Jesus that Nietzsche finds so unsympathetic. It is opposed to the masterful aristocratic spirit that has given us nearly all our systems of political economy, of religion, and of morals.

IV. The morality of Jesus was, however, distinctly "nonascetic." This is seen not only in the impression he made as in contrast with John the Baptist, "The son of man came eating

${ }^{1}$ Matt. $5: 20 . \quad{ }^{2}$ Matt. I8 : I4. ${ }^{3}$ Matt. $9: 13$. 
and drinking, and they say behold a gluttonous man, and a winebibber," "and in the non-observance of his disciples of rules for fasting, etc., but in the cardinal doctrine lying at the basis of all his morality. For asceticism as a means of self-discipline Jesus had no rebuke, although he evidently attached little importance to it, ${ }^{2}$ but the ethical significance of asceticism is the conception of self-mortification as a method of access to God. For such asceticism Jesus had no place. Anything that hindered access to the ethical Kingdom was to be ruthlessly sacrificed, hand, foot, or eye, but sacrificing the hand, foot, or eye would not give any access to the ethical Kingdom. ${ }^{3}$ This was the essence of the attitude of Jesus to riches. He saw in riches the bulwark of class pride, and a barrier to personal perfection, and he condemned them in that sense. At the same time mere poverty was no means of access to God. The interpretation put by Luke on the "sayings of Jesus" seems to favor the asceticism that marked much early Christian thinking, and no doubt as a means for ethical advance Jesus did regard ascetic practices differently from the average ethical thought of to-day. At the same time, even the expressions of Jesus on this subject, stripped of later interpretations, are singularly free from ascetic practice, and permitted only as a means of self-discipline for ethical life, and not as constituting the ethical life. The matter of fasting, for instance, is nowhere condemned as such, but as constituting an essential part of the outward religious life of the Pharisees it is condemned." And it is nowhere recommended, although presupposed as possible. ${ }^{5}$ The one passage often quoted in its favor ${ }^{\circ}$ has been omitted even by the Revised Version as textually untenable. Whereas it is distinctly asserted that his disciples did not fast. ${ }^{7}$

V. Jesus saw in righteousness a "good in itself," but the poetical expressions of the "sayings-collection" speak also of reward. At the same time the "reward" is given by a heavenly

1 Matt. II : I9.

${ }^{3}$ Mark $9: 42-45$.

${ }^{2}$ Matt. $9: 14-17$, friends of bridegroom.

'Matt. $17: 21$, "This kind goeth not out save," etc.

${ }^{5}$ Matt. 9 : I 5.

7 Mark 2 : 18. 
Father and is carefully differentiated from the "thanks" that sinners render to "sinners." 1 The Father is to recompense (the "openly" of Matthew is textually to be rejected). ${ }^{2}$ Unquestioningly and submissively and in secret righteousness is to be wrought, and all "reward" awaited from the Father. The character of the "reward" Jesus distinctly refused to define. ${ }^{3}$ We are to aim at perfection as God is perfect, and he expects no reward, "sending his rain upon the just and the unjust." 4 Who loses his life finds it, if it is for Jesus' sake, i. e., for righteousness' sake, ${ }^{5}$ and a righteous man receives the appropriate righteous man's reward. ${ }^{\circ}$

Undoubtedly Jesus looked forward to a coming Kingdom in which these rewards were to be dispensed. " In Luke the "reward" is eternal life, in Matthew it is "thrones judging Israel." It is impossible to say just how far Jesus went along this line of apocalyptic revelation, or just what the really underlying thought was. The ethical advance was the connecting even of the apocalyptic dream with a righteousness that in no way bargains but trusts, and the severing of the very conception of "reward" from the coarse material aspects of it with which even modern representations of heaven have often burdened the thought.

VI. To the empiric morality of the day Jesus thus gives an idealistic foundation. He probably accepted many of the current ethical maxims of his generation uncritically. $\mathrm{He}$, for instance, passes no comment on slavery or monarchical institutions as already there in force, nor did he in any way ethically examine fundamental rights in property or in fact any of the economical conditions whose ethical significance we are beginning slowly to recognize. Cæsar was Cæsar, and, as the acknowledged authority even among the Jews, was one of the facts to be taken for granted. At the same time the ethical inspirations of

${ }^{1}$ Luke $6: 32$.

${ }^{8}$ Mark 10: 40 . (Scene with the Sons of Zebedee.)

'Matt. 10: 39.

${ }^{7}$ Matt. 19: 28-29; Luke $18: 29$.
${ }^{2}$ Matt. $6: 4$

- Matt. $5: 45$.

- Matt. 10:41. 
Jesus were bound to be critically applied to empiric morality in every succeeding generation, with more or less success.

VII. The whole teaching of Jesus in regard to personal morality had its real significance in its relation to the Kingdom of God. This reign of Righteousness could only be introduced and partaken of by those who had thus given themselves up to "watching until their Lord should come." The establishment of it was to be on the earth, "Thy will be done on earth even as in heaven." The Kingdom Parables ${ }^{1}$ reflect the fact that Jesus expected that Kingdom suddenly and yet as the culmination of a divine process. It was to be sought for. ${ }^{2}$ It was at the same time growing amidst unfavorable conditions. ${ }^{3}$ The searching examination of the "Kingdom Parables," by Jülicher, ${ }^{4}$ supported as he is by Wendt and Weiss, make it impossible to use with confidence the details of these parables as in any way reflecting the direct teaching of Jesus concerning his conception of the Reign of Heaven.

The details, however, are not the important features. The character of the Kingdom is steadily represented as a divine fulfilment of righteousness on earth, introduced by calamity to all wrong-doers; an ethical revolution with the establishment in the world at large of a condition of things ideal in its peace and justice. The ethical conceptions are enlargements of such pictures as are found in the Exilic Isaiah. ${ }^{5}$ Jesus had compassion on the multitude, ${ }^{6}$ and shared their national feeling, as witnessed by his wonderful lament over Jerusalem. ${ }^{7}$ The redemption was not to be simply ethical, it was to be national and race redemption. It is evident that the universalism of Jesus had its basis in the prophetic conception of the ends of the earth coming up to Jerusalem to see the standard of Jehovah, and bringing with them the exiled wanderers scattered over the earth. ${ }^{8}$ That this proclamation of Jehovah was in the first instance a

\footnotetext{
${ }^{1}$ Matt. I3.

${ }^{2}$ Matt. I $3: 44$.

${ }^{3}$ Matt. I3 : 39-43.

" "Die Gleichnisreden Jesu," vol. II, pp. 3-I I, I 28-I33, I6I-I 7 I, 5I4-538, $546-554,569-5^{81}$ I, 58I-585.

$50: 9-3 \mathrm{I}, 4 \mathrm{I}: \mathrm{I}-20,65: \mathrm{I}_{3}-25$, etc.

7 Matt. $23: 37$, "O Jerusalem, Jerusalem!"

${ }^{6}$ Matt. $6: 34$.

${ }^{8}$ Isaiah $49: 22-23$.
} 
judgment is also on a line with the prophetic conception. In the despair of the solitary reformer before the massed corruption of his time, nothing but a judgment and a revolution seems adequate to effect the changes he sees must come. What differentiated the revolution Jesus expected from the ordinary political agitation was his reliance upon an ethically and spiritually trained community whose existence would justify the judgment, and whose office it would then be to exhibit the Reign of God.

This community was organized, so far as we can speak of organization, on the old Hebrew democracy basis. ${ }^{1}$ The nations had lords who exercised authority; it was not to be so in the spiritual community. In it the "first among you shall be your servant," for "the Son of man came not to be ministered unto but to minister." It is doubtful, to say the least, whether Jesus contemplated any rites or sacraments as marks of this community, but he probably expected it to re-establish the spiritual Judaism with which he had no quarrel. The relations that were to bind men together were the bonds of obedience and righteousness. ${ }^{2}$ Those doing the will of his Father were his brethren and his sisters and his mother. These bonds were of a more sacred character than flesh and blood, hence in the time of ultimate stress these bonds would give way and brother would deliver up brother to death, and the father his child. ${ }^{3}$ The proclamation of this coming ethical Kingdom would, Jesus felt, be attended with the same risks all such proclamations had to run, but he had firm confidence that when the night should be darkest suddenly would come the dawn and the light. All, therefore, were to watch and continue patient in the hour of tribulation, as knowing that the hour of deliverance was at hand.

VIII. The ethical teachings of Jesus were therefore grounded in faith that God was to create a new spiritual and ethical community. He felt himself to be the herald of that coming Kingdom, and to be its founder and teacher. In a certain sense that Kingdom was already potentially present, ${ }^{4}$ as all the elements of

${ }^{2}$ Matt. $20: 20-28$.

Matt. 10 : 21-22.
2 Matt. 12 : 46-50.

- Luke I7 : 20-22. 
judgment and ethical change were in the atmosphere, although its exact time of fruition could not be well determined. This realization of righteousness was to be the ethical revelation of God, the revealing of his heart and will. Jesus felt himself to be a revealer of that Father's heart, and a declarer of the only true life, that of union with that will and absolute obedience to it. Whether in the buoyant confidence of his earlier proclamation, when acceptance of his message by his own generation seemed a possibility; or in the darkening glooms of Gethsemane, when the day-dreams faded in the agony of great spiritual and physical strain, Jesus held firmly to the ethical character of a loving Father, and looked with assurance past the struggles of time to an overwhelming revelation of that compassionate and righteous will in the perfected Kingdom on earth. Thus the Reign of God became the real organizing ethical ideal and the sustaining hope of Jesus' life. It was, no doubt, a bitter heartbreaking disappointment to him that the nation refused to accept his ethical ideals and to enter at once upon the establishment of the Kingdom. He, however, never wavered in his faith that the Kingdom was to come, and when he turned to his disciples it was not to found an institution for conquest, but a spiritual ethical communion for proclamation. They were to eat of his flesh and drink of his life and live his ideals, and thus to share with him in the coming ethical triumphs of a redeemed humanity. He could, therefore, make no compromises, because his Kingdom was ${ }^{1}$ not of this world, $i$. e., did not share its ideals or its methods. Righteousness could not be established on any basis but that of the unquestioned supremacy of the Father's will. In the description of the temptations on the mount, which no doubt reflects Jesus' pictorial account of his struggle up to his ideal, Jesus represents himself as refusing empire as the basis of the Kingdom, because empire involved compromise and partial submission to another will than the Father's. Jesus felt himself alone on the heights of his ethical dreaming, and yet on the other hand such was the vividness of

${ }^{1} \xi \kappa$ with the genitive is genitive of origin $(\xi \kappa \tau 0 \hat{v} \kappa \delta \sigma \mu o v)$. 
his faith that he already saw empires falling, and even then heard the cries of victory in the coming sudden achievement.

In the earliest sources Jesus also linked the ethical triumph of the Kingdom with the spiritual energy of his own life and nature. He was himself the Bridegroom." He could "forgive sin." 2 The Fourth Gospel only emphasizes what is already in the "sayings." At the same time this energy is not magical, but spiritual and ethical. The way of attainment is union with him in doing the Father's will.

The organic basis, therefore, for the teaching of Jesus is found in the realization of the loving will of God on earth and in all human life, and in the revelation of God as essentially compassionate righteousness in the coming Kingdom. The dynamic force by which this is to be realized is the love of God awakened in men's hearts by the proclamation of his free forgiveness to repentant men, enabling them to live the forgiven life.

Sin was separation from the Father, and meant misery and death. Forgiveness brought men back to the Father's house and gave them peace. This peace is here and now, but is to be fully made manifest when the Prince of this World is fully overcome and God reigns supreme.

\section{THE ETHICS OF PAUL}

The Pauline interpretation of Jesus is based upon his own personal experience. ${ }^{3}$ Jesus grew up, as far as we know, in the unchanging sense of perfect unity of life and will with his Father.

Literature.-Stevens, G. B.: "The Pauline Theory"; New York, I892; revised edition, I897.-Bruce, A. B.: "St. Paul's Conception of Christianity"; New York, 1894.-Sabatier, Auguste: "L'Apotre Paul"; 3d ed.; Paris, I896; English translation by G. C. Findley, New York, I891.-Pfleiderer, Otto: "Der Paulinismus"; 2d ed.; Leipsic, 1890; also in English translation by E. Peters, New York, I885; in 2 vols.; London, 1877.-Juncker, Alfred: "Die Ethik des Apostels Paulus"; Halle, I904.-Titius: "Neutestamentliche Lehre von der Seligkeit"; Freiberg, I895-r900; 4 vols.-Ernesti, H. F.: “Die Ethik des Apostels Paulus"; 3d ed.; Göttingen, r880.

1 Mark 2 : 19.

${ }^{2}$ Mark $2: 5$

${ }^{3}$ Gal. I : II-I 7 ; $f f$. Acts 9 : I-9. 
He had indeed advancing visions of his work and its methods, ${ }^{1}$ and he passed through critical periods in his spiritual development as at Cæsarea Philippi ${ }^{2}$ or at Gethsemane, ${ }^{3}$ but there is no evidence of any anxious searching for God or convulsive reaction from sin, such as mark so generally the religious experiences that have told upon the world's history (Augustine, Francis of Assisi, Loyola, etc.). To love God with all his heart and his neighbor as himself was for Jesus the natural and inevitable outcome of the true relationship of the son to the Father." With Paul the case was very different. He worshipped a just but exacting Ruler, and for him righteousness had consisted in exact fulfilment of legal requirement. He longed to be "righteous," and he had all the advantages of birth and training for the attainment of a most distinguished career of righteousness, ${ }^{5}$ and he had utterly failed. ${ }^{6}$ Paul, like Luther, found no peace in the most exact ritual correctness. Suddenly he saw God in Christ Jesus, no longer as stern law-giver, but as Redeeming Father, and entered upon the freedom of loving sonship. $^{7}$

Neither Jesus nor Paul had any serious quarrel with the purer type of theological speculation prevalent in Judaism. Paul is not primarily a speculative theologian. God was for him one. His will was absolute and holy. He was present by his spirit in the world. The age was evil, and yet the world belonged to God and must one day acknowledge his governance. The Scriptures could not be broken, and the law had been given by Moses, and was holy. But Christ had died and fulfilled the law. How this happened Paul illustrated to himself from Hebrew history rather than cleared it up by any intellectual process. ${ }^{8}$ Prophecy had foretold the Messianic conquest of the whole earth, and Paul's Christology moves in the region of Messianic hope of the more spiritual and ethical character. The risen Christ was coming again, and God in Christ Jesus was the

\footnotetext{
${ }^{1}$ Matt. $4:$ I-II.

- Matt. 22 : 34-40.

2 Mark $8: 27-9: 2$.

3 Mark $14:$ 32-42.

7 Gal. 4 : I-7.

${ }^{5}$ Phil. $3: 4-6$.

B Rom. 7 : 7-24.

Rom. 9 and ro.
} 
Christian hope of glory. ${ }^{1}$ In Jesus the Jewish dream of sonship with Jehovah had been completely fulfilled, and we in union with Jesus could enter upon that sonship and cry Abba, Father!

In the Messianic death and resurrection the whole legal structure of the past had reached its climax and end. Henceforth there only remained the proclamation of the Messianic hope, the establishment of the Messianic group, and the spreading abroad of the good news that Jesus fulfilled the Messianic faith, and the waiting for the consummation of the new age in which corruption and rebellion, sin and defilement would have no .place.

This sinless new age takes with Paul the place of "the Reign of God," as Jesus used that term. Paul no more than Jesus ever ceased to be a loyal Jew in thought, in hope, or in expression. What Hellenistic culture he may have had contact with in Tarsus made no impression upon his fundamental view of the world, and it is exceedingly dangerous to a right understanding of Paul to use Greek categories in exchange for the Jewish ones in which Paul's thought so wholly moves. In Paul ethics was linked with a profound spiritual experience, and became a religious force for reorganizing a world socially and economically as well as morally and politically bankrupt.

Stoicism had no such saving force, for it was aristocratic, cold, unemotional, individualistic, and non-religious. Oriental religious fervors had no final saving power because they were despondent and essentially non-ethical. Neoplatonism was relatively barren because only within the reach of those who needed it least, and was loaded down with crude and false views of the world and life. Pauline Christianity swept with a mighty religious enthusiasm over a fevered and disorganized life, and brought with it new views of God's loving purpose and splendid vistas of ethical triumphs and coming victory over the world of $\sin$ and death.

The Pauline literature on which we may with assurance rely for a reconstruction of his essential message is mainly polemical.

'I Thess., and captivity letters. 
Leaving aside the vexed question of the doubtful epistles, Timothy, Titus, and II Thessalonians, we have two main groups of writings in which Paul unfolds very fully his ethical system. His main interest was ethical in both groups, but the background of the first group is theological and of the second Christological. To the first group belong Galatians, Romans, and the two letters to Corinth, as well as the first letter to the Thessalonians; in the second group are to be reckoned Philippians, Ephesians, and Colossians. And in Philemon we have a fine illustration of Paul's ethical method.

The first group of letters deals mainly with the ethical content of the word "righteous," and the second group treats in the main of the springs of ethical conduct. These divisions are not and could not be sharply made. Paul was dealing practically with the extreme ethical needs of dreadfully neglected human life. The nearest approach to a systematic treatise is the letter to the Romans, and its relatively abstract and systematic form may in part be due to the fact that he was writing to a church with which as such he was not personally acquainted. We will then deal first with the content of the ethical life.

I. Paul had no idea of breaking with Judaism any more than had his great master, but Judaism had to undergo an essential change if it was to fulfil its Messianic mission. ${ }^{1}$ Legal exactness was no substitute for essential righteousness. The proclamation of the secondary character of the "Torah" at once exposed Paul to honest and excited criticism by Jew and Jewish Christian alike. As a matter of most profound experience the Jewish community saw in their legal and ceremonial observances the only effective barriers between them and their children and the horrible corruptions of the slave-ridden world about them. The Jewish home was not what it should have been, ${ }^{2}$ but it maintained itself in relative security against the awful deluge described in Rom. I : 24-32 and chiefly because of the separations resulting from the law.

To the pious Jewish Christian the only way to the morality

${ }^{1}$ Rom. II : I-24.

${ }^{2}$ John $7: 53^{-8}:$ Ir. 
of Jesus was to become a Jew as Jesus had been a Jew, and when Paul's converts at Galatia went uncircumcised and sabbathless they naturally remonstrated. Moreover, when Paul was cited as an authority for such lawless conduct they quite naturally attacked his apostolic authority, and denounced him as "lawless," a destroyer of morality, and as dangerous to the purity of the church.

The poor Galatians were much taken aback, and followed the directions of the new teachers; upon which Paul wrote the immortal defence of his religious experience and apostolic character which we have in Galatians. There he asserts the freedom of sonship with God, ${ }^{1}$ and the fulfilment of the whole law in the one word "love." 2 But wherever he now went it was only to meet the suspicions, charges, and hatred engendered by his very radical treatment of legalism. Hence in preparing his way for work in Rome he puts his argument in still more systematic form as we have it in the wonderful treatise to the Romans.

It must be remembered in reading Romans, first that Paul had no quarrel with the theology of his critics, and secondly that the book is throughout, and not in the last chapters only, an ethical treatise.

The charge against Paul was that he was undermining morality, and was anarchistic and dangerous to the home and church life of the really God-fearing community. He mingled with the uncircumcised and ate with the unclean: hence his critics honestly thought of him as an immoral man, as the average Highland Scotchman would now regard the Sabbath observance of even a pious German as stamping him as unchristian. Paul was for the pious Jewish-Christians a corrupter of youth, and they saw in him a tendency toward all kinds of ethical looseness and license. To this charge Paul addresses himself.

Paul was therefore compelled to deal fully with the real content of the word righteous. ${ }^{3}$ With great tact therefore, after the first greeting, he puts himself en rapport with his readers by

${ }^{1}$ Gal. 5 : 1.

8 צִ Sוkacos or in its abstract form 
sharply denouncing in almost fierce abruptness the hideous sins of the heathen world which he was charged with condoning, but which he hates as they hate them, and for which he has a remedy. $\mathrm{He}$ is not ashamed of his gospel; it is a divine dynamic making for "righteousness." 1 It excludes absolutely the dreadful doings described in Rom. I : I8-32 against which God's just wrath is revealed. Paul puts himself at once on record as having no patience or sympathy with the man who leaves Judaism simply that he may be free to sink in this pool of corruption. ${ }^{2}$ God will judge all, and his wrath will mete out to all according to conduct. ${ }^{3}$ From this judgment none can escape by simply leaving Judaism.

But, alas, Paul goes on to show, there are Jews who glory in the law, are ceremonially correct, who deem themselves guides to the heathen, but who as a matter of fact cause God's name to be blasphemed by their immoralities, so that it should be apparent to all that mere ritual correctness was not "righteousness." These Jews were ritually correct! Hence, he argues, Judaism is not a letter but a spirit. Circumcision must be of the heart.

This dreadful experience of the powerlessness of ritual and legal correctness to really keep a man pure raised a fearful question. The Jew had suffered terribly for his faith. The pious Jew saw in "righteousness" for himself and loved ones the reward of his faithfulness. If the law could not secure this then all his sufferings were in vain. "What did it profit" to be a Jew and suffer the exclusions and ignominies of circumcision ?

Paul's answer to this question is wholly ethical in its interest, and is very noble and lofty in character. He makes four points, the last one in the fifth chapter, after a long parenthesis. First, to the Jew belongs the high honor of a peculiar service. To him were committed the oracles of God. He at least might know the will of God. Secondly, although the Jew has not kept the law, this was his unrighteousness and reveals simply the fact that he is with the Greeks under a common condemnation, all have sinned, and all will be judged. Thirdly, but as God is the

1 Rom. I : I6.

- Rom. 2 : $17-29$.
2 Rom. 2 : I-I6.

- Rom. 3 : 1 .
Rom. 2 : 6.

- Rom. 3 : 2-8. 
God of both the Jew and the Gentile, so he has provided a righteousness, and made it manifest which is by faith in Jesus Christ, set forth to be a mercy seat through faith, and this righteousness is accessible to all Jews and Gentiles, and the sins done before time are borne with in the goodness and forbearance of God, so that a man is justified apart from all legal correctness, and both the circumcision and the uncircumcision are justified by faith.

At this point the historical question emerges which Paul seeks

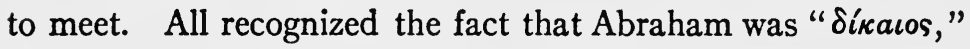
or a "righteous man." Now Paul links all "righteousness" with a dynamic faith in Christ, and so seems to leave no place for Abraham. With great dialectic skill Paul turns the objection into an argument for his position. He makes three points. (a) Abraham's righteousness was "reckoned to him" and was therefore of grace and not of works, ${ }^{1}$ a fact that David regarded as a blessing. (b) This righteousness, moreover, was reckoned to him while yet uncircumcised, that he might be the father of all who live in faith outside circumcision; ${ }^{2}$ and so, as no part of the ritual law is more important than circumcision, it is evident that it is a mere seal of something more vital, $i$. e., of the faith needed by both the circumcision and the uncircumcision for the attainment of true "righteousness." (c) Hence he who would

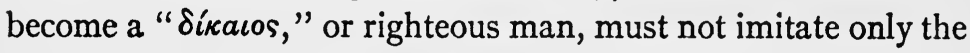
outward sign, but take part in the vitalizing faith which made Abraham the father of the faithful. ${ }^{3}$

Paul thus makes it clear that he has no legal forgiveness in mind, but a dynamic force that will actually enable a man tolive the righteous life. And this dynamic is of grace, through the love of God shed abroad in our hearts in Christ Jesus." The fifth chapter is given up to the exposition of the gift of God by grace of a free forgiveness on the basis of one act of righteousness, as sin came by one act of disobedience. Sin came as a dynamic for unrighteousness, and this loving faith appears as a dynamic for producing righteousness. This brings Paul back to his

$$
\text { ' Rom. 4: 3-8. } \quad{ }^{2} \text { Rom. } 4 \text { : 11. 'Rom. 4:23-25. 'Rom. } 5: 5 \text {. }
$$


argument concerning the function of the law, and he argues, fourthly and lastly, that the law came in to make trespass abound that grace might still more abound.

This was no doubt one of the points Paul had often argued, and to which objection must have been most strongly taken. "What," said the objectors, "shall we continue in sin that grace may abound?" This was the charge of lawlessness so often levelled at Paul, and he meets it at once. "No," he exclaims in the sixth chapter, "let this never be so!" We are dead to sin. His answer is a twofold one. (I) We are in vital union with Jesus Christ, who died once to sin, and rose, and we are arisen in the likeness of his resurrection. This is Paul's teaching of a vital, mystic union with the risen Christ, by which an actual force for living the righteous life becomes ours. ${ }^{1}$ (2) We are now bond-servants of righteousness as once we were bondservants of unrighteousness. We are free from sin as once we were free from righteousness. We must therefore now bring forth fruit unto holiness as we once brought forth fruit unto iniquity, and the wages of $\sin$ is death, the gift of God is eternal life. ${ }^{2}$ For Paul ethical purity is life and unrighteousness is death.

Paul thus only pushes to its logical outcome the old prophetic description of Jehovah. He is righteousness, and to share his life is to live righteously. And we share his life in union with the risen Christ, for Paul in the seventh chapter pushes the image of death to all outward legal regulation, and life to a spirit of righteousness, under the figure drawn from the marriage relation. ${ }^{3}$ Then he plunges into personal experience. The law has revealed to him in the past his utter helplessness. The law was holy but could only flash its light upon the darkness of a helpless longing. It was powerless to give peace. For even while Paul felt in his mind the holiness of the law, he had no power in his flesh to keep its precepts.

Then came deliverance. The spirit of life ${ }^{4}$ in Christ Jesus brought the power to subdue the flesh and its passions; as Christ

\footnotetext{
${ }^{1}$ Rom. $6: 2-14 . \quad{ }^{2}$ Rom. $6: 15-23 \quad{ }^{3}$ Rom. $7: 1-6 . \quad$ 'Rom. $8: 2$.
} 
Jesus condemned sin in the flesh and gained control of it, so all who are not in the flesh, $i$. e., living in its ideals and bondservants to its passions, by union with him may live the life of the spirit. Here, then, Paul develops his teaching of an ethical dualism as a matter of profound personal experience. There is ${ }^{1}$ a mind of the flesh $(\sigma a ́ \rho \xi)$ and a mind of the spirit. This mind of the flesh has a natural affinity with the body $(\sigma \hat{\omega} \mu a)$ and the mind of the spirit a natural affinity to the human spirit, but it is not at all clear that Paul so far left the healthy thought of all Judaism as to think of the body as in itself evil. It was only the seat of this antagonistic principle, and would be redeemed by the spirit of Him who raised up Christ Jesus. ${ }^{2}$ Thus we enter upon our highest freedom when we are raised as sons of God with Christ Jesus and cry Abba, Father! ${ }^{3}$

The closing part of the eighth chapter is a splendid identification of all suffering with the redemptive life and suffering of Christ Jesus just so far as these sufferings bind us to the love of God in Christ Jesus, from which naught can separate us. Thus for Paul all the suffering of the world points to a coming redemption, for nothing can separate us from such love as God has revealed in Christ Jesus.

At this point Paul again interrupts his argument to defend himself against the charge of an unpatriotic depreciation of Judaism. Nothing is dearer to his heart, and he could wish himself separated even from Christ for his brethren's sake. ${ }^{4}$ He revels in the glorious history of past possession of God. ${ }^{5}$ At the same time he must also recognize the fact of a dual Israel. There is a spiritual Israel, larger than the circumcision, ${ }^{6}$ and this spiritual Israel is not such by virtue of any works or legal claims, but simply in the inscrutable election of an omnipotent God, making vessels of wrath as the potter makes his dishes, willing to show both his power and his goodness. ${ }^{7}$ Paul is dealing here in no sense with the philosophical question of freedom, which could

${ }^{1}$ Rom. $8: 6$.

- Rom. $9: 3$.

${ }^{7}$ Rom. 9 : 19-29.
${ }^{2}$ Rom. 8 : 10-II.

s Rom. $9: 5$.
${ }^{3}$ Rom. 8 : I 2-I 7 .

' Rom. $9: 8$. 
hardly arise from his stand-point, but with ethical freedom within the limits set by the omnipotent purpose of God. It is a national election to special service with which Paul deals in the famous ninth chapter, and he charges Israel with failure as pronounced as that of the nations to attain to righteousness, and for the same reason-they sought it not by faith but by ritual correctness, whereas the nations who now seek it in faith do attain to it. ${ }^{1}$

Paul argues further that this confusion of legal correctness with actual righteousness is what is hindering even those who have a zeal for God among the Israelites; ${ }^{2}$ hence it has happened that the nations have entered in where Judaism has failed. ${ }^{3}$ Not, indeed, that Judaism has completely failed. There remains a large remnant " whom God's grace has spared and chosen, and indeed the Gentiles will need to remember that if God did not spare the tree onto which he grafted the Gentile church, no more will he spare the branches if they fail to stand in that righteousness which Paul regards as the goal of all being and the secret of all life. He hopes, moreover, that Israel will be provoked into a saving faith by the Gentile church, and to this end he pleads for that complete consecration of life to the perfect will of God which alone is rational service. ${ }^{5}$

What, then, is the content of this righteous life? In pursuit of his plan to demonstrate the ethical character of his gospel, Paul goes on to explicate the actual content of the ethical life. He deals first with the personal temper and attitude of the ethical man, including the forgiveness of enemies and the overcoming evil with good. Then he sketches the ethical life in its relations to the social organization, thought of, however, as an outside power, ${ }^{7}$ and to the social organization thought of in the second place as neighborhood, ${ }^{8}$ and then to the community of faith thought of as organized in a religious community, ${ }^{\circ}$ and so he closes the ethical treatise with an exhortation to common

\footnotetext{
${ }^{1}$ Rom. $9: 30-33 . \quad 2$ Rom. 10: 1-3. 'Rom. 10:21. 'Rom. Ir :4-5.

'Rom. $12: 1-2 . \quad{ }^{\circ}$ Rom. $12: 3-21 .{ }^{7}$ Rom. $13: 1-7 .{ }^{\circ}$ Rom. $13: 8-14$.

- Rom. $14: 1-15: 7$.
} 
work and personal testimony to the ethical effectiveness of his proclamation of which so many seem afraid.

The content of righteousness is therefore, according to Paul, loving faith working out the will of God in all life. He opposes to all ritual and legal correctness the spirit of loving obedience by faith in God as seen in the life, death, and resurrection of Jesus Christ. From this loving faith will proceed that which the law failed to produce, the really ethical life.

Thus the ethics of Paul are based on the liberty of loving sonship through faith in Christ Jesus. For Paul this faith was dynamic in character, a force that alone could overcome sin and death and give victory over the world. This was his own personal experience. What the authority of law, perfectly and sincerely recognized as holy, could not do in producing ethical character, because of the weakness of the flesh, he found could be done by faith working through love.

Throughout Romans the contrast is between faith ( $\pi i \sigma \tau \iota$ )

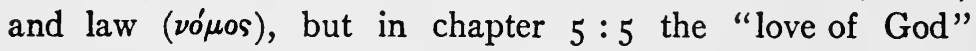

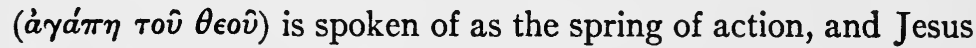
Christ is the standing evidence of the love of God. The supreme sacrifice of love is a revelation of the Father's love and redeeming

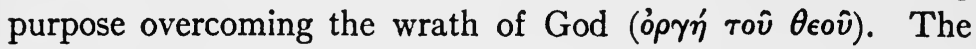
transition, however, from faith to love, and the ultimate identification of the two, is not fully made in Romans.

In his letters, however, to the church at Corinth, the ethical system of Paul has a further practical unfolding.

To the man or community used to the pressure of external coercion, and accustomed to make such external coercion the measure of morality, the first period of freedom is fraught with danger. Liberty to do right degenerates into license to do evil. The boy at college after the strict discipline of a home, the church after the Reformation, and the little religious community at Corinth are but examples of the common historical happening. Paul's doctrine of freedom from the outward coercion of law, and subjection to the inward coercion of faith working by love was not only misunderstood by his foes, but misinterpreted by 
those who thought themselves his friends. The thing Paul's enemies charged his gospel with-lawlessness-appeared in Corinth. No man and no community was ever quite "ripe" for the full exercise of ethical freedom. We learn by our mistakes and abuses. The community at Corinth broke up into quarrelling sects, and fornication appeared in a most disgusting shape. All sorts of questions of casuistry, some exceedingly intricate, appeared. For Paul it seemed very simple to decide at any moment just what was the "loving thing" to do, but for raw, ignorant followers there was wanting both his religious genius and the trained purpose.

Even Paul was not always able to separate between social conventions and ethical laws, as in his treatment of woman's dress. . And Paul himself begins the substitution of "tradition ", for the body of legal enactment he so firmly rejected, and he himself laid the foundation for a judging and condemning community with the power of the social ban, and even the assumption of divine authority in inflicting the penalty for the soul's sake. ${ }^{3}$

At the same time he knew what must be at the root of the new life, and the letter to Corinth introduces another antithesis. The danger of substituting for "faith" a "knowledge" ( $\gamma \nu \hat{\omega} \sigma \iota \varsigma)$

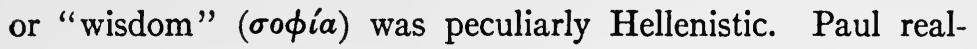
ized that not upon knowledge any more than on the outward coercions of a legal system could the ethical life be built. Hence, after meeting the pressing questions of discipline and casuistry forced upon him by the disorders of Corinth, he develops that which he only hints at in Romans, his doctrine of the effective spring of ethical action. This spring is love ('a $y a \dot{\pi} \eta \eta)$.

Faith and hope function constantly, but love remains the eternal spring of life and action. In this letter Paul uses also the phrase "Kingdom of God," " but it has not the same content that the phrase bears in the synoptic usage, but rather only one side of that content, the eschatological.

1 I Cor. II : 2-16.

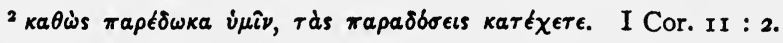

3 I Cor. 5 : 3-7.

- I Cor. 15 : 50. 
The triumph of the new age was to culminate with the reappearance of the risen Lord, and all would be changed: mortality

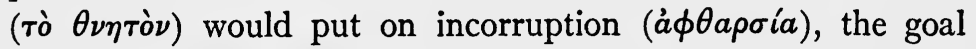
of the ethical endeavor would be fully realized in the Messianic reign. This eschatology is bound up with the ethical struggle in the first letter to the Thessalonians. ${ }^{1}$ This new life of sanctification is already the new age, but the consummation is not yet, and comes as a thief in the night, bringing condemnation to the wicked and splendid justification to those appointed unto salvation in Christ Jesus. ${ }^{2}$ The whole scheme of Jewish rewards and punishments, fitting but badly as it does into the Pauline ethical construction, is, however, always there, and indeed forms at times a very real moment. ${ }^{3}$ The content of the righteous life, the purity, peace, goodness, and all the fruits of the spirit, ${ }^{4}$ are to have a timeless exemplification in the new age.

IV. The character of the love which is with Paul the spring of ethical action finds its fullest exposition in the letters ${ }^{5}$ to the Philippians, Ephesians and Colossians. The type is found in the humble loving service of Christ Jesus. ${ }^{8}$ The mind of Jesus is to be in us, and we are to know in it the power of his resurrection, the fellowship of his sufferings, and are to be conformed to his death. ${ }^{7}$ This identification in suffering and service is to be so complete that the believer fills out what was lacking in the redemptive sufferings of Christ. ${ }^{8}$ This love is primarily for the "household of faith," " but the whole "Kingdom of the Son of his love," ${ }^{10}$ and then the whole new order is the ultimate object of this loving service. In these letters the writer is forced to oppose the life of service in love as the spring of action to "philosophy and vain deceit" "11 proposed as a substitute. The mystic union of the church with the risen Christ, as a loving

${ }^{1}$ As II Thessalonians furnishes the ethical student no new point of view, it is for us unimportant to discuss its genuine Pauline character.

${ }^{2}$ I Thess. $5: 9 . \quad{ }^{3}$ I Cor. I5: I 2-I9. "Gal. $5: 22$.

${ }^{5}$ These letters are Pauline, whether by Paul or no, and represent the progress of his thought.

${ }^{8}$ Col. $1: 24$.

${ }^{6}$ Phil. 2 : I-II.

7 Phil. 3 : 10-16.

11 Col. 2 : 8.

- Gal. 6 : ro.

${ }^{10} \mathrm{Col}$. I : I3. 
fellowship, becomes more and more his theme, ${ }^{1}$ and each letter ends with practical exhortation and explication of the sanctified life. Salvation is indeed sanctification, ${ }^{2}$ it is light as over against darkness. Christ is to dwell in our hearts through faith that we may be rooted in love. ${ }^{3}$ And more and more Christ Jesus becomes for the writer the absolute and complete manifestation of the Father's loving redeeming will.

This loving divine will is to be our will, this love our love, and if this be the case then in the true freedom of sons we live the life of complete service, and evil will not be so much as named among us as becomes "holy ones." 1 This conception of the community of "holy ones" is taken from the Old Testament, but the spring of action is no longer fear and the coercions of an external law, but an actual indwelling of the invisible but risen Christ, who is present in the holy community for their complete sanctification, and who will ultimately reveal himself in his body which is the church. ${ }^{5}$

For the writer the spiritual man as such could not sin, but we

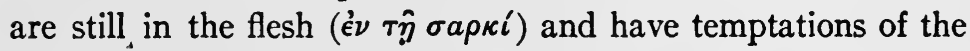
flesh, as in Gal. $4:$ I $^{-15}$, which must be overcome, and he does not count himself as having laid hold of but as pressing on to the prize, ${ }^{\circ}$ hence his practical experience taught him that those who were "spiritual" must restore such as were taken in a fault, in the spirit of meekness, lest they also be tempted, ${ }^{7}$ and discipline of the flesh was necessary to maintain the supremacy of the spirit. ${ }^{8}$ The spiritual life on earth was a conflict, and that not with things visible, but with the invisible; not simply against flesh and blood, but against spiritual wickedness, ${ }^{\circ}$ and the final triumph would come only with the appearance of the Lord and the complete establishment of the sinless age. ${ }^{10}$ The dualism of Paul is therefore ethical and not metaphysical. The flesh is only the occasion of sin and is not in itself sinful, and spiritual forces are mustered on both sides of the conflict.

1 Eph. 3 : I-19.

- Col. 1 : 24.

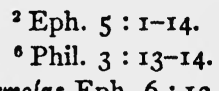

${ }^{3}$ Eph. $3:$ : 7 .

Eph. $5: 3$.

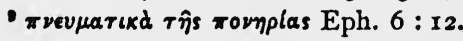

7 Gal. $6: 1$. I Cor. $9: 27$.

${ }^{10}$ I Thess. $4: 13-18$. 
About the nature of the resurrection body Paul did not care too closely to inquire; it would, however, be free from corruption and be spiritually complete. ${ }^{1}$ This hope was based upon the triumph of Christ over death and the grave, whose power and sting were $\sin ^{2}$ The ultimate triumph is ethical, and the goal the establishment of a kingdom of love and of righteousness, in which all members have their place and function, and without envy or jealousy, with Christ Jesus as the head and this community as his body."

In the application of his fundamental principle to the conduct of life, with which Paul closes all his main treatments ${ }^{s}$ and which adorn all hi letters, Paul deals largely with the personal life and the life of the small ecclesiastical community. The early Christian could not be held responsible for that social order, which Jesus and Paul rightly regarded as rapidly passing away and as in itself condemned. Any social order was, how-ever, ordained of God, and obedience to it within the limits of the primary obedience to Christ was the duty of every Christian." In the beautiful little note to Philemon returning him a slave whom Paul had converted to the hope of the gospel, Paul puts the whole relationship between man and man on such a basis that its logic excludes not only slavery but most of what to-day is held as being legitimate in the wage-relationship, as the slaverelationship was held legitimate in Paul's time.

Onesimus was to be received as a brother, and in the wellregulated family the brother is neither exploited nor devoured. Brotherhood does not exclude service, and the slave is to remain a slave if God so wills ${ }^{7}$ (Philemon $\mathrm{r}_{3}$ ), but it includes mutual service, ${ }^{8}$ and the bond is not financial profit, but love in Christ Jesus.

The holy community was one of activity, and working with the hands for daily bread was a Christian obligation in which Paul

\footnotetext{
II Cor. $15: 35-45$.

${ }^{2}$ I Cor. $15: 55-56$.

I Cor. 12: 12-31.

- I Cor. $12: 27$.

Rom. 12 : 1-15 : 4; Gal. 5 : 13-6 : 10; Eph. 4 : 25-6 : 20; Phil. 3 : 1-4 : 9;

Col. $3: 5-4: 6$

- Rom. $13: 1-6$.

7I Cor. $7: 21$.

'Philem. 19.
} 
himself had his share. So that the saying in II Thess. 3 : ro and the account there given of Paul's habit, if not from his pen, is certainly in accord with his habit and spirit.

On sexual purity Paul naturally laid great stress, as the family is with him as with Jesus the constant type of the reconstructed society, and the relationship of husband to wife the most fitting figure of the relationship of Christ to his church. ${ }^{1}$ To defile the body was, for Paul, to defile the temple of the Holy Spirit, to make a member of Christ's body impure. ${ }^{2}$ The virtues Paul emphasizes are those of spirit and heart, and the simple daily life of the average convert is glorified by making it a communion with God in Christ Jesus.

When one contrasts the ideal character as drawn from Paul's letters with any reasonable fulfilment of Plato's ideal, one is struck with the softer, tenderer, more child-like conception. The self-centred, almost haughty, aristocratic righteousness of the good man, the just citizen, the noble patriot, the loving friend, and true seeker after truth in Plato's dialogues seems cold and beautiful as a Grecian marble, compared to the loving gentleness of the Christian ideal. Not indeed that Paul's picture is fulfilled either in the feminine type or the monkish ideal, but in the warmer, softer lines we recognize a distinctly new ethical ideal emerging from the religious enthusiasm born of his contact with Christ Jesus.

His picture of the relation of husband to wife, of child to parent, of fellow-Christian to fellow-Christian, whether bond or free, of citizen even to the oppressive and passing social order, is entirely different from any painted even on the heights of Roman Stoicism or amidst the beauties of Platonic ideals.

Most striking and impressive is the vision of God in the face of Christ Jesus as Paul saw and proclaimed him. The righteousness of God is no legal exactness, no unrelenting enforcement of holy law. God's grace is free; we are the free sons of a Father whose love has been not only exhibited but poured out in the life and blood of his Son, and what that Father longs for is our

\footnotetext{
${ }^{1}$ Eph. 5 : 22-33.
}

${ }^{2}$ I Cor. $6: 12-20$. 
sanctification, that we may be companions of his holiness and sit together in heavenly places with Christ Jesus.

This is not the place to discuss especially the dogmatic system of the Pauline letters. It is easy to show that as we have them Christology is not quite clear or self-consistent, and that the doctrine of redemption moves in lines still Judaistic. Perhaps had we more of Paul's teaching, or had it in a less polemical form, some things now obscure might be cleared up, though it is equally possible that more difficulties would arise.

Such was Paul's genius and so lofty and splendid his ethical point of view that he could not make room for the real difficulties his doctrine of ethical freedom raises. We all come out from authority timidly and looking back to the easy flesh-pots of past slavery. Few men shake off the chains wholly. The strain is tremendous, and Paul's poor little household churches seemed from any past race-experience wholly unfitted for the struggle. Paul's faith was in the supernatural indwelling grace of the forgiven life, but more than once he had to appeal to his own authority and even to threaten with spiritual penalty. But where, then, is the spiritual independence? Who is to decide between Paul claiming independence of even the apostles, ${ }^{1}$ and some prophet claiming independence of Paul? The church was to try the spirits whether they were of God or not, but by what standard? The only answer Paul could give was "by my gospel." Paul himself had to go back to a tradition for the administration of the communion feast, as "received from the Lord," 2 and even with him the traditions were not lightly to be despised. He himself felt that even while throwing aside a whole system of past legal enactment, in some way its perfection and completeness had to be maintained and defended.

Practically Paul seems to have sought to answer the question along the only lines possible. He founded organizations charged with the task of oversight and control. He could not foresee that there would arise out of this organization a legalism and spiritual tyranny as oppressive as the synagogue ever was, and

2 Gal. 2 : I-2I.

${ }^{2}$ I Cor. II : 23-29. 
vested with completer political and judicial powers than was ever the Sanhedrin. The ethical systems of Jesus and Paul are for mature minds. Undeveloped human life lends itself to tyranny, the weak long for shifted responsibility, the strong eagerly grasp the opportunity for exploitation.

Jesus founded no church and laid no stress on any ritual or sacramentarian system, but Jesus was taken from his followers before the movement compelled organization. Paul and the apostles were faced by conditions that compelled organization, and the ethical system of Paul presupposed an organization sufficiently sanctified and transformed by vital union with the redeeming purpose of God in Christ Jesus to be entrusted with loving fraternal authority, as he felt he could himself be intrusted with the paternal authority, an authority that has as its goal not feeding children always with milk, but developing men and women free in Christ Jesus to do righteousness.

The early Christians, however, were not freemen, they were only freedmen. Paul was not understood, ${ }^{1}$ and his words were wrested by more than the ignorant and unsteadfast. To some the freedom in Christ Jesus meant, in spite of all Paul could do, license and antinomianism; to others his organization was a permanent source of power not for the training of independent spiritual life, but for holding in spiritual subjection, of course for their professed ultimate good, men and women.

In all ages multitudes readily seek refuge from distracting but educative questioning in the dogmatisms of priestly and legal systems. Paul himself had sought peace in such surrender to a hierarchy. It was the last thing his spirit would have desired to establish again another hierarchy as exacting. Yet that is exactly what happened. In the system of Paul are the germs of all that came after. For weal or woe an organization sprang up that would have been an historic impossibility without his activity, which changed the dynamic into status, and gave to the world the hierarchy whose ethical systems it will become later our task to take up.

2II Pet. 3 : 16. 
III. THE ETHICS OF THE JOHANNINE INTERPRETATION OF JESUS

As time passed the Jewish-Christian danger of narrowness and legalism had seemingly been overcome. Paul's ministry was no longer doubted, and the tragic fate of Jerusalem finally handed the hegemony of the Christian organization over to the Gentile section. At the same time the Jewish world was still the door through which Christianity was passing into the world's history, although it was now the Hellenized cosmopolitan Judaism which was scattered over the whole world, but which we know best through Philo and his following in Alexandria. ${ }^{1}$ And now the danger was a complicated one. Redemption was the theme of this religious view of the world against which, perhaps rather instinctively than with full consciousness of what it was, Paul and John protest. This redemption from darkness, error, and sin was thought of by the various sects and mysteries as essentially freedom from the body, and this freedom, it was taught, could be gained by initiation into various cults and by learning mystic formulæ in connection with equally mystic rites. Even Judaism began to identify "wisdom" with these formulæ, and to interpret its own primitive ceremonial in terms of the various astronomical and vegetal cycles which gave character to these oriental sects. ${ }^{2}$

Even Paul's own teaching of the risen Christ, known henceforth not after the flesh, ${ }^{3}$ seemed to give a common standing-

LITERATURE.-The best of the large literature is collected by Schmiedel, P. W., in Cheyne's "Encyclopædia Biblica," and by Reynolds, H. R., in Hastings's "Bible Dictionary"; $c f$. also Sanday, "Authorship and Historic Characters of the Fourth Gospel"; New York, r905.-Holtzmann, H. J.: "Johannes-Evangelium," in his "Hand-Commentar zum N. T.," 1890, and Bacon, B. W.: "The Fourth Gospel in Research and Debate," rgro. The more recent discussions are dealt with in the "Theologische Rundschau" for January, r9ro.

\footnotetext{
'Schürer, E.: "Geschichte des jüdischen Volkes," 3d ed., vol. I, pp. 187190; vol. II, pp. 21-67 and 72-175; also English translation.

2 One of the best introductions to this world of religious thought and feeling is the work already mentioned, Cumont's "Les Religions Orientales dans le Paganisme Romain," Paris, r 906.

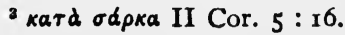


ground. The historical Jesus could be thrust aside and a divine light-giving principle placed in the foreground and identified with the risen and mystic indwelling Christ of the Pauline Christianity. Yet neither Paul nor John contemplated such a thing, and the Fourth Gospel is one long protest against this very process. This oriental intrusion was almost immediate. Gnostic Judaism was contemporary with Jesus and Paul, and even Paul had to guard his teaching from Gnostic distortion.

The Fourth Gospel is a brave protest against an unethical and essentially irreligious explanation of Jesus as a magic appearance that was not really human because humanity as flesh was evil. Jesus, he insists, was actually human, and he calls the witnesses from friend and foe to attest the reality of the man Jesus and to prove his earthly life. He also wishes to demonstrate that this historic figure is identical with the divine Person of the Pauline thought. The Johannine literature is more directly Christological than even Paul. The ethics is not so systematically developed, but a religious ethics is the central interest. The same fundamentally Jewish world of thought is at all points apparent. Ethics is in the last analysis the essential element in the religious life, and in the foreground is Paul's doctrine of the freedom from death and sin and the victory over the grave by love.

From the opening hymn to the final scene after the resurrection, the Fourth Gospel is one long protest against the resolving the historic Christian experience of God in the person of Jesus Christ into a vague metaphysics and a magic sacramental mystery. ${ }^{1}$

For this reason the Gospel summons the witnesses one after another not only to attest the historical character of Jesus, as over against Doceticism, but also that they may bear witness to what Jesus meant for them. It is Jesus in the actual flesh who has miracle-working power and can raise the dead or turn water

\footnotetext{
1 The treatment of baptism and the omission of the sacrament feast are perhaps noteworthy protests against the substitution of sacramental magic for ethical and religious life in the Hellenic and oriental mystery-worship.
} 
into wine. It is he that has power to lay down his life and to take it up again. ${ }^{1}$

The surest tests of these oriental pagan fellowships was orthodox repetition of theological formulæ and the right administration of the sacramental mysteries. John felt sure that only those who willed to do the will of the Father would even know of the knowledge ${ }^{2}$ or teaching. The essentially unethical magic of sacred places common to all primitive paganism, but elaborated by these oriental sects, the Fourth Gospel attacks in Jesus' talk with the Samaritan woman. ${ }^{3}$

The way to redemption is not magic or formulæ, but obedience to the Father's will as Jesus obeyed his Father." According to the Fourth Gospel the teaching of Jesus is very simple, and all the speculative elaboration of the oriental cult was simply obstructive. ${ }^{5}$ For the Fourth Gospel the actual ethical experience of overcoming the world and sin is bound up, not with some vague, transcendental Logos-principle, but with the actual incarnation of God in an actual human being. The chief office of the Christian is as a witness to this ethically transforming power.

There are those who cannot believe because they are of the world and the world loves its own, but hates the Father, ${ }^{7}$ and to them the exhibition of God is only to their condemnation, seeing but not believing the "works." 8 Of course there is the mystery of the pre-existent divine life becoming flesh, but this is attested by the signs and wonders, and "the witness" of those who beheld his glory.

The faith is thus based upon the impression Jesus made upon his generation, for many believed him who were afraid to say so, and upon the words and works Jesus did among men. And all classes and conditions of men are successively described as coming under this influence and accepting the claims of the

\footnotetext{
${ }^{1}$ John II : I-I6; $2:$ I-II; IO : I8.

2 John $7: 17$.

John $4: 20-25$.

John 17 and 15 .

John $3:$ i 2 .

- John $14: 25-30 ; 21:$ 15-18; I John I : $5^{-2}: 6$; and many passages.

${ }^{7}$ John $15: 18-23$. 8 John I5 $: 24$.

'John $12: 42$.
} 
Messianic messenger: John the Baptist, Philip and Nathanael, Andrew and Peter, the Ruler of a wedding feast, Nicodemus, the woman of Samaria, the nobleman of Capernaum, and so on. The content of righteousness is the loving acceptance of this manifestation of God's love as seen in the historic Jesus, and the confession not with the lips only, but in loyal surrender to him that Jesus is the Christ, is the test of discipleship. ${ }^{1}$

Without doubt we have here a serious transposition of emphasis. Orthodoxy rather than a right attitude of the heart toward the purpose of God is made the standard. As so often happens in trying to bar out the loose intellectualism of vague Neoplatonism and Jewish Gnosticism, the way is prepared for the substitution of formulæ for life. For our author it was almost unthinkable that any one should sincerely repeat the now slowly gathering catchwords of the young ecclesiasticism, and not be devoted, as was the author himself, to those ethical ideals with which he had had communion in sharing the Kingdom purpose of Jesus Christ.

The ethics of the Johannine literature is contained largely in the first letter. The criterion for the Christian life assumes a double aspect. For the author they must be held together. He who believes that Jesus is the Christ is begotten of God, and whosoever loveth him that begat loveth him also that is begotten of him." The ethics flows from this "belief," but this belief is more than an intellectual perception, it is the verdict of the heart. ${ }^{3}$ At the same time the formulæ begin to have a place which Jesus never gave them and which Paul never asserted." However, love is still an essential element of any true "belief," for if we cannot love our brother whom we have seen, we cannot love God whom we have not seen, ${ }^{5}$ and out of this fountain of love flow all the real elements of good conduct."

Ethics consists in overcoming the world by faith ${ }^{7}$ and thus possessing here and now eternal life. ${ }^{8}$ The man begotten of

2 I John'2: 23 .

-I John $4: 1-6$.

II John $5: 4-5$.
2I John $5:$ I.

I John $4: 20$.

I John 5 : 11 .
I John $3: 19-24$.

-I John 3:3-12. 
God cannot sin, and the evil one toucheth him not. ${ }^{1}$ Yet the point of view is not clear, for directions are given for dealing with the sinning brother, who sins "not unto death." For in this letter we have also that fateful beginning of a classification of sins into venial and mortal. ${ }^{2}$

If we read the literature of the early church in the light of other young enthusiasms we can understand this complete identification of opinion with conduct. It was hard for any Christian teacher to understand how we could suffer in the name of Jesus Christ, repeat the catchwords of the following, and not also share the ethical enthusiasm which lent real value to these phrases. Either test was sufficient for establishing the good-will of a disciple, either his orthodoxy or his conduct, because these could not be thought of as really separated. Exactly the same point of view appears in the time of the Reformation or to-day in the Socialist party.

The Johannine literature is aimed evidently at the beginnings of that reinterpretation of Jesus in the phrases, rites, and mysteries of the popular pagan cults round about. In this reinterpretation the catchwords of a Judaistic Gnosticism and a Hellenic syncretism were given a Christian sense, and the historic Jesus was explained away in eternal emanations, and in the identification with a creative Logos was made really a tertium quid between man and God, and all significance for human life was in danger of being lost in vague and unethical Gnostic speculation. Hence it is almost painful to find attributed to the simple-hearted Johannine author opinions he hardly understood, but so far as he did understand them desperately fought. . $^{\text {. }}$

If any one had asked the author of the first letter what he meant by the expression "greater is he that is in you," "can any one doubt that his reply would be that of the Old Testament

\footnotetext{
1 I John $5:$ is.

${ }^{2}$ I John $5: 16-17$.

"Vide Ziegler's treatment, pp. 105-114, "Geschichte der christlichen Ethik," 1892.

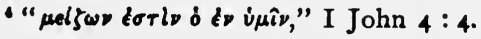


and not of Greek metaphysics? that is to say, the union is ethical, one of love and purpose, one of sonship and parentage, not one of metaphysical unity which he would neither deny nor affirm because he was no more interested in it than many of the AngloSaxon readers of these pages will be.

The heart and life of the Johannine author's faith was that in the historic Jesus God had become manifest to the world as forgiving, redeeming love, and that all who had faith to accept this appearance of God in human life as the Messiah would have worked in them the new birth and in union with the risen Christ would serve God in love and holiness.

One thing more remains to be remembered. The ethics of both Paul and John were profoundly religious, they were an impartation from above or rather the outcome of an impartation. The spirit of God came as a dynamic force into the human life, ${ }^{1}$ and thus life was sharply divided between those living the life of God, of love and righteousness; and the life of Satan, of hate, the world, and unrighteousness. The "natural virtues" were for the early Christian enthusiasts, as they have been to religious enthusiasm in all ages, but "glittering vices." There might be "sons of perdition" among the disciples, ${ }^{2}$ but sooner or later, either in doctrine or conduct or both, they would be revealed and judgment meted out to them. To import into the Johannine literature, with its simple religious view of the world, ethical, philosophical, and metaphysical subtleties born of the Grecian schools is to misunderstand its message in all the strength and weakness of its religious enthusiasm born of contact with a great religious manifestation.

NotE.-The distinctly Jewish character of John's Gospel appears in the supremacy of God as Creator of all things (I : 3 ). The Jews were "God's own" (I : II; cf. also I : 3 I), although he does not use the Pauline expression "sons of God" (ívi rov

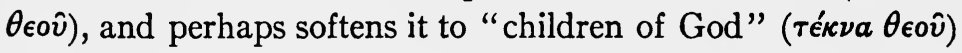
( $I: 12$ ), yet this is in obedience to strong Jewish feeling of God's

${ }^{1}$ John $3: 3-12$.

${ }^{2}$ John $17: 12$. 
supremacy and separateness. Jesus is the "only begotten"

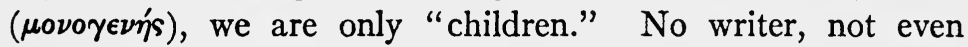
Matthew, is more insistent on the fulfilment of Scripture (I : 23; $2: I 7 ; 5: 45 ; 7: 42 ;$ I2 : I5, 38-40; I3 : I8; I5 :25; I7 : I2; I9 :24; I9 :28, $36-37 ; 20: 9$ ), or more careful to identify Jesus with the Jewish hope of the Messiah (I : $4 \mathrm{I}-45 ; 4: 22-26$ ), or dwells more on the exclusive claims of Judaism ( $4: 22 ; 7: 19$; $8: 33$ ). Even a high-priest must prophesy the truth (II $: 5 \mathrm{I}$ ), though unwittingly.

\section{THE ETHICS OF THE OTHER CANONICAL WRITINGS}

The Book of Hebrews. - The modern student finds it hard to understand how any one could ever have assigned this letter to Paul. The style, aim, and argument separate it entirely from the literature we identify with him. The question of the circle to which the letter is addressed is not so easy. ${ }^{1}$ The prevalent opinion among recent critics that it is addressed to the Gentile Christians at Rome presents many difficulties, and it seems almost easier to fall back on the older opinion that it was addressed to the free, allegorizing, Hellenistic Judaism, although not especially dealing with Gnosticism.

The special purpose is to show how the continuity of religious history is to be maintained by the right understanding of the place of faith, and the letter reflects a time when the Pauline conception of faith had been accepted although by no means fully understood.

Although the letter closes with ethical instructions ( I $_{3}: \mathrm{I}-\mathrm{I} 7$ ), and is religious-ethical throughout, its main emphasis is a working philosophy of religion; a brave attempt to demonstrate that all the spiritual values of Judaism had been conserved in the

'Cf. Zahn, Theod.: "Einleitung in das Neue Testament," 2 vols., 2d ed., Leipsic, 1900, vol. II, p. I I (English translation by M. W. Jacobus, Edinburgh, I909, 3 vols, vol. II, pp. 293-366); Harnack, A., in "Die Zeitschrift für die neutestamentliche Wissenschaft," r900, p. r6; and Holtzmann, H. J.: "Einleitung in das N. T.," 3 d ed., 1892, pp. 292-309, where literature is given very fully; Vincent, M. R.: Word Studies in the N. T., Scribner's, I900, vol. IV, pp. $36 \mathrm{I}-585$. 
Christian group. For the author faith is the assurance of things hoped for, ${ }^{1}$ and this faith joins all the heroes of religious history into a great cloud of testifiers while the runner in the race leaps forward for the prize of high calling in Christ Jesus. ' The recurring sins of fornication, money-loving, the running after "strange teachings," and injunctions about meats are all condemned, and the virtues of hospitality, visiting prisoners, obedience to rulers, and offering sacrifices of praise are commended. ${ }^{3}$

The letter is at one with the Johannine literature in the emphasis upon the oneness of the suffering historic Jesus and the risen Christ, and the making perfection in a future glory the end of the Christian life. The book deals with the question of angels as in a sense rivals of Jesus Christ, ${ }^{4}$ thus pointing to an abuse that allegorizing Judaism (Philo) was likely to foster, but the letter can hardly be classed as an anti-gnostic document.

One of the questions raised has ethical significance, although generally treated as a theological topic, namely, the significance of sacrifice. And the answer of the letter is vague and unsatisfactory. The real interest is in establishing the priestly character of Jesus rather than in using his death as symbolic of sacrifice. At this point the contacts with the Pauline and Johannine conceptions are strikingly few.

The covenant character of the sacrifice is brought out, ${ }^{\mathbf{s}}$ but the letter does not stop here; Jesus is at once sacrifice and priest. True it is that Jewish sacrifices cannot take away sin, but the one sacrifice can and does. ${ }^{7}$ How, the letter does not

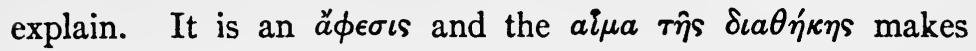
the believer holy, and is the way into a living communion with God. $^{8} \quad$ There is almost the contempt for the blood of bulls and goats characteristic of the eighth century prophets, ${ }^{\circ}$ at the same time they are done awa" with by fulfilment.

${ }^{1}$ Heb. II : I.

${ }^{2}$ Heb. II : 4-I $2: 4$.

Heb. I3 : 1-17.

- Heb. I : I-2 : I 2 ; cf. Col. 2 : r8.

- Heb. $6: 13-20 ; 7: 18-25 ; 8: 6-13 ; 9: 1 ; 11-18$.

- Heb. $10: \mathrm{r}-4$.

- Heb. 10: 18 and ro : 28-3r.

7 Heb. ro: 14.

- Heb. ro : $1-5$. 
Sacrifice has always carried with it some taint of the immoral conception of God as a demon to be feared and bribed into good nature. At the same time the significance of sacrifice as a sharing of the meal with God and thus inviting him to fellowship and communion with the tribal group is almost equally potent, and both of these conceptions color the somewhat hazy view of Hebrews. On the one hand it is linked with the turning away of God's vengeance, ${ }^{1}$ and on the other, as we have seen, it is the signal evidence of covenant relations with God. Thus sacrifice in some way cleans the conscience and prepares a way to God, but it is the living sacrifice of Jesus and not the sacrifices of beasts. This ethical interpretation of sacrifice marks an advance, although it had its distinct perils for the thought of the future church. ${ }^{2}$

James and The Revelation to John.-Two canonical books reflect almost nothing of Christianity as Paul and the author of the Fourth Gospel understood it. The contents of the Apocalypse and the letters of James have as their common interpretation of the Christian message the near coming of the Messiah, the formation of a community to await that coming in a spirit of loving brotherhood and good works. James ${ }^{3}$ may not be, probably, indeed, is not, a polemic against Paul, but it is directed against the outcome of Paul's teaching in the minds of some of his followers. The legal Jewish character of both books is quite beyond dispute, and even if we allow for the fact that no author is likely to put his whole theology into one letter, yet Luther's judgment on both books is not far wrong. Luther called James a "strawy letter" ("eine recht stroherne"), meaning dry and juiceless from the evangelical point of view.

The ethics of James is a noble and forceful statement of the loftiest morality of the Old Testament, combined with the old democracy of the Holy Community, in its best estate. It is filled

1 Heb. $10: 26-31$.

"Cf. Professor George F. Moore's article on "Sacrifice," in Cheyne's "Encyclopædia Biblica" for full exposition of the Biblical material.

2 : 14-26, particularly. 
with fine practical common sense and clear insight into the weaknesses that began to show themselves in the Christian community, such as excessive respect for any exceptionally rich man who "patronized" the Christian community. ${ }^{1}$ What that temptation was and is every observer knows. The Jewish dictum that he who offends against the law in one point is guilty of all, ${ }^{2}$ is in James $(2: 10)$ used to very different purpose from that to which Paul puts it. For Paul it was the condemnation of the whole law. For James as for Matthew (5:19) it was an incentive to still greater legal care over conduct. James, however, had no quarrel with the law of liberty, ${ }^{3}$ which had become, no doubt, a catchword of the Pauline Christianity, but with the abuses arising from identifying license with liberty.

But to combat this he goes about his task very differently and distinctly on a lower level than either Paul or John. He makes no such application of the "inborn word which is able to save," 1 as Paul makes of it in Romans. Christianity is with him an ethical ideal to be attained; with Paul it was a dynamic for attaining the ideal. The letter of James would no more set a world on fire with new ethical enthusiasm than did Seneca's "Epistolæ Morales." The letter shows no such grasp of the power of the forgiven life as is reflected in the Johannine message or the letter to Hebrews.

The same is true of the Revelation of John. All that immediately concerns us are the ethical exhortations of the first chapters ${ }^{5}$ and the closing beautiful poems of the consummation. ${ }^{6}$ All of these move on the highest plane of Old Testament enthusiasm. The exhortations are fine reproductions of eighth and seventh century prophecy, and the consummation is a noble climax to Messianic dreaming; but there is nothing distinctively Christian in the whole book as Paul and John understood Christianity. It was Christian as, no doubt, many understood Jesus, and although Paul may not be deliberately ignored in $2 \mathrm{I}: \mathrm{I} 4$, his omission from the apostolic number is significant.

\footnotetext{
${ }^{1}$ James $2: 1-13$.

‘James I : 2 I.

${ }^{2}$ Gal. 3 : 10.

${ }^{3}$ James $I: 25$.

${ }^{5}$ Chapters 2 and 3 .

- Chapters 20 to 22.
} 
The God of the Revelation is the old conception of the war god of Sinai, who comes down in wrath and power to restore the chosen Holy Community to a place of prosperity, and to reward all its sufferings with appropriate bliss.

This Holy Community is indeed no longer Jewish, but the persecuted Christian sect that has been called of God, because it saw in Jesus the Messianic hope and looked for his speedy coming in power, but without any serious change in its thought of God, because of the "Lamb of God," or any profound impression of the real force that was to transform human life and make the Messianic Kingdom possible. It moves between the poles of repentance and ultimate victory, along the path of suffering, in true Jewish fashion, the only real contact with Christ Jesus being the fact that he is the suffering Lamb already entered upon the victory and coming in power to share it with all who name his name and do his works.

The Ecclesiastical Literature.-However little Jesus may have formally organized a following it was inevitable that a fellowship should gather about his memory. The faith in his resurrection became the foundation-stone of the new organization. Its triumphant proclamation of a risen Christ called many to the new life for which Jesus stood, and the new hope of his reappearance in glory, which stirred the hearts of his disciples, and. made them ready to face danger and death in the name of their risen Master. The task of separating the materials that enter into the book of Acts may be left to the experts; we can only note that the simple Baur-Tübingen explanation of a deliberate attempt to harmonize two distinct conceptions does not explain the complicated phenomena by which the student is confronted in the New Testament literature. There were not simply two, there were many diverse tendencies, as we can see in the frequent rebukes of sectarian strife and by the way the church at Corinth was torn by faction.

More and more a strong organization arose in the minds of the leaders as a necessity for holding together the various elements. We have seen how against his great fundamental 
principle Paul found it necessary to assert himself as an outward authority, and to call upon the organization to assert its authority for the same purpose.

Whatever may have been Paul's own theoretical conceptions about his fallibility, ${ }^{1}$ he, like all great leaders, had no doubt at all about his being able to discern between the essential and nonessential elements in his teaching, and had no doubt whatsoever about the infallible character of his teaching when dealing with the essential things of faith. ${ }^{2}$ As, however, the great leaders died or were removed from the organizations they founded, the note of triumphant certainty could not be transferred to another generation, and an organization and a tradition began to take the place of the living voice, and memories of the "words of the Lord" or of directions given by the great apostles gradually became the rule of the organization's life.

The formation of a Christian morality became the immediate concern of the church. It was enormously important that the persecutions should be for righteousness' sake, ${ }^{3}$ and that the persecutors should have no excuse for their oppression. And it was all-important that when Jesus came again he should find a holy community waiting for him." For all the leaders, Paul, the authors of I Peter, I Timothy, and Matthew, obedience to even oppressive rulers within the limits of loyalty to God was a most important duty. Only such innocent suffering bound life up with the life and sufferings of Jesus; and the reality of the religious enthusiasm was alike for Paul, John, and James attested by "fruit unto holiness."

The new church was born of a divine longing for vital justice, a justice neither ritual nor philosophy had attained to, but which faith born of contact with the life and death of Jesus gave assurance of; and the new fellowship was called together to realize that justice and give to the world the Holy Community. Paul addresses himself to the "saints" or "holy ones." s

It was inevitable, therefore, that there should grow up a litera-

\footnotetext{
${ }^{1}$ As in I Cor. $7: 25$.

${ }^{2}$ Gal. 2 : Ir.

I Pet. 4 : 15-19.

'Rev. $2: 1-3: 22$.

'Rom. $16: 15$.
} 
ture based on the teachings of the great leaders, and often in their name, in which this organization was now a most conspicuous factor.

The first letter to Timothy in the name of Paul, but hardly likely to be as a whole or even in part from his pen, reflects the special moralities growing up for the church and its officers. Sound doctrine is as important as correct life, and the officers must be most especially beyond ethical reproach. ${ }^{1}$ The beginnings of a false and legal asceticism are boldly condemned. ${ }^{2}$ The freedom of the gifts is now limited by the ecclesiastical arrangements. $\quad$ Arrangements are already made for the support of those giving themselves to ruling well. ${ }^{4}$ The responsible leaders are protected by special arrangements. ${ }^{5}$

When we ask ourselves what did "sound doctrine" mean to the average ignorant early Christian, it is impossible to believe that the things that interest us as theologians had then any more than now a real place in the lives of the religious following. "Sound doctrine" meant, however, unity for a fighting organization. Early the little Christian church meant to gather from the whole world a "holy community" to prepare for the coming Utopia and to receive the Master when he came. This organization had to defend itself and give a reason for the faith that was held so firmly. ${ }^{\text {I }}$ It was quite as important that all should give the same reason as that that reason should be right. The unity of a fighting propaganda was the real reason for the gradual formation of an ecclesiastical dogma ${ }^{8}$ in which an ethics was, of course, included. The traditions had to be organized, and not Paul and Peter only; but the words of Jesus, the teachings of James and John, the traditional interpretations of the Psalms, and the usages of the early communities, had all to be woven into a unity and a self-consistent "teaching." The real interest was not theoretical, but practical, a platform on

\footnotetext{
${ }^{1}$ I Tim. $3:$ I-I3.

${ }^{2}$ I Tim. $4: x-5$.

I Tim. $4:$ i4.

I Tim. $5: 17-18$.

I Tim. 5 : 19.

- Matt. 28 : 19.
}

I Pet. $3: 15$.

"Cf. art., "Socialism as a Rival of Organized Christianity," "North American Review," June, r904. 
which to stand and a definite picture of the future hope. In the Gospel of Matthew we have also the beginnings of this ecclesiastical programme. The words of Jesus are taken out of their historical setting and arranged as an ethics and constitution for the coming Kingdom of Justice, ${ }^{1}$ and the law of the church begins to be based definitely upon the personal authority of the apostles. $^{2}$

In Paul the one intense longing was for personal holiness; to the vast mass to whom he addressed himself the longing was not so much for their own personal holiness as for a world without the wrongs and hardships other people's unholiness brought upon them. For Jesus and Paul, as for John also, righteousness and peace with God were eternal life. For the vast mass of Christians righteousness was a condition on which an eternal life could be secured, and eternal life was the new era of social justice, when the possessionless working class would enter upon its rights, joys, and rewards. The Gospel of Luke is full of this hope and longing of the oppressed proletariat. ${ }^{3}$ Hence steadily the ethics of ecclesiasticism becomes a law to be imposed on others, rather than, as in the beginning, an autonomous regulation of each life by a common loving enthusiasm.

In the ecclesiastical portions of Matthew and Luke, and in I and II Timothy, I and II Peter (including Jude), and in the Christian material in Revelation, we come more and more in contact with a law-giving organization to take the place of a dynamic spiritual principle. Nor was it possible for Paul the great organizer to overlook this obvious need. The dynamic spiritual voice, when it failed or grew weak, must be strengthened or even supplanted by the law-giving organization. ${ }^{4}$ The essential difference between law and ethics is the character of the coercion. For law external coercion is essential, for an ethical compulsion the coercion must be internal.

1 Matt. 5, 6, and \%.

${ }^{2}$ Matt. I6 : 17-18.

'Cf. Rogge, C.: "Der irdische Besitz im Neuen Testament," I897, and Cone, Orello: "The Rich and the Poor in the New Testament," New York, rgo2.

- I and II Corinthians and the Captivity Epistles. 
True the early church had no force of a physical character to enable it to transform its ethics into law, but the force of the communal ban ${ }^{1}$ was even by Paul used evidently as a powerful external coercion; and more and more as fellowship with the Christian church cut a man off from other life and social contacts did the communal ban become a terrible instrument of external coercion.

Let, for instance, in a manufacturing district in Germany, a Social Democrat who has cut himself off by his political opinions from all fellowship of an intimate character save with his fellow Social Democrats, fall under the displeasure of his group, and he has to choose between complete isolation or some kind of submission to his group.

The splitting up of the Christian church into many followings has happily robbed her of this compulsion. The excommunicated Roman Catholic either maintains his social contacts or joins a Protestant body. In the early church this was not possible. To go over to Christianity meant the severing of the most sacred ties. ${ }^{2}$ It was the strength of the early church, as of early Methodism in England or the Social Democracy in Germany, that public ridicule and official and class hatreds made those who were thus outcast dependent in a singular degree upon each other. The beautiful prayer put on the lips of Jesus in the Fourth Gospel reflects this exclusive brotherhood spirit as over against the "world" which Jesus himself came to save.

At the same time and for this very reason schism was most peculiarly weakening, for just as soon as a schismatic arose it was his intense interest and purpose to capture as large a following as possible so that social isolation would not result. ${ }^{3}$ And it was peculiarly the interest of a ban-enforcing church to make her penalty as heavy as possible. The bitterness against the schismatic was therefore tenfold greater than toward the world. So Paul does not forbid social intercourse with fornicators "of the world," but does forbid it with any Christian brother so guilty."

${ }^{1}$ I Cor. $5: 9-13$; II John Io, II; and John I7 : 9 .

2 Matt. 10 : 34-39.

${ }^{3}$ Phil. I : $15-18$.

I Cor. $5: 9-13$ 
Exactly the same forces and interests may be seen at work to-day in any manufacturing centre; where the trades-union, if fighting for life, is confronted by the same questions. The whole question of the "open shop," the "scab," and the enforcement of the boycott throws a flood of light upon the gradual transformation of a Pauline ethics into a moral coercion, and finally an ecclesiastical legalism.

The enforcement of this doctrinal and ethical unity became soon the enforcement of a mere external uniformity. Moral enthusiasm does not admit of unlimited external coercion, but does soon feel the need of regulation. And for such enforcement all the arrangements of church discipline, officers, and acknowledged authority sprang up under the direction of the leaders. ${ }^{1}$ The Pastoral Epistles only represent a little more advanced stage of the inevitable progression. To quarrel with this organization is to quarrel with the facts of human life. At the same time we must not close our eyes to the truth that, from the very inception of the early church, there were forces at work changing a moral enthusiasm into an organized and eventually a tyrannical and immoral ecclesiasticism.

Moreover the character of this authority deserves attention. The ecclesiastical canonical literature assumes an infallible leading of the spirit granted to the leaders of the movement. Paul's apostolate may have been seriously disputed, but when Paul or Apollos or Cephas had once been accepted as apostles, we may be quite sure that they wielded an authority no one in Christian circles dared to challenge. Later the "writings" given by inspiration took this place of undisputed authority. It is exceedingly unhistoric to try and import into the view of the world of the primitive Christian church the fine distinctions and -perhaps-justified doubts of a later century.

It no more occurred in that age to any devout worshipper that his authority could make a mistake and still remain an authority, than it occurs to a well-trained child that father and mother may be wrong. The moral judgments of an ethical genius of the

${ }^{1}$ Acts $6: 1-6$; $15: 1-29$; Gal. 2 : I-10; I Cor. 12:28-29, etc. 
first class like Paul had for his hearers and had for himself an absolute character. When he "felt that he had the spirit" he had no doubts as to the infallible character of his moral judgment. There were times and places when he wavered or had "no commandment," 1 but once he had established his real apostolic character, as in his letter to the Galatians, then from his moral judgments when speaking in the Spirit he felt his hearers could not safely dissent.

The New Testament literature moves in the atmosphere of these first great moral certitudes. In Hebrews "the things that were heard" ( $2: 1$ ), and in II Timothy, "the scripture inspired of God," begin, indeed, to mark the transition, but the passing over is not complete. Indeed it is never complete. For practical purposes John Wesley and Martin Luther thought themselves as fully infallible as did Paul or the author of the Fourth Gospel.

It is characteristic of the ethical judgment at its best and in its highest potency that with it goes this sense of absolute finality. On the sureness of that judgment the moralized man will stake earth and heaven, life here and hereafter (Who shall separate us? Rom. $8: 3^{8}$ ). No definition of scriptural inspiration is given within the canonical limits, but who can doubt that had it been given it would satisfy the most exacting traditionalist? And one reason why no definition was given was because of this exceeding sureness. None of the canonical books sinks to the level of a discussion of past ethical authority; in even the slightest and most doubtful contribution there is the freshness and spontaneity of ethical finality on the basis of an ethical enthusiasm that brooked no useless questioning.

The very identification of later writings with the names of the apostles marks the feeling that one infallible spirit moved upon the early church, that the religious and ethical feeling springing from this enthusiasm must be one ${ }^{3}$ and that the truth upon any point of conscience was reachable, and could be infallibly made known. Indeed the sense that it had been made

\footnotetext{
II Cor. $7: 25$.

$3: x 6$.

One Lord, one faith, one baptism, Eph. $4: 5$.
} 
known gave power and vigor to the proclamation of the ethical content that had its origin in the enthusiasm and love awakened in men's hearts by the life and death and resurrection of Him whom His disciples accepted without reservation as the founder of that new order of social and personal righteousness-the new Heaven and the new Earth men dreamed of amid the corruptions, fears, and oppressions of a rotting social state. 


\section{CHAPTER III}

\section{THE ETHICS OF THE EARLY CHURCH}

Introduction on the Types of Controlling Interest.-I. The Ethics of Unorganized Christianity: Hermas; The Letter of Barnabas; The First Letter of Clement; The Teaching of the Twelve Apostles; The Letter of Polycarp-II. The Struggle for Individualization: The formation of sects; The Ebionites; Gnosticism; The Ophites; Valentinus; Ptolemaeus to Flora; Marcion; Recognitions; HomiliesIII. The Intellectual Formulation of Christianity: Justin Martyr; Clement of Alexandria; Origen; Tertullian-IV. The Ecclesiastical Formulation of Christianity: Ignatius; Cyprian-V. The Ethical Forces of Early Christianity: Family Purity; The Economic Brotherhood; Poverty; Slavery; Martyrdom; Hospitality; Social Organization; Democracy; Education.

\section{INTRODUCTION}

Before the canonical writings as we have them were finally edited and accepted, the expectation of a speedy coming of Jesus in person had begun to grow weaker. ${ }^{1}$ In the place of this hope another interest was beginning to exercise its power. The ecclesiastical group with its own organization, aims, and life was

Literature.-The various editions of the Apostolic Fathers.-Migne: "Patrologiæ Græcæ" (Greek and Latin); vols. I-II; Paris, I857.-Funk, F. X.: "Opera Patrum Apostolicorum" (Greek and Latin); 2 vols.; Tübingen, rgor.Lightfoot, J. B.: "The Apostolic Fathers" (Greek and English); London, I89r; also in 5 vols., I889-1890.-Gebhardt, Harnack, and Zahn: "Patrum Apostolicorum Opera"; Leipsic, 1876-1878; smaller edition, Leipsic, 1877; reprinted 1894.-Hatch, Edward: "Organization of the Early Christian Churches"; London, I88I (Bampton Lectures, I880).-McGiffert, A. C.: "A History of Christianity in the Apostolic Age"; New York, 1897 (International Theological Library).-Ritschl, A.: "Die Entstehung der altkatholischen Kirche"; 2d ed.; 1857.-Müller, K.: "Kirchengeschichte"; Band I; Freiburg, I892.-Möller, W.: "Kirchengeschichte"; Band I; 2d ed.; Freiburg, 1902; English translation of

1 II Thess. $2: 2$. 
becoming an interest in itself. It was not only being organized as a great propagandist society, but it fulfilled many functions in the great human life in which it was placed. Of course the propaganda was its primary reason for existence, ${ }^{1}$ at the same time hospitality to strangers, the supply of social life to the lonely, of organized strength to the weak, of burial to the poor were all functions of the early church. ${ }^{2}$ One thing was, as we have seen (pages ror, 102) most essential. In the midst of a critical and hostile community it was of tremendous importance to maintain the outward unity of the organization. Uniformity became confused with unity, and indeed real unity was often seemingly less important in the eyes of the leaders than uniformity of conduct.

It became, therefore, wellnigh essential to gain a lasting and satisfactory basis for uniformity. The account in Acts $^{3}$ of the meeting at Jerusalem reveals the spirit and method that must have animated the early group.

For Paul the only basis for the church life consisted in possession by the Holy Spirit. This possession must, of course, result in a distinct religious-moral type, and the approach to this type could alone be a basis for effective fellowship, which is the

first edition, London, 1892.-Harnack, A.: "Lehrbuch der Dogmengeschichte"; Freiburg, 1888-1890; 3 vols.; English translation in 7 vols., Boston, 1895-1900. -Harnack, A.: "Die Mission und Ausbreitung des Christentums in den ersten drei Jahrhunderten"; Leipsic, 1902; second very much enlarged edition in 1906; English translation of the first edition by Moffatt: "The Expansion of Christianity in the First Three Centuries"; New York, 1904-1905; 2 vols.Gass, W.: "Geschichte der christlichen Ethik"; Berlin, 1881-1887.-Ziegler, Theo.: "Geschichte der christlichen Ethik"; Strasburg, 1892.-Bestmann, H.: "Geschichte der christlichen Sitte"; Nördlingen, r880-1885.-Smith, W., and Cheetham, S.: "A Dictionary of Christian Antiquities"; 1875-1880.Luthardt, C. E.: "Geschichte der christlichen Ethik." Last edition two vols. in one, 1888-1893; also English translation of the first vol. of first edition, Edinburgh, 1889.

1 Matt. 16: 13-20; $28:$ 16-20.

"Harnack, A.: "Mission und Ausbreitung des Christentums," Book II, chap. 3, pp. 105-128, ed. 1902. English translation (1904-1905), vol. I, pp. 18I-219.

I 5 : I-29. 
holy temple of the Spirit. ${ }^{1}$ No outward ritual such as baptism, ${ }^{2}$ and no ordinances or ritual days; ${ }^{3}$ no external government or even intellectual system apart from this possession by the Spirit could serve for Paul as a satisfactory basis of unity. But although Paul thought the fruit of the spirit was easily judged in its results, ${ }^{4}$ yet in point of fact, even in his own day, men claimed membership who, though very far from the ideal type, Paul himself did not care to expel from the society. ${ }^{5}$

Hence a basis for unity was sought by the church of a more definite kind than the enthusiasms on which the early teachers so largely relied. This basis was found in various interests, and the prevailing emphasis determined the peculiar type.

There were, roughly speaking, three distinct types of this emphasis made prominently central in the struggle for the uniformity and unity of the fighting organization. In historical order we may see first the Judaistic and legal moral ideal insisted upon as the central and important thing. Along with this moral ideal and interwoven with it were certain ceremonial and ritual customs, so that the high-minded Christian Jew could hardly understand how any one, for instance, could hold fast to this moral ideal as portrayed in Hermas and at the same time eat blood or things strangled. Hence the struggle, touched upon in Acts, which embittered the life of Paul was not simply a struggle for circumcision and the outward law, but for these things as symbols of a distinctly thought out moral type and ethical ideal.

In the letter of James and in Hermas this ideal may best be studied, and one realizes at once how impossible it would have been to found an enthusiastic martyr church on such a basis. The ideal is noble, cold, and formal. It can no more stir the blood than Lessing's "Nathan the Wise," however willing we may be to assent to the admirable character of the type. It involved an entirely different conception of God and estimate of sin from that of Paul's teaching. However much the actual

1 Eph. 2 : II-22.

- Gal. 5 : 16-21.
2 I Cor. I : 17 .

- Gal. 6 : 1 ; Cor. 2 : 5-11.
'Gal. 4 : ro. 
activities of the Christian life may be described in the same words, the religious ideal is most emphatically not the same.

It was, as we have seen, no intentional polemic against Paul that found its way into James, for even his use of "the faith of Abraham" was only a reference to a standard illustration of the relationship of works to trust ( $c f$. Philo's treatise, "De Migratione Abrahami," especially $\$ 16$ and 20 ); but none the less it should be quite impossible to honestly overlook the fact that the Old Catholic, or Bishop's church, had sooner or later to choose between the two conceptions of the Christian life as a basis for the establishment of a conquering organization.

The second great historical interest was speculative. To the Hellenistic mind a unified view of the world, a common theory of knowledge, and a cosmogony deeply tinged with symbolic mythology took the place that the Jew gave to a common worship, a legal system and training in a distinct moral system.

For the Jew, his cosmogony, which he probably borrowed directly from Babylon, was only a background for the exhibition of Jehovah as the Creator. For the Hellenic mind the essence of the religious life was the interpretation of the world in a speculative system of truth. To hold this truth was to know God. The attempt to translate the religious and ethical enthusiasms of the early church into a speculative system and to make that system the uniform and essential basis of the worldwide propaganda, was the work Gnosticism undertook, and it was under the pressure of this attempt that the Old Catholic church, with the help of Greek-trained minds, formulated her creed accepting and rejecting various elements, though constantly doing so with another interest than the purely intellectual one dominating her action. ${ }^{1}$

For historically a third interest triumphed. The political instinct of Roman imperialism, which makes itself felt even in Clement's first letter, had a conception of law distinctly different

${ }^{1}$ Cf. Hatch: "The Organization of the Early Christian Churches," I88r, pp. 68-72; Ritschl: "Die Entstehung der altkatholischen Kirche," 1857, pp. 347-436. 
from that of Judaism. For the Roman world law was the expression of the group life in its relation to the individual; for Judaism law was the expression of a relation of the group to Jehovah.

The collective responsibility of the group to Jehovah for the keeping of the law by the individual was exceedingly pronounced. In the thought of the early church this element was, no doubt, ever present. A holy group awaited the coming Messiah. But before long the eschatological interest ${ }^{1}$ was swallowed up in the organization interest. Law becomes the basis of the propagandist organization because it regulates the conduct of the group to the individual in the thoroughly Roman sense.

This legal regulation was all the more necessary as the church became more and more homogeneous and her influence increased. In the life of this organization slaves and women found spheres for activity forbidden them in the "secular" world. The humble slave who was no factor in the public political life of Rome or the empire could yet become an important element in the "Imperium in imperio" (Bishop Calixtus). Uniformity of political organization, uniformity of ritual and worship, uniformity of authority and life, were symbols of the world-wide character of this new imperialism, and both intellectual systems and moral ideals were important but subject in the last analysis to these high political interests and worldconquering enthusiasms.

Hence the ethical systems of the Old Catholic church from James to Augustine may be classed as belonging mainly either to the Judaistic, the Greek, or the Roman type, but with the last interest dominating. And although the three ideals are never wholly exclusive of other interests, yet the main current of ethical thought is always determined by the central interest, and often we must interpret current phrases, not in their historic or natural sense, but in the light of the interpretation put upon them by new conditions. There is a gradual assimilation of some exceedingly uncongenial elements in the prevailing dog-

${ }^{1}$ Matt. 24; Mark 13; Luke 21; Apoc., etc. 
matic construction, but the assimilation is never quite complete, and many contradictory ethical conceptions jostle one another within the system.

As a dogmatic interest gradually usurped the place of the ethical the picture becomes more and more confused, and as the political interest gradually asserted its power and forced a dogmatic uniformity upon the world, it was a queer, discordant, systemless system both in theology and ethics that became "orthodox."

One of the interesting examples of the old, essentially Jewish, conceptions of what should be the moral type on which the Christian church should build her life is found in the extraordinarily popular book, "The Pastor or Shepherd of Hermas" $(\pi \circ \iota \mu \bar{\eta} \nu)$, which enjoyed canonical or quasi-canonical authority in the early church. Irenæus, Clement, Origen, and, in his early days, even Tertullian, quote it as with authority.

\section{THE ETHICS OF UNORGANIZED CHRISTIANITY}

The Shepherd of Hermas.-In the "Shepherd of Hermas," " written about Ioo to I 50 A. D., we find a further development of that type of thought which, if not actually hostile to the Pauline interpretation of Christianity, was either perfectly ignorant of it or wholly failed to catch its real meaning. The ethical conception of Hermas is Judaism touched by the asceticism of Hellenistic thought. Righteousness consists in obedience to commandments. "Be not confounded," says the heavenly Shepherd messenger to him, "but stir up in thy mind virtue, through the

\footnotetext{
${ }^{2}$ Greek editions: F. X. Funk, Latin translation, Tübingen, I881, 2 vols.; also Otto von Gebhardt and Harnack, in "Texte und Untersuchungen," and also Latin translation, Migne, vol. II. Translation in "Ante-Nicene Christian Fathers," vol. II of the "Apostolic Fathers." German translation by J. C. Mayer, I869. Literature is very extensive; cf. Harnack's "Geschichte der altchristlichen Litteratur bis Eusebius," vol. I, pp. 49-58, for the sources and manuscripts. Text and translation in Lightfoot's "Apostolic Fathers," London, 1885,2 vols., in four parts, where also copious notes and literary references are given, with short introductions, revised texts, and translations, in one volume, London, 1891 .
} 
commandments which I am about to give unto thee." 1 These commandments are preceded by a series of rather stupid and pointless "visions." Hermas finds the Lord "angry with him" for the sins of his family, and the church in the image of an old woman delivers messages in which martyrdom is placed very high. ${ }^{2}$ Hermas wants to sit at the right hand and is rebuked; ${ }^{3}$ only those who have endured "scourgings, prisonments, great tribulations, crosses, wild beasts on account of his name" have given to them this "certain glory" ( $\delta o^{\prime} \xi a \nu \tau(\nu a)$ of sitting at the right hand. Baptism is the foundation of the church." The righteous life is filled with recurring repentance, ${ }^{5}$ and yet after baptism only one repentance is permitted. ${ }^{\circ}$ This is only one illustration of the hesitancy in the casuistry to which ethics sinks in the treatment of the "Shepherd." Another is the attitude toward marriage. One wife is permitted, but a second marriage is deplored. ${ }^{7}$ The opening scene rebukes Hermas for what surely must be interpreted symbolically, namely, longing for a wife of such beauty and grace as he once had seen in a slave girl whom he loved as a sister. ${ }^{8}$ The lesson being that even innocent love for things earthly is distracting for the soul. For the coming of the Lord is so nigh that possessions, except as affording a chance for giving alms, are a burden and a hinderance to the divine life. ${ }^{\circ} \quad$ Yet the rich man may be the elm-tree to which the vine (the poor man) clings, and by giving fruit under the elm's (rich man's) protection contributes to the rich man's salvation, "for when therefore the rich man hands out to the poor man those things he needs, the poor man prays unto the Lord for the rich man, and God grants unto the rich man all good things; because the poor man is rich in prayer, and his requests have great power with the Lord." 10 The crassness of this conception contrasts

${ }^{1}$ Vis. V, 4 .

Vis. III, c. 2, I-4. The references are to Funk's edition.

Cf. Mark ro: 35 .

- Mand., IV, c. $3,6$.

'Vis. III, c. 3, 5. Vis. III, c. 5, 2-5.

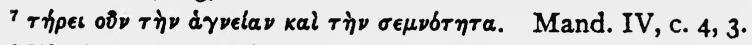

- Vis. I, c. I, I-2; of. with the interpretation in C. I, 8.

- Sim. I, I.

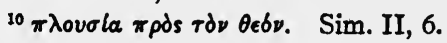


most unfavorably with James, ${ }^{1}$ and reveals the lowering of the conception of the righteous man even from the Jewish Christian point of view. ${ }^{2}$ Hermas is a lineal descendant of the James type of moral ideal, but the enthusiasm has largely departed. At the same time fasting is to be of the spirit, and the true fast is keeping one's self from evil, and making the abstinence an opportunity for giving to the poor-therefore not in itself to be too highly thought of. ${ }^{3}$ Angels play a leading part throughout, and the judgment scene is a very complicated estimate of various classes of men far removed in power and beauty from Matt. $25: 3 \mathrm{I}-45 .^{4} \quad$ As in the Apocalypse, the figure twelve plays a distinct part, ${ }^{5}$ but the apostleship is enlarged to forty, ${ }^{6}$ and a further thirty-five "Prophets and ministers of the Lord" added." The virtues are set over against the vices in an instructive way,

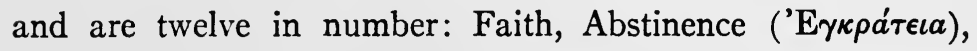

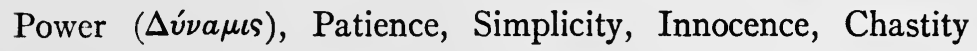
(Ayveía), Cheerfulness, Truth, Understanding, Concord, and Love: over against these are set Want of Faith ('A Intemperance, Faithlessness ('A $\operatorname{ci}_{\epsilon} \theta \epsilon \iota a$ ), Voluptuousness, then Despondency $(\Lambda \dot{u} \pi \eta)$, Malice, Lust, Anger, Lying, Stupidity

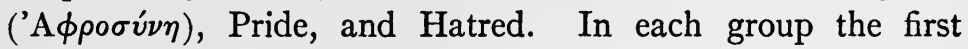
four are singled out as the chief ones, the others being below them in value. ${ }^{8}$ Baptism is a symbol of death to the old life, "For before a man receives the Name of the Son of God, he is ordained unto Death; but when he receives the seal he is freed from Death, and delivered unto Life. Now that seal is water, into which men go down under the obligation unto Death, but come up appointed unto Life." " This whole paragraph is interesting in relation to Paul's teaching of baptism for the dead, and the passage in Peter about preaching to the spirits in prison. ${ }^{10}$

For according to the Shepherd the apostles die, who "preached

12 : r-ro.

${ }^{2} C f$., however, James $5: 16$, "Prayer of a righteous man."

${ }^{3} \mathrm{Sim} . \mathrm{V}, \mathrm{I}-5 . \quad C f$. the whole Sim. VIII. $\quad 5$ Sim. IX, c. 17, 1-4.

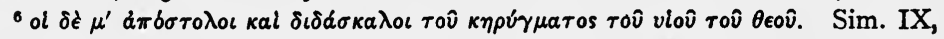
c. 15,4 .

${ }^{7}$ Sim. IX, I5.

${ }^{8} \mathrm{Sim} . \mathrm{IX}, \mathrm{I} 5,1-4$.

- Sim. IX, 16, 2-7.

${ }^{10} \mathrm{I}$ Cor. $15: 29$ and I Pet. $3: 18-22$. 
in the name of the Son of God after they had received his Faith and Power, and preached to them who were dead before, and they gave the Seal to them. They went down, therefore, into the water with them, and again came up." 1

Interesting as is the book from an historic point of view, it opens our eyes to the enormous difference between the spiritual and ethical ideals of the New Testament and the average life of the early Christian church, yet this difference between Hermas and the New Testament was felt; and although the book is freely used with the canonical writings by Clement of Alexandria, and is called by Origen a "divine writing" (Ep. ad Rom. com. $\mathrm{X}$, c. $3 \mathrm{I}$ ), yet it never really attained the spiritual and ethical influence of even its nearest progenitor in the New Testamentthe book of James.

The thoroughly Jewish character of the book is seen in not only the free use of the sacred numbers, especially twelve, but in the gross eudæmonism of its ethics. ${ }^{2}$ The ethics has room for works of supererogation. "If you do any good beyond what is commanded by God, you will gain for yourself more abundant glory, and will be more honored of God than you would otherwise be." 3 And like the Jewish ethics in general, it is a group ethics. Throughout it is the "household" that is warned, praised, and punished." Infants are innocent and holy, "for all infants are honorable before God, and are the first persons with him." 5 There is as yet no taint here of original sin as a characteristic of the body.

The contrast with the New Testament conceptions, even on their lowest levels, is striking. It compares unfavorably even with such a letter as that of Barnabas.

The Letter of Barnabas. - This general letter ascribed by

${ }^{1}$ Sim. IX, 16, 3-4.

${ }^{3}$ Loc. cit.

${ }^{2}$ Sim. V, c. 3 , and many other places.

- Vis. I, c. 3; Sim. 7, and many places.

'Sim. IX, c. 29; cf. Mark 10 : 13-16.

- Editions: F. X. Funk, 1887, vol. I; Otto von Gebhardt and Harnack, in "Texte und Untersuchungen," I878; W. Cunningham, London, I877; A. Hilgenfeld, 1877. English translation in Ante-Nicene Library, vol. I, p. 97 of "Apostolic Fathers"; also in Lightfoot's "Apostolic Fathers" are text and 
Clement of Alexandria to Barnabas, but probably incorrectly, ${ }^{1}$ is under the distinct influence of the Pauline interpretation of Jesus Christ. It breathes the Pauline spirit and uses many of his favorite phrases. "I think that I love you more than my own soul (i்tè $\tau \dot{\eta} \nu \psi \psi v \chi \eta \dot{\eta} \nu \mu o v$ ) because of the greatness of the Faith and Love that dwelleth in you," 2 The days are evil, and the virtues that are to assist faith are Fear and Patience, with Long Suffering and Abstinence as fellow-fighters, when then Wisdom, Knowledge, Prudence and Understanding will rejoice together with them. The problem of how to use the Old Testament without becoming entangled again in legalism is met with the blunt assertion that the Lord had himself rejected sacrifice by the word of the prophets, quoting Isaiah and Jeremiah as evidence that "these things therefore hath God abolished, that the new law of our Lord Jesus Christ which is without the yoke of such necessity might have an oblation not made by men." ${ }^{3}$ The coming of the Lord is near, ${ }^{4}$ and hating the evils of the present era men are to look forward to the happiness of the new era. Enoch and Daniel are quoted, and the last times warn us to "strive to the utmost of our power to keep His commandments; that we may rejoice in His righteous judgments." The fall of Jerusalem is spoken of in $4:$ I 4 and I6 $: 4$ as a warning of what will overtake unfaithfulness. The ethics of the book centre about the two ways, one of truth and the other of darkness. The formalism of circumcision is condemned, and symbolic and mystic interpretations of the Old Testament and of the passion of our Lord take the place of arguments against Jewish legalism, and are made to instruct in

translation and copious notes. Cf. also German translation by J. C. Mayer, Sources and critical aparatus in Krüger's "Geschichte der altchristlichen Litteratur," 1895, pp. 12-14; English translation by Chas. R. Gillett, pp. 18-21. New York, 1897; Harnack's "Geschichte der altchristlichen Litteratur," pp. 58-62. Cf. Weizsaecker's "Zur Kritik des Buches Barnabas," I863. The references are here to Funk's edition.

${ }^{1}$ Against the authorship by Barnabas is usually alleged that the writing displays ignorance of Jewish usage.

${ }^{2} \mathrm{x}: 4$.

$22: 6$.

$4: 3$. 
morals by unnatural and indeed impossible interpretations. Over the "ways" are appointed angels of light and angels of Satan. "One is the Lord from Everlasting, the other is the Prince of the time of Unrighteousness." 1 Then follows a short summary of the Christian life in which the virtues are enforced. Interesting is the injunction with regard to gentle treatment of the "slave who fears God," and the command to love the neighbor "better than thine own soul," 2 and the injunction, "Thou shalt not call anything thine own," and "Thou shalt communicate to thy neighbor all that thou hast. ${ }^{3}$ The Christian is also to "call to remembrance, day and night, the future judgment," and to "meditate how thou mayest save thine own soul." $\mathrm{He}$ is also to "labor with his own hands that his sins may be forgiven him." " The way of darkness is a vivid description of the sins so well known in all the history of man's transgressions, witchcraft having a prominent place in the list, ${ }^{5}$ and the special sexual sins being duly rebuked. The closing exhortation is again based upon the near expectancy of the coming of Jesus, and the firm faith in a resurrection from the dead, and a final retribution. The whole ethical tone of writing is lofty and gracious, and though below even the less important New Testament letters is full of fresh creative moral enthusiasm, its morals are still matters of life, and the outlook is on a freer and fairer world yet to come. What is most depressing is the lack of real intellectual seriousness, the failure to rationally grasp the meaning of the Old Testament religious movement, and to follow up the hints of Paul as to the real significance of the law. The arbitrary and fanciful misconstructions of the Old Testament, so prominent in this early literature, have lasted in their evil effects into our own day.

There is in the letter no such clearly cut dominant interest as we find in the letter of Clement.

The First Epistle of Clement.-The name of the author is only a matter of tradition. It is a letter sent by the Roman church
${ }^{1}$ 18 : 1 .
' 19 : 10.
2 I9: 5 .
b $20: \mathrm{r}$.
I9: 8.
21 : 1 . 
to the church at Corinth, ${ }^{1}$ and is of early date as it is used by Polycarp, and is mentioned by Hegesippus (Eusebius, "Church History," III : I6; IV : $22:$ I). It was not reckoned by Eusebius as canonical, but was highly esteemed by him. Its date may with fair certainty be said to be anywhere from about 98 to I 20 A. D. Of all the writings ascribed to Clement, this alone can be used by the historian as really reflecting the ethical development of the first centuries. To the student of ethics the letter has great significance. The political sense of the Roman church is in marked contrast to the wholly unpractical character of the Greek-Oriental speculation with its constant disputations, sects, schools, and personal followings. With the dogmatic interest of the letter we are not concerned.

The letter emphasizes the virtues of the organized life, submission to authority, humility in personal judgment, freedom from envy and ambition. Abraham is praised not for his faith but for his obedience. ${ }^{2}$ So also Lot's wife failed not in faith but in obedience or lack of concord. ${ }^{3}$ And this lack of harmony is traced throughout the Old Testament, always bringing its appropriate disaster. Pride, boasting, foolishness, and anger are especially condemned. And thus obedience to the organization is identified with obedience to God: "We should become obedient unto God rather than follow such as through pride and turbulence have made themselves leaders and authors of detestable emulation." " We see in the letter all the virtues so constantly heralded by the Roman military organization, obedience, humility, submission to authority, the unquestioning acceptance of authority, all iterated and reiterated, and see also the profound

${ }^{1}$ Greek editions are those of Funk, F. X., Tübingen, r88I; Gebhardt and Harnack, 1876; Hilgenfeld, 1876 . An English translation in the AnteNicene Library, vol. I. A German translation by J. C. Mayer. A Latin translation in Funk edition. Text, notes, and English translation in Lightfoot's "Apostolic Fathers." Full accounts of the letter are contained in Wrede's "Untersuchung zum ersten Klemensbrief," Göttingen, r897, and in Harnack's "Altchristliche Litteratur," pp. 39-47; also in Krüger's shorter work with the same title. Translation by C. R. Gillett.

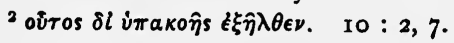

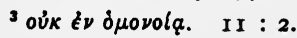

I4 : I. 
instinct underlying the demand. Peace and concord and unquestioning acceptance of the established doctrine and system were the corner-stones on which the new organization was to be built.

So again the letter goes on to emphasize the concord of the universe: "The Heavens holding fast to his appointment are subject to Him in peace." "Spring and summer, autumn and winter give place peaceably to each other." "Even the smallest creatures live together in peace and concord," 1 It remains, therefore, only to "hold fast to those to whom God has given grace," ${ }^{2}$ and to above all things avoid "love of novelty," which is placed among the abominable lusts together with "detestable pride."

Highly suggestive and characteristic is also the reference to the Roman military organization as a model for the church. "Let us consider those who fight under our leaders-what order, what obedience, with what submission they follow out the commands! All are not prefects or captains of thousands nor of hundreds, nor of fifties nor yet of tens." 3 And naturally Paul's figure is also used." Moreover regular seasons and ordered service are by no means to be neglected, ${ }^{5}$ these things are by divine appointment as "ordained by His supreme will and authority, both where and by what persons they are to be performed." " The high-priest again finds his place in the once priestless early organization and "the layman ${ }^{7}$ is confined to the things of the laity." 8 Thus all the foundations are laid for the priestly organization with its own code of morals and appropriate ethical emphasis. The letter also brings in again the abandoned sacred place. "The daily sacrifices were not offered everywhere ... but only at Jerusalem ... and there only at the altar before the temple." " It now only remains to identify the apostles with the existing ecclesiastical order and the argument

$120:$ I, 9, 10.

$230: 3$.

$37: 2$.

I I Cor. $12:$ : $2-30$, the body and the members.

$50: \mathrm{I}-2$.

$60: 3-5$.

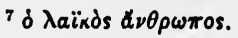

$80: 5$.

-4I : 2. 
is complete; this the writer also does. These apostles, knowing that contention would arise, "appointed persons," and when "they should die other chosen and approved men should succeed in their ministry," and "it would be no small sin in us to reject those from their ministry who holily and without blame fulfil its duties." 2 The letter of Paul is cited, and "the sedition" is condemned. There is no attempt to enter into the merits of the question; the appeal is to the authority of tradition or the Bible $^{3}$ or the appointed "presbyters." " The whole ethical horizon of the Pauline freedom of love is obscured again by the codes required for organization purposes and by the virtues needed in a closely compacted fighting propaganda. Love is sung in truly beautiful echoes of the Pauline proclamation, ${ }^{\mathbf{5}}$ but it is only the love that submits that says, "I am ready to depart; to go away whithersoever ye please, and to do whatsoever ye shall desire of me, only let the flock of $\mathrm{Christ}^{\circ}$ be in peace with the presbyters that are set over her. He that shall do this shall get to himself a very great reward in Christ, and every place will receive him." 7 Submission to the presbyters is then identified with submission to God, ${ }^{8}$ and with a very beautiful doxology the letter closes.

Lofty and beautiful as is the letter in many of its appeals, and true, and, no doubt, very essential as was its emphasis upon unity, concord, and peace, the ethics of the book is the ethics of an unquestioning submission to an outward authority. It is from Rome, and almost startles us with its anticipations of the dramatic changes that so soon overtook the ethical ideals of the spiritual kingdom of Jesus' dream.

The Teaching of the Twelve A postles. ${ }^{\circ}$-It is very tempting to deal in the contrasts between Jewish and Christian, between Greek and Roman tendencies; but one may easily be thus led

$$
\begin{aligned}
& { }^{1} 42: \text { I-5. } \quad 34: \text { I-3. } \quad 345: \text { I. } \quad 47: 6 . \quad 34 \text { and } 50 .
\end{aligned}
$$

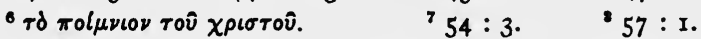

- The first edition, 1883 , by Bryennios, was followed by many editions: Harnack, I884; Hilgenfeld, I884; Wünsche, text and German translation, 1884; J. Rendell Harris, 1887 (with facsimile autotype); Philip Schaff, 1885 ; Hitchcock and Brown, 1884 ; and a literature too large for complete citation. 
astray. For the ethical student there are more imperative forces than national or even racial factors. The needs of an organization, whether in China or Japan, in England or Germany, will produce rules of conduct and habits of mind exactly resembling each other so far as the needs of the organization happen to be the same. The early church was soon a fighting organization, with a settled purpose. It had as traditions the life of Judaism, but was made up of those who belonged also to the life of Rome and Greece. The compacting force of hostile attacks compelled it to adopt a special ethics and to consolidate its life and traditions. It took freely wherever it could find that which suited its purpose. In the Teaching of the Twelve Apostles we have the consolidation process which we have seen in the Roman letter going on in the atmosphere of the more strictly Jewish tradition. For our purpose it is of little consequence to trace the relation of the "Teachings" to the "Two ways" or to the Barnabas letter. The relation is evident." As Clement's letter reminds us of Paul, the "Teaching" reminds us of James, but in both works the movement from the ethical freedom of the primitive apostolic enthusiasm to the conventional morality of an institutional life is the marked feature. The subjective and final certainties of a great moral insight begin to seek refuge in the traditions of the elders, the institutions of a church, and the conventions of a sect. This must be deplored, but we are not to suppose that any early institution ever lived on the level of Paul or John's religious convictions. The church as such never was on those heights, and without the formulation of the apostolic attainments, and the fixing of standards in an institutional life, we might never have had contact with these sources of constantly reviving enthusiasm. The church began to teach, not as Jesus and Paul had taught, but as the scribes.

The Didache deals with Christian ethics on the basis of the Matthew tradition of the teachings of our Lord, then gives liturgical instructions and ecclesiastical directions, and ends

${ }^{1}$ If the author had to have an opinion he would follow Holtzmann in thinking of a common origin for both; so also Lightfoot. 
with the expressed hope of the near coming of the kingdom in power.

It is entirely without vital contact with the Pauline interpretation of Christianity, but the omission of Paul in the "twelve" apostles only reflects perhaps unthinking usage, as in Justin Martyr's ${ }^{1}$ 39; at least there is no obvious polemic against Paul's way of thinking such as even James suggests to some. One of the obvious "organization" virtues was alms, and these are duly enforced. Hospitality was another virtue of great weight in the loosely knit community, and it is carefully

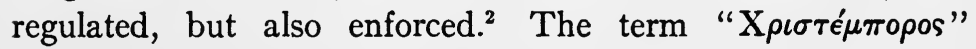
("Christ-monger"), showing how much this virtue was played upon by pretenders, and perhaps the quotation from a lost source in $1: 6$, "Let thine alms sweat ${ }^{3}$ into thy hands till thou know to whom thou shouldst give," is a hint at this same evil of promiscuous aid to the unworthy. The commandments are enlarged to forbid sins not mentioned in the Matthew source nor in the Old Testament." As in Barnabas and perhaps taken from a common source, we are bidden to love our neighbors better than ourselves, ${ }^{5}$ and the directions about the treatment of the slave recall Barnabas. ${ }^{\circ}$ They are not to have commandments laid upon them in bitterness, "lest they should not fear him who is God over both."

In chapter IV we find the organization virtues receive the emphasis: "My child thou shalt remember night and day him that speaks to thee the word of God, and thou shalt honor him

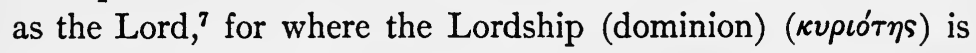
spoken of there is the Lord." 8 "Thou shalt not desire (make) division." " Thou shalt not turn away him that needeth, but shalt share all things with thy brother, and shalt not say that they (possessions) are thine own, for if you are sharers in that which

\footnotetext{
1 A pologia pro Christianis.

2 1 $2: 1-5$.
}

Accepting Bryennios's emendation of the text.

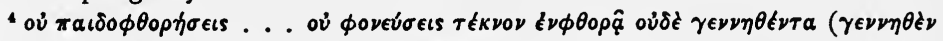

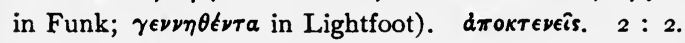

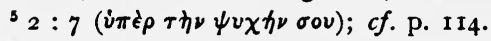

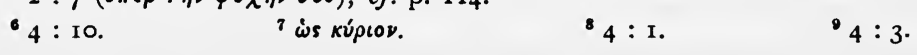


is imperishable, how much more in perishable things ${ }^{1}$ Slaves are to be subject to masters "as to the image of God." 2 "In the congregation thou shalt confess thy sins." 3

The gospel of work had become very necessary (II Thess. 3:7I2); and chapter XII refers probably not to the individual attitude so much as to the associated church life and its responsibility for the wayfarer. The exceedingly un-Pauline character of the Teaching is plain in such an admonition as "Take heed that no one lead thee astray from this way of teaching, since he teaches thee apart from God. For if indeed thou art able to bear the whole yoke of the Lord, thou shalt be perfect, ${ }^{4}$ but if thou art not able, what thou art able that do!" and "against idol-offerings be exceedingly on thy guard, for it is a sacrifice of dead gods. ${ }^{5}$ The attitude toward fasting is characteristic of the rapidly formalizing process. The fasts of the hypocrites are condemned, and are not to be kept, but on other days. The prayers are not to be as the hypocrites, but the Lord's Prayer is to be said three times a day! ${ }^{\circ}$

Forms of prayer are arranged for the sacramental seasons, but the old freedom is still permitted the "prophets." 7 The fact that wandering prophets, like the modern evangelist, often gave trouble to the regular incumbents, and were in danger sometimes of leading the church to despise the regular officers, is evident from XXI : $1-3$. And the money-making character of some of the wandering prophets is also evident. ${ }^{8} \quad$ These prophets were still the memories of the primitive and spontaneous ethical enthusiasm which, however, mingled, according to modern standards of judgment, with hysteria and with purely psychopathological elements, was yet the great force on which the movement at first rested for success.

These early prophets spoke from a subjective conviction that was for them finality, and they made a similar impression on

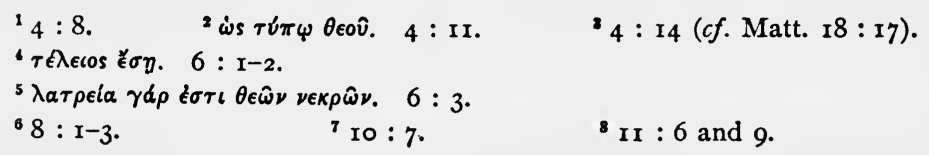


their hearers. From now on, however, their teaching had to conform more and more to certain standards, rules, and previous ethical judgments. These steadily become an increasing burden upon prophetic freedom. We saw how in I John ${ }^{1}$ a dogmatic statement about Jesus Christ begins to limit theological freedom, and now also certain ethical conceptions and postulates must be dogmatically accepted before the wandering prophet can obtain a hearing.

In the "Teaching" these begin to find their formulation, and the "prophets" are watched and tested whether they teach in accordance with a certain standard, and these standards are set by established officers. Yet the prophetic freedom can never be completely fettered, and again and again we shall see it breaking the bonds of conventional ethical estimates and seeking, sometimes rightly, sometimes wrongly, to readjust conduct to life.

In chapter XIII elaborate arrangements are made for the payment of the prophets from the "first-fruits," and on the ground that they were "high-priests," 2 thus the natural but dangerous reintroduction of the priestly conception is made to go hand in hand with the organization development. And as a consequence priestly views of ethics and a priestly morality reassert them-even on the ground Paul had most prepared. An elective priesthood is an anomaly, but as yet the bishops and deacons were elected, ${ }^{3}$ and they were to be honored with the prophets and teachers."

The time of coming judgment was still thought of as at hand, and the appearance of the Lord was an ethical motive of first importance. No past faith or conduct would be of any value if on this coming the watch was not kept "for the whole of your faith shall not profit you except in the last season ye be found perfect." 5 The closing vision is the familiar outline of apocalyptic vision as in Matt. 24:3-5I, where one can hardly

2 I John $2: 22$.

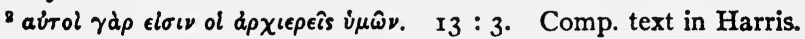

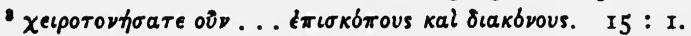

I5 : 1 .

I6: 2. 
resist the impression that here as in the Apocalypse of John we have a Jewish document used in a Christian sense." "Then shall the race of men come to the fire of testing, and many shall be offended and shall perish; but they who endure in their faith shall be saved from the curse." 2 "Then shall the world see the Lord coming upon the clouds of heaven." 3

Thus we have again an interesting mingling of the social catastrophe as a hope which stayed the hearts of despairing sufferers during the long infancy of the early church, and which moulded not only their piety, but their conceptions of right and wrong, of the values of family life, of private property, and of labor, and which only slowly gave way as an ecclesiastical organization because so identified with the social order that all thought of an entire upturning of it ceased to be attractive to the ruling class.

To this interesting chapter in the process we now turn.

The Letter of Polycarp. ${ }^{4}$ - This letter may be with fair certainty accepted as genuine, and the address, "Polycarp and the presbyters that are with him unto the church of God which sojourneth at Philippi," is, no doubt, ancient. Hence the letter must have

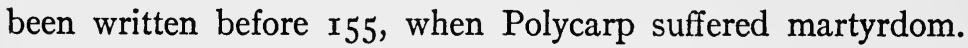
The letter breathes a gentle spirit of that loving freedom characteristic of Paul, to whose letter to the Philippians witness is borne. $^{5} \quad$ A lamentable failure of one Valens, a presbyter, calls attention to the sin of covetousness-probably Valens had misused the confidence of the church-and great emphasis is laid, therefore, by Polycarp upon the evil of this vice, and all widows, deacons, and the church generally are warned again and again

${ }^{1} C f$. the way Justin refers to the Jewish apocalyptic literature as authoritative for foretelling the future, "Apologia pro. Chris.," p. 44 .

${ }^{2} \mathrm{I} 6: 5$. ${ }^{3}$ I $6: 8$.

"Greek editions are those of Funk, F. K., with Latin translation, I88I; Lightfoot, J. B., "The Apostolic Fathers," vol. II, § 2, with notes and English translation. Also an English translation in the "Ante-Nicene Fathers," vol. I. A German translation by Mayer, J. C. Besides the histories of Harnack and Krüger, see Ritschl's "Entstehung der altkatholischen Kirche," 2d ed., I857, pp. 584-600, and an article by Cotterill, J. M., in "The Journal of Philosophy," XIX (I89I), on the "Epistle of Polycarp."

\& 3 . 
against the love of money. The young men are to submit themselves to the presbyters and deacons "as to God and Christ." 1 The ethics are centred about the duties of Christians as members or officers in the organization, yet hardly more so than in the pastoral letters (canonical). In $\S 7$ the Johannine formula for acceptance into fellowship is given, and "Every one who shall not confess that Jesus Christ is come in the flesh, is Antichrist; and whosoever shall not confess the testimony of the cross, is of the devil." But the letter has little of especial interest to the student of ethics, save as revealing the power and influence of Paul, even when his central thought had either been misapprehended or ignored; and as also showing how the enthusiasm awakened in the Christian movement formed characters of such powerful influence as was that of Polycarp, although when that enthusiasm was formulated by the enthusiast, the tremendous distance between the real life and the supposed explanation of that life becomes at once apparent.

\section{THE STRUGGLE FOR INDIVIDUALIZATION}

Introduction.-Social disorganization, whether in the modern industrial competition or in the political disruptions of a conquer-

Literature.-Baur, F. C.: "Das Christenthum und die christliche Kirche der drei ersten Jahrhunderte"; Tübingen, I853.-Baur, F. C.: English translation by Allan Menzies: "The Church History of the First Three Centuries"; 3 d ed.; 2 vols.; London, 1878-1879.-Baur, F. C.: "Kirchengeschichte der drei ersten Jahrhunderte"; 3 d ed.; Tübingen, 1863.-Baur, F. C.: "Die christliche Gnosis"; Tübingen, I835.-Lightfoot, J. B.: "Epistles to the Colossians and Philemon"; 1886.-Friedländer, M.: "Der vorchristliche jüdische Gnosticismus"; Göttingen, 1898.-Harnack, A.: "Geschichte der altchristlichen Litteratur bis Eusebius"; I893; I Teil; I Hälfte; pp. I4I-23I.-Krüger, G.: "Geschichte der altchristlichen Litteratur in den ersten drei Jahrhunderten"; 1895; pp. 43-54; English translation by Chas. R. Gillett; New York, 1897; pp. 68-96.-Hilgenfeld, A.: "Die Ketzergeschichte der Urchristentums" (particularly the second book); I884; pp. I62 ff., 230-283.-Harnack, A.: "Dogmengeschichte"; 3d ed.; I894 seq. (particularly vol. I, pp. 507-590, $603-646$, and 692 seq.); English translation by Neil Buchanan, Boston, 1895I900; vol. II, pp. 231-319, 332-378; vol. III, pp. 5I seq.-Ueberweg-Heinze: "Geschichte der Philosophie"; r898; vol. II, § 7, pp. 32-46; full literature. 
ing imperialism, produces inevitably strange sects and fellowships whose strength is that they minister to the religious hunger on its communal side. The early days of Roman imperialism were marked by restless seeking after a basis for communal unity, and it expressed itself in all manner of societies, guilds, fellowships, and cults. The strongest bonds have ever been the religious and the ethical. The state religion had largely broken down. Philosophy took the vacant place among the thoughtful and the more educated; all manner of theosophies, strange oriental cosmologies, ascetic brotherhoods, mysteries borrowed from various sources but coming to the Roman world from Greece, and many weird faiths, filled the void or tried to fill it among the less informed.

The dying pagan enthusiasms left a trail of fantastic symbolisms, and a Judaism becoming static gave the world almost equally remarkable reminders of its religious and intellectual greatness. Judaism itself was divided. There was the common type of pharisaic Judaism, as at Jerusalem, but in the time of Jesus, as in all time, Judaism had readily sought points of contact with foreign thought, and proved itself hospitable to new cultures. We have only to look at the Judaism of our own day to understand how all shades of belief were found between the "liberal" and "orthodox" Judaism of the time of Jesus.

Probably the Orient, both directly and through Hellenism indirectly, worked upon Judaism. We see in Josephus and in Philo how intelligent Jews sought to be true alike to the lofty religious and ethical instincts of the race and at the same time to maintain intellectual self-respect. For it is harsh and historically untrue to think of Josephus as a mere flatterer of Rome. The educated Jew was forced to a distinct attitude toward cultures he had to confess were in some respects superior to his own, while still maintaining the historical significance of what he knew from experience to be an unsurpassed religious life.

When Christianity sprang into being on the basis of an unshaken faith in the resurrection of the crucified Jesus, and his teachings, religious and ethical, became a power in a little group, 
moving men and women to the most devoted life of loving selfsacrifice, and to an enthusiasm for the spread of their faith, men at once asked what was this faith. An answer has been hardly given yet, and it would be absurd to think of the little primitive group really being in a position to analyze the situation, and give in a series of dogmatic propositions an intelligent philosophy of the new-born enthusiasm.

There were, however, worked out theosophies only too eager to claim as their own the Christian enthusiasm. And the world regarded the movement as simply a new Jewish sect among many such sects. ${ }^{1}$ There is plenty of indirect evidence that many would have even gladly accepted the Christian organization and given it recognition. ${ }^{2}$

There was, no doubt, a common vocabulary of religious enthusiasm, and the early Christianity of the synoptic gospels has points of contact with religious movements from which, however, it essentially differed, as Essenism, Ebionitism, etc., and perhaps with other sects of which we now know nothing.

The looking for a "parousia," the outward rite of baptism, a simple love meal, the initiation ceremonies, and various grades of instruction in ethics and ritual, all belonged to the common religious machinery of the day. We see the same process going on now. New sects arising in the United States take over with them the outward forms of the evangelical movement from which they spring in so far as these do not actually contradict the special teaching of the new movement.

It was a matter of great moment that Christianity should formulate her message far enough to disentangle her life from religious movements which employed much the same machinery but had different aims.

How this machinery took form in Judaism we are unfortunately most ignorant. Beside the temple had grown up the synagogue,

${ }^{1} C f$. Justin Martyr, "Dialogue with Trypho," chap. 80, and the seven sects there given.

${ }^{2}$ Cf. Hilgenfeld, A.: "Die Ketzergeschichte der Urchristenthums," I884, pp. 84-r6r. 
alongside the priest had arisen the scribe or learned theologian, baptism had taken its place beside circumcision, prayers took the place of sacrifice, but how this all happened we do not know. It is simply evidence of the power of adaptation in Judaism to circumstances.

Jesus was a Jew and died as one, so that it was inevitable that sooner or later Jewish sects should see in the teaching of his followers something of their own ideals. And on the other hand Paul's deliberate universalism suggested to every OrientalHellenistic cult a possible ally.

The struggle for a unified ethical ideal is therefore no simple struggle between a Pauline and Petrine party as the brilliant and still useful work of Baur would suggest. ${ }^{1}$ The syncretism of Christianity is far more complex than a simple compromise between these two forces.

The foundation for Christian ethics was laid deeply in the Old Testament. Yet after the fall of Jerusalem the influence of the narrow Judaism was almost nothing. ${ }^{2}$

The sense of continuity with Judaism did indeed give rise to some sectarian ethical ideals whose influence was, however, small. In search after an historical ideal the early church went rightly to the Old Testament, but she needed to interpret those pages for herself. We must glance at some misinterpretations. Among them were

The Ebionites. - In Irenæus's account of this heresy ${ }^{3}$ one sees that in his day those sectarians were neither feared nor much

${ }^{1}$ It is constantly tempting in reading Ziegler's most attractive but misleading "History of Christian Ethics" to enter into discussion with him where he has been misled by an hypothesis which in its original form has been practically abandoned by all schools of ecclesiastical history. But space forbids.

${ }^{2}$ Cf. Ritschl, A.: "Die Entstehung der altkatholischen Kirche," ad ed., Bonn, I857, pp. 30I-484; Harnack, A.: “Dogmengeschichte," I, 3d ed., pp. 27I-300.

3 "Adv, Hær.," I, 26, 2 and III, 21, I, where he says: "Qui autem dicuntur Ebionaii." I. Use only Matthew's Gospel. 2. Denounce Paul as recusant to the law. "Et apostolum Paulum recusant apostolum eum legis dicentes." 3 . Maintained such Jewish customs as circumcision. 4. Looked to Jerusalem as the House of God, "Quasi domus sit dei." 5. Deny the deity of Christ. 6. Deny the virgin birth. 
opposed, and what we know of their teachings ${ }^{1}$ suggests just such an interpretation of Jesus' teaching as would inevitably spring up in the early days among those influenced by Christianity in the mixed Jewish population. They, like the Essenes, may have been older than the Christian church.

The Essenes.-Against the Essenes we find no polemic in the New Testament writings, but far from this suggesting some connection between them and Jesus it surely points the other way, and implies that they lay altogether apart from the field of early Christian interest. ${ }^{2}$

The number of the Essenes seems to have been exceedingly small. It is given by Philo as only four thousand, and the verdict of Schürer is certainly to be accepted that in them on the basis of an extreme Pharisaism, Hellenistic, and more especially Pythagorean influences are to be seen working out their effects. The contrast between the teaching of Jesus and the Essenes could hardly be more complete, and the likenesses between Essenism as described by $\mathrm{Philo}^{3}$ to Christianity are due probably more to the fact that both were modified by the same Hellenistic influence than that the one borrowed from the other.

The ethics of Essenism were essentially formal and legal, that

${ }^{1}$ Cf. Hilgenfeld: "Die Ketzergeschichte des Urchristentums," r884, pp. $42 \mathrm{I}-446$.

${ }^{2}$ Hilgenfeld, A.: "Ketzergeschichte des Urchristenthums," Leipsic, r884, pp. $87-149$; F. C. Conybeare: art. "Essenes," in Hastings' "Dictionary of the Bible," vol. I, I898, pp. 767-772; Ritschl, A.: "Entstehung der altkatholischen Kirche," 2d ed., Bonn, 1857, pp. I79-203; Harnack, A.: "Dogmengeschichte," 3d ed., vol. I, p. 232, note 2; Schürer, E.: "Geschichte des jüdischen Volkes," vol. II, 3d ed., I898, pp. 556-584, vol. II, 4th ed., I907, pp. $65 \mathrm{I}-680$ (English translation, $\$ 2$, vol. II, pp. I88-2 I8, with very full literature given); Uhlhorn, G.: art. "Essener," in Herzog-Hauck "Realencyklopädie," vol. V, r898, pp. 524-527, English translation, New York, 1909, vol. IV, pp. I79-180; Jülicher, G. A.: art. "Essenes," in Cheyne's "Encyclopædia Biblica," Igor; Lightfoot, J. B.: "Epistles to the Colossians and to Philemon," 2d ed., 1876, pp. 349-4I9; Zeller, Edward: "Die Philosophie der Griechen," III, 2, 277-338, 4th ed., 1903, pp. 307-384.

3 "Quod omnes probus liber," I 2 f., and in a quotation by Eusebius, "Præpar.

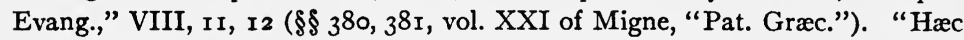
Philo in 'Apologia,' Cujus item, in eo libro, quo probus omnes liberos esse defendit hæc verba sunt," taken probably from the lost Apology. 
of Jesus inward and free. The Essenes were rendered impure by contact with even inferior members of their own order; Jesus mingled freely with publicans and sinners. The Essenes laid stress on countless washings; Jesus neither himself baptized nor permitted his disciples to be rebuked for eating with unwashed hands; what came out of the mouth defiled the man and not what he ate or drank. For the Essenes angelology was an essential element in their teaching, for Jesus it was simply the acceptance of popular speech. The Essenes were dualistic and ascetic; Jesus based his whole view of the world on the oneness of God and his complete control of the physical world, his footstool; and so little was he an ascetic that men called him a winebibber and boon companion of sinners. Jesus frequented the temple from which the Essenes were excluded. If the passages from Josephus are accepted as accurate, ${ }^{1}$ the contrast is even more striking, for there the Essenes are said to worship the sun and to maintain sexual usages completely excluded by the ethics of Jesus.

Gnosticism.-Very different must the verdict be when the question is asked what influence had Hellenistic oriental speculation upon the growing Christian church. Within the national limits that speculation had worked already with characteristic eroding force upon Jewish thought (Philo and Alexandrian Judaism). It was not possible for a force so alive and so attractive not to seek out the Christian enthusiasm as a fitting field for propaganda. New schools of thought have a common bond in the taboo of older and more highly organized and intrenched systems which resent their intrusion. There is a tendency on the part of the new movements to try and work together against the old. There was already at this time a well-defined religious language and world of thought. Christianity had in some way to be related to it; and Gnosticism was primarily the perfectly natural and indeed necessary attempt to rationalize the primary Christian enthusiasm, and to fix in-

${ }^{1} C f$., however, T. K. Cheyne's note 2 on $\$ 5$, art. "Essenes," in "Encyclopædia Biblica." 
telligently its relationship, on the one hand to the Judaism, out of which it sprang, and on the other to the Syrian-Hellenic synthetic religious world into which it came.

The attempt to fix the relation of Judaism to the Hellenic culture had begun before Christ." Indeed in the "wisdom literature" we see already the beginnings of an ethical Gnosticism, and in Paul there are the beginnings of the inevitable adjustment of Christianity to the intelligence of an outward world of philosophic thought. As we have seen, Paul was Jewish in all his fundamental thinking and only lightly touched by the Hellenistic culture whose tongue he employed and amid which he had grown up. All the more necessary was it that he should offset the "gnosis" of the Hellenistic culture by the better gnosis, which with Paul is a charismatic impartation. ${ }^{2}$ Here Paul distinguishes between the "word of wisdom" 3 and the word of knowledge, ${ }^{4}$ or rather, perhaps, he parallels the "wisdom" of the Old Testament with the "Gnosticism" after which the Greeks sought. And in Colossians he enters upon a controversy with those who would too closely identify Christianity with a system of world speculation. For those who see in Paul the beginnings of such an identification of Christianity with explanations of the world ${ }^{5}$ miss the point that what with Paul was at most a secondary interest was for Gnosticism the essence of the religious life.

As early as the first letter of John ${ }^{6}$ the church began to hedge her teachers about with formulæ which should, as we have seen, distinguish them from false teachers, and many of these were undoubtedly the Gnostic system-builders. We are, unfortunately, almost entirely dependent upon the extracts and quotations given by orthodox opponents of Gnosticism for our knowledge of its life, hope, and teaching.

What sort of picture would we get of Protestant ideal aims and ethical enthusiasms if all we knew of them were from the Roman

${ }^{1} C f$. Friedländer: "Der vorchristliche jüdische Gnosticismus," I898.

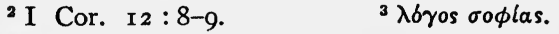

'Cf. A. Jülicher, in "Encyclopædia Biblica," art. "Gnosis."

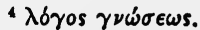

- I John $2: 22$. 
Catholic writers of the sixteenth and seventeenth centuries? Even when the apologists sought to be fair they were quite incapable of calm objectivity in their accounts. Happily a few Coptic translations have come down to us, giving a few fragments of ancient Gnostic literature, and abundantly revealing the fantastic character of all this early Gnostic teaching. An example may be seen in

The Ophites. ${ }^{1}$-Hippolytus groups under the name Ophites or Naasseni ${ }^{2}$ a number of sects whose doctrines, as he portrays them to us, and as we find them in Irenæus and in the few fragments of writings still surviving, seem to have been a strange mingling of heathen elements and Greek philosophy with Christian ethical inspirations and enthusiasms. What probably bound them together was the resistance to the growing pressure of the ecclesiastical organization. They demanded, evidently, room for boundless speculation. They were, as Harnack justly observes, the heralds of the coming theologians. They felt the power of the ethical inspiration of Jesus as seen in the church, but they were also under the spell of cosmogonies and views of the world which they felt must be intellectually unified. The symbolic interpretation of the myths of polytheism had been begun by Plato, the Greek mysteries had still further developed this escape from vulgar idolatry, now the Old Testament had to submit at the hand of friend and foe to the same process. In this attempted synthesis much that seems to us absurd had then real meaning. The vague longings, the imperfect sciences, the crude but often searching inquiries into nature and history find their expression in mystic hymns ${ }^{3}$ and

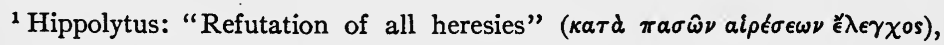
book V, chaps. I-23; Irenæus: "Adversus Hæreses," book I, chap. 30; Clement of Alexandria: "Stromateis," book III, I-4, and book IV, I2-13.

${ }^{2}$ From $\delta \phi i s$ or $\underset{T}{\operatorname{tin}}$, i. e., serpent.

${ }^{3}$ Hippolytus has preserved to us $(\mathrm{V}, 5)$ a hymn, the text of which is corrupt, but of which Harnack ("Sitzungsberichte der K. P. Akademie der Wissenschaften," 1902, Anhang II, pp. 542-545) has given a critical version; following this text, save in two small particulars, the following is a rude rendering: "Nomos was the producer of the all, the Prostitos (or firstling) was Nous, the second was of the Prostitos, chaos outpoured, the third was Psyche born of both, fulfilling
} 
secret rites. These rites and hymns sought to express the relation of God to evil, of the redemption of Jesus to the sense of forgiveness, and at the same time to give content to the loved memories of religious forms whose real meaning was either lost or deliberately rejected.

The ethical weaknesses of these fantastic speculations lie on their face. The world-view is dark and despondent. Redemption is either magical and mechanical or is a matter of intellectual perception and not of ethical struggle. Death is the evil that must be overcome and not sin. Ignorance and not moral depravity, weakness and not will, are the subjects of interest. The allegorizing of old impure rituals did not really take away the superstitious debasing character inherent in them, and the ignorant accepted the superstitions and ignored the allegorizing morality.

Indeed we may see in Irenæus and Hippolytus how, in fact, Gnosticism was bringing the superstition of Egypt, Phrygia, Assyria, Persia, Greece, and Rome under allegorized forms into the life of the early church, already too superstitious on its own account, and although all were not evil, many of these sects were actually bad and debasing. ${ }^{1}$ It would be out of place here to

the law (Harnack takes $\epsilon \rho \gamma a \zeta 0 \mu t \nu \eta$ as passive, and apparently omits $\nu \delta \mu o \nu$; Macmahon translates 'received its law of toil'). Hence in the form of a deer she (Psyche the soul), trembling, struggles with the clinging death, (his) opportunity. Now having mastery she sees the light, now in misery plunged she wails, now bewailed she rejoices, now being judged she dies, now the unfortunate one sunk in misery, wandering is canght in a labyrinth! Then says Jesus, 'See Father! a being sought out by evils far from the (life-giving) breath wanders on earth, she seeks to flee from bitter chaos, and knows not whence to fly. On account of this one send me Father, having the seals I will descend, I will

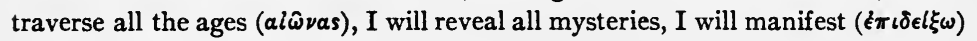
the forms of gods, the secret things of the holy way I will hand down-called gnosis."

1 The religious customs that seem to us so strange and horrible, such as prostitution in the temple and jus prima noctis, were survivals of past moralities. In early tribal life at a certain stage it was immoral for a woman to refuse herself to the men of her marriage group, and as sexual exclusiveness arose, prostitution in the temple and many other strange customs became the price paid for this exclusiveness. The religious character of the price paid rendered it permanent long after the origin had been forgotten. 
attempt to describe in detail the Peratæ, the Sethians, the Cainites, the sects founded by Simon and Justinus. Some were evidently interested in adjusting Christian inspiration to the older heathen cults, some to the Old Testament, some to Hellenic speculation. Had we fuller material a division of Gnostic sects might, perhaps, be made on this basis, but it is often hard to say how far we are dealing in the pages of Hippolytus, Irenæus, or Tertullian with caricatures and how far with actual faiths.

In some of the Gnostic sects Jehovah is thought of as an actual evil demon, in some as righteous but not merciful, in some as good but limited. According to some the world was formed against the will of the Highest God; ${ }^{1}$ according to others it represents a lower but necessary state of existence. ${ }^{2}$

Practically, in all systems, speculation seeks to mediate cosmologically between the finite and the infinite, and to identify goodness with the infinite and evil with the finite. This struggle with the problem of evil gives Gnostic its significance to the ethical student. The early church never fully overcame the intrusion of the dualistic and magical explanation of evil, and as the allegory in exegesis still haunts the theological study in refined form, so in subtle dress oriental dualism still casts its shadows over Christian explanations of evil. At the same time, the attempt, fanciful as may seem the outcome, to reconcile the existence of the God and Father of our Lord Jesus with the actual facts of sin and misery showed a deeper grasp of the inward difficulties of a religious philosophy than do some of the dogmatic orthodoxies of a growing but stiffening Catholic church.

Valentinus ${ }^{3}$ in particular may seem in the pictures of the eccle-

'Cf. Irenæus, "Adv. Hær.," II, 2, I-6. $\quad 2$ Irenæus, "Adv. Hær.," II, 8, I-2.

"Came from Alexandria to Rome under the bishopric of Hyginus, and remained for a long time in connection with Rome, establishing a school of which Ptolemæus was the head. Irenæus, "Adv. Hær.," I, 2. Tertullian, "Adv. Hær.," I, cap. 4, etc. ("Ante-Nicene Fathers," vol. III, pp. 503-520). Besides the standard histories, see the admirable article by Preuschen, E., in HerzogHauck: "Realencyklopädie," vol. 20, pp. 395-41 7; and Hilgenfeld, A.: "Ketzergeschichte des Urchristenthums," pp. 283-316. 
siasticisms of his day an exceedingly absurd teacher, more especially if we are to believe Irenæus and Tertullian, and think of him as inventing out of his own fantasy the "triads" and "monads" and "syzygies," the "æons" and the "ogdoads" which seem to us so meaningless and fanciful. But this is a false conception of the entire situation. Valentinus found these things as much a part of an intense ethically religious life as washings and circumcision and feasts were part of the intense ethical life of Judaism; and they were linked with antiquity. Indeed they were linked with an antiquity that rivalled Judaism. In default of other and more effective measures of truthfulness, the antiquity of an opinion was the standard by which it was measured. We see that in the way the "fathers" are forever citing the past traditions, and we see it in the way the Old Testament was clung to with feverish anxiety lest Christianity should be charged with being unhistoric.

The Gnostic heresy was evidently the desperate attempt to weave together two mighty impulses whose fundamental notes were the ethical longings of religious hearts. The one was the oriental despondent dualism of India and Persia, mingled with elements from Thrace and Greece, and bound together in the weird conglomerates of the mysteries of Asia Minor with Ephesus as chief centre. ${ }^{1}$ The other was the new fresh enthusiasm of the Christian church, despairing also of the present æon, but looking forward with splendid faith to a new æon in which should dwell righteousness. Valentinus evidently saw in Christianity, as he understood it, the new and long-expected revelation or reincarnation of the light-bringing Logos. Even amidst the ignorant caricatures of the ecclesiastical opponents we see how he expected in Christianity to find East and West, Asia and Rome at last united on the basis of an exceedingly elastic symbolism in one religion sweeping in all the nations. For this synthesis the allegorical method, built up in order to explain away vulgar heathenism, could also be used to explain

${ }^{1} C f$. King, C. W., "The Gnostics and Their Remains," x864, pp. r-33. 
away alike vulgar Judaism and the vulgar literal and narrow Christianity of the day.

The view of the world thus gained seems to us childish, but all the views of the world of that day seem so to us.

Tertullian lived in a demon-peopled world, surrounded by the most fantastic miracles, amid the most extravagant superstitions, and only guarded by the magic of sacramental water and sacramental rites from present peril and everlasting death. ${ }^{1}$ Between the neo-heathenism of the rising Catholic church and the fairly full-fledged heathenism of Valentinus it was, as a matter of fact, only a question of degree. But what was it that gave force to the Gnostic movement and made it under Valentinus, Ptolemæus, Basilides, Isidor, and Marcion one of the most living antagonists the Christian church had? Very suggestive is Harnack's exposition ${ }^{2}$ of the letter of Ptolemæus to Flora, a Gnostic teacher to a devout Gnostic Christian, who is troubled by the law of Moses. The letter is preserved to us, in fairly good text, by Epiphanius ("Contra Hær." 33, 8-r2, ed. Dindorfius, vol. II), and was written about I60 A. D. We have in it the key to the Gnostic symbolism. The ethics of Jesus and his view of God, as Harnack justly points out, are the standard by which the Old Testament is judged, and by that standard it is divided into three parts. One part is from God, for Jesus says, in the beginning God made man and wife: one part is from Moses, for Jesus says Moses for the hardness of your hearts, and one part is pure human tradition, for Jesus says, "Ye have made the word of God of none effect through your traditions," but even then Ptolemæus goes on to show that the lofty character of God revealed by Jesus Christ as belonging to the Eternal Father could not belong to the Jehovah of the Old Testament, hence that this Jehovah is the demiurge of creation, just and righteous, but not the Eternal Redeeming Father of Jesus Christ.

${ }^{1}$ Cf. Tertullian, "De Baptismo."

2 "Sitzungsberichte der K. P. Akademie der Wissenschaften," May I 5, 1902, pp. 505-545. 
We see at once the ethical problems with which Gnosticism struggled. It was because of their more perfect perception of the religious value of the conception of God as Jesus revealed him that made the acceptance of the growing Catholic theology difficult. It was just because of the growing valuation of antiquity ${ }^{1}$ as a standard of truth that made the ancient symbolisms of Persia and Asia Minor attractive, and it was because more and more the original ethical and religious enthusiasm that looked for another æon was being dimmed by intellectual substitutions for it, that Gnosticism was a formidable force with which the growing church had to battle.

It was not, as some have supposed, that Gnosticism presented a break with the historical continuity, but that it presented the wrong continuity. As over against Marcion and Ptolemæus the Catholic church asserted her continuity with the religious life of Judaism. To this day this attitude includes strange contradictions and quite arbitrary use of the powers of non-observation, but the instinct was truthful. The ethics of Judaism and not of the Orient; the monism of the Old Testament prophets and not even the spiritualized polytheism of India, Babylon, or Asia Minor; the optimism of the New Testament and not the despondency of theosophy were to win in the encounter which from the later letters of Paul until the council of Nicæa gave color to the whole development of the Christian life. For in these things a vital Christianity had her roots.

Did we know more of the practical ethics of the Gnostics we might find that in some things they had advanced upon the everyday morality of the official church. The Essenes denounced slavery, and the Gnostics were evidently under the influence of Buddhist pity for all animal life. And in spite of the bitterness of the attacks made by Irenæus, Hippolytus, Tertullian, and others upon Valentinus and the Gnostics generally, it was their speculation and not their conduct which aroused the zealous hate of their opponents. In fact one of the developments of

${ }^{1}$ Cf. Tertullian, “Adv. Hær.," chaps. 29, 30. 
Gnosticism was an attempt to reform the church in the interests of an extreme ascetic morality.

Marcion ${ }^{1}$ distinctly stood for the oriental dualistic worldview. This appears not simply in his sympathy with Gnosticism, but in his emphasis upon a strict asceticism and a morality that precluded any mingling with the world. Wine, the theatre, all amusements, and the delights of home were forbidden. Marcion read into Paul this oriental asceticism, and in the interests of his redemptive theory rejected the God of the Old Testament as Judaistic and legal.

In this god he saw an antagonistic principle to the Redeeming God. Matter is inherently the seat of evil, and redemption is freedom from the flesh. He was not a system-builder like the Gnostics, and his ethics are stern with self-renunciation. He favored martyrdom and looked to a gradual winning of the whole Christian church to his views. He organized his church on the basis of the first canon of sacred writings, which, however, he arbitrarily chose and mutilated. His dislike of legal Judaism was excessive.

Marcion sought to exclude even Abraham from the inheritance with the saints, ${ }^{2}$ and in very sharp criticism he tried to strip the ecclesiastical canon of the elements he disliked, and which he regarded as a corruption of the faith.

It was no mean attempt, but of course lacked all critical instruments. The excisions were arbitrary and subjective and as

1 Marcion was a rich ship-owner who as a Christian in Rome about I39 attempted to reform the local church. In $\mathrm{I} 44$ he was expelled and founded his own church, which lasted on until the sixth century. He was deeply interested in Cerdo the Gnostic, but his system is widely apart in many ways from Gnosticism. For literature, see Harnack: "Lehrbuch der Dogmengeschichte," vol. I, 3 d ed., 1894, pp. 254-27 I, English translation, I, pp. 266-285, and his article in "Zeitschrift für wissenschatliche Theologie," XIX, r876, pp. 80-r 20, "Beiträge zur Geschichte der marcionitischen Kirchen"; Müller, Karl: "Kirchengeschichte," I, I892, pp. 75-77; Möller, W.: "Lehrbuch der Kirchengeschichte," 2d ed., r902, I, pp. 158-r6r; English translation of rst ed., I, r892, pp. 148-r5o. The chief source is Tertullian versus Marcion and the attacks of the apologists Justin and Irenæus. $C f$. McGiffert's "Eusebius," p. I84, note 24.

'Irenæus, " Adv. Hær.," book IV, chap. 8. 
uncritical as the acceptance of the official church. Moreover the instinct of the official church was in the main truer, as we can now see, to the great ethical verities than was the clever but speculative and headstrong radical. In various ways the oriental character of the Gnostic thinking expressed itself. Marcion is accused by Hippolytus especially of "sorcery" and "sleightof-hand," and of carrying on "operations by demons," 1 and dealing with the eucharistic cup as a cup of enchantments. So also Carpocrates and his followers "practise magical arts and incantations, philter and love potions." 2 The Gnostics are accused in the same chapter of antinomianism. No doubt extreme libertinism and extreme asceticism marked various schools. At the same time it is dangerous to accept the assertions of ancient bigoted orthodoxy passing judgment some time after those thus condemned were dead and unable to reply. It is interesting for instance to contrast the judgment of Clement of Alexandria on Basilides and Valentinus, who probably actually knew by personal contact what they taught, with the accounts of

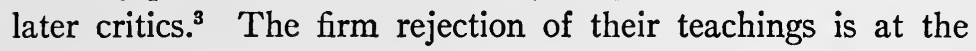
same time temperate, and even in the frank dealings with the peculiar views on sexual matters in book III there is evidence of a desire to understand and do justice to the divergent and false teaching.

Bardesanes is one of the few whose views on the philosophical question is given us. He stood for free-will as over against the mechanical views that crass dualism logically involves, but on the whole such discussions were probably carried on in too symbolic a fashion to have greatly affected the actual thinking of the church. Those who were struggling for church unity on the basis of submission to an ecclesiastical machine found their strongest foe in the intellectual independence of Hellenistic Gnosticism. If the teachings of Marcion were so utterly without historic basis, and were so entirely personal as the later apologists

\footnotetext{
${ }^{1}$ Book VI, 34 .

2 Irenæus, "Adv. Hær.," book I, 25, 3.

3 Clement of Alexandria, "Stromateis," book II, 3, 6, 8; book III, I-4; book IV, 12.
} 
are fond of making them appear, it is very remarkable how large a space he and his teachings take in the early apology of the growing Catholic church.

If the attractive suggestion of $\mathrm{McGiffert}{ }^{1}$ is accepted, we owe the so-called Apostles' Creed in its older form to the effort of the Roman church to counteract the influence of Marcion and his followers. We certainly have in the pseudo-Clementine fragments ${ }^{2}$ skilful attempts to offset in the name of Clement the dangerous division threatened by Marcion. The "Recognitions" 3 and the "Homilies" are certainly the remainders of probably a much larger literature. For our purpose the question of the literary dependence of the two on each other or on a third source is of little importance. We see here reflected an effort on the part of the rapidly organizing church to fight fire with fire, to oppose Marcion and his false gnosis by portraying Peter and the true gnosis.

Marcion claimed Paul as his authority, so Paul is ignored, though not attacked, as where the Gentiles are represented as "wholly without a champion," 4 for Simon the magician is rather Marcion than Paul, and the warning against any teacher coming without a letter from James in Jerusalem, or whomsoever would come after him, ${ }^{5}$ would not affect Paul, but did affect the Marcionite teachers.

${ }^{1}$ McGiffert, A. C., "The Apostles' Creed: its Origin, its Purpose, etc.," New York, r902.

${ }^{2}$ For the state of the texts, see Harnack and Preuschen, in "Geschichte der Altchristlichen Litteratur bis Eusebius" (1893), Erster Theil, pp. 21 2-23r.

3 "Recognitions." 'A $\nu a \gamma \nu \omega \dot{\sigma} \epsilon \iota s$. Text in Migne, "P. G." tom. I, cols. I 20II474 (whence quotations are taken), pseudo-Clementine; Gebhardt and Harnack's edition of "Apostolic Fathers": "Prolegomena," pp. xx, ff.; Lightfoot, J. B.: "The Apostolic Fathers," part r, London, r890; Hilgenfeld: "Die clementinischen Recognitionen und Homilien nach ihrem Ursprung und Inhalt dargestellt," Jena, 1848; Ritschl: "Entstehung der altkatholischen Kirche," 2d ed., Bonn, 1857, pp. 205 ff.; Uhlhorn, G.: "Die Homilien und Recognitionen des Clemens Romanus," Göttingen, 1854; cf. also his article in Herzog-Hauck, "Realencyklopädie," vol. IV, r898, pp. I63-179; English translation, New York, r900; Harnack, A.: "Lehrbuch der Dogmengeschichte," I, 3d ed, r894, pp. 294-300; English translation, vol. I, r895, pp. 31 I-332.

" "Recognitions," book III, 7 .

s "Recognitions," book IV, 35 
The ethical world in which the writers and readers of the "pseudo-Clementine" literature lived was dominated by the principle of authority. The "prophet" was indeed to be examined with due care as to whether he were really a prophet or not, ${ }^{1}$ but once the prophet was accepted then he was to be "believed in everything." 2 All sense of moral relativity is thus lost, and all moral independence is undermined. Hence for the world of the "Recognitions" antiquity had as much importance as for the High-church party of Newman's day in England, and for the same reason, in default of any true criterion of knowledge, age alone was left: hence again the value to the writers of this literature of the Old Testament.

Of course the Old Testament had to be in large part explained away; for this the Hellenistic allegorical method was of much use: then also the Gnostics, with their distinction between Moses and his laws and God and his will, were helpful. Hence in the "Recognitions" Moses and not God is said to have established sacrifice as a concession, ${ }^{3}$ reminding us of the letter of Ptolemæus to Flora and the position of Moses in his thought. Of course such acceptance of the Old Testament led to an almost extreme legalism. God's friendship is secured by living well and obeying his will. ${ }^{4}$ Indeed the difference between Judaism and Christianity is found simply in the acceptance or non-acceptance of Jesus as prophet, ${ }^{\mathbf{5}}$ and the Christology is correspondingly crude. Christ is chief by appointment over men. ${ }^{\circ}$ This approach to Judaism was made possible, no doubt, by the fact that a ritually independent Christianity was now assured and a great separation had really taken place. For instance in the "Homilies"

\footnotetext{
1 "Recognitions," book I, r6.

${ }^{2}$ The important passage reads: "Et ideo ante omnia fidem prophetæ, omni cum examinatione oportet probari; quem cum cognoveris vere esse prophetam, de reliquo cuncta ei credas oportet, nec ultra discutere eum per singula quæ docuerit, sed habere firma et sancta quæ dicit, quæque quamvis fide suscipi videantur, antehabita tamen probatione creduntur."- "Recognitions," lib. I, I6 (MPG, I, 1215 B.).

" "Recognitions," book I, 36 .

- "Recognitions," book I, 26.

s "Recognitions," book I, 43.

o "Recognitions," book I, 45.
} 
and "Recognitions" appears a surprising ignorance of Jewish economy and sects. ${ }^{1}$ Baptism is a magical cleansing, so that Clement is represented as withdrawing while Peter prays, for he had not yet been "washed from the sins committed," and works and righteousness are the way to the new kingdom, ${ }^{3}$ the gate of which is the magic Christian rite. "Let him be baptized in order that, stripped of his past evils, he may for the future become heir of heavenly blessings in consequence of his good conduct." " This raised interesting ethical questions discussed in the next book as to sins that "pollute the garment of baptism," and these are given as sins of separation from God the Father by receiving another teacher than Christ, or by thinking unworthily of the substance of the Godhead; these "fatally pollute the garment of baptism." In actions the chief sins that pollute are these: "murders, adulteries, hatreds, avarice, evil ambitions"; and the things that corrupt "at once soul and body" are, "to partake of the table of demons, that is, to eat things sacrificed (to heathen gods), or blood, or a carcass which has been strangled." 5 The line of separation is baptism rather than circumcision, but the separation is as complete. There should be no common table with those not baptized, ${ }^{6}$ and it is the water that confers salvation." 7 It alone can extinguish the eternal fires. ${ }^{8}$

The note of the literature is the separation of an organization on the basis of authority and ritual. Bishops are to be obeyed as having the place of Christ. ${ }^{9}$ There are throughout traces of the influence of Gnosticism, but the main interest is entirely separate, and the distinct teachings are more than once combated. Sin is not, for instance, in substance, for there is "no

1 "Recognitions," book I, 54, and corresponding passages in "Homilies."

2 "Recognitions," book II, I9.

4 "Recognitions," book III, 67 .

6 "Recognitions," book VII, 29.

3 "Recognitions," book II, 2 I.

5 "Recognitions," book IV, 36 .

7 "Recognitions," book VI, 9.

8 "Confugite ergo ad aquas istas, solæ sunt enim quæ possint vim futuri ignis exstinguere; ad quas qui moratur accedere, constat in eo infidelitatis adhuc idolum permanere, et ab ipso prohiberi ad aquas quæ salutem conferunt." - Loc. cit. (MPG, I, $1352 \mathrm{C}$.)

" "Recognitions," book III, 66. 
evil in substance." 1 The intellectual independence of the Gnostic literature is opposed by the mandate of authority (passage quoted). Although the main issues in Gnosticism are touched upon, namely, whence comes evil ? $^{2}$ and the question of the cosmogony, ${ }^{3}$ they are in the method of their treatment marked as side issues. So also the Christological questions that meant so much for Gnosticism are barely handled in this literature. Christ is chief among men, and evil springs from ignorance. Even the apologetic interest of Gnosticism is less emphasized. The apology is confined to the commonplace arguments familiar to all readers of the early literature. Jesus a true prophet as shown by (I) words, (2) works, (3) fulfilment of law, (4) foretold in Old Testament, and (5) awaited by all nations, etc., etc. ${ }^{5}$ The interest is the separation of an organization with a distinct life, a distinct teaching, and a distinct ethics.

This last is what concerns us, and the examination of the ethics has shown its legal and Jewish character. There are, however, still fine touches of the primitive Christian freedom. In distinguishing between the false works of the pseudo-prophets and the true works of the Christian teacher the character of the works is the determining factor. The works of the sorcerer Simon are wonderful, but those of Jesus Christ are marked by their loving redeeming quality. ${ }^{b}$ And in so far as the redeeming works are imitated, it is only because of the end of the age coming with its final and confusing tests. For the old eschatological interest still survives ${ }^{7}$ and the æon passes away and the better æon is coming, and righteousness is the bond of that coming age, so that the Christian is to "show by good works the likeness of that Father" who has begotten us. ${ }^{8}$

The real strength of this movement is still seen in such a

1 "Recognitions," book IV, 23.

3 "Recognitions," book I, 20.

5 "Recognitions," book, V, ro.

- "Ista ergo signa quæ ad salutem hominum prosunt et aliquid boni hominibus conferunt, malignus facere non potest, nisi in fine mundi tantum."-Loc. cit. (MPG, I, I308 B.) ("Recognitions," book III, 60.)

7 "Recognitions," book I, 52.
2 "Recognitions," book III, r6,

" "Recognitions," book V, 4 .
8 "Recognitions," book VI, Io. 
simple statement of faith as we find in book VIII, 47, where chastisement is thought of as part of a purifying process, "but the chastisement turns to the advantage of the pious, that, being affected in the present life, they may become more pure in the future life, in which a lasting rest is prepared for them." Thus sin and its weary restlessness is seen as the real evil of life, and the only real redemption is righteousness with its corresponding peace.

But the freedom of Paul is gone and the dynamic love of Jesus is hidden in magic rite and cumbersome organization.

\section{THE INTELLECTUAL FORMULATION OF CHRISTIANITY}

The particular view of the world which any one of us holds rests in part upon the authoritative traditions of the group in which we live and in part upon the rational reflective process working upon our own experience. Parents, teachers, companions, and all intercourse with the world supply us with a certain sum of knowledge, opinions, prejudices, and rules of conduct. In greater or less degree we seek to analyze and rationalize this heritage of ours in the light of growing experience. No one can, perhaps, ever rationalize the whole content of his heritage. We only deal with those elements of most immediate concern to us. With some the rationalizing process never proceeds very far. Between the two extremes of those who accept blindly the whole content of the tradition handed to them without any conscious rationalization at all, and those who seek to rationalize, however vainly, the whole traditional view of the world, there are all degrees of the rationalizing process.

Upon the Catholic church came the necessity of rationalizing her content of authority-given faith. A heathen world insisted upon asking questions. The authority of antiquity it offset by the claim of still greater antiquity, which claim had to be met. Moreover, this same heathen world was in possession, and could enforce with death penalty its determinations. The Christian world was forced on the defensive, and the attack was primarily upon the morals of the Christian system. 
The existing order always sees in a new religious enthusiasm a distinct danger and from its point of view rightly resists it. A new religious enthusiasm is always a danger for the existing political state, the accepted morality and the conventional way of thought. It was not the bad Roman rulers who most intelligently fought the rising power of the Christian church. In fact the far-seeing and large-hearted Marcus Aurelius struggling for unity of empire in order to resist the encroachments of the northern tribes could only see in the new faith a divisive force and a destructive influence.

And he was right. An uncompromising Christianity must involve the overthrow of all government of mere force no matter how just or how benevolent. The enemies of the cross often saw more clearly than its defenders that the logic of Christ's teachings were dangerous in the last degree to the existing order. The position of the early apologists was that it was possible to have a spiritual imperium within the worldly imperio, and that a man could be loyal to both. ${ }^{1}$ At the same time Paul's dictum (Rom. I3:1) that every soul should be subject to the higher powers was offset by the saying of Peter that the Christian had to obey God rather than men, ${ }^{2}$ and by Paul's own conduct when he came into collision with the state. The refusal to worship the imperial image was only the outward and visible evidence of a divided allegiance which the theory of Roman imperialism could no longer brook. The friction was bound to increase the wider the influence of Christian thinking and ethics became. The first reflective rationalization of the faith as over against propaganda literature or moral writings for the use of the group sprang from the need to defend the Christian teaching.

Justin Martyr ${ }^{3}$ was the first of a long line of apologists. His undoubtedly genuine extant works contain his defence,

1 Justin Martyr, Ist Apol. I7.

${ }^{2}$ Acts $5: 29$.

- Justin Martyr, he tells us, was the son of Priscus and grandson of Bacchius, Apol. I, I, who came from Flavia Neapolis, in Syria, which is the modern Samarian city of Nablous. He was born about I04, and probably suffered martyrdom under Marcus Aurelius about 165. For literature and facts of his life, consult the article by Professor Bonwetsch, in Herzog-Hauck, "Realencyklopädie," vol. 
on the one side against Judaism, in his dialogue with Trypho, and on the other against the might of Rome in his "Apologies." Interesting as is the curious Christology of the dialogue for the student of dogmatics, the ethical significance of this work is slight. The most interesting feature is the attitude taken to the law. The Mosaic ritual law is, according to Justin, given for the sake of the hard-heartedness of the Jew. Now a new law has come in Christ Jesus, of world-wide application. In some passages this would seem to be thought of as wholly moral and spiritual. ${ }^{1}$ But on the other hand baptism, the eucharist, and the simple externals of the growing Catholic church are also considered part of this law. ${ }^{2}$ Already the freedom of sonship, although proclaimed, ${ }^{3}$ is sorely straitened. Baptism is placed alongside of repentance as an external requirement, but also as a semi-magical rite. ${ }^{4}$

The whole attitude toward Judaism and the Old Testament is under the constraint of the notion of authority. In consequence the Old Testament is treated as allegory in a way that would really utterly destroy its value as an authority. The oblation of fine flour is a distinct proclamation of the eucharist, ${ }^{\mathbf{5}}$ and the bells on the high-priest's garment plainly foreshadow the twelve apostles. ${ }^{6}$ Moreover, both law and prophecy are explained away in allegory and figure.

As over against heathenism Justin denounced the gods of the nations as demons. The philosophers, however, had grasped

IX, 1901, pp. 64I-650. English translation appearing soon. For texts, see Otto's edition, 5 vols., Jena, 1876-r881, 3d ed., with Latin translation; Migne, "P. G.," tom. 6 (whose text is followed in these pages). Translations in the "AnteNicene Fathers," New York, 1896, vol. I; Engelhardt, M. von: "Das Christenthum Justins des Märtyrers," Erlangen, 1878; Ritschl, A.: "Entstehung der altkatholischen Kirche," 2d ed., Bonn, 1857, pp. 298-311; Harnack, A.: "Lehrbuch der Dogmengeschichte," 3d ed., vol. I, I894, pp. 464-470 and 482-507; English translation, II, 1897, pp. I79-166, 202-230; Harnack, A.: "Geschichte der altchristlichen Litteratur," I, I, I893, pp. 99-1 I4, 838-840, II, I, pp. 274-284, 508-5I7; Kattenbusch, F.: "Das apostolische Symbol," I 900 , vol. II, pp. 279-298 and 508-983; Krüger, G.: "Geschichte der altchristlichen Litteratur," 1895, pp. 65-72; English translation, 1897, pp. 105-116.

${ }^{1}$ Chaps. ${ }^{28-30}$ of the dialogue with Trypho.

${ }^{2}$ Chap. 4r. ${ }^{3}$ Chap. 140. 'Chap. 14. ${ }^{5}$ Chap. 41. ${ }^{6}$ Chap. 42. 
after the truth, Socrates came by wisdom with a word of truth, ${ }^{1}$ and the Christians, far from being atheists, proclaim the true God as over against the demons. ${ }^{2}$ This God is one of justice and compassion as over against the evil spirits. And the Christians are not lovers of evil but of good; if some are said to be evil Justin demands that the case be inquired into, first whether they are really.so, and also whether the evil-doers are really Christian. $^{3}$

The apology then is an ethical defence of Christianity in which Justin seeks to show that it stands for righteousness, chastity, justice, humanity, and the other qualities of divine love. In reply to the real point of the attack, namely, the incompatibility of the claims of the Kingdom of God with the claims of Rome, Justin draws a distinction between a divine and a human kingdom, ${ }^{5}$ and seeks to show that Christians are the maintainers of law and order, condemning cheats, usurers, assassins, and teaching a choice between eternal life and eternal damnation. $^{6}$ Indeed for Justin the morality of Christianity is personal. Once "we loved unchastity, now we prize chastity," once "we loved money" and "prized above all things the gain of goods, now we place all we have in the service of the whole." 7 The whole passage ending with the declaration of love for those that hate us is a very beautiful summary of the personal Christian standards. The attitude of the Christian toward the Roman state was obedience, but not of worship, and a final judgment stood higher than all earthly tribunals.

In regard to philosophy, Justin proclaims the superiority of Christianity over the best pagan thought, but admits the kinship between them. ${ }^{8}$ In the actual life of Rome, however, Justin sees the work of the demons, and his picture of Roman life is a terrible vision of iniquity. ${ }^{9}$

Over against the philosophers and poets he puts Moses ${ }^{10}$ and only the activity of demons has brought about the prohibition

\footnotetext{
${ }^{1}$ Apol. I, 5. $\quad{ }^{2}$ Apol. I, $6 . \quad{ }^{3}$ Apol. I, 7. $\quad$ Apol. I, ro.

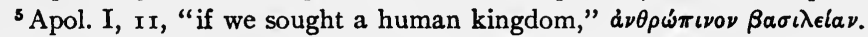

-Apol. I, I 2.

${ }^{20}$ Apol. I, 44 .

${ }^{7}$ Apol. I, I4. $\quad{ }^{8}$ Apol. I, 20.

-Apol. I, 27.
} 
of reading those books through which men might come to God. For men who lived rationally even before Christ came may be claimed as Christian. ${ }^{1} \quad$ Justin lays great stress on the freedom attained by the Christian life; the Christians are "Children of freedom and knowledge," ${ }^{2}$ and as over against the Stoics he asserts the freedom of the will, ${ }^{3}$ which freedom he finds begins in the highest sense in the waters of baptism." The end of the Christian life is "having learned the truth, that by works we may be counted good citizens, guardians of the commandments in order that we may be saved with an eternal salvation." 5

Thus Justin's main apology is based upon the dynamic character of Christianity to produce personal character and good citizenship.

Justin never seems to have given up the philosopher's gown," and his respect for ancient philosophy marks the beginning of that process of harmonizing the primitive Christian faith and enthusiasms with heathen culture which was part of the inevitable demand for a unified system of thought. As the Gnostics compelled the official church to define her theology, so the increasing number of philosophically trained minds compelled her to formulate her ethics.

Thus Justin is compelled to take up an attitude toward the ethics of the Stoics, which he finds admirable, ${ }^{7}$ and in them as in the poets the seeds of reason are found. ${ }^{8}$ But just so far forth they also have been opposed by the demons and hated and put to death. And Socrates, Heraclitus, and Musonius are evidences of this. ${ }^{9}$ The difference, however, is that the philosophers only sought and found part of the word, ${ }^{10}$ but Jesus was the whole word. Thus when Justin became a Christian he strove to be found Christian, "not because the teachings of Plato are different from those of Christ, but because they are not in all respects equal, ${ }^{11}$ as neither are those of the others, Stoics, poets,

'Apol. I, 46. 'Apol. I, 6r. 'Apol. II, 7. 'Apol. I, 6r. 'Apol. I, 65.

- "Dialogue with Trypho," chap. I, and Euseb. H. E., 4, I I, 8-ro.

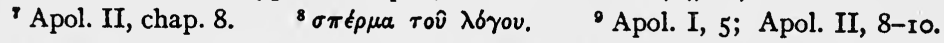

${ }^{10}$ Logos.

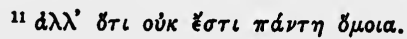


or historians. ${ }^{1}$ For Justin philosophies are the broken lights of the eternal word, the "scattered seed," whereas in Jesus there is a full revelation. At the same time there is no systematic attempt in his works to really set up a complete Christian ethical system as over against the incomplete pagan ones, and no consciousness of the real significance of Jesus Christ in a thoroughgoing Christian ethics.

The formulation of dogma was, in fact, to play a much larger part in Christian history than the formulation of an ethics, and so ethics was most rapidly swallowed up in dogmatics.

The Pseudo-Justinian Tracts addressed to the Greeks represent the attitude, no doubt, of average Christian opinion of the better-informed sort to Greek culture, and the tone differs much from Justin's. The impatience is with the sanctioned immorality of pagan mythology, and the appeal is to a final judgment. Antiquity and authority are the basis of the appeal, and the moral issue is beginning to be obscured by the identification of Christianity with a cosmogony.

The inevitable adjustment of Christian ethical enthusiasm to culture made some understanding with Hellenistic thought necessary, and this process of adjustment is seen most plainly in Clement of Alexandria. ${ }^{2}$ In Clement of Alexandria the process

${ }^{1}$ Apol. II, 13.

${ }^{2}$ Titus Flavius Clemens was born about I89, and died about 2 I I-2 I6 (Bonwetsch). His school in Alexandria was where Origen also was trained and afterward worked. For a good account of the literature, see Bonwetsch's article in Herzog-Hauck's “Realencyklopädie," vol. IV (1898), pp. 155-162; English translation, New York, vol. III, pp. I37-139; and Harnack's "Geschichte der altchristlichen Litteratur," I, I (1893), pp. 296-327; II, 2 (I904), pp. 3-23; and his "Dogmengeschichte," I (1894), pp. 33I-335, and elsewhere; English translation, II (1897), pp. 32-36. The best text is that of Bishop Potter, Oxford, I 7 I5, which is reprinted in Migne, 1857, "P. G.," VIII and IX. Oberthür, Fr., has an edition in three volumes, Würzburg, $1778-1779$. English translation in "Ante-Nicene Fathers," vol. II. German translation of the "Protreptikos," " The Pedagog," and "Quis Dives," Kempten, 1875. Winter, F. J.: "Die Ethik des Clemens von Alexandrien" ("Studien zur Geschichte der christlichen Ethik," I), Leipsic, I882. Bigg, Ch.: "The Christian Platonists of Alexandria," I886. Hort, F. J. A.: "Lectures on the Ante-Nicene Fathers," London, I895. Kaye, John.: "Some Account of the Writings and Opinions of Clement of 
of adjustment of Christian enthusiasm to Grecian culture is seen, perhaps, almost at its best. The religious-ethical spirit is still in the foreground, and an exceedingly lofty conception of God gives a strong foundation for the religious teaching.

In the "Protrepticus," 1 or "Appeal to the Greeks," ${ }^{2}$ we see a thoroughly broad-minded and tolerant apologetic in which stress is laid upon the pure and lofty ethics of Christianity in contrast to the absurdity and obscenity of the heathen mythology.

The character of God is drawn in fine and strong lines as the loving Father, "O surprising love for man! Not as a teacher speaking to his pupils, not as a master to his slaves, nor as a God to men, but as a Father does the Lord gently admonish his children." 3 The supreme goodness and power of God are the basis of a faith that shines with strong loving hopefulness. The influence of Plato is apparent. He is much praised, and the traditional Christian position that he had some contact with Moses is reasserted. ${ }^{4}$ Nor does Clement deny that some gleams of the truth are to be found in the poets, ${ }^{5}$ although we must go to the prophets for the fuller revelation. ${ }^{6}$ The appeal is strong and lofty in tone and full of learned and interesting criticism of the ethics of the Hellenic-Oriental mystery cults which were Christianity's chief rivals.

In the "Pedagogue" or "Instructor" " we find one of the early systematic treatises upon ethics, which suggests how large a literature of this character may have been lost to us as dogmatic and speculative questions forced themselves to the front, and the interest in religious-ethical questions became secondary, so that the dogmatic writings were preserved as the more important.

The influence of Musonius upon Clement has been demonstrated by Wendland. ${ }^{8}$ At the same time the very important

Alexandria," London, I835. Wendland, Paul: "Quæstiones Musonianæ de Musonio Stoico Clementis Alexandrini aliorumque auctore," Berlin, I886.

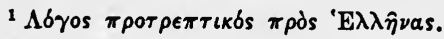

Protrepticus, IX.

- Protrepticus, VI.

2 Cohortatio ad Gentes.

- Protrepticus, VIII.

$7 \pi\llcorner\delta a \gamma \omega \gamma \delta s$

8 Wendland, Paul: "Quæstiones Musonianæ de Musonio Stoico Clementis Alexandrini aliorumque auctore," Berlin, 1886. 
differences must not be lost sight of. Clement puts in the very beginning the emphasis upon the ethical as over against the intellectual life. "His (the teacher's) aim is thus to improve the soul, not to teach it, and to train it up to the virtuous not to the rational life." 1

The very character of God which forms the basis of Clement's system separates him from the Stoic and Epicurean schools, with their aristocratic thought of God as Ruler.

But Clement separates himself also by his identification of "reason" (Logos) with the personal Christ, who has indeed inspired philosophy, but only dimly and uncertainly. Whereas we "have as our teacher him that filled the universe with his holy energies in creation, beneficence, legislation, prophecy, teaching, we have the teacher from whom all instruction comes," and therefore "need not, I think, go any more in search of human learning to Athens and the rest of Greece, and to Ionia." 2

The fact is that Clement stands exactly where scholasticism later stood. Reason must coincide with revelation. Hence philosophy is judged by revelation, and yet in philosophy rightly comprehended God does reveal himself. It is a "preparatory training for righteousness." 3 Indeed in several passages Clement puts it almost on a level with the Old Testament as a school-master to bring men to Christ."

Thus at this point Clement again separates himself from philosophy. Against Gnosticism he defends the unity of the Old and New Testaments. ${ }^{5}$ The law only inspires with fear that it may heal. "But it is the highest and best good when one can lead any one back from doing evil to virtue and well-doing, as the law does." " But at the same time this law must be interpreted in the light of the full revelation of the Logos. ${ }^{7}$ The Pauline thought of the law as a school-master, pedagogue, to bring men to Christ dominates Clement's whole system.

\footnotetext{
${ }^{1}$ Pedagogus, I, I.

- Strom. I, 5; I, 7; I, I9.

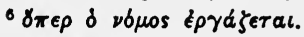

7 Pedagogus, I, I I

${ }^{2}$ Protrepticus, XI.

Strom. I, 26; I, 27.

Strom., I, 27, C.
}

Strom. I, 5.

- Loc cit. 
Thus in a sense even the Gospel is thought of as law, but a law that brings freedom. It inspires fear, but a reverential fear only. "There is a twofold kind of fear, one of which is joined with reverence, ${ }^{1}$. . as right-minded children to their parents, ${ }^{2}$ and the other is a kind of fear which is mixed with hatred, which slaves feel toward hard masters, and the Hebrews felt who made God a master not a Father." 3 Thus by a clever turn Clement answers the objection of the Gnostics who rejected Jehovah as a God of terror, on the ground that this was a Jewish misrepresentation.

Thus for Clement the Logos is the source of all ethical knowledge, and the canons of Scripture are uncritically accepted on the basis of tradition as containing the revelation, the church being an authoritative source of instruction about them, as over against mere individual opinion. ${ }^{4}$

The goal of the virtuous life is to do the will of God, "and this virtue is a state of the soul ${ }^{5}$ made harmonious by the Logos throughout the whole life." " "And the end of godliness is eternal rest in God." ?

Duties are essential only for divine discipline, "and Christian conduct is the action of the rational soul according to correct judgment and seeking after the truth, which reaches its end through the body, accompanying and struggling with it." 8 The goal is, of course, thought of strictly individually. Life is a training for immortality. ${ }^{\circ}$ The Kingdom of God in the sense in which Jesus used the term has practically no place in Clement. Even the final triumph of the ecclesiastical group is hardly a defined hope.

${ }^{1} \mu \epsilon \tau \mathrm{d}$ alठov̂s.

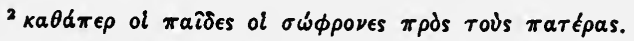

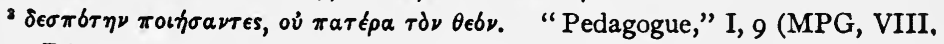
353, B.).

'Strom., VII, r6-I7.

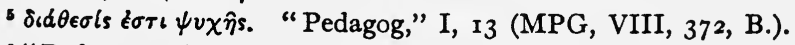

" "Pedagogus," I, I3.

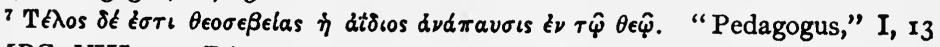
(MPG, VIII, 373, B.).

- Pedagogus, I, I3. $\quad$ Pedagog, II, 1. 
The possession of riches is a danger to the individual soul, but they can be used rationally, ${ }^{1}$ and all thought of a primitive group-communion has completely disappeared.

The content of the ethical life is a development of the Pauline ideal, and the beginnings of an elaborate casuistry found in him are still further developed by Clement. Dress, baths, shoes, rings, etc., are all described and their use by the Christian fully set forth, ${ }^{2}$ and on the whole a wise good sense dictates the various regulations suggested. At the same time the painful impression grows that the ethics of Christianity are being more and more externalized and formalized at the expense of the inner inspirations.

In regard to marriage Clement is still sane and wholesome, ${ }^{3}$ although there are indications of the coming intrusions of a false asceticism. ${ }^{4}$ The false dualism and perversions of the Gnostics are frankly disavowed, ${ }^{5}$ and indeed the whole sexual question is treated with great openness and freedom. ${ }^{6}$ Clement was a Christian gentleman, and the "true Gnostic" of Clement's pages was taught very valuable lessons about the good manners that have love as their basis and self-respect as their guardian.

True the note of increasing compromise with the thoughts and feelings of a world essentially pagan in its culture, even while it called itself Christian, marks Clement. The sense of rebellion against the "æon" ruled by Satan, and the hope of a new "æon" of lasting righteousness, is giving way to salvation by knowledge of God and right life amidst the world's follies. ${ }^{7}$ The sense of isolation from the world is not quite gone, "we have no country on earth, that we may despise earthly possessions." 8

In the practical ethics of Clement slaves were to be treated as ourselves, "for God is the same to free and to bond," ${ }^{\circ}$ and in the closing prayer the note is, "God is not a severe judge, but a good God, whom we may know."

\footnotetext{
${ }^{1}$ Pedagogus, III, 6.

- Strom. II, 23.

' Strom. VI, 8.

${ }^{2}$ Pedagog, II and III.

5 Strom. III, I.

8 Pedagog, III, 8.

${ }^{3}$ Strom. VII, I 2.

- Strom. III, I-I 7 .

- Pedagog, III, 12.
} 
Yet when all has been said the student notices how far the church has gone along the line of compromise with the existing order. Christianity is a better and nobler ethics and philosophy, but is essentially a philosophical ethics and a theoretical knowledge. The forms of ancient thought are of necessity taken over, but with them have gone many of the aristocratic and material prejudgments so interwoven with even the best pagan philosophy. The vast gulf that separates Jesus and Augustus Cæsar is bridged by a rationalizing compromise that includes not only the adaptation of Christianity to the forms of rational process, but the adaptation of her faith to an ideal that included the slavery and poverty of Rome and the splendor and injustice of imperial power.

This comes out most clearly in the third part of Clement's great treatise, the "Stromateis." Here the attempt is made to range the products of Christian enthusiasm along with literature of the pagan world. The attempt is not, indeed, to give a systematic dogmatics, but to adjust Christian thinking to the philosophy of the day in a more thorough manner than had been hitherto done. For Clement philosophies "are illuminated by the dawn of light," 1 and have "plucked off parts of everlasting truth," and he who can "bring together again the separate fragments and unify them may without danger be certain to contemplate the perfect word-the Truth."' 2 Thus the Grecian philosophy becomes a herald of the "truly royal teaching" and is "in some degree a training in one way or other, moulding the character, and preparing him who believes in Providence ${ }^{3}$ for the reception of the truth." 4 This identification of Christianity with speculative search after a world-philosophy outweighs in its historical consequences the actual results of Clement's own attempt.

The question of the existence of evil in the world is lightly and unsatisfactorily treated, ${ }^{5}$ and the cosmological interest, so uppermost in the oriental dualistic systems, is not apparent to any

\footnotetext{
1 Strom. I, 13.

${ }^{2}$ Strom. I, I3.

3 isbrocav.

' Strom. I, I6.

Strom. I, I7.
} 
great degree in Clement, but the door is opened for the entrance of an entirely new and disastrous set of interests, which were almost wholly to supersede the moral and spiritual enthusiasms on which Jesus founded his movement.

It is no accident that Clement ${ }^{1}$ arranged the elements of the Christian life under three heads, of which the first is speculative, the second the performance of the precepts thus gained, the third the forming of good men; and that the speculative elements contain many things wholly foreign to the original simplicity of the early movement.

It is, of course, to Plato and the Stoics that Clement turns for definite contact with Grecian philosophy. At the same time the dependence noted by Wendland (see above, page I49) upon Musonius and others of the Stoic school does not exclude the influence of all the various philosophies and systems of moral teaching that were jumbled together in the wide Hellenistic world. So that both to the poets and philosophers Clement owes much. Philo's influence is also seen in many places, and particularly in the allegorical interpretation of the Scripture. ${ }^{2}$

In point of fact the picture of the true Gnostic could never be taken from the pages of the Stoics alone. All hedonism is distinctly rejected. "Could we, then, suppose any one proposing to the Gnostic whether he would choose the knowledge of God $^{3}$ or eternal salvation, and if these, which are absolutely identical, could be separated, he would without the least hesitation choose the knowledge of God," 4 and Clement feels that this knowledge is ethical rather than speculative, and has clearness while in the realm of physics (metaphysics) there was distraction. ${ }^{5}$

The old immediate enthusiasm which was greater than organization or any outward authority is still for Clement the basis of the true Christian life, and not outward law, "for the righteous man's righteousness does not rest on contracts nor the commandments of law, but springs from his own spontaneous

${ }^{1}$ Strom. II, ro.

Strom. IV, 22.
2 Strom. VI, Ir.

Strom. IV, 25.

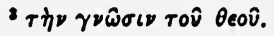


action and from his love to God." 1 And love is still the completion of knowledge.

Yet here also Clement marks a distinct change in the Christian emphasis, and we note a further advance in the transformation of Christianity from a religious-ethical enthusiasm for a kingdompurpose to an intellectual system containing many elements, some definitely hostile to that great fundamental purpose. The ethical ideal becomes individualistic, and, in spite of disclaimers, the hope of individual salvation rather than devotion to the Kingdom of God as Jesus proclaimed it makes the ethics a refined hedonism which was bound in the long run to triumph all along the line.

Origen $^{2}$ in a still more marked manner emphasizes this change that came over organized Christianity. In Origen we see Christianity thought of as a more perfect knowledge and a new key to the speculative cosmological questions which had bothered the philosophic schools. The few Greek fragments of the "De Principiis" abundantly demonstrate the activity of Rufinus in trying to make Origen conform to later conventional traditional Christianity, but on the other hand it must be admitted

Strom. VI, I5.

2 Origenes Admantius, born at Alexandria 185 or 186 , pupil there of Ammonius and of Clement, died 254. His principal works are the $\pi \epsilon \rho l$ 'A $\rho \chi \hat{\omega} \nu$ or "De Principiis," in four books, only partly existing in Greek fragments, and in a Latin paraphrase by Rufinus, who confesses to omissions, alterations, and additions (Preface by Rufinus), and his "Contra Celsum," in eight books, written in reply

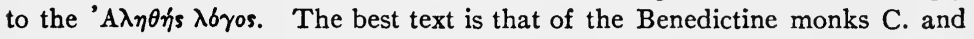
C. V. de la Rue (Paris, I733-I756), and reprinted in vols. XI and XII of Migne "P. G.," from which text the present references are taken. Translation in "AnteNicene Fathers," IV, 22I-669; IX, 289-5I2; translated by F. Crombie (and A. Menzies, vol. IX). For literature, $c f$. Harnack, A.: "Dogmengeschichte," I (I894), pp. 603-647; English translation, vol. II (I897), pp. 332-380; Krüger, G.: "Altchristliche Litteratur," pp. 107-126; English translation, 173-205; Redepenning: "Origenes: eine Darstellung seines Lebens und seiner Lehre," 2 vols., Bonn, I84I-1846; Mehlhorn, P.: "Die Lehre von der menschlichen Freiheit nach Origenes' $\pi \epsilon \rho l$ 'A $\rho \chi \hat{\omega} \nu$ in der Zeitschrift für Kirchengeschichte," II (I878), pp. 234-253; Westcott, B. F.: "Origen and the Beginnings of Christian Philosophy," in "Contemporary Review," XXXV (I879, April-August), pp. 324-338 and 489-502; Bigg, Chas.: "Christian Platonists of Alexandria," Oxford, 1886 . 
that Origen himself never wilfully departed from the traditions of the church. "Yet as the teachings of the church, in an orderly succession handed down from the apostles, and abiding up to the present day in the churches, is preserved, and that alone is to be accepted as truth which differs in no respect from ecclesiastical and apostolic tradition." 1 The interest of Origen was, as far as we can gather from the rather sparse remains of an exceedingly abundant literature, ${ }^{2}$ far more philosophical and theological than ethical. Even his homilies are theological and speculative, and he may justly be called, as Harnack says, the creator of an ecclesiastical dogmatism. For him is Christianity a revealed philosophy more complete and adequate, yet along the lines of Grecian speculation and oriental cosmology.

The wise man finds in this revealed knowledge his satisfaction, and distinctly in Origen comes to light the element of ascetic world flight. For Clement the married state was normal, and even had spiritual advantages; for Origen "God has allowed us to marry because all are not fit for the higher, that is, the perfectly chaste life." 3 For Clement also a traditional Christianity was not the bondage it was for Origen, for its lines were less distinct, its spirit still practical rather than theoretical.

For this reason Origen even more than Clement has to assume a mystical sense as a way of escape from the difficulties raised by the Old Testament. " The Scriptures were written by God's spirit, but have significance, not only such as is apparent at the first sight, but also another meaning, which eludes the attention of most readers." " It would have seemed a natural thing to assign to the Old Testament the ethical relativity and value that

1 "Illa sola credenda est veritas, quæ in nullo ab ecclesiastica et apostolica discordat traditione."-Prefatio ad "De Principiis," § 2 (MPG, XI, x I6 B).

2 Jerome says he wrote more than any individual could read (Crombie's translation [American reprint, "Ante-Nicene Fathers," vol. IV (I887), p. 229], vol. II, p. xxxiii), and Epiphanius says he wrote 6,000 volumes ( $\mathrm{Si}$ enim verum est, quod de te percrebuit, sex librorum millia a te esse conscripta, o infelix, qui inanissime desudaris, .. . ), "Hæres.," LXIV: 63 (MPG, XLI, II78 D).

3 "Contra Celsum," book VIII: 55 .

"Prefatio ad "De Principiis," §8. 
Clement as well as Origen himself assigned to Greek speculative ethics. But as the whole proof of Christ's divinity began to rest more and more upon the theoretical value of the arguments from prophecy in the Old Testament and less upon the immediate impression of his person and teachings, the more essential was it to defend the Old Testament as on the same level of direct inspiration as the writings of the New Testament.

A really truth-loving writer such as Origen could therefore only have recourse to the allegory and unnatural sense in the way Philo had taught educated Jews to think of their scriptures. ${ }^{1}$

In the interest of Origen in cosmology, the origin of evil, the problem of sin, the hierarchy of the spirit world, and an allinclusive view of the world may be plainly seen the influence of Gnosticism. At the same time, like Clement, he turns away deliberately from some of the most dangerous oriental traits of the Neoplatonic and Gnostic speculation. "No one is impure either essentially or naturally," ${ }^{2}$ and it lies within ourselves to possess either happiness or holiness. He overcomes the eternal cosmological dualism that hangs like a shadow over all Christian thinking influenced by Gnostic speculation. "We think, indeed, that through his Christ the benevolence of God may call back all his creatures to one end, even his enemies being conquered and subdued." 3 This being a far more ethical and religious solution of the problem than the relegating the God of the Old Testament to a lower plane, even if this also had a profound ethical instinct as its basis. ${ }^{4}$ Indeed the ethical insight of Origen was keen. He defends the proposition that goodness and justice on God's part are the same, ${ }^{5}$ and life is for him not a probation, but an education up to divinity. We light our own hells and inflict our own punishments. "By these words it seems to be pointed out that every sinner lights for himself the

${ }^{1} C f$. also book IV, I : II-I3.

2 "Neque substantialiter, vel naturaliter esse aliquem immaculatum, neque substantialiter esse pollutum."-"De Principiis," book I, 5:5 (MPG, XI, $164 \mathrm{C})$.

'Cf. book II, $4:$ I. 3 "De Principiis," book I, 6: I. s "De Principiis," book II, $5: 3$. 
flame for his own fire, and is not thrust into some fire which has been already lit by another or exists before him." 1 For Origen life was a struggle with sin, temptations coming both from the spirit-world without and from our own constitutions within; but happily we are never tempted beyond the power to resist if we only earnestly will. ${ }^{2}$ Holy souls, "after being purified by lengthened continence and being filled with holy and religious discipline," assume a "part with divinity" and so gain the grace of prophecy and other divine gifts, ${ }^{3}$ while others place themselves under the influence and power of demons.

Platonism appears in Origen's speculative explanation of the early appearance of good and evil impulses. For him the preexistent soul has already made decisions that tell on the earthly life. "And it is probable that these movements provide a foundation for merit (meritum) even before anything is done in this world (probably Origen used the Greek word æon), so that by reason of these merits they are immediately on their birth, or even previous to it, picked out by Divine foreknowledge for the reception of good or evil." " 4

For Origen, as for Clement, the summum bonum is to become like God, but for Origen the likeness is distinctly more on the metaphysical and less on the ethical plane than in the pages of Clement, ${ }^{5}$ here again revealing the change of emphasis. Authority also means more for Origen than for Clement. Even Jesus came not to bring freedom of thought and action only, but to restore authority and to reinstitute the broken-down law, and teach again the art of ruling and being ruled, ${ }^{6}$ seeing that authority has broken down. When at last God's authority has been restored, even death will disappear. For though it is not evil but good in itself, it is only good so long as the purpose of man's heart is evil.?

1 "De Principiis," book II, I : 4.

2 "De Principiis," book III, 2 : $\mathrm{I}-6$; $c f$. book III, I : I-22.

3 "De Principiis," book III, $3: 3$.

s "De Principiis," book III, $6:$ I.

- "De Principiis," book III, $5: 6$. Regendi regnandique.

7 "De Principiis," book III, $6: 5$.

" "De Principiis," book III, $3: 5$.

$$
\text { Regendi regnandique. }
$$


In Origen's defence of Christianity against Celsus the ethical elements are not neglected, but they play a rather disappointing part. Origen recognizes the fact that in the last analysis the conduct of the Christian is the final apology. "Jesus makes no audible response, but places his defence in the lives of his genuine disciples, which are the foremost witness, and one that is above all false witnesses, and rebuts and overturns vain accusations and charges," 1 and again and again, in answer to the charge that Christianity is a system of deceit, Origen replies, "Who can with logic maintain that a better moral life which daily lessens one's sins could proceed from a system of fraud?" 2 And again, in $2: 79$, the emphasis is upon what Christianity has done for men in making them prudent, temperate, etc., etc. ${ }^{3}$

It is, however, as a world-system and a religious philosophy that Origen defends Christianity, and often with little success. He attempts to put the ethics of the Old Testament upon the level of the New. ${ }^{4}$ His world is still the demon-peopled world of primitive thought. He will not allow that God has created evil, ${ }^{5}$ and he has a most exalted conception of God. "God loves all existent being and despises ${ }^{\circ}$ nothing he has created, for in hatred he would create nothing" " ; but the existence of evil and such a good God gives Origen much trouble, and as Christianity is a complete philosophy of religion he must give an answer. Thus he plunges constantly into discussions of the spirit-world whose existence and character he considers the Christian revelation as completely explaining.

For the student of dogmatics the Christology and theology of Origen, as foreshadowing that of the great Roman church which disowned the father of it, will have perpetual interest. For the ethical student Origen, as we have him, presents almost nothing that may be considered an advance in this regard on his great teacher the Christianized-Platonized Stoic Clement of Alexandria.

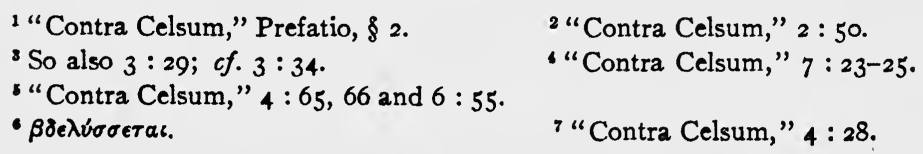


In marked contrast to the Alexandrian Origen is found Tertullian, ${ }^{1}$ the occidental writer, whom Hoppe says founded the Latin patristic style, but whose influence must have been somewhat limited by his going over to heresy. About his style opinions differ. He certainly wrote strong, virile Latin, but Lactantius complains with justice that "Septimius Tertullianus was indeed versed in letters of all kinds, but in eloquence he possessed but little skill, and was not sufficiently polished as well as being exceedingly obscure, wherefore he did not achieve a sufficient fame." ${ }^{2}$ And so also Jerome complains of his rugged and uncouth style. ${ }^{3}$

All that we have from his pen reveals a strong, rugged. and

${ }^{1}$ Quintus Septimus Florens Tertullianus was born in Carthage probably somewhere about I60 A. D. He was the son of a proconsular centurion, and was learned specially in Roman law. Somewhere between 202 and 207 (compare "Contra Marcion," I, I5, "up to the fifteenth year of Severus") he broke with the Roman church, Jerome says, on account of quarrels with the priesthood there, and joined the Montanists, with whom in turn he broke. He died, therefore, a "heretic" about 220. Besides the older editions of "Beatus Rhenanus," Basel: Froben, I521; Jakob Pamelius, Antwerp, 1562, etc., the best collected editions are that of Semler, J. S., 6 vols., Halle, 1769-1776; Migne, "P. L.," vols. I and II, Paris, I 844 (whence for the most part the citations in text are taken); Oehler, Franz, 3 vols., Leipsic, I853-1854 (3d ed.), English translation in the "Ante-Nicene Fathers," vols. III and IV (unequally done); a German translation by Kellner, H., Cologne, I882 (Bonwetsch says "careful"). For complete literature, see Bonwetsch, G. N., in Herzog-Hauck: "Realencyklopädie," 3d ed., 1907, vol. XIX pp. 537-55I, and Harnack, in "Encyclopædia Britannica," vol. XXIII, pp. I96-198. Life, of which little is known, in Migne; cf. also Harnack, A.: “Altchristliche Litteraturgeschichte," II, 2 (1904), pp. 256-296; also Krüger, G.: "Geschichte der altchristlchien Litteratur" (1895), pp. 158-174, English translation (1897), pp. 256-280. The older literature (Allix, de Nourry, Mosheim) scarcely touches the ethics of Tertullian, and deals almost exclusively with his theology. Of an enormous literature, the reader may best perhaps consult: Kaye, Bishop John: "The Ecclesiastical History of the Second and Third Centuries Illustrated from the Writings of Tertullian," 3d ed., London, 1845; Neander, Aug.: "Antignostikus, Geist des Tertullianus und Einleitung in dessen Schriften," Berlin, 1825; Bonwetsch, G. N.: "Die Schriften Tertullians nach der Zeit ihrer Abfassung untersucht," Bonn, 1878; also his "Geschichte des Montanismus," Erlangen, I88I; Ludwig, G.: "Tertullians Ethik," Leipsic, 1885; Hoppe, Heinrich: "Syntax und Stil des Tertullians," Leipsic, I903.

2 "Divinæ Institutiones," book V, I.

${ }^{3}$ Epist. $5^{8}$ : 10. 
interesting but not very attractive personality. The undoubted brilliancy is rough. The unquestioned strength is rude, almost coarse.

In the ethics of Tertullian it is hardly necessary to draw too sharply the line between his Catholic and his Montanist ${ }^{1}$ periods. He broke only with Rome, not with his own hard legal system of morality. One reason he is so severe with Marcion is just because the ethical question that so troubled Marcion was not even present to the thought of Tertullian. The God of Tertullian is, alas, not the forgiving Father of our Lord Jesus Christ, but the stern Law-giver, the Avenger, and the absolute Ruler." God is, indeed, here described as "good," and his mercy and free forgiveness stated. At the same time the dominant note in all Tertullian's thought of God is power and law. So completely does he bow to God as law that he sees no difficulty with love and mercy as running counter to the actual plan of the world as we see it. To Tertullian revenge was a necessary attribute of any God who really deserves respect. "Now if he is offended he ought to be angry, if angry, he ought to visit with punishment, ${ }^{3}$ for this is the ultimate fruit of anger," and "nothing is so unworthy ${ }^{4}$ as not to punish what he does not wish, or to permit what he has prohibited." 5 The son of a Roman procunsular trained in law speaks throughout rather than the disciple who has seen the Redeeming Father in the face of Christ Jesus.

He cannot conceive of the love that casteth out fear. "How,"

\footnotetext{
1 The Montanist heresy was a strange mixture of primitive reactionary chiliastic hope with Gnostic and heathen elements. Montanus claimed prophetic freedom and exacted extraordinary severity from the organized church. He forbade the reception of those who had once denied the faith (lapsi) or those who had handed over to the authorities the sacred writings (traditores). Martyrdom was sought, and all payment of money to escape persecution (nummaria fuga) was deadly sin. (Cf. Bonwetsch, G. N.: "Geschichte des Montanismus," I88I; Ritschl, A.: "Entstehung der altkatholischen Kirche," pp. 462-554, 2d ed., 1857.)

2 "Contra Marcion," book II, chap. I I-I 7 .

'Si irascitur, debet ulcisci. (MPL, II, 278 A.)

"Atqui nihil Deo tam indignum. (MPI, II, 277 D.)

s "Contra Marcion," book I: 26.
} 
he exclaims, "can you love, unless you are afraid not to love." 1

In point of fact the solution of the problem of evil as raised by Marcion is not answered very differently by Tertullian. He states that problem fairly enough, ${ }^{2}$ although heralded by the gentle address, "Dogs, whom the apostle has expelled, yelping (latrantes) at the god of truth." s Yet in fact his answer includes a devil who is simply a rival to God very much as Marcion makes the creator God a contrast to the Redeeming God of Jesus Christ and Paul.

To Marcion, however, the ethical difficulty was far more real than to Tertullian. Marcion seems to have had a vision of God as redeeming love setting men free by the dynamic of loving faith in him. He found it hard to reconcile this vision of God with the hard, vindictive outlines of the Jehovah of Judaism. He came thus to hate Judaism, and flung out the child with the bath, breaking the continuity of religious history and blinding himself and his followers to the religious and ethical values of the Old Testament by the crude artifice of a creation-god other than the redeeming-god of the Pauline theology.

For Tertullian the antithesis that troubled Marcion hardly existed, and for the simple reason that the conception of God as free redeeming love, in the Pauline sense, is never used by Tertullian as his organizing interest, even though it be asserted in terms. ${ }^{4}$

The ethics of Tertullian are profoundly religious, but the system is not Christian. His interest is indeed mainly ethical. It was his intense desire for ethical reformation and transformation of a lukewarm church that finally carried him over to Montanism. He had no real interest in the prophetic freedom of Montanism. His interest was in its legal puritanism, and stern asceticism.

\footnotetext{
'At quomodo diliges, nisi timeas non diligere? "Contra Marcion," I, 27. (MPL, II, 278 D.)

2 "Contra Marcion," book II: 5 .

${ }^{3}$ Book II: 5 .

"As in "Contra Marcion," book II: 7 .
} 
The theology of Tertullian is most distinctly defective simply because his interest was ethical rather than intellectual. His crude Christology is decisive evidence at this point. ${ }^{1}$ And, indeed, the sketch of Christian doctrine given in the Apology ${ }^{2}$ in his Catholic period reveals the theological weakness of the man.

His ethics, however, have had a great influence upon the thinking of ecclesiastical Christianity. Jerome says that Cyprian called him "Master," 3 and this can only have been on account of the extraordinary moral fervor of the man, for to Cyprian a Montanist heretic cannot have been otherwise attractive.

The basis of Tertullian's ethics is the authority of tradition; in both his Catholic and Montanist periods the ultimate basis is thus an external authority. ${ }^{4}$ This authority is found in the Bible, ${ }^{5}$ interpreted in the strange literalism of the day. ${ }^{\circ}$

Hence his system of ethics degenerates rapidly into a weary and burdensome casuistry with the most exacting hair-splitting and often absurd abuse of words. ${ }^{7}$

The goal of ethical struggle is the individual attainment of the crown of righteousness. ${ }^{8}$ The end of the world is judgment and destruction (Apol., chap. 48), the transcendental elements only being saved. ${ }^{\circ}$ It is quite in keeping with the marked individu-

${ }^{2}$ Et cum radius ex sole porrigitur, portio ex summa; sed sol erit in radio, quia solis est radius, nec separatur substantia, sed extenditur. Ita de Spiritu Spiritus, et de Deo Deus, ut lumen de lumine accensum. Manet integra et indefecta materiæ matrix, etsi plures inde traduces qualitatum mutueris. Ita et quod de Deo profectum est, Deus est, et Dei Filius, et unus ambo. " Apologeticus," cap. XXI. (MPL, I, 399 A.)

2 Chaps. I7-2r.

- Kaye, Bishop John: "The Ecclesiastical History of the Second and Third Centuries Illustrated from the Writings of Tertullian," p. 6, 3 d ed., London, 1845 .

" "Contra Marcion," I : I; I : 2I; cf. Apol., § I 9.

5 "De Spectaculis," cap. 3 .

"David's "seat of the impious" and "way of the sinner" is shown to refer to the "seats" and "ways" of the theatre.

${ }^{7} C f$. "De Oratione," cap. XIV to cap. XVII or cap. XXII.

8 "Ad Martyres," chap. 2, "Ad Scap.," chap. I.

-Quæ ratio universitatem ex diversitate composuit, ut omnia ex æmulis substantiis sub unitate constarent ex vacuo et solido, ex animali et inanimali, ex comprehensibili et incomprehensibili, ex luce et tenebris, ex ipsa vita et morte: eadem ævum quoque ita destinata ac distincta conditione conseruit, ut prima 
alism of his point of view that the clause in the Lord's Prayer, "Thy kingdom come," is explained away as a final catastrophe. "Nay, Lord, Thy kingdom come with all speed, this is the Christian prayer, the confusion of the nations, the exultation of angels." 1 There is really no sense in Tertullian of the kingdompurpose as proclaimed by Jesus. There is no feeling of any controversy with an existing social disorder. The Roman state is of God's ordering, and the Roman emperor is next to God. ${ }^{2}$ Christianity and its ethics are for Tertullian a new Judaism, a better type of ritual correctness, and a more exacting law. ${ }^{3}$

It was therefore only natural that the content of Tertullian's ethical system should fall far short of the New Testament standard, even at its lowest. He defends the lex talionis. ${ }^{4}$ His views of marriage are low and unworthy. ${ }^{5}$ Both in his Catholic and Montanist periods he is narrow and harsh, ${ }^{6}$ and abounds in petty and confused casuistical hair-splitting. He is superstitious, but that was the fault rather of his age than of his ethics. At the same time his superstition had fearful terrors. To offend the law was damnation. Montanism held out, Harnack suggests, an authority settling many questions of grave practical importance on which the Scriptures were not sufficient. ${ }^{8}$ He had no interest in its prophetic freedom, but only in its new lawgiving. It condemned second marriages, imposed new fasts, re-established the Sabbath, and reintroduced asceticism.

The asceticism of Tertullian is legal and disciplinary rather

hæc pars ab exordio rerum, quam incolimus, temporali ætate ad finem defluat, sequens vero, quam expectamus, in infinitam æternitatem propagetur. "Apologeticus," Apol., XLVIII. (MPL, I, 526 A.)

1 "De Oratione," cap. V.

2 Apol., chaps. 30-34.

" "Contra Marcion," book IV: I 2.

" "Contra Marcion" II: I8; though $c f$. "De Exhortatione Castitatis," cap. VI.

3 "Ad Uxorem," libri I et II, and "De Monogamia."

- "De Spec.," cap. XIII.

7 "Ad Scap.," cap. III-IV; Apol., cap. XXII-XXIII.

${ }^{8}$ Harnack, A.: "Dogmengeschichte," vol. I, p. 396, 3d ed., 1894; English translation (1897), vol. II, p. Ior. 


\section{THE ETHICS OF THE EARLY CHURCH ${ }^{165}$}

than oriental, ${ }^{1}$ whereas Tertullian was not a dualist in this metaphysical sense. ${ }^{2}$ True oriental asceticism seeks to rid the spirit of the body, because matter is essentially undivine. Tertullian was too much a Roman and a convert to Judaism to deem the body evil in itself, for God had made it. For Tertullian asceticism is simply the guarantee of separateness from the evil world in a holy community. ${ }^{3}$ Holiness is minute obedience to legal enactment, and asceticism an aid to this obedience. ${ }^{4}$

Tertullian's interest does not seem to have been sufficiently intellectual to have given philosophical Stoicism any great influence over him. Even when phrases and conclusions remind us of Stoicism, the general spirit warns us against connecting too closely the two types of Puritanism that were struggling in the church for mastery. Tertullian's ethics are pharisaic rather than Stoic, built up, that is to say, rather upon a traditional theology than upon a philosophical view of the world. There is no trace of philosophical pantheism, and no philosophical fatalism, ${ }^{5}$ and even in the practical ethical homily the contrast in treatment between Tertullian and Stoicism is marked. ${ }^{6}$

Naturally this new pharisaicism produced the fruits of pharisaicism, and the ethics of Tertullian abound in harsh absurdities ${ }^{7}$ as well as in definite and clear moral insights.

The ethics of Tertullian are quite distinct, and give unity to the otherwise somewhat confused and turgid torrent of his thinking. But the system is pharisaic and not Christian. It is profoundly religious, but the religion is not that of Jesus or

1 The Montanist asceticism seems to the writer to have been distinctly dualistic. Contra Bonwetsch, G. N.: "Zur Geschichte des Montanismus," I881, p. 87.

2 "De Resurrectione carnis," V : 47, which belongs to his Montanist period.

" "Ad Uxorem," book 2.

" "De Exhortatione Castitatis," cap. III, VII, et XI.

"Contra Marcion," II : 5.

-Cf. "De Patientia," for instance.

"Cf. "De Exhortatione Castitatis," cap. IX: "Leges videntur matrimonii et stupri differentiam facere per diversitatem illiciti, non per conditionem rei ipsius. Alioquin quæ res et viris et fœminis omnibus adest ad matrimonium et stuprum? Commixtio carnis scilicet, cujus concupiscentiam Dominus stupro adæquavit." (MPL, II, $924 \mathrm{C}$ and 925 A.) 
of Paul. There is tremendous rugged strength in Tertullian, but it is pagan moral energy. He had a vision of the living God, but he had not seen him in the face of Jesus Christ. $\mathrm{He}$ bowed in lowly reverence before God, but it was as Judge and Master not as Father and Friend.

His interest is therefore an excessive individualism. Even the church is a mere way of escape, and when a better disciplinary group claimed him he went over to it. His compromise with the Roman State is complete. "A Christian is enemy to none, least of all to the emperor, whom he knows to be constituted by his God, and it is necessary that he should love and reverence and honor and desire his salvation, together with the whole Roman Empire, as long as the age lasts for so long it will last. ${ }^{1}$

Never, even in his Montanist period, does the chiliastic hope which he cherished really organize his message or his hope. True, he thinks it absurd that Christians should concern themselves about posterity, "to whom there is no to-morrow," " but that refers rather to the individual's renunciation of marriage than to any definite conception of a new æon.

There remains always a profound impression of strength and sincerity in the writings of this great father of Puritanism, but his abiding influence on the ethical thinking that calls itself still Christian marks the distance travelled from the loving Gospel of Jesus Christ.

What he really sought was a church separating itself from the world for its own soul's sake, rather than a church separated for the saving of the world. Here again the pharisaic separatism marks all his thought and feeling, giving his ethics a haughty and aristocratic cast, preparing the way for compromise with the State where compromise was out of place, and for separation from life just where such separation works most mischief.

1 "Quousque sæculum stabit" ("Ad Scapulam," cap. II). (MPL, I, 700 A.)

2 "Quibus crastinum non est" ("De Exhortatione Castitatis," cap. XII). (MPL, II, 927 B.) 


\section{THE ETHICS OF ECCLESIASTICAL ORGANIZATION}

As early as the Ignatian Letters ${ }^{1}$ the Episcopal organization was demanding the unity under the will of the bishop which seemed so essential for the conservation of the young church's life. "It is right, therefore," says Ignatius, "that you should run together according to the will of the bishop who rules you according to God," "2 and in the same chapter he says, "For your justly well-known presbytery, worthy of God, is tuned exactly to the bishop, as the strings are to the lyre." Already the hierarchy had made its appearance, as was almost inevitable, and the laity depend on the bishop, as the church does on the Lord Jesus and the Lord does on God his Father. ${ }^{3}$ The great sin is already separation from the church. "For he that yields not obedience to his superiors is self-confident, quarrelsome, and proud." " The early Christians were taught to be loving and gentle to all the heathen world. "For say ye to those that hate you, 'Ye are our brothers,' and the Lord's name may be glorified," " but toward the heretics of their own number no bitterness was misplaced. " $\mathrm{He}$ is lying, fraudulent, soothing, fawning, traitorous, rhapsodical, frivolous, discordant, wordy, sordid, and cowardly." " "Whosoever 'being waxen fat' and 'become gross' sets at naught His doctrine shall go to hell." " All the

${ }^{1}$ Ignatius Theophorus, second or third Bishop of Antioch (Euseb., H. E., III, 22), of whom little is known save his alleged martyrdom under Trajan at Rome, either 107 or II6. Many letters are attributed to him. The accepted form is in seven letters to the Ephesians, Magnesians, Trallians, Romans, Philadelphians, Smyrnæans, and to Polycarp. (Harnack and Zahn following Lightfoot.) The longer collection contains many additions and spurious attributions. The best editions are Migne, "P. G., V," cols. 643-960; Zahn, Theod., I876; Funk, F. X., I881; Lightfoot, J. B., I 885 and I89r. Translation in the "Ante-Nicene Fathers," vol. I, 1887. The general literature is enormous; compare Harnack, A.: "Altchristliche Litteraturgeschichte" (I893), pp. 75-86, and also his treatise, "Die Zeit des Ignatius," Leipsic, I878; Krueger, G.: "Geschichte der altchristlichen Litteratur" (1895), pp. 18-22; English translation (1897), pp. 28-34.

${ }^{2}$ Ephesians, chap. IV. $\quad$ Ephesians, chap. V. 'Ephesians, chap. V.

Ephesians, chap. X. $\quad$ Ephesians, chap. IX (longer form).

${ }^{7}$ Ephesians, chap. XVI; Trallians, VI. 
freedom of moral supremacy over the law is swallowed up in the awe and reverence due to the bishop. "It is becoming, therefore, that ye also should be obedient to your bishop, and contradict him in nothing; for it is a fearful thing to contradict such an one." 1

The whole tragedy of the Old Testament is not lack of vital righteousness, or even failure to be faithful to monotheism, but the lack of obedience to the appointed spiritual rulers and the consequent divisions and schisms. ${ }^{2}$

The denial of Judaism is formally very fierce. The Sabbath is no longer to be kept in a Jewish manner as a day of idleness, but as a day of work. But it is really only a transference from the eighth day to the first, for the resurrection day becomes for all practical purposes the Jewish Sabbath. ${ }^{3}$ The spiritual supremacy of the moral man as lord of the religious life is an almost wholly lost conception. Obedience to the bishop and subjection to tradition have usurped the place given by Jesus to the Son of Man. The dangers to the church are intellectual vagaries like doceticism ${ }^{4}$ and all manner of schismatics ${ }^{5}$ and a divided eucharist. ${ }^{\circ}$ Marriage is, however, still held in esteem, and wholesome counsel is given against despising it. "Not, however, that I blame the holy ones because they entered into the marriage state. For I pray that I may be found worthy of God and may sit at their feet in the kingdom, as at the feet of Abraham and Isaac and Jacob, as of Joseph and Isaiah and the rest of the prophets, as of Peter and Paul and the rest of the apostles that were married. For these entered into these marriages not on account of appetite, but to propagate mankind." 7

Martyrdom is longed for as a means of attaining God. "Pray, then, do not try to do me any greater favor than that I be sacrificed to God while the altar is still prepared ... deemed worthy to be found and sent for from the East to the West to

\footnotetext{
${ }^{1}$ Magnesians, III.

${ }^{2}$ Magnesians, III.

3 Magnesians, IX.

4 Trallians, X and XI.

${ }^{7}$ Philadelphians, IV.

'Philadelphians, III.

- Philadelphians, IV.
} 
become a martyr in behalf of his own precious sufferings so as to pass from the world to God, that I may rise again unto him": ${ }^{1}$ and again, "suffer me to become food for the wild beasts, through whose instrumentality it will be granted me to attain to God." 2 Throughout the letters there breathes the earnest and devoted spirit of the sincere and faithful ecclesiastic, whose sense of duty is wellnigh coterminous with the life of the outward organization, and to whom the organization has become the sensible incarnation of the divine life.

Thus in Ignatius there is firmly laid the foundation for a church that usurps the supremacy of the spiritual man, and it now only remained to define and defend that organization and to establish her ethics.

This work is reflected in very great completeness in Irencus. ${ }^{3}$ For this writer the church as a sacramental institution has full authority over the individual life, and Christianity is simply a new type of Judaism. ${ }^{4}$ The ethics of Jesus are simply the old law revised by adding dogmatic theses to it. Our righteousness must simply exceed the righteousness of the scribes and Pharisees by "believing not only in God the Father but in the Son," and in doing the law instead of simply repeating it, and making it

${ }^{1}$ Romans, II.

${ }^{2}$ Romans, IV.

${ }^{3}$ Irenæus was born probably in Asia Minor and probably not before 120 or much later than 130 . He may have been martyred, although this tradition is late and the date of his death is unknown. His books are mostly lost. Among

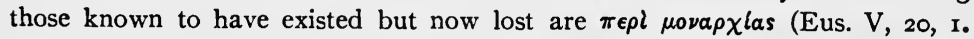

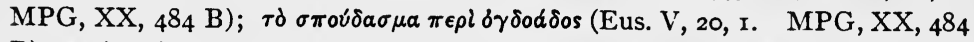

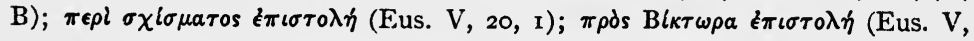
24, I I-7. MPG, XX, 496). (Letters to Victor, Bp. of Rome.)

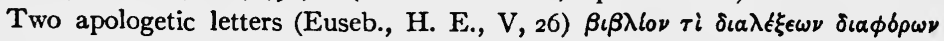
and some other fragmentary apologetic writings. There remain, however, the five books of his chief work, although only in a literal Latin translation,

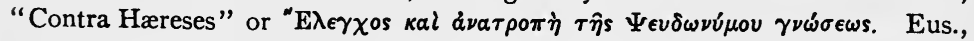
H. E., V, 7, I. (MPG, XX, 445 D.) Numerous remains of the Greek enable us, however, to judge of the faithfulness of the translation. There are many editions. Among the best known are "Erasmus" (Basel, I526), Migne, "P. G.," VII, cols. 433-I322. Translation in the "Ante-Nicene Fathers," I, pp. 307578. For general literature, consult Harnack, "Gesch. der altchristl. Litteratur," I, pp. 263-288.

- Book IV, 12 : 2. 
our desire as well as doing it. ${ }^{1}$ The sacrament is already the "oblation." 2 Eating defiles the man, "For instance. they (heretics) do not scruple to eat meat offered unto idols, imagining that they cannot contract defilement." 3 It is, moreover, inconceivable for Irenæus that intellectual heretics should be good men. Marcion is charged with disgraceful conduct," and the Gnostics have been distinctly instigated by Satan "to a denial of that baptism which is regeneration to God." 5

Moreover, God is thought of in terms of the Roman Empire, and fear at his name becomes the foundation of conduct, ${ }^{6}$ so that the mere name has potency, and the Jews do by its means put demons to flight. ${ }^{7}$ There is a twofold standard of authority. On the one hand the books of the apostles, and on the other the tradition which "originated with the apostles and is preserved by means of the successions of the presbyters in the churches. ${ }^{8}$ The theory of inspiration is already rigid: "All scriptures given to us by God will be harmonious." 9 Hence the rule for interpretation is very simple. The parables are to be made to harmonize with those passages which are perfectly plain. And all these scriptures and traditions are the new codes by which the Supreme Creator rules his creatures.

The whole conception of the relation of God to his world is utterly uninfluenced by the vision of God as redeeming love in the face of Christ Jesus. The Son reveals the Father, but reveals him "as one only God, the Creator, he who is above every principality and power and dominion and virtue," who made by wisdom all things, in opposition to the Gnostic teaching of mediate creation. ${ }^{10}$ Already the gospel message is hardened and formalized into a "plan of salvation." "It is a "doctrine of the

${ }^{1}$ Book IV, I3 : r.

- Book I, I3 : I-7.

${ }^{7}$ Book II, $6: 2$.

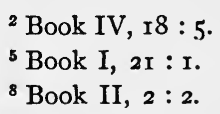

${ }^{5}$ Book I, 2 I : I.

${ }^{8}$ Book II, 2 : 2.

3 Book I, $6: 3$.

${ }^{6}$ Book II, 6 : 2. Hær.," II, 28, 3. (MPG, VII, 806 C.)

${ }^{11}$ Non enim per alios dispositionem salutis nostræ cognovimus, quam per eos, per quos Evangelium pervenit ad nos. "Contr. Hær.," III, r, r. (MPG, VII, 844 A.) 
Son of God," 1 and a dogmatic system is already completely identified with the "only true and life-giving faith." This body of truth is safely housed in the central church at Rome, "the tradition is derived from the apostles of the exceeding great and ancient and universally known church founded and organized at Rome by the two most glorious apostles Peter and Paul . . . for it is a necessary thing that every church should agree with this church on account of its pre-eminent authority." 2 Under such circumstances the ethics becomes primarily an ethics of the organization, and that organization is a sacramental ark of safety. The chief virtues are submission, faith in the church and the sacraments, undying fidelity to the profession of faith.

The ethics are a new law, and Jesus goes before "fulfilling the law by performing the offices of the high-priest, propitiating God for ${ }^{3}$ men. The Decalogue is the permanent norm. ${ }^{4}$ Even sin has as a part of its chief heinousness the fact that it injures the organization life. ${ }^{5}$ The problem of sin as a tremendous challenge of either the goodness or the power of God, which so staggered the Gnostic thinkers, has no terrors for Irenæus, who argues that God could have made man perfect, but that man's infancy could not receive perfection. ${ }^{6}$ The reasoning is slipshod in the extreme, for the interest has changed. The centre of that interest is no longer a vital dynamic righteousness, but a strong propagandist, sacramental organization to which Gnostic speculation is only abhorrent because divisive, and whose basis is the unquestioned acceptance of an outward authority.

From some oriental intrusions Irenæus turns definitely away. His contention that the flesh is sound, and although it will not and cannot inherit the kingdom, the kingdom can and must inherit it, is substantially Pauline and Christian. ${ }^{7}$ He denounces the preaching against marriage on the part of the Encratite. ${ }^{8}$

1 Book III, preface.

${ }^{2}$ Propter potiorem principalitatem. "Adv. Hær.," III, 3, 2. (MPG, VII, 849 A.)

${ }^{3}$ Book IV, 8 : 2.

- Book V, I7 : r.

5 Book IV, $33: 7$.

- Book IV, $3^{8}:$ I-4.

'Book V, $9: \mathrm{r}$; book V, 10:2

3ook I, 28 : 1. 
At the same time the coming oriental ascetic type of piety already casts its shadow over orthodoxy. "Adam shows his repentance by covering himself with fig-leaves, although there were many other leaves that would have less irritated his body," 1 and continency is a gift by itself.

The whole atmosphere has now changed. The ethics of Jesus, founded upon the spiritual supremacy of the redeemed life, has given way to an organization legalism. The church is no longer an organization of men and women for redeeming the world, but a sacramental system under bishops and presbyters in which men may seek safety. Morality is no longer a redeemed purpose consonant to the will of God, but an outward and wholesome bondage laid upon us for the saving of our souls. God is no longer thought of in terms of vital righteousness, but in terms of creative activity and over-lordship. For the development of an ethics on this basis we turn from Irenæus to Cyprian. ${ }^{2}$

In grace of style and simple straightforwardness Cyprian greatly excels both Tertullian and Irenæus. He has also his ecclesiastical theory more fully worked out than Tertullian, and his practical interest is even greater than that of Irenæus. In his innumerable letters we see the ecclesiastical mind actually moulding the ethics of the community, and being itself constantly directed by the interest of the organization.

For Cyprian this organization was the final authority. "From

${ }^{1}$ Book III, $23: 5$.

${ }^{2}$ Thascius Cæcilius Cyprianus was born about 200 and probably in Carthage. He was of good family and was an educated teacher of rhetoric: he was won for the church by the presbyter Cæcilianus, and soon was made bishop. During the Decian persecution he was in hiding, but under Valerian he met a martyr's death in September, 258. For full list of letters and works, see Harnack, A.: "Altchristliche Litteraturgeschichte," pp. 688-723; Krüger, G.: "Geschichte der altchristlichen Litteratur" (1895), pp. 174-180, English translation (1897), pp. 280-304. The text has been edited from Erasmus ( 1520 and $\times 530$ ) down to Migne ("Patrologia Latina," vol. IV, cols. 19I-1032), from which text the quotations are taken. Translation in the "Ante-Nicene Fathers," vol. V, pp. 26r-596. Compare also article in Herzog-Hauck: "Realencyklopädie," by K. Leimbach, vol. IV, pp. 367-375, English translation (1909), vol. III, pp. 331-332. 
the beginning, therefore, of my bishopric I determined to do nothing on my own private opinion without your (his copresbyter's) advice and the consent of the people." 1 And this organization is a fighting propagandist army. "We are still in the world, we are still placed in the battle-field, we fight for our lives daily." 2 This sense of the utter corruption of the world, and the horror of its injustice, cruelty, and vice, finds strong expression in Cyprian, and although the church is to conquer, yet the only present relief for the individual is to seek tranquillity in "withdrawing from the whirlpools of the distracting world and to lift his eyes from earth to heaven. He who is really greater than the world can desire nothing from it." 3 Indeed in Cyprian one feels the same sense of underlying terror and horror of existing conditions which breathes in so much of Seneca. But while Cyprian feels like Seneca that "It is a crime now to be innocent among the guilty," yet Cyprian looks forward with confidence to the conquest of the world by the ecclesiastical organization. In the very martyrdoms of the church she is overcoming the world. ${ }^{4}$ The day of affliction overshadows the church and the end of the world, and the time of the Antichrist draws near, but the end is to be a glorious triumph. ${ }^{5}$

Hence it is all-important that the organization have unity, and one of Cyprian's chief works is "De Unitate Ecclesiæ." This unity is on the basis of the sacraments and Peter the Rock. ${ }^{6}$ These sacraments are magic rites by which, "by the help of the water of the new birth, the stain of former years had been washed away," 7 and sustaining grace is magically imparted in the eucharist. ${ }^{8}$ It is therefore of the greatest moment to keep the control of baptism within the organization, and to acknowledge heretic baptism would be fearfully weakening. Heretic baptism is therefore null and void, ${ }^{9}$ for how can any one give to

${ }^{1}$ Eps. $5: 4$. Mea privatim sententia.

${ }^{2}$ Eps. $6: 2$. ${ }^{3}$ Eps. I (ad Donatum), 14.

Eps. 8 : r.

Eps. 57 : 1 .

- "De Unitate Ecclesiæ," 6 and Eps. 52 : 8; English translation, 51 :8; Eps.

$55:$ 14; English translation, $54: 14$.

Eps. $9: 2$.

${ }^{7}$ Eps. I (ad Donatum), 4.

Eps. 7 I : 1 . 
another remission of sins who himself, being outside the church, cannot put away his own sin.

The church is to be conserved by the maintenance of the authority of the bishops, who are higher than even the presbyters, ${ }^{1}$ and the chief virtues are those most essential to the organization life. "The whole foundation of religion and of faith springs from obedience and fear." 2 The strong appeal for purity of life is the life and welfare of the organization, and for its sake the Christians are to watch one another." "Its life is continuous through the bishops. Thence through all the changes of time and successions, the commands of the bishop and the routine of the church go onward, so that the church is founded upon the bishops, and every act is to be controlled by these rulers." "The emphasis upon organic unity is constant and insistent. "There is one God, and Christ is one, and there is one church and one chair founded upon the rock by the word of the Lord. Another altar cannot be constituted or a new priesthood made, except the one altar and the one priesthood." 5 Moreover, this unity has a local place, "Since Rome from her greatness plainly ought to have precedence of Carthage."

No teacher then should even be listened to who is outside the pale of the church; "he who is not in the church of Christ is not a Christian." 7 This Rome is "the throne of Peter," and is the chief church "whence priestly unity has its source." 8

Naturally such strict ecclesiasticism bred laxity, for it was vastly important not only to keep outward unity but to insure salvation to as large a number as possible, so that Cyprian writes: "I remit everything, I shut my eyes to many things, with the longing and the hope to gather the brotherhood together"; and again, "Even those things committed against God I do not inquire into with the exact judgment of religion. Almost do I

\footnotetext{
${ }^{1}$ Eps. $9:$ I.

2 "De habitu Virginum," 2.

${ }^{3}$ Eps. $6: 5$.

4Eps. $27: \mathrm{r}$; English translation, $26: \mathrm{x}$.

${ }^{5}$ Eps. $40: 5$; English translation, $39: 5$.

${ }^{6}$ Eps. $49: 2$; English translation, $48: 2$.

${ }^{7}$ Eps. $55: 4$; English translation, $5 \mathrm{I}: 24$.

${ }^{8}$ Eps. 55 : 14; English translation, 54 : I4.
} 
myself sin, as I remit more sins than I should. I embrace those who in penitence return confessing their sins with humble and sincere atonement, with speedy and complete love." 1

Of course, as with Ignatius and Irenæus, the sacraments are a magical system imparting grace per se. "Infants are to be baptized at once, for the mercy and grace of God are not to be refused to any born of man," 2 and therefore sacramental correctness is of primary importance, ${ }^{3}$ and the priesthood is invested with peculiar spiritual powers after the analogy of the Aaronic priesthood; and as the unhappy Korah, Dathan, and Abiram were swallowed up for disobedience, so all rebels against the bishop are in serious danger. ${ }^{4}$ Indeed this incident figures largely from Ignatius on down through all the ecclesiastical writers.

The outcome of moral thought on such a foundation is a minute and external casuistry. It is based on rewards and punishments measured according to the legal measure of the transgression. Even the persecutions that take place come on account of the sins of the community. The picture Cyprian draws of the state of the church shows how far the formalizing externalizing process had gone. In the treatise "De Lapsis" he catalogues these sins. They are increasing estates and covetousness. Priests have no devotion to religion. Ministers are not sound in the faith. Works of mercy fail. Discipline is lax. Men deface their beards. Women paint their faces, color their eyes, and stain their hair. Frauds are practised. Marriages are contracted with unbelievers. There are slanders, false swearing, and quarrels, and the bishops take up secular business.

There was mingled with the ethics the most mechanical conception of pollution. In this same treatise ${ }^{5}$ a story is told of an unhappy infant, temporarily abandoned by the parents, being forced to partake of bread and wine offered to idols. This

${ }^{1}$ Eps. 55 : 16; English translation, $54:$ i6.

${ }^{2}$ Eps. MPL, $59: 2$; English translation, $58: 2$.

${ }^{3}$ Eps. MPL, $63:$ II; English translation, 62 : Ir.

"Eps. MPL, $65: 1$; English translation, $64: 1$.

5 "De Lapsis," 25. 
"crime" is unknown to the parents, who on recovering their infant take it to the church, and there the "little girl among saints" is impatient of the prayers and "was at one moment tossed about like a wave of the sea by the excitement of her mind," and on the deacons forcing upon her the sacramental cup, the wine "burst forth from her polluted body," revealing the "crime," which her infant years made it impossible for her to either understand or relate.

The conception of God is that of a judge to be convinced and a ruler to be appeased. Those that have proved weak in the hour of trial and who have fallen must not think that "the Lord can be quickly appeased"; "do you think that he will easily have mercy upon you, he whom you have pronounced to be not your God?" and the appeasement is by watching, weeping, fasting, spending days and nights in prayers and tears, dressed in sackcloth and filth, earnest in good works, "whereby sin may be purged away, frequently doing alms, whereby souls are set free from death." 1

So completely has the conception of God changed to the old pharisaic thought of him, that even in the interpretation of the Lord's Prayer we are told that we say "Our Father" because he has begun to be ours and ceased to be the Father of the Jews who have forsaken him. Martyrdom is pleasing to God per se, and the martyrs have peculiar power with God, ${ }^{2}$ and prayers are winged by these sufferings. ${ }^{3}$

Cyprian is generally milder than Tertullian, but there are some fiercely pagan passages, as in the address to Demetrianus, where he describes the joy of the saints in seeing the tortures of Gehenna inflicted upon those who once persecuted them, ${ }^{4}$ and this in spite of his own acknowledgment that "we must not hate." 3

In fact, to sum up the ethics of this type of thinking, it is not only on the lower planes of pharisaic Judaism, but it does not

1 "De Lapsis," 35.

3 "De oratione Dominica," 33.

s "Liber ad Demetrianum," 25.
2 "De oratione Dominica," 24.

- "Liber ad Demetrianum," 24. 
even rise to the higher planes of Stoicism. The whole conception of man's moral freedom and supremacy over the law is hopelessly gone, and the enthusiasm is for a churchly organization with a superstitious and fanatical confidence in an outward sacramental magic.

\section{THE ETHICAL FORCES OF CHRISTIANITY}

Any review of the formal ethics of this early Christian literature leaves the reader wondering how Christianity succeeded in surviving the entire change of emphasis from the message of Jesus in the synoptic Gospels and the Pauline and Johannine interpretation of that message to an emphasis upon things Jesus either ignored or hated.

The main quarrel Jesus had with the religious life of his day was with the pharisaic conception of God as law-giver, and of the religious life as obedience to an outward legalism, and of the kingdom of God as the success of a selfish temporal and ecclesiastical organization. And now before three generations have passed away these three misconceptions are seemingly firmly implanted in the fighting ecclesiastical organization. God was already thought of as only the Father of the law-abiding Christian church; the religious life was construed as essentially seeking personal safety amid the magic of sacraments, and by conformity to dogma and casuistry; and the kingdom of God was substantially identified with a priestly organization; and this elaborate misconstruction was complete in the time of Cyprian.

At the same time many noble and striking passages show that in the midst of this radical misconception of Jesus and his purpose there still remained in the teaching of Clement of Alexandria, Irenæus and Cyprian, and even Tertullian, the power of the primary revolution. Jesus was still a living force in the lives of these and thousands of others. The world could never again think exclusively of God in the terms of pharisaism, and even the most exalted Stoicism was unsatisfactory in the presence of the actual ethics of Jesus, and the Gospels were still read. 
The very deification of Jesus compelled men, even when most caught in formalism and legalism, to translate the life and purpose of God into the concepts of a tender and loving humanity. So that no clouds of dreary Hellenistic speculation, and no dream of Roman imperialism could wholly shut out the forgiveness of the cross and the absolute freedom of God's love.

The Gospel story was still imbedded in the paganized churchly life, and unconsciously or subconsciously the message of Jesus to the world that God was redeeming moral purpose cut across the formal dogmatic contradictions. Even while thousands professed with their lips the God of Pharisaism or the Absolute of Stoicism, they worshipped with joy in their hearts the God and Father of Our Lord Jesus Christ.

Thus the transforming power of the old enthusiasm for God as seen in Jesus Christ remained as a purifying ethical force along many lines. And nowhere was it seen to better advantage than in the family group. Judaism had seemingly ceased to represent the highest type of monogamy even in the time of Jesus. $^{1}$ No doubt it was chiefly amongst the economically prosperous that this was the case. But as always, so here, legalism brought forth its inevitable fruit. ${ }^{2}$ No doubt then, as always, the sexual relationship was relatively pure and wholesome among the simpler toiling masses. That this was true even in the worst ages of Greece and Rome we need have little doubt. Athens was not Greece, nor was Rome Italy, any more than Constantinople is Turkey. Even in the upper classes the pictures of the satirists are not to be taken too literally. ${ }^{3}$

Though this is true, however, it is also true that just as soon as one class is economically dependent upon another the ethical standards in matters pertaining to sex suffer terribly. It is impossible to conserve woman's purity or men's ideals of virtue amid a slave population, where the slave women are the helpless dependents upon the men. The agrarian slavery of old Rome

${ }^{2}$ Matt. $5: 27-32$.

${ }^{2} C f$. Schürer: "Geschichte des Jüdischen Volkes," II, 493-496, Ist ed, I898.

"Cf. "Seneca ad Marciam," I3-14. 
brought with it evils, but the household slavery of predatory imperial Rome loosened the whirlwind of luxury and abuse. ${ }^{1}$

Yet there are evidences that not only was this confined to certain ranks of society, but that, as Hatch points out, ${ }^{2}$ a reformation was in progress in the pagan world. Christianity early embraced false and unworthy conceptions of the married state. Even Paul's utterances permitted grave misconstruction. Very early, virginity was ranked as per se a higher ethical condition, in utter contradiction of the higher and purer Jewish estimate of the family. The story of the virgin-birth was interpreted as a slur upon the married relationship. ${ }^{3}$

These very aberrations, however, serve to show the extreme reaction of the ethics of the early church against sexual indulgence. The indignation of Paul in his letters to Rome and Corinth against laxness at this point, and the thorough-going attitude of Jesus," made a marked impression. The early Christian church stood firmly for a standard of purity equally high for man and woman, for free and slave. The HellenicRoman world was not destitute of high ideals. Pliny's letters reflect the sweetest devotion to his wife Calpurnia, and many families, no doubt, lived on the high plane of Seneca's teaching. Yet the demands of this same society on the growing boy or the married man were very low. The actual result of Christian teaching was the exaltation of an ideal strange and wellnigh undreamt of in a pagan philosophy. The beautiful imagery of $\mathrm{Paul}^{5}$ was an ethical force of great value.

To read some writers one would suppose that hypocrisy was introduced into the world by Christianity. That the exaltation of an ideal and that fading enthusiasms produce hypocrisy need not be gainsaid; while still maintaining that the very hypocrisy

${ }^{1}$ Cf. Friedländer, L.: "Darstellungen aus der Sittengeschichte Roms," 7 th ed., I 901 , part 2, pp. 228-23r.

${ }^{2}$ Hatch, Edwin: "The Influence of Greek Ideas and Usages upon the Christian Church," 2d ed., I89r, pp. r40-r 70.

Tertullian, "De Carne Christi," cap. XVII.

-Matt. 5 : 27-32.

Eph. 5 : 22-33. 
which has so often stained the page describing human conduct at this point is an evidence of a heightened standard of thought.

The humblest Christian was taught to defend personal purity as a fundamental demand of the new organization. In the midst of the foulness and sexual brutalities of paganism a new conception was given birth. Even a beautiful story of the Gospel ${ }^{1}$ was probably omitted from the early canon lest it should hinder in the church's battle with her deadliest enemy.

The economic struggle was in those days as fierce if not even fiercer than to-day. The slave labor pressed upon the proletariat with fearful force and depressing power. ${ }^{2}$ In a twofold manner the possessing class appropriated the product of labor, on the one hand by the brute force of slavery and on the other by excluding freemen from the soil save on the most onerous terms of rental. In this struggle of the proletariat the Christian church brought in a new bond of union between the weaker oppressed workers. It bound together in a religious enthusiasm the interests of both slave and proletariat freeman. The socalled communism of the early church $^{3}$ had no economic foundation, but simply represented the revival of a strong feeling of economic brotherhood. ${ }^{4}$

Any strong enthusiasm that really brings men into fellowship with each other will lead to a relative sharing of the material things of life. But the Christian enthusiasm taught natural helpfulness, exalted giving of self and possessions for others' sake; thus the oppressed proletariat were bound together in a great organization for common helpfulness and mutual aid in trouble. The union produced strength. ${ }^{5}$

${ }^{1}$ John $7: 53-8:$ ir.

${ }^{2}$ Cf. Mommsen: "Roemische Geschichte," vol. II, 8I, 397; III, 510-5I I, ed. I889.

Acts $2: 43-47 ; 5:$ I-II.

-Rogge, C.: "Der irdische Besitz im Neuen Testament," 1897, pp. 68-76; Holtzmann, Oskar: "Gütergemeinschaft," in "Zeitschrift für Kirchengeschichte (I894, edited by Brieger), XIV, pp. 327-336.

s Uhlhorn's "Christliche Liebesthätigkeit in der alten Kirche," Stuttgart, 1882, pp. 248-256; English translation, "Christian Charity in the Ancient Church," New York, 1883, pp. 255-263. 
This organization was not only international, but exceedingly mobile. The general poverty reflected in James and in Acts, and in the constant appeals for the poor "saints in Jerusalem," suggest the way in which a sense of responsibility for the weakest members of the group was fostered, producing a sense of fellowship and strength of great social and ethical value in a day of such constant disintegration of social bonds.

In theory, at least, within the organization poverty was no :disgrace, for Jesus had been poor and had called the poor blessed. So that in one circle, professedly the economically inferior, the groups were equal before God and could claim amid all degrees of poverty the equal possession of the higher riches.

In very many forms the social kingdom-aspiration survived. The church still prayed amid increasing compromise with the existing social order, "Thy kingdom come on earth." And the old apocalyptic dreams still haunted the imaginations of the oppressed, particularly in times of stress and persecution (Apocalypse of Peter, of Baruch, etc.). The triumph of the ecclesiastical organization began increasingly to take the place of the hope for a magic revolution, judgment, and a new world. As that organization grew in power it gradually changed from a propagandist society of social and heavenly hope and became itself an end. Its wide sweep, its powers of adaptation to many levels of need, its conservation of so many differing types of value, made the ecclesiastical organization a social force in the dwarfed and narrowed lives of the world's teeming, ignorant millions. She caught up into herself with splendid inconsistency the most diverse factors that were making for ethical reformation and social reconstruction.

In many ways her attitude was highly anomalous. Riches began to be her portion, and her power increased as the influential began to join the Christian ranks. ${ }^{1}$ Unlimited giving was her

${ }^{1} C f$. evidence in Harnack's "Die Mission und Ausbreitung des Christentums in den ersten drei Jahrhunderten," Leipsic, 1902, pp. 376-407; English translation by Moffatt: "The Expansion of Christianity in the First Three Centuries" (2 vols., New York, I904-r905), vol. II, pp. 183-239. 
constant message. At the same time all compulsion to give would have robbed the gift of its healing efficacy. ${ }^{1}$ Not all could become ascetics, so compromise was again necessary. A sort of voluntary communism remained as an ideal, but on the other hand the rich and powerful were special stewards of God for the church's sake, and need not fear diminishing estates if they freely gave. ${ }^{2}$ Any critical estimate of the economic and ethical advantages and disadvantages of private possession was quite beyond the scope of the church's thought.

In like manner the attitude toward slavery was utterly uncritical. Slavery as slavery was not condemned. Paul sent back a runaway slave, but as "a brother," ${ }^{3}$ and no early Christian had any more inkling of the inherent ethical wrong of exploiting a fellow-being economically for one's own ends than has the Christian "sweater" of wage labor of to-day." It must be confessed that slavery disappeared not because Christianity ever officially fought it, but because it became economically wasteful as a method of exploitation and so was displaced by serfdom and the wage system. At the same time one reason why it became increasingly unprofitable was the growing humanity of masters, in which growth the Christian organization had a very large share. The canons of Elvira ${ }^{5}$ undertake to regulate the treatment of slaves by the masters and mistresses, and as over against academic ideals do it more effectively, seemingly, than Stoicism. ${ }^{\circ}$ The church as such never contemplated the doing away with slavery as such, ${ }^{7}$ even though Stoicism had denounced it as "contra naturam." 8 In fact the church constantly taught, as did the New Testament writers, that the slave was to be

${ }^{1}$ Acts $5:$ I-II.

'Cf. Cyprian's "De opere et eleemosynis," especially chaps. X and XI. "Metuis ne patrimonium tuum forte deficiat, si operari ex eo largiter cœperis, et nescis, miser, quia, dum times ne res familiaris deficit, vita ipsa et salus deficiat," etc. (MPL, IV, 609 B.)

${ }^{3}$ Philemon, r6.

I Cor. $7: 20-24$.

5 and $4 \mathrm{I}$.

-Overbeck, F.: "Studien zur Geschichte der alten Kirche," 1875," pp. I58230.

7Rivière, Armand: "L'église et l'esclavage," Paris, 1864.

s "Ulpian. Dig.," I, 54, § I (quoted by Overbeck, loc. cit., p. I69). 
obedient to the master set over the slave. ${ }^{1}$ And only gentle treatment of the slave by the master was demanded. ${ }^{2}$ The slave of a Christian master could only be taken into the community by consent of the master, and slaves were forbidden to ask the community to buy them their freedom. ${ }^{3}$ As might be suspected, Tertullian is especially insistent upon the submission of slaves." Chrysostom taught that there was a threefold servitude brought into the world by sin, that of woman to man, man to the master, and all to the State, and the slave relationship was natural and permanent. ${ }^{5}$ Slavery was the natural atmosphere of life, and its many drawbacks and impossible consistency with her highest ideals were not apparent to the official church then, any more than the official church to-day is aware of any standing contradiction in the social order of to-day and her proclamation of brotherhood and equality before God.

Slaves, however, under certain circumstances might become bishops and presbyters. Thus Calixtus rose to the highest office in Rome. Hippolytus, however, attacks him for many things, and among others for permitting marriage between a slave and a free-born woman. ${ }^{\circ}$ Nor was it customary to make a slave a presbyter without the consent of the slave's owner, as witness the controversy between the wealthy Simplicia and Basil and Gregory of Nazianzus. The worst abuses were very distinctly condemned, ${ }^{7}$ and thus the church became in some measure a court of appeal for the slave.

Nor were there lacking individuals who saw the evil. ${ }^{8}$ And it is doubtful whether any organized protest on the part of the official church would have greatly inured to the benefit of the slave population.

Of great ethical importance was the place the church gave to martyrdom. In all ages sealing personal sincerity by the

${ }^{1}$ Eph. $6: 5-8$; $c f$. Col. 3 :22; I Tim. $6: x$, and I Peter $2: 18$.

${ }^{2}$ Eph. $6: 9$.

'Ignatius ad Polycarp, c. 4.

- "De cor. mil.," c. r3. "Apologeticus," cap. 27; "Ad uxorem," II : 8.

"XIX Homily on I Cor; $c f$. XII Homily on Eph.

- Philos., IX, $7: 9$.

7 "Apostolic Constitutions," $4: 6$.

${ }^{8}$ The Carpocrateans according to Clement of Alexandria, "Strom.," III, $2: 6$. 
giving up of life for the sake of truth has exercised a great influence. Socrates became the reformer of Grecian thought by his tragic death. In an age of cowardice and great moral strain, Jesus died the death of a martyr. The church became extravagant in her estimate of martyrdom, but it is impossible to estimate the services to moral sincerity rendered by the countless martyrs from all àges and classes in the community. In an age of loose cosmopolitan syncretism there was set up a claim for an exclusive faith, and its power over men was proved by their sufferings and their death. The world slowly sought higher ethical levels, and in the movement upward the Christian church gave the longed-for stamp of reality and genuineness to the professions of this seeking faith. The actual power of religion was dramatically set forth.

The international character of the Christian movement gave rise to special emphasis upon certain distinct virtues. Foremost among these to be singled out was that of hospitality. As one sees in both the "Teaching of the Twelve Apostles" and in "Hermas," not to speak of later writers, this hospitality was subject to abuse. Yet no abuse quenched the virtue, and far down into church history Christians demanded and received hospitality simply because they were Christians. This not only bound the church together, but it reacted upon its entire life and gave it breadth and strength. The church consisting so largely as was the case of the non-possessing class, had a large number evidently wandering about seeking economic opportunity.

The sympathies of this somewhat ignorant and narrow-visioned membership made up of the less successful classes broadened and deepened under the training of a world-wide hope and a constantly increasing knowledge of the actual world. If the last chapter of Romans be genuine, and it is exceedingly likely, it is evidence that the early Christians wandered like the Jews from city to city with great ease. They thus learnt statesmanship and interest in world-wide movements as they took part in the establishment of a spiritual autocracy, which thankfully used 
every help toward reaching the somewhat unfortunate goal of imperial power.

The social bond was strong. A common suffering and isolation, even at the best of times, compelled the early Christians, as it now compels German Social Democrats, to trust to each other for companionship and social intercourse. The very ecclesiastical politics that soon usurped a large part of the time of both leaders and people gave a certain seriousness and purpose to the social bond, lacking in other more superficial contacts.

It was thus a steady pressure from within and from without that kept the growing organization strong and united. It meant a great deal to be cast out as a heretic, for unless one could, like Marcion or the Montanists, gather a wide following, the heretic was lost to social intercourse with the old heathen world, and was deprived of all friendships in the new world rising in power and influence every day. Only the very strongest can stand alone against their social world, and when a Christian had given up his old pagan atmosphere, to be thrust out from the new-found circle was to die the death.

Although a democracy that tolerates economic dependence of one class upon another, as the early Christian democracy permitted slavery, can at best only be a foreshadowing of things to be, yet in Christianity were many elements of democracy. The communion of saints meant still even to Cyprian the democracy of the congregation. ${ }^{1} \quad$ Part of the educative force of Christianity was the self-governing character of the more primitive congregations. As the trades-unions are educating men to capacity for concerted action and wise compromise in behalf of united effort, so early Christianity was training men for the time when, even while probably yet in a minority, they should be asked to share the responsibility of helping to govern the empire.

Thus in spite of vast changes for the worse in the theoretical ethics, and in spite of great lowering of the spiritual-ethical en-

\footnotetext{
${ }^{1}$ Cyprian, Epis. $5: 4$.
} 
thusiasm, enough of primitive faith in God as the Father of Our Lord Jesus remained to give sweep and reach to the onrushing conquest of the great ecclesiastical movement which from now on we may call the full-grown Roman Catholic church. 
CHAPTER IV

\section{THE OLD CATHOLIC OR BISHOP'S CHURCH AND ITS ETHICS}

Note of Introduction.-I. Athanasius and Monasticism-II. The Message of the Great Preachers-III. The Monastery and Asceticism-IV. The Bishop's Church and Culture-V. The Bishop's Church and the Cult and Its Ethics-VI. The Church and Her Theology-VII. The Ethics of the Councils.

\section{NOTE OF INTRODUCTION}

To trace the growth of an imperial, ecclesiastical, paternal, and benevolent tyranny from the simple teachings of Jesus is one of the strange tasks set before the historian. Jesus stood so absolutely for the supremacy of the spiritual man that it is difficult to even connect him with a strong centralized imperialism. One by one Jesus was confronted by all the various manifestations of authority which hedge about the normal human life, and over against them all, while recognizing their place and function, he asserted the ultimate supremacy of the Son of Man. The spiritual man might have to abandon father and mother, refuse to follow scribe or priest; he must realize his lordship over days and rites and past commandments. Tradition, sacred and useful, must yet yield to the pressure of a new commandment born of the inward sense of sonship with God. The State had its function and we were to render to Cæsar the things that belong to Cæsar, but in case of conflict the spiritual man must resolutely assert his freedom, and if need be do as Jesus did, and die as an expression of final supremacy over life and death.

This freedom of the son of God was a cardinal teaching of Paul and echoes more or less clearly in all the canonical literature. Yet not three centuries had passed away, and this supremacy was 
yielded to the claim of a priestly, sacramental organization fighting for power and place in every corner of the civilized world of its day. Thus the Catholic Christian of the third century stood in a twofold attitude. As over against the world, the State, the forms of faith acknowledged by the ages, he felt himself free. The cowering slave was raised to a new manhood, and the seal of that freedom was the blood of a long list of past martyrs. In baptism the sinner passed from slavery to sin and death to the new life of forgiveness and virtue. The church was the brotherhood of the forgiven life; the little community was the family of God.

It is out of this family relationship that the ecclesiastical tyranny rose quietly and naturally. The temporary authority of the family was elevated into a permanent pressure upon the individual." The time came when for the ordinary "lay" Christian there were no adult years. He remained a "child of the church," the priest became a permanent "father." The temporary function of teacher became a permanent status. If over against the world there were indeed freedom, as toward the church with its magic sacraments there could only be one attitude, that of humble, reverential submission to its overwhelming authority.

The transition did not take place without protest and schism. The Gnostics, as well as Marcion, Montanus, Novatius, Donatus, and many others instinctively rebelled, but the sweep of a great movement was against them. The assertion of this supreme authority of an organization over the individual could not be made without many a compromise, and ever again the student notes the surrender of this or that secondary interest in favor of the great primary demand for submission to the unity of the sacramental organization.

${ }^{2}$ The Roman conception of the family was always highly aristocratic. The potestas patria survived from the old tribal agrarianism long after the essential economic condition had changed. In the Hellenistic world Stoic notions of jus naturale gradually undermined this conception, but it passed naturally into the church, the ecclesia taking the father's place of absolute power. Cf. Morey, Wm. C.: "Outlines of Roman Law," New York, I893, 6th ed., pp. 23, I29 ff.; see also Ferrero, G.: "The Greatness and Decline of Rome," New York, I907 (English translation by Zimmern), vol. I, pp. 5, 6 . 


\section{THE OLD CATHOLIC OR BISHOP'S CHURCH 189}

It was no accident that this imperial claim should increasingly be identified with the fortunes of the Roman church. Even while the great drama of dogmatic construction was being seemingly played out at Nicæa, Constantinople, or in Asia Minor, the real force at work was that ambition for world-wide supremacy which ever nerved the Christian heart.

That ambition was, however, far better served by the mild, practical, skilful statesmen of Rome than by the quarrelling, hair-splitting theologians of the Eastern church. It was in Rome that religious syncretism was, on the one hand, demanding religious unity in the interests of threatened empire, and on the other willing to make large concessions to every religious cult that did not too exclusively press its claims.

The simple faith of Jesus was not the force that battled for political supremacy, but an elaborate religious syncretism into which had entered elements of paganism from Egypt, Persia, Babylon, Greece, and Rome. The strength of the Catholic Bishop's church did not consist simply in its purer morals, its more certain faith, its brighter promise, and its more tender, loving trust in a one redeeming God. These were its better portion and its nobler advantage, but as a matter of history it met the guilds of Egyptian Isis and Serapis cults by a more closely knit guild organization. It was confronted by the sacramental symbolism of the Magna Mater, and evolved a virgin devotion and a sacramental system simpler and more effective. It found itself threatened by the cult of Mithra and the weird mysteries of the sun-worship, and caught the imagination to which Mithraism ministered by an ascetic practice as compelling and a priestly organization even more effective.

It is now seemingly quite impossible to always say whence came the machinery or apparatus of the religious life in the Nicene period. Undoubtedly much belonged already to all cults, having been borrowed by them from still older strata of religious expression. Probably both Egypt and Babylon gave much to the common tradition. From the oriental mystery-cults seem to have come the tonsure, the white-robed priest, the matins, 
nones and vespers, bells, litany, solemn processions, the mingled wine and water, the sacred wafer, the sacramental magic, the Easter feast, the Christmas feast to the child-God.

They apparently entered Christianity at many points, but Alexandria seems especially prominent as the meeting-place of the cults of Isis, Magna Mater, and Mithra. (See full literature cited, "Hellenistic Preparation," p. 9.)

From the synagogue may have come the sacredness of a weekly day, the assembly for instruction and religious inspiration, the common prayer, reading of sacred books, the singing of psalms and hymns, collections for the poor, the sermon, and the relatively democratic organization of the congregation.

How far the dogmatic and moral reconstruction of the Christian message was influenced by the weightiest and most serious rival in popular affection which the Christian organization had, namely the Mithra cult, we shall probably never know, for the elaborate theology and liturgy of this remarkable synthesis from the Orient have, it is to be feared, been wellnigh entirely lost. Only the monuments and inscriptions to which reference has already been made (page 26) tell us of its wide influence. Some things, however, suggest so close a parallel that it would be strange, indeed, if much more was not common property, perhaps, of the whole religious world of that day. Both Mithraworship and the Old Catholic church had in common sacraments, holy water, called members "brothers" and the older ones "fathers," had baptism or lustration, a communion feast, with holy wine and water and a wafer. Both had introduced monastic vows for men and women. Both had a "Pontifex Maximus." Both had grades of membership, withholding the sacramental elements from the lower grades. Both taught eternal life and made sacramental grace a preparation for it. Both laid emphasis upon purity of conduct, and especially sexual purity, as a condition of blessedness. Both claimed in rite and sacrament to give strength for the battle with evil. Both called the members "milites" or soldiers of virtue. Both were aggressive, convert-making organizations, appealing to the economi- 


\section{THE OLD CATHOLIC OR BISHOP'S CHURCH I9I}

cally oppressed and the down-trodden, and finally both found in Germany and the north of Europe their most splendid field for propaganda and also looked for a final triumph of their cult. ${ }^{1}$

That the ethics of Christianity were influenced we see from the fact that Tertullian holds up the refusal of the "soldier of Mithra" to be crowned because he is to be crowned by Mithra, as an example to Christian soldiers to refuse the pagan triumphal crown because awaiting the crown of Jesus.

The Bishop's Church simply swept into itself all the elements of the successful religious life about the Mediterranean Sea. Some of these elements were good, some were relatively indifferent until identified with the essence of the religious life, others were harmful and debasing. The Christianity of the Nicene period was, on the whole, a wholesome syncretism, powerful enough to organize again the religious and even intellectual life of a sadly distracted world.

It ministered to the ethical longing of the sinful, it satisfied by cultural pomp the æsthetic sense of Roman and Greek. It took uncritically from all what it needed for its purpose. It had a more potent ethical life than any rival, so that at last Constantine was compelled by political necessity to use it as the one organization with sufficient vitality and unity to bind together the tottering empire. Hence Mithra-worship was proscribed and persecuted and, save for a brief resurrection under Julian, the so-called apostate, it seemingly disappeared, because in part, evidently, it had been practically taken up into the Bishop's church.

The oriental cults were divided. There was the Isis cult, the Mystery of the Great Mother, as well as the Mystery of Mithra and many other lesser cults. They all taught a substantial speculative monotheism and linked religion with types of ethical life. All had their priesthood, their judgments after death, with heaven and hell. All sought dominance in the

1 Tertullian "De præscriptione hæreticorum," caput XL, and "De corona," caput XV. Tertullian attributes the resemblance to the wiles of an imitating devil, careless of the fact that Mithra was older than Christ. 
Roman State. It was recognized on all hands that the imperial power was a prize worth having. Long before Christ the old paganism of Italy had given way and the population turned to all the varied superstitions of the Orient for help. ${ }^{1}$ The emperors sought successively among these cults for a national imperial religion. Vespasian built a temple to the Mater Magna at Herculaneum, but even imperial favor could not give her a monopoly. So the Flavians gave their support to Isis, and at one time under the Antonines her triumph might have seemed assured. But then Mithra was popular among the soldiers, and the cult suited the robuster Roman temper better than the gentle Egyptian Isis cult. Then with dramatic suddenness Christianity became the heir of them all, and even though only a minority of her population could by any possibility be called Christian, circumstances compelled the state to establish the Roman Catholic organization to the absolute and intolerant exclusion of her religious rivals with which the state had so long coped. ${ }^{2}$

This is not the place to discuss the many reasons for this triumph, but in studying the ethics of this period it must be constantly remembered that we are dealing with a new world imperialism whose life and hope were very far removed from the ideals of Jesus and Paul. For the kingdom-dream of a holy community of loving brethren was substituted the vision of a triumphant ecclessiastical organization; for the spiritual independence of the loving heart was substituted the reverent submission of the worshipper to a mystic authority; for the freedom and joy of forgiven sonship with God was placed the attitude of penitent lowly seeking of magic sacramental purity; for the gift of a present eternal life was substituted the rewards and penalties

${ }^{1}$ Already in I9r B. C. a decree of the Senate welcomed the Magna Mater. "Rœman Festivals," p. 70, quoted by Dill, Sam.: "Roman Society from Nero to Marcus Aurelius," 2d ed., London 1905, p. 550. See also Mommsen, Th.: "Rœmische Geschichte," 8th ed., Berlin, I889, vol. II, 4 : 12, pp. 4 I I-423.

${ }^{2} C f$. Harnack, Adolf: "Kirche und Staat bis zur Gründung der Staatskirche," in "Die Kultur der Gegenwart," edited by P. Hinneberg, Berlin and Leipsic, 1906, part I, 4. Section "Die christliche Religion," Ist half "Geschichte der christlichen Religion," pp. I 29-158. 
of a hell, heaven, and purgatory, described in an imagery borrowed almost in its entirety from pagan mysteries.

How far the change from an inner spiritual brotherhood to a secular world-conquering power had gone is seen in the mechanical definition and treatment of sin and in the elaborate ecclesiastical machinery for its forgiveness, as well as in the extraordinary claims of the ecclesiastical hierarchy. This change of emphasis resulted also in the relative displacement of the ethical interest by metaphysical and political questions. The energies of the official church were no longer bent upon the question of how, in the midst of a sinful, ignorant generation, a holy community might be built up, but on how an artificial unity, only useful for political purposes, might be preserved on the basis of metaphysical definition. This was the theme of the Nicene council. It is one of the sad commentaries upon the Christianity that claims Jesus as its founder that the abstruse and perfectly incomprehensible metaphysics of the Nicene creed should still be regarded as the bulwark of truth by so many communions, while nearly all that Jesus really stood for is openly neglected.

Yet amidst this declension there still rang out the message of a lofty devotion to inward holiness, and an appeal was made to a high and spiritual ethics.

\section{ATHANASIUS AND MONASTICISM}

This we see clearly in the life and work of Athanasius, ${ }^{1}$ who has become for so many the incarnation of Christian orthodoxy. Athanasius was, however, far more than the great dogmatic

${ }^{1}$ Athanasius, Archbishop of Alexandria, was born probably in Alexandria somewhere between 296 and 298. Cf. art. "Athanasius," by F. Loofs, in Herzog-Hauck's "Realencyklopädie," vol. II (1897), pp. 194-205, English translation, New York, 1908, vol. I, pp. 343-346 (in the New Schaff-Herzog). He was closely associated with Bishop Alexander and became his successor. He wrote his "Operationes contra Gentes" before 3 I9 (Migne, Vita). The Synod of Nicæa was in 325. Five times he was in exile, fleeing from his political and ecclesiastical foes: From July II, 335, to November 23, 337, after the Synod of Tyre, whence he fled to Trier. Again he fled, on March 19, 339, to Rome, only to return October 21, 346. A third time, when Julian ascended 
theologian and untiring defender of a theological formula. There was in Athanasius a profoundly vivid revival of the old dream of a religious holy fellowship. The concept "religious" had been indeed already largely construed into intellectual and metaphysical exactness of belief, but such a construction did not exhaust its content for Athanasius, even though such exactness had become for him as for his age a sine qua non.

Two things make Athanasius of special interest to us. Quite apart from the disputed authorship of the "Life of St. Antony,"

the throne, he fled to the monks of the Thebaid on February 9, 356, to remain until February 21,362 , and to the same refuge he betook himself in the same year, October 24, 362, to remain until September 5,363 . The last exile was short, from October 5,365 , to January $31,3^{66}$, and he remained then in Alexandria until his death on May 2, 373. (These dates are all still in discussion, but are approximately correct). For a full list of his genuine, spurious, and uncertain writings, see Archibald Robinson, in "Nicene and Post-Nicene Fathers," vol. IV, pp. lxiii-lvi, and Migne's "Patrologia Græca," vol. XXV, "Animadversiones in vitam et scripta S. Athanasii," pp. clvi-clxxxiv. For the genuine character of "Contra Gentes," cf. Loofs' article in Herzog-Hauck, and for the full discussion of the vita S. Anthonii, see the literature given in foot-note below. For our purposes have been consulted as the books of most interest to us, "Oratio

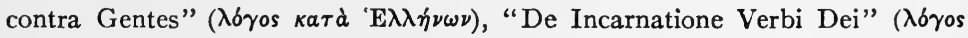

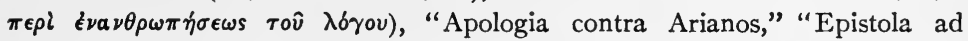
Episcopos Ægypti et Libyæ," “Apologia ad Constantium," "Apologia de fuga sua," "Historia Arianorum et epistolæ ad Monachos," "Epistola ad Serapionem de Morte Arii."

Translations of selected writings by Archibald Robinson, in the "Nicene and Post-Nicene Fathers," edited by Schaff and Wace, vol. IV. For the list of best texts, see F. Loofs, in Herzog-Hauck's "Realencyklopädie," vol. II (r897), p. 194, English translation, vol. I (1908), p. 346, or "Nicene and Post-Nicene Fathers," vol. IV, p. xi; also the introduction to Migne, vol. 25, of the "Patrologia Græca," which text is the one consulted in this work.

'For discussion of the question of the authorship, see Weingarten, H.: "Der Ursprung des Mönchthums im nachconstantinischen Zeitalter," Gotha, 1877 (appeared first in the "Zeitschrift für Kirchengeschichte" (Brieger's), I (I877), pp. I-35; 545-574, reviewed by Hilgenfeld, in "Die Zeitschrift für wissenschaftliche Theologie," XXI (1878), pp. I39-150, by J. Cropp, in "Jahrbücher für deutsche Theologie," XXIII (I878), pp. 342-346, and Lucius, P. E.: “Die Quellen der älteren Geschichte des ägyptischen Mönchtums," pp. I63-198, in "Zeitschrift für Kirchengeschichte," Th. Brieger, VII (I885); also Gass, in "Geschichte der christlichen Ethik," I (I88I), pp. I 2 I-I 25, and his article, "Zur Frage vom Ursprung des Mönchthums," in "Zeitschrift für Kirchengeschichte," II (1878), pp. 254-275; Hase, K.: "Das Leben des heiligen Antonius," in 
in Athanasius we see the first signs of a linking of monastic asceticism to the world-purpose of the Christian hierarchy; and in Athanasius is also found the identification of the Logostheology with the ethical content of the redemption by an incarnation of the divine life in the historical Jesus, ${ }^{1}$ with the ultimate subordination or loss of the principal interest in the Logos-conception.

Whether Athanasius wrote the "Vita Antonii" is still in dispute. It is certainly far below the intellectual level of his undoubted works, and it would be a relief to place the "Life" among the forged romances in which the age abounded. Moreover, the simple-minded Gregory of Nazianzus ("Oratio," 2I) might easily, nine years after Athanasius's death, accept as genuine even a rank forgery. But whether this is so or not, Athanasius stood in intimate relationship with the monks of Egypt. He shared their world of demons and wonders. ${ }^{2}$ He overcame their distinctly anti-clerical feeling, ${ }^{3}$ and bound them and the whole monastic development to the world-purpose of the sacramental imperialism. When Athanasius himself was raised to the episcopate it was as "one of the ascetics." 4 To Egypt he fled for safety, and with the ascetic ideal he linked his conception of redemption. There is thus in Athanasius a transference of emphasis. The Alexandrian school is given an ethical interpre-

the "Jahrbücher für protestantische Theologie," VI (I880), pp. 4I8-448; Eichhorn, Albert: "Athanasii de Vita ascetica testimonia collecta Dissertatio theologica," Halle, I886; Loofs's art. on "Athanasius," in Herzog - Hauck's "Realencyklopädie," vol. II (I897), pp. I94-205, English translation ("The New Schaff-Herzog," New York, I908), vol. I, pp. 343-346; Keim, Theod.: "Aus dem Urchristenthum," vol. I (Zürich, I878), pp. 204-220; Israel, W.: "Die Vita S. Hilarius des Hieronymus als Quelle für die Anfänge des Mönchthums kritisch untersucht," in "Zeitschrift für wissenschaftliche Theologie" (1880), pp. I29-165; Gwatkin, H. M.: "Studies in Arianism" (I882), pp. 98103.

${ }^{1}$ Cf. Harnack, A.: "Lehrbuch der Dogmengeschichte," vol. II (I894), pp. I55-273.

2 "Contra Gentes," $\S$ I5 $: 5 ; 18: 4 ; 25: 5$; and many other passages.

${ }^{3}$ Cf. "Epist. ad Dracontium," XLIX; see also Grützmacher "Pachomius und das älteste Klosterleben," 52-64.

- $\epsilon_{\nu \alpha} \tau \hat{\omega} \nu \dot{a} \sigma \kappa \eta \tau \hat{\omega} \nu$. 
tation that marks a distinct advance, at least over Origen's conception of redemption.

These two conceptions, the monastic-ascetic and the ethicalsocial, are never brought in church history into any real unity. On the one hand the "Life of St. Anthony" teaches a crass eudæmonistic ethics. In exchange for the pleasures and joys of a short life the monk receives the eternal joys that do not pass away. ${ }^{1}$ The eudæmonism is only softened by the characterization of the "goods" that are thus acquired. "Why acquire those things which we cannot take away with us? Let us rather acquire those things which we can take with us-that is, prudence, justice, temperance, courage, understanding, love, kindness to the poor, faith in Christ, freedom from wrath, hospitality. If we possess these things we shall find them of themselves preparing for us a welcome in the land of the meek-hearted." 2 For Anthony the lusts of the flesh were to be conquered, and not simply the flesh overcome. ${ }^{3}$ For Athanasius the flesh was not in itself evil. He, in fact, expressly condemns "certain Greeks" who, not knowing Christ, "have ascribed to evil a certain substantive and independent existence." \& Whereas Athanasius argues that matter cannot in itself be evil, as all is the creation of God. ${ }^{5}$ The absolute monism that excludes all dualism is defended in the same treatise. ${ }^{6}$ The following of Christ is a work or labor whose reward is eternal life, and Judas in one night destroys all his labor and loses his reward. ${ }^{7}$ Although the real individualistic selfishness of this conception of salvation is not plain to Athanasius, yet personally he sees in the monastic development a nobler and more social purpose than the salvation of one's own soul. It is for him also a dramatic sermon to the pleasure-loving. "For let him that will go and see the proof of virtue in the virgins of Christ and in the young men that follow

${ }^{1} \S \S \mathrm{r} 6,17$.

${ }^{2} \S_{17}$, "Vita S. Antonii" (italics ours), Newman's translation.

3 $\$$. “ "Contra Gentes," \& $6: \mathrm{r}$.

- "Contra Gentes," $\$ 7: 1-5$.

7 I8, "Vita S. Antonii." 
holy chastity." 1 And no doubt this apologetic value was very great indeed.

At the same time the monastic conception of the Christian life was probably a greater danger to real Christianity than Arianism, and Athanasius is quite blind to the inherent impossibility of reconciling the two ideals. The social-ethical ideal which Jesus proclaimed under the head of the reign of God appears, nevertheless, in Athanasius's conception of redemption, which is fundamentally a renewal of the world and humanity by a new creative indwelling. Nor is this wrought simply physically or mechanically or metaphysically, but by the revelation of the ethical life. ${ }^{2}$ Men once more are enabled to see God in human life fully revealed. ${ }^{3}$ Thus the doctrine of the Logos was given a changed significance, and Athanasius identified the two interests, the ethical-social interest with the metaphysical interest, for from his point of view Jesus had to be fully God in a metaphysical sense in order to reveal him fully. ${ }^{4}$

With the dogmatic question we are not here concerned, but when Athanasius attacks heathenism it is always along ethical lines; and if "impious opinions" are as evil in his sight as the unethical life, it is because he could not believe an ethical life could be built upon aught save what he regarded as the only sound opinion. Hence he was willing to stake all on the struggle with Arius. "It is our all," he himself exclaimed.

To understand the attitude of the organized church to the monastic-ascetic ideal it must be carefully resolved into its elements. Asceticism in a broad sense means simply "training." Any one who truly seeks from day to day to subject the lower impulses to the higher purpose is in this sense an "ascetic." For Athanasius, for instance, sin consisted in "the rejection of better things," 5 and the Christian life was a struggle upward.

${ }^{1} \S 48: 2$, "De Incarnatione Verbi Dei."

${ }^{2} \S 7$, "De Incarnatione Verbi Dei."

"I 4 : 2, "De Incarnatione Verbi Dei."

"This is best brought out in the "Four Discourses against the Arians," particularly in II chap. $17: 25-30$.

\& $5: 2$, "Contra Gentes." 
Yet it is easy to see that monasticism was more than that. It rested upon the conception of virginity as a good in itself. This notion was wholly foreign to Jewish thinking. Not even in Paul (cf. p. I 79) are we to find, what some see there, the oriental conception of virginity as per se good. ${ }^{1}$ It is the result of dualism thought out to its last analysis, and could only arise where high intelligence united a despair of life with the religious motive of rescue from its turmoil.

Amidst the natural passions let loose by wealth and slavery in the Roman-Greek world virginity became a dramatic and effective assertion of conquest over the world and self. All the Christian apologists dwell on the contrast between the purity of monastic life and the lusts of the heathen world. ${ }^{2}$ Monastic virginity was, of course, directly contradictory to the socialethical ideal built upon the notion of the family, and rejoicing in fatherhood and motherhood. Yet it gave at once a fighting weapon into the hands of the propagandist organization with its dream of world-conquest. Nor was Athanasius slow to see this, and he first binds the monks to the church. ${ }^{3}$ His residence amongst them, his relations to Pachomius, ${ }^{4}$ his care for their orthodoxy, and his life of St. Antony (if genuine) compel us to regard Athanasius as the first of the ecclesiastical leaders to see the importance of subordinating the monastic development to the imperial church. He realized what it meant to have a body of men cut off from the ordinary joys and duties of the home life, and finding in the life of an organization the field of their hopes and ambitions. Thus the strange contradiction was seen, of men, whose fundamental postulate was the negation of life, becoming the foremost fighters for an organization whose affirmations demanded the whole of life here and in eternity.

${ }^{1} C f$., for contrary view, Ziegler: "Geschichte der christlichen Ethik," p. I92, who, however, admits that the opportunist reasons for celibacy were foremost. For fuller discussion of Asceticism, see author's article in Hastings's "Encyclopædia of Religion and Ethics," vol. I.

${ }^{2}$ Athanasius, "De Incarnatione Verbi Dei," cap. 48 : I-4, and many passages.

${ }^{3}$ Epistola, III, ad monachos.

"Cf. Grützmacher, G.: "Pachomius und das älteste Klosterleben." Freiburg, 1896. 
Such a body of men could only come into existence under the influence of the oriental religious estimate of virginity as a good in itself. So more and more this conception in theory triumphed over the Jewish and natural valuation of the family. Never was the contradiction really faced. The motherhood impulse found in the worship of the Madonna, and the family impulse in the very name "father" as a religious title, abundant recognition. The extension of celibacy to the clergy ${ }^{1}$ made the monastery really unnecessary, but this extension was a necessary step the moment virginity was considered as a good per se. Yet the monastery persisted and gave rise to its own type of ethical ideal, and has always been the main support of the baleful twofold morality which has so seriously hampered the progress of Roman Catholic ethics.

Many factors made the evolution a natural one. The looking for an early coming of Jesus seems to make the founding of a home a useless care. The duty of sounding the alarm, going everywhere to do so, made "the leading about a wife" a heavy burden. Jesus was himself so soon cut off that he never seems to have married. Very early Alexandrian influences and the intrusion of Gnostic philosophy converted the early essentially Jewish atmosphere into one more nearly in sympathy with the oriental-Hellenistic world of thought. In this atmosphere world-flight and the negation of the world as being itself essentially evil were natural conceptions. Then came persecution. The world did seem to grow worse and worse, and flight from it was a natural relief. Whatever may have been the influences of the Serapis cult ${ }^{2}$ or of the celibate band connected

\footnotetext{
1 The attempt to force celibacy upon all the clergy from deacon on was made at the council of Elvira, 306, but a canon to that effect is said to have been rejected by the council at Nicæa, on the plea of Paphnutius, himself a celibate monk ( $c f$. Hefele: "Hist, Councils," vol. I, p. 435 ff.). In the East bishops were soon by custom compelled to live in celibacy, but the struggle lasted in the West down to the time of Gregory VII (I073). Here, as in some other directions, Africa, with Augustine as its representative, played a baleful part.

${ }^{2}$ Cf. Weingarten, Herm.: "Der Ursprung des Mönchthums im nachconstantinischen Zeitalter," Gotha, I877; also in "Zeitsch. für Kirchengesch," vol. I.
} 
with Mithra-worship, ${ }^{1}$ it is easy to understand how these monastic and dramatic exhibitions of flight from the world appealed to the popular imagination. Indeed, they still appeal to certain orders of minds. Thus Christianity was almost compelled to compete in austerity and to exhibit, in her struggle for world-dominion, an asceticism more pronounced than even her rivals. Essenism had, so far as one can see, nothing to do with Christianity. $^{2}$ It was in its very essence the contradiction of the free spirit of Jesus and the early church. But it is an exceedingly interesting evidence of how the popular view of "holiness" was forced even upon Judaism by the oriental time-spirit. Moreover, it is also true that if oriental asceticism modified the social-ethical ideal of the kingdom proclamation, we shall also see in the course of our history how the social-ethical ideal also in turn modified the eremitic, world-flight conception and made the monks the bearers of a specific and most salutary message of culture. Both in Athanasius and Augustine as well as even in Tertullian, we see early Catholic Christianity reacting against the merely fakir type of celibate holiness.

The monastery was a distinct advance upon the hermit life. It at least compelled men to submit to a rule, and although there were, no doubt, as we shall see in the rules of Pachomius, indifferent spirits to be forced to a higher plane, the same was also true of the hermits, of whom many lived very far from the highest ideal pictured in the life of St. Anthony. The idea of acquiring a special virtue had by this time gone very far. The "martyrs" occupied a special place and gave letters of indulgence to less fearless brethren. As martyrdom ceased, virtue could be acquired by celibacy and heroic feats of fasting and self-torture. The whole doctrine of "Meritum," ${ }^{3}$ however, supposes an entirely different conception of God from that given us in the life and purpose of Jesus.

${ }^{1} C f$. note on page 26 .

${ }^{2}$ Contra Ziegler.

"Cf. Harnack, A.: "Dogmengeschichte," vol. II, 2d ed., 1894, pp. 15720r, for discussion of the doctrine of grace and sin; English translation, V (1899), pp. I6r-22r. 


\section{THE OLD CATHOLIC OR BISHOP'S CHURCH 2OI}

These two ideals of ethical relationship to God persist side by side in all the great teachers of this period, and the fundamental contradiction between the two has not even to-day been clearly recognized in Protestant dogmatic theology. ${ }^{1}$ On the one hand the ethical relationship is based on the free love of a father to the sinning child (prodigal son), who blesses even the wicked and rebellious (rain on just and unjust). Salvation is absolutely the free gift to any one coming in sorrow to the Father, whose love is over all and for all. The joy of the forgiven life is its own reward, and into this joy the Father calls all who will come. The ethical relationship of the ascetic to God is based on the other hand on the fundamental thought of God as one who is angry and must be appeased. This conception is found in both paganism and Judaism. So the ascetic thinks God is pleased by fasting and long prayers, whereas Jesus and his disciples did not fast, and he forbade wordy petitions. Between the worshipper and God the ascetic soon thrust the Mater Dolorosa in the very color and form of the Mater Magna of heathen mystery-worship; and the suffering Son in imagery borrowed, one is tempted to believe, at times much more from Horus the child-god and Mithra the fighting incarnation of justice than from the synoptic Gospels. Over against this God there can be "merit" heaped up as a claim. The relationship becomes legal rather than parental; the ethics are based upon exchange and calculation and not on the freedom of love.

Moreover, the sacramental organization begins increasingly to obtrude itself between the worshipper and this God. Optatus, Bishop of Mileve, struck a fearful blow at the independence of the ethical life when in opposition to the Donatists the phrase was formulated, "Ecclesia una est cuius sanctitas de sacramentis colligitur, non de superbia personarum ponderatur." ${ }^{2}$ More-

${ }^{1} C f$. Shedd's "Systematic Theology" on Atonement, for instance.

${ }^{2}$ De schismate Donatistarum," liber II, § I. MPL, XI, p. 94I. Cf. Müller Karl: "Kirchengeschichte," Band I, p. 249; Möller, Wilh.: "Kirchengeschichte," I, 2d ed., r902, pp. 53r, 532. 
over, the fantastic, hysterical moods bred of the desert and the unnatural life of the monastery made the transference of many superstitions to even the educated circles of the Christian church possible, where even paganism on the same intellectual level had cast them off.

The emphasis was changed. Jesus came to save the world, and sent his disciples to proclaim the kingdom of God; the monkish ideal was the salvation of the person's own soul, and, as always happens, just as far as monasticism sought to save its own soul it lost it. Strangely. enough, these two ideals could exist side by side in considerable measure, and in spite of the triumph of monasticism, its ethical ideal never could quite displace the social-ethical estimate of life. Hence the monastic development became detached from its Oriental and essentially dualistic philosophy of life, and, transplanted to the West in connection with a triumphant sacramental imperialism, it took up its cultural and ethical task of teaching and training Germanic Europe.

In the doing of this work it gained and deserved a large place in human history, and much of its honorable history is too often buried amidst polemics or lost sight of amidst the corruptions to which it inevitably fell a prey. The beginning of this subjection of the monastic ideal to the Roman Catholic sacramental system is seen in the work of Athanasius. How old the development itself was is in dispute. It is certainly older than Weingarten would have us believe. Its form is, however, thoroughly pagan, and how it gradually passed from its pagan form to superficial Christianity in Egypt and Palestine it is now impossible from the data at hand to say with any assurance.

\section{THE MESSAGE OF THE GREAT PREACHERS}

The questions relating to the transformation of dogma and creed have occupied, naturally, the attention of the systematic theologian, but it is often forgotten how small must ever be the number to whom such questions are really vital. The 
details of such discussions have only meaning for the mass of even thoughtful men as they are led by trusted teachers to connect them with their own vital religious and ethical experiences. Into the metaphysics of the question that involved the formulation of the relation of the essence of the second person of the Godhead to the first person, not one in ten thousand of the nominal Christian community was fitted to go. But the clear expression and the great religious earnestness of Athanasius, together with, no doubt, the real linking of the final formulation with the Christian experience of many, gave the new creed of Nicæa a tremendous and increasing hold upon the religious imagination of the church.

As over against the divided ranks of Arianism, with its political interest, its rationalistic basis and intellectualistic caste, as well as its reversions to older but exceedingly varied forms of heathen thought, ${ }^{1}$ the orthodoxy of Nicæa offered at least a seemingly united front.

The great ecclesiastical machine, built upon the devotion of martyrs, the spiritual visions of a thousand saints, the labors and toils and tears of uncounted and obscure followers of the cross, at last triumphed; and the shrewd Constantine and the emperors that followed him, with the single exception of the high-minded but misguided Julian, were compelled to seek in the sacramental hierarchy the only possible basis for a religious unity of the empire. It is hard to see in Constantine any large Christian inspiration. ${ }^{2}$ But he was shrewd and perhaps superstitious, and as he gradually saw the usefulness of the ecclesiastical organization and gave it freedom, the joy of the church covered a multitude of sins. The whole position was changed. Heathenism was now only tolerated, at times was even exposed to harsh treatment; and the ecclesiastical hierarchy became increasingly powerful.

${ }^{1} C f$. Gwatkin, H. M.: "Studies in Arianism," 1882, pp. 52-64, and Newman, J. H.: "The Arians of the Fourth Century," London, 1854 .

${ }^{2} C f$. Burckhardt, J.: "Die Zeit Constantins des Grossen," I88o, pp. 347397. 
To understand the strength of the church as an ethical factor we must turn away from the dogmatic disputes, whose bitterness was increased by the fact that to ever greater extent victory meant the dominion of the world. By the leaders the metaphysical questions were, no doubt, sincerely regarded as the key to the situation. As we study, however, the message of the great preachers of the immediate postnicene period, we must recognize the fact that the force and greatness of the Catholic organization lay not in its intellectual, but in its ethical and religious life.

The history of Nicene orthodoxy is morally sickening to the last degree. Bribery, persecution, repression, backstairs influence, and poison play their baleful rôles. But, apart from ecclesiastical orthodoxy, within and without it existed a great religious movement. ${ }^{1}$ When we compare Ambrose or Augustine, Basil or Chrysostom, as writers and thinkers with their classic models the difference is marked. But the leaders of the church had what neither Cicero nor Marcus Aurelius possessed-they had actually seen God in the face of Jesus Christ as forgiving and redeeming love. Much remained unchanged in their views of life and the world. Heathenism reasserted itself in saintly mythology and magic sacramentarianism; human nature imperfectly sanctified, even by that vision, gave room for pride and hate and fear and bigotry; but for all that, no veil could quite hide the shining of the faces of those who had seen God in pity and compassion, and these men became the messengers of redeeming grace.

In no man is seen more clearly the mingling of these two elements, the gracious messenger of redeeming forgiveness and the superstitious and sometimes hard and proud ecclesiastic, than in the great organizer Ambrose of Milan. ${ }^{2}$ One of his

${ }^{1}$ Cf. Burckhardt: "Die Zeit Constantins," I880, p. 378.

${ }^{2}$ Ambrose, born probably at Treves, of noble family, in 340 . His sister, like himself, was religious from early youth and became a nun. He was made bishop eight days after his baptism, and that by acclamation, in 374 . He died after a most successful bishopric in Milan in 3 . For our purposes the chief works are "De Fide," in five books; "De Spiritu Sancto," in three books; "De 
main works, "De Officiis Ministrorum," is an ethical treatise, in form far below the model, from which he borrowed wholesale, by Cicero. The intellectual and literary worth of the two books make a comparison impossible. But when the spirit of the two is considered, at once it is manifest why Cicero speaks even today to the few who need him least, and Ambrose became the teacher of the unshepherded multitude.

Even along the line where the ethical message most parts asunder from the teaching of the Jewish Christ, as in the matter of virginity, Ambrose makes his appeal tell for a higher sexual relationship, and demands of the man the same purity he demands of the woman. ${ }^{1}$ The corruption along sexual lines of a slave-ridden community made the appeal of virginity a very strong one, and Ambrose is insistent on the honorable character, indeed, of marriage, but the superlative virtue of continence. ${ }^{2}$ In the conception of the incarnation according to Ambrose lay a joining of the life of heaven with the bodies of men in a certain mechanical way that suggests the oriental dualistic conception. ${ }^{3}$ But in truth the message of Ambrose was not primarily a speculative system, however firmly he held as all important the conventional orthodoxy of his day. His whole life and teaching was a religious and ethical appeal.

Had Ambrose had his chief importance as even a theoretical ethical instructor, we might almost lament his transplanting

Mysteriis" (generally accepted as genuine); "De Pœnitentia," in two books; "De Officiis Ministrorum," in three books; "De Viduis" and "De Virginitate," as well as "De Institutione Virginis." Among his chief addresses may be mentioned the "Exhortatio Virginitatis," "De Excessu fratris Satyri," and "De Obitu Theodosii Oratio." His letters also abound in material of use to the student of his time. All the older editions of his works, from that of Venice, in 1485, to the Roman edition, I 580-1585, have been superseded by the Benedictine edition, Paris, 1686-1690, which is reprinted with additions by Migne, in "Patrologia Latina," vols. XIV-XVII. A new edition at Milan, 1875-1886, is said not to be an improvement. Select works and letters are translated in Schaff and Wace: "Nicene and Post-Nicene Fathers," second series, 1896, vol. X.

1 "De Officiis Min., book I, I $7: 65$, and other passages.

2 "Honorabile itaque conjugium, sed honorabilior integritas." "De Viduis," I 2 : 72, quoting I Cor. $7: 38$. (MPL, XVI, 256 B.)

3 "De Virginibus," I, $3:$ : 3 . 
Cicero and the Stoics, but this was not the case. The services of the pulpit as we see them rendered by Ambrose, Chrysostom, and Augustine, were of high intellectual value; they brought to the masses the intellectual life of Greece, even though decadent Greece, an intellectual life that had still further been lowered by contact with the practical issues at Rome. Nevertheless the prime value of the Christian pulpit was not on this side. Consciously or unconsciously the whole intellectual superstructure of the pulpit message of the postnicene period has gone from us or is going. There remains, however, the priceless ethical and religious services the Christian pulpit rendered.

Nowhere is this perhaps more beautifully brought out than by a comparison, for instance, of the sermons by Ambrose on the death of his beloved brother Satyrus ${ }^{1}$ with even the choicest comfort of the Stoics. "Death is not a penalty," for the Lord did not "inflict death as a penalty, but as a remedy," ${ }^{2}$ hence death is fundamentally not an evil, but a good; ${ }^{3}$ it is, however, not simply an escape from the thorns and briers that beset men's ways, but is God's way of purifying unto holiness. ${ }^{4}$ It was not as prophet, but as priest that the church felt most her responsibility. Protestantism may justly complain of the haughty claims of exclusive priestly function made by the Catholic imperialism. Yet it is the priestly service she rendered that forms still her highest claim to our gratitude. She did mediate the God and Father of Our Lord Jesus in a dialectic phraseology, indeed, that is losing meaning for us, but yet effectively to the world passing from one economic order with painful birth-pangs to a wholly different social arrangement.

It was this superb sense of being the proclaimer of forgiven sin that gave this imperialism conscious power. As over against the Novatians Ambrose asserts in unequivocal terms the power of the church to forgive $\sin ,{ }^{5}$ although she would only do so on conditions of her own defining; ${ }^{\circ}$ and she more and more

1 "De Excessu fratris Satyri" and "De Fide Resurrectionis."

2 "De Excessu.," II, 37.

3 "De Excessu," II, 39.

“"De Excessu," II, 4I.

s "De Pœnitentia," I, 2 : 6.

- "De Pœnitentia," I, 3 : Io. 
makes this power of her proclamation a selfish instrument of her might. It is a mark of the imperial character of her claims that Ambrose makes schism the only unforgivable sin, ${ }^{1}$ and that the dealing of the church with the "Lapsi," or those who in persecution had fallen away, was always controlled by the interests of her spreading power on the one hand and the cohesion of the organization on the other.

But the organization as Ambrose loved and served it was for the redeeming of men from sin; it was God's instrument for calling wandering sinners back to grace and holiness. Her works were to be those of love and mercy, and her strength was her indwelling with God. It was not so much what these great teachers taught in set dogma and formal creed, but what they were as men and leaders in the new life that gave them power and permanence.

What that power was is seen in the life-history of these great preaching bishops. One is strongly reminded of Savonarola as one reads the story of the life and final defeat of the eloquent John, called Chrysostom. ${ }^{2}$ The ethical theory is of less interest

1 "De Pœnitentia," II, $4: 24$.

${ }^{2}$ John, called Chrysostom ('I $\boldsymbol{\omega} \alpha \dot{\nu} \nu \eta s$ ò $\chi \rho v \sigma o \sigma \tau b \mu o s$ ), was born about 344 , in Antioch (on the Orontes), and was of noble birth. He was ordained reader by Bishop Meletius in 369. When first sought for as a bishop, in 374 , he evaded it by hiding, and embraced the monastic life in the following year. In 380 or $38 \mathrm{r}$ he was ordained deacon, and about five years later was made presbyter. On the death of Nectarius he was elected Bishop of Constantinople, in 398, and began a work of ecclesiastical and political reform which made him very unpopular in high quarters, but secured him the support of the masses. In 403 he was banished by Theophilus, Bishop of Alexandria, but had to be recalled, such was the popular uproar. Finally Eudoxia (the Empress) expelled him, and he left Constantinople in 404 . In 407 he was ordered to Comana, and on the way he died. In 438 his body was brought back in state to Constantinople. His works are very numerous, and those that interest us especially are the Homilies and Orations, the treatise on Virginity ("De Virginitate," in one book), and the treatise, "De incomprehensibile Dei natura," in five books. A history of the texts is given in Migne, "Patrologia Græca," tom. 47, cols. $263_{3}-276$ (see also Schaff, P., in "Nicene and Post-Nicene Fathers," series I, vol. IX, pp. 3-5). The text used is that of Migne, "Patrologia Græca," vols. 47-64, though the reader must guard against printers' errors. Translated in the first series of the "Nicene and Post-Nicene Fathers," edited by Schaff and Wace, vols. IX-XIV. 
to us than the actual ethical activity of the man. He was bent upon securing a holy church. To this end he proclaimed his ideal of the ascetic monastic priesthood and the sacramental power of the ecclesiastical organization.

For the theologian his work must be of intense interest as one notes how God is thrust further and further away by Greek metaphysical speculation, and the religious interest fills the gap thus left by putting steadily in the foreground the Incarnate Logos. ${ }^{1}$ Yet, in spite of Greek spirit and oriental atmosphere, the organization instinct was almost as strong in Chrysostom as in Ambrose. This is what Christianity accomplished and philosophy failed to do. It made men give themselves to the new communal ideal. Even if this was priestly, ecclesiastical, and sacramentarian, the effect was the evolving of a new standard of human conduct.

In Chrysostom we see the new and relatively democratic organization force its way against the military tyranny which was the essence of the Byzantine Empire. And in the treatise, "De Virginitate," we see how the needs of the organization compel even so stout an ascetic as Chrysostom to adapt his morality at this point to social needs. Hatred of marriage as proclaimed by Marcion, Valentinus, and Manes, Chrysostom says, is of the devil, ${ }^{2}$ and he boldly says that he who condemns marriage takes away the glory of virginity; ${ }^{3}$ and even though the defence of marriage is often put on the low grounds given in the English "Book of Common Prayer," "the social meaning is not wholly lost sight of.

As over against a vulgar fatalism that excused on the ground of human nature every surrender to personal sin, Chrysostom lays emphasis upon ethical freedom and the nobility of man. Upon the sinner is put the burden of his $\sin .^{5}$

${ }^{1}$ Cf. "De Christi precibus, contra Anomœos," IX.

2 "De Virginitate," III.

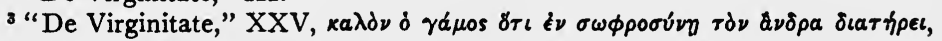

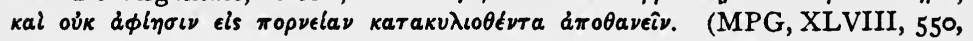
KE.')

- Marriage service.

$s$ "De diabola tentatore," Hom. III, 2, and many passages. English translation in "Nicene and Post-Nicene Library," vol. IX, p. I92, American edition, I903. 
He taught the exercise of loving humanity in the treatment of slaves, and, according to Burckhardt, demanded the entire abolishment of slavery. ${ }^{1} \mathrm{He}$ faced a corrupted priesthood with the stern excision of thirteen bishops, and by holding up an ideal of personal purity and consecration forced the secular power to terms.

The great preachers of the new Catholic church organized the pulpits of the churches into a tremendous power with which the rulers of the world have had to reckon ever since. Even in Chrysostom one sees how the credal and ethical-legal development began to balance the tendency of fierce differences in opinion, and how the tradition of the organization hardened into creed and canon as a formal bond for ecclesiastical and political union.

Such a formal bond the political power also sought, but nothing save a new ethical and religious enthusiasm could make it a reality. And such enthusiasm and religious zeal as an Ambrose or a Chrysostom were possessed by could not be tamely yoked to the half-disrupted political machinery of the old era. In the life of $\mathrm{Basil}^{2}$ we see the far-reaching vision of a world-wide ecclesiastical dominion as it took hold of these new leaders of the world's way. ${ }^{3}$ Like Ambrose, Chrysostom, and the others, Basil proclaimed the ascetic-ethical type. He was himself the founder of orders, and had travelled in Egypt," Palestine, Syria, and Mesopotamia, seeking those who had left all to follow Christ. ${ }^{5}$

1 "Die Zeit Constantins des Grossen," 2d ed., I880, p. 379.

${ }^{2}$ Basil was born in 329 or 330 , in Pontus (Neocæsarea), or in Cæsarea in Cappadocia. Two of his brothers were also bishops, i. e., of Nyssa and Sebasteia. In 370 he was consecrated Bishop of Cæsarea, and died in 378 or 379 (probably January ist of the later date). Of his numerous works, those that concern us

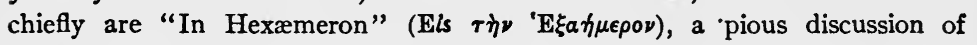
creation; Tractatus Prævii," "Proœmium de Judicio Dei," "Moralia" ( $\tau \alpha$ 'H $\theta(\kappa \alpha)$, the "Homilies" and "Letters." The numerous texts given in Migne, "Patrologia Græca," vols. XXIX-XXXII. Translation of selected writings, VIII of "The Nicene and Post-Nicene Fathers," second series, edited by Schaff and Wace, vol. VIII.

${ }^{2} \mathrm{Cf}$. Epistola, 70, and the grounds for a demand for church unity in Epistola, 65.

- Epp. I and 223.

- Epistola 223, \& 2. 
His mind is clear and sharp-cut, and although impulsive, domineering, and perhaps arrogant, his ethics are lofty and his purpose very high. For him God was the source of all good. "Equally blasphemous is it to assert that evil has its origin in God; for from the opposite cannot spring the opposite. If, then, evil is neither God-created nor uncreated, whence comes its being? No one who lives in the world will say that evil does not have a being. What, then, shall we say? Evil is not a living, breathing being, but a condition of the spirit which is opposite to good, and arises in the unthinking because they decline from God." 1 We are therefore not to go beyond ourselves to seek for the origin of evil or to imagine that there is a primal essence of evil. ${ }^{2}$

Basil, moreover, distinguishes between such misfortunes as "sickness, poverty, obscurity, death, in brief, all human ills, which should not be estimated as evils, since we do not estimate as being their opposites things that are the greatest boons. ${ }^{3}$ But on this problem of problems that led astray so much of the best strength and thought of the oriental and Hellenistic worlds, Basil does not dwell. He has found his message, and in the authority of the sacramental organization and in the security of traditional orthodoxy he, like thousands of others, took refuge and gives his strength to the cultivation of the church which is to him the symbol of the divine sovereignty on earth.

The beauty and lofty character of Basil's ethical message may be seen in Epistola XXII, which is a little ethical treatise drawn up for a "brotherhood" or "cœnobium," although the sterner side appears in the injunction not to laugh or suffer jesters. The great social power of the organization is shown in the mere demand: "No Christian should consider himself his own master, but each should think himself as a slave given by God to the brethren who think with him,", quoting as proof I Cor. I5 :23. The conception of the Christian as servant of

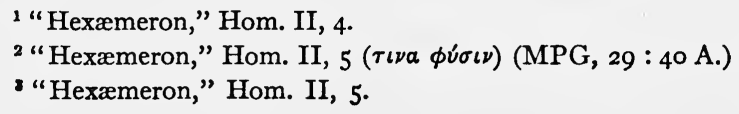


all underlay even the haughty claims of the growing hierarchy, and Basil is haunted by the vision of a community actually given up to the pursuit of holiness in loving service.

In the letter to Chilo, ${ }^{1}$ upon which unnecessary doubt has been cast, he gives a picture of life as men of earnest mind saw it then. No judgment could be more sweeping. "The world's good things are mingled with evil things, and the evil things have decidedly the advantage." He sought everywhere relief. "I heard many discourses which were wholesome for the spirit, but I failed to discover in any teacher one whose life corresponded to his teaching. Then I heard the tuneful lyre, the applause given to actors, the jokes of clowns, the jests, the follies, the murmur of the rabble. I saw the tears of the robbed, the agony of men under tyranny, the cries of the tortured did I hear. I looked, but no holy communion, but only a wind-tossed,'tumbling sea, seeking but to submerge all in its waves." Despair fills his soul. Good works are on this sea as a drop of fresh water in the ocean. World-flight is the remedy, and to save one's own soul the suggested way out. "For this reason I fly to the hills as a bird." Yet from this despair the growing hierarchy saved men. In the church's power was promise for a better future.

Just as to-day many an earnest soul overlooks the materialism, the crudeness, the bickerings and divisions of political Social Democracy, and sees in it the hope of a coming state of brotherhood and love, so souls like that of Basil and Gregory of Nazianzus turned to the church, and forgave its divisions and its narrowness because they saw in its hope, at least, the ideal of that life after which they longed, and they shared with it the delusion that this ideal community could only be built up on the basis of orthodoxy and sacramentarian correctness.

Hence the message of forgiveness in its ethical relations occupies much of the attention of these preachers of the new righteousness. How could men be saved from the awful yoke and curse of the law without falling into license and sin? And how could the church proclaim the sinner forgiven? These were

\footnotetext{
${ }^{1}$ Letter 42.
} 
burning questions of far-reaching ethical importance. Paul met them early in Corinth, but as the church became more completely a substitute for the secular power the difficulty greatly increased. Stern puritans like the Donatists, the Montanists, and the Novatians, would have wrecked the political organization by limiting its power to forgive sin.

The dynamic of baptismal grace was exhausted by the past, and the sinner was denied approach to the source of sacramental grace in the eucharist. The great leaders began ever more frequently to surrender this ideal of a holy church, and to comfort themselves with the conception of a holy fellowship within the church. Athanasius, as we have seen, was a foremost thinker along these lines, but Ambrose, and especially Basil, did much to promote the change. Even priests and nuns fell from baptismal grace, and Basil has to face again the serious question of their relation to the church. He does so in the wider spirit. engendered by the experience of the past, and extends even to these the hope of forgiveness. ${ }^{1}$ At the same time the condition is repentance and penance. So now is organized even more completely the process by which a full recognition of the sinner could be secured.

Long periods of time had to intervene, and men were summoned by canonical law to abstain from the sacraments, standing first at the church door as "weepers," ${ }^{2}$ and then entering as "hearers," 3 then for another period "kneelers" 4 before the altar, at last staying during the mystery, although the oblation was withheld, until at last, after ten or fifteen years, complete forgiveness was assured and the sacraments could be partaken of by the sinner. ${ }^{5}$ The shortening of these periods was only possible by acts of special grace. The holy priest in benediction actually imparted holiness, "for benediction is the imparting of holiness." " Hence the penitent could seek the intervention of such as "by their way of life in the Evangel could be able to prevail with God." ?

${ }^{1}$ Epp. 44-46.

${ }^{5}$ Cf. Epp. 199 and 217 .
$2 \pi \rho \circ \lambda \lambda a i \omega \nu$.

B Epistola $199: 27$.
¿ $\dot{\pi} \pi \boldsymbol{\pi} i \pi \tau \omega \nu$.

${ }^{7}$ Epistola 284 . 
Very interesting are Basil's letters on the canons ${ }^{1}$ and those that refer to the judicial decisions made in cases of fault. They reveal to us how completely the ecclesiastical order was superseding the political as a social-ethical force. At the same time they open our eyes to the externalizing influence of canon law and to the legalism into which the ethical freedom of Jesus and Paul had sunk.

The old maxims of Roman law reappear as with authority. ${ }^{2}$ "Custom" is quoted as even offsetting the words of the Lord, ${ }^{3}$ Moses is reinstated as an authority in determining penance, ${ }^{4}$ and even the words of Jesus to the poor Samaritan woman are exalted into a code-law against exceeding the limit of second marriages. ${ }^{5} \quad$ Grave concessions are made in the case of wrongdoing between the sexes to the disadvantage of the woman. ${ }^{6}$ Men are forbidden to marry their sisters-in-law, and even a deceased wife's sister may not be married. ${ }^{7}$

In the ethics of the church the regulation of the family always played a chief part, and to this theme the preachers and bishops were constantly returning. Ambrose was legally trained, and Basil had imbibed the spirit of the law whose formulation went hand in hand with canon law. ${ }^{8}$ The dual rôle of preacher and

${ }^{1}$ Epp. 188, 199, 217.

${ }^{2}$ Cf. Epist. $188: 3$.

5 Epist. $188: 4$.

${ }^{3}$ Epist. 188 : 9 .

- Epist. I88 : I I.

: Epistola 199 : 23.

8 The decentralization of the Roman Empire involved finding a new bond of union. As from the time of Diocletian on it became not Roman but an international world confederation, the personal element was prominent, and the decisions of the emperors, under legal advice, became a body of laws for the world's guidance, subject, however, to many local peculiarities. The formulation of this into a code from the time of Constantine on was undertaken by Theodosius (438), and the formulation was accepted by the Emperor of the West, Valentinian III. The Justinian code, or rather codes, together with the Digest or Pandects, were drawn up in 529-533, and the "Novels," or new decisions of the emperor, in the years following, 535-559. The church canons were collected about the middle of this century, and to church canon law Justinian gave legal character in the decision of the "Novels," CXLI. Basil died in 379, the year in which Theodosius practically began to suppress heathenism, and which Harnack calls the year (380) of the birth of a State church. (Harnack, A.: "Kirche und Staat bis zur Gründung der Staatskirche," p. 157, in "Die Kultur 
law-giver is a marked feature of these great bishops. It is the weakness of their ethics that it was legal and formal, and it is the weakness of their judicial work that it was too often undertaken in the heat of passion and under the strain of prejudices and prepossessions. "The accidental homicide should be excluded from the sacrament for ten years, the ten years to be passed as follows: For two years he will weep, for three years continue among the hearers, for four he should be a kneeler, and for one he should stand. Then he may be admitted to the holy ritual," "1 and while accidental homicide is thus punished, "he who has denied Christ ought to weep all his life long," and only receive the sacrament in the hour of death. Intellectual digressions from the conventional orthodox ways of thinking are placed on a plane with fornication, murder, and robbery.

The ethics of these preacher-bishops reveals also the inevitable effect of aristocratic over-lordship. Basil was imperious and domineering. Even in the eulogy by Gregory Nazianzien, ${ }^{2}$ we see the forceful will overstepping the bounds of meek and lowly service. No admiration of ascetic humility has been an antidote for ecclesiastical pride and arrogance. The frank forcefulness of Basil was, of course, temperamental, but in all the great ecclesiastics upon whom now came the burden of a sacerdotal imperialism the effect of this over-lordship is manifest. The ethics of this period is marked by the very distinct contrast between the qualities needed for a fighting, organizing, militant sacerdotalism on the one hand, and the ascetic, world-flight, pathologically humble attitude of the monk and hermit. In Basil are united in wonderful manner these two extreme modes of thought and feeling, and he becomes representative of a long line of haughty, ascetic over-lords, commanding a world of confusion and readjustment and moulding a new era and a new life.

der Gegenwart" (I906), Teil I, Abt. 4, Iste Hälfte.) Thus from Justinian on canon law was a constituent part of Roman jurisprudence. (Consult v. Jhering's fascinating first volume, "Der Geist des römischen Rechts.")

${ }^{1}$ Epistola 218 : 57.

${ }^{2}$ Oratio 43. 


\section{THE MONASTERY AND ASCETICISM}

Asceticism, as we have seen, was first subordinated by Athanasius to the growing imperial Bishop's church. But it had to undergo a distinct change before it could be of the highest usefulness to the hierarchy. The hermit conserved much of that extreme individualism with which an organization built upon authority cannot work. Jesus and the very earliest church had scarcely to weigh the question of the relation of the individual to the external political power. The world was soon coming to an end; the powers that existed were ordained of God, and in general were for the punishment of the wicked and the protection of the weak. Even Paul appealed to Cæsar against illegal violence. Yet in Christianity there is a constant appeal from all outward authority to the inward voice as final for the individual, at least, hearing that voice. This appeal has always been a source of danger to all outward authorities, no matter how sacred.

The hermit in his cell, seeing visions, and having left all to follow holiness, was not apparently good material for the political structure of the Bishop's church. Yet in the hermit piety was also the element of submission. The body and its desires must submit to the demands of a higher ideal. Hence as soon as the hermit's cell became a canobium, and younger hermits gathered about an older and venerated "hero of the ascetic life," the virtue of submission and obedience was easily added to those of poverty and virginity.

None the less it is evident that the monastic ethical ideal could not remain the same with the hermit's ideal. ${ }^{1}$ In the life of Pachomius clear evidences are at hand that there was a distinct struggle on the part of the cloistered monks with the original primitive ideal. The monastery of Pachomius was not the first of such groups, but he gave them central organization, special rules, and seems to have fought the battles needed on the one

${ }^{2} C f$. Harnack, A.: "Das Mönchtum, seine Ideale und seine Geschichte," Giessen, 188r; 5th ed., 1901. English translation by Charles R. Gillett, New York, 1895 . 
hand against the solitary ideal of the hermit, and on the other of the bishop-conception in the secularized church. ${ }^{1}$

This monastic ideal was a highly composite product. It involved not only, as Harnack says, flight from the world, but also flight from the world in the church. ${ }^{2}$ It had within it the remains of the Egyptian religiosity cultivated through thousands of years, whose main passion was for ritual perfection as a key to personal immortality. ${ }^{3}$ When one notices the enormous place this consuming longing for personal immortality had in early Christianity, it becomes perfectly evident that its source was not the Old Testament nor the teachings of Jesus, nor even the mysticism of Paul. It is in the monastery that we find it mainly developed, and the thought forces itself upon us that the Egyptian religiosity has made itself deeply felt, in part, indeed, through Alexandrine Neoplatonism, but perhaps also more than we realize directly through the Egyptian monastic movement. Certainly in it we see the over-emphasis upon this hope, and a transposition of emphasis. So that to-day the average Christian thinker regards a religion without a doctrine of personal im-

1 The writer depends upon the French translation of the Coptic and Arabic versions by Amélineau, "Annales du Musée Guimet," tome XVII; "Monuments pour servir à l'histoire de l'Égypte chrétienne au IV siècle, histoire de St. Pakhôme et ses communantes," Paris, 1889 , and upon the history by the same author: "De historia Lausiaca," Paris, 1887 ; see also the criticisms and commentary by Grützmacher: "Pachomius und das älteste Klosterleben," Freiburg, 1896. The scepticism of Weingarten concerning Pachomius ("Ursprung des Mönchthums," pp. 50-53) is far too sweeping, and there seems little reason for doubting the existence of cloistered Christian monks very early in the history of Egyptian Christianity, even before the time of Pachomius ( $c f$. Butler, Dom Cuthbert: "The Lausiac History of Palladius in Texts and Studies," edited by J. Armitage Robinson, vol. VI, I, 1898, pp. 230-256). Nor is there any reasonable doubt concerning the influence of Athanasius on the development, even if we may hesitate in dogmatically affirming or denying his authorship of the Vita Antonii. See for discussion, p. 194 note. Cf. the work on Palladius, by Cuthbert Butler, ad loc. cit., and $c f$. Preuschen, Erwin: "Palladius und Rufinus, ein Beitrag zur Quellenkunde des ältesten Mönchtums," r897.

${ }^{2}$ Harnack, A.: "Das Mönchtum," etc., pp. 16, 18. English translation, pp. I $7,20$.

${ }^{3}$ Cf. Breasted, Jas. H.: "History of Egypt," r905, pp. 62-73, and Erman, Adolf: "Die ägyptische Religion," Berlin, 1905, pp. 87-147. 
mortality as wellnigh unthinkable. Yet the Old Testament religion made little of it. Buddhism is wholly without it, and nearly all modern philosophic substitutes for Christianity, in spite of intense religious feeling, generally either ignore or deny the doctrine.

This passion for personal eternal life gives the early monastic ideal an almost selfish egotistical character, borrowed from the hermit-conception out of which it sprang. In fact, we see that as Pachomius turns for perfection to the hermit-life away from his former Christian loving and helpful activity, he does so distinctly because he thinks there is a higher perfection obtainable than by such activities. He had himself been brought to Christianity by the kindly offices of Christians to the thirsty recruits, ${ }^{1}$ and busied himself with the poor and the sick, both as a Serapis monk and as a Christian, but as he takes up the life of a hermit he renounces these things. ${ }^{2}$ So that in the midst of the very monastic ideal itself there is a dualism. Between the extremes of the silent seclusion of the Trappist monk and the activities of the modern lay-Jesuit there are all shades of attempted synthesis. But the antithesis is there. The monks of Egypt not only supported themselves, but by industry, co-operative organization, and great frugality, as well as by the fact that the expenses of family fell away, became rich and were able to contribute to the poor. In the rules of Pachomius ${ }^{3}$ work and organization are constantly presupposed, and food is to be supplied in the inter-

${ }^{1}$ Cf. Krüger's scepticism in regard to the story, in "Theologische Litteraturzeitung," 189o, col. 620 ("Revue of Annales du Musée Guimet," tome XVII, Paris, 1889, "Histoire de Saint Pakhôme et de ses Communantés. Documents coptes et arabes inédits, publiés et traduits par E. Amélineau"), and for the story "Annales du Musée Guimet," tome XVII, p. 316 seq.

2 "Cette action de servir beaucoup de gens dans un village n'est pas le fait d'un moine, mais celle des prêtres et des vieillards fidéles," "Annales du Musée Guimet," p. 345, Amélineau's translation.

3 The rules are translated into German from the Ethiopian version, edited by Dillmann: "Chrestomathia Æthiopica," Leipsic, I866; by König, Ed.: “Die Regeln des Pachomius aus dem Äthiopischen übersetzt und mit Anmerkungen versehen in Theologische Studien und Kritiken," 1878, pp. 323-337, and into Latin by Jerome, in Migne's "Patrologia Latina," tome XXIII (vol. II of Jerome's works), cols. $65-86$. 
ests of strength for this work. "Let every one eat and drink, and according to their food give them service, preventing neither fasting nor eating, only (seeing that) the food is strong for the strong and mild for the weak" (Ethiopian version), and, unless Jerome is wholly untrustworthy, into the rules entered also the element of education, ${ }^{1}$ as, indeed, is assumed in the older Ethiopian version, where, after the devotional meeting of the order, each goes to his dwelling-place discussing or reading the lesson of the day. Nor was this cultural element wholly added on to the monastic institution. Even the Serapis monks acted to some extent as the apostles of charity and letters. ${ }^{2}$ It lies also in the very nature of such a life of contemplation and devotion that it should conserve the sacred traditions of the past. We have only to think of the priestly writings (hieroglyphics) of Egypt to see how naturally an Egyptian monastic institution turned to the conservation of sacred writings of Christian character.

The second great force in this development was the passion for personal purity represented in the main by sexual continence. The whole monastery movement is under the sway of this intense longing for "perfection." The legend of Anthony represents him as going from one sacred person to another to gather the virtues of all, and when a hermit hears of one "more perfect" he straightway visits him. Jerome relates in his life of Paulus how Anthony was dwelling in a solitary place, and it occurred to him "that no monk more perfect had taken up abode in the desert," but it is revealed to him that one "more perfect" lived in the desert, and he ought to visit him; so at the age of ninety

1 "Qui rudis monasterium fuerit ingressus, docebitur prius quæ debeat observare: et cum doctus ad universa consenserit, dabunt ei viginti Psalmos et duas Epistolas Apostoli, aut alterius Scripturæ partem. Et si litteras ignoraverit, hora prima, et tertia, et sexta vadet ad eum qui docere potest, et qui ei fuerit delegatus, et stabit ante illum, et discet studiosissime, cum omni gratiarum actione." Regula 139 . Hieronymus. (MPL, XXIII, 78 B.)

${ }^{2}$ Cf. Brunet de Presles, C. M. W.: "Mémoire sur le Sérapéum de Memphis in Memoires presentés a l'Académie des Inscriptions," series I, vol. II, pp. 552-576.

2 "Vita Antonii," \$ 4 . 
he sets off. 1 The conception of perfection varies, of course, with the level of culture, the racial character, and the individual peculiarity of the seeker after it. But two or three things mark especially the monastic ideal as we find it affecting the message of fourth and fifth century Christianity. In the first place, although intensely orthodox, perfection is not, and never has been, in the monastic development resolved into a simply intellectual correctness. From Pachomius to Francis of Assisi the interest is only secondarily intellectual. Orthodoxy is assumed, but orthodoxy is not primarily what accords with the facts, but what is handed down by tradition. Authority and not reason is the basis of the search for perfection.

In the second place, perfection is, like the conception of holiness in post-captivity Judaism, largely to be resolved into ritual observance. Prayer and fasting are in themselves pleasing to God, and the ascetic hero by pain actually does draw nigh to perfection.

But thirdly, the virtues of the canonical books are taken up, however unequally in the emphasis, into the monastic conception of perfection. So that love, gentleness, truth, faithfulness, and particularly such group-virtues as concord and the apostolic ideals of unselfishness and sacrifice, have a place even when world-flight seems most to contradict this active social ethics.

Then again the world of monastic life, though an unnatural world, was still a world in which living together compelled the formation of a social rule of life. In the first rules of Pachomius it is easy to see the various social problems that arose. The moment that monasticism was drawn into the service of the Bishop's church this social side became pronounced. Two things happened. The Bishop's church became monasticized and the monastery became secularized. The resulting compromise had all sorts of shadings. Far into history the hermit was still recognized as a grade of Catholic perfection, and in modern days the lay-brother and the lay-member of the society of Jesus

I\$ 7 of "Vita S. Pauli Primi Ermitæ." M. P. L., tome XXIII, col. 22. 
represent the secularizing influence of the imperial ambition; but in all grades personal perfection is kept constantly in view.

And lastly, the monastery became the refuge for many conceptions most prominent in primitive Christianity but incompatible with the secularization of the Bishop's church. Thus in it we find conserved the primitive communism, the primitive under-valuation of the social order, the primitive estimate of "saints" as being all on a level of possible attainment of holiness. Amidst an organization that was becoming more and more aristocratic in its temper and government, the monastery remained a refuge for a mutilated democratic ideal. Thus this ideal constantly reacts upon the hierarchy. Ambrose and Basil often revert with a certain longing to the primitive communism, although they realized that it was utterly incompatible with either the secularized church or the social order with which that church was preparing its elaborate Middle-Age compromise. ${ }^{1}$

The struggle between the two ideals, the aristocratic imperialism of the Bishop's church, in which the individual "lay-member" was more and more utterly subordinated to the priestly and sacramental organization, and the relative communal democracy and individualism of the monastery in which the unordained man might yet "attain" to the highest perfection, has never quite ceased. If any one doubts this let him inquire as to how the members of the recently suppressed congregations view the papal organization.

The compromise, however, was effected. . The priesthood of the Bishop's church accepted celibacy and was in other ways "monasticized"; the monastery became the active agent for the spread of the influence of the imperial hierarchy. And although at each new revival of the monastic ideal the sacramental imperialism has resisted the movement as long as it dared, ${ }^{2}$ yet in the end it has always on the one hand accepted the compro-

${ }^{1} C f$., among many passages, Ambrose, "De Offic." I : $28: \mathrm{r}_{32}$, and Basil, Epistola, I 50, § 3 .

${ }^{2}$ Francis of Assisi and Rome. Cf. "Vie de Francis d'Assisi par P. Sabatier," ı896, pp. ror-1 6 . English translation by Mrs. Louise S. Houghton, New York, 1894, pp. 88-ıо2. 
mise, and on the other known how to subordinate in large measure the monastic enthusiasm for its own ends. Thus the conception of a kingdom of God, a righteous community with God's will the living law, survived on the one hand in the ecclesiastical Bishop's church with its world-wide ambition, but with all manner of concessions to the world it hoped to rule; and on the other hand in the monastic community in which special holiness was the aim of a communal life that, however, resigned itself to a but partial realization of the communal dream, and weighed itself down by the maintenance of foreign remnants of past religiosity.

\section{THE BISHOP'S CHURCH AND CULTURE}

The Bishop's church not only accepted the empire, but began to occupy itself with the art and culture of the passing Roman world. It lay in the very Jewish origin of Christianity that it should not be hostile to learning and letters. However exclusive pharisaic Judaism became at one time in its history, yet in all ages Judaism has been foremost to acquire such elements of learning as it could make useful.

So the new Nicene Christianity was along the line of sound tradition from Paul on in taking what elements it could from the superior literary culture of the pagan past. The rigid ideal of the monastery, indeed, should cut off the seeker after its perfection from all the cultural acquirements of the forsaken world. But as a matter of fact the monastery directly and indirectly has served a most useful purpose in the preservation of that very culture it had itself foresworn.

Very early, therefore, we have attempts at history in the Acts of the apostles; and, indeed, as all history was more or less biographical, the canonical gospels may almost be included. In the new Nicene Bishop's church the impulse was strongly felt to continue this historical work, and we cannot pass the historical and literary activity of this period without glancing at its ethics and ideals. A foremost figure in the literary move- 
ment of the period is Eusebius of Cæsarea. ${ }^{1}$ In a credulous and uncritical age Eusebius seems to have been cool and careful. There is no such acceptance of miracle and wonder-working as in Sozomen, and in general he seeks to give his authorities. Yet the impression of the condition of the church made by his history is unpleasant and saddening. He seems conscious of the dawning of a new age, but unconscious of the wide chasm that lay between the ethical ideals of the New Testament and those of the Bishop's church.

Several things stand out plainly in the history. The ethics are dominated by the needs of the growing ecclesiastical imperialism. Hence "unity of opinion" is the foremost virtue. Eusebius was fully in accord with Constantine in demanding submission by the extremes of both factions in the Arian struggle to the will of the majority, and the despotism of the ecclesiastical leadership seemed to him fully justified in the interests of this "unity." 2 For Constantine the interests of the empire demanded religious uniformity, and Eusebius therefore fills his pages with criticism of the "heretics" whose "impious blasphemies" cast shadows on this fair unity. He has no sort of insight into the ethical situations which produced the Novatian and Marcionite struggles, and no comprehension of the intellectual cravings which gave rise to Gnosticism, and this in spite of the fact that in his own intellectual life he had found Origen so highly fruitful.

The imperial dream overshadows all else, and unless the church was "one" this dream seemed impossible, hence the

${ }^{2}$ Eusebius of Cæsarea, in Palestine, was born about 260, probably in Palestine, and died about 339 or 340 . He was a most industrious and prolific writer (see, for full account, Lightfoot's life of him in Smith and Wace's "Dictionary of Christian Biography," vol. II, I880, pp. 308-348). The works that interest us especially are his "Historia Ecclesia" ( $\left.\varepsilon_{\kappa \kappa} \lambda \eta \sigma \iota \alpha \sigma \tau \iota \kappa \eta े ~ l \sigma \tau o \rho l a\right)$, in ten books,

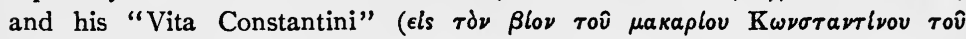
$\left.\beta a \sigma i \lambda \epsilon^{\prime} \omega s\right)$, in four books, together with the oration of Eusebius on Constantine. The fullest text is that of Migne, and the history has been often translated, the best translation being that by A. C. McGiffert and Ernest C. Richardson, "Life of Constantine," in the "Nicene and Post-Nicene Fathers," second series, vol. I, where fullest literature is given.

${ }^{2}$ Cf. "Vita Constantini," chaps. 64 and 65 . 
enormous and increasing emphasis upon "unity of faith," meaning by that unity of opinion. " The supreme virtues are "obedience" and "submission," as must always be the case in a fighting organization.

And again the situation produced the false estimate of martyrdom. It had meant so much for the ecclesiastical organization that men and women had faced torture and death for their convictions, that the tendency is soon noticed to treat martyrdom as a good in itself and to ascribe to the martyrs a special and sanctifying power. ${ }^{2}$ Hence also the ethical ideals are often debased by fanaticism and mingled with sensuous and unworthy motives, the exchange of hours of pain for an eternity of bliss, and the reverence for the martyrs was soon exchanged for prayers to them; and the substitution of their intercession for the free gift of forgiveness.

The politic ecclesiasticism of the Bishop's church constantly tended to a "middle way" in its treatment of ethical questions. The necessities of an organization that now grew with tropical luxuriance, but which began increasingly to embrace all sorts of spiritual and ethical laxness, forced upon the leaders like Eusebius patience with ethical mediocrity and impatience with any extreme puritanism. The monastery became the outlet for such vigorous ethical force as could not reconcile itself with the via media of the politic bishops.

Moreover, in the history of Eusebius we may see plainly the growing distance between the Bishop's church as a sacramental priestly organization and the people. He makes a daring comparison between the gathering at Pentecost and the Nicene council to the advantage of the latter: "But that assembly was less, in that not all who composed it were ministers of God; but in the present company the numbers of bishops exceeded two hundred and fifty, while that of the presbyters and deacons in their train, and the crowd of acolytes and other attendants, was

${ }^{1} C f$. treatment of Novatus Ecc. Hist., VI : $43:$ I-22; of Paul of Samosata, VII : $27:$ I $f f$.

${ }^{2} C f$. "Martyrs of Palestine." 
altogether beyond computation." 1 For Eusebius, as for Socrates, Sozomen, Rufinus, and Theodoret, the church is substantially the ordained clergy. The priesthood of all believers and the apostolic democracy has gone altogether. Yet the church is not wholly a centralized imperialism.

To this last step the force and political wisdom of Constantine contributed much. In Eusebius we see how the imperial protection rendered the bishops servile instruments of the royal will. It was, alas, only too natural. The church at last had come to her own, and the imperial master who broke her bonds easily substituted a golden bondage from which as yet no ecclesiasticism in any age has completely freed itself. The quiet substitution of himself as head of the church by Constantine is hidden under vast deference to the orthodox, $i$. e., submissive bishops. He says: "You are bishops whose jurisdiction is within the church: I also am a bishop, ordained of God to oversee whatever is external to the church." ${ }^{2}$ And in his power as ruler he appoints the Sunday as a special occasion for prayer. $^{3}$ When one remembers that he was not even at that time baptized, one sees how far the ecclesiastical organization had struck hands with the imperial power on the basis of a compromise. On the cringing flattery of Eusebius we must not dwell too hardly. Far worse rulers have been even more cringed to by stronger ecclesiastics in all ages; and no doubt Eusebius had a well-grounded respect and affection for the strong, mild, and politic Constantine to whom the church owed so much.

Constantine speaks fair words for religious freedom and responsibility: "Perceiving long ago that religious liberty ought not to be denied, but that it ought to be granted to the judgment and desire of each individual to perform his religious duties according to his own choice." 4 But as soon as he has power

\footnotetext{
1 "Vita Constantini," E. C. Richardson's translation, III : 8.

2 "Vita Constantinii," IV : 24.

3 "Vita Constantini," IV : I8.

"Imperial Decree, Euseb. Ecc. Hist., X : V : 2.
} 
we find him persecuting under episcopal guidance the heretics, and later on even the pagans. Liberty of conscience and the superiority of sincere intellectual misjudgment to insincere orthodoxy is not even yet an accepted ethical canon.

The continuation of Eusebius's history by Socrates ${ }^{1}$ marks no change in the main ethical conceptions upon which we have so far dwelt. True it is that Socrates is fairer in his treatment of heretics than Eusebius, probably because he was himself tainted by Novatianism. But in his pages we trace the same struggle going on by the bishops for the consolidation of the ecclesiastical empire. The miracle and the prodigious find even more ready credence by Socrates than by Eusebius, although he is superior in this respect to his contemporary Sozomen, ${ }^{2}$ whose credulity passes all bounds. More and more pronouncedly do the ethics become those of a great compromise between the secular state and the bishop's sacramental organization. Yet in both Socrates and Sozomen we see a people's church not altogether to be identified with the bishop's sacramental organization. On the one hand the ascetic development grew up independent of and even hostile to the somewhat secularized church, and on the other the democracy found expression in the sectarian development which fills the pages of Eusebius, Socrates, and Theodoret. With the first the Bishop's church never has dared to wage open war; but with the second it was always a conflict for life or death.

The low literary ethics of this period the new Christian literature shared with paganism. Either Socrates or Sozomen stole without conscience one from the other. Deliberate forgery in

\footnotetext{
${ }^{1}$ Born in Constantinople about 380 , he died .some time after 439 . Little is known of his life. He was either a Novatian or had reasons for special interest in the Novatian Church. Cf. G. Lœschke's article in Herzog-Hauck's "Realencyklcpädie," XVIII (I906), pp. 481-486, and Smith and Wace's "Dictionary of Christian Biography," III (1887), pp. 709-7II, by Wm. Milligan.

${ }^{2}$ Born in Palestine about the beginning of the fifth century, and living in Constantinople at the court of Theodosius the Younger, little is known of him. Cf. Smith and Wace's "Dictionary of Christian Biography" (bv Wm. Milligan), vol. IV (1887), pp. 722-723.
} 
a good cause was not uncommon. Gregory of Nyssa forged letters to bring about a reconciliation between Basil and his uncle. "You forged one letter," Basil writes," "and took it to me from our very holy uncle"; the forgery was found out, but it did not prevent two more attempts. Stories are related of Pachomius as though by eye-witnesses, which are mere copies of the Coptic "life" from which all stole and to which all added. ${ }^{2}$ The forged decretals, the pseudo-apostolic writings, and the interpolation of passages and extirpation of others are the common evidence of the low standard of truthfulness common to the period. ${ }^{3}$

An interesting insight into the ethical-religious life of that day is gained in those religious romances which have been so often taken for sober history. Whether Athanasius wrote the "Vita Antonii" " or not it can hardly have been meant for anything but a pious romance, of which literature we have the remains in Jerome and perhaps also in the famous "Historia Lausiaca of Palladius," ${ }^{5}$ whose pages abound in the stories which must have circulated freely as incitements to devotion in this period. It is impossible to take the accounts of Palladius as sober matter of

${ }^{1}$ Epistola $5^{8 .}$

${ }^{2}$ Cf. Amélineau, E.: "Histoire de St. Pakhôme," Paris, 1889 , and "De historia Lausiaca," Paris, 1887.

'Cf. the evident confusion of Jerome, in the "Life of Malchus," between himself and "the source of" his information. He related as an eye-witness things evidently told him by Bishop Evagrius. The mere fact that Gregory of Nazianzus attributes the "Vita Antonii" to Athanasius, nine years after the death of Athanasius, does not therefore prove that he was the author or even that Gregory thought he was.

- Cf. discussion under "Athanasius."

5 Bishop Palladius was born about 368 , although the date is uncertain, and he died about 430. He was the friend and defender of Chrysostom, assuming that the "Dialogue" is also by him. His "Historia Lausiaca" was written probably about 405 to 420 , and receives its name from the one to whom it was addressed ( $\tau \delta \Lambda a v \sigma a \tau \kappa 6 \nu)$. The most exact researches are by Erwin Preuschen ("Palladius und Rufinus," I897) and Dom Cuthbert Butler ("The Lausiac History of Palladius," I898 and 1906, in "Texts and Studies," edited by J. A. Robinson, vol. VI). Cf., also, Lucius, P. E.: "Die Quellen der älteren Geschichte des ägyptischen Mönchtums, Zeitschrift für Kirchengeschichte," edited by Th. Brieger, VII (1885), pp. 163-198. 
fact, although, no doubt, he had seen much that he relates. When one reads the contents of the novels and tales of that period given us by Rohde, ${ }^{1}$ with their superabounding wonders, strange animals and miracles, their struggles against fate, and tales of love's faithfulness, one is tempted to see in Jerome's "Life of St. Hilarion," "Life of Paulus the Hermit," and "Malchus the Captive Monk," an effort to do for the Christian society what these mediocre artists were doing for the pagan community.

Whether this be so or not, these stories open our eyes to the strange religious world in which the Bishop's church had its place. The monks retained memories of the primicive communistic ideals. Malchus sighs for his captivity after he had left his cell, and seeing the ants at work, he remembers "how Solomon sends us to the shrewdness of the ant and quickens our sluggish faculties by setting before us such an example," and he longs "to imitate the ant in the monk's cell where toil is for the community, and since nothing belongs to any one, all things belong to all." 2

These monks and hermits live in a world of wonders and strange adventures which, no doubt, were accepted about as the pagan world accepted the stories of fauns and satyrs.

Jerome $^{3}$ was one of the most famous and useful scholars of the period. He was fanatical and narrow in temper, and pressed, for instance, his heresy case against Origen with a bitter and unchristian partisanship. But that was, alas, the

1 "Der griechische Roman und seine Vorläufer," 2d ed., Leipsic, 1900, pp. 3 ro- 554 .

2 "Life of Malchus," $\S 7$.

3 Hieronymus, or Jerome, was born at Stridon, in Pannonia, about $340-350$. He died about 420 . For full account of him and his writings, see Smith and Wace's "Dictionary of Christian Biography," vol. III (1882), pp. 29-50, by Wm. H. Freemantle. His translation of the Bible into Latin (the Vulgate version), and his defence of the ascetic life and his propaganda for it in the West, have given him extraordinary influence in the later history of the Roman church. The best edition is Migne's reprint of Vallarsi, "Patrologia Latina," vols. XXII-XXX, translation of selected writings in the "Nicene and Post-Nicene Fathers," second series, vol. II, pp. 359-38I ("Lives of Illustrious Men"), and vol. VI ("Select Works and Letters"). 
spirit and temper of the day. When once Origen was proclaimed heretical, then no terms could be too strong and too severe in condemnation of him, ${ }^{1}$ even though he praised him unguardedly before and had made him known to the Western world by translations. In fact, Jerome, like nearly all his ecclesiastical contemporaries, dreaded only one thing-to be called unorthodox. For him, "heretics who depart from the straight path of the faith shall be consumed if they will not return to the Lord whom they have forsaken. ${ }^{2}$

Childish credulity is mingled with real culture and learning. ${ }^{3}$ For he also lived in the demon-haunted world from which Christianity had failed utterly to rescue paganism. Athanasius, Augustine, Basil, and the highest and finest minds of the period were still in bondage to demon-fear which perfect love had not cast out.

As ascetic Christianity made its way, the essentially dualisticoriental conception of body and spirit reappears, ${ }^{4}$ and with it the despondency and world-weariness which we shall also find in Augustine. ${ }^{5}$ No longer is the sense of loving sonship the only root of ethics with Jerome and his contemporaries; it is the fear of hell as well as the longing for heaven. ${ }^{6}$

The false basis for ethics in this ascetic dualistic estimate of the body makes itself felt in the whole attitude toward marriage. The sound common-sense of uncorrupted Judaism saw only God's blessing in a happy marriage, the multiplication of the race, and the united life of man and woman. For Jerome the virgin is one degree higher than the widow, and the widow a degree higher than the married faithful wife. And in fact the only way a mother can get herself real sanctity is by guarding the virginity of her daughter and thus becoming "the mother-in-law of God." 7

${ }^{2}$ Cf. Epist. 6I : I-4 MPL, vol. XXII, col. 602.

2 "Dialogus ad Pelagianos," I : 28.

${ }^{3}$ Epistolæ and his lives of Paulus the Hermit and of St. Hilarion, etc.

' Jerome, Epist. $22: 4$.

${ }^{5}$ Cf. Jerome, Epistolæ $22: 5 ;$ I $28: 4$.

${ }^{6}$ Epist. $22: 7$.

${ }^{7}$ Epistola $22: 20$. 
Yet even Jerome felt the force of healthy Jewish thinking in the Old and New Testaments, and now and again enters upon a feeble and qualified defence of marriage. ${ }^{1}$

The result of such teaching was the rousing of most unnatural passion, ${ }^{2}$ and a reduction of piety to a passionate, vague physical longing with corresponding misuse of the unfortunate Song of Songs. ${ }^{3}$ That this unhealthy development was challenged we see in the quotations from Jovinianus, whom, unfortunately, we only know in the unfair and abusive controversial writings of Jerome. But evidently Jovinianus was not the only one to protest. The sanity of northern Europe has never made full surrender to oriental pathological dualism at this point. Hence Jerome raised by his writings on the subject of virginity a storm of protest. ${ }^{4}$ And the work of Helvidius is preserved to us in the intemperate but able reply of Jerome. Helvidius had pointed out that Mary herself calls Joseph her husband and that Jesus had brethren and sisters.

In the work of Jerome we see clearly what tremendous force the cool-headed political ambition of Rome had over against the divided East. ${ }^{5}$ His letters are indeed most interesting as showing how naturally the Bishop's church fell a prey to the central Roman bishopric. The Eastern church forced on the Western her dogmatic development and her asceticism, but in doing so wellnigh lost her independence. For both Eastern and Western churches the principle of outward authority had triumphed. ${ }^{6}$ The only question was whose authority was supreme.

At one point the church has much cause for thankfulness to Jerome. In spite of many expressions of contempt for pagan literature, Jerome really was the father of that monastic learning to which we now owe so much. No one has spoken more vigorously for a learned clergy than Jerome. To both his men and women disciples he says: "Read often, learn all that you

${ }^{1}$ Epistolæ $22: 2 ; 22:$ I9-20.

${ }^{2}$ Epist. $22: 7$.

${ }^{3}$ Epistola 22 : 1 and 6 and 24-25.

4 Epistolæ 45 and 48-49.

${ }^{6}$ Epistolæ $15: 4 ; 22: 38$.

${ }^{3}$ Epist. I5 : I. 
can." 1 And he scoffs vigorously at the ideal of ignorance as piety; " as Horace says:

'Doctors alone profess the healing art, And none but joiners ever try to join.'

The art of interpreting Scripture is the only one of which all men everywhere claim to be masters. To quote Horace again: 'Taught or untaught, we all write poetry.' The chatty old woman, the doting old man, and the wordy sophist, one and all take in hand the Scriptures, rend them in pieces, and teach them before they have learned them." ${ }_{2}$ He was himself learned, and even when taught in a vision not to overestimate Cicero, he does not abandon the classics, ${ }^{3}$ and his letters teem with quotations and allusions to Virgil, Horace, Homer, and many other classic writers. He was a painstaking student. His Vulgate version is for that uncritical day a wondrous work, and his own style is charming and strong.

And yet Jerome is sad reading. The ethics are formalized and externalized and orientalized out of all semblance to a really Christian ethics. Fasts and feast days ${ }^{4}$ and the reverence of relics ${ }^{5}$ reflect the heathen intrusion. Fear takes the place of love. Life is bondage to law amidst the terrors of a demonworld from which alone sacramental magic and stern selfsuppression can free us.

Moreover, in his letters we see the natural outcome in a sordid and greedy hierarchy. The Emperor Valentine had to pass laws forbidding priests and monks to inherit, so great was the misuse of death-bed terror, and yet by trusteeships these laws are evaded and disobeyed ${ }^{\circ}$ and the description of the life of the clergy is discouraging. The canons of Nice and Elviræ had failed to deal with the "agapetæ" effectively, for we still find women living with the monks and priests in boasted purity, while sharing with them bed and board.

${ }^{1}$ Epist. $22:$ I 7 .

${ }^{2}$ Epist. 53:6-7. Freemantle's translation.

Cf. Epistolæ $58: 5 ; 60: 5 ; 61: 4 ; 70: 2-6 ;$ I $25:$ I2.

Epist. 7 I : 6.

5 Epist. $109: \mathbf{I}$.

${ }^{6}$ Epist. 52 : 6. 
The Bishop's church, even at its best, was not Christianity, and at its worst was paganism of a peculiarly depressing character. The learning of Jerome and Theodoret has lost the freedom and outlook that marked Greek culture at its best, and the ignoble fear of hell and longing for heaven rob even the Stoic ethics that now passes for Christian of a good deal of its charm. Religion threatens to be swallowed up in religiosity, hateful, fanatical, and ambitious. The zeal of the monastery misdirected the religious-ethical energies of the foremost races in history for nearly a thousand years, and although they conserved for us the pagan literature, and did advance agriculture and peace, their services were but by-products of their activity.

The learning of Jerome, Cassiodorus, and of Gregory of Nursia was genuine and profound, but relatively unfruitful because essentially scholastic and under the shadow of authority. It lacked freedom and faith in truth. The religious-ethical development of the Bishop's church was essentially the triumph of a distorted conception of social and individual righteousness. And the rendering relatively sterile of the religious-ethical leadership was a misfortune it is now quite impossible to estimate accurately. But it would be difficult to overestimate it.

\section{THE BISHOP'S CHURCH AND THE CULT AND ITS ETHICS}

It is difficult to gather from the scattered material a vivid picture of the ethical ideals of this period as seen in the external cult. All the elements that are to become familiar to us in the Middle-Age church are, however, now present. Churches and chapels have arisen everywhere attesting the living interest of the community in the religious organization. In Eusebius's famous discourse at Tyre, given in his history, ${ }^{1}$ we have an invaluable description of a church which shows how elaborate the elements of the cult were. The church is already a "sacred place," and hands and feet are washed before entrance in the cantharus or phiala, ${ }^{2}$ and Ambrose warns virgins against un-

${ }^{1}$ Book X : 4 .

${ }^{2}$ Euseb. H. E., 10 : $4: 40$. 
seemly talking and laughing during the mystery, ${ }^{1}$ on the ground of the special sacredness of the place. Churches were erected as memorials for the martyrs ${ }^{2}$ and were remembered by feasts, which, according to Augustine, were marked sometimes by excess. How early separate buildings were demanded cannot be exactly stated, but of course the first churches had no buildings but were the "churches at the houses" of the more prosperous converts, ${ }^{3}$ and sacredness could only begin to attach to the place after that period had passed. As early as 305 a church was destroyed at Cæsarea, ${ }^{4}$ but they must have existed long before that. During the Diocletian persecution the churches and the bishops were the special objects of attack.

The simple cult described by Pliny in his famous letter, ${ }^{5}$ with its hymns, love-feast, prayer, must soon have expanded under the influence of rivalry with the heathen mystery into an elaborate ceremony from which the uninitiated were excluded. From the early days singing formed a large element in the worship. ${ }^{6}$ The heretical movements which were often revivals of primitive enthusiasm and piety took also to hymn-singing, and in rivalry the Catholic party also wrote hymns and enriched the service of the "orthodox" party. So Ephraem the Syrian composed hymns to the melodies of the heretical Harmonius to wean the heretics from the error of their teaching and to save the church, ${ }^{7}$ and Chrysostom introduced processions with singing to outdo the Arians who were successfully making propaganda in that way. ${ }^{8}$ So also Ambrose in Milan enriched the service to head off the enthusiasm of the Arians by introducing the famous chants which have played so signal a part in church history. ${ }^{9}$ So, no doubt, the exceedingly old ceremonial of the Eastern church grew slowly by concession and compromise, and with a steady

\footnotetext{
1 "De Virgin." $3: 13$.

"Lactantius "De Mort. Persecut." I 2.

2 Maprúpıa.

${ }^{3}$ I Cor. 16 : 19.

${ }^{5}$ Epist. 97 to Trajan.

${ }^{6}$ Acts $16: 25$; and we may see fragments of hymns in I Tim. $3: 16 ; 6: 15$;

II Tim. $2:$ I1-13; Eph. $5: 14$ and 19-20; Col. $3: 16-17$.

${ }^{7}$ Sozomen, E. H., $3:$ r6. $\quad{ }^{8}$ Sozomen, E. H., $8: 8$.

${ }^{\circ}$ Cf. also Basil, Epist. $207: 3$.
} 
tendency to harden into the formal lifeless cult into which both simple and elaborate ceremonial may easily lapse. ${ }^{1}$

It was not the Christian church nor the Jewish synagogue alone that saw the danger and evils of image-worship. Clement of Alexandria says that Pythagoras and Zeno both forbade the making of images, and that Zeno included temples; ${ }^{2}$ and Tertullian, Clement of Alexandria, and Augustine all protested against images. But the cross and symbolic figures like the fish and the anchor soon were bound up with superstition, so that Julian taunts Christians with worshipping the wooden cross. Then the relics of saints began to have special value, ${ }^{3}$ and in Augustine's time a trade was driven with forged relics. ${ }^{4}$

Here again the symbolism of such cults as that of Mithras must have reacted on the Christian custom, and so we find a painting "of Christ or of one of the saints," Epiphanius does not remember which, hung up in a church at Anablatha as a curtain, and he indignantly tears it down and sends to Cyprus for another to take its place, ${ }^{5}$ for it was against the religion of Christ to have any image or painting of a man in a church. Expressions of a simple natural curiosity and reverence such as find expression in Gregory of Nyssa's own case, ${ }^{6}$ but which were harmless antiquarian interests did not long retain this character. The age was far too superstitious and far too uncritical to be profoundly moved by such associations. The reverence for relics and the hunt for them was part of the heritage of the ages, a memory of the old feeling for amulets and charms which has never really died out even among educated men and women of the twentieth century. As the religious enthusiasm waxed cold spiritual conceptions were being supplanted by mechanical and magic formulæ.?

"Cf. Neale: "Hymns of the Eastern Church," I863, and Koch: "Geschichte des Kirchenlieds und Kirchengesangs der christlichen Kirche," vol. I, I856.

2 "Stromata," $5: 5: 28$.

${ }^{3}$ Basil, Epist. I 55 .

" "De Opere Monach," 28. MPL, vol. XL, col. 575.

'Translated by Jerome, in Epist. $5^{1}: 9$.

- Epist. 17. MPG, 46, c. 1057.

${ }^{7} \mathrm{Cf}$. the familiar passage Augustine's Confess. $6: 2: 2$. 
The writers of the period, Basil, Gregory of Nyssa, Jerome, assume a declension in the morals of both church and population, but that is, of course, impossible to either affirm or deny. We cannot impartially estimate the morality of our own day or state definitely any tests by which to measure it. What we may assume, however, with a fair amount of assurance is that with the growth of the church as an imperial and successful hierarchy, on the one hand men entered it for a lower purpose than in times of persecution or neglect, and that on the other the responsibility of the layman was distinctly lessened, and with his responsibility also went sustaining strength as the priest and bishop usurped the place of the church.

From the time of Constantine on there seems to have been a steady rush to become "Christian," but that there was any corresponding spiritualization and moralization of the life is less likely. Crass paganism thus received Christian baptism, and the demi-gods became saints; the mythology of Greece became the miracle-stories of the monastery, the magic of the mystery, the sacramental grace of the altar.

The uncritical credulity of the day, common to pagan and Christian alike, accepted all kinds of miracles of healing as part of the regular cult. The exorcist and divine healer were regular parts of the religious structure, and even the most intelligent and sceptical observers, like Eusebius and Augustine, had a simple faith in miracles of resurrection and exorcism of demons. Jerome fills his pages with stories of pious wonders and miracles in which the pagan centaur and satyr reappear. ${ }^{1}$ The effect of superstition upon ethical development is always peculiarly unfortunate. There is an immediate transference of emphasis from the responsible personal factors in life to the irresponsible and impersonal elements.

In no region of our experience is it more difficult and more important to trace cause and effect than in that of conduct; and where superstition comes in with its relative suspension of ordinary causation the difficulty becomes simply overwhelming.

$$
1 \text { "Vita Pauli," } 8 .
$$


It is, no doubt, untrue to the facts to assume or affirm, as some have done, that the world was made credulous by Catholic Christianity, but what we may lament is that upon spiritual Christianity in its earliest and highest inspirations there was foisted so much credulous paganism, both oriental and Jewish, as well as Greek and Roman. The dark shadows of mechanical conceptions of guilt such as make Greek tragedy at once so gloomy and so inexplicable to us, where guilt and sin are actually separable quantities, as for instance in the Edipus of Sophocles, hang over much Christian thinking even before given character and place by Augustine in his theory of original sin.

The cult took form and character under the influence of this confusion, and becomes more and more the setting for a sacramental magic, and less and less the impartation of ethical and religious inspiration to mastery over self and the world.

\section{THE CHURCH AND HER THEOLOGY}

It has been a popular pulpit theme to trace the Roman decadence to its sexual excesses. ${ }^{1} \quad$ But, as a matter of fact, to sum up again what we have said, the sexual excesses had their deeper cause in the social organization, based as it was on slavery and the ownership of the land by a military aristocracy. Slavery handed over to the absolute power of the master women and boys, and an idle and luxurious life stimulated the powerful passions which grow on what they feed and produce all the strange enormities of unnatural vice. Against this all ethical religious life, whether Neoplatonic or Stoic, whether embodied in the Mithras cult or the priesthood of the Serapium, began to protest even before Judaism and Christianity raised their voices. And as in all such cases there arose as the form of the protest a sexual fanaticism. It even went so far as to brand the natural sexual desire as per se evil, and to treat marriage as a concession to the flesh and bar to the highest holiness.

Theoretical dualism had probably about the same relation to

${ }^{1}$ Following Augustine in "De Civitate Dei," book II : 4-29. 
this protest that scientific demonstration that alcohol is a poison has to the demand for total abstinence. But the whole treatment of the body as evil was directly related to the popular dualism, and sexual asceticism fitted in well, therefore, with the popular moral ideals. At the same time there were voices raised in protest against these ideals. We know nothing of Jovinian save what Jerome tells us, and what would we know of Pelagius if so untrustworthy a source as Jerome's writing against him were our only means of information? Jovinian at least maintained the perfectly true proposition that to married persons and widows the same attainment in holiness was open as to monks and nuns. ${ }^{1}$ And Vigilantius was, no doubt, only one of many to see the absurd and immoral phases of the monastery ideal. $^{2}$ The church, however, had been so absorbed in the theological and Christological question that the anthropological problems had never been officially dealt with. The formulation which received the nominal assent of the official church, although it neither understood nor really accepted it into its life, was that given by the great Augustine. ${ }^{3}$ He stamped by his transcendent

${ }^{1} C f$. "Hieronymus Contra Jovinianum," book I : 3 , where the four points Jerome contends against are given as (I) baptized virgins, widows, and married women are of equal merit; (2) those once baptized in faith cannot be overthrown of the devil; (3) all food can be taken with thanksgiving and fasting has no peculiar sanctity; (4) there is only one level of reward for all in heaven.

2 For Vigilantius, see "Dictionary of Christian Biography" (edited by Smith and Wace), vol. IV, pp. II4I-II43, by Wm. H. Freemantle; also Gilly, Dr. W. H.: "Vigilantius and His Times," London, I844; and Jerome's diatribe, "Contra Vigilantium."

${ }^{3}$ Augustine, Bishop of Hippo, born in Tagaste, November 13, 354. His father was a freeman in humble life, who remained a pagan until the sixteenth year of Augustine's life. His mother was the famous Monnica, whom church history has idealized, but whose character, as seen in the "Confessions," was not extraordinary for ethical insight. He died at the age of seventy-six, on the 28 th of August, 430. Abundant autobiographical material is contained in his "Life," written by Bishop Possidius of Calama ("Vita Sancti Aurelii Augustini, Hipponensis episcopi Migne Pat. Lat.," 32 ("Augustine's Works," vol. I), I84I). Good condensed lives are found in Smith and Wace's "Dictionary of Christian Biography," I (1877), pp. 216-225, by E. de Pressensé, and in Professor F. Loofs's article in Herzog-Hauck's "Realencyklopädiæ," vol. II (I897), pp. 257285, English translation; in the New Schaff-Herzog, vol. I (Igo8), pp. 365-372. 
religious genius the ethical development not only of his day but even of our own, with the dualistic despondent impress born rather of pagan and oriental decadence than of Jewish and New Testament common-sense.

The ethics of Augustine springs from his experience and is interwoven with his deeply religious feeling. To understand his ethical view-point we must take it in connection with that religious experience. His restless soul found at last, after years of moral and intellectual struggle, the peace that comes in the supposed surrender to an outward authority. ${ }^{1}$ As a matter of fact, in all that really concerned Augustine he led and did not slavishly follow. Like Athanasius, he would no doubt have stood against the world had his vital faith been touched. But having surrendered to the church, from thenceforth her sacraments, her type of piety, her authority, her imperial claim became identified with the divine life Augustine had found in her. Nowhere does the church become more pronouncedly a mediator between God and the soul than in Augustine. In the church he comes immediately in contact with God. In true Neoplatonic style the visible church is only a type of the colestis societas, but it is this visible church which can forgive sins, ${ }^{2}$ and so his re-

Of his numerous works those of most service to the student of ethics are "The Confessions," "De Civitate Dei," "The Enchiridion," and the controversial writings against the Donatists, Pelagius, and Julian. Numerous editions of separate works have appeared, but the best and completest edition is still the Mauriner editio princeps, reprinted by Migne, "Pat. Lat.," vols. XXXII-XLVI. A new edition in the "Corpus Scriptorum ecclesiast. Latinorum," Vienna, has been severely criticised by Adolf Jülicher in the "Theologische Litteraturzeitung," 1892, cols. 130-132; 421-425. This is not complete. An English translation of varying merit appeared in the "Nicene and Post-Nicene Fathers," second series, vols. I-VII, New York, Scribners, I886-r888. The general literature is too great to give in detail. Most useful the writer has found: Harnack's "Dogmengeschichte," vol. III (1890), pp. 54-215, English translation, vol. V (I899), pp. 6I-240; Reuter, Hermann: "Augustinische Studien," Gotha, I887; and the passages in the histories of Baur, Neander, and Schaff, where an enormous literature is noticed. See also the literature given by Harnack in note on pp. 54 and 55 of "Dogmengeschichte," English translation, vol. V (1899), pp. 6I-62.

${ }^{1}$ Evangelis non crederem, nisi me Catholicæ commovisset auctoritas.

${ }^{2}$ Per remissionem peccatorum stat ecclesia, quæ in terris est. 
ligious and ethical life, Augustine felt, was staked upon the sacraments and authority of the visible sacramental.communion.

This is why his first struggle within the church was with the Donatists, whose general demand for purity and reformation one might suppose would have been along the line of Augustine's sympathies. But Augustine could not brook anything that imperilled the authority of the sacramental organization, whose world-wide reach was a chief argument for her divine claim. In his struggle out of and then with the Manicheans his chief weapon had been this authority of the world-wide church. It alone had given him rest. Where ratio had failed him auctoritas had come to his aid. Now against the Donatists he had to defend baptism in all its magic sin-forgiving power. It is almost indispensable to salvation ${ }^{1}$ and is independent of the moral attitude of the baptized one's heart. "The sacrament of baptism is one thing and conversion of the heart another. ${ }^{2}$ This tremendous weapon of the church had to be guarded against doubt of its power, through the personal weakness of the agent on the one hand, and yet to be retained as the exclusive weapon of the church on the other. The ethical pitfalls are many into which this desperate venture brings Augustine. The external, magical, and offensively mechanical estimate of both baptism and forgiveness of sin runs a sword through the very heart of the Pauline doctrine of inwardness and spiritual independence. And it is sad indeed to find Augustine urging the persecution of the Donatists by the civil authorities. ${ }^{3}$ Even when he has to confess that bishops and councils have erred, and that later councils can correct earlier ones, ${ }^{4}$ yet Scripture is absolute, and the interpretation of Scripture is in the hands of the church. Moreover, the deadliest $\sin$ is schism from this sacramental Catholic church. ${ }^{5}$ Hence this Catholic church may use violence to force men to the truth.

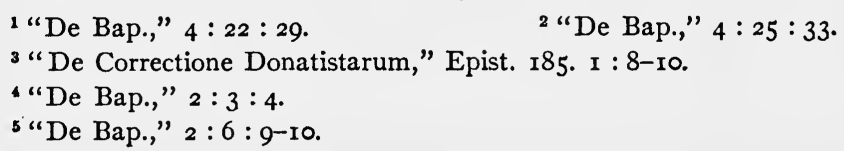


It is out of this identification of his personal religious experience with the church that even the details of his ethical ideals are sprung. It is, of course, extreme and essentially unhistoric to speak of "a wild youth" and "bog of sensual excess" or "African sensuality" as the cornerstones of the Augustinian system. From the highest Christian point of view Augustine gravely sinned in living, even in monogamous faithfulness, with his mistress for nine years. Such a relationship is demoralizing to both the personal and social life. But it is absurd to call it a bog of sensuality. He had a much-loved boy from the irregular union. His mother never seems to have had any objection to it. The church in its formal canons made provision for such unions, and did not exclude the parties from the communion. ${ }^{1}$ In fact the real sin was in sending away his mistress after nine years of such happy united life, instead of giving woman and boy such recognition as civil marriage involves. As far as one can judge from the "Confessions" and the "Life," Augustine was essentially a steady, well-controlled normal man, whose sexual relations were rather above than below even the Christian average of his day.

Not so, however, judged the sensitive and misinformed conscience of Augustine himself. His vision of God had been in connection with the sacramental church, and her monastic, essentially dualistic valuation of the sexual relation became Augustine's. He had, moreover, to intellectually justify this more profoundly than the church herself had done. Hence he saw in concupiscentia the root of all evil, and committed himself and the whole Middle-Age church to what Julian of Eclana justly calls Manicheism. Marriage thus becomes for him a concession to human infirmity, and brings with it more than the inconveniences, of which all the fathers speak, but an actual defilement in original sin. In fact, the whole doctrine of original sin in all its artificial logic and false ethics is the result of an extension of the dualistic, pessimistic valuation of matter we have so often noticed.

${ }^{1}$ Council of Toledo, canon I7; Mansi III, roor (A. D. 400). 
At this point Augustine had to face the consequences of his teaching and to face other ethical questions in his struggle with Pelagius. True Pelagius was in accord with him in the general monastic conception of the holy life, but between monasticism and a sacramental grace-dispensing organization under bishops there was, as we have seen, a fundamental difference in viewpoint. ${ }^{1}$ In strict logic the monk can earn his salvation without sacraments or church. In fact, the hermit cut himself off from both. In the interests of the sacramental church Augustine denied the freedom of will in even the measure the monastery needed it. Thus he came into conflict with Pelagius and Cœlestius, neither of whom were his intellectual equals and both of whom desired no break with the church.

The crucial point with Augustine is sacramental grace. By that and that alone we are saved. It is a reformation misinterpretation of Augustine to omit "sacramental." Augustine could not think of any grace apart from the sacraments. The sacramental church is ordinarily the only channel of grace, and that sacramental church goes back to the Jewish church, to Abraham, to Noah, and even to Adam. But if there is no present freedom of will, how are we saved? Only by the secret and inscrutable election of God. This was Augustine's only answer. It leaves, however, the human soul constantly hanging between hope and fear, and ever turning with feverish longing to the sacraments as the one channel of that saving grace.

This gloomy and essentially pagan conception of life was born of Augustine's vision of sin. He had fiercely fought with passions corrupted by the social organization in which he dwelt. He saw sin everywhere. "None is free from sin, not even the infant which has lived but a day upon the earth. ${ }^{2}$ He wished to avoid Manicheism by denying that sin was a "substance," 3

${ }^{1} C f$. the Egyptian proverb quoted by Cassianus: "De Cœnobiorum institutis," lib. XI, cap. I7; "Omnimodis monachum fugere debere mulieres et episcopos." MPL, 49, 4I8.

${ }^{2}$ Confess., $1: 7: 11$.

${ }^{3}$ Confess., $7: 12: 18$, and many other passages. 
but in fact he identifies it with the body and its natural impulses as such.

In his psychology Augustine swings, as does Aristotle, between will as the seat of sin and the reason which informs the will. But in fact, in common with practically all Catholic writers, opinion, i. e., the holding of "truth," is the all-important thing. And into his psychology enter, therefore, foreign elements. ${ }^{1}$ At the same time sin is not only an act of the will but a quality of the personality. At this point Pelagius seems shallow and unreal in comparison with Augustine, who unquestionably deepened and enlarged the whole conception of sin as an attitude of the personality toward God.

Yet even here his dualism prevented clear thinking. If sin is thus an attitude of the personality, how about the saved personality? In the state of sacramental forgiveness there should be no room for sin. Augustine was too keen an ethical critic of himself and the church not to see that there were sinners in the sacramental organization, and $\sin$ in the forgiven life. The only answer was again the recurrence to a constant renewal of sacramental grace, and there is given us the foundation for the weary struggle of the Middle-Age church to find ethical rest in sacramental forms. Moreover, lest human superbia should tempt us, all the merita which may be secured by the monastic discipline-which Augustine did not deny or dispute-were but the gift of God. ${ }^{2}$ The keen criticism of Julian of Eclana, ${ }^{2}$ Augustine could not at this point at all meet. Only when the reformers attempted to get rid of all merita does the Augustinian system at this point receive consistency.

Indeed, consistency is not the strength of the Augustinian thinking. He was the father of fides implicita, ${ }^{4}$ and the baleful

${ }^{1}$ Cf. Confess., ro : 8-21, and Siebeck, H.: "Die Anfänge der neueren Psychologie in der Scholastik," in "Zeitschrift für Philosophie und philosophische Kritik," vol. XCIII (r888), pp. r6 ז-216.

${ }^{2}$ Confess., $9:$ I3 $3: 34$. De Gratia et libero Arbit lib. 15 .

${ }^{3} \mathrm{Cf}$. admirable monograph by Bruckner, "Texte und Untersuchungen," vol. $\mathrm{XV}$, heft 3 , I897.

"Cf. Harnack, "Dogmengeschichte," III (I897), p. 75. 
influence of this one may read in Ritschl's history of it, ${ }^{1}$ and what has fides implicita to do with logic and consistency? $\mathrm{He}$ thus exalted an ethical element in the child's life to a permanent and unethical factor in the churchly development.

One of the splendid inconsistencies in the ethics of Augustine was the place he gave to love. He was "God-drunken," and the real ethical force in his life was his absorbing, consuming love of God. Not the "Confessions" alone, but the whole Augustinian literature is filled with this longing after the source of all ethical purity. Again and again Augustine sweeps away, seemingly, the elaborate sacramental apparatus to come into immediate contact with the life of God as forgiving grace. This vision of God is for him the summum bonum; and love is the power that lifts us up into the vision. In these places ${ }^{2}$ love is the new source of a new morals.

The place thus given to love in the system makes Augustine the father of so much of the mystic devotionalism of both the Middle-Age church and the mystic Protestantism on into our own day.

When we carefully inquire what Augustine means by love, the result is somewhat disappointing. In his system it could be, and in Calvinism was, successfully bound up with an ethical direction of the will. But as a matter of fact the distinct tendency in Augustine is to identify it with feeling almost to the exclusion of will, with a consequent inevitable trend toward quietism and Neoplatonic subjectivism.

With Augustine came again the more or less distinct linking of ethics with a social purpose of redemption. True, the city of God was distinctly in one sense transcendental. Yet the very object of the apology was to show how Christianity better comports with and conserves the social state than the heathen cults. The hope of a state subject to and serving the church, which Augustine even as a corpus admixtum still regarded as the

${ }^{1}$ Ritschl, A.: "Fides Implicita, eine Untersuchung über Köhlerglauben, Wissen und Glauben, Glauben und Kirche," Bonn, I8go.

${ }^{2}$ They are many. $C f$. Confessions, $4: 9: 14$. 
kingdom of God, Regnum Dei, is the vision that haunts him. And how distinctly he looked to this is seen in his unfortunate letter, de correctione Donatistarum.

Moreover, in the union of ethical with religious life and the distinct overcoming of the cold intellectualism of a Stoic morality, he rendered unquestionable service to the social organism. Between the poles of sin and grace, amidst the sweet pains of forgiven sin, Augustine saw a triumphant sacramental organization steadily moving on, and leading by word and sacrament the nations into the divine life and vision. Nowhere is the dream a perfect one. It is shadowed always by the despondency of oriental and Hellenistic pessimism so characteristic of African piety. The force giving it unity is, however, love.

All virtues were in it but as the signs of this one strong central principle. The four virtues (Stoic) were but manifestations of love. Temperantia is opposition to the love of the world from love to God. Fortitudo antagonizes pain because love strengthens. Justitia is love serving God. Prudentia is love choosing aright. ${ }^{1} \quad$ And all that proceeds not from love (divine) is vitia, or at least only relatively virtuous. ${ }^{2}$ Within this kingdom we may use the world, although we ought alone to enjoy God. ${ }^{3}$

Now through the continuance of sacramental grace a great throng, chosen in God's free love and mercy, was being fitted to take the place of the fallen angels and dwell in continual enjoyment of the beatific vision. In many passages modern religious sense is offended by the almost selfish emphasis upon this enjoyment, but on the other hand in the last analysis redemption for Augustine is freedom to live the divine life, and that life is loving holiness and the fulfilment of God's commandments.

The theological historian is, no doubt, constantly tempted to gravely overestimate the importance of formulated doctrine:

1 "De Moribus Ecclesiæ Catholicæ," I : 15 : 25.

${ }^{2}$ De Civ. Dei., 5 : r 2-rg.

'Utendum est hoc mundo, non fruendum; ut invisibilia Dei, per ea quæ facta sunt, intellecta conspiciantur. "De Doctrina Christiana," I, 5, Migne "Pat. Lat.," vol. XXXIV, col. 2 I $a$. 
even the non-theological Carlyle attaches too much importance to the Arian controversy. Had Arius even triumphed it is difficult to see how the church could have more crassly plunged into the worship of three gods with a throng of intermediate demigods (saints), angels, and demons than it did. The popular faith is the product of personality and social conditions, and the final dogmatic formulation is the work of a select few for a select circle.

So it is easy to grossly overestimate the influence of the Pelagian struggle upon even the history of the church. In point of fact the church never followed in her living faith either Pelagius or Augustine. She went on her way teaching freedom to do good works, the value of penance to wipe out sin and gain salvation, the beauty of co-operating grace; while she vigorously upheld Augustine-as far as she understood him.

It is interesting to note the things the Council of Africa in 4I8 condemned. (I) That those holding that natural death was independent of sin were to be cursed. (2) Those denying sin and guilt on the part of infants were to be cursed. (3) Those holding that unbaptized infants would have any sort of blessedness were to be cursed. (4) Those who refer the justifying grace of Christ only to past sins are to be cursed. Those who see in grace enlightenment only and no power to resist are to be cursed. (6) Those who do not see in grace an absolutely necessary power to well-doing are to be cursed. Those who saw in confession only an expression of humility (and not sacramental efficiency) were to be cursed. ${ }^{1}$ And this was the gist of Augustinianism as the church understood it!

The fact was that for the Greek church the freedom of the will was never seriously in dispute. Profound as was the influence of Augustine upon the Middle Ages, it was upon its piety rather than upon its dogma. And it is capable of demonstration that the freer, more human, more rationalistic, and more comprehensible view of the world taught by Pelagius, Cœlestius, and Julian of Eclana never lost its influence upon large numbers

${ }^{1}$ Cf. Harnack: "Dogmengeschichte," vol. III, p. 172, note, edition 1897 . 
of minds, although without doubt the system never had behind it so representative and overwhelming a personality as that of Augustine, whose very weaknesses (his entire acceptance of popular Catholicism) made him acceptable to the half-paganized church.

The actual piety and ethics of the period are, probably, far better represented in the pages of Johannes Cassianus. ${ }^{1}$ His "Institutes" and "Conferences" are of especial interest, not because he consciously set about the ethical reformation of the church, but because he proclaims the ideals that seemed to him the highest, and which represent the monastic morality, which was to be supreme in all its weakness and all its power for a thousand years. The setting is called "semi-Pelagian" on the basis of Collatio XIII of Abbot Chævemon. But in point of fact this represents the simple uncritical religious belief of ninetynine of one hundred Christians in all the centuries.

And the last man in the world to call an opinion his own was Johannes Cassianius. He would have subscribed with all his heart to the quod ubique, quod semper, quod ab omnibus of Vincentius of Lerins. ${ }^{2}$ Nor can it be disputed successfully that the system of Augustine was in reality as far away from any body of doctrine thus described as was that of Pelagius.

The picture of the ethical ideals of the Catholic church is full of the most significant contrasts. To dwell upon either side of

${ }^{1}$ Johannes Cassianus, born about the year 360 , Gennadius says in Scythia (Catalogus 62), but perhaps confused by the Egyptian Scetis, Scete, or Scyathis, where he spent much time. He died during the reign of Theodosius and of Valentinian. His chief works are his "De cœnobiorum institutis libri duodecim," the twenty-four "Collationes," and the seven books, "De incarnatione Christi," against Nestorius. The best edition is the Vienna edition by Petschenig, in "Corpus Scriptorum Ecclesiasticorum Latinorum," vol. XIII, parts I and 2, in two volumes. In Migne, "Patrologia Latina," tomi duæ, 49 et 50. Translation in the "Nicene and Post-Nicene Fathers," second series, vol. XI, I894, pp. I6I-62I. See also for literature articles in "Dictionary of Christian Biography" (Smith and Wace) and Herzog-Hauck's "Realencyklopädie," III, 1897, pp. 746-749, by Grützmacher, English translation, II, I908, pp. 435-436. Although less critical, we have used Migne for the sake of the most instructive commentary by Alardus Gazæus.

2 "Commonitorius," II : 6. 
the picture, to think only of the shadows, or see nothing but the high lights is equally to resolve history into an inexplicable mystery. The shadows are very deep. Nothing could be more revolting than the picture of a tortured and neglected child, purposely beaten and starved to test the father's renunciation, until at last he is told to throw the boy into the river, and proves his "holiness" by doing so, when the wretched boy is rescued by the monks. ${ }^{1}$

And truly pathetic are some of the cases of artificial piety with its sad issue in insanity, as where the old man Heron flings himself into a well in obedience to a "vision" which, as he dies from the effects, is attributed to a devil, and with difficulty does he escape a suicide's disgraceful burial. ${ }^{2}$ Nor can one be surprised at the low average intelligence indicated by the story of the anthropomorphic struggle. The monks, namely, were firmly of the opinion that God had hands and feet, and when the spiritual character of God was proclaimed, poor old Serapion (in actuali disciplina per omnia consumatus) was overwhelmed by the proof that the Catholic church taught it. But it left him desolate. "They have taken away my God," he exclaimed." $\mathrm{He}$ had no one to adore or address! Of course, in common with even the cultivated men of the age the popular piety was childishly credulous. Miracles abound, ${ }^{4}$ and it is hard to acquit such an one as Sulpitio Severus of deliberate pious lying. ${ }^{5}$ Moreover, the worship and life have become formal, rigid, and complicated to an extraordinary degree, ${ }^{\circ}$ and the ethics begins increasingly to harden into a casuistry with grades of merit, and classified in two divisions of venial and deadly sins. ${ }^{7}$ More-

1 "De Cœnob. Instit.," $4: 27$.

2 "Collatio," II : 5.

${ }^{3}$ Heu me miserum! tulerunt a me Deum meum, et quem nunc teneam non habeo, vel quem adorem aut interpellem jam nescio! "Collatio.," $\mathrm{X}: 3$. (MPL, 49, 824 B.)

"Cf. "Collatio," XV : 3-5.

" "De Conob. Instit.," lib. I et II.

${ }^{5}$ Cf. Vita S. Martinii.

7 "Nam ... nunc arripere colluctationem adversus octo principalia vitia vestris orationibus, Domino confortante, disponimus, id est, primum gastrimargiæ, quæ interpretatur gulæ concupiscentia; secundum fornicationis; tertium philargyriæ, quod intelligitur avaritia, vel ut propius exprimatur, amor 
over, as always happens when ethics becomes legal, the art of escape from impossible positions develops a defence of deceit and untruthfulness born of conscientious scruples. Very instructive is the discussion ${ }^{\mathbf{1}}$ as to whether solemnly given promises and vows may not be broken in the interests of the higher spiritual welfare. And Abbot Joseph proves from Scripture that lying and deceit are often the lesser evils, and therefore to be chosen. Indeed this whole discussion is a fitting prelude to the casuistry which has brought Jesuitism into such bad repute. ${ }^{2}$

Dreadfully prominent in the ethical ideals of this age is the separation between "good works" and social purpose. Obedience of the most slavish kind is exalted as a virtue per se. A monk waters a stick for years at the behest of his superior merely to test his obedience, ${ }^{3}$ and hard work at useless tasks is constantly praised. This unnatural separation of virtue from its social meaning results in actual brutality. A monk is praised for burning loving letters from home unread, lest they distract him from his prayers." A brother refuses the simplest act of assistance to his brother on the basis of his "being dead" to the world. ${ }^{5}$ A husband deserts a loving wife, to "save his soul," " and although it is evident that Cassianus is not quite sure of his ground, yet he praises the husband's conduct, while making a half-hearted excuse for marriage. The ideal is a false suppression of natural and legitimate human desires, and results, of course, in all kinds of questionable conduct. Above all, the gratia castitatis is, of course, most especially praised, and most questionable means of testing and proving it are suggested. ${ }^{7}$

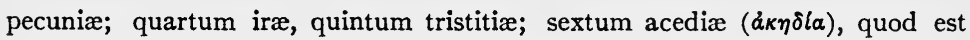
anxietas, sive tædium cordis; septimum cenodoxiæ, quod sonat vana seu inanis, gloria; octavum superbiæ," "De Cœnobiorum Instit.," V, I. (MPL, XLIX $202 \mathrm{D}, 203$ A.)

1 "Collatio," XVII : I-20.

${ }^{2} C f$. Newman's "Apologia pro Vita sua," edition I885, notes $\mathrm{F}$ and $\mathrm{G}$.

3 "De Cœnob. Instit.," lib. IV : 24.

" "De Cœnob. Instit.," lib. V : 32.

5 "Collatio," XXIV : 9.

o "Collatio," XXI : 9-1o.

${ }^{7}$ Most sadly suggestive are the notes given in the Commentary of Alardus Gazæus to "Collatio," XIX, caput I6, note $b$, Migne, tom. 49, col. I 446. 
The anchorite is placed as a matter of necessary logic higher than the monk in the cenobium, ${ }^{1}$ but this course of his has given the palm to the milder compromise. It is pathetic in the extreme to read the careful and most interesting psychological analyses of the mental states produced by the unnatural life of the monk. "The sixth struggle is what the Greeks call á $\kappa \eta \delta i a$, which we may render weariness and anxiety of heart. ${ }^{2}$ It is like melancholia, and is particularly severe with the hermit and a constant and dangerous foe of the solitary, attacking the monk at the sixth hour, as does a fever with its burning heat the sick man, at regular intervals ... and when it seizes some miserable one, he conceives a horror of the place, an utter disgust of his cell; of his brethren also with him or near him it begets disdain and contempt, as negligent and unspiritual." 3 The whole description is saddening in the extreme. The unnatural straịn producing all manner of mental disorders, and giving rise to visions, dreams, and fantastic modes of life which were then variously interpreted as either the visitation of angels or the attacks of demons.

The gracia castitatis giving rise to the natural pathological consequences ${ }^{4}$ and coloring the whole ecclesiastical ethical development in a most unhappy way. ${ }^{5}$

At the same time, dark as are the shadows, the picture as a whole gives promise of better things. The conception of work, and that in the main useful work, as the chief remedy for the languor, pride, melancholia, and "accedia" is strongly insisted upon, not only by Cassianus, but by the whole literature of

1 Preface to the "Collationes."

${ }^{2}$ Tædium sive anxietatem cordis.

2 "De Cœnob. Instit.," lib. X : r and 2.

" $C f$. "De Cœnobiorum Instit.," XII : 20, "Novi quemdam do fratrum numero, ... qui probatissimo cuidam senum vitio carnis semetipsum gravissimo confessus est impugnari; nam contra usum naturæ desiderio patiendi magis quam inferendi ignominiam intolerabili æstu libidinis urebatur." The unhappy brother was accused of blasphemy and thus the disorder was traced directly to the devil. (MPL, 49, 457 B.) Cf. Crafft-Ebing Psychopathia Sexualis, I894 (9th ed.), pp. 89-r 50.

sCf. Harnack: "Dogmengeschichte," vol. III (1897), note I, p. 204. 
Western monasticism at its best. In spite of theory and logic, the social monastery supplanted the loosely attached hermit gatherings, and almost entirely displaced the anchorite. The keen psychological analysis that marks both the "Institutiones" and the "Collationes" 1 is superior to anything the writer knows in classic literature, and reflects the process by which the inwardness and immediacy of the sense of sin came to its own in human thinking.

Amidst all the unnatural perversions of the monastic ideals, common-sense comes often to its rights. The familiar story of John, who defends his playing with his tame partridge on the ground that the bow must not always be bent, reveals the human side. $^{2}$

In the ethical ideals we see the almost extreme emphasis upon the inner life as the determining element in conduct. Angry acts may be wholly avoided and the soul be in mortal sin because of angry thoughts. ${ }^{3}$ All hate and passion must be banished, and love must hold absolute sway as the source of all goodness. ${ }^{4}$ Moreover, this love is independent of either the fear of hell or the longing for heaven, ${ }^{5}$ and becomes the strong barrier against all sin.

In spite of the dualistic remains in theory, at least, the Manichean estimate of body is overcome and the substantive character of $\sin$ is denied. As with Augustine, so in Cassianus and in the popular ethical estimate, sin is negative and not created by God, but only permitted.

The character of God is, of course, drawn far too much as Judge and Law-giver and too little as loving and forgiving Father. Yet this description is never wholly lacking, and such a passage as "Collatio," III : 7, leaves nothing to be desired in the way of evangelical fervor. God is longing for the salvation of the

${ }^{1} C f$. such passages as "De Cœnob. Instit.," XII : 27, 29, 30.

2 "Collatio," XXIV : 2 I.

3 "De Cœnob. Instit.," lib. VIII : $20 . \quad$ " Collatio," XI : 9-13.

$s$ "Collatio," XI : 8, "Et est quidem in illis gradus cujusdam profectus imbuens nos, ut dum vel pœnarum metu, vel præmiorum spe incipimus vitia declinare, ad charitatis gradum transire possimus." (MPL, 49, 854 c.) 
sinner, and all the most familiar passages of loving grace and forgiveness are beautifully grouped together. The practical consequences of Augustinianism are avoided, even if the resulting synergism is philosophically as unsatisfactory as a similar attempt on the part of Melanchthon. ${ }^{1}$

On the religious and ethical side, moreover, all the really important elements are carefully guarded. Fasting has no merit in itself, but is only a means to an end, and merit cannot be acquired as over against God. ${ }^{2}$ Man is responsible, but all good things come from God, including the gift of penitence, which must be from the heart, and is faithfully and even beautifully described. ${ }^{3}$ Language is, of course, used whose import is very different. The vulgar conception, however, of work-righteousness is constantly disowned, and Grod's free grace constantly proclaimed. Here, however, as elsewhere, two completely different views are brought together in no vital union either philosophically or religiously. And the component parts of the Catholic synthesis often creak against each other in great disjointment.

Perhaps one of the most instructive comparisons between classic paganism and the Christian-catholic synthesis is furnished by Cassianus's treatise on friendship as compared with Cicero's "De Amicitia." Everything that Cicero has Cassianus almost entirely lacks. Form, wit, grace, beauty of expression, and gentle dalliance with feeling, all are missing. But Cassianus has, beneath all the conventional devotionalism, that of which Cicero had no conception, namely, the union of souls in the eternal purpose of redeemed life. Even the Protestant critic, utterly out of accord with all the sacramentarian and, from his point of view, pagan monasticism, must feel the warm, solemn earnestness of the religious life that pulses through the "friendship" of Cassianus, but which is utterly lacking in Cicero.

We have dwelt on Cassianus just because, while he is not original, nor yet a leader, nor even a new formulator of the thought of his day, he does so abundantly, clearly, and deliber-

${ }^{1}$ Cf. "Collatio," XIII : 18.

2 "Collatio," XXI : 14 .

a "Collatio," XX : I-12. 
ately reflect what the great, nay, overwhelming, mass of the Christian church officially thought about God, conduct, and the world. In him we see how the ethical ideal has a synthesis, into which elements from Judaism, Neo-platonism, Aristotelianism, Roman Stoicism, African paganism, Persian dualism, Egyptian and oriental mystery-worship all entered; but that the strength and unity of this synthesis was the imperial hope of a kingdom of righteousness, and the real inwardness and glow came still from the life of Jesus of Nazareth, even though that life was only known in interpretations of it that varied in character and power from Paul to the superstitious anchorite of the Egyptian desert.

We must begin to seriously regard Christianity, as we know it, as the greatest and most successful of the great syncretistic religious movements in human history, and freely recognize the fact that we are debtors to the Greek and the Roman, to the bond and the free, and equally seriously begin to segregate the weak and beggarly elements, whatsoever may be their source, and to strengthen those things that remain as the gift of God from whatever quarter he sends them. The tests being the appropriate tests for the discovery of truth; and on the ethical field the final test being fitness for the promotion of individual and social righteousness in the divine-human fellowship of the kingdom of God.

\section{THE ETHICS OF THE COUNCILS}

The division between the East and West was long postponed. The intense feeling that organic unity furnished a guarantee for the truth handed down, as well as political considerations, made both the great wings of the church careful about division. Yet the two churches had most distinctly different aims and methods. The real intellectual leadership long remained with the East. The political leadership was almost as undisputed by a possession of the West. The councils that settled the great dogmatic questions were all under Eastern influence, but were then accepted by Rome as the authentic formulators of her 
teachings. Not, indeed, that Rome's interest was ever primarily dogmatic or theological. Indeed, it is quite evident that in many cases Rome had no very intelligent interest in many of the questions at issue. Even when such a bishop as Leo interposed to lead a dispute, it is easy to see in that leadership the predominance of the political over the abstract intellectual interest.

With the dogmatic development of the councils we have nothing to do, but the infallible authority of the council was not confined to dogma, but covered also matters of discipline; and the development of canon law was, according to the faith of the early church, a divinely inspired development. That is to say the authority was based on the divine leadership supposed to be assured to the bishops in council, and therefore different in character from the ordinary results of human intelligence, so that when the ecumenical council spoke, it spoke with inspired wisdom.

Interesting as are the canons of the councils, ${ }^{1}$ both to the student of the historical development and the social investigator, the dogmatic interest is so overwhelming that the student of ethics comes away from the study disappointed. We have already glanced at the canons of Bishop Basil (pp. 209, 210), and in them is reflected the same organization interest which appears throughout.

A few characteristic touches, however, may be noticed in passing. In the ecumenical synod of Nice all interest is for-

1 The classic work is Hefele, "Conciliengeschichte," I890 (English translation by Wm. R. Clark, "History of the Christian Councils," I87 I, seq.), where abundant bibliographical material is given. See also Schaff's "Creeds of Christendom," three vols., I877. We have also thankfully used Bishop Beveridge's " $\Sigma u \nu b \delta$ ckov, sive Pandectæ Canonum S. S. Apostolorum, et Conciliorum ab Ecclesia Græca receptorum," tomi I et II, 1672 (Greek and Latin). One or two of our references are also to Mansi's "Concilia," I759, simply because at hand. The translation of the canons and decrees by Dr. Henry R. Percival and his coworkers is well done ("The Nicene and Post-Nicene Fathers," second series, vol. XIV: "The Seven Ecumenical Councils," I900), but the notes and omissions betray the unconscious bias of one who can say: "I accept all the doctrinal decrees of the Seven Ecumenical Synods as infallible and irreformable," p. ix of Preface. 
bidden on money loaned by the clergy. Increasingly the canons restrict the prophetic freedom. As soon as the church could she forbade free religious assembly, ${ }^{2}$ and appealed, alas, to the civil authority to suppress those "meetings for private worship" which had been her own life so long!

At the same council access to the emperor is reserved for the higher ecclesiastics, ${ }^{3}$ and wandering teachers are hindered from proclaiming their message. According to canon VI of Laodicea heretics were not permitted to enter the house of God while in heresy, and the same council decreed that "no one shall join with heretics or schismatics in prayers." 4

In Chalcedon the monastery is finally subjected to the bishop; ${ }^{5}$ and secret societies and conspiracy are forbidden ${ }^{6}$ as dangerous, no doubt, to episcopal authority.

There are some interesting glimpses at the ethical level afforded by the canons. "Those who forcibly carry away women under pretext of marriage, and the abettors of such ravishers, if they be clergymen, shall be degraded." ? Simony has constantly to be enacted against, and covetousness, secular occupation, and absorption in money-getting are constantly rebuked. Some superstitions are also denounced; as, for instance, the giving of the sacraments to the $\operatorname{dead}^{8}$ and the wearing of amulets. ${ }^{9}$ The playing with dice, the attendance upon hunts, theatric performances, theatric dances are forbidden to clerics, ${ }^{10}$ who are also ordered to wear clerical dress. ${ }^{11}$ One curious provision forbids the taking of the testimony of "slaves, freedmen, actors, heretics, heathen or Jews." 12

${ }^{1}$ I Nice, Canon XVII; see also Laodicea, Canon IV, and $c f$. also African Codex, Canon V.

${ }^{2}$ Antioch, Canons II and V, and Gangra, VI.

Antioch, XI.

- Canon XXXIII.

${ }^{5}$ Canon IV.

${ }^{6}$ Canon XXXIV. Cf. Chalcedon, Canon XVIII.

${ }^{7}$ Chalcedon, Canon XXYVII. $C f$. also Trullan 92.

- African Code, Canon XVIII; cf. I Cor. 15 : 29.

- Laodicea, Canon XXXVI.

${ }^{10}$ Trullan L and LI.

1 Trullan XXVII.

12 African Code, Canon CXXIX. 
What strikes the student of ethics is the steady supplanting of the ethical interest by the dogmatic and organization points of view, and the steady separation of the clergy into a caste in which the celibate requirements play a most prominent and unfortunate part.

The development of the ecclesiastical mind and temper is plainly marked, and the unfortunate relations between the empire and the church, however great may have been the benefits, were constantly tending to make the ethics into a corpus juris, and to harden the whole treatment of ethics into a rather bloodless casuistry, with all the attendant unethical consequences.

The conciliar utterances are not engaged in stemming the tide of pagan intrusion which steadily flows into the stream of the ecclesiastical development.

It is one of the vivid illustrations of the uselessness of external infallible authority that not even the reverence for the letter of Scripture could stop the crassest idolatry and most vulgar witchcraft being foisted on the church in the name of Jesus and his disciples. In point of fact the doctrinal and ethical development was quite as dependent upon heathen philosophy as upon the New Testament for the form and method of its growth, and with the philosophy entered the pagan superstitions from which the philosophy had never wholly freed itself. ${ }^{1}$ For the learned even these things were dangerous (Augustine and his doctrine of demons), for the ignorant they were fatal. It resulted in the maintenance under other names of popular pagan superstitions without number.

We have seen how the mystery cult and the sacrament soon coalesced, and in the rites of baptism and the Lord's Supper, as by open doors, there entered the whole cycle of pagan magic conceptions, utterly undermining in the vulgar mind the ethical values of the simple symbolism. It was, no doubt, through this door that the cult of the dead (Egypt) also made its easy way. No doctrine came with greater force to a perishing social organ-

${ }^{1}$ Plato and the symbolic explanations of the myths. 
ization than Paul's proclamation of the resurrection-life. It was identified almost at once with purification by baptism, so that the baptized were "buried with Christ" and rose to a new life.

Soon also the sacrament of the Lord's Supper with its mystic interpretation (Johannine Logos theology) was the partaking of the divine life and the entrance from death into life. The saint and martyr were soon accorded special honor as having completed the work begun in sacramental mystery, and their relics were soon "reverenced," 1 and by the vulgar soon worshipped. ${ }^{2}$ It is quite vain to emphasize this distinction as important. No really intelligent pagan ever thought the statue made by hands really divine, but regarded it as a "help to devotion." The struggle over the worship of pictures was, however, in vain. The iconoclasts were wellnigh as superstitious as the picture-worshippers. Their arguments are based upon the essential wrong of any attempt at the portrayal of Christ because it implicitly denies his divinity, and the mother of God was not to be painted because painting was a heathenish art. ${ }^{3}$

Indeed the iconoclastic agitation came from without. Perhaps the Mahometan movement, with its military pictureless fanaticism, was the moving factor in the mind of the iconoclastic emperors and army.

Whether Vigilantius really represented an intelligent rejection of saint-worship and icon-superstition we do not know. We have only the intemperate and scurrilous abuse of Jerome as the source of our information. Canon Gilly's interesting book ${ }^{4}$ leaves us still guessing and very much in the dark. One thing is certain, the council of Nicæa (787) settled the question for both East and West, and settled it wrongly. For however the educated may guard against the puerile materialism represented in the image-cult, all historical experience has shown that the ignorant cannot be guarded against it, and that it debases worship swiftly and surely.

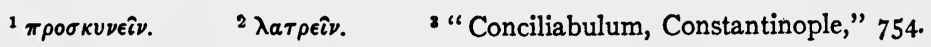

" "Vigilantius and His Times," 1844. 
As a matter of fact it simply opened the door to the worship of the heathen gods, which had probably never really ceased under other names. Mary becomes the Queen of Heaven, and the saints and apostles take the places of favorite demi-gods and pagan heroes. Their relics are worshipped, and a canon orders all churches to be supplied with them. ${ }^{1}$

In fact a crude Gnosticism prevailed, in which access to the highest divinity was only to be obtained by the intervention of intermediate demi-gods. Mary became toward the close of this period the influential intermediary between God and man, so that Nestorius protests against making her a goddess. She becomes the Bride of the Holy Spirit, the Mother of God (Athanasius), and to this day is the centre of a superstitious cycle of legends borrowed from pagan antiquity.

This period is constantly haunted by fears of Judaism. One of the canons of Laodicea ${ }^{2}$ forbids Christians to Judaize by "resting on the Sabbath day. They must work on that day, rather seeking to honor the Lord's day, and if they can by resting on that day." But in spite of this fear, through Judaism also came pouring in a flood of superstitions and ritual formalities. The Judaism of Christ's time had become dreadfully corrupt. Angel and devil worship, probably of Babylonian-Persian origin, had left many traces upon it.

Even the canonical Scriptures, though so generally representing the purifying processes introduced by propheticism in the eighth and seventh centuries, nevertheless contained many memories of the more primitive paganism out of which Judaism had so slowly emerged. Upon these remnants of heathenism the attention of the church was all too often fixed. It was a great gain in many respects that the Old Testament had received full canonical authority together with the New Testament writings. But at the same time it involved serious losses. The knowledge

'II Nice, Canon VII: "And if any bishop shall henceforth proceed to consecrate a church without holy relics, he shall be degraded as a transgressor against churchly traditions." $C f$. also Canon XVII of the Sixth Synod of Carthage. (Hefele, II, Edinburgh, I876, p. 426.)

${ }^{2}$ Canon XXIX. 
of its pages was utterly uncritical and unhistorical. It involved the reintroduction of false conceptions of sacrifice and of outworn conceptions of physical purification from which Jesus sought to free us, and they still hold their place in even some Protestant circles. ${ }^{1}$

The Gnostic Judaism of a Philo, with the artificial interpretation characteristic of the school played havoc with the Scripture reading of the early fathers, and made the Old and New Testaments ready sources for the defence of any particular superstition that served the momentary purpose of the ecclesiastical imperialism. ${ }^{2}$

At this stage the Eastern church hardened into the religious organization which it has remained almost up to the present. The struggle with Rome engendered the undying hate that kept the two communions apart, because subjection to the Vatican was the only condition of union. True, the final break was long postponed, ${ }^{3}$ and yet the break with Leo IX (1054) and the final rupture in 1204 were but the seals on what was really accomplished in the struggle over Photius (858).

For the student of the unrolling of a Christian morality the pages of the history of the Eastern church have an unending interest, but for the history of a development of ethics as a theory of conduct the book is closed with the canons of the second Nicæan council.

\footnotetext{
'Instructive is Ambrose "de Officiis Ministrorum," lib. I, c. 50, to which reference was made on p. 205.

2 "Jerome contra Jovinianum," lib. II, cap. I5.

"Cf. Müller, Karl: "Kirchengeschichte," vol. I (1892), pp. 369-372.

"Cf. Bonwetsch, G. N.: "Griechisch-orthodoxes Christentum und Kirche in Mittelalter und Neuzeit," in P. Hinneberg's series; "Die Kultur der Gegenwart," teil I, Abteil. 4 (1905), pp. I6I-182, and Kattenbusch, F.: "Orientalische Kirche," in Herzog-Hauck's "Realencyklopädie," XIV (1904), pp. 436-467.
} 


\section{CHAPTER V}

\section{THE MILITANT PAPACY AND ITS ETHICS}

I. The Separation of the East from the West; The Intellectual Elements and the Cult; The Political Ambition-II. Relations of Church and State in the Two Wings of Christianity; Gregory I; Bede-III. The Missionary Movement and the Monastery; Augustine; Bonifacius; Alcuin-IV. The Actual Working Ethics of the Roman Church; The Slave Question; Woman; Land Question; Dignity of Labor; Law.

\section{THE SEPARATION OF THE EAST FROM THE WEST}

Early in the history of organized Christianity, even before the days of Leo I (440-46I), the distinct difference in spirit between the Eastern and the Western churches became evident. For some time the African church formed a connecting link between the two, but as the centres of activity moved northward, and as Islam advanced, she ceased to influence the destiny of either branch.

In the East the metaphysical and the dogmatic interests had been supreme. But the crushing weight of Byzantianism transformed the life of the Eastern church. The old excuse of Constantine for the establishment of Christianity was the unity of the empire. From that fatal day the Eastern church became, and remains to a large degree, the mere tool of autocracy, with ignorance as its chief weapon.

The cult then took the place of any intellectual interest. Hence the struggle in the Eastern church over the icons was characteristic as a turning-point in her history, and from the triumph of those who substituted cult for thought the Eastern church almost ceases to interest the student of theoretical ethics. This triumph was due to the monks, whose fierce insistence upon the legitimacy of the worship of images carried the day. The 
interest of the anti-picture party, with the iconoclastic emperors at their head, was hardly confined to the establishment of a purer type of worship; it was the demand for a simpler basis of church unity and for freedom from the dominance of the monastery. And its deepest root was in the subordination of all other interests to those of cult correctness.

Hence the increasing ethical barrenness of the Eastern literature from St. Maximus the Confessor (580-662, about) to the voluminous and most influential John of Damascus. ${ }^{1}$ The liturgical and ritual development is rich, and if varied in value yet remains a wonderful product of religious genius. ${ }^{2}$ At the same time the energies seem to have been absorbed so completely in this direction and in the doctrinal disputes that the ethical suffered distinct eclipse.

On the other hand, it was a matter of life or death for the Roman church to impose her culture and her ideals upon the strong rude invaders from the north. That these were in many cases already nominal Christians prepared the way, but from Rome's point of view did not lessen her duty, for nothing less than complete subordination to Rome could fulfil the dream that had taken the place of the primitive conception of a spiritual kingdom of God. Not the Pope only but the seriousminded began to long for visible imperial unity again under religious leadership.

${ }^{1}$ John of Damascus (about 676-754), the great Greek theologian whose works are epoch-making for Byzantine dogmatic Christianity. Cf. Kattenbusch, F.: "Johannes von Damaskus," in Herzog-Hauck's "Realencyklopädie," IX, I90I, pp. 286-300; and for the controversy about images in which he played a principal part, see Bonwetsch, G. N.: "Bilderverehrung und Bilderstreit," in Herzog-Hauck's "Realencyklopädie," II, 1897, pp. 221-226; Schwarzlose, Karl: "Der Bilderstreit, ein Kampf der griechischen Kirche um ihre Eigenart und um ihre Freiheit," Gotha, 1890, and the discussion in F. Kattenbusch's "Lehrbuch der vergleichenden Confessionskunde," I, Freiburg, I892, pp. $45^{6-475 .}$

${ }^{2}$ See Neale, J. M.: "History of the Holy Eastern Church," 1850, Introduction, part I, book III, pr. 317-526; also "Christ et Paranikas, Math. Anthologia Græca carminum Christianorum adornaverunt," Leipsic, $187 \mathrm{r}$, with interesting introduction on the liturgical use of the hymn. 
Hence we pass in our history almost completely away from the East to follow the ethical development under the skilful and ofttimes unscrupulous, but generally forceful, leadership of the Roman hierarchy.

From the time of Leo I (440-46I) to Gregory I (590-604) the church is still the Bishop's church. Even Gregory I was profuse in his humble disclaimer of all supreme titles, ${ }^{1}$ while claiming for Rome powers of most arrogant interference with the internal affairs of other dioceses. Under the shrewd and forceful leadership of Gregory I we see the Roman church and the ethical ideals assume a distinct and permanent character.

The new factor in the situation is the rising Germanic civilization overgrowing and mastering the remains of Hellenistic power and culture. It was with true and sure instinct that Gregory I turned to Gaul and England as the future fields for Rome's activity. At the same time this transference of interest marks the growing separation between East and West.

As the conquests of Islam from this on weakened the African church and absorbed the energies of the East, Rome turned with increasing concentration of purpose to the subjugation of a new world.

Rome accepted as the basis for her mission the dogmatic construction handed over to her by the East. The intrusion of Leo I upon the field of dogmatic discussion had no real intellectual interest, but was simply the excuse for the assertion of central and final authority.

Dogmatic discussion goes on, it is true, but it is increasingly subordinated to questions of authority and cult. Both in the East and the West intellectual interest is almost wholly swallowed up in practical purpose. Even the remains of Hellenistic curiosity in the Eastern church are taken up with small details, and it is noteworthy that the disputes are about no great new dogmatic issues, but only concern the bringing of the Arian heretics under the sway of Rome and the fixing of the cult (Easter celebration, fasts, etc.).

${ }^{1}$ Epis., V. 18; cf. Gieseler, I, 2, p. 228. 
It is perfectly evident as one studies the life work of such an Eastern leader as Photius, ${ }^{1}$ that national or perhaps better, sectional feeling, the pride of history and tongue (Latin a "barbarous tongue"), the conception of life, the social ideals, had quite as much to do with the ecclesiastical schism as any doctrinal divergence. The tottering neo-Greek world could not and did not understand the new power rising in the West. The Roman pontiff did comprehend it in a measure, and as Rome died to Eastern sway she rose again to Western domination.

\section{THE RELATION OF CHURCH AND STATE}

The most complicated question the student of Christian ethics has to face is the relation of the Church to the State. It is involved in the whole complicated history of feudalism.

As a new social order rose on the basis of the great Roman estates, and the German and Frankish communal customs, ${ }^{2}$ the question that had to be answered on all sides was what relation the organized church was to bear to the new powers. Here Rome's claim to rule as over-lord in the name of Christ all the newly rising kingdoms of the north began to be formulated. From the time of Leo I onward this struggle for place in the

\footnotetext{
${ }^{1}$ Photius, patriarch of Constantinople from about 857 to 867 and 878-886; died about 897. Cf. Kattenbusch, F.: "Photius," in HerzogHauck's "Realencyklopädie," XV., I904, pp. 374-393, where the abundant literature is given. His chief works were "Bibliotheca" or "Myriobiblon" (Latin translation by Schott, I653), in which he reviews some 280 works with extracts ( $c f$. Migne, "Pat. Greca" tom. Ior-104); the "Amphilochia" ( $c f$. Hergenröther, J.: "Photius, Patriarch von Constantinopel, sein Leben, seine Schriften und das griechische Schisma," vol. III, p. 36), and his letters (Migne); also the author of many polemical works and miscellaneous tracts.

${ }^{2}$ For the literature of feudalism, see besides the standard histories an admirable little summary in Robinson, Jas. H.: "An Introduction to the History of Western Europe" (Boston, I903), pp. I04-II9. Much remains to be done in detailed investigation, as, for instance, the fidelity-oath to the English king which changed the land laws of England. But on the whole the main outline of the rise of feudalism is now settled. See Emerton, Ephraim: "Medieval Europe, 814-1300," (Boston, I894), chap. 14., pp. 477-508.
} 
new social order dominates the whole situation. Every bishop, every monastery, indeed, nearly every church, had property interests to be guarded in the new distribution of power and authority.

True it is that this struggle involved the church of necessity in all manner of palpable contradictions. For her mission of culture and education she needed both property and authority, while professing to disclaim both. She had no thought-out doctrine of the relation of Church to State. The old tradition of the State as a hostile power came down from the pre-Constantine days, and survives with a measure of truth to this day. On the other hand, from Constantine on the peace that had been established between the Church and State in the Eastern world never ceased to be the model for all the rising temporal authorities in the West, for this meant a large subordination of the Church to the State.

With this solution Rome, even at her worst, was never quite satisfied. She was constantly, though not always equally consciously, struggling for over-lordship in the fullest sense of that term, and her relative success still haunts her dreams, even though feudalism is most palpably a thing of the past.

It is evident that the State is a means of culture, and human experience has accepted it as quite as "divine" in its activity as any other agency for human progress is a "divine" agency. But Rome could not and cannot even to-day shake off the dualism that establishes a world-wide difference between that which is "secular" and that which is "sacred." The claim to mediate as by her magic between two worlds seemed too important to surrender. Hence Rome was bound to enforce her supreme claim as over-lord because the "secular" must be secondary in real importance to the "sacred." 1 Hence the struggle of the militant

1 Gregory I says in the preface to his "Moralium": "Blessed Job is bidden to intercede for them (the friends) because the sacrifice of heretics can never be acceptable to God unless offered for them by the hands of the universal church, so that by her merits they may obtain again salvation (remedium salutis inveniant) whom by the arrows of their words they did assail wounding her." VIII : I7. 
papacy for feudal power and acknowledged supremacy. In this struggle the organization was bound to suffer all kinds of injury. When she was successful, ambitious men took advantage of her success for their selfish purposes. When her leadership was weak, the same selfishness despoiled and robbed her of her possessions.

These facts stared Gregory $I, 1$ "the Great," in the face when he was called to take charge of "his rotten, leaky vessel." 2 The church had no force available to wring from the wild Lombardians any real acknowledgment of her claims. She had to turn in her dire need to the emperor, and from him Gregory had to seek confirmation of his election. The painful results of such an attitude of dependence upon a corrupt State is nowhere seen more plainly than in the attitude of Gregory himself to the murderous Phocas and his equally guilty wife. ${ }^{3}$ And when we

${ }^{1}$ Gregory the Great, I, was Bishop of Rome from 590 to 604 . He was born of noble and wealthy parents, probably about 540. Pope Felix III was one among his ancestors. He gave up his property and high official position to become a monk, from which vocation he was compelled by popular clamor to take up the bishopric of Rome. At least so we are told in the two short lives given in Migne, "Pat. Lat.," tom. 75, by Deacon Paul, cols. 4I-60, and Deacon John, in four books, cols. 59-242. His works are volumnious (Migne, "Pat. Lat.," 75-78). Most instructive for us are his letters, and his commentary upon Job, in 35 books. Cf. Walther, W.: "Gregor I," in Herzog-Hauck's "Realencyklopädie," VII, I899, pp. 78-89, and Lau, G. J. Th.: "Gregor I, der Grosse, nach seinem Leben und seiner Lehre geschildert" (Leipsic, I845), particularly the I 4 th chap. of part 2, pp. 527-54I. The illustrations (adornata) to his life from his own works in Migne, tom. 75 , cols. $241-462$ are suggestive. Cf. also Baxmann, R.: "Die Politik der Päpste von Gregor I bis Gregor VII," Elberfeld, I868-69, teil I, pp. 44-146. The Pastoral Rule and selected Epistles are translated by James Barmby in the "Nicene and Post-Nicene Fathers," second series, vol. XII, pp. 2 I 7-243, and vol. XII, pp. I-I Ir.

2 "Sed quia vetustam navim vehementerque confractam indignus ego infirmusque suscepi (undique enim fluctus intrant, et quotidiana ac valida tempestate quassatæ putridæ naufragium tabulæ sonant)," . . Epist. liber I : 4. (MPL, 77, 447 B.)

3 "Considerare cum gaudiis et magnis actionibus gratiarum libet quantas omnipotenti Domino laudes debemus, quod, remoto jugo tristitiæ ad libertatis tempora, sub imperiali benignitatis vestræ pietate pervenimus." Epistolarum, liber XIII, Epist. 38. When we think that this Phocas had 
turn to the actual morals of Gregory, as reflected in his very wearisome exposition of Job, we see, not a system of ethical thinking, but a conglomerate of oriental monkish quietism, of pagan ethics dominated by imperial ambitions, and strangely interwoven with real Christian feeling.

Here we see the materials of the culture by which the militant papacy gained her primacy among the peoples of the north. She came bearing an absolute authority. It is of slight importance who wrote Job: the author was but the pen of the Holy Spirit." The trials are sent by Satan, as Job represents Christ, or Christ in his church assailed by many enemies. ${ }^{2}$ Job's patience in his trouble is typical of the saints' attitude toward the various woes of life. ${ }^{3}$ The false friends are the heretics. ${ }^{4}$ Job himself is typical of Christ, as his name implies, ${ }^{5}$ and as Job receives double for all his losses, so also the saints will receive here one blessedness, and after the resurrection twofold. ${ }^{\circ}$ Throughout there is to be seen the "sensus historicus" and the "sensus allegoricus" and the "sensus moralis." Thus to fastidious souls are offered various kinds of food. ${ }^{7}$ The four cardinal virtues and the three evangelical ones are offset by formidable lists of vices, and free-will and predestination are both taught. ${ }^{8}$ Life is a series of struggles and temptations, and ascetic despondency seemed often about to gain the upper hand; ${ }^{9}$ but we must have joy even in our temptations and rise with new vigor for the conflict. $^{10}$ The use or rather misuse of Scripture is everywhere evident, and the contradictions and absurdities that mingle with much good sense and real piety are characteristic of the day and

brutally slain the eight princes before the eye of the father and then murdered the father whom Gregory had himself loaded with flattery and entreaty ( $c f$. Epistolæ III $: 65 ; \mathrm{V}: 20 ; \mathrm{V}: 30 ; \mathrm{V}: 40$, etc.), the baseness of the flattery fairly startles us. For Gregory was an upright man as few men in history have been unselfish and upright. (MPL, $77: \mathrm{I}_{2} 87 \mathrm{C}$.)

${ }^{1}$ Moralium, Præfatio I : 2-3.

${ }^{3}$ Præfatio V : Ir.

${ }^{5}$ Moralium, Præfatio VII : 16.

${ }^{2}$ Moralium, Præfatio IV : 9 .

- Præfatio VI : I5.

6 Moralium, Præfatio X : 20.

${ }^{7}$ Moralium, liber I : $36: 56$, and in IV. I. I sensus historicus.

8 Moralium II : $37: 60 ; c f$. with III : $14-27$.

- Moralium IV : I (Rec. V) r.

${ }^{10}$ Moralium V: $17: 34$. 
stage of the world's thought. There moves also throughout the moralisms a tremendously serious purpose and courage. The saint is armed and ready for all assaults, those of the sword of war, the tongue of scorn, and against internal and external foes of his peace. ${ }^{1}$ Amidst all the really puerile reasonings and false ethics there lives that faith that was to carry the half-culture of the paganized church to the nations growing up in the north.

The world as we see it through the glasses of the ascetic monkautocrat was indeed a disordered world. ${ }^{2}$ And yet it is unhistorical to forget that the world is always disordered, and that did we know the lower world of Rome and Athens at their best we would more vividly realize how disordered those worlds were in spite of the high culture of a very few.

We must remember that the world of Athens compelled Socrates to drink poison, sold Plato on the auction block into slavery, and slew Aristotle with homesickness in lonely banishment; and that the world of Rome thrust a golden needle through the tongue of Cicero's dishonored head, rejoiced in the fearful brutalities of the arena, and gave itself up to nameless excesses.

The almost childishly superstitious organization that claimed the name Christian was probably not more haunted by the ghosts of ignorance and primitive terror than the world at the height of Athenian culture. But it was now a larger world. The broken culture of the few was being made the possession of the many. It suffered in transmission. Culture always does so suffer even in our own day. But on the other hand there are ethical values in the Moralium of Gregory the Great and the sentences of Isidore of Seville which have no parallel in the classic ethics of paganism. The softer virtues of love, penitence, faith in the world-order, hope and joy in the triumph of virtue, are not only present, but take their place in the organization of the new world.

Much one could wish were otherwise in the morality of Greg-

${ }^{1}$ Moralium VI : $29: 46$.

${ }^{2}$ Cf. Sancti Gregorii Papæi Vita, ex ejus potissimum scriptis secens adornata. Migne "Pat. Lat." tom. 75, cols. 24I-462. 
ory. It is the ascetic quietist type that is often most attractive in him; but with all that we owe the monastery, it handed down a perverted ideal and Gregory accepted fully this perverted view of life. For him in theory the contemplative life was the full life, and yet even he realized that for most men life must be a struggle, and that on earth the "solitudo cordis" was only a means to strengthen us for that struggle. ${ }^{1}$ He plainly realized the need of compromise that the organized church might do her work, and so accepts both imperialism and the monastery in spite of all the contradictions that involved.

It is thus quite vain to attempt to systematize the thought of Gregory the Great. All the elements of a world that was "in process of becoming" were in him. Imperial ambition jostles with world-flight. Love of the brethren is a fellow-servant of hatred to the heretic. The family is praised and guarded, while celibacy is lauded and forced upon the lower clergy. The State is the guardian of the church and yet her leading rival. Haughty and arrogant claims are set forth in the meek and humble accents of a servant of the cross. Pagan and Christian motives walk hand in hand in a seemingly lasting friendship.

There is really no use attempting to construct an ethical system out of the massed-up contradictory elements that stare the reader in the face. Nor did Gregory himself consciously attempt any rationalization of the elements of conduct, faith, and culture thus handed over simply for reproduction and practical purposes. The age pressed for action rather than reflection. The old struggle of imperial Rome was being carried on on another field, and the struggle for power was only hampered by rationalization.

Nor was the work of the unifying hierarchy badly done by Gregory I. He was in many ways a truly great ethical factor. $\mathrm{He}$ was a real monk, with far more of the inwardness of the monastery ethical type than, for instance, Gregory VII. His services to the music of Europe are immortal. Not the music founded on erotic dance, nor even the melody of the laughing

${ }^{2}$ Moralium XXX : $16: 5{ }^{2-55}$. 
South have taken the place of primacy in the world of music; but the solemn choral based on the churchly chant echoes through Bach, Beethoven, Schubert, Weber, Wagner, and Brahms. And it was Gregory I that forced on unwilling Gaul and all the world of religious culture for ages the Gregorian chant.

With Gregory's name will also forever be linked the spiritual conquest of Great Britain. The oft-re-echoed story of Bede may or may not be true, but the sending of emissaries to take possession of Great Britain in the name of Rome was more farseeing than Cæsar's adventurous conquest.

The story of that missionary enterprise marks the beginning of the conquest of England's church by Rome. The details of the first founding of an English church are wrapt in myth and legend, for it is quite amazing that the history as transmitted to us by the venerable Bede, ${ }^{1}$ and which is full of wonders, miracles, and impossible dates, should be taken as seriously as it is by some critical historians. With this mass of miracles, legend, and allegory, amid which it is now quite impossible to pick out the actual history, as the only source of information on many points, one must simply be content to rest in ignorance, for the work of Bede is altogether too evidently uncritical and fanciful to be trusted.

Yet the history and his letters have for us one great value: they open up to us the world in which a really formative religious culture was doing its work. The angels, devils, dreams, miracles, and magic of Bede's world were not introduced by Christianity. That was the world in which a comparative barbarism was living.

${ }^{1}$ Bede (Beda, Bæda) Venerabilis, 674-735, was from near Wearmouth, and within the walls of her cloister did his great life's work. Best known from his "Historia Ecclesiastica Gentis Anglorum," best edition, Oxonii (Oxford), 1896. Collected works by Migne, "Pat. Lat.," tom. 90-95. See article by Wm. Stubbs in Smith and Wace's "Dictionary of Christian Biography," I, 1877 , pp. 300-304, and article by Seebach in HerzogHauck's "Realencyklopädie," II, 1897, pp. 5ro-5I4; cf. the New SchaffHerzog, II, I908, pp. 22-23, where complaint is made of the lack of a really critically edited edition. 
To this world Bede and his fellow-workers brought new elements and a new ethical purpose and life. The monks sent by Gregory to England came, Bede says, with a silver cross and the image of Our Lord painted on a board, with procession and with prayer. But the real content of their message he gives in the litany: "We beseech thee, O Lord, in all thy mercy that thy anger and wrath be turned away from this city, and from thy holy house, because we have sinned, Hallelujah!" The inducements to accept the message of forgiveness were everlasting joy in heaven, and the kingdom that would never end with God. At the same time "the service of Christ ought to be voluntary and not by compulsion." 1

The main virtue in Bede's mind is humility. In his history ${ }^{2}$ he pictures the tests by which the messengers of the cross are to be judged: "If, therefore, Augustine is meek and lowly of heart, it is to be believed that he has taken upon him the yoke of Christ, and offers the same to you to take upon you. But if he is stern and haughty, it appears that he is not from God, nor are we to regard his words." So that even in a world in which miracles are the ordinary accepted test of truth, the ethical test is put forward as the final and real one.

And again in Bede's letter to Eckbert the bishop, the conduct of the monastery and the life of the priest are treated as the conclusive evidence of the divine life in the church. The monastic temper of Bede is very pronounced, and yet like Jerome he bound it up with love of learning and art. Mathematics and music received his constant attention, and his historical effort, no matter how uncritical and untrustworthy, reflects the literary and historical interest that still bound the Western monastery to the world.

Moreover, to rightly estimate the ethical ideal Bede held up to the world of his day we must realize what medicine that sick world wanted. For the world was sick. It was an age of transition from one cultural stage to another, and the ethics of

1 “ Historia Ecclesiastica Gentis Anglorum," liber I, cap. 26.

2 "Historia Eccles," liber II : 2. 
the one period were not fitted for the direction of life in the new. The simple rules and habits of conduct whose observance keep men relatively moral in the routine of primitive life may be utterly inadequate for new and complex conditions. To the northern world these new complexities had come. And with them came the ethical entanglements that were inevitable.

Some critics of the period write as though the church had been the only bearer of Roman and Greek culture. That is not true. The armies of Rome were the first messengers both to Gaul and Britain. The destruction of primitive organization had gone far and wide. The work of reconstruction was only beginning. To make effective the work of Rome as an agent of culture it was essential that her authority be established and maintained. In far-off regions lonely missionaries loved to dwell upon the power and authority of Rome, and thus her missionary enterprises became important factors in the question between the Roman church and other forces. To make Rome supreme seemed to strengthen her all along the line of her missionary life.

\section{THE MISSIONARY MOVEMENT AND THE MONASTERY}

Among the agencies reconstructing human life not the least was the monastic missionary. Amid much corruption and decay in the Western church the constantly healing and redeeming factor was the social service rendered by the monastery. It was the monastery rather than the hierarchy that deserves the crown, but in Gregory the Great the work of Athanasius was completed. The monastery was merged more and more in the hierarchy and subordinated to its ends. So that from Gregory on the triumphs of the monastery were the glory and the profit of the church.

One remarkable feature of the missionary movement is the place that the cult has in it. From the time of the British missionary Augustine, sent by Gregory I to convert England, to the final subjugation of the north to Rome, the struggle is not so much for dogmatic correctness as for ritual unity. This was 
perhaps natural. Dogmatic disputes in the early Greek sense were above and beyond the hardy fighting Germanic aristocracy and wholly indifferent to the mixed lower classes that aristocracy governed. So, also, even making all allowances for the extravagance of Tacitus, in his preaching to Rome with the Teutons as a text, the ethics of the Germanic people did not need as much patching up as the morals of the decadent Italian population. To the fierce war-loving tribes, however, the message of the gentleness and suffering of Jesus, the tenderness of the "Mother of God," and the passive courage of the saints and martyrs came with power.

The earliest literature in England and Germany reflects the ideals thus created, the forerunners of the strange mingling of fierce passionate insolence with tenderest pity and grace which mark the feudal ideal as we shall study it in the Middle Ages. ${ }^{1}$

The missionary work of the church had, indeed, also to go on in the south and southern parts of the Roman Empire from the earliest day until the struggle with Mahometanism. ${ }^{2}$ Yet the main task was toward the north, and the storm of Mahometan invasion left the corrupted wellnigh heathen church of the south and Africa a mere ruin.

It is extreme to say with Felix Dahn that the Germanic tribes became Christians just because that was the State religion of Rome, and that had it been Buddhism or Isis worship they would have accepted that. ${ }^{3}$ In fact, Christianity had made progress among the Goths before ever it had become the official religion of the Roman State." Moreover, the fact that it was the

${ }^{1}$ Cf. Ebert, Adolf: "Allgemeine Geschichte der Literatur des Mittelalters im Abendlande bis zum XI Jahrhundert," vol. I (Leipsic, I889), pp. 6r 2-659.

${ }^{2} C f$. Duchesne, Abbé Louis: "Les Missions chrétiennes au sud de l'Empire Romain" (publications of the French School at Rome, I896), pp. 79-1 22.

'In Wietersheim, Ed.: "Geschichte der Völkerwanderung," vol. II, 2d ed. edited by Felix Dahn, Leipsic, I88I, p. 53.

-Waitz, Georg: "Ueber das Leben und die Lehre des Ulfila. Bruchstücke eines ungedruckten Werkes aus dem Ende des 4 Jahrhunderts." 1840, p. 35 . 
religion of Rome was evidently often rather a hinderance than a help, so far as the hardy Germanic tribes went, for they looked upon Rome as an enemy.

The material is, alas, rather insufficient for forming more than tentative opinions, yet so far as it is possible to 'estimate the great missionary movement it may be said, first, that it is true that the forms of Christianity were in some cases accepted simply as parts of the superior culture the missionaries brought with them; and, secondly, that the religious life of the Germanic tribes had broken down much as Roman paganism had broken down a generation before the Cæsars. Hence the tribes readily took up the new forms with which they mingled many elements of the old (Saint Stories and Germanic Mythology).

Sometimes this mingling of the ethics of Christianity as understood by the monastery and the remains of mythology was harmless and poetical. Sometimes it was much less so. Grave superstitions were thus foisted upon the religion of the Middle Ages (witchcraft, etc.). The Germanic tribes seem in general to have had no fixed priest caste, and the roving military life of the aristocracy had seemingly broken up such forms as had developed in more settled times.

And, thirdly, it seems perfectly evident that Christianity dealt not with the "proletariat" or "peasant" elements, so far as these were present, but with the roving military aristocracy, and so became the religion of the ruling class. This in part explains both the Saxon resistance and the exceedingly rapid spread of the monastery type of Christianity among the Goths, Ostrogoths, Longobardians, Franks, and eventually the Saxons.

With a special measure of success Gregory I evangelized England, and here perhaps the power of the church as a force for culture and economic reorganization might have been seen at its best had not the distractions of foreign invasion so constantly complicated the situation.

The monastery was saved from corruption and selfishness by its enthusiastic acceptance of this cultural mission in which it accomplished so much. The way in which Jerome, Ambrose, 
Gregory of Nursia, and Cassiodorus, Senator, ${ }^{1}$ made the monastery a refuge for learning and linked religion with life and scholarship atones for much of the fundamentally unsocial character of the monastery ethical ideal. Nearly all we know about Augustine as the first Archbishop of Canterbury we know from the exceedingly uncritical history of the venerable Bede. ${ }^{2}$ The failure of Augustine to win the British church to Rome was a sad one, but in the conditions he made one sees how much the ritual and the imperial interests dominated the ethical. The story goes that the British bishops asked a sainted old man if they should accept Augustine, and he told them "Yes," if Augustine had the spirit of Christ, and this they could know if he rose to greet them when they met. This Augustine did not do, and the haughty demand that they submit to him as the representative of Rome made them say: "If he treats us so before he is our acknowledged head, how will he treat us after it?" And they refused obedience. The conditions of submission were a correct Easter day, abstinence from blood and things strangled, and submission to Rome.

We see here how small a part ethical ideals played in the message, but how important the central authority was in the eyes of the missionary. Not less so was it important to Bonifacius, ${ }^{3}$

${ }^{1}$ Cassiodorus, Magnus Aurelius, Senator, was born about 469 or $47^{\circ}$ and died about 560 . He rendered important services to Theodoric and to Italy. He retired to a monastery of his own founding, and presented to it his library and by his writings became in good measure the mediator of Roman culture to Germanic Catholicism. Cf. Migne, "Pat. Lat.," tom. 69-70; and "The Letters of Cassiodorus," a condensed translation of the Variæ, with introduction, by Thomas Hodgkin, London, 1886; also HerzogHauck's "Realencyklopädie," II, I897, pp. 749-750, by A. Hauck; English translation, II, I908, pp. 436-437, and Smith and Wace's "Dictionary of Christian Biography," I, I877, pp. 4I6-4I8, by E. M. Young.

${ }^{2}$ Cf. Montalembert's "Monks of the West"; Stanley's "Memorials of Canterbury," 4th ed.; Gocelinus, "Vita S. Augustini"; Migne, "Pat. Lat.," tom. 80, cols. 4I-94, and also a smaller life in tom. 150 , cols. 743-764, which according to the editor "Auctorem vixisse circa ann. 1000 ex his colligi potest." (MPL, CL, 765-6.)

3 Winfred Bonifacius, born somewhere about 675 to 683 , and died 755 . His birthplace was Wessex in England. Early he attempted missions in 
who came to Germany as the herald of the hierarchy. The activity of the man is surprising, and no doubt the regulation of the somewhat formless Christianity he found sitting lightly upon the population of what is now Bavaria and Türingen was very necessary.

At the same time-one cannot but be struck with the formal legal character of his message and the extreme poverty of the religious and ethical ideals. Uniformity of worship, a celibate priesthood, the abolition of the primitive wandering bishop, the abstinence from horse-flesh as food, etc., etc.; these are the things we find insisted upon, and as all-important is the acceptance of the authority of Rome. Sexual purity and temperance are, of course, enforced, and the purity of the married relation is conserved as far as great legal severity could be made to conserve it. "Illegal relations with concubines on the part of laymen were broken up by the holy man's admonitions, and the (married) relations of priests to women were given up and they lived apart." "All was reformed and atoned for in accordance with the canons." The heathen relics, amulets, charms, etc., were banished, and Christian relics, amulets, and charms were introduced. It is related how wherever Bonifacius went he bore with him the relics of the saints. ${ }^{2}$

In fact it is evident from the wholesale way in which the conversions were made that no very important changes in life's ideals were demanded. Priests and sacred persons were indeed not permitted to go into battle; but sacred persons are seldom thus called upon at any stage of religious culture, and for the rest the church left the Germanic people about as fierce and warlike,

Friesland, and then, after consultation with Gregory II, he became Rome's chief agent in the attempt to centralize the Catholic power and induce the Germanic forces to submit to Rome. Cf. Migne, "Pat. Lat.," tom. 89, cols. 597-892, and especially "Vita," by Willibald (translated into German by W. Arndt, in "Geschichtschreiber der deutschen Vorzeit," vol. I3, Leipsic, I888); also Pfahler's "St. Bonifacius und seine Zeit," Regensburg, I880; A. Werner, in Herzog-Hauck's "Realencyklopädie," II, I897, pp. 301-306, English translation, II, I908, pp. 226-227

1 "Vita," 9 : 29. (MPL, tom. LXXXIX, col. 623.)

2 "Vita," $8: 23$. (MPL, tom. LXXXIX, col. 6rg.) 
as grasping and overbearing as it found them. It did, however, introduce some culture, order, respect for law, and by its own centralized political character trained the nations for central power and national organization.

In this deepening of national life by the introduction of the culture and the learning still preserved in the Roman church another Englishman had a most prominent place. The student of Bede's works and the teacher of Lindger (the apostle to Friesland), and one of the most influential men in the court of Charlemagne, was Alcuin, ${ }^{1}$ who transferred to the growing Frankish kingdom the learning and literature gathered and preserved in England, but which would soon have been lost there, perhaps, amidst the political disturbances of the following century had not the court of Charlemagne given it a restingplace.

Alcuin has for the missionary movement the special significance that he united with the transmission of the religious and ethical message a very large element of learning and culture. His ethical ideal was that of the monastery, but of the missionary working monastery. His ethics is that of Augustine, whom he largely transcribes in his book, "De Virtutibus et Vitiis," and his treatise, "De Animæ Ratione." He ruled several monasteries, but there is no evidence that he was himself a monk, yet his whole way of thinking reflects the monastic culture of his day. And he had a great deal to do with the most important process by which the monastery became the library,

${ }^{1}$ Alcuin (Flaccus Albinus) was born in Northumbria about 735 and he died before $8 \mathrm{I} 5$. He was probably not a monk, but belonged to the secular clergy. His works comprise his letters, exegetical works on nearly all the books of the Bible, works on liturgy, on dogmatic subjects, poems (including hymns, epigrams, and poetical letters), dialogues on grammar, rhetoric, logic, and various topics including natural science, and some works on moral philosophy, namely: "De Virtutibus et Vitiis"; "De Animæ Ratione"; "De Confessione." Cf. Migne, "Pat. Lat.," tom. roo and ror. Monnier, François: "Alcuin et Charlemagne," 2d ed., Paris, $186_{3}$, and also the accounts in Herzog-Hauck's "Realencyklopädie, I, I896, pp. 365-369, by Hahn, English translation, I, I908, pp. I I I-I I2, and Smith and Wace's, "Dictionary of Christian Biography," I, I877, pp. 73-76, by Wm. Stubbs. 
the university, the school, the refuge of the learned and the conserver of that worldly literature, art, and science the hermit so vigorously sought to escape. This change could not take place without a relative suppression of the religious conception, and the disorders of the monastery with which Rome struggled whenever she herself was religiously awakened appear steadily and persistently from now on.

Alcuin marks also the position the Roman Catholic scholar was to take in the important work of transforming Europe. As the constant counsellor of the king, he uses his place and power for the extension of the two-sworded kingdom, rejoicing when the arms of Charlemagne extended the hierarchy's influence, ${ }^{1}$ and seeing in that extension the victory of essential righteousness.

The place of emphasis now begins in the seclusion of the cloister to change from the ritualistic and administrative to the philosophic and dogmatic. The speculations of Greece begin again to work as ferment in the minds of those who found leisure in the monastery denied to the agressive missionary fighting forces which constitute the army of the militant papacy. We shall see at a later stage what an important part, for instance, in the spiritual life of feudalism was played by the works of the pseudo-Dionysius the Areopagite. ${ }^{2}$

The strange thing is how little it is possible to do more than fix the ethical ideal of the monastery and follow out that influ-

1 "Primo sciat dilectio tua, quod miserante Deo sancta ejus Ecclesia in partibus Europæ pacem habet, proficit ac crescit. Nam antiqui Saxones et omnes Frisonum populi, instante rege Carolo alios præmiis et alios minis sollicitante, ad fidem Christi conversi sunt. Sed anno transacto idem rex cum exercitu irrupit super Sclavos, quos nos Vionudos dicimus, eosque subegit suæ ditioni." Epistolæ III (anno 790). (MPL, C, 142 B.)

2 The "Writings" are by an author whose date is quite uncertain, probably before 400; the Neoplatonic and Pantheistic type of thought is pronounced. English translations by J. Parker, two parts, London, 1897-1899 (in the edition of 1894 is an introduction and defence of authorship by Dionysius the Areopagite); see also A. Harnack, "Lehrbuch der Dogmengeschichte," II, I887, p. 426, foot-note I, English translation, vol. IV, I898, p. 282, footnote 2, and also Herzog-Hauck's "Realencyklopädie," vol. IV, I898, pp. 687-696, English translation by N. G. Bonwetsch: Westcott. B. F.: "Religious Thought in the West." 
ence in its workings upon the ethics and law of the northern tribes.

Very early both in England and Germany the culture carried by the missionary begins to produce a distinct folk-literature, and that literature betrays its origin by the religious character of its themes (one thinks of Cædmon and of the "Christ" of Otfried or the "Heliand"). The hierarchy is now distinctly an aristocratic social form, but the celibacy of the priesthood ruled out a separate hereditary caste, or we might have seen a hereditary hierarchy grow up in Europe as in India. In consequence of this celibacy the hierarchy had a distinct secondary democratic influence. It was the easiest and most common way for the poorest and lowest to rise to the very highest place in life. Within the social form birth and wealth were, of course, of great advantage, but poverty and even serfdom were no absolute barriers in the way of ecclesiastical advance.

It is, perhaps, a mistake commonly made to attribute to the Christian church from Nicæa to Charlemagne too large a share in the formation of the social forms of the Middle Ages. Some things stand out plainly. The militant papacy served a most useful function in conserving and handing down many of the best traditions of Roman law. All commentators on the codes of Justinian and Theodosius are agreed upon the fact of Christian influence, although the estimates of the amount of it vary greatly. ${ }^{1}$ On the whole, however, the social forms of the feudal state were all well on their way before the organized hierarchy became a social force of the first importance.

The disappearance of slavery was not directly due to organized Christianity. Such protests as appeared against it were isolated and can all be duplicated from heathen sources. Neither Paul nor Gregory the Great nor Leo III thought of abolishing slavery. It became, however, under advancing humanitarian ideas and with the decreased supply from war, an unprofitable economic form, and disappeared in fact long before it disappeared from

${ }^{1}$ Cf. Troplong, R. Th.: “De l'Influence du Christianisme sur le Droit Civil des Romains," 2d ed., 1885. 
codes of law or of morals. ${ }^{1}$ It was too expensive and wasteful a system. ${ }^{2}$ The rise of serfdom is usually traced to the Roman "colonies," but as a matter of fact the relations between patron and client seem very early to have produced in the great estates (Latifundia) a full-fledged feudalism long before the northern invasions. So that the influence of the Germanic invasions and customs seems usually to have been much overestimated. Feudalism was in fact quite as much a demand that the tenant have secure possession as long as he fulfilled his obligations, as an attempt to secure fixed labor by tying the laborer to the soil. It was a protest against rack-renting, or the driving of the cultivators off the soil, as has happened among the crofters of Scotland or the truck gardeners in the neighborhood of London.

Save only as Christianity acted generally in the softened customs of life, it had little to do with the rise of feudalism.

1 The only fairly good history of slavery in English is J. K. Ingram's expansion of his article, "Slavery," in "Encyclopædia Britannica," 9th ed., vol. XXII, 1887 , pp. 129-177; in book form, "History of Slavery and Serfdom," London, 1895. The most elaborate and exhaustive work is Wallon, H. A.: "Histoire de l'Esclavage dans l'Antiquité," 3 vols., 2d ed., Paris, 1879, particularly see vol. III, pp. 296-443. Blair, Wm.: "Inquiry into the State of Slavery Among the Romans, from the Earliest Period to the Establishment of the Lombards in Italy," Edinburgh, 1833, has much useful reference, but misses the economic meaning. Fustel de Coulanges, N. D.: "Recherches sur quelques Problémes d'Histoire," Paris, I885, is a suggestive book. Serfdom in England is noticed in Stubbs, "Constitutional History of England," $1874-1878$. In the bonds of a theory but highly instructive are Letourneau's (C. J. M.) series on "L'Évolution de le Morale," I 887; “L'Évolution de la Propriété," I 889 (English translation, London, I892); and "L'Évolution de l'Esclavage," I897. Although he deals with the later phases, we have found most suggestive of all Sugenheim, Samuel: "Geschichte der Aufhebung der Leibeigenschaft und Hörigkeit in Europa," St. Petersburg, r86r. Biot's (E. C.) "De l'abolition de l'Esclavage ancien en Occident," Paris, I840, we have not seen. $C f$. also Larroque, Patrice: "De l'Esclavage chez les Nationes Chretiens," r864; Yanoski, Jean: "De l'Abolition de l'Esclavage Ancien au Moyen Âge et de sa Transformation en Servitude de la Glèbe," I860, particularly chap. II, pp. 33-75.

${ }^{2} C f$. Adam Smith's "Wealth of Nations," III, 2, pp. 427-440, of "World Classics," ed., I904. 
The papal State and the monasteries became great slave and serfholders.

In many indirect ways, of course, the church affected slavery. It was probably early regarded as meritorious to free slaves, a tradition inherited from Roman ethical teachers. Moreover, under certain conditions a slave could secure freedom by becoming a monk or priest. The church building became the asylum to which the slave could flee as the temple or grove of Roman life had been, and he could wait there until the priest had pled with the owner. The slave was also theoretically a full-fledged soul, with the rights of manhood or womanhood in a way no pagan philosophy had in practice taught.

The Roman law shows from Trajan on a steady improvement of the slave's position in the eye of the law. From being absolutely a chattel of the owner he came to enjoy legal rights of large significance. He shared in the Roman State's interest in its own poorer classes, ${ }^{1}$ but the process was greatly hastened by the democracy of the communion-table and by the trend of even ascetic morality.

The value set upon the person as a person increased. ${ }^{2}$ In the same way the new hierarchy took the place in the Frankish kingdom which the religious principle had in the formation of old Rome, ${ }^{3}$ and undoubtedly moulded the ever-increasing legal protection flung about the slave, rendering his labor economically ever more unprofitable until he was caught in serfdom and the wage system, as being more economical for the employing class.

The church fathers had almost without exception accepted slavery as founded in the natural state of things. Augustine saw in it a direct outcome of sin, and this conception, born partly

'Cf. Jhering, R. Ivon: "Der Geist des römischen Rechts," ed., I852, part 2, pp. $239-267$.

2 Cf. Gibbon's "Decline and Fall of the Roman Empire" (Bury's ed., I898), vol. IV, pp. 470-476.

"Cf. Jhering, R. von: "Der Geist des römischen Rechts," ed., I852, part I, pp. 256-28I. 
of Aristotle, partly of dualism, prevented the organized church from taking any stand against slavery per se. But from Chrysostom and Ambrose on, both in the East and West, the pulpit enforced the equality of all men in Christ Jesus, and dictated conditions for the slave which had they been enforced would have made his labor highly unprofitable. ${ }^{1}$

The Germanic tribes accepted, on the whole, the social arrangements of the later Roman Empire, with, of course, modifications due to the economic situation. In fact, both religious and social forms seem to have profoundly suffered during the time called, for lack of a better name, the "Völkerwandering" or Germanic invasion. The period of ecclesiastical reconstruction and missionary effort introduced the RomanGreek civilization founded upon the formulated law of Justinian and Theodosius, and thus the way was made ready for the feudal Middle Ages.

The period is one of long incubation, but is neither so dark nor so reactionary as has been commonly represented.

When once more the human spirit awoke to a realizing selfconsciousness, it discovered the fact that it was now not a question of a small class but of the race. The national democracy of the Old and the race democracy of the New Testaments are not the only factors in this reawakening. All through the period from Gregory I to Charlemagne, Aristotle and Cicero were still at work, and the ancient philosophy and science were kept alive both in the cloisters and among the Mahometans. But the Christian church was the popular even if very inefficient teacher. It is quite useless to attempt to depreciate her services in the tone of Yves Guyot. ${ }^{2}$ The barbarism and darkness of this period were not her fault. They sprang from the giving way of the social structure under the weight of warlike impact from the north. The social structure was rotten before the Christian church had power, and the northern invasion would

\footnotetext{
${ }^{1} C f$. Chrysostom, Epist. ad Eph. IV : and Hom. I $5: 3$.

${ }^{2}$ Etude sur les doctrines sociales du Christianisme (Guyot et Lacroix), I873, and new ed., I903.
} 
have been far more destructive of pagan law and culture had not the Christianized Papal church stood as mediator between two levels of culture and mitigated in a hundred ways the severity of the invasion.

Slowly but steadily the hierarchy became by processes of absorption and adjustment the almost perfect expression of the conglomerate religious life of the various national units that now rise on the ruins of Roman might. For one thousand years (400-1453) the Eastern church stayed the tide of Mahometan invasion, and bound together the life of the races to which she gave the only real unity they had. The Western church carried on her mission of culture and national unification with astounding vigor and enthusiasm. It must always be remembered, both by friend and foe, that neither the Eastern nor Western churches were the Christianity of the synoptic Gospels, nor even of John and Paul. Whatever may be our estimate of the elements that enter in, monasticism, Neoplatonism, oriental mysticism, etc., whether we regard them as obnoxious intrusions or as justified additions under the providential guidance of the promised Spirit, we must as historians take account of them and trace them to their sources as well as estimate their influence on the total culture. It is amazing that any man should really seek to explain the ethical ideals of the militant papal church from the pages of the New Testament alone. The papal church is herself wiser and more historical than that. She claims the inward authority of an infallible guidance progressively unfolding the truth according to her needs. From age to age she expects the same authority to guide her with equally infallible wisdom amid the future complications.

The logical modern Protestant has rejected all infallible guidance. He accepts unreservedly the relative character of all knowledge. All absolute truth is in the region of faith and hope. For him the period could hardly have been otherwise than it was, seeing that it had as its religious guides such very imperfect and yet such nobly imperfect ecclesiastics, whose ideals 
THE MILITANT PAPACY AND ITS ETHICS 28I

were the product of an historic synthesis which faith calls providential, but which none the less combined many elements whose weakness we now easily discover and whose limitations were definite and marked. 


\section{CHAPTER VI \\ SCHOLASTICISM AND ITS ETHICS}

I. Definition of Scholasticism and Its Beginnings-II. Constructive Scholasticism-III. Critical Scholasticism-IV. Mystical Scholasticism.

\section{THE ETHICS OF SCHOLASTICISM}

The definition of scholasticism for our purpose is not difficult to make. It was essentially the attempt to rationalize the growing experiences of the race within the limits of a system which, it was assumed, was closed. This closed system was the unorganized teaching of the culture-bearing church. She came to the Western world with the ethics of the Old and New Testaments, the ethics of Plato and the Orient, of Aristotle and the later Hellenism. All alike were accepted by her on the basis of tradition and fulfilled function. She in her turn gave them to the world of western Europe in the name of divine authority, and claimed for herself the right of final decision in all matters of ethical controversy. The innumerable contradictions within this conglomerate of systems she was altogether too busy to see. The supposed basis was her divine authority. What the faithful said or taught was final. The Fathers and the councils are ever on the lips of Gregory and Isidore.

In point of fact the system was one vast convenient compromise. The high religious culture of Judaism, with its lofty ethics culminating in the teachings of Jesus and Paul, was as much beyond the average comprehension as were the fine and subtile intellectual and artistic exactitudes reached by Greece at her best. The thorough-going metaphysical systems of the Orient, with their pessimism and passivity, were equally beyond the rude north, and were quite impossible teachings in the midst of her stern struggle with nature and life. 
From all this past the hierarchy took elements which she needed for her purpose; she came bearing gifts from Egypt, Persia, Greece, Rome, and Judea, but supposed that all came from one Christian source and that the message she brought with her had a single inspiration. For her practical purposes Aristotle and Plato, speaking with the voice of Augustine or Athanasius, were as divinely inspired as Amos or Paul. She adapted as best she could the various messages to the nations she was trying to train. For the work and services of the church we should all be thankful, while yet remembering that she was only one agent of culture among many and that the child who really learns is largely self-taught.

From the time of Charlemagne onward the organization of life takes another step forward. With the so-called "conversion" of the Saxons the nominal subjection of the north to southern culture was completed. The child became a youth. It is quite unhistorical to think of the Middle Ages as "dark" or as a fearful fall from the heights of Hellenistic attainment. In those ages of intense activity the foundations were being laid in song and art, in language and in law, in logic and religion for that certainly larger and we hope fairer temple that is yet to crown the world's acropolis.

Alcuin was no scholastic; that is to say, he had no deliberate purpose to rationalize the heterogeneous elements of culture he highly prized and profoundly appropriated. He is one of the greatest products of the unquestioning acceptance by the Western and northern races of the culture brought from the south.

But even in the time of Alcuin the signs of a coming independence are not wholly lacking.

The influence of authority has its wholesome limits. We all enter life under authority. The child must obey. Its life depends in a thousand cases upon a prompt and unquestioning obedience to an experience which, however faulty, is far superior to the child's. The Roman hierarchy demanded this unquestioning obedience. Her voice was God's voice. And she was so vastly superior to the untrained north that she received, if not 
a perfect obedience, at least a nominal submission of a very child-like character. The intelligent child, however, soon grows unconsciously restless under authority, and the wise parent or teacher hails with joy the tokens of coming maturity and patiently and steadily prepares the growing mind for its autonomous activity. Less wise teachers fret and worry because their wisdom is not accepted as unquestioningly as of old, and wonder only how they may hold in permanent dependence those whom they sincerely but most mistakenly love.

Among the less wise teachers was the Roman hierarchy. Her enormous property interests, her political power, her very place as teacher and leader betrayed her into the vain attempt to permanently hold the growing world in subjection to her claim to be the one infallible voice of God.

She based her claim on her cosmopolitan character, her antiquity, and the evident superiority of her culture. The real devotion of her sons and daughters gave her unique authority over all classes of men and in the whole Western world. In times of great strain she had succeeded in holding her world together, and men looked to her for relief and comfort under the tensions and hardships of the increasing complexity of life. The conceptions in which she did her work had proved themselves useful for certain purposes of human conduct in the past. The ethics that had become traditional with her were no arbitrary collection of maxims. They were, like all our conceptions, the result of an age-long selective process.

But that process was uncritical and relatively unreflective. Even to-day men shrink from nothing so much as from ethical reflection, if it be truly radical and thorough-going. To question the fundamental conceptions is to at least threaten them with destruction, and for most men, however really intelligent, there is a closed system-it may be the State or the creed or the family -within whose bounds they are ready to rationalize, but whose bounds are for them fixed and held sacred from all impious scrutiny.

The first signs of restlessness were, of course, when the Roman 
claims interfered with immediate and pressing purpose. This friction is first manifest upon the political field, where the interests of the hierarchy soon began to conflict with the rising national feeling. And it has always happened that when the hierarchy has challenged national feeling she has suffered her most disastrous defeats.

In the age of Charlemagne, however, it was still a strength to national purpose to work with the hierarchy under the strong sense of her spiritual and ethical supremacy, and this supremacy was as unquestioned as the multiplication table. It was assumed that she was the infallible teacher and that what she taught was a self-consistent system. We all move in some system we inherit. Most men assume the present social order to be permanent, a system of "law and order" within whose limits all "good men" think, just as the Roman hierarchy's system asserted herself as the pillar of a social order in which all "good men" had to live. The men of the Middle Ages all assumed as an unquestionable fact the supreme authority of the Roman Catholic papal power, and that even though on every hand were the palpable failures of the authority to achieve its ethical and spiritual purpose (corrupt priesthood and stained monastery life).

Few of us have the surplus intellectual energy to do our own thinking on any but an exceedingly constricted field. Most of life we take on authority. Life is too short to regard every question as open for discussion each day. The men of the ninth century had a tense and absorbing struggle for mere life. It is most wonderful what they actually did. The old slave world was transformed into a relatively ordered feudalism. Barbarism gave place to culture and civilization. Art again began to express a new world of longing and inspiration. It is little wonder that the claims of the church which played a part so important in the transformation went almost unchallenged everywhere.

The preparatory stage for the great attempt at intellectual reorganization of the world's thought within the limits of a closed 
system was marked by some of the most interesting phenomena in human history. The student of the ethics of Christianity cannot pass them by without seeking in some way to relate them to the ethical process which is his immediate interest. The age of Charlemagne and the years that intervene between him and Gregory VII ${ }^{1}$ have been drawn in very dark colors, ${ }^{2}$ and it would not be easy to refute in detail the many serious charges that can be made against that age.

The leadership of both Church and State after Hadrian and Charlemagne had passed from the stage leaves much to be desired. Weak, bad kings and popes follow one another in weary succession. Ignorance and superstition mark both people and clergy. On the other hand, when the evidence for special darkness and dissoluteness is weighed, as in so many other cases, the mind hesitates. It is so exceedingly hard to get objective criteria by which to judge; and so often the discontent and complaints are a sign of a rising moral standard on the part of the critics rather than of an actual lower moral life in the age thus rebuked. Personally the author doubts whether in the main the tenth century was not rather better off than the eighth or ninth.

It was at this time that Mahometanism reached its wellnigh widest European boundary. The forward movement that led to the capture of Constantinople (I453) was offset by the gradual driving back of the Saracene invasion of Spain, culminat-

\footnotetext{
${ }^{1}$ For this period, besides the chapters in the standard church histories of Neander, Gieseler, Schaff, Müller, see Reuter, N.: "Geschichte der religiösen Aufklärung im Mittelalter," 2 vols., Berlin, I875-1877.-Baxmann, R.: "Die Politik der Päpste von Gregor I bis Gregor VII," 2 vols., Elberfeld, I868-1869.-Ranke, Leopold: “Geschichte der Päpste (often translated into English; also in the Bohn Library).--Robinson, "History of Western Europe," I903.-Taylor, Henry Osborn: "The Classical Heritage of the Middle Ages," New York, rgor.-Adams, George B.: "Civilization During the Middle Ages," New York, I90o.-Mombert, J. I.: "A History of Charles the Great," London, I888.-Bryce, James: "The Holy Roman Empire," I871, new ed., New York, I904.

${ }^{2}$ As by Draper in his "History of the Intellectual Development in Europe," vol. I, pp. 274-283, 4th ed.
} 
ing in 1492 . The feudal system hardened into its classic phase, with the Emperor or the Pope as chief claimant for the logical climax of the system. The Western church lost steadily its feeling for and its contact with the Eastern church, and sought its strength rather to the north and west; while Byzantianism stiffened into a hard, cold dogmatism with but little ethical life or power.

The Roman church, re-enforced by the possessions granted by Charlemagne, and led by active even though often worldly minded bishops, asserted herself even under weak, bad popes as the centre of the world's Western unity. Spain conformed gradually. The Frankish Empire was fastened by bonds that held her substantially until 1907 to papal religious dominion. The centre of interest was ritual and not dogmatic. Alcuin and Charlemagne might have stirred up a struggle over picture and image worship such as distracted the Greek church, but the Carlovingian books ${ }^{1}$ made no real impression upon a population that had made up its mind already.

The strife over adoptianism was like Gottschalk's attempted revival of extreme Augustinianism, a really foreign intrusion. The age had not begun its work of mental reconstruction. It was still working with the tools in hand.

It is hard for us to estimate the work done in Charlemagne's time to revive learning and to inspire to thought. A triumphant hierarchy under the strong sway of Gregory VII did not preserve to us the literature of criticism, but it is amazing to find

1 The second council of Nicæa, claiming to be ecumenical (787), had condemned those refusing to venerate (venerare) images, and this was done under the direct inspiration of Hadrian. In the name of Charlemagne, and undoubtedly in his spirit, an opus Carolinum was sent as a reply to the Pope in which the worship of images was condemned. A synod at Frankfort a.M. (794) sustained this protest, but Hadrian's reply was a politic yet firm reiteration of the attitude of 787 . Moreover, the protest was in some measure uninstructed. The distinction between $\lambda \alpha \tau \rho \in i a$ and $\pi \rho \circ \kappa \kappa v i \nu \sigma$ is had been taken over in point of fact by Rome, only, unfortunately, the average man did not know the difference between veneration and adoration. See Hefele, "Conciliengeschichte," III : 4 I6 ff.; Baxmann, "Politik der Päpste," I : 297. 
the free simple spirit that moved a man like Claudius, Bishop of Turin. ${ }^{1}$ In his reversion to Augustine he did more than simply take his dogmatic system, but seems, from the imperfect fragments of his works that remain to us, to have accepted primitive Christianity on the basis of a pure spiritual metaphysical monotheism. God is all in all, and to find in him the absolute is redemption. The risen Christ is the real basis for the religious life, not the human and passing phenomenal appearances. Jesus is given his character as divine man by the Father. ${ }^{2} \mathrm{He}$ is the head of his church; the anointed. ${ }^{3}$ And by his enemies Claudius was accused of Arianism and Nestorianism, against which charges he defended himself in an apology, now lost to us, and in his commentary to Galatians."

The main ethical interest, however, attaches to his thoroughgoing rejection of images and crosses, and even though the Synod of Frankfort had permitted them for instruction, he turned them all out of the churches, and defends himself against Jonas and Dungalus on Scriptural grounds, in a work also, alas, lost to us. He also rejected all work-righteousness, and following Augustine makes an imparted divine grace man's only hope of salvation. $\mathrm{He}$, in fact, accepted Augustine as his great mas-

${ }^{1}$ Claudius, born in Spain about the second half of the eighth century, pupil of Bishop Felix of Urgel, Bishop of Turin by the appointment of Louis the Pious, who maintained him there all his life. He died some time before 832. Cf. Migne, "Pat. Lat.," tom. I04, cols. 609-6r6; "Notitia historica in Claudium."

${ }^{2}$ In describing the throne of Solomon in "Quastiones $X X X$ super libros regum, Liber III" (commenting on I Kings Io: 18 ), Claudius says: "Thronus eburneus æternam judicis potestatem auro divinitatis fulgentem, quam Dominicus homo a Patre accepit, figuram gestasse non dubium est." (MPL, I04, $75^{8}$ D.)

${ }^{3}$ Omnes quippe unctos ejus chrismate recte Christos possumus dicere. Quod tamen totum cum suo capite corpus, unus est Christus." ("Quæst. XXX," lib. I, MPL, I04, col. 645 A).

"In a fragment of a commentary to Galatians he says: "Quia enim et Filii et Patris una est operatio: et ut scias quia Deus est Christus, a quo ille est factus apostolus, diligenter adverte quod ante nominaverit Filium quam Patrem, contra calumnias Arianorum." (Migne, "Pat. Lat.," tom. ro4, col. 845 C-D.) 
ter, ${ }^{1}$ the "Pen of the Trinity," and went under his direction to Holy Scripture for his doctrine.

There is no direct evidence, so far as the writer is aware, that Bishop Claudius was the founder of the Waldensian church, but it is not a little remarkable that so strong an Augustinian and Pauline type of Christianity should have maintained itself in the Piedmontese valleys so directly under the influence of Claudius of Turin.

For the rest, his teaching is strongly influenced by the Moralium of Gregory I, and one may distinctly trace the threefold exegesis, the historical, the allegorical, and the moral, by which Kings and Leviticus are made to convey Augustinian and Pauline ethics. These ethical teachings are warm, personal, and loving in character, with the virtutes activa in the foreground. At the same time Claudius is neither a forerunner intellectually of scholasticism nor religiously of the Reformation, but a fine and refreshing reminder that even when superstition and ignorance lay heavy on men there were bright rays of light on strong men's paths.

Agobaud, or Agobard of Lyons, ${ }^{2}$ also fought image-worship and superstitions, such as judicial combat and trial by fire and water. He remained in the simpler type of teaching illustrated by Claudius, and, like him, as a theologian largely contented himself with exposition and collection of past opinions. But he introduces us to one serious and insufficiently studied chapter in the history of Charlemagne's time and the subsequent century, namely, the influence upon thought of Saracen and Jewish scholarship.

1 "Amantissimus Domini sanctissimus Augustinus, calamus Trinitatis, lingua Spiritus sancti, terrenus homo, sed cœlestis angelus, in quæstionibus solvendis acutus, in revincendis hæreticis circumspectus, in explicandis Scripturis canonicis cautus." (Migne, "Pat. Lat.," tom. 104, cols. 927-928.)

${ }^{2}$ Agobardus episcopus Lugdunensis was of Gallic parents but born in Spain, 779, and came to Lyons under Leidrad, the archbishop, became his successor, and died 840 or $84 \mathrm{I}$. Cf. Migne, "Pat. Lat.," tom. ro4, cols. 9-1 2, and A. Hauck, in Herzog-Hauck's "Realencyklopädie," I, I896, pp. 246-248, English translation in the new Schaff-Herzog, I, I9o8, p. 89. 
Agobard wrote much against the Jews. ${ }^{1}$ And when the really Christian student takes up his chief work against them, "De Judaicis Superstitionibus," he begins under Agobard's guidance a saddening review of the hatred and bigotry that has stained official and unofficial Christian history from early times. Agobard calls attention to the hard and cruel things he gathers from the fathers, beginning with Hilarius and going down through the list, Jerome, Ambrose, etc., and then he takes up the councils from Laodicea, ${ }^{2}$ etc., and then with the weird exegesis whose methods are not yet extinct, he proves how Jesus and Paul teach us to hate and condemn with all untruth and lack of charity those who rejected what the guileless Agobard called Christianity.

From his pages it is impossible to form any opinion of the actual influence of Judaism upon Christian thought. That it was considerable one may see from the place that polemic against Judaism has from Gregory I onward. Agobard accuses the Jews of little except rejection of Roman Catholic dogma, and of teaching that God has hands and eyes and ears, etc. ${ }^{3}$ and that they had another conception of the world's creation and maintenance, ${ }^{4}$ and that the letters of the alphabet and the law of Moses date from before creation. Agobard was opposed to several grave superstitions like trial by fire and water and magic against hail, ${ }^{5}$ but it is vain to go to him expecting superstition

1 "Liber de Insolentia Judæorum." “Epistola de Judaicis Superstitionibus." "Consultatio de baptismo Judaicorum mancipiorum." "Epistola De cavenda societate Judaica." "Epistola ad proceres palatii contra præceptum impium de baptismo Judaicorum mancipiorum." Cf. Migne, "Pat. Lat.," tom. ro4, cols. 70-I I 4 ; I 74-r 78, etc.

${ }^{2}$ The council of Laodicea of uncertain date. See for the canons against the Jews, the $37^{\text {th }}$ and 38 th. Cf. Hefele, C. J.: "Conciliengeschichte," 2d ed., Freiburg, vol. I, 1873, pp. 746-777. English translation, Edinburgh, vol. II, 1876, pp. 295-325.

a "Dicunt denique Deum suum esse corporeum, et corporeis liniamentis per membra distinctum, et alia quidem parte illum audire ut nos, etc." ("De Judaicis Superstitionibus," X : I. (MPL, CIV, 86 D.)

Ibid., X : r.

5See his polemic, "De Grandine et Tonitribus," Migne, “Pat. Lat.,” tom. I04, col. I 47 . 
as such to be condemned; it is only superstitions without any official sanction that he condemns. Whether the Jews and Saracens were really less superstitious than the world about them the writer has not been able to decide after taking some pains to find out. ${ }^{1}$ But they had another set of superstitions, and any thoughtful man can hardly reject some one else's superstitions without some inquiry as to the basis of his own.

That they were a disturbing factor, awakening in men disturbing doubts, we see from the pages of Agobard's attacks and from the constant repetition of the church canons forbidding Christians to eat or drink or intermarry with them. They were dreaded even more than heretics, ${ }^{2}$ who had some common ground with Christians, but the Jews had no truth at all.

In his controversy with Fredigis of Tours ${ }^{3}$ it is hard to see how in any important particular he in any way differed from his antagonist. Both accepted without any reservation the absolute authority of Scripture, church, and tradition, without any seeming consciousness of possible contradictions. The assumption was the one constantly made by all parties that human intelligence and the divine authority could only clash in cases of innate moral depravity. The sense of tribal unity, the overpowering need for unquestioning maintenance of the communal authority, on which politically the life of a nation or group has so often depended, was transferred to the religious field. Only "bad" men would weaken the authority of the religious bond by suggesting their own thoughts in opposition. It was "virtue" to think as the church thought, or rather to so bury the religious life in rite, ceremony, and superstitious acceptance of miracles that there was no time or strength for thought.

'See art., "Superstition," by Joseph Jacobs, in "Jewish Encyclopedia," vol. XI, r905, pp. 597-60r, and fuller literature in Güdemann, M.: "Geschichte des Erziehungswesens und der Cultur der abendländischen Juden," 3 vols., Vienna, r88o-r 888 .

2 "Judæorum autem ex toto mentire, ex toto blasphemare Dominum et Deum nostrum Jesum Christum et Ecclesiam ejus," "De Judaicis Superstitionibus," IX. (Migne, "Pat. Lat.," tom. ro4, col. 86 B.)

"Cf. Reuter: "Geschichte der Aufklärung," I : I : ro, pp. 36-4r. 
The political life was torn by the quarrels and violence of the children and grandchildren of Charlemagne and Louis the Pious. The feudal aristocracy, with customary patriotism, took this occasion, of course, to strengthen their own holdings and advance their fortunes. Of the life of the common people it is hard to even form an idea, but the condition from several signs seems, though very low, not to have been made much worse by the dynastic struggles. For one thing the feudal lords were strong in proportion as they could put men into the field as soldiers and maintain them by well-tilled fields, so population seems to have increased, barbarism was slowly supplanted by a rude civilization, the incursions of the Saracens, the Normans, and to the east the Wends, still made life on the borders hard and uncertain, but within, even at the height of the dynasty disputes, relative order was maintained by the feudal lords and the churchly bishops. Yet it is vain to look for original contributions to a theory of Christian ethics, and the intellectual energy was not mainly spent in that direction.

Even the unfortunate monk Gottschalk's ${ }^{1}$ quarrel with his day over an extreme theory of predestination represents no conscious break with Scripture, the church, and tradition as giving a closed system within which men must think, but only the insistence upon interpreting them all in the light of one principle, borrowed, it is true, from Augustine, but which is not really Pauline, and which the church had quite naturally found it impossible to use. Her method of enforcing unity was the primitive one, no longer fashionable in theology but still accepted

${ }^{1}$ Gottschalk the Monk was the son of a Count Beno, and as a mere youth was forced for some reason into a monastery. He maintained to the last his heresy of a twofold predestination based on Augustine and Paul. His chief enemies were Hinkmar of Rheims, Hrabanus Maurus, and Johannes Scotus Erigena. But his teaching also found powerful friends in Ratrammus of Corbie, Prudentius of Troyes, Remigius of Lyons, and others. They were not strong enough, however, to save him, and he died in a monastery prison after twenty years of confinement. For full literature, see the article by A. Freystedt, in Herzog-Hauck's "Realencyklopädie," VII, I899 pp. 39-40. 
as wholesome in other fields where more vital interests are supposed to be at stake.

The court of Charles the Bald was not on the level with that of Charlemagne, nor would it be historical to claim for either of them tolerance in the modern sense of that word, but both were willing within the limits of the accepted system to hear and encourage free speech, and both felt the need of culture for the mass of men as well as for the select few.

From 843 (Treaty of Verdun) the Frankish kingdom, with its semi-Latin Romance tongue, began to separate in speech and culture from the Eastfranks, or those who spoke "the people's tongue," $i$. e., "Deutsch." The more this was the case the more need was there for a basis of unity removed from the political chance, and the Roman cultus grew in importance in men's eyes as they saw the danger of the politically torn social state. Its tongue was Latin, and the educated clerical world spoke this language everywhere, and so bound the world together in culture in an extraordinary degree. Alcuin was an Englishman; Johannes Scotus Erigena was born in Ireland. Anselm was Piedmontese and English Archbishop. Yet all could write and be read and understood by the world of letters everywhere. This gave to the church that cosmopolitanism which is still the chiefest charm of the Roman communion and not a little of her strength.

Such a group of men as Hinkmar of Rheims, Lupus, Usuardus Ratrammus, Prudentius of Troyes, and Johannes Scotus Erigena shows what high capacity and learning could be gathered together even in the ninth century, and the practical work of Bishop Anskar ${ }^{1}$ reveals the fact that the church was still earnestly conscious of her missionary and cultural obligation. This was her real ethical life. It was her social service and not her strug-

${ }^{1}$ Archbishop of Hamburg about $83 \mathrm{I}-865$. See Hauck, "Kirchengeschichte Deutschlands," 2d vol., pp. 6r 7 ff., I890. Anskar was the father of Danish Christianity. Born about 801 , he accompanied Harold back from the "Reichstag" at Mainz, and after his deposition undertook missions to Sweden and then became Archbishop of Hamburg. 
gles over the question of whether Mary suffered birth pangs or not $^{1}$ that gave her place and power. And already she had awakened the spirit that demands a reason for a world of which the religious spirit insists upon postulating reasonableness.

\section{CONSTRUCTIVE SCHOLASTICISM}

The era of constructive scholasticism coincides with the need of a rational and unified view of the world on the part of an awakening intelligence. The place of honor in this process is usually given to Anselm (ro33-rrog), but in point of fact we must go back to the court of Charles the Bald for the reai founder of scholasticism, and examine the work of Johannes Scotus Erigena. ${ }^{2}$ Christlieb has refused to recognize him, it is

${ }^{1}$ It is hard to resist the impression that the unnatural suppression and distortion of the sexual life in monastery and cloister is in large part responsible for the constant morbid inquiries with regard to the birth of our Lord.

2 Johannes Scotus Erigena, it is now admitted, was born in Ireland, and probably somewhere about 820 , although the years of both birth and death are conjectural. He came to the court of Charles the Bald, and by his scholarship and knowledge of Greek, as well as by his humor-if William of Malmesbury is to be trusted-gained the constant support of Charles. After Charies's death the opposition of the clergy and his condemnation by the councils and a pope may have driven him from France. But the story that he was murdered by his own pupils in England, whither he had been called by Alfred the Great, is doubtful. His great work is "De divisione naturæ" (German translation by Ludwig Noack, 1870, said to be good); and important for its understanding is his translation of the Pseudoareopagite and the Scholia of Maximus the Confessor to Gregory of Nazianzus. His work on Predestination is also useful. For our purposes the fourth book of "De divisione naturæ" is the most important of his writings. His collected works by H. J. Floss, in Migne, "Pat. Lat.," tom. I 22 (I853), where also all that is known of his life, together with an ingenious suggestion with regard to the same, is given. (See "Provencia," p. I9.) Of the abundant literature there may be mentioned besides Ueberweg-Heinze and the standard histories of philosophy: Staudenmaier, F. A.: "Johannes Scotus Erigena und die Wissenschaft seiner Zeit," Frankfort, I834; "Christlieb Th. Leben und Lehre des Johannes Scotus Erigena," Gotha, 1860; Huber, Johannes: "Johannes Scotus Erigena," Munich, I86r; Prantl, C.: "Geschichte der Logik in Abendland," Leipsic, I86I, II, pp. 20-37; Maurice, F. D.: "Moral and Metaphysical Philosophy," vol. I, part 3, pp. 467-501. New edition, London, I886. 
true, as the father of scholasticism and mysticism, to which place Staudenmaier had raised him.

In regard to mysticism, Christlieb is undoubtedly right. Erigena was in no sense a mystic, although there are points of contact between his system and mysticism. But the reasons Christlieb gives for refusing to make him a scholastic are surely insufficient. He set about the same task, within the same limits, with the same tools and the same essential postulates; nor did he, in point of fact, reach very different results from the later men. He is the author of the oft-quoted phrase which almost defines the faith of scholasticism. ${ }^{1}$ Christlieb says he was free, but how could any one's speculations be really free starting with such a point of view and making the "regulæ," or "rules of faith," the essence of religion in the way Erigena did?

He only seems free in contrast with some of the later scholastics, because he has a somewhat wider range of authority, and transplanted Greek speculation into Latin soil. But he is not really free, and his interests are no more metaphysical than were Anselm's.

The usual definition of scholasticism as exclusive interest in dogma is too narrow. There are levels of interest distinctly marked. All, it is true, sought to rationalize within the closed dogmatic system, but some had the rational speculative interest foremost; such were Johannes Scotus Erigena, Anselm, and Abelard; others had the dogmatic interest in the foreground, and the speculative was but dogma's handmaid, as in the case of Peter Lombard, Albertus Magnus, and Thomas Aquinas. There is yet a further division, where the attitude toward both dogma and philosophy was so critical that all rationalization was seen to be impossible, as was the case with Duns Scotus and the Nominalists. They remained scholastics because they

1 "Quid est aliud de philosophia tractare, nisi veræ religionis, qua summa et principalis omnium rerum causa, Deus, et humiliter colitur, et rationabiliter investigatur, regulas exponere? Conficitur inde, veram esse philosophiam veram religionem, conversimque veram religionem esse veram philosophiam." ("Liber de Prædestinatione," cap. I, § I, Migne, "Pat. Lat.," tom. 122, cols. 357-358.) 
bowed to authority, but they unwittingly heralded the bankruptcy of scholasticism.

Before entering upon the examination of scholasticism, it must be remembered that the whole school is exceedingly unfruitful for our subject. Ethics on the basis of authority becomes a mere legal casuistry. Ethics was handed over to the confessional, and was dealt with in the distressing books of penitence, ${ }^{1}$ where the practical purpose of church discipline, of reformation of the sinner, and the preservation of the peace mingle with other and lower motives, as the exaltation of the clergy, the protection of property and class privileges, and the maintenance of a humble frame of mind among those whom the church governed.

And yet ethics could not be wholly neglected even by the most speculative and the most metaphysical; and the type of ethical thinking is determined by the emphasis in the interest of the writer. When, in turn, we come to the mystic scholasticism, we find feeling taking the place of thought and giving us another ethical ideal that in its logic displaces scholasticism as thoroughly as the nominalist logic.

The system of Johannes Scotus Erigena was primarily metaphysical. He enters upon his subject by giving us a fourfold division of all things, into the Uncreated who creates-i. e., God. The Created that creates-i.e., the world of ideas-these are the causce primordiales and give rise to the complexity of created

1 "Libri pænitentiales." These were books of penance introduced with English culture, and bearing the names-probably without warrant in the circulated form-of Beda, Egbert, Theodore of Canterbury, and many others. These were followed by Roman Libri panitentiales, and so there arose a considerable literature of no small importance for the history of conduct and culture, although they must be used with care. One does not go to books of pathology to get the statistics of a nation's health. The literature is made accessible by Wasserschleben (F. W. H.), whose "Die Bussordnungen der abendländischen Kirche," Halle, 185I, and whose edition of "Reginonis . . l libri duo de Synodalibus causis et disciplinis Ecclesiasticis ... adnotationem duplicam adjecit" (Leipsic, 1840), seem to be simply exploited by the other authors the writer has consulted, and without much advance upon his results. 
things as over against the absolute unity of God. These go forth from God, and are, of course, modifications of Plato's ideas and forerunners of realism's apparatus for the construction of the seen world. ${ }^{1}$ There is thirdly that which is created and cannot create. This is not, however, an eternal creation, like the primordial ideas and the Logos, but is in time; ${ }^{2}$ thus we have not only the prototypes but something like the $\pi \rho \omega \dot{\tau} \eta \tilde{v} \lambda \eta$ of Aristotle, only that Erigena rejects a formless matter, probably not wanting to suggest an eternal matter or "Urstoff," so that the form eternal moulds the matter from the beginning ${ }^{3}$ but in time. And, lastly, there is the uncreated that does not create. This is the principle that leads back from division and the many, where were weakness, sin and death, to unity, oneness with God, and eternal life. ${ }^{4}$ This is for Erigena the meaning of the incarnation and the redemption, and it is thought of in thoroughly Hellenistic-oriental terms as a swallowing up of the temporal in the eternal.

It is at this point that Erigena begins to have interest for the ethical student, and the type of thought here involved reappears throughout theological history. God is thought of as all in all. His conceptions are the realities of the seen world. But how then comes sin into the world? Because man is a secondary creative agent, ${ }^{5}$ he is the effectual agent. And thus, as with Origen, sin for God becomes negative and unreal. And the exegesis by which the fall of man and the need of redemption is explained is the regular symbolic exegesis common to many schools of thought. Man is thus a secondary agent beside God, responsible and free. Thus the double predestination of Gottschalk, robbing man of his dignity, was abhorrent to Erigena. It is as an intelligent being and moral agent that a man knows himself. $^{\boldsymbol{B}}$ Thus within his sphere man is actually the reality, and in his consciousness is the substance of his world. Thus the universe becomes a high feudal system with man as the inde-

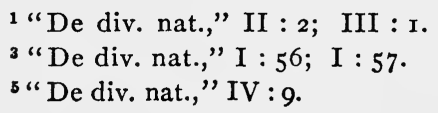

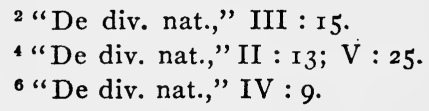


pendent lord within his realm. And in this sense, and no doubt under the influence of the new social organization taking place, Erigena constructs his ethical philosophy from the idealisms of Plato, Plotinus, Maximus, and Dionysius the Areopagite.

Within this admixture of pantheistic idealism and political and scholastic realism, this strange and difficult conglomerate of free speculation and slavish holding fast to traditional dogma, there is no logical room for hell and eternal punishment any more than in Origen; for all things return to God that God may be all in all. Adam never was in time in paradise, ${ }^{1}$ he is the idea of the whole race, and so far as time goes entered at once upon a sinful life. The fall is the actually entering upon this temporal existence. Hence man was not in a state of virtue, but of equilibrium, ${ }^{2}$ and his freedom led to the fall. ${ }^{3}$ Sin springs from pride, ${ }^{4}$ and came with the first sleep, and indeed according to Erigena the narrative in Genesis is by anticipation of what is yet to come, and all that is related of Eve, the serpent, etc., came after the first real sin which took place in sleep. ${ }^{5}$

The sensual character of $\sin$ is taken from Augustine or the monkish ethics of the day. Hence man awoke from his life as idea in God to the reality of sin. He never has been really sinless, but aims at a return to God when he will become sinless; for the very taking on of the body is a falling away from God and reality. The Neoplatonic and dualistic elements are here evident, and are really destructive of all freedom and all ethics. But Erigena does not see that nor does he go the whole length of the system. So also in this same book ${ }^{\circ}$ he teaches that sex is also a result of the fall as well as the very possibility of temptation by lust. Sin is in fact a relative removal by man geographically or ideally from God, and in no way does Erigena really relieve

1 "De div. nat.," IV : I5-19.

2 De div. nat.," V : 38 .

3 "Confectum est, Deum primo homini talem voluntatem et dedisse, et in eo eam condidisse in tantum liberam, ut per eam posset peccare, posset non peccare." ("Liber de Prædestinatione," cap. V:9, Migne, "Pat. Lat.," tom. I 22, col. 379 B.)

" "De div. nat.," IV :6; IV : 20-22.

" "De div. nat.," IV : I8-20, 23.

- "De div. nat.," IV : 20. 
God of responsibility for sin, since he knows as he creates his effectual agents what must result. Erigena's dialectic in no way covers the contradiction, and this he himself dimly realizes. ${ }^{1}$ Sin is for Erigena its own punishment, as virtue, $i$. e., existence in God, is its own joy. To be away from God is sin and hell, to be returned to God is life and joy. Here we have again Augustine and in some ways also Dionysius.

The sacramental magic that so marks and mars ecclesiastical ethics also appears, though but casually, in Erigena. In this fourth book baptism takes away the sin brought into the child by the very fact of conception. " The sin of the world is "The common sin of the whole world, i. e., of human nature, of which the guilt (reatus) is remitted by baptism, and which is itself destroyed at the end of the world in the resurrection of all." 3 Erigena is not at one with himself as to the relation of God to this sin of the world.

As foreknowledge with God means also predestination, Erigena makes God ignorant of $\sin ,{ }^{4}$ and yet this knowledge thus denied can only be the active creative knowledge, for outside of God is nothing. So as sin becomes a negative quantity it really should lose its character. But Erigena is too bound to the vocabulary of the church to go as far as that. He therefore at this point writes in the greatest confusion. In fact, to the present writer his tract, "De Prædestinatione," seems so full of contradictions and various mutually exclusive points of view, that it suggests either a certain apologetic opportunism or an intellectual carelessness not otherwise characteristic of the man.

With metaphysical mysticism the system has, indeed, many 1 "De div. nat.," V : 36 .

2 "Carnalia vero conjugia, etsi legitima sint et religiosis hominibus conjuncta, libidinoso tamen illicitoque motu carnalis pruritus carere non posse incunctanter affirmamus. Non enim aliunde nascentes in carne parvuli, nisi inde, æternæ mortis reatum attrahunt, quos solum catholicæ Ecclesiæ baptisma ab ipso reatu liberat." ("De Divisione Naturæ," liber IV : 23. Migne, "Pat. Lat.," tom. I22, col. 847 A.)

"Comment. in Evang. sec. Joannem, "Ecce Angus Dei!" (MPL, I 22, col. 299 A.)

" "De Prædest," XI : 6-8. 
points of contact. But it is not really essentially mystical. With the religious and ethical ideals that actually animate mysticism there is almost no real sympathy. That he widely and deeply influenced thought along that line is due to misunderstanding of him and to the fact that by his translation he did much to further the school.

The logic of mysticism is a thorough-going despondency with regard to this world. This Erigena will not allow. All is good so far as God has made it, only man's misuse makes of good an evil. Even hell in God is a good, and even for a good man not an evil, for heaven and hell are states of consciousness, as we have seen; and as the shadow is needed to see light in its beauty, so just punishment and pain but bring out eternal harmony. ${ }^{1}$

Never is Erigena consciously outside the dogmatic system, but he deals broadly with it.

Under the protection of Charles the Bald a certain rather wide latitude of opinion was permitted. Dogma is never really the fixed quantity that schools of thought try to make it. For there will always be as many different interpretations of the dogmatic statement as there are types of temperament and levels of intellect. The unity of political empire was, however, the model on which Rome began to steadily push for an organized and accepted body of philosophic teachings giving unity to the dogmatic system.

Each dispute gave Rome her opportunity to assert her claim of decision as a court of last resort. To strengthen these claims came very opportunely the forged Isidorian Decretals. ${ }^{2}$ It is

1 The best discussion of this theme is in Huber's "Johannes Scotus Erigena," pp. $358-428$, where he deals with the whole subject of Erigena's eschatology in what seems to the writer the most sympathethic and objective way possible.

${ }^{2}$ For the enormous literature, see Herzog-Hauck's "Realencyklopädie," "Pseudoisidor," by E. Seckel, vol. XVI, 1905, pp. 265-307. Text in Migne, "Pat. Lat.," vol. CXXX, edited by Heinr. Denzinger, 1853. The decretals are the work of a skilful and deliberate forger about the year 852 . The discovery of their forged character was made certain by Blondel ("PseudoIsidorus et Turrianus vapulantes ... ," Geneva, 1628), and convincingly proved by Paul Hinschius ("Decretales Pseudo-Isidorianæ et Capitula An- 
humiliating to realize how much the progress of the race has been mingled with and advanced by superstition, ignorance, and fraud, or rather how the ideals that have lured us on from ethical conquest to ethical conquest have been wrapt up in symbols that became the objects of superstition, have been cherished because of ignorance of the realities that masked themselves as the incorporation of these ideals, and have been advanced by frauds that lent themselves to ideal purposes.

The importance for the world's life of some unification of her ideals was so overwhelming that thoughtful men everywhere accepted with a most amazing lack of critical examination the spiritual claims of Christianity as a religion and of the papacy as her official representative.

The bishop's courts became the rival of the courts of the empire. Canon law became not simply a matter of ecclesiastical discipline, but of fundamental importance in matters of civil and penal process. ${ }^{1}$ The lower clergy and the monasteries were

gilramni ....," Leipsic, I863). There is now no reasonable doubt about the forged character of the decretals, but they have been the mainstay of the papal claims for over six centuries. They arose in the Frankish Kingdom, and pretended simply "canonum sententias colligere, et uno in volumine redigere, et de multis unum facere," but in reality the aim was to increase the power of the bishops as over against the civil government and to exalt the papacy. (MPL, I30, 7 A.)

1 The influence of law upon the whole churchly development is far too large a subject for these pages. Yet the ethics, particularly of the Western church, were deeply affected by the transition from the conception of the church as a vehicle of the evangelical proclamation to the church as a law-giving and law-enforcing organization. This progress may be traced

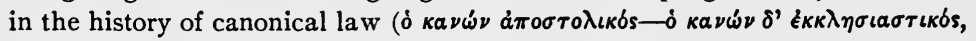
or $\left.\delta \kappa a \nu \omega \dot{\nu} \tau \hat{\eta} s \varepsilon^{\prime} \kappa \kappa \lambda \eta \sigma i a s\right)$. Canon meant at first the regulation of the churchly life by the synods. Then it received the fuller meaning of all churchly directions by the pope or churchly authority. The decrees of the popes and the decisions of councils form, from the sixth century onward, a body of law that runs parallel with the civil law and often covers the same ground. This body of canon law was full of contradictions, was, in fact, an undigested mass, and various attempts were made to collect and organize the body of law it contained. The most noteworthy attempt was made by Gratian, a monk in the cloister St. Felix of Bologna, between II39-1 142, the "Concordantia discordantium canonum," which is generally referred to as the "Decretum Gratiani," or simply "Decreta." (Herzog-Hauck, "Real- 
maintained in large part by the people, and they in some measure at least curbed the arrogance and stayed the injustice of the ruling class. Amidst all confusions the ritual and language of the Roman church loomed large as the firm maintainers of a glorious tradition of conquest and suffering, and as the sure symbols of more eternal triumphs still in the world to come. Miracles were the church's constant pride and boast. Sacramental magic was woven into every act of importance in human life. The babe was baptized to free it by magic from inherited guilt; the sacrament was taken to give magic strength in time of temptation or trouble. The sign of the cross kept witches and devils at bay. The church bells protected the village from the assaults of envious demons; the ground in which men were buried had to be blessed and magically set apart for this purpose. The priest in the Catholic church had full control of this magic. In the churches lay the wonder-working relics of the saints, and Rome controlled the priests and largely supplied the relics, and could alone guarantee the efficacy of the magic.

Thus magic was organized, regulated, and in some degree ethicized as well as limited. We have seen how Agobard attacked the unofficial magic of his day (page 289). It became sorcery, witchcraft, and of the evil one, even when exactly the same magic in the hands of the church was effective and divine. With an awakening intelligence the thought of the day had also to be organized, regulated, and kept within the bounds of creed and dogma. No one did more to advance this process than Anselm ${ }^{1}$ of Canterbury.

encyklopädie," X, I90I, p.II). This collection has never been officially recognized by Rome, but its influence was simply past computation. It has been succeeded by other collections, but to no one has papal authority been given, and the influence is therefore indirect. See for full literature, Schulte, Johann Friedrich: "Beitrag zur Geschichte des canonischen Rechtes von Gratian bis auf Bernhard von Paria," Wien, I873; Bickell, Johann Wilhelm: "Geschichte des Kirchenrechts," Frankfort a. M., I 843-1849 (vol. I, in two parts, no more published); Credner, Karl August: "Zur Geschichte des Kanons," Halle, I 847.

${ }^{1}$ Anselm (I033-IIO9) was born in Aosta, Piedmont, of parents whose hopes for him differed greatly. His mother was a pious and earnest 
Into the dogmatic questions that cluster about Anselm we cannot go. ${ }^{1}$ At two points, however, Anselm laid the foundation for the whole ethical development of the scholastic period. In his conception of God and his emphasis upon the ethical elements involved in the atonement he forced great issues upon the thought of the church.

His conception of God is a wonderfully religious and lofty

woman (see Rule, Martin, "The Life and Times of St. Anselm," in two vols., London, 1883 , pp. 7-14) and his.father's character seems to have been good, contrary to the ordinary tradition. Both parents were of high class, with royal blood in both lines of descent. But the father cherished, seemingly, ambitions rather for the temporal than the spiritual powers of a bishopric for his son. Anselm was in England when William II, on his sick-bed, desired to fill the rather long-vacant see of Canterbury and chose Anselm. Under Anselm England came to an understanding with Rome about investiture and the feudal vow. Anselm took the vow of loyalty to William, but his investiture from Rome. For full list of books, see Migne, "Pat. Lat.," tomi r58, I 59. There are many editions of his single works "Monologium" and "Cur Deus Homo?" English translations of "Proslogium," "Monologium," and "Cur Deus Homo?" by S. N. Deane, Chicago, I903 (Open Court Publishing Company). Hasse, Fr. R.: "Anselm von Canterbury," I, Leben II, Lehre (Leipsic, $1843^{-1} 85_{2}$ ), is still the fullest mine of information about Anselm. Rule's "Life" is full and attractively written though at times uncritical. Rémusat, Chas. F. M. de: "St. Anselme de Cantorbéry, Tableau de la Vie monastique ...." Paris, 1853. See also the article by Kunze, in Herzog-Hauck's "Realencyklopädie," vol. I, I896, pp. $562-570$, additional literature in the article by Beckwith in the New Schaff-Herzog "Encyclopædia," vol. I, 1908, pp. I88-190, and the "Vita," by Eadmer, in Migne, tom. I 58, cols. 49-1 I 8, of which a translation by the dean of St. Paul's is mentioned with praise by Rule, but the writer has not seen it.

${ }^{1}$ See Harnack, A.: “Dogmengeschichte," 3 d ed., vol. III, I897, pp. 355-359, English translation, vol. VI, I899, pp. 54-79; Ritschl, A.: "Rechtfertigung und Versöhnung," 3 d ed., I889, I, pp. 31-37; 52-54, English translation by J. S. Black, Edinburgh, I872, pp. 22-34, 38-40; Baur, Ferdinand Christian: "Die christliche Lehre von der Versöhnung . . . "Tübingen, I838; Cremer, H.: "Der germanische Satisfaktionsbegriff in der Versöhnungslehre" ("Theologische Studien und Kritiken"), vol. LXVI, I893, pp. 3I6-345; the same: "Die Wurzeln des Anselm'schen Satisfactionsbegriffes" ("Theologische Studien und Kritiken," vol. LIII, I880, pp. I-22;) Reuter, H.: "Geschichte der religiösen Aufklärung im Mittelalter," 2 vols., Berlin, 1877; Hasse, Fr. R.: "Anselm von Canterbury," part 2; "Die Lehre" (1852), and the standard works on theology. 
creation. Based as it is intellectually upon Augustine, and pervaded by his spirit, it is ethically an advance upon Augustine to whom God was still far too much thought of in the terms of an arbitrary oriental monarch whose main attribute was power (see p. $237 \mathrm{ff}$.). In the "Monologium," and still more pronouncedly in the "Proslogium," God is thought of as the ethically highest ${ }^{1}$ being, and his reality is postulated, because being is thus to be identified with our highest thought of it. In spite of the world of reflection that separates Kant from Anselm, there is in this ethical interest in God a common bond between the two. In the beautiful "Proslogium," Anselm pours out his soul to a loving, forgiving, good God, ${ }^{2}$ a God who is highest justice and highest mercy.

And yet the gulf that separates the God of Anselm's highest religious achievement from the God and Father of Our Lord Jesus is a great gulf. For Anselm's thought of God is built upon the legal constitution of the society of his day. ${ }^{3}$ God is the incarnation of a most just feudal Over-lord, who holds society

1 "Monologium," caput XVI: "Sed palam est quia quodlibet bonum summa natura sit, summe illud est. Illa igitur est summa essentia, summa vita, summa ratio, summa salus, summa justitia, summa sapientia, summa veritas, summa bonitas, summa magnitudo, summa pulchritudo, summa immortalitas, summa incorruptibilitas, summa immutabilitas, summa beatitudo, summa æternitas, summa potestas, summa unitas; quod non est aliud quam summe ens, summe vivens: et alia similiter." (Migne, "Pat. Lat.," tom. 158 , col. 165 C.)

2 "Proslogium," cap. I, V, IX, XVII, XXV. Very beautiful is the closing invocation of this wonderful meditation, cap. XXVI seq.: "Deus meus, et Dominus meus, spes mea, et gaudium cordis mei, dic animæ meæ, sic hoc est gaudium, de quo nobis dicis per Filium tuum: Petite, et accipietis, ut gaudium vestrum sit plenum," etc., etc. (Migne, "Pat. Lat.," tom. 158, cols. 241-242.)

'Into the interesting question of the origin of Anselm's conceptions of the satisfaction theory, whether it is to be sought in Roman or Germanic law, the present writer is not competent to go. But the correspondence of Anselm shows abundantly how the feudal system, with its lord and overlord and its conception of ranges of personal dignity, its distribution of power, was for Anselm the normal state of things and affected all his thoughts. For the controversy, see especially Cremer, H.: "Theologische Studien und Kritiken," r880, pp. I 7 ff.; 1893, pp. 316-345. 
together in loving but majestic sovereignty. For Augustine sin was the inherited alienation of the fleshly life from the source of its being. For Anselm sin is the infringement of the dignity of the sovereign Over-lord. As over against oriental despotism, both Roman and Germanic law exalt the place of the group and connect the dignity of the ruler with its conservation. God is for Anselm the Over-lord who punishes to conserve the peace of the universe and maintains his dignity as Ruler. ${ }^{1} \mathrm{He}$ must punish and he must reward, ${ }^{2}$ because it inheres in the very thought of the highest Ruler of the Universe that he should thus act.

This gives the basis, indeed, for an ethical conception of God, and yet it fails, as Kant's conception fails, really to exhaust the religious content of God thought of not as Ruler but as Father.

In Anselm's theory again of the death of Jesus as a satisfaction, in spite of its utterly untenable and legal character, there also enters an ethical element. The argument is built up to conserve the social values, justice, pity, and order in the universe. It is again an essential reading of the social order of that day into the wider experiences of all time, but it is an ethical advance upon the crude dualism that pervades the thought of atonement up to Anselm's time. Jesus does not die to buy us from the devil, and the devil has no just claim upon us. ${ }^{3}$

However little successful the attempt was, Anselm did attempt to make ethical valuation supreme as the test of dogmatic truth, always, of course, within the limits of the closed system.

From the point of view of a really Protestant ethics the theory has no value, for it rests substantially on the conception of works of supererogation (wrought by Jesus), which not only enable but compel God to reward the worker, and the only element of pity and love is in making the reward our redemption,

1 "Proslogium," cap. IX-XI. "Cur Deus Homo," lib I, cap. XIII. "Meditatio Super Mis.," $\S \mathrm{I}$.

${ }^{2}$ Harnack justly points out that Anselm's theory of the atonement is not on the basis of bearing punishment, but of giving reward to the Son for that which is superabundant merit. Cf. "Cur Deus Homo," lib II, cap. XIX.

a "Cur Deus Homo," lib. I, cap. VII. 
lovingly demanded by Jesus Christ and lovingly granted by the Father, which it was quite within God's power not to do. The whole scheme rests upon utterly unreal metaphysical relations between the triune persons, and in point of fact moves within the limits of a false legal conception of life born of the feudal system in which social structure Anselm played a weighty part. ${ }^{1}$

The fact that under Gregory VII the dream of world power for the hierarchy seemed near a possible realization has a large place in the history. It affected the religious and ethical development in the profoundest way. This dream had completely taken the place of the kingdom-dream as that vision had haunted the late Jewish and early Christian life. Even mystic scholasticism, whose real interest was so far away from temporal sovereignty, was, as we shall see, not unaffected.

But with Anselm the influence is overwhelming. He was a monk, but his world of thought is not dominated by the crude realism and particularism which marked the origins of the monkish intrusions. The international character of the hierarchy is seen in his abstract conception of God as over against all national and concrete ideas of him. The legal character of the church is marked in the external and formal relations postulated as being the relations of God to his universe. The attributes of God are played off against each other, justice against mercy, dignity against love, power against pity, etc. So, though Anselm has given us no developed ethics, it is easy to see along what lines alone he could have developed a system.

As the state, or states, found in the Roman law the basis for a new social reconstruction, so the eager minds of the scholastic

${ }^{1}$ It is interesting to recall the fact that the struggle of Anselm with William II of England compelled him to consider all the relations of Church to State. The King's demand that the church remain in his hands and Anselm's maintenance of Gregory's VII's position against lay investiture led to the long quarrel with Anselm, his twofold banishment, and at length to the compromise which lasted so long in English history. The effect of this legal struggle is revealed in Anselm's theology. For a good account, see Hasse, F. R.: "Anselm von Canterbury," part I, Leben (1843), pp. 235-454. 
period turned to the only systematic intellectual tradition within reach, namely, the Organum of Aristotle as it had been preserved and handed down by Jewish, Mahometan (Arabic), and Byzantine scholarship. ${ }^{1}$ Aristotle and later Plato were soon to be accessible in the original tongues and to assume their old places as the world's teachers, but Anselm knew them only in part. Yet he moves wholly in this world of conceptual abstractions, whose overwhelming usefulness for holding the world of thought together has so long led men to believe, even into our own day, that they have some divine and independent source of knowledge apart from experience; and so for scholasticism, ancient and modern, they become the really concrete realities by which experience is to be judged, and are thought of as existing before and beyond all experience.

For all the constructive scholastics, the great system builders, faith must precede knowledge, but faith is the acceptance of statements, either dogmatic or ethical or historical, as true, and knowledge is weaving these statements together with experience into an intellectually tenable system, i. e., into a system that will not exhibit internal contradictions.

From this point of view ethics, also, can only be a systematic treatment of revealed laws of action. Thus the canons and ethics mingle hopelessly as the process of externalization and formalization proceeds. The first demand of the church was

\footnotetext{
${ }^{1}$ So far as the writer can judge-without having access to the Arabic literature -all that the Arabic scholarship did was to hand down the Greek literature in somewhat faulty form. Their own thought was confined almost entirely to a few fundamental questions, and they were bound by the Koran as narrowly as Christian thought was by traditional dogma. But they wrote commentaries on Aristotle (Alkendi, circa 850; Alfârâbi, circa 950; Avicenna [ibn Sina], ro30; Algazel, r roo, and Averroës [ibn Roshd], 1200) and conserved something of the mathematical and astronomical tradition of the past. With them were associated in the minds of the scholastics Jewish thinkers like Avecebron [ibn Gebirol], about ro5o, the author of "Fons Vitas," and Moses Maimonides (1204). Dieterice, F.: "Die Philosophie der Araber im neuten und Zehnten Jahrhundert," 1858-r886; Prantl: "Geschichte der Logik im Abendlande," vol. II, pp. 297 ff. Good account with full literature in Ueberweg-Heinze: "Geschichte der Philosophie," r905, part 2, pp. 234-270 (\$\$ 28-29).
} 
for fides implicita, ${ }^{1}$ and the moral man was expected to submit absolutely to the authority of the teacher before he could rationalize his conduct.

Moreover, in order not to awaken suspicion, this rationalization must be within the limits set by the logic of the schools. Thus, for instance, Peter Lombard, ${ }^{2}$ though a pupil of Abelard's, was content to go back to the method of the compilers of the ninth century, and to collect the various sayings of the fathers and sentences from the Bible, with an attempted ignoring of the work of the speculative teachers, ${ }^{3}$ that all the various contradictions could be gotten rid of by proper exegesis of the words, or that where doubt still remained the greater weight of authority was alone to decide the matter.

There is therefore nothing in the great magister sententiarum that is intentionally new, and ethics was of such secondary importance beside dogmatics that only in the discussion of these are ethical questions indirectly touched upon; as in the discussion of predestination, ${ }^{4}$ where Augustine in the conventional churchly interpretation is closely followed, or in the famous discussion of the moral and physical characters of angels, ${ }^{5}$ or the creation and fall of man, or the imputation and impartation of grace. ${ }^{7}$ The ethics of the one important ethical section of the

${ }^{1}$ For historical treatment of Fides implicita, see Ritschl, A.: "Fides implicita. Eine Untersuchung über Köhlerglauben, Wissen und Glauben, Glauben und Kirche," Bonn, 1890; also Hoffmann, Georg: "Die Lehre von der Fides Implicita innerhalb der katholischen Kirche," Leipsic, 1903. His second volume: "Die Lehre von der Fides Implicitas bei den Reformatoren," Leipsic, 1906, the writer has not seen.

2 Petrus Lombardus was born of humble parentage in Lombardy, somewhere about the beginning of the twelfth century, in the town of Novara, and died about I 60 . He was a pupil of Abelard's and a distinguished teacher in Paris. His works are collected in Migne, "Pat. Lat.," tom. I91 (where also a short life is given) and 192, cols. $1-964$. Of the many encyclopædic articles the best is that by R. Seeberg, in Herzog-Hauck's "Realencyklopädie," vol. XI, 1902, pp. $630-642$.

" "Garruli ratiocinatores" (and the calm assurance), I : dis. $4: 2$; I : dis. $2: 3$.

" "Sentent." I : 40-42, especially I : $48:$ : $1-5$.

s"Sentent." II : 4-7.

- "Sentent. II : 19: $1-16$; II : 22 : I-1 2, etc. > "Sentent." II : $26: 1-2$. 
"Sentences" 1 are grouped about faith, hope, and charity, the four cardinal virtues, and the two tables of the commandments in almost mechanical carelessness. Under the head of marriage as a sacrament, all concupiscence is condemned, not indeed as sin, but as evil, thus distinguishing in the truly Hellenistic spirit between guilt and sin. ${ }^{2}$

Constructive scholasticism attained its greatest height in the monumental works of two great souls-Albertus Magnus and his great pupil Thomas Aquinas. The moral and intellectual greatness of these two men will excite respect and admiration as long as learning, sincerity, and character are valued among men. Albertus Magnus ${ }^{3}$ represents in its full glory the mediæval

1 "Sentent." III : distinctiones 26-40.

2 "Et nos dicimus illam concupiscentiam semper malam esse, quia fœda est, et pœna peccati; sed non semper peccatum est." "Sentent." IV, dis. 3I :8. (MPL, I92, 921 D.)

${ }^{3}$ Albertus Magnus was born of noble family - the von Bollstädt-at Launingen in Swabia, probably about Ir93, and early became a member of the Dominican Order. He was used by the order for the reorganization of their methods of teaching, and so lectured in Regensburg, Freiburg, Strasburg, Paris, Hildesheim, and Cologne, where his chief work lay. It was in Cologne and Paris that Thomas Aquinas became his pupil, and he outlived his favorite scholar and defended his orthodoxy after his death. He himself died r280, after a long and nobly useful life. His works are most numerous, and have been collected and reprinted in Paris by Abbé Auguste Bourgnet in thirty-eight volumes, $189 \mathrm{I}-1898$, with full reference to the critical work done on the life of Albert by Jac. Quetif and Jac. Echard. These pages, however, refer to the edition of Petr. Jammy, $2 \mathrm{I}$ vols., Lyons, $165 \mathrm{I}$, which, though uncritical and defective in accurate paging, is the more commonly cited edition, and is at the basis of the Paris edition. For discussion of the critical questions, see the Promia to the Paris edition. The sources of special interest to the ethical student are the "Ten Books of Ethics" (Jammy, tom. IV, pp. I-362), in which Aristotle is freely paraphrased and supplied with comments from other writers; the "Summa Theologiæ" (Jammy, tomi XVII and XVIII); and the "Paradisus Animæ, sive Libellus de Virtutibus" (Jammy, tom. XXI), which is one of the most interesting ethical works of this period, and should be read in connection with Albertus's "Commentary upon Beatum Dionysium Areopageticum" (Jammy, tom. XIII, pp. I-I96). The literature is very large; for a résumé of it see Ueberweg-Heinze, "Grundriss der Geschichte der Philosophie," 8th ed., 1898, part 2, pp. 264-265. The life by Sighardt, J.: "Albertus Magnus, sein Leben und seine Wissenschaft nach den Quellen dargestellt," Regensburg, 1857 , is still readable, although uncritical and indiscriminate. The English translation, "Albert the Great of the Order of 
thurch still fulfilling her function as authoritative teacher of western Europe along all lines. Never was the power of the Roman papacy more splendidly made manifest than under Innocent III; and few men ever summed up the learning, the religion, and the nobility of their age's character more completely than did Albertus Magnus that of his.

The scholastic faith that the dogmas and system of the church were absolutely in accord with reason and knowledge was never questioned by Albertus. At the same time these two are separate fields for many purposes. It is perfectly evident what Albertus really regarded as infallible; it is not the voice so much of church, council, or Pope as the general message of culture, science, and ethics which the church bears with her. Aristotle is Albertus's real teacher in matters of science. He boldly disputes with his great master about the eternity of matter and the nature of the soul, but in logic, metaphysics, and the natural sciences, Aristotle is wellnigh final. ${ }^{1}$ In matters of morals he trusts Augustine, in medicine and physics Galen, Hippocrates, and Aristotle. $\mathrm{He}$ is, of course, firmly persuaded that between the science of Aristotle and the religion (creed, dogma) of the church there can be no real dispute.

Hence we have an interesting twofold ethics in Albertus. On the one hand he gives us an ethics that reflects in its main outlines the intellectual and aristocratic ethics of Aristotle, but little softened by the reservations and comments of the Christian Albertus. The rejection of the eternity of matter, and the changes in Aristotle's psychology, which mark his paraphrase of the ethics, are not fundamental enough to greatly change the complexion of the whole.

But the later and real ideals of the teaching church are best set forth in the little book "Paradisus Animæ," which Albertus wrote late in his life, and which gives us the curious combination

Friar-Preachers," translated from the French edition by T. A. Dixon, London, 1876, the writer has not seen. Cf. also Hertling, Georg von: "Albertus Magnus, Beiträge zu seiner Würdigung . . . Festschrift," Cologne, I88o.

1 "Sent." II, dis. $13: 2$. 
of Aristotle and monk, which was made possible only because of the place the philosopher was given in the peripatetic philosophy, and whose conversion into a monk was difficult but not impossible.

Ethics, although a science, is yet for Albertus a science of practice. ${ }^{1}$ For the science we have only to follow Aristotle as he had passed into the thought of the church, but worked over more carefully by Albertus, and really intelligently altered for the church's purpose. As Albertus refused to confine reality either to post rem or in re or ante rem, but regarded the universal as first in God's thought (ante rem), then in nature (in re), and lastly as existing in our conception, or explanation (post rem), so the final good exists in God and is to be realized in personal life. This realization of the good is happiness, and happiness is the highest good. The summum bonum is thus the fulfilment of function, and exists in and for itself, as a good in itself $;^{2}$ but this is not the case with evil, ${ }^{3}$ for evil is privative, and has no place in reality finally.

Man's good appears in a threefold relation. There are the virtues of social citizenship-fourfold in character-of the home, and the monastic virtues. ${ }^{4}$ That which gives ethics its character as over against physics is man's freedom. At this point Albertus unwittingly follows Aristotle rather than Augustine, and in a matter that profoundly affects his theology, ${ }^{5}$ at the same time only as the church herself had done ever since Gottschalk, the unhappy monk, was condemned. Not only was man's freedom dear to Albertus as giving man his special likeness to God, ${ }^{6}$ but we are to use it for the mastery of the world and ourselves. ${ }^{7}$

1 "Et hoc modo bene consideremus, quod moralis docens theoretica est, et moralis utens practica," Eth. I : I : 4 .

${ }^{2}$ Eth. I : $3: \mathbf{x}$.

Eth. I : $2: 5$.

4 Eth. I : $3: \mathrm{r}$. At this point we notice the skilful adaptation of an essentially different ethics to the contemplative, ascetic ideal.

${ }^{5}$ Cf. "Summa Theologia," I, tract $\mathrm{I}^{-1} 7$ (Jammy, tom. XVII).

" "Paradisus Animæ," cap. XXVI; "De Libertate," opera, vol. XXI, I65I, p. 2 I.

${ }^{7}$ An interesting expression occurs in Albert's discussion of vegetables. $\mathrm{He}$ remarks on his own corroboration of the facts handed down on authority and 
Nature is in itself good and not evil, ${ }^{1}$ because so far as nature is positive and has had existence in God's thought it must be good.

Man is a social being, and although Albertus has to do violence to the real Aristotle, he is evidently quite unconscious of the gulf fixed between Augustine, even as modified by churchly tradition, and the simple humanism of Aristotle.

At this point the social note has a place in Albertus. The civil good is the highest good of the individual, ${ }^{2}$ but in point of fact he makes no real use of it, and his ethics always remains essentially individualistic and even other-worldly. The same may be said of his theoretically accepted relativity in ethics, ${ }^{3}$ which is a mere repetition of Aristotle's position, without the least intention of taking it seriously. The full life is the ethical life, but what Aristotle means by the life of the philosopher Albertus takes as the life of the studious monk. ${ }^{4}$ He was, of course, conscious of his difference from the great master, yet demanded freedom from the criticism of the stupid and inert who blamed him for following Aristotle without themselves reading the great master to discover why he taught as he did. Such stupid ones were those who killed Socrates, and compelled Plato to fly, and drove Aristotle himself into exile. ${ }^{5}$

And yet another picture is presented when we turn to the theological Albertus. $\mathrm{He}$ is not himself aware of it. The utter sincerity and nobility of his character shines in his books and is testified to by all who knew him. But he was a child of the paganized, orientalized organization which called itself the Christian church, and which still preserved some of the choicest fruits of the early Christian ethical uplift. It is a really beautiful ethical ideal that is unfolded before us in the "Paradisus Animæ." It is not the ideal of Jesus. There is no thought of a kingdom says: "Experimentum enim solum certificat in talibus; eo quod tam de particularibus naturis simile haberi non potest." "De Vegitabilibus," VI : I.

${ }^{1}$ Eth. I : $2: 6$.

${ }^{2}$ Eth. I : I : 3 and r $_{3}-\mathrm{I} 4$. Cf. his translation of the "Politics."

${ }^{3}$ Eth. I : $4:$ I.

1 Eth. I : $6: 8$.

s "Politicorum," VIII : 6. Opera, vol. IV. 
of God on earth in the prophetic sense; and the salvation of the soul is Hellenistic, not New Testament. Nor is it the lofty aristocratic ethics of Aristotle or of Plato with intellectual refinement in the foreground; it is the monkish ideal as that conception of life had been modified and ennobled by the active life of service in northern Europe.

If any Protestant critic is confounded by the pictures of depravity, ignorance, and coarse materialism presented by Roman Catholic historians as common in the monastic orders, and wonders how an institution with such dark shadows over it could so long and successfully maintain itself, let him turn with us to the "Paradisus Animæ" and remember that hundreds and thousands literally left all that ordinarily makes life attractive to devote themselves with more or less success to the ideal there presented.

The book has forty-two chapters, ${ }^{1}$ and opens with a prologue in which the great difficulty is pointed out of distinguishing between virtues that look like vices and natural virtues that look like those of grace, ${ }^{2}$ but which deserve no eternal reward.

Love is easily the mother of all virtue. ${ }^{3}$ Hence ethics begins with love to God and love to one's neighbor, ${ }^{4}$ and this love must spring from our sheer joy in holiness, and must not have its roots in any fear of penalty or hope of reward. The delicate mind abominates the very thought of loving God for reward, ${ }^{5}$ and so also we keep the commandments from no fear of punishment, but to purify our minds. We are to love our neighbor because we see God in him; he may be unloving and unlovely, but even with our enemies we are to rejoice in their joy and sorrow with their tears.

The second chapter deals with humility, which springs from a right attitude toward God, and the second chapter of Philip-

${ }^{1}$ In Jammy, tom. XXI.

2 "Virtutes gratuitæ Prologus."

3 "Et primo de charitate, quæ est mater et ornamentum omnium virtutum." "Paradisus animæ Prologus."

4 Caput I.

5 "Delicata enim anima, quasi abominatur, per modum commodi vel præmii amare Deum." Cap. I (A). 
pians is the key-note of the treatment. The mind of Jesus is to be our mind.

This leads to the third chapter and a treatment of obedience. Here the monastery conception comes fully into view. We are to obey our superiors as we obey God. True obedience asks no questions and never murmurs. Albertus neither raises nor discusses all the difficult questions an absolute authority suggests in the presence of the ethical autonomy on which Greek ethics was based.

All the chapters have a certain scheme. The virtue is defined, ${ }^{1}$ then illustrated in detail, often its advantages pointed out, the methods of its cultivation given, the evidences of true virtue on the one side and the false on the other made plain. So the evidence of true patience ${ }^{2}$ is the refusal to vindicate one's self or render evil for evil. But a false patience seems to endure while really complaining and becomes bitter. The next three chapters are devoted to the monastery-virtues of poverty, which is the relinquishing of all for God's sake, not from necessity; of chastity, which is purity of mind, and where possible with this the conservation of virginity and of abstinence, which is treated of as a virtue for God's sake and a means to an end, $i$. e., it leads us into the secret of God and enables us to hear his voice.

Prudence and fortitude enable us to hold life balanced and to maintain our way amid all terrors, because God is with us. Justice is the Golden Rule which Albertus insists must control entirely and without exception all our relations with our fellowmen. Temperance is beautifully defined as the exact regulation of the inward motive and the outward action-moderation in all things. Compassion is not only for our neighbor in this life, but for those in purgatory for whom we are to constantly pray, because as God has had compassion on us we must pity all who have sinned and are suffering. This compassion leads to pity, which has three forms: giving, condoning, and works of supererogation. ${ }^{3}$

1 Thus "Patientia vera et perfecta est, cum aliquis," etc. $\quad{ }^{2}$ Cap. IV.

s "Dando-condonando-supererogando," cap. XIV. 
Albertus then discusses Concord, Constancy, Generosity, which is giving of one's entire self to service and is false when done for praise or reward; Truth, which is an exact correspondence between heart and mouth; Magnaminity, Faith, which is very defectively defined as the acceptance as true of the dogma of the Trinity and the main articles of the creed. Hope is the expectancy of future felicity on the basis of God's promise, and Fear is also a virtue when regarded as due caution, and the sense that we may just come short. Joy is to be in God, and Sorrow is better than joy and more useful. We are mainly to sorrow for the insults offered to God since man's fall, and for this we should sorrow with many tears. Gratitude is to mark our whole life, which is to be one long expression of gratitude to God for his goodness and love.

In the discussion ${ }^{1}$ of Zeal the ascetic conception of life is again prominent; "sacred meditations, fervent desires, tears, prayers, vigils, fasts, preachings, confessions, advice, doctrine, and good works for the saving of souls" are the evidence of real zeal. How strange a note that would be in the Nicomachean ethics!

Liberty is defined in the terms of Anselm, who is quoted; to $\sin$ is not liberty but is slavery. Free-will is God's gift, and his evidence that he wants us to be free and like himself. But passions and lusts are chains. We must be free even from the desire to escape reproach or to escape the yoke. Religion is defined in the words of James, ${ }^{2}$ and thus in the discussion the passive rather than the active virtues receive the emphasis. Maturity and Simplicity are virtues which, as Albertus views them also belong largely to the monastic ideal. They involve divorce from earthly things. So also Silence, Solitude, and Contemplation are discussed, and mean fixing the attention upon heavenly things and not simply stupid dumbness. Discretion is fixing the exact shades in conduct between good, better, and best. The Christian man will be given to Congratulation, which is rejoicing in God, and will have Confidence in him. For God is

${ }^{2}$ Caput XXVI.

2 I : 27. 
omnipotent and faithful, and will never desert one trusting in him.

The next five chapters (XXXVII-XLI) are again thoroughly monastic in their spirit, and deal with contempt of the world; Maceration of the body "by fasts, vigils, prayers (!), hair-cloth, the discipline, and abstinence from food and drink"; with Contrition, which is constant penitence for our own and others' sin; with Confession, which must be made to a legitimate priest; and Penitence, which is really defined as penance. Then the book closes with a chapter upon Perseverance in good works and in prayer.

Here in sharp outline we see the ideal that animated the teaching church at her best, as Albertus Magnus strove to embody in the intellectual forms of Aristotle the ascetic monkish morality of the hierarchy. The endless compromises by which the result was attained were not patent to either himself or Thomas Aquinas, whose ethics presents little advance upon his great teacher, save in precision and by elimination; but the full and unreserved handing over of Aristotle to the learning world was bound, in the end, to compel men to take a position sic et non!

The final formulation, of a semi-official character for the Roman hierarchy on the field of ethics, is the work of Albertus Magnus's favorite pupil, the father of Roman Catholic theology, namely Thomas Aquinas. ${ }^{1}$

1 Thomas of Aquino was born about 1225 in the castle Roccasicca of his father, the Count Landulf, and died in 1274 at the age of fifty years (Contra Quetif). His life was that of the studious monk. At the age of five he was sent to his uncle at the Benedictine monastery of Monte Cassino, and while yet a boy he tried to enter the preaching order of the Dominicans, but was at first hindered by the family. He, however, after a year or two in confinement, succeeded in carrying out his plan, and the order sent him to Cologne, where he studied under Albertus Magnus (see page 309), whom he then accompanied to Paris, and thence back to Cologne. He again appears in Paris as struggling for the recognition of the preaching orders, and in this struggle was successful. He worked with Albertus in the reconstruction of the schools of learning controlled by the Dominican Order, and reorganized the theology of the day in his immortal "Summa Theologiæ." His death was a great blow to his generation, and more especially as he left the third part of the "Summa" incomplete. The critical 
The Ethics of Thomas Aquinas. - The twofold character of scholastic ethics as we have seen them so far is only apparently overcome in Thomas Aquinas. The exceedingly skilful interweaving of the Aristotelian-intellectual with the monkish-ascetic or authoritative-mystic ethics cannot blind us to the contradictions such a combination must involve us in. The threefold division of the virtues into theological, intellectual, and moral ${ }^{1}$

life of Quétif, J., and Echard, J., in "Scriptores Ordinis Prædicatorum," Paris, I 7 I9-I72I, 2 vols., is still quoted as authoritative ( $c f$. Prefatio to the Roman edition). See also Roger Bede: "Life and Labors of S. Thomas of Aquin," 2 vols., London, 1871; abridged and edited by Cardinal Vaughan, London, 1875 . For very full references to his life, see Ueberweg-Heinze: "Grundriss der Geschichte der Philosophie," vol. II, I905, \& 30.

The sources for the ethical student are mainly in the two divisions of the second part of the "Summa," known as "Pars prima et Pars secunda secundæ." The commentary upon Aristotle contains almost nothing that one would dare to place over against the plain statements of the "Summa"; and the two types of ethical thinking-pagan-classical and monkish-ascetic-which exist to some extent apart in Albertus Magnus are skilfully woven together by Thomas.

There are many editions of the complete works, but the only critical edition is not yet finished. "Sancti Thomæ Aquinatis, opera omnia jussu impensa que Leonis XIII, P.M. Romæ" (twelve volumes have appeared up to I908). The ethical portions of the "Summa" are complete in tomi VI-X. A handy edition of the "Summa" is that of "Abbe Drioux," Paris, 1869, 3 d ed., with French translation; "La Somma Théologique de Saint Thomas," fifteen volumes; the Parma edition in twenty-five volumes $\left(185^{2-1872}\right)$ is uncritical, but as the only complete edition is the one most quoted. A German translation of the "Summa," by Schneider, Ceslaus Maria, has appeared under the title "Die Katholische Wahrheit oder die theologische Summa deutsch wiedergegeben," twelve volumes, Regensburg, 1886-1892. An English compendium of the "Summa," by E. O'Donnell, two volumes, Dublin, 1859, and Rickaby, Joseph, has translated the principal portions of the ethics under the title "Aquinas Ethicus," two volumes, London, 1896. These last three the writer has not seen.

For the enormous literature reference must be made to the standard biographical articles or to the ninth edition of Ueberweg-Heinze, "Grundriss der Geschichte der Philosophie."

For helps the student will do well to turn to the "Thomas Lexikon" of Schütz, Ludwig, 2d ed., Paderborn, 1895. It is very useful though far from exhaustive, and omits important terms. The index to the Parma edition is good. The commentary of Cardinal Cajetan is published with the "Summa" in the papal edition, as well as with others, and is an excellent help to the study of Thomas's ethics as well as his theology.

1 "Summa," II : II : Iog, A. I, "Unde veritas non est virtus theologica, neque intellectualis, sed moralis." Ad. A. 3 . 
is itself a compromise between evangelical tradition and pagan culture, and the clash of the two ideals is never absent from the pages of the "Summa." Almost the last thing we can think of Aristotle putting in the foreground of his ethics would be the crucifixion of the body and the absolute submission of the mind to external authority. What Aristotle meant by the contemplative life was a life of ceaseless curiosity; what Aquinas meant by it was a life of devotional submission. For Aristotle fulfilment of function meant the full development of all human powers; for Thomas it meant the abstraction of the mind from the phantasy of the senses as the perfection of highest mental functioning, ${ }^{1}$ which was to be gained by chastity and abstinence. In taking over the pagan culture, with its lofty humanism, Thomas ignores what was its chiefest note, namely, the restless and ceaseless assertion of the individual as an end in himself.

The longer one studies Aquinas the more powerfully does the inherent incompatibility of these two ideals to live together in unity impress the student. All the fine dialectic and genuine knowledge and enthusiasm of Thomas Aquinas fail to produce more than a seeming unity. For Albertus Magnus the two ideals existed more or less consciously side by side, though in different spheres. ${ }^{2}$ With keener grasp of the actual needs of the hierarchy, Aquinas forced the religious and intellectual culture into a union that at bottom meant the complete control of culture by creed and dogma. Not without a measure of truth have the Jesuits given to Thomas Aquinas the place in. the Roman Catholic world of thought which Paul occupies in the world of post-Reformation Protestantism.

1 "Summa," II : II : I5. 3, conclusio, "Respondeo dicendum quod perfectio intellectualis operationis in homine consistit in quadam abstractione a sensibilium phantasmatibus; ...."

${ }^{2}$ When Harnack says in general of the Middle Ages ("Lehrbuch der Dogmengeschichte," vol. III, 3d ed., I897, p. 334: "Die Wissenschaft war kirchlich, theologisch. Es gab keine Laienwissenschaft"); (English translation, VI, I899, pp. 3I-32: "Science was ecclesiastical, theological. There was no lay science," he is no doubt right within limits, but Jewish and Arabic science must not be forgotten, and in Albertus Magnus we have a very near approach to a lay science on the part of a churchman. 
The skill with which Aquinas takes over the elements he needs for his structure, and twists and changes, utterly unconsciously, these elements into the likeness of the monastery ideal excites growing admiration as the work goes on to the climax; and this adaptation was possible only because there were distinctly common elements in the two ideals. Both are rooted in a thoroughly aristocratic conception of human society. Both are distinctly intellectualistic in fundamental note. Both deal with life in terms of the small, highly organized group, and finally both are related to analogous metaphysical conceptions clothed in physical and theological terms.

No one up to the time of Thomas Aquinas had formulated with such clearness the scholastic method. It may be called the authoritative-rationalistic method. Thomas does all his thinking within the limits of a framework given in past authoritative utterances, ${ }^{1}$ and humbly bows to the supremacy of the central hierarchy. At the same time the method is really a rationalistic one, for between the voices of authority reason must decide, and in the interpretation of the authority there is again room for the individual reason.

In fact the assumption that revelation not only is but must be rational is fundamental to all the culture that claimed Aristotle as its father. For this reason the Scriptures must be treated freely and as symbolic and mystical in order to escape the patent contradictions and unethical positions there recorded. The result is to make human reason really supreme, for the real power lies not with the giver but with the interpreter of a law.

Where, however, Aquinas especially falls far short of the work of Aristotle in ethics is his failure to realize the funda-

\footnotetext{
1 The "Summa" is written in a series of questions (quæstiones) in which the various problems are set forth (Deiude considerandum est de, etc.); then they are taken up one by one, introduced by the stereotyped phrase "Ad primum, secundum, etc., sic proceditur," with additional observations Preterea; then the opposite view is set forth, sed contra est, and then there follows Thomas's own opinion, which he invariably introduces by the phrase "respondeo dicendum quod, ad primum ad secundum," etc., and after that comes often a conclusion, conclusio.
} 
mentally empiric method of the great master. For Aristotle ethics was the discovery of the golden mean between extremes, and was a science of experience rather than of exactness in abstract conception. ${ }^{1}$ The two pillars upon which Thomas Aquinas rests his structure are definition and authority. In point of fact the entire inadequacy of this method is revealed in the way the contemporary social morality is reflected in the ethics of Aquinas ${ }^{2}$ and in the relative moral fruitlessness of the method. Slavery is condoned and the real evils of the world of exchange are passed over. The acuteness of the discussions and the wonderfully full and suggestive argumentation upon disputed points should not blind us to the inherent limitations of the whole procedure, and the inevitable bankruptcy which was already indicated in the restlessness of scholasticism itself. But for the time Thomas was seemingly completely triumphant. His method became the standard for all the higher schools, and his interpretation-or misinterpretation-of Aristotle became final in Roman Catholic theology.

Why this should be the case rests upon reasons apart from the real greatness of Thomas Aquinas and the merits of the system itself. The hierarchy had become a legal organization, with its own jurisdiction, closely related to and deeply influencing the legal system of the various states. The line of demarcation between ethics and law had never been sharply drawn since the surrender of Christianity to the paganism of the empire. But now, even more than in an earlier age, it seemed essential that ethics should be formulated as law.

This formulation Aquinas carried through with superb feeling for the existing needs of the quasi-political organization that had substituted itself for Christianity. Thus the ethics have throughout a legal rather than an evangelical character. This is especially marked in "Summa," II : II : Qs. 58 to $8 \mathrm{I}$, but it colors the whole treatment, and that not merely because of

\footnotetext{
${ }^{1}$ Eth. Nic. A. I : I-I5 (Susmühl's edition, I887), B. IX : I-3.

${ }^{2} C f$. Maurenbrecher, W.: “Thomas von Aquino's Stellung zum Wirtschaftsleben seiner Zeit," Leipsic, I898, etc.
} 
the legal method, but because of the end in view. What often seems to us dry and outworn defence of stupid conventions of thought and feeling was in its day a fresh, vigorous, conquering force overcoming ignorance, superstition, and disorder in the name of an undoubtedly higher culture and larger intellectual freedom. The weapons of one age are often forged into chains for the next one. The tyranny of mere brute force and possession found in the hierarchy a rival for control of the masses. And scholasticism was the intellectual and ethical preparation for fighting cohorts bidding for the people's obedience and allegiance. The struggle was no less real because it went on so quietly and steadily, only now and then rising to the dramatic climax of a Canossa or Third Crusade. How much the hierarchy actually did substitute law and morality for personal tyranny and centralized political might is seen in the way personal tyranny flourished for a time when the Reformation broke the supreme power of the hierarchy, and in the way such personal tyranny was compelled to compromise with the churchly code of law and morality.

The mission of culture to which the preaching orders felt themselves called, the work of educational reorganization which Albertus Magnus and Thomas Aquinas so successfully carried through, did indeed add strength to the papal personal rule, but it also purified and cleansed in very great measure, so that in the eyes of the vast mass of men that personal rule was justified by the results. The law is a school-master to bring us into the presence of the larger freedom, and the legal character of the ethics of Aquinas belongs to the very function which its ethics was to fulfil.

An outline of the ethics of Aquinas is not easy. In the first place they are interwoven with his whole theological system, and in the second place as a positive system they grow out of the doubts and difficulties which Aquinas so bravely and fully faced, and yet into the elaborate discussion of those difficulties space forbids us to go. The student of ethics who begins with "Pars Secunda Secundæ" soon finds himself compelled to take 
up the primary discussions in "Pars Prima Secundæ," and from thence he will generally be forced back to the theological discussions of the first part. The ethics may, however, be divided into two main discussions.

I. The Theoretical Ethical Questions.-These are contained in "Pars Prima Secundæ" and the "Pars Prima. We must glance quickly at the initial questions which must be answered for the sake of understanding the system more fully worked out in the "Secunda Secundæ."

The theory of knowledge, as related to ethics, which Aquinas actually makes use of is based fundamentally upon the postulate that science (scientia) deals, not with particulars, but with causes, and that which relates particulars together. ${ }^{1}$ For Aquinas the syllogism is thus the means by which the mind reaches certitude, because for him freedom from inner contradiction is the test of truth. ${ }^{2}$ So enormously important does the abstract conception loom upon the scholastic horizon that one pauses to ask why. Nor does the answer seem difficult. The overwhelming importance of concepts binding our world of otherwise seemingly unrelated experiences together forced upon the scholastic mind the conclusion that these concepts had something quite superhuman and independent of all particular human experience. Hence the vast importance of logic in the world of scholastic training. ${ }^{3}$ We ourselves often still speak with solemn voice of "mathematical certainty," and forget how completely mathematics is simply a science of definition that has proved highly useful and justified itself in age-long experience.

The Aristotelian world of conceptual structure was for Aquinas in his struggle to organize a new world of moral feeling what mathematics is to the modern engineer organizing a new

${ }^{1} C f$. discussion of God's knowledge, "Summa," I : Q. I4, A I.

${ }^{2} C f$. discussion of "intellectual virtues," "Summa," I : II, Q. 57, A. I.

${ }^{3} \mathrm{Cf}$. Aquinas's discussion of Aristotle's attitude, "Expositio in duo libris posteriorum analyticorum Aristotelis," 44 c. "Scientia importat certitudinem cognitionis per demonstrationem adquisitam," where, however, the demonstration is not a final reference to sensational experience, but to mental consistency. 
world of bridges and sky-scrapers. The "forms" of thought are real, Aquinas teaches, but not apart from the mind of God in which they exist. ${ }^{1}$ They are therefore ante rem and in re, existing before and in the individuals. "In the divine wisdom there are the conceptions (rationes) of all things, which we have called before 'ideas,' that is, pattern forms (formas exemplares) existing in the divine mind." 2 This twist to Aristotelian realism does not, however, lead Aquinas to a pure Platonism, for these forms have no existence apart from God's mind.

All ethical certainty depends, therefore, upon our contact with the mind of God, and realizing in our experience the eternal ideas. We need not go into the elaborate classification of forms, as essential and accidental, as absolute and relative, because they have little place in his ethics.

So also the theology only interests here as it affects the ethics. Aquinas's thought of God is distinctly influenced by the social forces about him. God is the Ruler and Creator who creates and holds the world together. ${ }^{3} \mathrm{He}$ is infinite in power and justice and pity. But throughout he is Lord and Ruler. There is no such tenderness as in Anselm's thought of God in the "Proslogium," and although devout and lofty in the extreme, Anselm comes more nearly to the thought of the God and Father of our Lord Jesus than does Thomas Aquinas. ${ }^{4}$ We have throughout the impression that the interest of Thomas is rather metaphysical and intellectual than ethical, and that his interest in the question of God's existence and being is dominated by the place he has in the system. The fatherhood of God is thought of almost exclusively as in the triune relationship and simply opposed to the sonship of Jesus. ${ }^{5}$ It is as metaphysical principle that his existence can be proved, ${ }^{6}$ and is of greatest

1 "Summa," I : Q. I5, A. I.

2 "Summa," I : Q. 44, A. 3.

"The discussion of the doctrine of God is in "Summa," I : Q. I to 44. Q. 4 deals with God's perfection and Q. 6 with God's goodness; Q. 20 with God's love; Q. 2 I with his justice and mercy; Q. 26 with God's blessedness.

"Cf. "Summa," I : Q. 20 and $2 \mathrm{x}$.

s "Summa," I : Q. 33, A. I-3.

- "Summa," I : Q. 2, A. 3. 
importance to us that the distinctions in the persons and the relations of the persons to the world be distinctly described and held in mind.

The ethical questions relating to the doctrine of man are answered prevailingly in what was supposed to be orthodox Augustinianism, ${ }^{1}$ and before man there is a lengthy discussion of the whole subject of angels and demons, which is still the classical form of the doctrine in Catholicism. ${ }^{2}$

The soul (anima) of man is not a body or "corpus," but is the actuality of a body. ${ }^{3}$ As heat is not a body, but is the active principle of things made hot, man is, as Augustine teaches, not a soul or a body, but a soul and a body. ${ }^{4}$ The psychology of Aquinas is the traditonal Aristotelian, as Aristotle was understood in the Middle Ages, with some modifications drawn from Augustine, in part resulting from his Platonism and in part made necessary by the Augustinian doctrine of $\sin$.

Man has free-will, or otherwise all counsels, exhortations, precepts, prohibitions, rewards, and punishments would be vain. $^{5}$ And this freedom is power, and as reason and intellect are not two powers, but one, so will and freedom are not two powers, but one. ${ }^{\circ}$ And this voluntary element is in all human acts, ${ }^{7}$ and though fear may produce acts that are a mixture of the voluntary and involuntary, lust, dealing as it does with the inner man, produces only voluntary action. ${ }^{8}$ But man has become corrupt in the fall, and all the guilt of sin rests upon him. In his state of innocence his life was quite different, and would have remained so but for the fall. ${ }^{9}$

${ }^{2} C f$. discussion of the cause of evil, "Summa," I : Q. 49, A. 2-3.

2 "Summa," I : Qs. 50-64.

3 For the full discussion, "Utrum anima sit composita ex materia et forma?" see "Summa," I : Q. 75, A. 5.

" "Summa," I : Q. 75, A. 4. "Sed contra est quod Augustinus commendat" ("De civ. Dei," lib. XIX, cap. 3), Varronem, etc., etc.

5 "Summa," I : Q. 83, A. r.

7 "Summa," I : II : Q. 6.

o "Summa," I : Q. 8, A. 4.

8 "Summa,' I : II : Q. 6, A. 6-7.

- For elaborate discussion of man in a state of innocence, see "Summa," I : Qs. 93-ror. All this knowledge is for Aquinas as sure and as attainable as the facts of every-day life. 
In the discussion of original sin, Augustine, who has been so widely departed from in the doctrine of the will, is now again followed. ${ }^{1}$ The corrupt nature must be restored by sacramental grace. This strange mingling of Aristotle and Augustine has its historic roots in the needs of the hierarchy, whose power is so entirely wrapt up in faith in sacramental grace. ${ }^{2}$ Having dealt with the great questions of theoretic importance, the actual system of ethics is unfolded, with some necessary repetitions, inevitable under such treatment, in Pars Secunda Secunda.

II. The Practical Ethics.-In the classification of the virtues we see at once the synthetic character of the ethics of Aquinas. The first three virtues are the theological ones, of Faith, Hope, and Love (caritas); then follow the fruits of love, $i$. e., joy, peace, pity, beneficence, alms-giving, fraternal correction. After these come the cardinal virtues, ${ }^{3}$ Prudentia, Justitia, Temperantia, Fortitudo, following which Thomas discusses Religion, Piety, Obedience, Truth, Liberality, Magnanimity, Patience, etc., etc., and introduces elements hitherto soméwhat strange to his system from Roman Stoicism and its ethics, borrowed, no doubt, through Ambrose.

After a discussion of a virtue, Thomas usually discusses also the corresponding vice not in order to find an empiric mean between extremes, but in order to define and condemn the forbidden sin. We have memories here of the method of Aristotle, but no fruitful attempt at an actual application of it to life. The basis is authoritative definition, and the authorities are the Philosopher himself or a church Father, or the Bible, seldom a council, and only now and then a Pope.

The very opening discussions on the subject of faith introduce us to the pagan-intellectualistic elements so evident in the system. Faith is at bottom "believing things to be true because God has said them," "and is therefore a more certain basis for knowledge than science, because nothing is more certain than

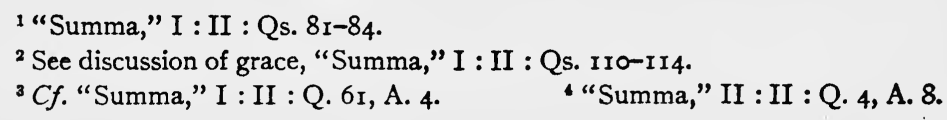


the word of God. At the same time these things are given in articles whose acceptance and interpretation belong to the intellect, ${ }^{1}$ and faith is a habit (habitus) both of the will and the intellect. $^{2}$ So no one article can be rejected without peril to faith and the immortal soul of the heretic. ${ }^{3}$ Here, therefore, we have an intellectual superstructure built up on a mystical piety, and in Thomas are co-ordinated the mystical elements borrowed by Christianity from Neoplatonism, and the scientific pagan elements borrowed from the pages of Aristotle. They are held together often in an outward and formal way. The central authority of the church, the overwhelming force of tradition begin to take the place both of the mystic inner vision and the rational conclusion of the mind.

It is always the failure of the aristocratic type of mind that it trusts in the outward might or wisdom of the few, and thus in ethical matters is inclined to look to the outward rather than the inward regulation of average human life. Hence in Thomas the outward church receives sharper definition and more outspoken support as the bearer of the outward authority than in almost any other scholastic. ${ }^{4}$ The ethics tend to become the outward code of regulative law. Thus are laid also in Thomas the foundations for the future elaborate casuistry. The monastery orders represented democratic elements in the social and religious life of the day, but they were not in themselves democratic, nor did they tend to democracy in the church. They, in fact, introduced and legalized the twofold order of Christianity by which only the highest attainment was open to the monk. They thus became with the priesthood the aristocracy of the church.

In Thomas the ethics reflect the monkish, ascetic ideals, and they are colored by the mystic piety-which took immediate knowledge of God as the principle of the existing, for the immediate goal of the religious life. The object of faith is

1 "Summa," II : II : Q. I, A. Iо.

2 "Summa," II : II : Q. 4, A. 4 .

" "Summa," II : II : Q. 5, A. 3 .

"Cf. discussion of the power of the keys, "Summa," III, supplement: Q. I7, A. I-3. 
formally first truth, and materially is God and the things that make the way open to God. ${ }^{1}$ This knowledge of God is reached by fasting and the contemplative life. ${ }^{2}$ And although the active life has place for religion, and there should even be orders devoted to the active life together with contemplation, yet "true religion embraces love, to God and one's neighbor," and the contemplative life deals directly with love to God, while the active life deals with the neighbor and so through the neighbor with God, ${ }^{3}$ but thus indirectly.

Of course the vows of poverty, chastity, and obedience are essential elements of the highest Christian life, because that life is thought of as a search after the knowledge of God and our relations to him. ${ }^{4}$ Love is defined in terms of Augustine ${ }^{5}$ as a motion of the soul (motum animi) toward enjoying God for his own sake (propter ipsum), and for those who can sustain it the solitary life of contemplation is the highest, but is not open to all. ${ }^{6}$

Yet in spite of these mystic and ascetic traits which logically exclude the social and political life, as forming religious opportunity, Aquinas is too thoroughly a child of the conquering ambitious hierarchy to omit the social and political elements from his conglomerate ethics. Though Aquinas gives us no definite doctrine and treatment of the church, he does give the materials for a construction of such a doctrine in his dealing with a state. ${ }^{7}$

1 "Summa," II : II : Q. I, A. I.

2 "Summa," II : II : Q, I47, AA. I-8 and II : II : Q. I80, AA. I-8.

3 "Ad dilectionem autem Dei directe pertinet contemplativa vita, quæ soli Deo vacare desiderat," etc. " "Summa," II : II : Q. I88, A. 2.

4 "Summa," II : II : Q. 8I, AA. I-8.

5 II : II : Q. 24, A. 2.

6 "Summa," II : II : Q. I88, A. 8.

${ }^{7} \mathrm{~A}$ quite large literature has grown up about this side of Aquinas's teaching. See Baumann, Johann Julius: "Die Staatslehre des hl. Thomas von Aquino ... aus seinen Werken authentisch zusammengestellt . . Beitrag zur Frage zwischen Kirche und Staat," Leipsic, 1873; Schneider, Ceslaus Maria: "Die sozialistische Staatsidee beleuchtet durch Thomas von Aquin," Paderborn, 1894; Walter, Franz: "Das Eigenthum nach der Lehre des hl. Thomas von Aquin und der Socialismus," Freiburg-in-Baden, 1895; Schaub, Franz: "Die Eigentumslehre nach Thomas von Aquin und dem modernen Sozialismus . . . Gekrönte Preisschrift," Freiburg-in-Baden, 1898. 
The church on earth is the ecclesia militans, but feels herself one with the ecclesia triumphans; ${ }^{1}$ she is the sacrament-dispensing power, which she exercises through priests, with the power of the keys and of absolution and excommunication. ${ }^{2}$ But the kingdom of God as the object of the Christian hope in the primitive sense is entirely wanting in scholastic theology. The only side of this hope that has any representation being the eschatological as the eschatological elements are taken over in Dionysius. In the explanation of Matthew ${ }^{3}$ Thomas gives four senses in which the expression the kingdom of God (regnum calorum) may be understood, viz., as Christ himself dwelling in us through grace, or as the Word of God, or as the present church militant (ecclesia militans), or, fourthly, the kingdom of Heaven may be the heavenly "curia." And in the "Summa" there is a definition of the kingdom which makes all turn upon the personal life of the individual. "The kingdom of God consists principally in internal acts; ${ }^{5}$ but as a consequence the kingdom of God also has to do with all those things without which internal acts are not possible; thus the reign of God is internal justice and peace and spiritual joy: it is necessary therefore that all external acts repugnant to justice or peace or spiritual joy, are repugnant to the kingdom of God, and should be prohibited in the kingdom of the Gospel." ${ }^{\circ}$

Yet even in this sense the phrase has little place in Thomas; the individual is in the foreground of his thought, and the salvation of the individual is the goal of the religious life.

III. Outcome. - The ethical outcome of such a conception of Christianity is on the whole disappointing. The social conditions of the day are in the main accepted, and however exalted the ideal for the personal life may be, the ideal is overshadowed by the unreality of the ascetic teachings.

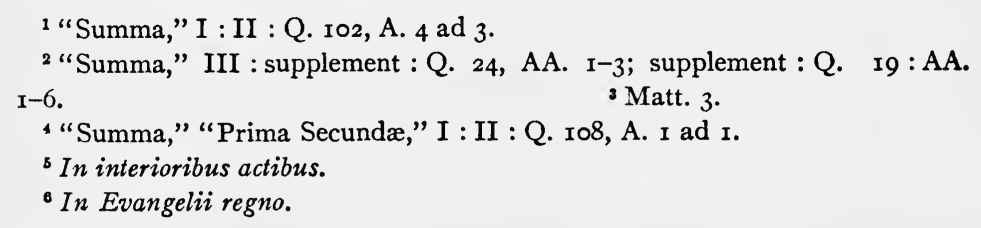


It was not the least of the services that the monastery had rendered to Europe that the monks worked with their hands and taught better methods of farming, gardening, fruit growing as well as household management. But industry as a virtue has no special treatment in the ethics of Aquinas. The life of solitary contemplation is the highest ideal. So even the service rendered by the studious monk is passed over in relative silence. One would hardly gather from the ethics of Thomas what noble ideals of study, research, and scientific effort his own order was spreading through Europe.

The enthusiasm that made the monastery orders the reformers of the church, and that kept them strong amid much corruption, was the enthusiasm for social service, which was rendered by preaching, teaching, and going into waste places with a message of new culture. But in the systematic ethics of the day there is none of this; indeed, it is shadowed over by what is logically and historically destructive of such service.

In fact, in the systematic ethics of Thomas the old pagan slave state with its attitude toward human life reproduces itself in many ways. There is the same aristocratic contempt for the lower ranges of human life and the same defence of existing evils on the ground that they must be so. Slavery is a result, for Thomas, of sin, and defensible on that ground. ${ }^{1}$ We need those who will do the meaner work for us, ${ }^{2}$ and the higher life of thought is only for the select. Of course mastery should be exercised with mercy and pity, but the whole conception of life is the pagan notion, that one small class is to rule and live upon the rest. So in the Roman Catholic literature aimed against socialism (see note, p. 327), the interpretation of Thomas not inaccurately represents him as consistent defender of this aristocratic attitude; for even the expressions taken from the Stoics are modified by the context to mean a real depend-

${ }^{1} C f$. "Der Heilige Thomas und die Sklaverei St. Thomasblätter," Jammy, 1889; Maurenbrecher, W.: “Thomas von Aquino's Stellung zum Wirthschaftsleben seiner Zeit," Leipsic, 1898 , where the material is gathered.

2 "Summa," II : I : Q. I05, A. 4. See whole article. 
ence of even those equal before God, upon the master in the flesh.

That the mastery is thought of in terms of spiritual domination as well as civil rather darkens than relieves the situation. It is vain to tell working-men to-day that in the ethics of Thomas there is any real outlook for the essential democracy based on the worth and dignity of all labor. ${ }^{1}$ Such modifications as feudalism made upon the Aristotelian ethics at this point were not directed toward democracy but the patrician aristocracy of the Italian city.

Thus, for instance, in the discussion of war there is no real attempt to bring its brutalities and horrors to the bar of a loving gospel. There are three conditions for a righteous war; ${ }^{2}$ first, it must be made by the authority of the prince and not by private persons. Secondly, the cause must be just, and thirdly, the intention must be to advance good and not evil. Augustine is the authority cited, and the New Testament has very little more place than in the ethics of to-day.

Of course clergy and bishops are forbidden to fight ${ }^{3}$ and deceit and strategy are permissible, as well as fighting on feast days. ${ }^{4}$ What we find, therefore, is the ordinary acceptance by Christian ethics in its scholastic form as, indeed generally since, of the evils of the day as necessary; and instead of a frank recognition of the prevalent paganism in contrast with the Christian ideal, we find lame defences of the pagan attitude. On the subject of slavery and equal manhood Thomas Aquinas is below Stoicism at its best, and in regard to war is about on the same level.

The ethics of property are those of Aristotle, but slightly modified by the monastery ideal. ${ }^{5}$ Man is in a twofold relation

\footnotetext{
${ }^{1}$ Cf. "Summa," I : Q. 96, A. 4; II : II : Q. 57, A. 3; II : II : Q. 1о, A. 10 ad 3 , etc.

2 "Summa," II : II : Q. 40, A. I.

3 "Summa," II : II : Q. 40, A. 2.

" "Summa," II : II : Q. 40, A. 3-4.

"See "Summa," II : II : Q. 66, AA. I-9, where the discussion deals with the questions: (I) Whether it is natural that men should be in possession of external things; (2) Whether private possession is permissible; (3) Is theft the
} 
to property; on the one hand he is competent to procure and dispense, and so far he has the right of private ownership. But he is also a user and enjoyer, and so far he has not private ownership, but must share with others. Private possession is not contrary to natural law, but is superadded by positive law. ${ }^{1}$ Theft from necessity is not harshly judged, and rapine is a graver offence than theft, because of its violence and danger to the life and honor of the person robbed.

The personal life is placed on a high level, thought of throughout, however, as contemplative rather than active. The ideals of personal purity are high, though here again the false conceptions of chastity ${ }^{2}$ as the normal Christian life, and the unmarried homeless life of the monk as normal makes the ethics at this point singularly barren and fruitless for an age when even Catholicism has in practice, if not in theory, abandoned, in Protestant surroundings, at least, its unnatural attitude. Even heretics are to be only lovingly put to death after the church has excommunicated them. $^{3}$ Truth, honor, fortitude, etc., are dwelt upon with force and intellectual vigor. The life of virtue is to be one of serious and constant struggle for divine perfection and inward purity, and there is to be no room amidst the spiritual joys ${ }^{4}$ for despondency and depression. How much the life of the monastery was plagued with depression and morbidness may be seen in the part the $\sin$ of acedia plays in the monastery ethics. Acidia or acedia is taken from the Greek, and came to mean the revolt of life against temporal and spiritual blessings; the sorrow or

secret taking of another's possession? (4) Whether rapine differs from theft; (5) Whether all theft is sin; (6) Whether it is mortal sin; (7) Whether one may steal in necessity; (8) Whether all rapine is mortal sin; (9) Whether rapine is a graver offence than theft.

1 "Summa," II : II : Q. 6, 6, A. 2.

2 "Summa," II : II : Q. I5I, AA. I-4.

3 "Respondeo . . . sed post primam et secundam correptionem, ut Apostolus docet: postmodum vero si adhuc pertinax inveniatur, Ecclesia de ejus conversione non sperans, aliorum saluti providet, eum ab Ecclesia separando per excommunicationis sententiam; et ulterius relinquit eum judicio sæculari a mundo exterminandum per mortem." "Summa," II : II : Q. II, A. 3.

- Gaudia spiritualia. 
depression of the soul which hinders spiritual exercise. ${ }^{1}$ For Thomas Aquinas the natural fruit of the spirit was joy and peace.

Apart from the monastery limitations the life of active teaching service, the healthy contact with reality, and, no doubt, the deep and lasting influence of Albertus Magnus, whose character shines in all his works, the ethics of Thomas reflect a noble ideal of manhood and womanhood.

With Thomas Aquinas the constructive stage of Roman Catholic ethics practically ceases. Not even the Council of Trent did more than clear away some inconsistencies and restate some teachings. If Roman Catholicism is to be identified with scholasticism, as the late utterances of the Vatican would seem to indicate, then the Jesuit estimate of the great Dominican is quite justified as it seeks to make him the formulator, final and complete, of Roman Catholicism as a closed system of knowledge about God, man, angels, earth, heaven, and hell, and how we may escape hell and purgatory, and gain heaven and the vision of God. All completely given and subject to no doctrine of growth or evolution. ${ }^{2}$

For Thomas Aquinas the new social structure was subject to exactly the same ethics of conduct as the social structure of the early Christian church. Nothing is more noteworthy in scholasticism than its entire lack of interest in history. Abelard could outrage his world more by an historical doubt concerning the identity of Dionysius with the Areopagite than by a serious heresy with regard to the Trinity. This unhistorical trait of scholasticism makes it for modern thought, with its predominantly historic interest, a strange world. There is in the ethics of this world no question of adaptation to new historical situations in the broader meaning of the term. There are no ethical lights and shades. The balancing of pros and cons does not

\footnotetext{
1 "Acedia vero est quædam tristitia quâ homo redditur tardus ad spirituales actus," "Summa," I : Q. 63, A. 2 ad 2.

2 "Acta Sanctæ Sedis," vol. 40, fas, 10, 1907. Litteræ encyclicæ, "Pascendi," pp. 6r $7-621$.
} 
mean that there can be any half-lights in which even the wellmeaning man may take darkness for light; it only signifies that a sharper and more self-consequent dialectic is needed and a larger and more exhaustive examination of authorities.

Theology is for scholasticism not only a divine system of knowledge about God and our relations to him, but the explanation also of a divine system of knowledge about the world, its past, and its future. The hopelessness of substituting this flat, non-plastic picture of human conduct; this colored map, with its lack of all elevation and depression, with its strained surfaces and unreal projections, for the actual living organism ethics is called upon to deal with and to explain, should surely slowly dawn even upon the obtuse.

From this point of view Aquinas is in a sense the last word. As far as dialectic and authority can bring us he has brought us. The service he rendered was no little one. The "silent Sycilian bull" did make his roar heard in all the world, and the voice is not silent yet. His firm faith that all religion and all knowledge could be summed up and that it was the theologian's duty to sum up the religion and the knowledge of his day gave impetus to serious study and research and gave a new starting-point for the world's advancing culture. Alas, that men so easily mistake the starting-point for the goal.

\section{CRITICAL SCHOLASTICISM}

It may seem artificial to separate out some of the scholastics from their fellows and call them critical. They were not themselves consciously or willingly more critical than those whom we have discussed. But it is by the outcome of their work rather than by their aims and methods that we so judge them. It lay in the very undertaking of scholasticism that serious doubts should be raised, and that the answers given should raise critical objection. When in older pre-scholastic days Bœthius raised the question as to the kind of reality possessed by the 
so-called universals or "prædicabilia," 1 he was simply asking again the question of all questions in philosophy, but when scholasticism identified religion with a final answer to that question it was inevitable that sooner or later religion should herself be challenged in the name of philosophy.

It was possible for Johannes Scotus Erigena to hold alike the dogmatic system of the East and a pagan culture, because the Western intellectual world was young; but as it grew older the questions became more and more insistent and minds constantly more critical. Even Anselm was an educator of the questioning mind. He undertook to satisfy the doubter, not simply by piling up authority upon authority, but by satisfying the reason. Sooner or later the question must arise: "If reason contradicts authority, which must yield? Whether they wished it or not, the substantial outcome of critical scholasticism was the impression that men had to flee from reason to authority or surrender authority.

If ethics is a system clean cut, sharply defined, based upon final divine utterances, then examination and exposition of those utterances is the only method of approach. Scholasticism however, had accepted Aristotle and Plato as ethical teachers, and these teachers had started with man, with his longings, his impulses, his intentions, his search of happiness and the final good. It is this conception of ethics that dominates the men we are now to consider. They were all true children of an authoritative church. The judgments of Cousin and Reuter ${ }^{2}$ upon the first of these critical scholastics, Peter Abelard, ${ }^{3}$ in

${ }^{1}$ As in his commentary upon the Isagog of Porphyry, "Mox de generibus et speciebus illud quidem, sive subsistat, sive in solis nudis intellectibus posita sit, sive subsistentia corporalia sint an incorporalia, et utrum separata a sensibilibus an insensibilibus posita: et circa hæc consistentia dicere recusabo." See MPL, vol. LXIV, col. 82.

${ }^{2}$ Reuter, H.: "Geschichte der religiösen Aufklärung im Mittelalter," vol. I, Berlin, 1875, pp. 183-259.

${ }^{3}$ Petrus Abælardus, or Abélard, was born ro79 at Palais, and studied under Roscelinus, William of Champeaux, and Anselm of Ruan. His relations to Heloise the niece of Canon Fulbert, and the revenge Fulbert took are well known. 
which the impression is left that he is to be regarded as a conscious herald of the coming illumination, is unjust to him. He was honestly persuaded of his own orthodoxy, and the ideals and freedom of the illumination would have been strange and even repulsive to him. This one sees plainly not only in his attitude toward the controversy with Roscelin about the Trinity, but in his defence of the method of dialectics. ${ }^{1}$ His point of view was that authority, indeed, was the last resort, but that to understand authority one must have a dialectic.

Upon us the arguments of Sic et non produce the effect of hopeless confusion among the authorities. But for Abelard and his age the authority of the church as the protectress of all culture was unshaken, it remained only for the faithful son of the church to properly understand the authority. Abelard, as Cousin rightly argues, in full good faith applied dialectic to theology with a keenness hitherto lacking. ${ }^{2}$ And in good faith he was persuaded that reason and faith had no conflict with each other. Of course the effect was inevitable. The process became even in the hands of Abelard a trial of the conclusions

He had a restless, tragic life, and died in 1 142. Paris was the place of his greatest triumph and bitterest humiliation. The sources for the ethical student are found in his collected works. Victor Cousin: "Ouvrages inédits d'Abélard," Paris, 1836 , and Petri Abælardi: "Opera hactenus scarsim edita nunc primum in unum collegit," Paris, $1849-1859$, in two volumes. The first volume contains, besides other writings, the famous "Sic et non," and in the other volumes are found the "Theologia" and "Ethica," the last under the title "Scito te ipsum." These, together with parts of the "Dialogue between a Philosopher, a Jew, and a Christian," form the main sources for the ethical teachings of Abelard. All are found reprinted in MPL, tom. 178,1855 . His life is sketched by his own pen in the famous "Epistolæ." For the "Historia Calamitatum," see Epistola I, opera, tom. I, p. 3 (Cousin). There are many French translations of the letters to Heloise (M. Gréard, I870, and others), and also free English renderings. Victor Cousin's introduction to the first volume ("Ouvrages inédits") is an excellent guide, but must be read critically. The literature concerning Abelard is very great, but his ethics have been but slightly dealt with. $C f$., however, a good review by Ziegler, Th.: "Geschichte der christlichen Ethik," 2d ed., Strasburg, I892, pp. 262-27 I, and in Ueberweg-Heinze: "Grundriss der Geschichte der Philosophie," Berlin, 1905, \& 24 .

${ }^{1}$ Epist. XIII, Migne, tom. 178, col. 351 .

2 Cousin, V.: "Ouvrages inédits," introduction, clxxvii. 
of authority before the bar of reason, with the new dialectic as the method of inquisition.

It was thus inevitable that the ethics of Abelard should break the bounds of legal enactment, and that he should endeavor to deepen and spiritualize the basis of conduct. This involved him at once in controversy with the existing tradition, for he tries in Scito te ipsum ${ }^{1}$ to show that vices (vitia) must be of the mind, that mere defects are not vices. He argues that there is a difference between the vice inclining to evil (malum) and sin (peccatum), and that to sin there must be the intention of the will; and that in any act, as of self-defence upon the part of a slave resulting in murder, the sin of the act is measured by the intention. ${ }^{2}$ Thus sin is not in being tempted but in having a mind that is inclined to temptation and in yielding to it, for God will not suffer us to be tempted beyond our strength. So that even the suggestions of demons can be resisted.

The committed sins are, indeed, more heavily punished than intended but uncommitted ones, but this is for examples' sake, and because we can only judge from results, but not so with God's judgment, who tries the heart. Since all sins are of the mind and not of the body, what is meant by spiritual and carnal sin is that the bodily lust is yielded to by the mind. ${ }^{3}$

Thus there can be no sin unless there is an offended conscience. Sin is contempt of God (Contemptus Dei). Those who ignorantly persecuted God's saints sinned by not knowing God, but not in following conscience, hence Stephen prays for them. Sin is often used for penalty. Adam sinned and the penalty (pæna) has fallen on all. And God suffers men to be punished, not for intended sin on their part, but for their purgation or probation. Moreover, God knows from the beginning the minds and intentions of men, and acts accordingly. Sins vary in degree, and Abelard's conclusion, of course, is that we must study to please God and find out what his will is. Perfection, there-

\footnotetext{
${ }^{1}$ Cousin, V.: "Opera," vol. II, pp. 593-642; also in Migne, tom. 178, cols 633-678.

${ }^{2}$ Cap. III.

${ }^{3}$ Cap. VI and VII.
} 
fore, involves a knowledge gained only by fearless and skilful dialectic and an intention to do the right when it has thus been disclosed.

In the following discussions of the treatise on penitence, confession, and the priestly power of the keys Abelard moves in the traditional world of thought. He neither here nor elsewhere plainly sees the real effect of his teaching upon sacramental grace, a magic priesthood, or the blind acceptance of churchly authority. Any one going to Abelard's works, and expecting to find them what Reuter in his history of the illumination would seem to regard them as being, namely, reformationwritings before the Reformation, will, it is to be feared, be greatly disappointed. But in so far it is just to call Abelard a forerunner of the illumination in that he did actually show the process by which scholasticism, on the one side, developed its system in Aquinas, and on the other destroyed it in humanism.

But even humanism was not of necessity hostile to the church, because, while rejecting the particular solution of the question given by scholasticism, it could do its thinking within the limits of ecclesiastical cult and ritual. This is substantially, indeed, the solution Abelard urges upon philosophy in the "Dialogue between a Philosopher, a Jew, and a Christian." This dialogue resolves itself in the later phases into an ethical treatise and a discussion of the highest good. This begins where the Christian takes up the argument, ${ }^{1}$ and shows that Christianity has all that the Jew and the Philosopher have and the promise of more. That philosophy is right, as far as it goes, Abelard does not question: so also Judaism is right up to a certain point, but both have need of an authoritative guidance, and this Christianity alone supplies. ${ }^{2}$ The little treatise on the virtues given in the "Dialogue" 3 represents, no doubt, fairly the ethical content of

\footnotetext{
${ }^{1}$ Victor Cousin's edition, vol. II, pp. 643-7 I8, MPL, tom. I 78, col. 1635 .

2 "Exoratio Magistri ad discipulum de inquisitione summi boni." Victor Cousin's edition, vol. II, pp. 715-7 I8, MPL, I78, col. I68I-I684.

${ }^{3}$ Victor Cousin's edition, vol. II, pp. 687-69I, and MPL, tom. I78, cols. 1654-1660.
} 
Abelard's own teaching, but such a knowledge of good and evil only increases man's responsibility and need, and only the light of the church gives the fulness of divine guidance. ${ }^{1}$ Moreover, for Abelard the weight of the argument is to show the justice and goodness of the God whose forgiveness and punishments are matters of revelation. The defence of God by the Christian reminds the reader often of the defence of him made by Job's false friends, but that which Abelard deems of importance is rather the rational character of ecclesiastical ethics as revealed. So at the close the Master exhorts his disciple, "that he should listen indeed to the natural law proclaimed by the philosopher, and to the law defended by the Jew, but that grace and truth only came by Jesus, and he is anathema who teaches other than the word of evangelical doctrine, ${ }^{2}$ which alone strengthens the will by grace preceding and accompanying its acts, and gives us to see and taste the highest good which is the Father, the Son, and the Holy Spirit, in one God. ${ }^{3}$

In some sense Abelard may be called the founder of the scholastic method, for his Sic et non marks distinctly the spirit of all the later writers. There is the same balancing of the various authorities, the objective statement of the intellectual difficulties, and then the attempted resolution of the difficulties. This is seen in weary perfection in the entirely indigestible Duns Scotus. ${ }^{4}$

1 "Mystice tamen intelligi facile est lunam tunc ut solem fulgere, id est ecclesiam electorum sicut et ejus solem Deum indeficientem lucem habere, et in ipsum ejus solem tunc quoque ita lucem ipsius lunæ transcendere, ut in ipso solo lucis sit perfectio, quæ septenario designatur numero." Victor Cousin's edition, vol. II, p. 705 .

2 "Verbum doctrinæ ipsius evangelicæ, plena et veritate." Migne, "Pat. Lat.," I78, $1684 \mathrm{D}$.

"The closing words of the "Exoratio magistri ad discipulum," attached to the "Dialogue." Migne, "Pat. Lat.," cols. 108I-1084.

1 Johannes Duns Scotus was born either in Duns (Ireland) or in Dunston (Scotland), between the years 1265 and I274. He became a member of the Franciscan Order, and taught in Oxford, Paris, and Cologne. He died about 1308. The main sources for his ethics are the "Distinctiones in Lib. Sententiarum," tomi V-X. Complete edition of his works by the Irish fathers of the order, Lyon, 1639 , in thirteen volumes, and a new Paris edition in twenty-six volumes, Paris, 189I-1895. 
For the student of ethics his works are highly unfruitful, save only as he laid the foundation for a deep distrust of all merely rational ethics, and exalted the science. Theology (theologia) is for Duns Scotus practical and not speculative, ${ }^{1}$ yet no system seems at times more hopelessly speculative, for Duns Scotus gives back on bare authority, as he interprets it, all the metaphysical philosophy he takes away by his sceptical dialectic acuteness. As a good example of his learned confusion one may turn to his discussion of the Aristotelian teaching concerning "habitus" in the ethical realm. ${ }^{2}$ His interest is to assert the will as superior to the intellect and as ordering the whole spiritual life. This spiritual life is then shown to be a supernatural gift. Reason is powerless. God is the supreme giver, and maker of the good. But his decree includes man's freedom of choice, ${ }^{3}$ and hence a contingency which, as far as the writer knows, he never really adjusts to God's foreknowledge, which he also, of course, postulates." In this freedom man can do justly or can $\sin$, but mere conformity of outward acts to what God purposes does not constitute moral good, it must be an inward conformity only possible by grace. ${ }^{5}$ Man's sin is his own, and God's responsibility is only secondary, or mediate. ${ }^{6}$

In discussing whether "intention" constitutes the sole act of the will Duns Scotus insists upon defining the intention and showing an intellectual element in each decision. ${ }^{7}$

In the actual ethics Duns Scotus follows in the same general line drawn by traditional theology before either Aquinas or himself, ${ }^{8}$ although the familiar thoughts of Dionysius and the Platonic school have larger influence, and the ethics is even more essentially legal, as simply the expression of God's infinite

1 "Prologue Distinctiones," 4, Paris edition, 1893, tom. 8, pp. 195-293.

${ }^{2}$ Lib. I, dist. XVII, Quæst. I-6, Paris ed., tom. I0, I893, pp. 32-1 22.

${ }^{3}$ Lib. I, dist. XXXIX, Paris ed., I893, tom. Io, pp. 61 2-675.

4 The full discussion in Lib. I, dist. XXXIX to XLII, and Lib. II, dist. XXVIII to XXIX.

${ }^{5}$ Lib. I, dist. XLVIII, Q. I.

${ }^{6}$ Lib. I, dist. XXXVII, Q. I.

${ }^{7}$ Lib. II, dist. XXXVIII, Q. I, Paris ed., I893, tom. I3, pp. 398-405.

${ }^{8} C f$. the ethics of Lib. III, dist. XXVI to XL. 
and powerful will. Nor is it encouraging to see the way the subtile Franciscan changed the loving freedom of his great master St. Francis into sacramental magic. For to the sacraments and their particular magic power he devotes special attention. ${ }^{1}$ There is a devotional tone in Duns Scotus which, however, does not soften, as one might expect, his ethics, nor indeed his general outlook. ${ }^{2}$ In him appears also all the childish scholastic speculation at greater length than ever. ${ }^{3}$ And great as is his dialectic skill, the result of his teaching was not and could not be constructive. It was too critical of the philosophical basis upon which the school philosophy rested. His continual refuge is to authority, because reason gives way, and he thus unwittingly admits the bankruptcy of rationalization.

It is not the place here to decide how far Abelard and Roscelinus were nominalists, and how far they agreed or disagreed, nor yet what was the exact relation to the controversy about universals sustained by William Ockham.4 He was one of those who disturbed the peace by simply raising again the question on which the whole traditional thinking rested.

Often the scholastic writers seem to the modern reader like exceedingly clever children discussing a world they only know

1 The discussions are found in Lib. IV, dist. I to XIII, Paris ed., 1894, tomi 16 and 17 .

${ }^{2} C f$. his discussion of whether the damned and their sufferings are seen by the saved. Lib. IV, dist. L, Q. 3, Paris ed., tom. 21, pp. 543-548.

${ }^{3}$ Cf. Lib. IV, dist. XXX, Q. 2. "Utrum inter Mariam et Joseph fuerit verum matrimonium?"

1 William Ockham was born in Surrey, England, about 1300 , and died April, 1347. He was a pupil of Duns Scotus, and a Franciscan monk. He distinctly influenced Luther in his conception of the relation of the Pope to the State. (Cf. Rettberg, Friedr. Wilh.: "Ockham und Luther, oder Vergleich ihrer Lehre vom h. Abendmahl" in Theologische Studien und Kritiken, 1839, pp. 69-136.) His works are not accessible in a complete edition. (No reprint in Migne, "Pat. Lat.") All the writer has had access to are: "Super Potestate Summi Pontificis . . . " 1496; "Disputatio inter clericum et militem," 1495; "Summaria . . . operis nonaginta Dierum," I495; "Compendium errorum Johannis pape XXII," Lyons, I 495. He was driven from Paris and took refuge with Louis of Bavaria. In the works to which the writer has had access is no systematic treatment of ethics as such. 
by hearsay, and firmly persuaded that their parents and teachers are incapable of blundering. To merely suggest that the dialectic method was at so important a point seriously at fault was to shake the foundations of the elaborate theological structure, so painfully reared, and which was so intimately identified with the actual living faith of the mass of thinking men and women.

Nor can it be successfully disputed that this elaborate structure has its logical outcome in an infallible living voice, and that the Pope has the best historical claim to be that voice. If religion consists in accepting infallible authority, then surely it is of high importance that the authority be as unquestioned and as unquestionable as possible. Hence the attitude of Ockham toward the papacy, and indeed the attempted independence of the University of Paris and the Gallican church, were serious matters and disturbing factors in the last degree.

Nominalism failed to go the logical lengths of the system, and took refuge in authority as over against speculation, and so really strengthened the papacy: but for a little time it seemed as if the new type of piety-introduced by the mendicant orders ${ }^{1}$-might so separate itself under the leadership of critical scholasticism as to produce a serious revolution in the religious and ethical thinking of the church. This type of piety we study best in the works of another set of scholastic thinkers.

\section{MYSTICAL SCHOLASTICISM}

What Harnack calls the "tedious doctor's thesis question," 2 concerning the relation of mysticism to scholasticism, will always be answered in accordance with one's understanding of these two terms. Mysticism is found throughout in scholasticism because it belongs to the systemless conglomerate with which scholasticism as an organizing intellectual force had to deal. The Western world did not accept Christianity primarily as a system either of theology or ethics, but as religion and life.

${ }^{1}$ See p. 357.

2 "... durch Confusion und Langeweile ausgezeichnete Doctorfrage." "Dogmengeschichte," vol. III, p. 328, 3d ed. 
This religion had from early days its mystical elements. Whether they are legitimate divine additions to the simpler ethical monotheism of Judaic prophetism or whether they are obnoxious intrusions is still a mooted question.

It is, however, important that it be clearly understood what in these pages is meant by mysticism. The term would be more useful if more narrowly defined, not as covering emotional and sentimental piety, but as referring to the profound faith that religion is knowledge of ultimate reality and that this knowledge can only be obtained by abstraction from the sensuous and phenomenal. In this sense mysticism is despondent with regard to the present and the seen; it is essentially dualistic, dividing between the ultimate reality, unchanged and unchangeable, and the transcendent phenomenal; it is generally ascetic, desiring to strip off the body that the soul may see. It may be intensely monotheistic with God symbolized and even conceived anthropomorphically, but the tendency must always be toward pantheism.

He who deals with mysticism is primarily occupied with psychological states, and the division of the mystics should be on the basis of the psychological interest. When the emphasis is upon religion as knowledge of reality, the mysticism is intellectual in its caste. When the emphasis is upon religion as union with reality the type of mysticism may become emotional and ecstatic. On the other hand the emphasis may be so placed that this union is thought of as union of the will with reality, and we have what the writer ventures to call thelemic ${ }^{1}$ mysticism. This thelemic mysticism may again in its fundamental character be dominated either by the intellectual or the emotional interest. One characteristic of mysticism, as thus defined, is the inevitable monotony of its processes. It must be prevailingly passive, and the mental processes are usually fantastic and readily become pathological. Ethics cannot be more than a secondary interest, for the heart of ethics is a right relationship to the phenomenal world, while for mysticism abstraction from the phenomenal

2 From rd $\theta \epsilon \lambda \eta \mu \alpha$. 
world is the necessary means to the goal that is primarily intellectual and not ethical, namely, knowledge of fundamental reality.

The history of Christian mysticism, or, as the writer would prefer to say, of mysticism within Christianity, has yet to be satisfactorily written. ${ }^{1}$

Unfortunate misuse of the conception of the Logos in the fourth Gospel, and the linking of Hellenistic Judaism (Philo, etc.) with early Christianity, gave rise to many weird combinations. In Victorinus ${ }^{2}$ the process may be seen, but was surely older and deeper than his personal influence. In Augustine

'For the literature of mysticism, see Vaughan, Robert Alfred: "Hours with the Mystics," 2 vols., London, I856, Ist ed.; Görres, Johann Joseph von: "Die christliche Mystik," 5 vols., Regensburg, 1836-1842, new ed., r879-1880; Helfferich, Adolph: "Die christliche Mystik in ihrer Entwickelung und ihren Denkmalen," 2 vols., Gotha, I842; Noack, Ludwig: "Die christliche Mystik nach ihrem geschichtlichen Entwickelungsgange im Mittelalter und der neuern Zeit," Königsberg, I853; Royce, Josiah: "The World and the Individual," vol. I (Gifford Lectures, I899), lectures 2, 3, and 5, New York, I900; Münsterberg, Hugo: "Psychology and Life," Boston, 1899, pp. 229-282; Cousin, Victor: "Cours de l'histoire de la philosophie moderne," new edition, Paris, I847, 3 vols. (vol. II : Leçon 9), English translation by G. W. Wight ("Course of the History of Modern Philosophy"), 2 vols., Edinburgh, 1852, also New York, 1857, 2 vols.; Preger, Wilhelm: "Geschichte der deutschen Mystik im Mittelalter nach den Quellen untersucht und dargestellt," Leipsic, 1874-1893, 3 vols. (the fourth volume has not yet appeared); Hügel, Friedrich Baron von: "The Mystical Element of Religion as Studied in Saint Catherine of Genoa and Her Friends," 2 vols, London and New York, I908; Zahn, Josef: "Einführung in die christliche Mystik," Paderborn, r908; Récéjac, E.: "Essay on the Bases of Mystic Knowledge," translated by Sara Carr Upton, New York, r899; Inge, William Ralph: "Studies of English Mystics" (St. Margaret's Lectures, 1905), London, 1907.

${ }^{2}$ Victorinus, Cajus Marius. A teacher of rhetoric in Rome, who accepted Christianity in later life and identified it with his Neoplatonic speculation founded upon Plotinus and Porphyry. His commentaries on Galatians, Philippians, and Ephesians, as well as his essay, "De generatione verbi divini," some hymns, etc., are preserved. See Migne, "Pat. Lat.," tom. 8, cols. 993-1310 ff.; and some of his influence may be traced to his extreme orthodoxy on the question of the omouvoios. He died about 363. Gore and Harnack regard him as having deeply influenced Augustine, "an ihn hat sich Augustine-wenn ich nicht irre-in der entscheidenen Epoche seines Lebens gebildet." Harnack: "Dogmengeschichte," III, 3d ed., p. 3I, English translation, vol. V, I899, p. 33; ed. 1890, p. 30. 
there is identification of God with ultimate reality, and the underlying longing to be lost in God, but speculation is subordinated to the religious-ethical interest. This speculative side is not the predominant note in the theology of the Western world which looked to Augustine, and only in the fifth or sixth century do we find, even in the Greek church, a man who completely subordinates the religious-ethical to the speculative knowledge of reality. Through Johannes Scotus Erigena the writings of Dionysius the Areopagite ${ }^{1}$ became the possession of the Latin world. Erigena translated them at the command of Charlemagne, but, as we have seen, had himself but superficial contact with the fundamental character of mysticism. Indeed it is hard to believe that the scholastic writers who make so much use of Dionysius really fully understood how completely he stood on pagan and non-Biblical ground. It is scarcely too much to say that mysticism hardly needs an ethics and ultimately renders it superfluous. Goodness is for Dionysius not really a moral but a metaphysical attribute. It is "complete-

1 The Pseudo-Dionysius the Areopagite has given much trouble to the critical world. But it may now be accepted that the writings are forgeries of the fifth or sixth centuries, perhaps on the basis of lost writings more or less incorporated in what we now have. The writings are conveniently collected with Latin translation in Migne, "Pat. Græca," tom. 3. (The scholia of Maximus and

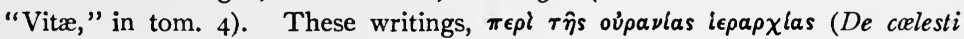

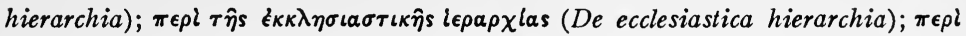

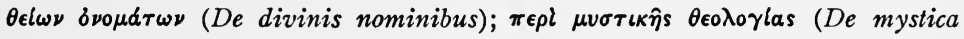
theologia); Epistola, and the so-called Liturgia S. Dionysii have been enormously influential. De colesti hierarchia and De ecclesiastica hierarchia have been edited and translated into English by Colet and Lupton (Joannes Coletus super opera Dionysii. Two treatises on the hierarchies of Dionysius, . . . now first published with a translation, introduction, and notes by $\mathrm{J}$. $\mathrm{H}$. Lupton, London, 1869), another translation by John Parker, London, I894. A translation into German of all the writings by Engelhardt, Sulzbach, 1823, and into French by Darboy, Paris, 1845, and Dulac, Paris, I865. Full literature is given by Bardenhewer, Otto: "Patrologie," Freiburg-in-Baden, r894, pp. 284-290, English translation by T. J. Shahan, St. Louis, 1908, pp. 535$54 \mathrm{I}$, and by J. H. Lupton in the article on Dionysius (I) in Smith \& Wace's "Dictionary of Christian Biography," vol. I, Boston, I877, pp. 84I-848; see also Siebert, Otto: "Die Metaphysik und Ethik des Pseudo-Dionysius Areopagita, Dissertation," Jena, 1894; and Harnack's "Dogmengeschichte," especially II, pp. $423 f f$., 3d ed., English translation, vol. IV, Boston, I898, pp. $33^{8} f f$. 
ness," "unity," "freedom from division," "power," "ultimate causality," "light," and "the source of all light," etc. " Evil is a non-existent quantity, a weakness, an absence of strength. ${ }^{2}$ Not even the demons are really evil in themselves and by nature, ${ }^{3}$ and all being in its phenomenal existence is relatively good, but to become absolutely good must strive to shake off the mutable and separable and become again one with God, from whom all things spring.

God is therefore "good" as the metaphysical source of all being, and in strict logic there is no evil and there is no good, but only relative grades of existence. The hierarchy is useful, not as an ethical training and teaching organization, but simply as a ladder by which men are led up from the divided and visible to the undivided and invisible. The Scriptures are for Dionysius useful as the revelation of the source of all being, and indeed they are the only source, as all our thinking and acting is vain and empty." In the "Mystic theology" Dionysius is absolutely outspoken: salvation is a sinking of the soul in God, a becoming one with God in metaphysical sense. Salvation is the imparting of God to the soul in fuller measure, and Jesus is the intermediary by whom the inexpressible is given expression. All the contradictions and extravagances of Neoplatonism, together with its profound longings and almost psychopathic ecstasy are found in Dionysius.

The mysticism of the pseudo-Areopagite is almost wholly metaphysical and intellectual. But under cover of the developed ritual and organization of the church this metaphysical interest is cleverly substituted for the religious and ethical life.

The essence of Roman Catholic piety as developed under a monastic papacy was the absolute submission of the soul to authority. This authority was thought of as divine but incorporated in the hierarchy. The ethics of this development have

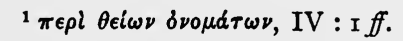

${ }^{2} \pi \epsilon \rho l \theta \epsilon i \omega \nu \delta \nu 0 \mu \alpha+\tau \omega \nu$, IV : 20.

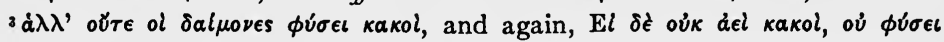

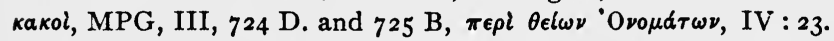

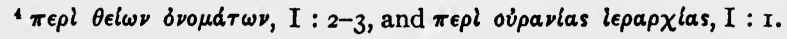


therefore their specific type. While on the other hand the essence of Neoplatonic and mystic piety is the attainment of the divine, and obedience and submission may or may not be means to that end, but do not constitute its life and essence. There is a certain haughty individualism always present in mysticism, and it was a triumph of diplomacy for the Roman hierarchy that as it subdued the intense individualism of the ascetic ideal, and forced it into the modified communism of the monastery, so also it understood how to harness the haughty individual aspirations of Neoplatonism, in men like Gregory of Nyssa and the pseudo-Dionysius, to the chariot of a political organization whose formative impulse was obedience.

Yet this mysticism always remains a foreign and troublesome intrusion. It is profoundly so in Augustine, where the mystic elements clash discordantly with his truly ethical system of thought. The language of Paul, with its ethical dualism and its relative underestimate of the worth of this life, has been the loop-hole by which Neoplatonic mysticism has inserted itself into the Christian synthesis; and profound misinterpretations of the Logos teachings of the fourth Gospel have made the invasion easy.

At the same time, probably the real hold that mysticism, in its philosophical sense, had upon the Roman hierarchy, came with the rite and cult, whose history is linked, as we have seen, with the pagan mystery. Dionysius and Maximus the Confessor made the rites and worship of the church the commentary upon the dogmatic teaching which was needed by the unlearned and incompletely instructed, and thus introduced Neoplatonic speculation into the life of the church even for those who had no real interest in the speculation. ${ }^{1}$

The traditions of the monastery carried out of Egypt an elaborate sacramental apparatus. The binding together of the papacy and the monastery thrust these sacramental and cult

\footnotetext{
${ }^{1}$ For brief discussion, see article, "Mystagogische Theologie," by Ferdinand Kattenbusch, in Herzog-Hauck's "Realencyklopädie," vol. XIII, Leipsic, I903, pp. 612-622; with references to his "Lehrbuch."
} 
elements into the foreground, and with them the memory of the mystical teaching closely identified with the monastic aspiration. $^{1}$ In this work the main figure for the Western church was also Dionysius the Areopagite. Thus in his "Cœlestial Hierarchy" we see the idealized picture of the actual ecclesiastical system, as it had worked itself out in Syria, in Asia Minor, and the Eastern provinces, toward the close of the fourth and the beginning of the fifth century.

The triumph of monasticism was marked not only in the reformation of the Roman hierarchy under Hildebrand, but by the rise of the mendicant orders (Dominicans, Franciscans, etc. $^{2}$ ). The religious life of the Roman Catholic church received not only new impulse but a new unity. This unity was gained by the absorption and adaptation into the intellectual structure of scholasticism, of mystical elements, which in themselves have nothing in common with the intellectually organizing spirit of scholasticism. The work of thus incorporating these elements was much advanced by the really great and interesting Hugo of St. Victor. ${ }^{3}$

When Harnack calls Hugo of St. Victor the most influential

"For discussion of "Mönchthum und Mystik" in the Greek church, see Ferdinand Kattenbusch's "Lehrbuch der vergleichende Konfessionskunde," vol. I, Freiburg-in-Baden, I892, pp. 522-542.

${ }^{2}$ See for brief ethical estimate, pp. 357,358 .

'Hugues de Saint Victor was born about ro97 and died I I4 I in either Flanders or Saxony. He was weakly and from the first devoted himself to learning, and was a life-long monk in the Benedictine order. His works are collected (together with much dubious material) in the reprint of the Rouen edition of 1684 in Migne, "Pat. Lat.," tomi I75-177. The biographical material is collected in "Histoire littéraire de la France," tom. I2, Paris, I830; O. Zöckler's article in Herzog-Hauck's “Realencyklopädie," vol. VIII, Leipsic, I900, pp. 436-445, English translation, vol. V, New York, 1909, pp. 390-392, is an admirable résumé of his work and teaching. The student of ethics will turn with most interest to "Institutiones in Decalogum legis Dominicæ," "De sacramentis Christianæ fidei," "De arca Noe morali," "De arca Noe mystica," "De vanitate mundi," but cannot afford to neglect his very influential mystical writings, found in Migne, "Pat. Lat.," tom. I76, cols. 88I-998. The large literature can be seen gathered in the modern histories of the Christian church (W. Möller, Ph. Schaff, or Kurtz-Bonwetsch-Tschackert). Of the "Victorines," he was the greatest. 
theologian of the twelfth century, ${ }^{1}$ he doubtless is right, but for the student of ethics his interest is almost wholly his place as the formulator and interpreter of a "mystical orthodoxy," and here ethics plays a poor part.

There is almost no element of Hugo of St. Victor that may not be directly traced to Maximus the Confessor, Dionysius the Areopagite, or Johannes Scotus Erigena. The point of view is that faith must be comprehended, but not with the intellect only, but in the last analysis by direct and immediate vision. That God is one is the truth by which we are illuminated and made perfect. $^{2}$ Love to our neighbor has two aspects: the one is present and temporal, the other is the sharing with him the vision which is eternal. ${ }^{3}$ Obedience is the fundamental virtue, because only by obedience do we know the operation of grace. ${ }^{4}$

The border line between dogmatics and ethics is not a sharp one, but to dogmatics rather than to ethics belongs the elaborate discussion of the fall of man and angels and God's relation to evil. $^{5}$ The conclusion is that God is not responsible for man's activity within the rather narrow range left to his free-will, ${ }^{6}$ although, of course, he foresaw the consequences. Original sin is in the fact of inherited lusts, which are always pain, and may be pain and guilt and ignorance which lead us inevitably to offend God. ${ }^{7}$

As in all the mystic scholastics of a certain type the sacraments assume the magic character of a medium by which the soul is

${ }^{1}$ Harnack's "Dogmengeschichte," vol. II, p. 346, 3d ed., English translation, vol. VI, Boston, r899, p. 44 .

2 "Institutiones in Decalogum," cap. I.

3 "Institutiones in Decalogum," cap. 2.

4 "Obedientiam exhibe, gratiam intellige, veritatem agnosce." ("Institutiones in Decalogum," cap. r.)

5 "Summa Sententiarum," tract III, cap. I-I5. The genuine character of the sentences is assumed quite uncritically by the present writer; see for a critique, Heinrich Denifle in "Archiv für Geschichte des Mittelalters," vol. III, I887, pp. 634-640.

${ }^{6}$ Cap. 8-9.

${ }^{7}$ Cap. ro-r2. Cf. also "Dialogues de Sacramentis legis," MPL, tom. 176, col. 26 . 
cleansed for the spiritual vision. Jesus is baptized by John, not that he needed baptism, but to sanctify the water, so that its use in the name of the Trinity might confer remission of $\sin ^{1}$

The unethical character of such outward magic means of grace has hardly even yet dawned upon Protestantism, which took over much of the sacramentarianism of mystical scholasticism (Hugo, Bernard of Clairvaux, Tauler), because of a supposed affinity with the inwardness of mysticism.

In truth, however, the mysticism of Hugo of St. Victor is not a really Protestant inwardness toward which the logic of Abelard unconsciously moved. Abelard, as we have seen, had the full assurance that faith and reason were in ultimate harmony. Hugo is a mystic because he despairs, in point of fact, with regard to reason reaching the knowledge of God, and would substitute immediate vision for mediating reason. Hence the whole ethics centres about humility, which meant for the Middle Ages surrender to authority. ${ }^{2}$ The experience upon which the religious life is built is not the reaction of the whole personality upon our world, but the immediate ecstatic vision of ourselves and others, guaranteed to us by church and sacrament. ${ }^{3}$ This "inwardness" is therefore the very opposite of evangelical freedom, and even when it seems most to resemble it remains a stranger to its spirit. ${ }^{4}$

In such ecstatic experiences assurance of salvation was obtained, and in the sacraments the grace is conveyed to the partaker which makes such experience possible.

I "Summa Sent.," tract V, cap. I. The whole discussion of sacraments is interesting, but concerns dogmatics rather than ethics. See "De Sacramentis legis naturalis et scriptæ" and the "Summa Sententiarum," tractati IV to VII. Cf. also Harnack: "Dogmengeschichte," vol. III, p. 488, 3d ed, English translation, Boston, r899, vol. VI, p. 2 r 9.

${ }^{2} C f$. "De fructibus carnis et spiritus," where love springs from the root humility as luxury springs from pride. Migne, "Pat. Lat.," tom. I 76, cols. $997 f f$.

${ }^{3} C f$. "De sacramentis," lib. I, pars. III, Migne, "Pat. Lat.," tom. I76, cols. $217-234$.

- It was this essential misunderstanding that led Luther to his overestimate of the train of reflection found in the little book called since his day "Teutsche Theologie." 
In Hugo is seen also the subtile ascetic quality which makes Middle-Age mysticism attractive to poetic and artistic natures. The rude north was awakening to a new art life. The gloom of the forest was to be idealized in splendid cathedral arches, and the songs of the south, chastened and solemnized, were to stimulate to an art expression the north has made peculiarly her own.

As in the sacraments, so in the service. Hugo sees a method by which the emotional life is awakened, and the clothing of the priest and the details of the ritual assume a great importance for him. ${ }^{1}$ At this point we see again the hierarchy carrying artistic culture to the north, and awakening in the forming national life aspirations for beauty and harmony, which it sought to gratify in ornate service, in splendid churches, and in the high cultivation of monastic solitude. All of this marks a strange contradiction within the message of the Roman church, because contempt of life and world-flight, together with asceticism and tears, comport but ill with the splendor and grace the hierarchy unfolded. ${ }^{2}$

At bottom mystic scholasticism has no really original ethical contribution to make. The virtues are the theological virtues expounded in connection with the familiar Aristotelian and Platonic lists. The centre of gravity is shifted to the knowledge of God as ultimate reality, gained not by reason or revelation to the reason, but by immediate contacts of the soul with God, which contacts are historically for Roman Catholic piety only to be genuinely gained within the circle of experiences vouchsafed by the church.

In the writings of Innocent $\mathrm{III}^{3}$ for instance, we see the

${ }^{1} C f$. "Expositio in Regulam beati Augustini," Migne, "Pat. Lat.," tom. I76, cols. $88 \mathrm{I}-924$.

2 For Hugo's attitude to the world, see "De arca Noe morali," lib. I, cap. I, and "De vanitate mundi," Migne, "Pat. Lat.," I 76, cols. 6r9-62I and 703-740. It received classic expression in Innocent III. See p. 353.

${ }^{3}$ Lothar, Count of Conti, I 160-1 216 (as Pope Innocent III from I I98-1 2 I6), was the guardian of Frederic II. His writings are most numerous; $c f$. Migne, "Pat. Lat.," tomi 214-217. The works that concern us most are found in the 
strange admixture of mystical elements, with world-flight as the climax of the religious life on the one side and the outspoken ambition to rule the world and subdue to the papacy all secular thrones on the other. And in no one is this combination seemingly more influential and along all the lines upon which Catholic piety moves.

Any Protestant, for instance, who has stood watching the strange, and to him meaningless, postures and kneelings of the mass would do well to turn to Innocent III's "Mysteries of the Altar." ' For the understanding of Roman Catholic piety on a certain level of culture there is no literature more informing than Innocent III. He is almost as representative of the piety of the Middle Ages as Thomas Aquinas is of its learning.

Mysticism has deeply affected that type of piety, and the secret is found rather in its sacramentarianism than in its speculative philosophy. Speculative mysticism would have had but little influence, probably, upon the Western type of thought had it not been linked with the cult by Dionysius the Areopagite and with the sacramental machinery by Hugo of St. Victor and Innocent III. ${ }^{2}$

That mystic elements in the very narrowest sense were thus incorporated cannot be denied. The goal is to know God as

fourth volume (tom. 217): "Sermones," cols. 313-690; "Dialogus inter Deum et peccatorem," cols. 691-702; "De contemptu mundi," cols. 701-746; "Libellus de eleemosyna," cols. 745-762; "Encomium charitatis," cols. 761-764; and "De sacrificio missæ," cols. 763-9r6. The other volumes are his letters and decrees and various papers, "Regesta sive Epistolæ." For the enormous literature, see the standard church histories, or the article, "Innocenz III," by Carl Mirbt, in Herzog-Hauck's “Realencyklopädie," vol. IX, Leipsic, I90I, pp. I I2-I 22, English translation in the new Schaff-Herzog "Encyclopædia," vol. V, New York, I909, pp. 498-502.

1 "Mysteriorum evangelicæ legis, et sacramenti eucharistiæ," lib. VI, in Migne, "Pat. Lat.," tom. 217, cols. 763-916 ("De sacro altaris mysterio" or "De sacrificio missæ").

${ }^{2} C f$. "De sacro altaris mysterio, Prologus": "Tria sunt, im quibus præcipue divina lex consistit: mandata, promissa, et sacramenta. In mandatis est meritum, in promissis est præmium, in sacramentis est adjutorium." The importance of the sacrament, therefore, being that it enables us to keep the commandments and to obtain the promises. (MPL, tom. 217, col. $773 \mathrm{~B}$.) 
ultimate being, and that immediately. The world is evil, God only is really good that is "reality." Thus in "De contemptu mundi" the whole ethics centres about the attempt to slay pride, which is the head and root of all sin, ${ }^{1}$ and by making man humble to exalt him to God.

The despondency of much literary Christian activity probably misrepresents the average Christian thought and feeling. The oppressed classes in early years were not on the whole, probably, as miserable as the few cultured ones among them, who could alone voice the discontent. For culture makes the soul sensitive to its sorrows. But from Augustine to Innocent III even the prosperous thought it a religious frame of mind to feel contempt for the joys of life and to speak meanly of man. This abnormality, based upon Ecclesiastes and misunderstandings of Job and isolated passages of Scripture, is classically formulated by Innocent III and some of the mystics, and has passed over into the quasi-Protestantism of Puritanism in England and Pietism on the Continent. ${ }^{2}$

The test of goodness not being normal and healthy relationship to one's world, but metaphysical identification with an eternal reality, man is in a very bad way; for whereas "the stars were made from fire," and the atmosphere and winds from the air, and birds and fishes from water, man and vegetables were made from earth! ${ }^{3}$ He is utterly corrupt both morally and physically. How utterly physically sin is conceived one sees in the crass coarseness of Innocent III in describing original $\sin ^{4}$ in its origin.

All the miseries of life as described by Innocent are not just

1 Prologus, "De contemptu mundi."

${ }^{2}$ The hymnology of the Protestant churches is particularly marred by this fundamentally irreligious conception.

3 "De contemptu mundi," lib. I, cap. 2.

4 "De contemptu mundi," lib. I, cap. 5 : “. . . quo cibo conceptus nutriatur in utero. Profecto sanguine menstruo, qui cessat ex femina post conceptum, ut ex eo conceptus nutriatur in femina. Qui fertur esse tam detestabilis et immundus, ut ex ejus contactu fruges non germinent, arescant arbusta, moriantur herbæ," etc., etc. (MPL, tom. 21 7, col. 704 C-D.) 
so many challenges to a battle with unrighteousness as they are now becoming to the modern world, nor yet are they evidences of the sure coming of a just judge and ruler as they were to Judaism and apocalyptic types of Christian thought in the early days; they are to him but proofs of the necessity to seek in the sacraments and alms-giving certainty that these miseries will buy us eternal joy. ${ }^{1}$

The misery of the slave, so graphically described, no more awakens in Innocent than in Aristotle the feeling that the slave would yet be freed by a great deliverer, ${ }^{2}$ but only forms one more proof that man has to flee the present and seek the future.

The nearest approach to a systematic ethics in Innocent III is contained in the second book of the "De contemptu mundi." There sins are catalogued and rebuked. Cupidity, avarice, partiality or respect of persons, ${ }^{3}$ selling of justice, gluttony, drunkenness, luxury, ${ }^{4}$ unnatural vice, ambition, pride, arrogance, extravagance in dress and ornaments, uncleanness of heart, and all the evil consequences are discussed and denounced, and the eternal consequences are set forth. At the same time the catalogue reads rather like an indictment of the Creator than an attempt to overcome the evil by the presentation of the good. The tract belongs, in fact, to the gloomy and despondent view of life so generally found in connection with ascetic religion. The ethics is negative and the morality savors sadly of personal desire for individual extrication.

${ }^{1} C f$. the crassness of this conception in the little book, "Libellus de eleemosyna": ". . . quia Deus per eleemosynam maculas peccatorum eliminat, et sordes abluit vitiorum. Eleemosyna quidem est indigenti pietatis intuitu subvenire; cujus quantus sit fructus, Scriptura sacra demonstrat. Nam eleemosyna mundat, eleemosyna liberat, eleemosyna redimit, eleemosyna protegit, eleemosyna postulat, eleemosyna impetrat, eleemosyna perficit, eleemosyna benedicit, eleemosyna justificat, eleemosyna resuscitat, eleemosyna salvat." (MPL, tom. 217, col. 747 A.)

2 "De contemptu mundi," lib. I, cap. r7.

3 "Clamat pauper et nullus exaudit, loquitur dives et omnes applaudunt." "De contemptu mundi," lib. II, cap. 4. (MPL, tom. 217, col. 718 D.)

"Against which he writes strongly: "Every age, every sex, every grade of society, old and young, it invades and corrupts." Lib. II, cap. 2I. (MPL, tom. 217, col. 725 B-C.) 
Thus also in the tract on alms-giving ${ }^{1}$ this virtue is placed before even fasting, ${ }^{2}$ but not because it has social meaning or aids in the redemption of the world, but because of its saving potency for the individual's soul. True it must be done in love, ${ }^{3}$ and in purity of life and conduct, for alms-giving in sin does not help us at.all, ${ }^{4}$ but the end is the soul's own felicity and it must be in obedience to rule. ${ }^{5}$

No wonder that the alms-giving of the Middle Ages corrupted both the givers and the receivers.

As throughout the Roman Catholic ethics, there is a strange conflict between antagonistic conceptions of life when marriage comes into view. The otherwise beautiful ethics of the marriage state proclaimed by Innocent III, ${ }^{6}$ like all the subsequent teaching of Rome, is marred by really pathological estimates of the natural functions of healthy men and women.

On the one hand marriage is made a sacrament and treated as the sweetest image of the holiest relationship of God to his church (following Paul), and on the other it is denounced as a sad concession to man's fallen and wicked condition. ${ }^{7}$ The truth being that the Roman interest in celibacy has always had a political side. To possess an army of men cut off from the natural ambitions of the family and devoted to the maintenance of the Roman imperialism could not but be attractive to men like Gregory VII and Innocent III, whose real faith was in force and power for the organization, however much they might genuinely admire gentleness and meekness in the individual. Hence it was that the imperial ethics of Rome sought eagerly alliance with the ascetic world-fleeing ethics of the monastery.

To comprehend the development of the mystico-ascetic ethics

1 "Libellus de eleemosyna." Migne, "Pat. Lat.," tom. 21 7, cols. 745-762.

2 "Bonum est jejunium, sed melior est eleemosyna," cap. 4. (MPL, tom. 2I 7 , col. 752 D.)

4 "De eleemosyna," cap. 3.

3 "De eleemosyna," cap. 5 .

5 "De eleemosyna," cap. 5.

'Cf. "De quadripartita specie nuptiarum." Migne, "Pat. Lat.," tom. 217, cols. $92 \mathrm{I}-968$.

${ }^{7}$ Whether this contradiction is fundamental in Paul is a mooted historical question. See p. 77 . 
within the church of the Middle Ages we must glance at the rise of the orders whose compromises with Roman imperialism involved both contracting parties in many contradictions. ${ }^{1}$ Without question the whole development was grounded in a very serious attempt to conform to the supposed ideals of the early church, nor can it be that words of Scripture and distinct positions set forth by Biblical writers (Paul and Apocalypse) seemed to bear out some of the most grotesque perversions of the evangelical message.

In the tenth century monasticism was moved by the general spirit of reform and became once more a potent force in the hierarchical church. The old Benedictine orders had been reorganized through the efforts of Berno of Clugny, and the rise of the congregations of Cluny, whose work in purifying the monasteries lasted over a century, ${ }^{2}$ further emphasized the social character of the monastic life. At the same time the attempt to strengthen the cloister by association seemed to weaken discipline, and so a compromise was attempted by the Vallombrosian order (founded in the Vallis umbrosa) which was the first order, as far as we know, to introduce a lay element, not so strictly bound, that the monks proper might live the more strictly contemplative life. This is interesting as pointing to the fact that the motive to founding lay brotherhoods was still rather the vita contemplativa than the social purpose. These

\footnotetext{
${ }^{1}$ Besides the standard church histories and the literature referred to on p. 216 , see special histories of the orders, as by Wadding, Lucas: "Annales Minorum seu trium Ordinum a S. Francisco institutorum," 2 d ed., Rome and Naples, 25 vols., 1731-r860; Mabillon, Jean: "Acta Sanctorum Ordinis S. Benedicti," Venice, 1733 , etc., 9 vols (?); Heimbucher, Max: "Die Orden und Kongregationen der katholischen Kirche," Paderborn, 2d ed., r907 (all from Roman Catholic point of view); Hospinianus, Rodolphus: "De Monachis: hoc est, De Origine et progressu monachatus, ac ordinum monasticorum, equitumque Militarium," I609. For abundant literature, see Hélyot, Pierre: "Histoire des Odres Religieux et Militaires," Paris, 1714-1721, 8 vols.; new ed., Paris, 1792; also in Migne's "Encyclopédie Théologique," tomi 20-23, 1846 seq.

${ }^{2}$ For the work and life of Odo of Cluni, see G. Grützmacher's article, "Cluni und die Cluniacenser," in Herzog-Hauck's "Realencyklopädie," vol. IV, r898, pp. 18r-186, English translation, vol. III, New York, x909, pp. 146-148.
} 
cloisters emphasized for the full membership silence and exceedingly strict enclosure.

But in spite of all new rules and constant reorganization the inevitable result of relative idleness and selfish attempts to save one's own soul reappeared, and so there arose the Cistercians, founded by Robert of Molesme, Io98, at Cîteaux, with a still further elaboration of the congregation conception, and some attempt to distribute the responsibility by compelling the attendance of all the abbots of the order at a kind of parliament. What might have happened to these powerful and wealthy, yet really corrupted and corrupting oligarchies had they gone on without rivals it is quite impossible to say. Roman imperialism feared them while it used them, and Innocent III was directly responsible for the drastic action of the Lateran council

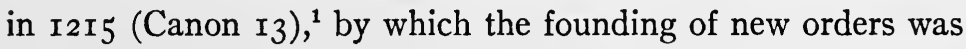
forbidden, and all wishing to enter the monastic life were commanded to submit to a rule already approved.

The force of events, however, was too strong for Innocent III. There had existed from early times what were probably survivals of older types of piety. They were scattered as sects all over the Christian world under various names and no doubt with many shades of doctrine. ${ }^{2}$ Under the name of the Cathari, or Pure Ones, ${ }^{3}$ they gathered force in southern France and Lombardy. They sent out missionaries two by two, with preaching and teaching of an undoubtedly mystic piety, with primitive memories, and with the New Testament taken ignorantly and literally.

Among them the perfect $i$ were bound to a very strict asceticism, and the teachers enjoyed a high regard in the people's mind. As over against the wealth and aristocracy of both the Roman

${ }^{1}$ Hefele-Knöpfler: "Conciliengeschichte," 2d ed., I886, vol. V, § 647, p. 886.

2 The essentially dualistic type of thought is assumed by most historians (Littledale-Harnack), and is set forth by Hefele-Knöpfle: "Conciliengeschichte," vol. V, 2 d ed., I886, $\$ 645$, pp. 827 ff., on the basis of the researches of Schmidt, Charles: "Histoire et Doctrine de la Secte des Cathares ou Albigeois," Paris, I849, 2 vols.

${ }^{3}$ ka $\theta a \rho \circ l$, whence the German word for heretic, ketzer. 
hierarchy and the allied monastic system these sectarians threatened to become a people's church. Had Peter Waldo's proposals to Alexander III, in II79, been accepted, the whole movement might have been as successfully bound to Rome's purpose as the older movement was in the days of Athanasius. But this was not to happen in exactly that way. Under Innocent III, however, the sectarian movement had grown beyond the power of papal persuasion, and Dominic de Guzman began the famous movement, started on a different level and with different inspirations, but at the same time by Francis of Assisi, by which the cloistered monk became an itinerant friar and the older Gnostic speculative piety was re-enforced by the new life of the monastic reformation.

In reading the account of the "errors" and "heresies" of the Cathari and Albigenses as given by Hefele, the ordinary mind is at a loss to see where in its popular presentation the message of these sectaries greatly differed from that of St. Francis of Assisi ${ }^{1}$ (II82-I226), save in the more thorough-going acceptance of the dualism which underlay both. The two orders rose out of social purpose, and had their strength in the missionary zeal with which they sought to advance the interests of the kingdom as they saw it in the hierarchy. Their success was so immediate and their loyalty to Rome was so unquestionable that in spite of the Canon XIII of Lateran both orders were launched and soon were as petted and as spoiled as all the others. The mystic speculative ethics, as we have seen, was a part of the teaching of the two famous Dominicans, Albertus Magnus and Thomas Aquinas, but did not organize their thought. In the Franciscan teacher Bonaventura the systematic and intellectual elements fall into the background and the mystic piety does actually control the system.

The fact that this mystic type of piety has been from so early a date a possession of the church, and that it has certain æsthetic

${ }^{1} C f$. the admirable life by Paul Sabatier: "Vie de S. François d'Assisi," 8th ed., I894. Exceedingly well translated into English by Mrs. Louise S. Houghton, New York, I894. 
leanings which enable it very readily to ally itself with religious sentiment and feeling, as well as the fact that it has been a feature of many marked religious awakenings, hides from many, even to-day in Protestant circles, its essentially Gnostic character. On the ethical field nothing is so remarkable as its studiously maintained lack of freshness and originality.

The two most influential formulators of this method of thought are Bernard of Clairvaux ${ }^{1}$ and Bonaventura, and though both men were really great souls and most extraordinarily useful as leaders of the religious life of their day, they are painfully unfruitful in the field of systematic ethics.

Bernhard, in his five books of pious direction to Pope Eugene III, moves in the conventional lines laid down by the practical life of the monastery. The active life is a concession, the real life is the contemplative one. The mystic elements in Augustine receive some new emphasis, but there is really nothing new in the treatment. The end of life is the love of God for his own sake, which is the third stage of man's progress from selfish love to unselfish love of God, for his own sake. ${ }^{2}$ The ascetic life

\footnotetext{
${ }^{1}$ Bernard of Clairvaux (I090-I I53), of good family and with an exceedingly pious mother. He was born at Fontaines, near Dijon, and in the "life" given first in Migne, "Pat. Lat.," tom. I85, cols. 225-467 ("Vita," liber primus. Auctore Guillelmo), are related stories of early piety. He became the reformer of the monastic life through his connection with the new monastery at Citeaux, and he went out from it to found a connected monastery at Clairvaux (Claræ-Vallensis), and though he never was the actual head of the order, as he refused to leave Clairvaux and go back to Citeaux, he was the life of the Cistercian movement. He was the adviser of kings and popes, and really seated Innocent II upon the papal throne by his opposition to Anaclet II, who was probably the canonically elected Pope. Of his many genuine writings those that interest the student of ethics most are his letters ( $c f$. Epist. XI and XXXIV) and "De consideratione," "De moribus et officio episcoporum," "Liber ad milites Templi de laudi novæ militix," "Tractatus de gradibus humilitatis et superbiæ," and the "Sermones." Migne, "Pat. Lat.," tomi 182 and I83. For wellnigh complete bibliography, see the admirable work of Leopold Janauschek: "Bibliographia Bernardina," Vienna, I89I, and the still useful monograph by Neander: "Der heilige Bernhard und sein Zeitalter," 3 d ed., Gotha, 1865; new edition by S. M, Deutsch, Gotha, I889, English translation by Matilda Wrench, London, I843; Storrs, R. S., "Bernard of Clairvaux," I892.

2 “Non jam propter se, sed propter ipsum.” Epist. XI, \& 8. (MPL, I82, II4 A.)
} 
is the ideal, and to be chosen before all other. ${ }^{1}$ Contemplation of the mystery of God in his oneness and threeness is of the highest religious value. ${ }^{2}$ The Song of Songs mystically interpreted is the key to heavenly love and its light and meaning, and in Bernhard's sermons on the canticles is gathered up the dreamy, half-sensuous, half-speculative rapturous piety which is so marked a characteristic of the monastery life. ${ }^{3}$

There is a threefold perfection of the soul, as is seen in kissing the feet, the hands, and the mouth of the Master. ${ }^{4}$ Rhapsody and absorption in divine exercises form the pinnacle of the religious life, ${ }^{5}$ and the æsthetic side of the service has great significance and attraction for Bernhard as for Innocent III. ${ }^{6}$ It is quite worthy of note how distinct a place the sacraments have in this type of thinking. They are an æsthetic means toward the esctasy which is the goal. In mystic scholasticism the magic elements in the sacramental teaching are variously emphasized. In the more intellectual types they are minimized, but in the æsthetic, sensuous types they almost become central. ${ }^{7}$

Bernhard cannot be classed as among the intellectual organizers of mystic scholasticism. Instinctively he feared the rational process, and his attack upon Abelard was, no doubt, a result of that fear. He was an agitator and organizer. His effective work in arousing men for the miserable crusade which cast a shadow over his last days is evidence of his preaching powers. His influence, however, was religious. Like Augustine, he was

\footnotetext{
'Epist. XXIV; $c f$. also the tract "De gradibus humilitatis." Migne, "Pat. Lat.," tom. 182, cols. 94I-972.

2 "De consideratione," lib. V, cap. I3. Migne, "Pat. Lat.," I82, cols. 804805 .

"Sermons in canticæ." Migne, "Pat. Lat.," tom. 183, cols. 779-1198.

4 "Sermo," IV. (MPL, I83, 796-797.)

5 "Sermo.," VII, 8o6-8ro.

" $C f$. the interesting little dialogue on the church music, Migne, "Pat. Lat.," tom. 182, cols. Ir 53-1 66 .

${ }^{7}$ This asthetic element is seen in Bernhard's excessive devotion to the Virgin Mary. Cf. the prayer Dante puts into his mouth in "Paradise XXXIII," which Professor Marvin R. Vincent calls "one of the gems of literature." Cf., also, Vincent, M. R., "Age of Hildebrand," chaps. XVI and XVII.
} 
a religious genius of the first class, ${ }^{1}$ but the Platonic-mystic elements are taken unsystematically.

This is not the case, however, with the great Seraphic Doctor, Bonaventura. With him, following in the footsteps of the "Sentences," all is systematized, and everything said under divisions of three or seven or ten, sometimes to the obliteration of all finer shades of difference. From the point of view of ethics he is profoundly disappointing. The Stoic ethics are but feebly warmed by the mystic emotional piety, and there is lack both of intellectual sharpness and of real ethical insight. The scheme of the little ethical treatise, "De decem præceptis," illustrates his method.

It is divided into two parts. One of these deals with the motives for keeping the commandments, the other with the commandments themselves in general. Under part one he sets forth four main motives for keeping the commandments. First the authority of the law-giver, because he created us, rules us and saves us. Secondly, the keeping of the commandments has a threefold usefulness, the imparting of the gifts (charismata), the revelation of Scripture, and the assignment of rewards in heaven. Thirdly, there is a threefold peril in transgression,

${ }^{1}$ Harnack calls him "Augustinus redivivus," "Dogmengeschichte," vol. III, 3d ed., p. 314; English translation, vol. VI, I899, p. го.

${ }^{2}$ Bonaventura, Giovanni di Fidanza, r221-r 274. Born in Italy of humble parents, and the champion of the Franciscans in their rivalry with the Dominicans. He is said to have been a pupil of Alexander of Hales, though this is doubtful. (Hales died in r 245.) His main teaching was in Paris, and as general of his order he exercised a wide influence for good. The editions of his works most cited are those of Lyons, 7 vols., I668; that of A. C. Peltier, Paris, 1864-r87 I, I5 vols., and the new edition, Claras Aquas, 1882-1902, ro vols. "Opera omnia jussu et auctoritate Fleming, David P." In the tenth volume is an essay on the life of Bonaventura, vol. X, pp. 39-73, with admirable condensed references to all the sources of information. The indices are in the fifth volume for vols. I to IV. Besides the general ethical interest of the "Sermones," vol. IX, I 901 , the writings of special interest to the student of ethics are the comments upon the sentences of the Lombard that deal with ethics especially, namely, his commentaries in "Distinctionem XXIII,", and on through the cardinal virtues, vol. III (Claras Aquas edition), pp. $460-731$. And also in vol. $\mathrm{V}$ is a neat little ethical treatise on the Ten Commandments, "Opuscula varia," 1891, pp. 307502. The mystical writings are gathered together in vol. VIII, pp. $3^{-159 .}$ 
namely, we lose the best of good gifts, we rush into degrading sin, and deserve eternal punishment. Fourthly, the legitimate character of the commandments is seen in that they demand nothing that is impossible or burdensome or iniquitous.

The second part is given up to a general discussion of the duties to our God and our neighbor, and it lacks both grip and freshness. The first table makes three demands, with reference to the triune God, and the second table deals with our relation to man. The ethics are weak and individualistic and ever haunted by the consciousness that the native virtues are in the second place and are a mere means to an end. ${ }^{1}$ The ethics of the preceding treatise on the seven gifts of the Holy Spirit ${ }^{2}$ are even more confused, and mingled with the theological material which is always the first interest.

The mystical writings ${ }^{3}$ reveal nothing new. In the "threefold way" there is set forth the threefold progress of the soul by purgation and illumination to perfection. The way of reaching this is also threefold, $i$. e., by reading and meditation, by prayer, and by contemplation." The "Soliloquium" is a dialogue between a man and his soul, and the exercises suggested remind us painfully of the Indian fakir, only he does the thing more thoroughly and more scientifically. The rules laid down are, in fact, nothing more than the methods for self-hypnotism by concentration and auto-suggestion.

The cult of "Jesus and Mary," with all its weakening and unethical motivation of life, pervades both the theology and the ethics of these mystic writings. How unreal the ethics are may be seen in the little tract, "Lignum Vitæ," 5 which has played a great part in Roman Catholic piety, where sentimental pity exhausts itself in vain longing and fruitless tears. Indeed through-

1 "De decem præceptis," collatio I, opera vol. V (Claras Aquas edition), pp. 507-532.

2 "De septem donis spiritus sancti," opera vol. V, p. 457.

3 These are gathered together in vol. VII, pp. 3 to 159 of the Claras Aquas edition.

4 "De triplici via," vol. VIII, opera omnia, p. 3.

5 "Opuscula mystica," vol. VIII, p: 68. 
out Bonaventura the strong feeling is that mysticism is a mere disturbing element attempting, indeed, a reconstruction of the thought without really reaching it.

\section{THE ETHICS OF "GERMAN" MYSTICISM"}

The so-called German mystics are in reality simply those who laid hold upon the metaphysical mysticism present from Augustine on in Catholicism and worked it out in various degrees and with different emphasis. When Harnack identifies mysticism with Roman Catholic piety, "save only in so far as it was not fides implicita," ${ }^{2}$ he seems to the writer to make the definition of mysticism too wide.

The simple, sweet trustfulness of Francis of Assisi in his loving attempt to do as Jesus and his apostles had done had no philosophy of ultimate reality in it. This trustfulness and longing after God is not "mystic" or "Catholic" or "Protestant" or "German," it is religious, and breathes throughout all mediæval piety in its prayers, hymns, and simple works of mercy and devotion. Only when this trustfulness and longing unites itself with a distinct theory of union with the source of all being in some metaphysical sense do we have the basis for the extraordi-

${ }^{1}$ The enormous literature of mysticism sadly needs sifting. For the history of Middle-Age mysticism, see among the older works: Schmid, Heinrich: "Der Mysticismus des Mittelalters in seiner Entstehungsperiode," Jena, 1824; Preger, Wilhelm: "Geschichte der deutschen Mystik im Mittelalter," 3 parts, Leipsic, 1874-1893. See also the article, "Mysticism," by Andrew Seth, in "Encyclopædia Britannica," gth ed., Scribner's, New York, 1884, pp. 128-135, and the article, "Theologie, mystische," by S. M. Deutsch, in Herzog-Hauck's "Realencyklopädie," vol. XIX, Leipsic, I907, pp. 63I-644, and the several sections in Harnack's "Dogmengeschichte," especially vol. III, 3d ed., pp. 392-40r; English translation, vol. VI, Boston, 1899, pp. 97-108; Gregory, Eleanor C.: "An Introduction to Christian Mysticism," London, 190r; Swainson, William P.: "Christian Mystics," vol. I; "Francis of Assisi, Saint and Mystic," London 1903; Langenberg, Rudolph: "Quellen und Forschungen zur Geschichte der deutschen Mystik," Bonn, 1902. Some material also in Baron Friedrich von Hügel's "The Mystical Element of Religion as Studied in St. Catherine of Genoa and Her Friends," 2 vols., London and New York, r9og. See also p. 343. 2 "Dogmengeschichte," vol. III, p. 392, 3d ed., English translation, vol. VI, 1899, p. 98. 
nary development which is alike constant in its reappearance and monotonous in its inevitable outcome.

The "ethics" of the so-called German mystics is not separate from the ethics imported into the north by the church. The only thing that seems in any way characteristic is the overweening individualism, and the dependence upon Neoplatonism as interpreted by Dionysius the Areopagite. And what is most striking is the monotony of the teaching. Love is thought of as feeling; and emotion, ecstasy, and rapture are means to the ultimate knowledge of and union with the final reality. No genuine ethics could develop out of mysticism so defined, hence the ethics of the mystics is simply what they found in the religious life about them, thought of generally as a means to their end, with the speculation, more or less vague, which gives character to mysticism.

Two of the earliest works of mysticism on German soil are "Das fliessende Licht der Gottheit," by Mechthild of Magdeburg (about I 273), edited by G. Morel; "Offenbarung der Schwester Mechthild," Regensburg, I86r, in which fantastic piety is mingled with metaphysical phrases, half understood, borrowed from Dionysius. Nor can one say much more of Meister Eckhart (I260-1329). Like Heinrich Suso (I295-I366), there is nothing novel in their teaching save that it is in the language of the people. Union with God as essential substance, and the attainment of this union by abstraction and esctasy, form the groundwork of the teaching. In Johannes Tauler (I300-I36I) the mysticism proper is mingled with æsthetic and religious elements, and Catholic piety as it developed on German soil, with a strong sense of the worth of the soul and keen feeling of separation from God in conduct, makes itself manifest. The sermons of Tauler are, however, Roman Catholic and not Protestant, nor in any sense a foretaste of real Protestantism. The same may be said of the whole movement of the "Friends of God," identified with Nicholas of Basle, and the "Brethren of the Common Lot," with Gerhard Groot (I340-1384). The teachings of poverty, of -communism, of self-denial, etc., have 
underlying them what we have seen was characteristic of monastic piety generally. It had no social or ethical significance apart from the general Roman Catholic teaching at this point.

The elements of inwardness and trustful relationship with God, which give such books as "Teutsche Theologie" ${ }^{1}$ and the "Imitation of Christ" permanent value, are not inseparably connected with the Neoplatonic conceptions which underlie them both, and which in the last analysis they falsely (historically considered) identify with the teachings of the New Testament. In a history of mysticism it would be proper to trace the ethics taught by the several mystics to their source, but mysticism has no important contribution of its own, nor is it in point of fact in a position to render such service,-for reasons already pointed out (see page 350). Hence we pass over what is an important chapter in the history of Roman Catholic piety but which has no special ethical interest. ${ }^{2}$

${ }^{1}$ Well translated by Susanna Winkworth, "Theologia Germanica," Andover, 1856 , etc.

2 The reader should recall the author's definition of mysticism (p. 342). It is the failure to keep to some consistent definition of mysticism that renders most discussion of it so irritating and fruitless. Even Baron von Huegel, in his interesting second volume on "The Mystical Element of Religion," is constantly talking of elements common to all religious experience as if they were peculiar to the mystical type of that experience. 


\section{CHAPTER VII}

\section{THE ENGLISH REFORMATION AND ITS ETHICS}

Note of Introduction.-(a) General Conditions of the Reformation; (b) The Special Conditions in England-I. The Ethics of the Forerunners of the Reformation-II. The Ethics of Puritanism-III. The Ethics of Anglo-Catholicism-IV. The Ethics of Independency

-V. The Ethics of Philosophical Protestantism (in England).

\section{NOTE OF GENERAL INTRODUCTION}

\section{THE HISTORICAL CONDITIONS OF THE REFORMATION}

It is only for temporary human purpose that history can be divided into chapters and sections. The Reformation, from one point of view so dramatic and sudden, was in reality but the fitting climax to a long series of innovations. There are no single causes and no single effects. The historian can only describe the conditions under which history works itself out. In the description great personalities will always be in the foreground, partly because the dramatic element is strong in us all, but chiefly because every historical movement has its highest interest for us when it becomes incarnate in a great personality.

It is alike vain and unscientific to ask whether history is the creation of great men or of the conditions under which all men work. It is neither one nor the other. It is the story of the actions and reactions of human purposes upon the conditions under which alone those purposes can realize themselves. The age that gives us genius is not the creation of that genius, but an age has only its highest interest for us when some child of genius formulates and incarnates its manifold purpose, and to the outlooker the thousand-and-one conditions which made the 
work of genius possible are hidden by the interest of the personality.

From one point of view the Reformation may be said to have begun with the Council of Constance (I4I4), or the nailing of Luther's theses to the church door ( $I_{5} I 7$ ) over a hundred years later; but these are only important episodes in the birth of a new human spirit, steps which the race in western Europe was taking to a larger, diviner freedom and life. We cannot regard it as our special task to describe the historical conditions that made Wyclif or Luther possible. The standard histories are in a much better position to do this than the special historian of ethics. Nevertheless, we must, however briefly, glance at the outward conditions under which that new world was forming, which sought intellectual and ethical formulation in the Reformation period.

One of the foremost factors in the determination of Europe's political character was the fundamental struggle between the East and the West. In the growth of Mahometanism the West was challenged, and the crusades bore this special mark because, amid great and growing diversity of tongue, of interest as well as of race, religion still gave the largest and firmest basis for united action. Not that the crusades were wholly religious. The most eloquent preaching of Peter the Hermit and the most convincing arguments of the Pope could not have aroused Europe had not material interests, such as a growing trade, increasing population, and political restlessness given the crusades ${ }^{1}$ an especial significance. As Europe ceased to seem homogeneous and began visibly to separate

\footnotetext{
${ }^{1}$ For the literature, consult Emerton, Ephraim: "Mediæval Europe, 8141300," Boston, 1894, chap. 14, pp. 477-508; Kugler, Bernhard: "Geschichte der Kreuzzüge," Berlin, I880 (in Wilhelm Oncken's "Allgemeine Geschichte in Einzeldarstellungen," abt. II, vol. V); Prutz, Hans: "Kulturgeschichte der Kreuzzüge," Berlin, 1883; Henderson, Ernest F.: "Secret Historical Documents of the Middle Ages," book III pp. 333, etc., London, I896 (Bohn's “Antiquarian Library"); Robinson, James H.: "An Introduction to the History of Western Europe," Boston, 1903, chap. 15; Duruy, Victor: "The History of the Middle Ages" (English translation of the $\mathrm{r} 2 \mathrm{th}$ edition by Whitney, with notes by Professor Adams, New York, I89r, book VII, pp. 26I-304.
} 
into organized and differing groups, trade routes and access to the sea became determining elements of the social and political life. The church, like imperial Rome, hạd stamped a certain cosmopolitan character upon her agents. She alone was in a position to summon Europe to a defence of Western culture. Yet even while she did this, the crusades both weak ened Rome and strengthened nationality. They weakened Rome by the exaltation of the military power and by bringing again an Eastern culture into direct contrast and contact with her own life (Arabic scholarship, etc.). Nationality was strengthened by the actual losses on the battle-field of the cosmopolitan military ruling class. The story of the relationship between commercial Judaism and the crusades, and of the growing power of this intellectually and spiritually highly gifted race from the time of Agobard's first anti-semitic outbursts (see page 290) to the time of Reuchlin, who was accused by his Catholic enemies of being paid by the Jews, has yet to be written. Instinctively ecclesiasticism recognized the Jews as a rival power, in that they offered a commercial cosmopolitanism as a substitute for the ecclesiastical bond. The enormous development of trade routes and seaport towns due to the crusades laid the foundation for that new industrial Europe which is even now transforming human thought and ideals.

The crusaders brought back from the East new science, new art, and many new inspirations, but also new vices and new doubts. On the principle that the best defence is a swift attack the crusades were not wholly failures, although at the end the Holy Sepulchre was still in Moslem hands. The crusades did, in fact, break the power of Mahometan invasion and stay the onward rush of Eastern culture.

They also shook the imperial papacy, partly by their relative failure, but still more by transferring the power of government to the armed secular force. Heroism and demoralization walked hand in hand. The saint and the runaway serf both fastened the cross to their sleeves, and democracy advanced as the fearful mortality of the Eastern wars carried off the flower of feudalism. 
The trading free city grew from the lowly beginnings of fortified camps and centres for protection along the main thoroughfares, until it became a menace to the feudal land-owning nobility. The Middle Ages are full of the struggle for freedom and selfregulation on the part of the city, a struggle which not even the concessions of von Stein ${ }^{1}$ have yet quite ended in Germany. The crusades undoubtedly aided the growth of these centres, and the seaport republics, like Venice and Genoa, almost owed their greatest days to the supplying the needs of crusading armies.

Feudalism was weakened by the encroachments of the free city on its life, and the increasing power of nationalism has never been a strength to cosmopolitan imperial Romanism. True it is that she has at times played off nation against nation, but in the end she has always lost the game. When one reads of Cardinal Richelieu making war one year on the Huguenots and the next year a treaty with Christian IV to save what was left of Protestantism in the north of Europe, one realizes how far the national and dynastic interest, even in Roman Catholic France, outweighed the imperial dreams of Rome.

With this feudalism Roman Catholicism is firmly knit together. In every land where feudalism has been overthrown her ecclesiastical polity is an exotic (United States, England, France, and even Italy), and the weakening of feudalism in the lands she still dominates goes hand in hand with diminishment of her power.

The fixing of the final boundary between East and West by the fall of Constantinople (1452) and the recapture of Granada (1492) cleared, as it were, the way for the internal revolution, which we call the Reformation. Men's minds were so far set at rest and the fear of Moslem invasion has never since gravely affected the nerves of Europe. Now men began to seriously ask questions both of nature and of history. The spread of a new spirit of inquiry has been called the Illumination. And

\footnotetext{
1 Maurenbrecher, Max.: "Die Hohenzollern-Legende, Kulturbilder . . . aus dem 12 bis zum 20 Jahrhundert." vol. II, pp. 624-634, Berlin, I905 and I906.
} 
this "Aufklärung" has its own special literature." It is easy to see how bitterly the small nobility felt in the early stages of the Reformation, and both in England and Germany signs were not lacking of a disposition on the part of the smaller aristocracy to make common cause with the proletariat in their revolt against feudalism. It could, indeed, only be a temporary fellowship, and such leaders as Oldcastle in England and Franz von Sickingen in Germany soon found themselves hopelessly outnumbered by the instant alliance of monarchy, middle-class, and larger nobility, overwhelmed by the dread of the proletariat, just as, in the past, all classes at Rome could be instantly united by the dread of a servile war.

The ignorance of Greek before the Illumination has probably been overdrawn. At the same time the crusades and the fall of Constantinople did undoubtedly greatly increase the interest in Greek and heighten the curiosity as to the sources of the culture possessed only at second hand by the great scholastics. The break with Latin was coincident with the rise of national tongues, giving birth to their own literature. Dante in Italy sang the scholasticism of Thomas of Aquinas in the entrancing strains of a native Italian, and mingled with mediæval Aristotelianism something of Cicero's ethics. Petrarch almost frankly tried to substitute the ethics of later Greece and of Rome for what passed as Christian ethics. Boccaccio had still fewer scruples, and, so far as he was at all interested in ethics, those of Stoicism and Epicurus were far more to his mind than Albertus Magnus or Thomas Aquinas.

Yet the great humanists had no wish to break with the church. Valla, Erasmus, and Reuchlin needed, indeed, more intellectual and artistic atmosphere, but to reform the church from within was their ideal, and the Reformation was the responsibility of the church authorities rather than of humanism. Humanists had, they thought, but one task and high privilege. To human-

${ }^{1}$ In Reuter's "Geschichte der Aufklärung" the older literature is given, and in Robinson's "Introduction to the "History of Western Europe," pp. 352-353, additional English works are given. 
ism was intrusted the new culture and the new art and the new learning.

It is impossible now to say whether any reformation of the church could have come out of the scorn and scoff of humanism alone. Certainly, however, the Reformation in its ethical earnestness and intense, even if often narrow, religiousness, could not have sprung from humanism, and was even on its finer sides misunderstood and suspected by the men trained in humanism.

It made ready the way, however, for the Reformation. The Greek Testament was its most precious gift to the cause. Save for men like Reuchlin, Hebrew and Old Testament learning would never have stood where they were when Luther and others opened at last the chained Bible. Nor is it just to lay the blame of the paganism, which is all too apparent in the pages of humanist writers, at the door of humanism. Reuchlin was no pagan, nor was Erasmus one. Paganism was found in Rome as well as in humanism. The unnatural vices and the debauchery which soil some of the pages of humanism were, alas, part of the decay and degeneracy which long lack of moral guidance had produced. There is good reason for believing that the monastery system, after the heart had gone out of it, was the home of the foulest sin, and needed no humanism to teach it the vices of Rome and Athens. The Council of Constance is a standing witness to the abuses and debaucheries of the existing ecclesiastical situation.

The fact was that no intellectual system could save the world. There had to be a new birth, a new baptism of fire and earnestness, a new faith in things unseen and eternal. The Reformation has been far too much estimated in theological terms. Protestant theology was a distinct advance upon the scholastic systems, but rather in its negations and omissions than in its positive contribution. And in comparing the best Protestant systems with the best scholastic ones, the student may sometimes feel a distinct sense of disappointment with Protestantism. The fact remains that the Reformation was a new birth and a new 
baptism, both of what we now call Protestant Europe and of Roman Catholicism.

Christianity entered upon a chapter in its life's history which is not yet fully written. This chapter is dominated by Protestantism, more especially upon its ethical side, and although we shall have to trace ethical development in Jesuitism and the Jansenist movement, the Roman church has more and more identified herself with the scholasticism of the Middle Ages, and the ethical development in her thought has been rather unconscious than systematic.

It only remains to say a word about the morality of the world's life before the Reformation. Were men and women better or worse than in preceding centuries? The question cannot be categorically answered. The outward morality of the days before the Reformation can be painted in very dark colors. There is no question about the existence of a shocking amount of violence and vice. But we have no statistics, and even if we had there is no more difficult and dangerous task than the ethical interpretation of statistics. Increased notice of crime may mean increased sensitiveness to it and not increase of the crime itself. Some things are unquestionably true. Life was cheap. The roads were insecure. Private warfare was common and frightfully cruel and demoralizing. Duelling was universal in the better class, fighting and brawling in both better and lower classes. Monks, friars, and priests were suspected of the lowest passions: and many were the tragic histories wept over in cloistered cell and monastery prison.

The mere story of Abelard's life shows how darkly the picture may be drawn. Capital punishment, inquiry by torture, brutal injustice, and mad revenge all reflect themselves in the pages of story, poem, and history. However, these things stirred men then as they do now, and must have been in great measure, then as now, exceptional as compared to the great mass of human life. There were, no doubt, thousands upon thousands of happy, peaceful, prosaic lives with unquestionably great limitations; yet limitations are relative and the consciousness of them very unequal. 
There are some things that mark themselves powerfully in the ethics and the religion of the days just before the Reformation. Death was markedly premature. Life was burdened by the dread of pest, war, and sudden death through the uncontrolled forces of nature. Probably in a well-ordered community where nine out of ten of the adults lived out life to its full present limit, the fear of death would give way to a distinct sense of its welcome release from weakness and dependence. What weighs on adult minds is only the fear of premature death, with the result of dependent women and children, unfinished work, and capacities for usefulness and enjoyment undeveloped and untried.

Heaven, hell, and purgatory played a far greater part in the Middle Ages than they do now. They were needed to complete in fantasy the unfinished lives that were all too common. The question, however, is an interesting one, whether they played any really serious part in the encouragement of virtue or the restraint of vice. So far at least as one can observe, their practical disappearance as ethical motives from the lives of educated men and women to-day has not changed the ethical character of the daily life of such.

To this dread of premature death and judgment may be due the sombre character of so much of the church literature and even of the people's poetry. The northern sagas are full of longing after a fuller and freer life. In this respect both Protestantism and Catholicism, after the Reformation had drunk of the spirit of the newly awakened humanity, show a marked improvement. There is a note of joy and elation in Chaucer, Spencer, and Shakespeare, as in Boccaccio and Valla, which belongs to the newly found faith in humanity and its future. This note is found, indeed, in almost every religious awakening. Paul cries out, "Rejoice in the Lord always, again I say rejoice," and Francis of Assisi calls upon the little brother birds to help him express his joy. In Tauler, in Erasmus, and in Luther the note is not lacking. The great forward movement of the race began, indeed, with the low, soft note of the nightingale, but the lark's triumphant outburst marks the new day spring from on high. 
The disappearance, practically, of chattel slavery, an economic advance with which Christianity had little or nothing to do, and its merging into serfdom and then free labor, must have greatly affected the moral standards and the objective morality of the day; But we are not in possession of the facts. The outward face of the matter was at first gravely discouraging. Peasant revolts, dreadful suffering, the breaking of old ties between masters and servants, hate instead of trust, treachery for loyalty, discontent and suspicion, misery and helplessness mark the transition period.

It is at least doubtful whether on the Continent or in England the immediate effect of the Reformation was not seemingly ethically disastrous. The reaction from liberty to law which marks Calvinism and the Jesuit counter-reformation had the roots of its power in men's fears before the immediate results of the demand for ethical autonomy and the breaking loose from old bonds. It was at this time that the most fearful and dramatic scourge of sexual sin made its appearance and spread misery and suffering all over Europe. ${ }^{1}$ If, as now maintained, it came back with Columbus on his first return from the West Indies, Europe paid a bitter price for the discovery; for bad as this awful scourge is even now, it is mild compared to the disease on its first appearance. ${ }^{2}$ The sexual excesses of the days immediately following the Reformation may not have been worse than just before, but undoubtedly sexual standards were changed, and that there was temporary confusion and uncertainty Protestantism can well afford to admit. In fact it would have been strange if this were not the case.

In a view of the world where the married state is regarded as inherently inferior, standards of sexual morality are formed which give way at once when that view is rejected. It takes time to form ethical norms, and that a generation found itself

\footnotetext{
${ }^{1} C f$. Professor Ed. Lesser (Berlin), "Neue Forschungen über eine alte Krankheit," in "Internationale Wochenschrift für Wissenschaft, Kunst und Technik," I Year; No. ro, June 8, Munich, r907, p. 317.

${ }^{2}$ Cf. Ulrich von Hutten's description and the literature cited in Professor Lesser's paper.
} 
singularly without guidance is evidenced, as we shall see, in Luther's own discussion of the matter. At the same time the rapid spread of the sexual scourge we have noticed shows how loose was the morality of Europe long before the Reformation or even the demoralization of the Thirty Years' War.

It was upon this world that saw gun-powder enter the actual field of war, that learned of a new continent beyond the seas, that found new freedom in the printing-press and new fields for the individual in the self-government of the Free City that the Reformation broke. Its beginnings lie far back. Wyclif's preachers were suggested, in part at least, by the early Franciscan friars, and as England had longest maintained the forms of the early Bishop's church, so it was chronologically first in England that the elements of the Reformation are apparent.

THE ETHICS OF THE ENGLISH REFORMATION

Introductory Note

One of the great forces at work in the transformation of the Middle Ages was, as we have seen, the rise of the national feeling. As early as the ninth century the division between the language of cultivation (Romance) and the vulgar (Deutsch) speech had begun to be on national rather than class lines. In England the nation rose out of a mingling of many peoples, and the island character of the country contributed to the rapid blending of varied elements. At the same time the amalgamation has never been complete, ${ }^{1}$ although the elements making for unity have been on the whole greater than those telling for division. England has developed along lines strongly individual on the one hand, and on the other hand has conserved many useful primitive virtues and opinions. That this relative isolation involved loss as well as gain need hardly be disputed.

One of the marked influences of this separation from continental interests was a strong feeling of nationality, particularly

1 For amusing evidence of England's conciousness of being a mixed race, see De Foe's "True-born Englishman, a Satire" (eighteenth century), London, I7or, and other editions. 
among the plainer people. The aristocratic Norman element still thought of itself as linked with Europe, and England's possessions in France made her aristocracy cosmopolitan, imperial, and Roman Catholic. For the common man, however, the French wars were often an insufferable burden, and though profoundly Catholic in his faith he felt that there was a British church and an independent tradition.

When, then, an English ethics begins to emerge as a separate line of thought from mediæval scholasticism, the dominant note is political and the leading inquiry is as to the foundation of authority and the origin of dominion. Practical religious and political wants mark the progress of England's ethical development from Wyclif to Wesley. This immediate practical aim as over against the theoretical and scholastic temper may be a result of the national character, though this the writer doubts, but certainly it is bound up with immediate pressing questions which sought insistently for an answer.

The ethics of English Protestantism has nevertheless its roots deep in scholasticism. The influence of mediæval culture has nowhere left more permanent memorials than in the centres of English intellectual life, London, Oxford, and Cambridge. Moreover, Scottish Protestantism, in spite of its intense reaction along some lines against mediæval scholasticism, has through the influence of Calvin remained bound hand and foot at important periods of her development to a scholastic, authoritative, and aristocratic view of life.

Here again some would maintain that the Celtic blood had something akin to Roman Catholicism, but the political and economic factors seem the more influential ones. The habit of practical compromise has been painfully and bloodily forced home upon the English mind. Freedom of opinion has been bought with a bitter price, and thus it happens that in her ethics England exhibits, on the one hand a remarkable independence, and on the other a curious refusal to press home the accepted axioms as a French thinker would be likely to do.

Then again English thought has had such direct and imme- 
diate relation to political action that a certain conservatism was bred of the responsibility this involves. Up to Fichte, the German intellectual life was almost entirely apart from political activity. It had its own rules and canons, and often seems to have purchased freedom in the things of the spirit by surrender of the more material liberties. It is almost with impatience that the English mind views the elaborate speculative systems that France and Germany have given to the world. Intellectual empiricism has been the legitimate offspring of England's system of political compromises, by which alone the heterogeneous elements which constitute her life have been held together for national purpose.

The ethics of English Protestantism cannot be sharply separated into those of organized Christianity and purely philosophical systems. We must deal with men like Hobbes and Hume, although to characterize their morality as Christian is to extremely strain this long-suffering predicate. Happily the systems of many of the more distinctly philosophical writers, like those of Hume, Adam Smith, James Mill, etc., are so well expounded in other pages, and so familiar in English literary history, that we can afford to deal with them only as they affect our more immediate interest, namely, the history of ethics within organized Christianity.

In point of fact, systems of ethics within the church and professedly built upon the teachings of Jesus are often further away from his ideals than noble systems, like that of John Stuart Mill, for example, which are drawn up in conscious antagonism to all revealed religion as that term was generally understood among Englishmen. The philosophical utilitarianism of Mill really comes much nearer to the Gospel ideal than the coarse eudæmonistic appeals that have so often marred even high types of Christian thought.

The character of the national church has also been forced upon it by political exigency. The existence of non-conformity has compelled the established church on the one hand to emphasize her exclusive claim to be "the" church, and on the other 
to make membership within it as easy as possible. We cannot therefore, set aside systems of ethical thought within this all-embracing Protestantism simply because they do not carry an ecclesiastical stamp, nor can we make the description "Christian" depend upon the attitude assumed to some purely theological formula.

The main lines in the history of our subject are fairly well marked. We shall deal first with the early reformers within the church, although their followers were often driven out, and we have happily in the writings of Wyclif, Tyndale, and Hooper typical examples of the thinking along these early lines. After the political reformation by Henry VIII, which had been only made possible by Wyclif and Lollardism, ${ }^{1}$ three great separate movements appear in English ethical thinking. Puritanism arose with its peculiar and perhaps unfortunate reflection of Geneva and political Calvinism. On the other hand AngloCatholicism rises to the defence of many things Puritanism spurned. With a separate history, and often with another economic background, separatism or Independency begins slowly to come to self-consciousness. It will be only possible to take leading and characteristic examples along these three lines, and we may do this the more cheerfully because the ethics were so often and so unfortunately swamped in theological, ecclesiastical, and political disputations. And lastly there sprang up in ethics the great school of English rationalism, which may be subdivided into those consciously indifferent or hostile to the forms of organized Christianity and those who professed either to defend or to reinterpret Christianity. Here the lines of demarcation are difficult, and there are some whose attitude leaves us seriously in doubt as to where they may be classed. On the other hand there are not wanting brilliant formulators of distinct types of ethics that may claim the name English, and which possess a peculiar practical character, although the representatives are found both within and without organized Christianity.

\footnotetext{
${ }^{1}$ Contra Gairdner.
} 
I. THE ETHICS OF THE FORERUNNERS OF THE REFORMATION -WYCLIF, THE LOLLARDS, TYNDALE, HOOPER

The ethics of $W y c l i f^{1}$ are in some respects even more distinctly social and political than those of Luther. Just indignation at the way in which the Romish Curia was exploiting the national church aroused Wyclif as it did the later German reformer. Neither leader ever lost wholly the scholastic turn of mind natural to all highly trained intellects in those days. But Wyclif had the advantage of coming out of a more critical and sceptical type of scholasticism (Duns Scotus. Ockham) than that of Luther's order. Hence his ethics are more homogeneous and more critical than those of Luther, though they lack on the other hand the warmth and religious fire of the great German. Following the arguments of Archbishop Richard Fitz-Ralph

${ }^{1}$ Literature.-The English works of Wyclif are made accessible by various editors: Arnold, Thomas: "Select English Works of John Wyclif, Edited from Original MSS."; Oxford, 1869-1871; 3 vols.-Matthew, F. D.: “The English Works of Wyclif, Hitherto Unprinted" (Early English Text Society); London, r880.- Todd, James T.: "Three Treatises by John Wyclif, with Notes and a Glossary"; Dublin, 1851.-The Religious Tract Society: "Writings of John Wyclif" (Selections); being the first volume of their Reformer Series, and containing other Lollard writings; London, 183I; first American reprint, Philadelphia, 1842 .-Wyclif Society (Miss Dorothy G. Matthew, Hon. Sec., 70 Belsize Park Garden, London, N. W.): Latin works of John Wyclif, edited by various scholars and published by the society.-Lechler, Gotthard: "Joannis Wiclif Trialogus cum supplemento trialogi"; Oxford, r869.-Buddensieg, Rudolf: "Lateinische Streitschriften"; Leipsic, r883; 2 vols.; English edition under the title: "John Wiclif's Polemical Works in Latin"; London (Wyclif Society); 2 vols.; I883.- Shirley (Walter Waddington) has published "A Catalogue of the Original Works of John Wyclif" (Oxford, 1865) that has superseded that of Bale and others, but itself must be corrected from the more recent research of Loserth, Buddensieg, Matthew, and others.-Lechler, Gotthard Victor: "Johann von Wiclif und die Vorgeschichte der Reformation"; Leipsic, 1873; 2 vols. (translated partly in "John Wiclif and his English Precursors, Additional Notes by Peter Lorimer"; London, 1878 ; 2 vols.) is still most valuable.-Buddensieg, Rudolf: "John Wiclif, Patriot and Reformer, Life and Writings"; London, 1884.-Buddensieg, Rudolf: "Johann Wiclif und seine Zeit, zum 500 jährigen Jubiläum"; Halle, I885; ("Verein für Reformationsgeschichte, Schriften").-Vaughan, Robert: “John de Wycliffe, D.D., a Monograph"; London, 1853.-Trevelyan, George Macaulay: "England in the Age 
(Armagh) in his tract "De pauperie Salvatoris," " on to their logical conclusion that the civil government, namely, had supreme control under God of all the temporal possessions of the church, Wyclif even more thoroughly than Luther in his letters to the Protestant princes makes the church dependent upon the civil power.

The church should, according to Wyclif, have no temporal possessions of her own at all. ${ }^{2}$ She should be poor and live on the free-will offerings of each parish. These free-will offerings or tithes could then be withheld by official action of the parish from a bad priest. $^{3}$ Then following up the suggestions of Marsiglio of Padua, ${ }^{4}$ Wyclif defended the essentially divine character of the State and the social order. He took seriously the doctrine of the two swords, but the State was not to yield the sword up to the church, rather was the church to submit herself loyally even to bad princes. For though only a righteous man can lawfully hold possession of anything, yet God does

of Wycliffe"; 3d ed.; London and New York, Longmans, I900.-See also the article: "Wiclif und der Wiclifismus," by G. Loserth, in Herzog-Hauck's "Realencyklopädie"; vol. XXI (rgo8), pp. 225-244, which is the latest and most critical review of Wyclif's life. There is a very large literature dealing with Wyclif's work and life, but it is generally uncritical, and often without proper access to his writings. The chronology of Wyclif's tracts and sermons is still much unsettled, and even the separation by critical process of the genuine from the later writings attributed to him leaves much to be desired. The dependence of Huss upon Wyclif is now firmly established by the researches of Loserth, Dziewicki, and others. The date of Wyclif's birth and the exact place he was born are alike unknown. He was born in Yorkshire and died in $\mathrm{I}_{3} 84$. He himself escaped a martyr's death, though his bones were dug up, burnt, and cast into the water forty years after his death.

${ }^{1}$ Published in part in the series of Wyclif's Latin works (1890), by the Wyclif Society, in the volume containing "De Dominio Divino," edited by R. L. Poole, pp. 257-476, with a useful analysis in the Index, pp. xxxiv-xlvii.

${ }^{2}$ In many passages of his sermons; see, for instance, Sermon LXXX, vol. I, p. 268 (Arnold's "Select English Works"), "And goods put in priest's possession is root of all his sin," etc.

"Arnold's edition "Select English Works," vol. III, p. I76.

"Marsilius de Padua "Defensor Pacis seu dictiones vel libri tres adversus usurpatam Romani pontificis jurisdictionem" ( 1324 to 1326 , about). Many editions. An old English translation by Wyllyam Marshall, 1553, London (not seen). 
permit unrighteousness to have possessions ${ }^{1}$ and passive sufferance or resistance are all the weapons a really Christian man may use. ${ }^{2}$

At first this attitude left Wyclif still loyal to the Pope and "the holy mother church," but he could not long maintain this position, and when the Pope condemned his teachings, like Luther after him, he appealed from Pope and council and tradition to his sole authority, the "Word of God in the Bible." 3

Up to a certain point that "reverence for the keys," which kept Dante from speaking his whole mind to Pope Nicholas III, concerning that Pope's avarice and the unfortunate so-called "gift of Constantine" 4 kept Wyclif also from fully expressing himself. But this attitude of reserve gave way steadily under the attacks made upon him after his outspoken opposition to Roman supremacy from the time of the so-called "good parliament" (1376-77) and the attempted trial for heresy. This period seems to mark an era in Wyclif's thinking, and he steadily becomes more radical and more vigorously Protestant.

As in Luther, so in Wyclif there is a growing freedom from scholasticism as the mother tongue takes the place of Latin. The Latin sermons, and even the Latin controversial tracts, are not only more elaborate, as befitting a more learned circle of readers, but they are in thought and method much more bound in the older modes of thought and feeling. They lack the freedom of the English sermons. They reveal an interest in questions never raised in the English works. Did all the Trinity come to the world, for instance; or whether it was necessary to have angels to keep the world moving. ${ }^{5}$ So also the ethics of

1 "De Civili Dominio," London, Wyclif Society, I885-r904, liber I, cap. 6, pp. 42-44. (R. L. Poole, editor, vol. I.)

${ }^{2}$ For an extreme statement of this position, among many, see Sermon CXLVI, Arnold's edition of "English Works," vol. II, pp. 40-44.

'Cf. "De veritate sacræ scripturæ," edited by Rudolf Buddensieg, in 3 vols., Leipsic, 1904, with much valuable material by the editor.

"Cf. "Inferno," canto XIX, lines roo-r ro.

5 "Nontamen video quod oportet angelos movere orbes celestes (ut fingunt philosophi), etc., etc. "Latin Sermons," Loserth's edition, vol. I, p. I4. 


\section{FORERUNNERS OF THE REFORMATION 38I}

the Latin sermons ${ }^{1}$ are still much under the influence of scholasticism, although breaking away from the authority of the church.

As with Duns Scotus, so with Wyclif, God is supreme will. $\mathrm{He}$ is over-lord by creation. ${ }^{2}$ But we share his being as the gift of his grace, and sin is a negation for which God is not responsible. He willed not the sin, but only the punishment of it. ${ }^{3}$ Man is free to sin, and has free-will, and God permits sin because of the ultimate good to mankind. ${ }^{4}$

All power and lordship comes from God and is conditioned upon our right use of it. The prince forfeits his throne and the priest his power of the keys of righteousness by lacking it. ${ }^{5}$

We look then to a threefold "law" as the expression of the terms upon which we hold any authority. Wyclif constantly refers to "natural law," "the law of Scripture," and "the law of conscience," "and thus begins the inevitable break with all external authority as final and absolute for the thinking man.

The authority of the Pope had already been challenged by Ockham in his dispute with John XXII, ${ }^{7}$ and he had written a small compendium of the errors of that Pope. In fact he denied the need of a pontifex summus for the church. ${ }^{8}$ Wyclif went on further to call popes and cardinals and associated friars "Antichrist" and "tares among the wheat." ${ }^{\circ} \mathrm{He}$ strikes at indul-

${ }^{1} C f$. the exposition of the commandments in the nine sermons, XIII to XXII, vol. I, "Latin Sermons," Loserth's edition, pp. 86-154.

2 ". . . sed eo ipso quod creatur, Deus habet de ipso dominium," in "De Dominio Divino," liber I, cap. III, p. I6 (Poole's edition, I890), and many later passages.

3 "De Dominio Divino," liber I, cap. I4, pp. II6-I2I; cf. Poole's edition, 1890.

“ "De Dominio Divino," liber I, cap. 14, pp. I21-125, Poole's edition, I89o.

5 "De Civili Dominio," liber I, cap. I, p. 6, Poole's edition, vol. I, I884, and many passages.

${ }^{\circ} C$. Lechler: “Johann von Wiclif,' vol. I, pp. $377-380$, an exceedingly just estimate at this point.

${ }^{7} C f$. his "Dialogus," Lyons, 1494.

8 "Dialogus," pars III, cap. 25.

-Sermon XXXVI, vol. I, p. 97, Arnold's edition of "English Works"; cf. Sermon XLVIII, vol. I, p. I38, and many other places. 
gences, auricular confession, the celibacy of the clergy, the worship of images, the magic of the mass, and the power of Rome to absolve from sin and vows. The claim of Rome to over-lordship is heresy, ${ }^{1}$ and indeed Rome by setting up this claim shows she is Antichrist, and these are the last days. ${ }^{2}$ Wyclif shared a popular view that Satan had been bound a thousand years, but now was loosened and allowed to prey upon the church, but that his doom was fixed and would shortly take place. ${ }^{3}$

Wyclif follows Thomas Aquinas in denying the material transmission of sin through the physical seed. ${ }^{4}$ It is an attitude of man's will, a negation of the good. All sin may become mortal; there is no inherent distinction between venial and mortal sins, ${ }^{5}$ and in the same sermon in which he brings that out he emphasizes the fact that the flesh is not sin, but only the occasion of sinning, and claims that that is the teaching of Paul. Sin is yielding to the lusts of the flesh as over against higher claims. All that God made is good, but by choosing the lower rather than the higher man sins.

In the Latin sermons the Judgment Day plays a very important and solemn rôle, ${ }^{6}$ and more than once Wyclif emphasizes the fact that we can never be sure of salvation in this life because we may not persevere. ${ }^{7}$ Indeed there is painfully lacking in Wyclif's message the joyful evangelical note which rings out so often in Luther. On the principle of justification by grace and faith, however, Wyclif had just as clear a hold as any of the later reformers, ${ }^{8}$ but at this point orthodox scholastic Catholicism need have had no quarrel with the Reformation.

${ }^{1}$ Sermon LXIV, vol. I, p. I99, Arnold's edition.

${ }^{2}$ Sermon LXVI, vol. I, p. 206, Arnold's edition "English Works."

'Sermon XI, vol. I, p. I I 2, Arnold's edition.

"Cf. "Trialogus," III, 26, pp. 218-222, Lechler's edition, Oxford, r869, with "Summa Secundæ," I, Qu. 83, Art. r.

'Sermon XXIV, vol. I, p. 6r, Arnold's edition "English Works."

- $C f$., for example, Sermon II, vol. I, p. II, of Loserth's edition.

${ }^{7}$ Sermon XII, vol. I, p. 85, Loserth's edition.

${ }^{8}$ Cf. "Of Faith, Hope, and Charity," p. 347, of Matthew's edition of "English Works." 
In the third book of the Triolog ${ }^{1}$ there is a little compact ethical treatise, but it is in dialogue form, and reflects more of the scholastic method than when Wyclif in his English tracts deals trenchantly with the seven deadly sins, ${ }^{2}$ and takes strong ground, for instance, against all encouragement of war by the Church as inherently sinful. The crusades of the Pope were wicked per se. War in anger is sinful. All violence even by the State must be in love and righteousness. This is one of the most important ethical distinctions in Reformation literature. There are also, according to Wyclif, seven works of mercy of a spiritual (ghostly) type and seven of a bodily mercy. Of these the spiritual take the pre-eminence. They are teaching, counselling, reproving, comforting, forgiving, suffering, and prayer, as over against the "bodily" works of mercy, feeding the hungry, giving of drink, hospitality, clothing the naked, visiting the prisoners, the sick, and burying the dead. ${ }^{3}$ This last being on the authority of the Book of Tobit.

This is the new "law of love" in Christ Jesus, which demands new rites and ceremonies as Paul shows in Galatians." Wyclif does not deny that the life of Christian contemplation is the highest. But, he argues, the life of contemplation does not exclude the active life (vita activa). His definition of the contemplative life is therefore essentially non-ascetic. ${ }^{5}$ Jesus chose according to the same teaching the life of poverty not because of gaining merit, but because it is intrinsically the best and happiest.

So also true fasting is abstaining from vice, ${ }^{b}$ and actual fasting must never incapacitate the body for Christian service, which is the main thing.

Wyclif assumes that it was John the Evangelist who was

${ }^{1}$ Pp. 1 28-238 of Lechler's edition.

2Arnold's "Select English Works," vol. III, p. IIg.

"Cf. Arnold's "Select English Works," vol. III, pp. I68-182.

"Sermon VIII, vol. I, p. 57, "Latin Sermons."

sermon VII, vol. I, p. 49, of Loserth's edition of "Latin Sermons," and many passages.

- ". . Ad jejunium spirituale quod est abstinencia à viciis," "Latin Sermons," VIII, vol. I, p. 56, of Loserth's edition. 
married at Cana of Galilee, and glories in this as a rebuke to those who deprecate marriage in itself. ${ }^{1}$ He refuses to accept the allegorical explanations of texts showing marriage to be a duty. Indeed, although Wyclif maintains in theory the old scholastic "four senses" of Scripture, ${ }^{2}$ yet in reality he is a great literalist. .

He saw the sexual dangers in celibacy and the temptations of the frequent pilgrimages, and condemns them. ${ }^{3}$ Such pilgrimages and the indulgences granted for them only deceive men, for the Pope is blasphemous when he grants pardons for sin in God's name." In fact the priest cannot forgive sin, he only declares God's forgiveness in cases of true repentance. ${ }^{5}$

Wyclif's position with regard to the relation of the State to the Church is a weakness in his ethical thinking. The State has not only a right but a duty to root out heresy, ${ }^{\circ}$ at the same time must keep within God's law. Which, however, assumes that the State knows what is God's law, a knowledge Wyclif has just before generally denied to all prelates, who can no more distinguish between "catholic" and "heretical" than they can between mortal and venial sins. ${ }^{7}$ Wyclif thought that laymen were better than ecclesiastics, ${ }^{8}$ at the same time at this point Wyclif had no more thought this matter through to a logical Protestant toleration than did Luther or Calvin later on. Per-

1 "Latin Sermons," S. XI, vol. I, p. 73, Loserth's edition.

2 "The plain or literal, the allegorical which looks to the future, the tropological (ethical), teaching how men should live here in virtue, and the anagogic, telling about the future." Cf. Sermon XII, Arnold's "English Works," vol. I, p. 30 .

'Sermon XXXII, vol. I, p. 83, Arnold's edition "English Works."

"Sermon LXI, vol. I, p. 189, Arnold's edition of "English Works."

${ }^{5}$ Sermon XIV, vol. I, p. 35. Cf. also XIX, vol. I, p. 47, Arnold's edition "English Works."

' Cf. "Latin Sermons," XIV, vol. I, pp. 96-97, Loserth's edition, for full statement.

7 "Et isto porismate diaboli stabilito ad tantum cecavit animas prelatorum, quod nesciunt distinguere inter catholicum atque hereticum, sicut nesciunt distinguere inter peccatum veniale hominis et mortale," etc., etc., Sermon XIV, p. 96, Loserth's edition of "Latin Works."

${ }^{8}$ Sermon CXL, vol. II, p. 28, Arnold's edition "English Works." 
haps the need for a unified life seemed then more insistent than it does to us.

It is interesting to note that Wyclif pleads for a GermanAnglican alliance against the extortions of the church. ${ }^{1}$ For Wyclif was sure that if the church was poor and not blinded by selfish interests reason and faith would have no conflict. ${ }^{2}$

Of course the temper of the time was hard. Wyclif is far from loving in his fierce and often indiscriminate attacks upon all "cardinals, priests, and other children of the devil." $\mathrm{He}$ felt that the joys of the redeemed would be heightened by

- seeing the pains of the damned, which comports but poorly with his doctrine of the immorality of all unloving violence. Indeed his ethics often sinks back to the level of a stern legalism; and God is in many places, especially in the Latin works, portrayed in terms of the familiar feudal over-lordship of the Anselmic theology. Yet in spite of all this, the more Wyclif is made accessible to us in the printed page the more will he be duly recognized as one of England's greatest Protestants. Nor has English theology fairly realized what a mighty ethical leader she possessed in the simple yet profound priest of Lutterworth.

As Canon Shirley (Walter W.) says, "If Wyclif had died before his denial of transubstantiation ... his name might have come down to us in another form and miracles might have been wrought at the touch of their founder by the brother preachers of St. John Wyclif." But as a fact the Lollard "poor preachers" are the apostolic predecessors of Wesley's circuit preachers and the Salvation Army's lay workers. And they were Wyclif's direct creation in exactly the spirit of John Wesley and General Booth.

1 " Et quam graciosa foret anglicorum et almanorum confederacio per quam restitueretur in ecclesia Christi ordinacio," Sermon XIX, vol. I, p. I44.

- $\quad 2$ "Sed veritas est quod lumen naturale ordinatum a Deo ut inducat in fidem non est contrarium lumini fidei, sed in fidem catholicum inductivum," Sermon XXV, vol. I, p. r7o, "Latin Sermons."

"Introduction to his admirable "Fasciculi Zizaniorum magistri," p. xli, London, $\mathrm{r} 85^{8}$. 


\section{THE ETHICS OF THE LOLLARDS}

It is not the place here to speculate upon the reasons for the relative failure of Lollardism $^{1}$ in England. The causes lay largely in the economic and political conditions. Nor does the movement show any ethical advance over the conclusions of Wyclif. The writer has failed to discover in the literature accessible to him any single ethical conclusion not already in Wyclif. Seldom does a movement seem so completely expressed by its founder as Lollardism was by Wyclif. The movement grew bitter under persecution, but even this is altogether natural, and when one reads the fierce attacks of Wyclif upon the friars one sees the inspiration to the stern denunciations, often no doubt partial and indiscriminate, which Peacock ${ }^{2}$ so strongly condemns. Men like Hereford, John Ashton, John Parker, and less-balanced minds like Swynderley, Crampe, and William Smith, simply followed in the wake of their great master.

The movement was a protest against the cosmopolitan imperialism of Rome. Had Francis of Assisi been possessed of Wyclif's learning, and set himself as Wyclif did to making translations of the Bible into colloquial Italian, Italian supremacy in the continental church might have been effectively challenged long before Luther.

The ethics of the Lollard movement were centred about Wyclif's interpretation of the New Testament. For the Lollards

${ }^{1}$ Literature.-Besides the works of Lechler and Walter W. Shirley already mentioned (p. 378): Peacock, Reginald: "The Repressor of Over Much Blaming of the Clergy," edited by C. Babington, in the "Master of the Rolls" series, 2 vols., I858, etc.-Wright, Thomas: "Political Poems and Songs Relating to English History, Composed During the Period from the Accession of Edward III to that of Richard III," 2 vols., I859.-Foxe, John: "Book of Martyrs" (many editions).-Gairdner, James: "Lollardy and the Reformation in England, an Historical Survey," 2 vols., London, Macmillan, 1908.-See also the excellent article, "Lollarden," by Professor Rudolf Buddensieg, in HerzogHauck's "Realencyklopädie," vol. XI, 1902, pp. 615-626, where fullest literature is given.

2 See Peacock's "The Repressor of Over Much Blaming of the Clergy," "The Rolls" series, edited by Babington, in two vols., 1858 , etc. 
Christianity was a fierce protest against rich institutional religiosity. And without question that is a very distinct note of the early Gospel. In Lollardism Christianity once more allied itself with the cause of the proletariat, but the day of the proletariat was not economically or politically fully come. Lollardism was put down in England by the same forces that suppressed the Anabaptists and revolting peasants in Germany, and for the same reason.

Several historians have wondered that the final overthrow of such Lollard leaders as Oldcastle did not excite more indignation. But they forget that the indignation of the disinherited does not get into history. ${ }^{1}$ The members of the possessing class who played with Lollardism or seriously joined themselves to it were like the small aristocracy of Germany who in like manner for a little led the revolting peasants. But in the end the Reformation was to be carried forward by the class and the interests represented by the Free City, and not by the unorganized and relatively helpless proletariat. Even the Lollard poems of Piers Ploughman and the fierce invectives of the Oxford leaders failed to stir the great middle class, into whose hands history was slowly but surely passing.

Hence for the historian of the ethics of the Protestant Reformation the Lollard movement is summed up in Wyclif, and we pass to the new movement as it became personified in one profoundly influenced by both humanism and Luther.

${ }^{1} C f$. the curious Latin poem published in the "Roll" series by Thomas Wright, "Political Poems and Songs," I 859 , for a hostile estimate of the Lollards. A single verse gives an idea of the poem:

\footnotetext{
"Lollardi sunt zizania, Spinæ, vepres ac lollia, Quæ vastant horum vinæ; Nam pejor pestilentia Non fuit in ecclesia, Incedens tam erronea. Quorum linguæ viperæ Et dentes sunt ut framex, Omni pleni fallacia. Hi telæ sunt aranea, Parvis et magnis foveæ, Cuntis occultant retia."
} 


\section{WILLIAM TYNDALE}

Nowhere do we find a better expression of the ethics of the early English Reformation party than in William Tyndale. ${ }^{1} \mathrm{He}$ shared the conception of all historical Protestantism that in the Bible an absolute rule of faith and practice was contained, while at the same time making the uncritical subjective personal interpretation of those Scriptures the real norm. Tyndale more than any of the other early reformers, save some of the Anabaptist leaders (through ignorance of scholasticism), divorced

Literature.- "The Works of the English Reformers," Tyndale and Frith, edited by Thomas Russell, in 3 vols., London, 183r. (Part of a series entitled "The Works of the English and Scottish Reformers," of which no more than these were ever published. It had also been the publishers' intention to prefix the series with a preliminary volume containing Tyndale's New Testament; this also never appeared; see Preface.).- "Doctrinal Treatises, and Introductions to Different Portions of the Holy Scriptures," by William Tyndale (Parker Society), edited by H. Walter, Cambridge, I848.- "An Answer to Sir Thomas More's Dialogue, The Supper of the Lord After the True Meaning of John vi and I Cor. xi, and Wm. Tracy's Testament Expounded by William Tyndale and Edited for the Parker Society by H. Walter," Cambridge, 1850.-The Folio Edition (Black letter), "The Whole workes of Wm. Tyndall, John Frith, and Doct. Barnes, three worthy Martyrs, and principall teachers of this Churche of England, collected ... [with a commendatory preface] by John Fox," I572, 1573, 2 vols. - "Writings of Tindal, Frith, and Barnes." Selections from their works; with biographical notices of each; 2 parts, London, Religious Tract Society, 1830 .

The student of ethics will find his material chiefly in "The Wicked Mammon," "The Obedience of a Christian Man," and the Prologs to his New Testament and Pentateuch. A life is published by R. Demaus ("William Tyndale, a Biography, a Contribution to the Early History of the English Bible," London, 1871; new edition, London, I886), in which Foxe's notice is critically reviewed. See also the valuable Prolegomena in J. R. Mombert's "William Tyndale's Five Books of Moses, Called the Pentateuch, Being a Verbatim Reprint of the Edition of $1530 \ldots$, New York, I884.

${ }^{1}$ William Tyndale, born about 1484 , and who died a martyr's death near Brussels in 1536 , translated the Bible into English and published the first printed New Testament and Pentateuch in English and with collaboration the whole Bible. His life was spent mainly on the Continent, where he sought refuge. For full bibliography, see the introduction to Mombert's "Critical Reprint of the Pentateuch," New York, I884; critical abstract of his life in Demaus's "William Tyndale," London, I87r. 
the reform from metaphysics, and gave it a distinctly political and ethical character.

How much Tyndale knew of scholasticism does not clearly appear in his works. But he disavows Aristotle in words that sound like Luther, ${ }^{1}$ and in a clever paragraph dismisses the whole scholastic training. ${ }^{2}$ His theology is simple, uncritical, and formed on lines akin to Luther's middle period.

It is his ethics that reveal him at his best. And not even in Luther does the ethics of the Reformation rise higher than in Tyndale. Faith and good works are not separate, but are organically connected. In a wonderfully beautiful little prologue to "The Wicked Mammon" he condenses his whole teaching of the character of faith. ${ }^{3}$ Faith is the acceptance of God's love in all conditions and an attitude of trustful dependence in all circumstances. ${ }^{4}$ Good works are the natural fruit of the loving life, ${ }^{5}$ and must be done without any ulterior purpose, or any vain-glory. "I think not myself better for my working, nor seek heaven, nor any higher place in heaven, because of it." ${ }^{8}$ Our working love carries with it its own reward. God is the life and beauty of all good deeds, and where good deeds are there is God. ${ }^{7}$ Hence the New Testament was from the beginning of the world, ${ }^{8}$ for God is the source of all right-doing everywhere, and Aristotle's doctrine of free-will is false. ${ }^{9}$ The whole interest

I "The Obedience of a Christian Man," Russell's edition, vol. I, p.Igr. See his list of scholastics.

2 "The Obedience of a Christian Man," vol. I, p. I94.

3 "That faith, the mother of all good works, justifieth us, before we can bring forth any good works: as the husband marrieth his wife before he can have any lawful children by her. Furthermore, as the husband marrieth not his wife that she should continue unfruitful as before ..., but contrariwise to make her fruitful; even so faith justifieth us not, that is to say, marrieth us to God, that we should continue unfruitful as before . . . but to make us fruitful."-"Works," Russell's edition, vol. I, p. 76 .

" "Prolog to Exodus," vol. I, p. I6, Russell's edition.

'Russell's edition, vol. I, p. 23.

- Russell's edition, vol. I, p. 24; cf. also p. 43, and many passages, as vol. I, pp. 99-roo.

7 Russell's edition, vol. I, p. 35 .

" "Prolog to Exodus," Russell's edition, vol. I, p. 24.

'Russell's edition, vol. I, p. 38 . 
that Tyndale has in "free-will" is ethical and not metaphysical. $\mathrm{He}$ wishes to clear faith and right living from every taint of "work righteousness" and coarse hedonism.

The "rewards" spoken of in the New Testament are not the ends toward which we move, but simply the inevitable accompaniments of the good life. "Now, then, as after evil living followeth his reward unsought for, even so after good living followeth his reward naturally unsought for, or unthought upon. ${ }^{1}$

This love has no limits. "I am bound to love the Turk with all my might and power; yea and above my power . . . neither to spare goods, nor body, nor life to win him to Christ." 2

As with Luther, so with Tyndale, the common task is holy. "A kitchen page" is equally doing God's service as a "preaching apostle," 3 which passage suggests Tyndale's dependence upon Luther, although with great freedom. ${ }^{4}$ Chastity is of thought and there is hardly any saner treatment of the topic than by Tyndale. $^{5} \quad$ Asceticism has no place in his ethics at all. Even more thoroughly than Luther has Tyndale stripped his ethics of the sombre dualism of Augustine. ${ }^{\circ}$ The subjection of the body is only for the sake of rendering more complete and acceptable service to God. Beautifully in passage after passage of "The Obedience of a Christian Man" does Tyndale bring out the nature of the Christian life as service. All things are for man's sake, and all life is giving. Law must be kept, but there are three tempers, fear, hope of reward, and for love's sake. Only the last is Christian, and this love is service unto death. ${ }^{7}$

1 “The Wicked Mammon," Russell's edition, vol. I, p. IO2.

${ }^{2}$ Russell's edition, vol. I, p. I32; cf. p. 134 and vol. II, p. 7 , in answer to Sir T. More.

Russell's edition, vol. I, pp. I36-r37.

- Tyndale spent some time with Luther at Wittenberg between.May, 1524, and April, I525; cf. Demaus's "Life," p. 93, and pp. 98-101, edition of r886, and "Prologomena to the Reprint of the Pentateuch," p. xxvii, New York, I884. He may also have lived for some time there in secret.

${ }^{5}$ Russell's edition, vol. I, p. 47.

- $C f$. Russell's edition, vol. I, pp. I 2 and I 27.

${ }^{7}$ Many passages; see especially Russell's edition, vol. I, p. 2 I6. 
In this service there is a democracy of believers in Christ, where neither equality nor inequality comes into view ${ }^{1}$ as in holy wedlock.

What is common to Tyndale and the whole reforming English group is, however, the mechanical attitude toward the Scriptures. Never does Tyndale rise to the height of faith that gives Luther at times a certainty greater than Scripture, and a norm (the mind of Christ) by which any word of Scripture is to be tried. Hence the ethics, not so much in Tyndale as in the later men, becomes legal and mechanical.

But a still greater weakness is shared fully by Tyndale. The authority of the Church and State are misapprehended. Tyndale preached that the king was answerable only to God. ${ }^{2}$ In England men's interest in this position was to set up king against pope, as Wyclif had also done and to show that the Pope's interference in temporal matters was usurpation. ${ }^{3}$ True there were, and always had been, evil rulers, but they are sent of God, as signs of God's wrath, ${ }^{4}$ and must be left to God for punishment.

This non-resistance doctrine arose not only from literal interpretation of Romans xiii, but also from the confusion in men's minds about the postulates "all government is divine," and "therefore any particular government is the final divine form." It took years of sad and bloody experience for the reformers to reach even a working theory of the relation of Church to State; and the direct cause of much Protestant weakness and confusion must still be sought at this point.

This weakness in the ethics of Tyndale is joined with a kindred misapprehension as to the function of law. The false antithesis

1 "The Obedience of a Christian Man," Russell's edition, vol. I, p. 290.

2 "If the king $\sin$ he must be reserved to the judgment, wrath, and vengeance of God ... hereby seest thou that the king is in this world without law, and may at his lust do right or wrong, and shall give account, but to God only." Even a heathen prince, according to Tyndale, must not be resisted. "Obedience of a Christian Man," vol. I, p. 21 2, Russell's edition.

3 "Obedience of a Christian Man," Russell's edition, vol. I, p. 220.

"Russell's edition, vol. I, p. 229. 
between law and grace, based upon Paul's teaching, separates the Old Testament from the New, and yet leaves law in force. While Tyndale had rightly apprehended the Christian man's attitude toward law, he does not find place for the historical unfolding of our ethical experience as to what is the good. Nor was it possible, probably, at that time, for any man to separate himself sufficiently from an absolute view of life to realize the relative character of all ethical standards.

The Reformation ethics were deeply political. The caustic and not impartial survey of history given by Tyndale in his "The Practice of Prelates" must have been tremendously influential in the later stages of the English Reformation. In this treatise Tyndale disavows and denounces the proletariat revolt as strongly almost as Luther, ${ }^{1}$ at the same time traces the social revolt to bad princes and prelates. Princes and preiates should only rule in a kingdom of service. ${ }^{2}$ To them is, however, committed the sword, and although the church has the right to use only spiritual weapons, such as exclusion from communion and fellowship with the saints, Tyndale evidently regards, as Wyclif also did, princes as the rightful guardians of the faith. The character of this assumption is not plain to thousands of Protestants yet. $^{3}$ Kings should, of course, assert righteousness and rule according to Scripture, but if they do not there is no appeal save to God.

Tyndale's denial of sacramental magic, of work-righteousness and papal usurpation could not be more complete than it is. $\mathrm{He}$ is often stern, but seldom so violent as Luther or Wyclif. The Pope is Antichrist, and the whole Roman communion is gone astray and is no church of God. Sometimes Tyndale is witty: "They pray in Latin, they christen in Latin, they bless in Latin, they give absolution in Latin, only curse they in the English tongue." " The language of Tyndale is refined and

1 "The Practice of Prelates," Russell's edition, vol. I, p. 389.

2 Russell's edition, vol. I, p. 396.

- See discussion by Tyndale, Russell's edition, vol. I, p. 399.

- Vol. I, p. 305, Russell's edition. 
gentle, and his great learning shines in his translation. With him the ethics of the English Reformation made, indeed, a good beginning.

Tyndale lived most of his troubled, stormy life away from England. Perhaps because of this the careful reader notices in him a singular indifference to the details of ecclesiasticism in England. The interests in his ethics are, indeed, political but not mainly churchly.

For this interest one must turn to the writings of another group of men who felt themselves directly responsible for the English church, and whose ecclesiastical interest affects not only their theology, with which we are not concerned, but also their ethical point of view.

For the purposes of our examination the works of Bishop Hooper ${ }^{1}$ sound distinctly this note and practically express accurately the attitude of Cranmer, Ridley, and Latimer, and the great mass of churchly reformers. ${ }^{2}$

These men were churchmen, to whom ethics therefore had practically a twofold basis, for although the church was bound to the Scripture, the traditional interpretations of the (true)

${ }^{1}$ John Hooper (Hoper or Houper) was born in Somersetshire. The exact date is unknown. He studied at Oxford (Merton College, according to Foxe), and entered the Cistercian monastery at Gloucester. On the dissolution of the monasteries he joined Bullinger at Zürich, whose writings, together with those of Zwingli, had deeply affected him. Upon the establishment of the Reformation in England he returned to be Bishop of Worcester, to which afterward Gloucester was added. During the persecutions of Queen Mary he suffered martyrdom, I555, by burning at the stake.

His works are collected and edited by the Parker Society in two volumes, the "Early" and the "Later Writings," I843-1852. The Religious Tract Society has also published "Selections" in their vol. V. The best sketch of his life is attached to the second volume of his works by the Parker Society. A list of Bishop Hooper's writings is given in Tanner's "Bibliotheca Britannica-Hibernica."

The writings that have most interest for the ethical student are: "The Declaration of Christ and His Office"; his "Declaration of the Ten Holy Commandments of Almighty God," both in first volume of the "Collected Writings," and "Brief and Clear Confession of the Christian Faith," in the second volume.

2 The works of these early reformers are made accessible in the publications of the Parker Society, and selections are published by the British Tract Society. 
church were authoritative. The marks of the true church are "the pure preaching of the Gospel and the right use of the sacraments," 1 and in her spiritual life, though subject to the State, she is to be independent of it. ${ }^{2}$ The very letter of Scripture is to control, and yet the rejection of the whole ritual law and the subjective and arbitrary interpretation of even the Ten Commandments goes without protest.

Over Hooper more than Tyndale fall the shadows of scholastic dualism. Man's total depravity, as taught by Bullinger and Bucer in its extremest form, appears in Hooper. We are "the enemy of God, the image of the devil, the library of lies, the friend of the devil, right heir of eternal death, and the child of damnation, murderers by means of sin, not only of ourselves, but also of the Son of God, that never sinned." 3

This low estimate of humanity reacts upon the doctrine of the church. For although the "true" church cannot err, man's depravity is such that any church may err ${ }^{4}$ and become a bloody tyranny. This faith in an inerrant transcendental church might be harmless, but no distinction is in point of fact made between the empiric and the transcendental church, and the identification of an existing empiric church with the "true" church leads Hooper and the ecclesiastical group far astray.

This, in fact, leads their ethics back to a legal and outward interpretation of Scripture, and gave rise to all manner of disputes. ${ }^{5}$

The church in her bishops, with the sacraments and the Scripture, become the real measure of conduct. The king, although he is not to be resisted, if he disobeys the church is yet to be set right by the church. "As to touching the superior powers of the earth, it is not unknown unto all them that hath readen and marked the Scripture that it appertaineth nothing

1 "Christ and His Office," vol. I, Parker Society, p. 8r.

${ }^{2}$ For a typical instance of confused thinking at this point, see "Christ and His Office," chaps. ro and II, vol. I, pp. 73-87.

3 "Christ and His Office," chap. I2, vol. I, p. 87.

" "Christ and His Office," chap. 3, vol. I, p. 23.

${ }^{5}$ Bishop Hooper himself refused consecration in certain vestments he declared unscriptural. 
unto their office to make any law to govern the conscience of their subjects in religion." ' 1 Yet this expression of the spiritual character of Christ's kingdom is never really carried through. Christ is head of the church, but the king is head of the State, and the church gives laws to the king and so to the State. This leads Hooper and others into endless ethical confusion.

There is also in Hooper, in striking contrast to Tyndale, a predominantly aristocratic tone. The Reformation was already in the hands of the upper and middle classes. Even in Tyndale we may see society constantly thought of as made up permanently of "estates of men" in substantial dependence one upon another. The husband is as God to the wife, the master as God to the servant, and the parent as God to the child. ${ }^{2}$ In spite of this, however, Tyndale's ethics are profoundly individualistic and democratic. But Hooper and the churchly group still think of society as made up of dependent castes, with prescribed duties and rights in a fixed and somewhat rigid social order. The church is still a hierarchy, only the relation of the State to the hierarchy is left somewhat undefined. Hooper appeals to Parliament to adjust all religious questions on the basis of the "law and the Gospels," 3 but in the last instance the "reformed" church is to control the interpretation of the "law and the Gospel." 4

The Bible was to be put into English, and then it was fondly hoped that all would agree upon what it taught. Historic Protestantism has, of course, revealed the fact that in essentials and non-essentials disagreements among honest men are inevitable, and that even on the question of what is essential and what

1 "A Declaration of the Ten Commandments," vol. I, p. 280.

${ }^{2}$ Tyndale's "Obedience of a Christian Man," vol. I, Russell's edition, p. 172.

2 "Appelatio ad Parliamentum," "Satis enim est christiano homini Christi lex et evangelium: tyrannicum autem et plane satanicum est ad illam religionem christianum hominem compellere, quam lex Christi et evangelium penitus ignorant." $C f$. the whole argument that the Turks have their Koran and the Jews are faithful to the Old Testament, and the Roman church alone is afraid of her own book. " "Later Writings," Parker Society edition, vol. II, p. 393.

1 "Appellatio ad Parliamentum," vol. II, pp. 396-397. 
non-essential personal subjectivity is ever in control. For men like Hooper, Ridley, and Latimer, however, "the Truth" was so evident, and the pages of the newly opened Scriptures so simple, that only dishonesty of purpose kept men blind.

Already in this group the influence of political Calvinism can be traced, and the logical outcome of reformed theology only awaited a thorough-going advocacy. It was within the established church that this logic produced a new school of thinking to which the name Puritanism was given, at first in scorn, but like so many other such names, it became at last an accepted term.

III. THE ETHICS OF PURITANISM-THOMAS CARTWRIGHT, TRAVIS, JOHN KNOX

The Puritan movement had its real beginnings in the somewhat cramped and narrow life of the English foreign colony in Frankfort-on-the-Main. It is probably impossible for us at this distance of time to realize what those conditions must have been. The authorities gave the exiles a warm welcome. But the letters and documents now given us by historians abundantly reveal the hard struggle for mere daily bread, and the great poverty that constantly oppressed them. It is under such circumstances that the smallest differences become reasons for the most serious irritations.

The reaction from the church at Rome and the growing horror of idolatry were, moreover, greatly strengthened by the influence of reformed theologians who had early taken stronger ground along these lines than the Lutherans.

The seeming success of the new theocracy established at Geneva by Calvin, and the really wise and learned counsels of Calvin, Bullinger, and Bucer, made a deep impression on the wandering English Protestants. When, therefore, they could return under Elizabeth's reign, they came back with a distinct mark upon their thinking and ideals.

The earliest struggles of the little colony over vestments, the use of a ring at weddings, the sign of the cross at a baptism, the 
right position of the communion table, all mark the inevitable "levitical stagnation" due to a re-establishment of priestly authority under another name.

The age was not one of easy tolerance of divergence. A more tolerant spirit might have meant at that day in England only laxity and indifference. Even to-day Bishop Paget seems unable to realize the need of great variety in religious expression, and regards the confusions then common in ritual as "discreditable and dangerous," ${ }^{2}$ although a visit to the services of the London churches within the English establishment would probably reveal to-day a divergence of custom and thought even greater than that mentioned in the paper cited by Strype. ${ }^{2}$

The attempt to enforce uniformity, however, raised even more serious questions than those that had divided the church at Frankfort, for they concerned themselves with fundamental issues in regard to the character of both Church and State, and of the legitimacy of the orders and discipline of the reformed establishment. Out of these questions came English Puritanism. $^{3}$ Two separate interests more or less divide Puritanism in all its history. On the one hand it stood for "pure," i.e., Calvinistic doctrine, and on the other for a simple ritual and a severe church discipline. Nor did these two interests always go together. At the same time, just as in the established church of England to-day ritualism and high-churchmanship are usually associated, so in Puritanism Calvinistic doctrine and simple ritual were generally allied.

Nevertheless, with these we are not primarily concerned.

Underneath the life of all Puritanism lay certain assumptions and a distinct conception of the world which color their ethics and mark the movement as a whole. We must begin with the

\footnotetext{
${ }^{1}$ Paget, Bishop of Oxford, in his "Introduction to the Fifth Book of Hooker's Ecclesiastical Polity," chap. II, p. 25, 2d. ed., 1907.

2 "Life of Archbishop Parker," book II, chap. 5.

"Neal (Daniel), in his preface to his "History of the Puritans," thus defines a Puritan: "A Puritan therefore was a man of severe morals, a Calvinist in doctrine, and a non-conformist to the ceremonies and discipline of the church." New edition, London, 1837,3 vols., vol. I, p. v.
} 


\section{real English formulator of Puritan ideals and Puritan life,} Thomas Cartwright. ${ }^{1}$

True it is that Cartwright has left us no systematic ethics. The Puritan movement as a whole, like every movement under the inspiration of reformed theology, is singularly barren in

${ }^{1}$ Cartwright, Thomas, born in 1535 , in Hertfordshire. Studied in Cambridge and was eminent for attainments in Latin, Greek, and Hebrew. Driven from his professorship by Whitgift for his attacks upon the Anglican church as organized by Elizabeth, he fled to Beza in Geneva, whence he issued his famous "Second Admonition to Parliament," in which English Presbyterianism is plainly outlined. He returned to England, but only again to flee, and became minister to the little English church in Antwerp and Middelburg. From here he wrote his "Replie" to Dr. Whitgift's "Second Answer Touching the Churche Discipline," I575. Here also he translated Walter Travers's "Ecclesiasticæ Disciplinæ Explicatio," published Rochelle, 1574, under the title "A full and plaine declaration of ecclesiasticall Discipline owt of the Word off God . . . 1574." (Also Geneva, r580; Cambridge, $\mathrm{r}_{584}$ and ${ }^{6} 6 \mathrm{r}_{7}$.) He returned in I 585 to England, and although arrested and imprisoned for six months, escaped by the protection of powerful friends, and was installed in charge of a hospital in Warwick. He continued his activity for a Presbyterian church discipline, and the "Directory of Church Government anciently contended for, and as farre as the Times would suffer, practiced by the first Non-Conformists in the Daies of Queen Elizabeth," found in his room after his death, is reflected in the Westminster Statements. A reprint of this, from the edition of 1644 , appeared from the press of James Nesbit in 1872. And Bishop (Francis) Paget reprints the Latin original (in the British Museum and Lambeth Palace) as appendix III ("Disciplina Ecclesiæ sacra") to his "Introduction to the Fifth Book of Hooker's Polity" (2d ed., r907). As Cartwright fought the Episcopacy on the one hand, so on the other he was beset by the Brownists and Independents, to whom his reply, published by Browne, is temperate and in fine spirit. Arrested once more and tried before the Star Chamber, he was again protected. He died in peace at Warwick, December 27, 1603. In Latin there are extant a harmony of the Gospels, "Harmonia Evangelica," Elzevir Press, Amsterdam, 1627 and 1647; "Commentaria practica in totam historiam evangelicam," same press, r630, in three volumes. Several lives have been published. In Cooper (Charles Henry) and Thompson's "Athenæ Cantabrigienses," vol. II (Cambridge, $185^{8}$ ), is a short sketch. Hanbury (Benjamin), in his edition of Hooker's "Ecclesiastical Polity," and other works (London, I830, 3 vols.), has given also an outline. Brook (Benjamin), in his "Lives of the Puritans from the Reformation under Queen Elizabeth to . . . I662" (London, 1813, 3 vols.), is uncritical. Nor can Dexter's (Henry Martin) sketch in his "Congregationalism of the Last Three Hundred Years" (New York, 1879), be taken as a wholly just estimate. See also Dr. Charles A. Briggs's "American Presbyterianism, Its Origin and Early History" (New York, 1885), pp. 26-86. 
systematic ethical discussion. Nor is the reason far to seek. The Old and New Testaments are for Cartwright inspired codes of divine law. We have only to explicate that law, and church governments, rituals, conduct in private and in public life at once receive normal and final regulation. Not even the apocryphal writings should be read, because only the canonical books have this supreme authority. ${ }^{1}$ The church has been directly established by God, and there is only one true church, which may be known by three notes: "preaching of the word purely, maintaining the sacraments sincerely, and ecclesiastical discipline which consisteth in admonition and correction of faults severely (sic)." 2 Hence the names of officers not warranted by Scripture were unchristian. ${ }^{3}$ On the basis, therefore, of Scripture he demanded a church with only pastors, doctors, elders, and deacons, and denied that the office of bishop in the English church was Scriptural. All ministers were to be equal, and each chief in his own cure. The ministers were to be chosen by the people, but once chosen seem to have ruled unchecked, save for open $\sin$ or heresy. ${ }^{4}$ The church is a theocracy, and should be protected by the State as well as established and endowed. But no pope in Rome could be haughtier or more exacting in his demands for submission by the State to the rule and dominion of the church. Just as in Geneva the old Roman theory of the two swords made the State Calvin's ready tool to strike down Servetus, so Cartwright would have had the State do the bidding of the church, and banish by fire and sword all idolatry, heresy, and rebellion against the church.

1 "In reformanda ecclesia necesse est omnia ad apostolicam institutionem revocari," the seventh of Cartwright's "Propositions." "Omnis scriptura pari dignitate et reverentia est habenda, ut et omnia Dei nomina," the fourteenth "Proposition."

'An admonition to Parliament (Field and Wilcock), but endorsed by Cartwright.

"Archiepiscopi, decani, archidiaconi," etc., were "officia et nomina impietatis," Strype, "Annals," vol. I, part 2, p. 373.

"Cf. Strype's quotations, "Annals," vol. I, part 2, pp. 379-381, and the "Second Admonition to the Parliament." 
As it is not in the great movement to reform the government of the church and its discipline, with which Cartwright and Travers are so nearly concerned, that we are immediately interested, we turn from the controversial work of Cartwright for the present and try to get his point of view from his great work upon the Gospels. ${ }^{1}$ With him as with Calvin, the nobler, sweeter, and more evangelical aspects of his thinking appear in his dealing with the Bible. And yet at the very outset his doctrine of total depravity. in its crudest form, and man's utter inability, make ethical system exceedingly difficult. ${ }^{2}$ Faith is an impartation of God, ${ }^{3}$ in the secret of his own will, and this faith, though but as a grain of mustard-seed, works salvation. The assurance of this salvation can only be found in obedience to law. And Jesus Christ is the revealer of this new law." The "damnable" heresy of the Pope is to make salvation depend on works, which, however, give only evidence of the saving faith. Here, as elsewhere, the whole function of the Old Testament is misunderstood. The ritual law has passed away, it is true, but a higher and in some respects a more exacting law has its taken place. At this point Puritanism is never quite self-consistent, for certain ritual laws-like the Sabbath-are carried over into the new dispensation. The ethics, then, of the new life is obedience-by God's grace-to a new law given by the new law-giver, Jesus Christ.

And all the Old Testament regulation of life is taken over into the new dispensation. The church is thus made a new theocracy which it is the business of the State to protect, establish, and obey in all spiritual things. ${ }^{5}$ This church is not infallible: but must be constantly purged and cleansed by the word of God. All the Old Testament regulations against heresy, idolatry, and

1 "Harmonia Evangelica, Commentario, Analytico, Metaphrastico, Practico, 1647."

" "Harm. Evang.," p. 208. Comment on Matt. 5 : I-13 (Praxis). Cf. pp. I $136-$ I 137 .

3 "Harm. Evang.," p. II 24, and many passages.

" "Harm. Evang.," 216 b-219 b.

3 For the high-church conception of Cartwright, see his "Historia Christi ex IV Evangelistes," liber secundus, pp. 302-305, edition I630. 
false doctrine are taken over by the new church, so that the sword of the State is to be at the bidding of the theocracy. ${ }^{1}$ God is to be praised, not because he is our Father, whom to know in Christ Jesus is to love, as Tyndale and Luther at their best taught, but because he has saved us whom he has in the secret councils of his own will chosen and redeemed. ${ }^{2}$ Throughout, the permanent relationship between the believer and God is thought of in terms of ruler and subject, of law and obedience to law.

The kingdom of God is, however, a spiritual and unseen power and does not consist in earthly glory, ${ }^{3}$ but is a twofold reign manifesting itself on the one hand in God's creating, preserving, and sustaining all things, and on the other in the elect called to life eternal. ${ }^{4}$ The earthly kingdom is in strong contrast with this latter kingdom, ${ }^{5}$ which may even exist without the pomp and outward circumstance of the civil sword.

From such premises the ethics of Puritanism were evolved, and splendid as was often the ethical result of personal struggle for an ideal, the total effect was hard, legal, and narrow.

The literal interpretation of Scripture in that uncritical age gave rise to a thousand differences, and as all were laws from the mouth of God nothing could be of little importance. Details of rite and government were on the same level as essential justice and divine mercy. The intolerance of the Puritan was a direct heritage from Rome. He shared with Rome the false conception of the relation between C'nurch and State, and simply broke from the personal rule of the Pope, to hand over his power to a practically infallible ordained eldership interpreting the final word of God on every subject, from the family's sweetest relationships to the borders upon men's garments and the velvet upon their caps.

${ }^{1}$ Cf. Passages quoted from his debate with Whitgift by Bishop Paget, in his "Introduction to the Fifth Book of Hooker's Ecclesiastical Polity," pp. 30-3I. The I $3^{\text {th }}$ of Deuteronomy exercised an unfortunate fascination upon the priestly mind of these centuries.

2 "Harm. Evang.," pp. 39-40.

" "Harm. Evang.," p. 242. 
The ethics are not only autocratic, but also, in essence, priestly and aristocratic. The ideal theocracy is a constitutional monarchy with the Bible as the constitution and a ministry and eldership to rule. Civil liberty and freedom of conscience have historically gained a great deal from Puritan struggles and Puritan sufferings, but nothing from Puritan theory. And of nothing were the early Puritans more afraid than any identification of their cause with democracy and individualism. ${ }^{1}$

Had they gained the upper hand they would have persecuted as ruthlessly and relentlessly and as self-consistently as Rome. This lay not simply in the spirit of the times, but in the very heart of their theory of theocracy. Cartwright thought that for the civil power to begin death penalties with the second table of the commandments was to reverse the very order of things.

Naturally the question rose about conformity to the State established church with its unscriptural bishops and its unlawful rites. Here Browne pressed Cartwright very hard, but Cartwright felt that in protesting and hoping for further reformation the individual was obeying God in staying within the established church. Nor is it easy to see how those who followed the Old Testament rather than the New could well come to any other conclusion. Presbyterianism has always stood historically for an established State church. ${ }^{2}$ And whether in the New World or the Old, it has always sought alliance with the State after the model of the Jewish theocracy.

It was a serious embarrassment to Puritanism, representing as it did a middle-class movement, when men identified its hostility to rites and ceremonies with hostility to class privilege, and we find Cartwright and his friends seeking most earnestly to separate themselves from these democratic outbursts. ${ }^{3}$ The mainte-

\footnotetext{
${ }^{2}$ Most instructive at this point is Cartwright's controversy with Browne.

${ }^{2}$ Even the Scotch Free church broke from the establishment from no sense that the theory of establishment was wrong, but because of what they regarded as oppression in its workings.

$s$ "Libels at this time were publicly scattered in the schools, viz., that poor men toil and travel, but the prince and the doctors licked up all." Strype, vol. I, part 2, p. 374 .
} 
nance of all ecclesiastical privilege was quite as dear to the heart of Puritanism as it was to the Anglo-Catholics. At the same time the State was not to control these ecclesiastical privileges. "Neither let the magistrate think (although in respect of their civil authority the church be subject unto them) that in this behalf they are to be exempted from this precept and commandment of the apostle, who chargeth every one to be subject to those who in the Lord are set over them"; "they must also as well as the rest submit themselves and be obedient to the just and lawful authority of the officers of the church." 1

And as the clerical mind constantly assumes that ecclesiastical privilege is identical with religion, and that the maintenance of the one is the furtherance of the other, so Cartwright demands "that the civil magistrate (the nurse and foster-father of the church) shall do well to provide some sharpe punishment for those that contemn this censure and discipline of the church, for no doubt it is in the degree of blasphemy, of a heathen our Saviour faith, that renounceth God and Christ, and thus much of that." 2

While on the other hand the magistrate has his office "which consisteth in those things which belong to our life and our goods, and hath not to do with the holy ceremonies." 3 Thus high-church Presbyterianism shares with Gregory the Great the theory of relationship between Church and State now maintained by the Vatican, ${ }^{4}$ and like the Roman Catholic system rested upon the belief in an outward infallible guide in faith and practice.

In England the Puritan movement never did more than leaven a little England's life. Presbyterianism never really controlled that life. But it was otherwise in Scotland, where substantially the ethics of Puritanism became the dominant theory of the nation.

\footnotetext{
${ }^{1}$ Cartwright's translation of Travers's "Discipline," p. ro2, of the 16 I 7 reprint (Bodleian).

2 "Second Admonition," p. 60, of the reprint of $16 \mathrm{I} 7$.

3 Cartwright's translation of Travers's "Discipline," p. 43, reprint of 1617 .

"Some of the best statements of this position have resulted from Rome's late controversy with France.
} 


\section{No one did more to bring this about than brave old John Knox.}

The ethical outlook of John Knox ${ }^{1}$ is wholly dominated by his theory of the relationship existing between the Church and State. Under the influence of Calvin he took over with but slight modification the theory as formulated in Roman Catholicism by Gregory the Great and which pervades the scholastic development. The Church and State are both subject to the word of God, but the Church is the interpreter of God's word to the State. Nowhere is this more clearly taught than in

${ }^{2}$ John Knox (1505-1572) was born at Haddington. He was educated for the priesthood, but in 1544 turned to the newer way of thinking, and in 1547 was called to the ministry at St. Andrews. When St. Andrews was taken by the French he was, contrary to the stipulations of surrender, made to serve in a French galley. On his release, probably by the direct request of the English king, he went to England and became preacher at Berwick. Soon after he became one of the six chaplains to Edward VI ( $155 \mathrm{I}$ ). He declined all preferment, and on Mary's accession fled to the Continent. He acted for a little while as the minister to the colony at Frankfort a. M., and then in Geneva. In 1555 he began his real labors for Scotland, which were only interrupted, and not broken off, by his further visit to Geneva. In I 559 he left Geneva finally and joined the Protestant insurgents in Scotland. He was twice married, and had two sons and three daughters. His ministry in Edinburgh was really to the whole of Scotland, and upon the establishment of the reformed faith as Scotland's religion he was the life and leader not only of the Scottish church but of the Scottish nation. His life, by Thomas McCrie (Edinburgh, I840), has been republished with critical notes by A. Crichton (Belfast, 1874; later edition, London, 1880 and I889, Nelson \& Sons), but still needs critical revision. His collected works are in six volumes by David Laing (Edinburgh, 1846-1864, Woodrow Society). Cf. also Lorimer's (Peter) "John Knox and the Church of England, His Work in Her Pulpit, \&c," London, 1875. A recent celebration called out a mass of literature, but of unequal critical value, and some of it of no value at all.

Among the more important books on Knox are: Stalker, James: "John Knox: His Ideas and Ideals," New York, Armstrong, I904; Glasse, John: "John Knox: A Criticism and an Appreciation," London, Black, r9o5; Lang, Andrew: "John Knox and the Reformation," London, Longmans, I905; Cowan, Henry: "John Knox, the Hero of the Scottish Reformation" ("Heroes of the Reformation" series), New York, Putnam, I905; Huraut, Etienne: "John Knox et ses relations avec les églises réformées du continent" (Thése Paris), Cahors, 1902; Rogers, Charles: "Genealogical Memoirs of John Knox and the Family of Knox," London, 1879; Brown, Peter Hume: "John Knox: A Biography," London, 2 vols., 1895. 
Knox's "Confession of Faith" at Edinburgh." Here we find set forth the foundation of "The Church" in the Protevangelium, and the Old Testament is the history of the church from Adam to Christ.

In the sixteenth chapter we have the notes of the church. It is a "company of men who, chosen of God, rightly worship and embrace him." It is marked by "true faith in Christ," and "is the body and spouse of Christ Jesus," is Catholic and therefore one Lord, one faith, and one baptism, "and out of the which kirk there is neither life nor eternal felicity," and "therefore we utterly abhor the blasphemy of those that affirm that men which live according to equity and justice shall be saved, what religion soever they have professed." And alas, "this church is invisible and known only to God."

In the eighteenth chapter, however, it is denied that the notes of the true church are either antiquity or usurped title, lineal descent, place appointed, or multitude of men in any error, but are "the true preaching of the word of God," the "right administration of the sacraments," and "ecclesiastical discipline, ministered as God's word does prescribe, whereby vice is suppressed and virtue nourished." 2 It is worthy of note that Knox disclaims personal or public interpretation of the Bible, and says that only the spirit of God can rightly interpret it. Councils therefore can err, and although to be treated with respect they must be tested by Scripture. The sacraments are the continuance of circumcision and the passover, ${ }^{3}$ and they are more than signs: by them grace is imparted. We have all the foundations here for a new priestly structure, which Knox then builds up out of the ordained eldership. Only a "lawful ministry appointed to preach the word" can rightly administer the sacraments, and they must be administered in the "ways of God's appointment." Here we see plainly the conception of sacramental magic in the power of a priesthood coming back into Protestantism, or per- 
haps more accurately, never having been clearly enough repudiated, and so again re-establishing themselves. ${ }^{1}$

It is now only a step to ask the State (magistrate) to maintain by force this new priestly structure, and this Knox accordingly, following in the footsteps of Calvin, proceeds to do. Knox boldly says that to the civil magistrate pertains "chiefly and most principally the reformation and purgation of religion." They are appointed "for suppressing idolatry and superstition as David" suppressed false teachers. Parliament, therefore, is asked to pass acts forbidding mass, and to place penalties for being either present or saying or hearing of it. These punishments are to be punishment of the body and confiscation of goods for a first offence, then banishment or death.

All doctrine repugnant to the word of God (which in point of fact is alone interpreted by a priestly ministry) is by Parliament to be utterly suppressed "as damnable to man's salvation. ${ }^{2}$ All teachers of false doctrine "ought not to escape the punishment of the civil magistrate." Only duly "elected, examined, and admitted ministers" are given any real voice in the interpretation of Scripture, so that the State has simply to do again the bidding of the priest. The "office and duty of the godly magistrate is not only to purge the church of God from all superstition and to set at liberty from bondage of tyranny, but to provide . . . how it may abide in the same purity to the posterity." 3

The bann with all its horrors, including the withholding of baptism from helpless children, is reinstated in the "Book of Discipline," and although the book with true priestly unction says, "We do not dare to prescribe unto you what penalties shall be required of such ...., but we affirm that the one and the other deserve death." 5

As Knox took over the Roman Catholic theory of the two swords, and the practical hegemony of the churchly sword, so he took over the Roman Catholic conception of God. With the

\footnotetext{
1 "Works," vol. II, pp. II5-II7.

3 "Works," vol. II, p. 209.

2 "Works," vol. II, p. I85.

s "Book of Discipline," "Works," vol. II, p. 254.
} 
dogmatic structure we are not concerned, but in its ethical significance the God of John Knox is the God of mediæval theology. In the actual life and piety of Catholicism, however, there is put between the worshipper and the law-giving Creator and Ruler the gentle Virgin Mary, the suffering, crucified man, the babe, the saints, the sacramental forgiveness system. Whatever the dogmatic weaknesses of this may be, the ethical outcome is a thought of God far less hard and inhuman than the God of dogmatical theory.

In Knox's picture of God all save the cross drops away, and the cross is largely used to bring into sharp relief not the human heart of God, but the wickedness of man. In spite of tender devotion to the Saviour, which beautifully marks the piety of Knox from beginning to end, the thought of God is hard, fierce, and even passionate with profoundly human anger. God is a God of vengeance ${ }^{1}$ who visits his wrath in the manner of Jehovah of Chronicles upon the nation for not driving out the "idolatry of the mass." Knox was an Old Testament prophet of the eighth century, but not a proclaimer of the evangel of Jesus Christ. Any one who reads the almost coarse diatribes must remember Knox's experience of the galley and exile to even excuse them. ${ }^{2}$

It is not, therefore, strange that, like Calvin, Knox also took over the intellectualism (Aristotelian) of the mediæval scholasticism. He has a pathetic faith in dialectics, and is sure that a debate would convince Queen Mary of the truth of Protestantism, and he assures Mary that God's word is absolutely plain to all but wilful ignorance, and that in the face of the divisions in Protestantism confessedly arising among the best of the leaders. ${ }^{3}$

His point of view is the old familiar conception of an absolute external authority, only for Knox it is the letter of Scripture

1 "Works," vol. III, p. 166; cf. also vol. IV, p. 33.

${ }^{2}$ Cf., especially, "Works," vol. III, pp. $259-330$, or pp. $157-215$ of the same volume, or the paganism of the prayer, on p. 286.

"The dialogue with Mary is reported by himself in his history, "Works," vol. II, book IV, p. 284 , and has nothing hard or disrespectful to Mary in it. 
arbitrarily torn from its literary and historical setting and made almost a fetish of. ${ }^{1}$

A regular, god-fearing, lawfully appointed ministry is put in the place of the Pope to direct the civil sword and so secure man's safety by perpetuating sound doctrine and severe discipline.

A mind still so fettered by scholasticism could not be expected to shake off its superstition, and there is abundant evidence both in Knox and Scottish life of this survival. ${ }^{2}$ His view of life is shadowed over by the darknesses and dimnesses of a pagan fear of God. The bright evangelical confidence so missing also in Calvin is much lacking in Knox. He takes a naturally dark view of life ${ }^{3}$ as evil. One cannot but read with sorrow and pity the sad letter he writes to the dear friend and faithful fellowsufferer for the faith whom he had in Mrs. Bowes, his motherin-law. He writes of her that "I have seen her (not for a start, but in long continuance) pour forth tears, and send to God dolorous complaints, oftener than ever I heard man or woman in my life." 4 The poor woman was troubled by the thought that she might not be of the elect, and in John Knox's letter of "comfort," he practically tells her she cannot know, but must act as if she were although it will have no possible bearing upon the matter, as God's sovereign will and his own glory is the only end. ${ }^{5}$

His own faith rested really on an intellectual perception of Jesus Christ. He writes: "Except our comfort be grounded upon the foundation which never can be moved, it is not perfect. And that ground is this, that when we understand that presently we believe in Jesus Christ, because we were ordained before the beginning of all times to believe in him; as in him we were elected to the society of eternal life, then is our faith assuredly grounded, and that because the gifts and vocation of God are

${ }^{1}$ Cf. "Letter of Wholesome Counsel," "Works," vol. IV, p. ${ }_{3} 6$.

${ }^{2} C$., for example, "Works," vol. II; "History," book IV, p. 269, where Mary's landing brought bad weather!

${ }^{3}$ See his letter to England (1554), "Works," vol. III, pp. 259-330.

4 "Works," vol. VI. p. 5 r4.

5 "Works," vol. VI, pp. 515-520. 
without repentance." 1 And again, as "therefore faith springeth from election, so it is established by the true knowledge of that doctrine only, which this day is most furiously oppugned by those who do not understand the same." 2

For Knox, God's glory is the end of all life, and all means therefore to that end are justifiable. ${ }^{3}$ It is tremendous faith, but divorced from the kingdom of God as his truest glory it makes sad shipwreck of the Gospel. To the political student must be left the services of Knox to Scotland which were very great indeed. But the student of ethics comes away from the study of Puritan thought as seen in Knox with the profound conviction that whatever gains the Reformation made in systematic ethics were not made by Puritanism, but rather in spite of it; and that, however splendid its record as a religious force, as an ethical teacher it was too fast bound in scholasticism to advance our ethical freedom in Christ Jesus.

The aristocratic character of the whole tone of Puritan thought is bound up with its very conception of an elected few to whom God has given the governance of this life and the keys of the kingdom. Exactly as the hierarchy of Rome is fundamentally incompatible with democracy, so the whole ethical outlook of Puritanism presupposes an aristocratic structure of society, and cannot cherish equal opportunity for every man as even an ideal. Exactly as the Roman church opened a door of hope to the economically oppressed by which to enter the ranks of special privilege, so Puritanism by its doctrine of election and its open appointed ministry made the basis of aristocracy broader than birth or possession; but the structure of its life remains the dominance of the many by the few, its faith is in the elect, and through its teaching there breathes almost a contempt for the common unprivileged man.

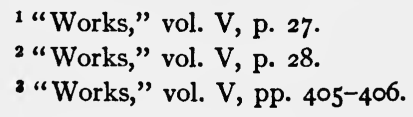




\section{THE ETHICS OF ANGLO-CATHOLICISM}

However violent and outrageous the conduct of Henry VIII was in his rude separation from Rome, and in his confiscation of the property of the Roman church, at least this must be said for him, that he succeeded in gathering about him strong men and women, who were genuinely loyal to the new and somewhat anomalous ecclesiastical creation. Cranmer, Ridley, Latimer, Hooper had able successors in Whitgift, Jewel, Hooker, and Laud. With all its faults the church Henry VIII founded and gave substantially character to has enlisted the passionate devotion of countless thousands in generation after generation of earnest men and women ever since.

This Anglo-Catholicism has also produced a distinct type of both ethical thought and feeling. It is true that the main outlines are taken over bodily from mediæval thinking, and that it has no very constant or normal type, nay, it boasts often of its very comprehensive character. The true significance of this catholicity is the fact that the centre of its organizing life, and its really dominant interest, is not chiefly either intellectual nor yet emotional, but political and cultural. This has given it an exceedingly definite character, and many things otherwise quite inexplicable in its history are plain when this fact is remembered. Hence this special character and interest must be studied in any examination of the ethics of the Reformation period.

The story of the rapid shifts and changes in the ecclesiastical world from Henry VIII up to the revolution (I688) is a sad and humiliating one. The pages of history are dark with evasions and cowardice, with brutal violence and mad fanaticism. But there were also hosts of men and women, both Protestant and Roman Catholic, who vindicated the essential nobility of conscience and the strength of moral feeling by dying rather than betray the faith in which they had found peace. Martyrdom does not prove the truth of the martyr's opinions, but it does demonstrate the truth of the martyr. And through all the strife and turmoil there were, no doubt, also hundreds of quiet, 
earnest persons whose substantial working faith remained untouched by all the outward changes.

Lollardism as such had early become identified with the proletariat struggle for political and social recognition. This proletariat movement was seemingly crushed. The Reformation tended temporarily to advance local and national despotism. For the appeal to Rome against despotism had been an everpresent threat and was sometimes a most effective weapon. Such appeals to be effective had to tally, no doubt, with Rome's political interest, but the mere danger of appeal kept a check on tyranny. Rome and local despotism had, however, combined to root out Lollardism as a political and religious movement. Dr. Gairdner ${ }^{1}$ assumes that therefore Lollardism had but little to do with the Reformation. He surely forgets that the crushing of an organized movement does not by any means imply the destruction of the ideals and fundamental faiths that underlie it.

Henry VIII, with all his power, would have been perfectly helpless in the face of Rome had not a large minority, at least, of the nation been with him, and had not the ideals of Lollardism really undermined the unity of opinion upon which alone Rome can stand her ground. The crushing out of Swynderly and his following, and the burning of men like Sawtré (sometimes spelt Chatrys), and indeed the workings of the whole evil statute de Haretico Comburendo, ${ }^{2}$ might put Lollardism as an organized movement outside the pale, but no such measures could stop men thinking along Lollard lines.

The real weakness of Wyclif's movement was that it seemed most dangerous to the newly rising middle-class and the recently created nobility. For a glance at the history of England's great families shows how rapid had been the changes there. ${ }^{3}$ This

${ }^{1}$ Gairdner, Dr. James: "Lollardy and the Reformation in England," an historical essay, 2 vols., London, Macmillan, 1908.

${ }^{2}$ Stat. 2, Hen. IV, cap. ${ }_{5}$ (I40r).

3 The story of these changes has yet to be satisfactorily written. The underlying economic causes are hinted at by Rogers (James Edwin Thorold) in his "Six Centuries of Work and Wages . . . ," 3d ed., London, Swan Sonnenschein, 
new aristocracy was hungry and did not mind gobbling up the possessions of the monasteries, although as over against the proletariat it was exceedingly sound upon the rights of property.

When, therefore, Henry VIII proclaimed a national Catholic church he addressed himself not only to a deep national feeing, and profited by the hopes he awakened for freedom and new life amidst dogmatic and material oppressions by the Roman hierarchy, but he also gave material re-enforcement to this new aristocracy.

Men had, alas, become accustomed to associate the head of the church with vice and untruthfulness, so that as compared with some of the popes even Henry VIII was not too shocking. Nor had men as carefully considered the basis of Church and State as they were compelled to do in the later years of Edward VI, Mary and Elizabeth, and later still under the Stuarts. The expansion of England's power was so great that many fundamental questions could wait for their answer. It was in intense action that Anglo-Catholicism formulated its ethical ideals.

In those days every religious movement followed in the wake of Rome and sought immediate political expression. AngloCatholicism found it in Laud and the Stuarts; Presbyterian Puritanism in John Knox and the Westminster Assembly; Independency in the Commonwealth and Oliver Cromwell, and even Quakerism in William Penn and Pennsylvania.

So it happened that the great founders of Anglo-Catholicism, Whitgift, Parker, Jewel, Bilson, Bancroft, Hooker, Laud, were rather statesmen and ecclesiastics than students of systematic ethics. Yet they were students, and remarkably gifted and learned students.

No organized movement stood at that day openly for toleration of differences in religious opinion. ${ }^{1}$ Toleration has always had 1890, and "The Economic Interpretation of History, Lectures, etc.," London, T. F. Unwin, I888. See also Marx's (Karl) “Das Kapital," English translation, edited by Frederick Engels, Chicago, Kerr \& Co., I907-1908 (the opening chapters).

${ }^{1}$ Individual voices were indeed raised in behalf of toleration. So far as the writer's knowledge goes, the earliest expressions in England are Busher (Leonard), 
its bounds fixed by supposed social expediency. To-day those bounds are as inexact and in some respects as inconsequent as they were in the days of Henry VIII, Mary, and Elizabeth.

It was as much political necessity as ethical insight that stayed the hand of persecution. The leaders of Anglo-Catholicism placed in the very foreground of their teaching the unity of the church, by which they and men generally understood uniformity of dogmatic opinion and conformity to the cult. It was both logical and historical for them to push for that unity by political force. Puritan Presbyterianism within the established church was pressing for exactly the same ideal of uniformity on the basis of other dogmatic conceptions and another cult, and with exactly the same conception of exclusive claim to absolute truth. In the controversy between Travers and Richard Hooker ${ }^{1}$ the spirit of tolerance is more apparent in Hooker than in Travers. At the same time Anglo-Catholicism could not be true to itself and be really tolerant of that which seemed to it to threaten the vital things of both Church and State.

In Whitgift's controversy with Cartwright ${ }^{2}$ the attempt is made to identify Cartwright's position with the Anabaptist movement, but this was a real misunderstanding of the Puritan

"Religious Peace, or, a plea for liberty of conscience. . . . Presented to King James... printed I614 reprinted 1646 , and 200 years later (I846) by the Hanserd Knollys Society," London. Murton (J.), "Objections answered by way of dialogue, wherein is proved by the Law of God, by the Law of the Land, etc., that no man ought to be persecuted for his religion, so he testifie his allegiance by the oath appointed by law." Published anonymously 1615 (reprinted 1846). Williams (Roger), "The bloudy Tennant of Persecution for cause of conscience discussed," London, I655 (edited by Edward B. Underhill, reprinted I846-1867 by the Hanserd Knollys Society). Richardson (Samuel), "The necessity of Toleration in matters of religion, or, certain questions propounded to the Synod. . . . " London, 1647 (reprinted, 1846, by the Hanserd Knollys Society, edited by E. B. Underhill). And then, of course, the celebrated letters of Locke (John) on "Toleration" closed the battle for larger freedom.

${ }^{1}$ Cf. "A Supplication Made to the Council by Master Walter Travers," reprinted in Hooker's “Works" (Keble's edition, I845), vol. III, pp. 548-569, with Hooker's answer following it.

${ }^{2}$ See p. 42 I for Whitgift's answers; see his "Works," edited by the Rev. Mr. Ayre for the Parker Society, in three volumes, $185 \mathrm{I}-1853$, vol. I to vol. III, pp. I-564. 
spirit, although there were some reasons for thinking them alike. It was a struggle for political supremacy between two kindred spirits that gave to Anglo-Catholicism its organized body of thought. This systematic presentation of its case was classically given by Richard Hooker ${ }^{1}$ in his famous work upon ecclesiastical polity.

Hooker's theology and ecclesiastical polity have only indirectly interest for the student of ethics, and directly systematic ethical treatment is almost lacking. ${ }^{2}$ At the same time the ground is so cleared and foundations are so laid that the ethical thinking within the English church has been deeply influenced and foreshadowed by the "Polity" (as in Butler and Paley).

Hooker is a most attractive writer, and has a charm and grace of character that shows in all his utterances. In fact few writers seem so completely to reveal themselves as does Hooker in his "Polity." There we see the patient, painstaking, gentle scholar, timorous in almost every relation of life, save on his own field of inquiry, and even there greatly hampered by excessive reverence for the past, and the submissive deference of an unworldly man for strong and seemingly triumphant conditions.

${ }^{1}$ Richard Hooker ( $1553-1600$ ) was educated in Oxford. On his marriage he had to resign his fellowship there, and after a short ministry became the Master of the Temple, where Walter Travers, the Puritan leader," was a "reader." Controversy was inevitable. As Fuller writes: "The pulpit spake in the morning pure Canterbury and in the evening Geneva." Travers thus aroused Hooker to his great defence, and after a few years at the Temple he begged for a quiet parish in order to finish what he deemed his life's work. This request was granted to him, but the last three books of his "Polity" have never seen the light, although he must have finished them. What purports to be the conclusion has not the full authority of undoubted authorship. For its character, see Keble's preface to his edition of Hooker's "Works" ( $7^{\text {th }}$ ed., in 3 vols., Oxford, r888, a revised edition by Church and Paget). The editio Princeps is of the first four books in 1594 and of the fifth book in 1597 . (Books 6 to 8, purporting to be by Hooker, were not published until r6r8.)

Lives of Hooker have been written by Walton, J., in Gauden's (J., Bishop of Exeter) edition of the "Polity" in r666, London, and sketches by Keble and Paget in their introductions. Very helpful for the student of Hooker is Paget's (Francis, Bishop of Oxford) "Introduction to the Fifth Book of Hooker's Treatise of the Laws of Ecclesiastical Polity," 2d ed., Oxford, 1907.

${ }^{2}$ See, however, book V, cap. $76 f$. 
Not the most bigoted defender of the establishment would now attempt to maintain the ideal character of those conditions. They were the outcome of rude, far-seeing, but impetuous tyranny. In God's good grace strong men of earnest life, such as we have already mentioned, and lesser ones like Thirlby, Bonner, Goodrich, Cox, Grindal, Coverdale, Sandys, Fox, made an apostolic succession to whom even these conditions came as opportunity. Yet one cannot but feel as one reads Hooker's noble plea that it is often special pleading and lacks both historical background and philosophic thoroughness. His justified impatience with much in the Puritan's position blinded him unduly to the great ethical questions to which they were giving their fiercely dogmatic answer. There is much in Hooker that reminds the reader of Melanchthon, and like Melanchthon, Hooker took refuge again in the essential à prioriism of the scholastics.

We have seen in our former chapters how scholasticism is essentially an attempt to superimpose upon the rational foundation supplied by pagan culture a supernatural structure born of tradition, with its two component parts of Scripture and the traditional creeds of the church. The quiet assumption was that this system was rational and could be thoroughly rationalized. This is the foremost presumption of Hooker. ${ }^{1}$ For him the curious historical compromise that resulted in the established church of England was a fixed system built upon reason, Scripture, and church tradition; his task was to rationalize that system, and within it he sought room for all that world of modern doubt and difficulty that had just been opened to men's excited hopes and fears.

It is difficult, as we have seen, to contrast objectively the morality of one age with another, but in the literature of the period, and particularly in Hooker, one sees reflected the ethical confu-

1 "Some things she (Wisdom) openeth by the Sacred Scriptures; some things by the glorious works of Nature; with some things she inspireth them from above by heavenly influence; in some things she leadeth and traineth them only by worldly experience and practice," book II, I : 4 . 
sion of the new era. The Puritan party had Geneva, with its stern attempt at legal suppression, ever in view. The ethical aims were undoubted, the means for reaching those aims Hooker exposes to a searching and prolonged criticism. ${ }^{1}$ He does not deny that men need authority and indeed has a somewhat aristocratic contempt for the common herd. He no doubt sympathized with Calvin when, as he writes, that great Geneva preacher, "considered how dangerous it was that the whole estate of that church should hang still on so slender a thread as the liking of an ignorant multitude is." 2 He takes, however, issue with the Puritan demand that Scripture should be the one sole rule for the determination of all things great and small in the common life, "For in every action of common life to find out some sentence clearly and infallibly setting before our eyes what we ought to do (seem we in Scripture ever so expert) would trouble us more than we are aware." 3 Hence in a certain range of moral action, as well as in ecclesiastical government, men's common sense must govern them. It is alike injurious to Scripture to claim, as Rome does, that it is insufficient without tradition for salvation, or to do as the Puritans do, and claim that it suffices for life without the use of men's reason." With these two guides mankind has all that is needed for "everlasting felicity." "It sufficeth therefore that nature and Scripture do serve in such full sort that they both jointly and not severally either of them be so complete that unto everlasting felicity we need not the knowledge of anything more than these two may easily furnish our minds on all sides." 5

Hooker is thus deeply influenced by the somewhat loose theory of knowledge fashionable in humanistic circles. $\mathrm{He}$ would maintain the thorough-going trustworthiness of reason in a way Puritanism has always regarded as distinctly irreligious. ${ }^{\circ}$ Authority must never be either against or above reason. At

${ }^{1}$ Preface, chaps. I and 2, pp. I 25-142, Keble's 3 d ed., I855.

2 Preface, chap. 2, I.

${ }^{3}$ Book II, chap. 8. $\$ 7$.

- Book II, chap. 8, § 7 .

5 Book I, chap. ${ }^{4}, \S 5$.

- See, as illustrative of many passages, particularly book II, chap. $7, \S \S$ I-IO. 
the same time we notice that it is the reason of the expert in the higher matters of life and in the fields of more erudite inquiry. The apostolic tradition is not always binding, as in the case of the oscula sancta, or holy kiss, which was harmless in apostolic times, but would now be scandalous, though commanded. ${ }^{1}$ Hence there is need of a strong final and authoritative decision in matters of dispute, and these things are found by Hooker in either the submission to the public order or to a general synod. ${ }^{2}$

He then devotes his first book to a discussion of what law really is and what are the kinds of law and its various effects. It is characteristic of Hooker that he neglects the discussions which were having such powerful influence upon men's minds in relation to the degree and character of secular authority. ${ }^{3}$ He goes back to Aristotle, and even Aristotle is, of course, interpreted and supplemented in true scholastic fashion by sayings from the Old Testament.

Law, Hooker defines broadly as "any kind of rule or canon whereby actions are framed." " God is thus by his perfection an eternal law unto himself, and this law he imposes upon his creation. Upon natural agents as the law of their kind, which they keep unwittingly as individuals and as societies. Upon angels, who are bound by it in their being, their relations to one another in a hierarchy, and in this relation to us. Then also it is imposed upon men as a law of perfection, or progress toward perfection, by the knowledge of truth and the exercise of virtue. ${ }^{5}$ These laws again are natural laws of reason; supernatural laws revealed by God, to teach men how to reach the final goal of perfect felicity in God; and human laws, which are imposed by societies, and rest upon consent, express or

\footnotetext{
${ }^{1}$ Rom. I6 : I6; II Cor. I3 : I 2; I Thess. $5: 26$; I Pet. $5:$ r4. Cf. Tertullian, "Lib de Oratione," chap. r4.

${ }^{2}$ Preface, chap. $6, \S \S 3-6$.

'It is natural to seek in Hooker's first book some reference to Wyclif's "De Dominio Divino," or Fitz-Ralph's “ De Pauperie Salvatoris," or Marsilius of Padua's "Defensor Pacis," or Machiavelli's "Prince," but there are no such references. In book V, chap. $2, \S_{4}$, there is a reference to Machiavelli's "Prince," but it is slight and contemptuous.
}

"Book I, chap. 3 , \$ I.

${ }^{3}$ Book I, chaps. 3-7. 
implicit, and are binding by reason of the natural law God has implanted in societies for binding them together. ${ }^{1}$

All of these laws are either pure, $i$. e., have reference to perfect nature, or they are mixed, $i$. e., have their reference to corrupted nature.

Man's highest good is communion with God thought of in terms of Augustine's Platonism, ${ }^{2}$ and reason alone cannot give us the conception of eternal "felicity and bliss." A desire for happiness is natural, but this happiness may be either sensuous, intellectual, or spiritual and divine, unto which latter "we tend by supernatural means here, but cannot here attain unto them." These are the familiar scholastic evangelical virtues of faith, hope, and charity, with the supernatural duties they bring in their train. ${ }^{3}$

Thus into Hooker's ethics and into the ethics of the whole Anglo-Catholic school down to Newman is introduced the fatal intellectual dualism, so destructive of clear thinking, between the natural and the supernatural claims upon conscience." This confusion is abundantly obvious in Hooker. "When supernatural duties are necessarily exacted, natural are not rejected as needless," 5 and so Hooker goes on to attempt a reasonable separation between things essential and non-essential.

He does this under the category of natural and positive, and all laws supernatural as such are positive. But all the laws of Scripture are not immutable. "Positive laws are either permanent or else changeable, according as the matter itself is concerning which they were first made." The church is a "supernatural society" and "doth differ from natural societies in this, that the persons unto whom we associate ourselves, in the one are men simply considered as men, but they to whom we be joined in the other are God, angels, and holy men." " ${ }^{\circ}$ At the same time

${ }^{1}$ Book I, chaps. 5-II.

${ }^{2}$ Book I, chap. II, $\S 3$, and other passages. $\quad 3$ Book I, chap. II.

${ }^{4}$ In the appendix to the fifth book Hooker elaborates this point, and rightly cites Calvin as holding substantially the same position.

${ }^{5}$ Book I, chap. 12.

6 Book I, chap. I5, § 2. 
the church is also a society serving the social instincts of men and under natural laws.

In spite of the care and shrewdness of Hooker's discussion at this point he cannot and does not really draw the lines between Church and State, and leaves the reader considerably confused as to the relative weights of both in case of conflict.

In the second book, Hooker has no difficulty in showing that the Puritans cannot maintain the thesis that Scripture is the rule for the whole of life, nor need we stay to consider the contention of the third book, that Scripture does not supply a polity in its details complete de jure divino $;{ }^{1}$ and the fourth book is equally unimportant from our point of view, in which the special form of polity in the established State church is defended with both learning and acumen.

The famous fifth book is almost complete in itself as an apology for the existing ecclesiastical status as Hooker found it, and its ethics presuppose the acceptance of the prevalent scholastic definitions. It is full of good sense and many of its propositions have ethical bearing, but it does not deal directly with systematic ethics.

He establishes four first principles for knowing what is acceptable to God. The external religious life must comport with the greatness of God and the dignity of religion; in doubtful cases the judgment of antiquity must establish a presumptive claim; the authority of the church, though but recently appointed, must have due weight with obedient children, where no law divine or invincible argument or notable public inconvenience stays that obedience; and lastly, the orders of the church are greater presumption in favor of certain courses than private opinion, particularly when the latitude is given which is proper. Hooker does not carry his reasoning much further than the polity of the church, but it is easy to see along what lines he would have had to develop his ethics. His whole position is still that

\footnotetext{
${ }^{1}$ The arguments here and elsewhere seem so contradictory of much appearing in book VII on this subject that one rather gladly dismisses it as either not Hooker's or not his maturest thought.
} 
of substantial scholasticism, only with somewhat different data upon which to work. The ministry is, of course, an order and indelible even after heresy. ${ }^{1}$

The death of even saints is "punishment." 2 Contingency as Aquinas understood it, on the mediæval Aristotelian basis is defended, ${ }^{3}$ and foreknowledge does not, Hooker thinks, involve necessity.

On the power of the keys, however, Hooker seems to regard the end of church discipline to be repentance, and to limit the church's action to this life. ${ }^{4}$ At the same time he held high doctrine with regard to the sacraments. "Sacraments serve as the instruments of God to that end and purpose," i. e., imparting the saving grace which Christ originally is, "moral instruments the use whereof is in our hands, the effect in his; for the use we have his express command, for the effect his conditional promise." 5 And "Baptism is an action in part moral, in part ecclesiastical, and in part mystical: moral as being a duty which men perform toward God; ecclesiastical, in that it belongeth unto God's church as a public duty; finally, mystical, if we respect what God doth intend thereby to work." ${ }^{\circ}$

This being the high-church position of the reformed theology, and substantially representing Calvin's position, yet having in it the assumption of grace linked to outward and non-moral actions in a way that comes painfully near to sacramental magic with all its unethical concomitants.

As over against the Puritan's position, though hardly the equal of some of the best of the Puritan theologians (Calvin, Bucer, Bullinger) in either logic or fearless dialectic, Hooker is singularly effective. At the same time the modern mind recoils from some of his most favorite assumptions, and the

${ }^{1}$ Book V, cap. $77, \S 3$.

${ }^{2}$ Appendix r, to book V, p. 570, Keble's 3 d ed.

${ }^{3}$ Appendix $\mathrm{r}$ to book V, p. 559, Keble's 3 d ed.

4 This from book VI, chap. 3, § r. Fairly certainly from Hooker's pen, though perhaps not in place.

${ }^{5}$ Book V, 57, \&5.

- Book V, 62, §XV. 
impression of special pleading for the existing condition just because it did exist weakens the book as a whole.

The logic of the book would be a new absolutism, without some of the historic safeguards that checked the papacy as an ecclesiastical power or the spiritual independency that made Catholicism more than once a protection against political tyranny.

That this is true may be gathered from the struggle for absolute power of the party to whom Hooker's plea came with greatest force. The turmoil and confusions of the years from the death of Hooker to the revolution (I688) can only be understood when we remember that high-church Puritanism and high-church Episcopacy were struggling for supreme and absolute power. Neither of them sought any strengthening of democracy, nor did any real democracy ever become supreme, but the platform upon which English political life was built up was greatly widened. Democracy gained ground amid the disputes between the various parties.

Were we studying the polity of Anglo-Catholicism it would be our duty to take up in detail the answer of Whitgift ${ }^{1}$ to Cartwright in its bearings upon Hooker and the Anglo-Catholic movement in general, but systematic ethics was only indirectly involved in the question of church polity. It was directly involved in the attempt to translate the movement into political reality.

This attempt was made by the strong hand of Archbishop Laud, ${ }^{2}$ whose horizon was narrow and unlit by historical spirit.

${ }^{1}$ The works of John Whitgift, D.D., Archbishop of Canterbury, in three volumes, published by the Parker Society, Cambridge, I851-1853; "Lives," by Sir George Paule (the "Life . . o of John Whitgift, Lord Archbishop of Canterbury," London, I61 2, I699; also in Wordsworth, Christopher: "Ecclesiastical Biography," etc., vol. IV, London, I8I8), and a sketch in vol. III of "Works," by the editor, Rev. John Ayre.

${ }^{2}$ Laud, William, was born at Reading, 1573, died I644. He was educated at Oxford, was rapidly advanced. President of St. Johns I6II; Deanery of Gloucester, 1616; Bishop of St. Davids, 1621; Bishop of London, 1628; Archbishop of Canterbury, I633. Impeached by the Long Parliament, and, after long waiting, condemned and executed in 1644 at the age of seventy-one. His works are published (Oxford) in seven volumes (nine parts), 1847-1860. William Scott, editor of vols. I and II, and James Bliss, editor of the other volumes. His 
His were the legal ethics of absolutism and authority. He was content with a somewhat loose appeal to Scripture and tradition, "whereas," he writes, "according to Christ's institution, the Scripture, where it is plain, should guide the church, and the church, where there is doubt or difficulty, should expound the Scripture; yet so as neither Scripture should be forced, nor the church so bound up as that upon just and further evidence she may revise that which hath slipped by her." 1

Laud's one demand was outward uniformity. In theory he recognized that this was only a secondary matter, but he in reality thrust it into the foreground as the one essential for England's religious life. He sees in the separations from the church and the restlessness of the time but one demand, namely, decent order and uniform service. ${ }^{2}$ Hence he laid the emphasis just upon those things which were most likely to inspire hate in the Puritan mind and awaken distrust in the minds of those who, though not Puritan, greatly dreaded the political power of Rome. "Ceremonies," he wrote, "are the hedge that fence the substance of religion from all indignities which profaneness and sacrilege too commonly put upon it." 3

life has been written by Peter Heylen under the title: "Cyprianus Anglicus: or the History of the Life and Death of . . . William [Laud] . . Archbishop of Canterbury ... Also the Ecclesiastical History of ... England ...." London, 1668, and also by W. H. Hutton ("William Laud," in "English Leaders of Religion" series, London, Methuen, 1895), by Arthur Christopher Benson ("William Laud, Sometime Archbishop of Canterbury, a Study," London, I887 and 1897), and by Samuel Rawson Gardiner in the "Dictionary of National Biography" (edited by Leslie Stephen [continued by Sidney Lee], in 67 vols., London and New York, Macmillan, 1885-1903), vol. XXXII (I892), pp. I85194. Uncritical invective in William Prynne's "Canterburies Doom; or the First Part of a Complete History of the Commitment, Charge, Tryall, Condemnation, Execution of William Laud, late Archbishop of Canterbury," London, I646. The materials for a life and estimate of the man are contained in his works, and his "Defence" and "Diary" are candid and patently sincere. See also the standard histories of England, and especially Gardiner (Samuel Rawson), "History of England from James I. to the Outbreak of the Civil War," London, Longmans, $186_{3}-1882$, in Io vols.

1 "Epistle Ded. Works," vol. II, p. xvi.

2 "Epistle Ded. Works," vol. II, p. xvi.

a "Epistle Ded. Works," vol. II, p. xvi. 
He was unquestionably a bad adviser for both James and Charles, and they found in him an able defender of their theories of absolutism. Laud taught the doctrine of an absolute subordination of the clergy to the State ${ }^{1}$ and that non-resistance was a Christian duty even in the case of bad princes. To the newly awakened ethical sense of England he seemed morally utterly callous, and he had no real perception of the evils of his day.

Of course his point of view brought with it an entirely different emphasis. The intimate friend of men of the moral stamp of the Buckinghams and Strafford could only wink at their conduct because like Rome he placed heresy before all other sin, and saw in faithful subordination to the outward demands of church far too great a make-weight against serious transgression of the Ten Commandments. ${ }^{2}$ Laud was in no sense in touch with the real feeling of the great middle-class movement in England and Scotland. In Scotland he said: "For the present troubles in Scotland novations in religion are so far from being the true cause, as that it is manifest to any man that will look upon it with single eye, that temporal discontent and several ambitions of great men which had long been working were the true cause of these troubles." 3 No doubt the land hunger of the newly risen nobility had much to do with Scotland's unrest, but the awakened religious and ethical life was a factor for which Laud had no understanding.

In the canons (1635) Laud handed over supreme power to the king in the church, and the ever-constant dread of a return by the king to Rome made such a power fateful in the last degree. ${ }^{4}$ That Laud was as sincere as he was narrow need not be denied. In his pathetic "Defence" and "Diary" we see the earnest, pious, and energetic nature of the man at its best. He was not learned as were Whitgift and Hooker, nor was he a man of

${ }^{1}$ Conference with Fisher. "Works," vol. II, p. 228.

2 See Conference with Fisher. "Works," vol. II, p. I64.

3 "History of Laud's Troubles and Tryals," edition r695, p. 87.

1 "Troubles and Tryals," edition I695, p. Iо०; cf. cap. I, I. 
supreme force like Calvin or John Knox, and he was least of all a thinker; but he sought resolutely to translate again AngloCatholic absolutism into political terms. He was firmly persuaded "that my order as a bishop and my power of jurisdiction is by divine apostolic right, and unalterable (for aught I know) in the church of Christ. But all the power I or any other bishop hath to exercise, any the least power of order or jurisdiction within the realm of England, is derived wholly from the crown, and I conceive it were treasonable to derive it from any other power foreign or domestic." 1

Laud mistook uniformity for unity; he indeed called Aristotle "his old master," 2 but he had not learned from him either scientific method or political good sense. That Laud should go to the scaffold in his seventy-second year on charges that were, to say the least, not proven, is another blot upon the page of history. But, alas, despotism had taught Parliament that the surest way with opposition was death, and Strafford and Laud were both skilled and courageous opponents.

Within the Anglo-Catholic world of thought systematic ethics has little scope for development. Mediævalism was the real ideal and inspiration, although the primitive church was supposed to be the model. Lack of historical sense and critical insight has crippled the undoubted learning and devotion of those who simply desired to nationalize the Roman hierarchy and restore the Byzantianism of the fourth and fifth centuries.

\section{THE ETHICS OF INDEPENDENCY}

Note of Introduction. - If Anglo-Catholicism was born of the political and economic situation, no less is it true that Independency had its origin in the demand on the part of a rising class for a new atmosphere in which to breathe. Independency fought for the things it needed for its life and thus demanded toleration, not on the basis of theory, that came later, but on the ground of

1 "History of Troubles and Tryals," edition 1695, p. 155.

2 "History of Troubles and Tryals," edition 1695, p. I59. 
vital necessity. Independency, Puritanism, and Anglo-Catholicism are sharply divided points of view, but intellectual clearsightedness and self-consistency are not common gifts, so that as a matter of fact the lines are not drawn sharply in the English or American history of Independency-perhaps least sharply in the American historical congregational development of it. ${ }^{1}$ In fact it is quite impossible to say with accuracy how the theory of Independency grew up. That Browne had much to do with it is perfectly true. But not only did he die in the established church, but he was not himself clear in his teachings. And when Independency took root in American soil Puritanism and its thinking had already invaded its life, and to this day Puritanism is most constantly confounded with a type of Independency as abhorrent to many of the leaders of Puritanism as was Rome itself.

Yet the ethical outlook was in this period largely determined by the definition of the relation of the Church to the State. No one thought of life without a final and absolute external authority both in doctrine and in morals. No one questioned seriously the supremacy of the State in temporal things or the supremacy of the church in spiritual things. But what was the church? Where were the boundaries between secular and spiritual con-

\footnotetext{
${ }^{1}$ The literature is very large, and although the bibliography in Dexter's (Henry Martin) "Congregationalism of the Last Three Hundred Years as Seen in its Literature," New York, 1880 , is now far from complete, it is a most valuable aid. See especially Fletcher, Joseph: "The History of the Revival and Progress of Independency in England Since the Period of the Reformation," 4 vols., London, 1847 , etc.; Hanbury, Roger: "Historical Memorials Relating to the Independents," 3 vols., I839-1844; Vaughan, Robert: "English Nonconformity," London, 1862; Skeats, Herbert S.: "History of the Free Churches of England from 1688 to I851," London, I869; Dexter, Henry Martin: "Congregationalism of the Last Three Hundred Years as Seen in its Literature," New York, I88o; Price, Thomas: "History of Protestant Nonconformity in England, from the Reformation under Henry VIII," 2 vols., London, I836-1838; Wilson, Walter: "The History and Antiquities of the Dissenting Churches . . . in London, Westminster, and Southwark, Including the Lives of Their Ministers, from the Rise of Nonconformity to the Present Time . . . " 4 vols., London, I808-18r4; Waddington, John: "Survey of Congregational History, 1 200-1567," London, 1866 and 1869 .
} 
cerns? Who was in the last analysis to draw the lines between these provinces? Rome still maintained her spiritual supremacy even over the State by demanding the right to define the duties of the State. Anglo-Catholicism resisted that claim, but gave in practice the spiritual supremacy to the State by making a national church with the secular ruler as its head, "as far as the law of Christ permitted," it is true, but with no organ save the State to decide finally what was "the law of Christ." Puritanism found the "law of Christ" in the Bible binding both Church and State, but it had also no organ for finally and with authority determining just what the Bible meant. Hence as Protestantism came to self-consciousness there were inevitably restless spirits who would be bound by neither Church nor State, as they then existed, in the interpretation of what all men nominally bowed to as a final authority, namely, the Bible.

Independency rose thus as the assertion of the individual over against not only the existing group, but as over against the past history of the group. Nor could it itself be really selfconsistent. It in fact appealed quite as fundamentally as did Romanism or Anglo-Catholicism to tradition. It accepted the Bible as the "word of God written" on what?-on the tradition of the church which fixed the canon, so far as it ever has been fixed. Its real appeal was to subjective religious experience, but it neither realized this nor saw the full significance of its revolt from the ecclesiastical tradition and the intervention of the physical power of the State in spiritual things.

The ethics of Independency no more received a systematic treatment than did the ethics of Puritanism, but they have their own special color and in the writings of Browne ${ }^{1}$ may be said

\footnotetext{
${ }^{1}$ Browne, Robert, born about $\mathrm{I}_{55} \mathrm{O}$, died $\mathrm{I}_{33}$. He was the third child of Anthony Browne, and of good family, being connected with Cecil, Lord Burghley, who took deep interest in him as a kinsman. He was educated at Corpus Christi College, Cambridge (B.A. in 1572). In 1580 founded an independent congregation at Norwich (but soon after at Bury St. Edmunds) to realize the apostolic church along the lines of the separatists and Lollards of previous generations. But in the autumn of $\mathrm{r} 58 \mathrm{r}$ he immigrated (congregation and all) to Middelburg, in Zeland (Cartwright's old church), to gain the freedom he
} 
to have their beginnings. It is not easy to hold the balance in judging of the life and ethical teachings of a man so strange and in some ways so inconsistent. It seems to the writer extravagant to say with T. G. Crippen, in his interesting introduction to the "Treatise of Reformation Without Tarrying for Any," that Browne formulated the principle of a "Free church in a free State." After reading all the extant writings of Browne save one to which the writer could not get access, no such formula seems even to be supposed as a groundwork of the thinking. In the very treatise itself Browne says, after alleging that the Pope was Antichrist and had no authority over Queen Elizabeth, that her power was civil, "and that power she hath as highest under God within her dominions, and that over all persons and causes. She has power of death by law, and none may resist her or the magistrate under her by force or wicked speeches, when they execute the laws."

required. At the close of 1583 he, however, returned, and although Elias Thacker and John Coppin (or Copping) were hanged ( $\mathrm{I}^{8} \mathrm{8}_{3}$ ) for simply possessing and distributing his writings (Thomas Gibson imprisoned for the crime of binding them!-for contrary view see "Dictionary of National Biography," article "Browne"), he could go to Scotland, and was in 1584 in Edinburgh, and only in 1586 was he finally excommunicated formally by Howland, the Bishop of Peterborough. He then made his submission, and received the mastership of the Stamford Grammar School (St. Olaf's) under exceedingly humiliating conditions. After five years became rector of Achurche-cum-Thorpe (in Northamptonshire) for more than forty years. Throughout his life he was protected by Lord Burghley, who perhaps thought him insane. He died in jail at Northampton, after having been arrested for assaulting a constable. This was in 1633 , or soon after. He was strange and erratic at all times, and disappointment, suffering, and unsuitable intellectual and spiritual surroundings may well have unbalanced an undoubtedly fine mind. A bibliographical list of his works is given by Crippen (T. G.) in his edition of "A Treatise of Reformation Without Tarrying for Any," published for the Congregational Historical Society, I903. Besides this he wrote "A Book which showeth the life and manner of all true Christians, and how unlike they are unto Turks and Papists and heathen folke," printed Middelburg, I $^{82}$; "A Treatise upon the XXIII of Matthew"; also "A True and Short Declaration," and "An answer to Stephen Bridewell, his first Book against the Brownists." For further details, see Dexter's (Henry M.) account in his "Congregationalism of the Last Three Hundred Years," although the present writer finds much to dissent from in the account and estimate of the man. 
At the same time he argues that the spiritual reformation of the church must be the work of the preachers who, however, have broken their spiritual swords and now call upon the State to reform the church. The pastor should have oversight of the magistrate, but only as spiritual guide, and though he has power of cutting off, it should only be with a spiritual weapon. At the same time the magistrate is really supreme, for Browne claims that when the pastors are cold the magistrate may "remove me from church and withhold me from preaching. Indeed the magistrate may force him (the preacher), but it is his shame to tarry till he be forced. Neither durst Moses nor any of the good kings of Juda force the people by law or by power to receive the church government, but after that they received it, if they fell away and sought not to the Lord, they might be put to death." The church is to be pure and then the magistrates will "abase themselves unto God before the face of the church." But given what Browne would call a pure church, and there were for him practically no limits to its despotism. This pure church he defines thus: "The church planted or gathered, is a company or number of Christians or believers which by a willing covenant made with their God are under the government of God and Christ, and keep his laws in one holy communion: because Christ hath redeemed them unto holiness and happiness forever, from which they were fallen by the sin of Adam." 1

Cartwright had written a really beautiful and broad-minded letter to Harrison in defence of a Presbyterian staying in the established church, and to this Browne rejoined. There he plainly says that the courts of the land are to be praised for passing and enforcing laws for punishing "Idolatries, forswearing, usurping of lordship, rebellion, murder," and all "outward gross wickedness." So that "the laws are a wall to the church round about" and "whereas the law doth bind us to come to church, it doth well, for no man ought to refuse the church of God, yet if when we come to church we find there an unlawful minister, and a wicked confusion of all sorts of people,

1 "Book Which Showeth the Life and Manners of All True Christians." 
the fault is not now in the law, but in the bishops which place such ministers."

Browne's objections, therefore, were not to an established church but to the established church. The church is marked by three things: "preaching of the word, ministration of the sacraments, and reformation of life, which is the chiefest thing of all to set forth Christ and his kingdom."

The church has power to loose and bind, and must keep the table of the Lord pure from the defilement of unworthy members. "And if one man could make an assembly a true church, he has power to bind and loose." 1

Moreover, in Browne's constant appeal to the Old Testament theocracy one sees that he had no hold upon the modern theory of spiritual independence of the State. The sacraments are for him the continuance of the sacrifices. "For if it be true that as all sacrifices then so all sacraments now are rebellion against the Lord, being ministered without the visible church of God." ${ }^{2}$ Indeed Browne makes much of the "outward discipline," and he regarded the persecutions of Mary as a judgment upon the half-hearted reformers of the preceding reigns. The unfortunate priestly story of Korah, Dathan, and Abiram ${ }^{3}$ plays its part in Browne, and he has his share of priestly blood-thirstiness. "Wherefore I would say there were holiness in the dumb ministry, if all the dumb ministers were hanged up in the churches and public assemblies, for a warning and terror to the rest, that they are ready to enter such a function." 4 He disclaims the error of the Donatists, who wished an absolutely sinless church, but "if in any church such gross sinner be incurable, and the church hath not power to redress them, or rebelliously refuseth to redress them, then it ceaseth to be the church of God, and so remaineth till it repent and take better order." The sacraments are disfigured "when dogs and swine do communicate therein," when "papists and atheists, drunkards, May-game-

${ }^{1}$ P. 7 of tract against Cartwright; cf. also p. I5.

2 "Answer to Cartwright," p. 19; cf. p. I8.

'Num. I6 : $1-40$.

4 "Answer to Cartwright," p. 23. 
sters, and such like are presented as sweet bread at the table of the Lord." 1

The interest with Browne was ethical rather than theological. His ideal was a pure church, and purity involved, of course, pure doctrine and sacraments, but mainly pure life. This pure life was based upon a covenant relationship entered into with God by the believer, and was conditioned upon keeping the commandments. "The second point of discipline is that the covenant promises and Gospel of Christ, and the sacraments of his kingdom, being established among the worthy, then that they keep the covenant and sacraments unpolluted."

This covenant conception gives to both the theology and ethics of Browne a hard and legal character, which is a bond between him and Puritanism; and like the Puritans the sacraments depend upon a "lawful ministry." And for Browne the lawfulness of a minister is the essence of a ministry." After discussing at some length the decline of the church, he says: "By all these places it is evident that though preaching may sometimes be without the present act of ministering the sacraments, yet the sacraments might never be ministered but of preachers and with preaching." 2

Yet the strong individualism of the man and his confidence in the individual's judgment makes him give really destructive powers of inquisition to every church member. "The individual must watch, and if offence arise must ask the church to join him in condemnation, but if the church will not do so, then he must proceed himself," and he thinks that "Christ hath given power to every Christian to retain the sins of every brother whom he knoweth to trespass against him, and not to forgive him unless he repent."

If Browne is to be historically classed, his independency and ethical outlook is rather of latter-day Plymouth brethren than American Congregationalism. And like the Plymouth brethren he was very impatient with a good deal of organized churchly Christianity. "For the sacraments," he said, "which the read-

\footnotetext{
1 "Answer to Cartwright," p. 34. 2 "Answer to Cartwright," p. 54.
} 
ing ministry do give us are neither his (sic) sacraments, neither the Lord's, as we proved before, but are polluted pledges of a wicked communion." 1

In a series of questions and answers, Browne gives the gist of his teaching in "A Book which showeth the Life and Manners of All True Christians, and how unlike they are unto Turks and Papists and heathen folke" (printed Middelburg, I582). He grounds the whole Christian life upon the voluntary covenant relationship with God. And we should lead a godly life "By knowing God and the duties of godliness, and by keeping those duties." 2 The covenant is mutual. God on one side, we on the other, and baptism is the seal of the covenant. ${ }^{3}$

"We must watch one another and try out all wickedness. We must privately and openly rebuke the private and open offenders. We must also separate the wilful and more grievous offenders and withhold ourselves from them, and gather the righteous together."

The sections 88 to 182 is a little ethical treatise as well as a little treatise on polity. In it Browne claims that elders should not only have gifts, but also "parentage and birth," for in a note he adds: "Birth and parentage is a gift whereby they have greater authority as by natural desert of kindred and blood or of begetting and bringing up, if so be that they answer in worthiness otherwise." 4 In point of fact Browne was neither a modern democrat nor a very radical independent. The phrases which are sometimes quoted to show his modern spirit, such as that "for the civil magistrate there must be an agreement of the people or commonwealth," are not so modern, taken in their connection, where he shows that the consent is a matter of antiquity, and that their real authority comes from God, "they are received" of the people and come from God "by birth and succession." 5

Yet Browne undoubtedly exercised a large influence. $\mathrm{He}$ was an erratic, seemingly quarrelsome man whose strong

\footnotetext{
2 “Answer to Cartwright," p. $85 . \quad 2$ \&. $\quad$ \& 36.

"This is not the only passage pointing the same way. $\quad$ \& II7.
} 
personality made him an intense individualist. He was probably often temporarily insane. Not simply as Dexter suggests toward the close of his carreer, but all through it, with the pride and egotism that often marks the neurotic patient. But he was a man of acute mind. His ethics are in the foreground, and consist of duties faithfully performed in a covenant relation to a somewhat harsh and unforgiving God. Though Independency repudiated him, it, no doubt, learnt much from him, and reveals in its history some of both his virtues and his blemishes. From our point of view, however, it can hardly be claimed that his extant writings would do much to spiritualize and deepen the morality of Independency, or to properly separate between ethical autonomy and one-sided individualism.

To be a "Brownist" became a reproach. At the same time the influence of Browne, was felt for long in the various sects that now began to arise. The spread of such bodies as the Baptists, Quakers, and groups of people with fantastic names, sometimes given them as nicknames, sometimes taken seriously by themselves, mark two things: first, the rise of individualism due to the breaking up of the old authoritative group centres; and, secondly, the gradual coming to self-consciousness of a religious life apart from the masterful leadership of a hierarchy.

These independent and separatist modes of thought found, no doubt, much in the Brownist movement that was fundamentally sympathetic, more particularly as it developed its life and emphasized the more constructive ideas flung out by Browne, so that the strange and erratic leader brought forth spiritual followers who did not know how far they had departed from the real teaching of the man who gave his name to the movement.

Nor is it possible to speak of any ethical system as common to the innumerable sects that sprang up on the Continent and especially in England, as a result of the breaking down of centralized authority. ${ }^{1}$ The religious view of the world inherited

${ }^{1}$ A most fascinating account of this ecclesiastical chaos is given by Mr. Robert Barclay in his large volume, "The Inner Life of the Religious Societies of the Commonwealth." We have used the $2 \mathrm{~d}$ edition, 1877 . 
from the mediæval church was now supposed to be held upon the authority of Scripture, and had to be read into its pages. Even when men like George Fox and Robert Barclay denied the primary significance of Scripture and put the Living Spirit in its place, ${ }^{1}$ they also proceeded to give back much the same message only ennobled by a little greater freedom, although also often made fantastic by the intrusion of an utterly unhistorical and uncritical subjectivism.

The Anabaptist movement had its distinct echoes in England. The cry for toleration and freedom in causes of conscience, which, so far as the writer knows, was first raised by Dr. Balthasar Hubmaier, ${ }^{2}$ found a ready response, no doubt, in many hearts in England. But the first expression was in I6I4, by Leonard Busher, in a letter to King James, ${ }^{3}$ in which even higher ground is taken for toleration than that by Balthasar, who would suffer the wheat and tares to grow together until the harvest because the Master said so, ${ }^{4}$ whereas Busher demanded it on the ground of each man's duty to think for himself. But on the whole the "Ranters," the "Seekers," and the strange sects that sprang up were as narrow and as intolerant as their persecutors. To this Roger Williams ${ }^{5}$ is a noble exception, and

1 "An Apology for the True Christian Divinity," by Robert Barclay, 1675. We have used the Irth edition, London, r849. Cf. "Prop." III, I-3.

2 "Von Ketzern und iren verbrennern vergleichung der gschufften zesamenzogen durch doctor Balthaser ein fridbergen pfarrern zu Waldschut zu gefallen bruder Anthoniu vicarin zu Costantz den ausserlesne thorwächter on am Pusanne. Die warheit ist untodtlich. Anno M. D. 24. yar."

3 "Religious Peace or a Plea for Liberty of Conscience," I614. Reprinted in I 846 by the Hanserd Knollys Society, together with other tracts. This society has also reprinted pleas set out in 1615 and 1620 anonymously.

" "Der acht Artickel."

${ }^{5}$ Born probably in London ( 1604 ?). B.A. of Pembroke College, Cambridge, 1626. Sailed for America December I, 1630, and visited Salem, Plymouth, and Boston. He was immersed as a Baptist but soon became "a seeker." The literature is given in Samuel L. Caldwell's admirable edition of his great work, "The Bloudy Tenent of Persecution for Cause of Conscience" (Ist ed., London, r644), and his answer to Cotton, "The Bloody Tenent yet more Bloody by Mr. Cotton's Endeavor to wash it White" (Ist ed., London, I652). Publications of the Narragansett Club, first series, vol. III, IV, V, and VI. (Containing also his letters and other writings, as against Fox.) 


\section{his pleas are based on the sacred character of man's liberty in the Holy Spirit. ${ }^{1}$}

The chief difficulty was that all parties still regarded some absolute external authority as necessary. Only men like Roger

1The preface to Roger Williams's "Bloudy Tenent" is as follows:

"First, That the blood of so many hundred thousand souls of Protestants and Papists, spilt in the wars of present and former ages for their respective consciences, is not required nor accepted by Jesus Christ the Prince of Peace.

"Secondly, Pregnant Scriptures and arguments are throughout the worke proposed against the Doctrine of persecution for cause of conscience.

"Thirdly, Satisfactory answers are given to Scriptures, and objections produced by Mr. Calvin, Beza, Mr. Cotton, and the ministers of the New England Churches and others former and later, tending to prove the Doctrine of persecution for cause of conscience.

"Fourthly, The Doctrine of persecution for cause of conscience is proved guilty of all the blood of the souls crying for vengeance under the Altar.

"Fifthly, All civil States with their officers of justice in their respective constitutions and administrations are proved essentially civil, and therefore not Judges, Governors, or Defenders of the Spiritual or Christian State and Worship.

"Sixthly, It is the will and command of God, that, since the coming of His Son the Lord Jesus, a permission of the most paganish, Jewish, Turkish or Antichristian consciences and worships be granted to all men in all Nations and Countries: and they are only to be fought against with that sword which is only (in soul matters) able to conquer, to wit the sword of God's Spirit, the Word of God.

"Seventhly, The State of the land of Israel, the kings and people thereof in Peace and War is proved figurative and ceremonial, and no pattern nor precedent for any Kingdome or civil State in the world to follow.

"Eighthly, God requireth not an uniformity of religion to be inacted and inforced in any civil State; which inforced uniformity (sooner or later) is the greatest occasion of civil war, ravishing of conscience, persecution of Christ Jesus in his servants, and of the hypocrisy and destruction of millions of souls.

"Ninthly, In holding an inforced uniformity of Religion in a civil State, we must necessarily disclaim our desires and hopes of the Jews' conversion to Christ.

"Tenthly, An inforced uniformity of Religion throughout a Nation or civil State, confounds the Civil and Religious, denies the principles of Christianity and civility, and that Jesus Christ is come in the flesh.

"Eleventhly, The permission of other consciences and worships than a State professeth, only can (according to God) procure a firm and lasting peace (good assurance being taken according to the wisdom of the civil State for uniformity of civil obedience from all sorts).

"Twelfthly, Lastly, true civility and Christianity may both flourish in a State or Kingdom, notwithstanding the permission of divers and contrary consciences, either of Jew or Gentile."

Preface to the reprint from the Hanserd-Knollys Society, edition of 1848 . 
Williams and George Fox had confidence in the subjective leading of the Holy Spirit in the interpretation of the external authority, and had learnt that violence only begot violence. The unhistoric subjectivism of men like Fox and even Barclay made a consistent ethical system impossible, and splendid as were the religious-ethical results of the Quaker movement, it was always hampered by an almost childish literalism-like saying "ye" and not taking off the hat to men-on the one hand, and an unrestrained subjectivism on the other, as when it was "opened" to Fox that he should go barefoot in Lichfield and cry, "Woe to bloody Lichfield," because forsooth one thousand martyrs had been killed there by Diocletian." This lack of historic sense and feeling for the continuity of history and tradition made Quakers bold in proposing great innovations. They opposed war, slavery, persecution, all unloving violence; they were foremost in the reform of schools and prisons. They strove for simple worship and the unworldly life; but they still had an absolute authority to be used uncritically and unhistorically. They still placed the Old Testament on the same ethical level in all its parts with the New, while recognizing an equally uncritically accepted "inner voice," with many times a dash of very unethical magic in its utterances.

On the whole, the ethics of an intelligent Independency is best formulated by John Milton. ${ }^{2}$ He stood for toleration as between the Protestant bodies in the interpretation of Scripture. Each man who went to the Bible must be free to find out what was there, but he had no toleration for papists or atheists, or any who did not acknowledge the Scriptures as the one sole source of authority. In fact Milton was a very hard and very inconsistent literalist. On the one hand he attacks all Sabbatarianism on the ground that the Decalogue is not binding,

1 "Journal," 3d ed., I 765 , pp. 48-49.

2 The classic life by Masson, 6 vols., I859-1880, gives all the details; $c f$. also Masson's own condensation, in "Encyclopædia Britannica," article "Milton." 
and on the other pleads the second commandment as excuse for suppressing the "idolatry of the mass." 1

In fact all the difficulties which a half-way Protestantism always must face appear in Milton's ethics. Yet his "Doctrina Christiana" ${ }^{2}$ is the most able and complete system of Independent ethics which we possess. It is divided into two parts. With the first part we are not mainly concerned, ${ }^{3}$ and our review of the second part must be hurried. The attempt is most interesting. The ethics are summed up in the second book." The true service of God is especially the study of good works. But good works are by faith and not of the Decalogue (p. 388). They are wrought by the Holy Spirit through faith to God's glory and our hope of salvation and the edification of our neighbor (p. 390). The primary efficient cause of good works is God; the secondary are "habits of good." 5 These virtues are general or special. The general are in the intellect

1 The quotations are from Symmon's edition of the prose work, 6 vols., 1806 . See vol. IV, p. 265, and his "Doctrina Christ.," I825, Cantab. edition, lib. II, cap. VII, pp. 446-454.

${ }^{2}$ Published posthumously, Cantab., 1825, and Bronswiga, 1827 .

3 Milton thought he drew his system wholly from the Bible. The theologian who reads the subjects can judge whether he did or not. He deals in thirty-three chapters with the doctrine of God; the divine decree; predestination; the Son of God; the Holy Spirit; creation; providence of God and his general government; the special ministration of angels; the government of men before the fall; whence the Sabbath and marriage; the fall and sin; the punishment of sin; about death called mortal; the restoration and redemption of Christ; the mediatorial office in its threefold character; renewal and vocation; regeneration; repentance and faith; about saving faith; renewal in Christ; justification and adoption; the mystical or invisible church; glorification, and assurance of faith and perseverance; the free covenant, or concerning the law of God; the Gospel and Christian liberty; the external signs of the free covenant (under the law circumcision and passover, under the Gospel, baptism and the Lord's supper); the visible church; the sacred Scriptures; particular churches; ecclesiastical discipline; the perfect glory and the second coming of Christ; the resurrection of the dead and the conflagration of the world.

All of this is so evidently the old Aristotelian scholasticism in framework and organizing interest that it is plain Milton was really only deceiving himself.

"Liber II, Cantab., edition 1825, pp. 387-536.

s "Habitus boni quæ virtutes nominantur." 
or the will. The intellectual are wisdom and prudence. In the will are sincerity, promptness, and constancy.

The special virtues pertain either to our duty (officium) to God or man. So that a knowledge of God as one versus atheism or polytheism is a first duty. Then come love, fidelity, hope, gratitude, fear, humility, patience, obedience, and Milton describes these with their opposing vices in Aristotelian or Stoic terms and Scripture texts. The external duties are the cult and prayer; sacred days and places, which last two he rejects, are dealt with.

Then come immediate duties to our neighbor, with a good deal of repetition, but an admirable discussion of love and justice. There are indirect duties to our neighbor as to ourselves. At this point Milton seems confused, and indeed the whole last part is condensed and unorganized, and closes with duties political and ecclesiastical. Religion is to be defended but not enforced by the magistrate. ${ }^{1}$ The ecclesiastical duties are hurriedly summed up in closing.

The dependence upon Aristotle and Cicero is apparent throughout, in spite of the elaborate Scripture quotation. The Old Testament is on the same level with the New Testament. The exegesis is painstaking and daring, but both uncritical and subjective. And what is remarkable throughout is the slavish acceptance of the letter.

Within the scholastic Protestantism of churchly thinking there was no chance for any real unification of ethics. The acceptance of a whole vast range of literature as a standard gave each man his chance to pick out what suited him, and the denial by Protestantism of a living absolute authority left unhistorical subjectivism to do its work. That in the confusion and in part as a result of it men should at last come to see the need of a larger liberty was inevitable. Jeremy Taylor's "Liberty of Prophesying" was no clearly thought-out platform any more than Milton's, ${ }^{2}$ but

\footnotetext{
${ }^{1}$ Lib. II, cap. I7, p. 528 .
}

${ }^{2}$ Both men get credit for a larger measure of toleration than they possessed. Neither of them, for instance, would have wanted the mass permitted in England. 
was the voicing of a felt need of a larger atmosphere. The sense that all external authority had in the last analysis, whether men believed it or no, to submit to the more or less critically trained reason and feeling had to grow up outside of organized ecclesiastical Protestantism.

\section{THE ETHICS OF PHILOSOPHICAL PROTESTANTISM}

Outside organized ecclesiastical Protestantism there arose a mighty force. It was a true child of the protest against usurped authority, and belongs therefore to Protestantism. It was essentially an empiric philosophy with an ultimate faith in man's capacity for co-operation with God. It must be included in any history even of organized Protestantism because the church is never so inclusive in Protestantism as in Roman Catholicism. There is a Protestantism of the stoutest kind whose home is in none of the churches, but whose work and development have deeply affected the religious thinking of all the churches, whether they realized it or not. Our history seeks indeed to follow the history of ethics rather within the organized church and to deal more particularly with ethics of the church, so that these last sections upon the ethics of philosophical Protestantism can only scan the field. This is the less to be regretted because a large literature already deals with philosophical ethics with a minuteness impossible in these pages. ${ }^{1}$

One of the first tasks of Protestantism should have been to free thought from the arrogant claims of ecclesiasticism, ${ }^{2}$ but

Even Lecky seems to exaggerate their breadth at this point. Cf. "History of Rationalism," vol. II, 79-80.

'An admirable sketch of English ethics is given by Sidgwick, H., in his article in the "Encyclopædia Britannica," and published in enlarged form as a book, "Outlines of the History of Ethics," 3d ed., 1892.

${ }^{2}$ The well-known books of Draper and Andrew D. White on the struggle for a real scientific freedom against the ghosts of ecclesiastical tyranny that even now still haunt the churches to their great hurt should be read and gravely pondered by all really thoughtful ecclesiastical leaders. Particularly the work of Andrew D. White deserves more especial attention, because of the temperate, reverent 
this was not only exceedingly difficult but also exceedingly delicate. The unity of life is such that no one phase of it can be touched without a potential alteration all along the line. We may hold mutually exclusive positions for a long time in our minds until some action depends upon our thought-process, and then at once the contradiction is made clear and one or other position must in fact be surrendered.

A great deal of Protestant thinking has been done under the shelter of forms its thinking really undermined. Men have bought the boon of inner freedom at the price of outward conformity in all ages. In Protestantism, however, the conformity has been, perhaps, generally sincere and unaffected, because Protestantism unconsciously but no less really moved the emphasis in the Christian life from the contemplative and the intellectual to the active and voluntary elements. The only possible basis for ecclesiastical unity is capacity for co-operation, and this capacity is conditioned by many other things than intellectual agreement.

In the theory of Rome, life was divided into a religious and a secular sphere. The doctrine of the two swords expressed this faith on the political field. This distinction early Protestantism sought to take over into the field of intellectual inquiry. It was assumed that the two had separate instruments but that the outcome must be the same. The faith of scholasticism that the closed system could be completely rationalized was handed over to the new Protestantism, but the contents of the closed system were different and the religious authority was, in fact, far less concrete and vital.

In England the political situation dominated all examination of ethics, and when philosophical Protestantism began independent research it was inspired by this interest. The founder of speculative ethical philosophy upon this new Protestant

spirit of his very severe criticism. The quarrel between "science" and "religion" is the inevitable readjustment of human life to new truth. Neither "science" nor "religion" can be more than a tentative formulation of human experience. 
English soil may be, without much fear of dispute, named as Francis Bacon. ${ }^{1}$

The excessive praise of Bacon has led to criticism and perhaps underestimates of his work and teaching. It can hardly be denied that his method has not taught the modern scientific laboratory how to work. ${ }^{2}$ It was Newton and Galileo and Harvey who really did that. At the same time Bacon saw clearly that real knowledge of experience and its laws was what men needed to gain power. He made familiar the thought of

${ }^{1}$ Francis Bacon, Baron Verulam and Viscount of St. Albans, was born in York House, in London, January 22, 156r. He spent his life in official service under Elizabeth and James, eventually having to retire with diminished fortune on charges of corruption from which he could not clear himself. He died April 9, I626. The best edition of his works is that collected and edited by James Spedding, Robert Leslie Ellis, and Douglas Denon Heath, London, Longmans, in 14 vols., $1857-1874$ (the same in Boston in 15 vols, $186 \mathrm{r}$; other editions are in progress); Methuen's "Standard Library," "The English Works of Francis Bacon, Lord Verulam," vol. I, "Essays and Counsels," and "The New Atlantis," appeared March, I906 (no more appeared up to December, 1908); "World's Classic" series, Clarendon Press; and "New Universal Library."

For most extensive literature, see the last edition of Ueberweg-Heinze, "Grundriss der Geschichte der Philosophie," Berlin, vol. III, $\S \mathrm{X}$. Besides the wellknown and oft-edited "Essays" (with annotations by Richard Whately, 6th ed., revised and enlarged, London, 1864, is especially well known), the works that have most interest for the student of ethics are "Colors of Good and Evil," "The New Atlantis" (in H. Morley's "Universal Library," vol. XXIII, I885, edited by A. T. Flux, 'Macmillan, 1899; by D. W. Bevan, "Royal Standard" series, London, 1899; and in Methuen's series mentioned above, 1905), and the ethical sections of the "Advancement of Learning" (Cassell's "National Library," vol. CLXXIII, I889, books I and II, edited with notes by F. G. Selby, in 2 vols., Macmillan, 1892 and 1895 ), which corresponds to the enlarged treatment in his "De Dignitate et Augmentis Scientiarum" (London, 1623, Argentorati, 1635, Amsterdam, 1662, etc.). The literature about Bacon is enormous, and a classified bibliography is much needed. The "Catalogue of the British Museum" (its section upon Bacon can be had separately) would furnish the basis. Especially important is Kuno Fischer's final (roth) volume in his "Geschichte der neueren Philosophie," 3d ed., Heidelberg, r904 " Bacon und seine Schule"; cf. also his "F. Bacon. Die Realphilosophie und ihr Zeitalter," Leipsic, 1856; in English: "Francis Bacon. Realistic Philosophy and Its Age," translated by J. Oxenford, London, 1857 ).

${ }^{2}$ On this point see the controversy raised by Liebig in Germany and the replies of Sigwart and Kuno Fischer. The literature is given by Kuno Fischer, p. 335 of the tenth volume of his "History of Modern Philosophy," 3 d ed., I 904. 
experiment as the only pathway to firm assurance. He raised most important issues and asked most searching questions to which the modern world is still trying to give an answer. $\mathrm{He}$ also created an atmosphere within which a wholesome sceptical empiricism could do its work while retaining a working faith in an intelligible world, and a good God; and in most unexpected places, and in many ways his influence may be traced, not only on the philosophical, but also upon the scientific and practical thinking of the world.

His first and quite impossible demand was that "divine" and "human" knowledge should be kept apart. He thought their intermingling "hath filled the one full of heresies, and the other full of speculative fictions and vanities." 1

Thus Bacon sought to free science from troublesome intrusions of a dogmatic character, because he did not realize how sweeping the research of science was bound to be. All knowledge was to be limited by "religion" and was "to be referred to use and action." 2 Bacon thought this pragmatic test would keep the two spheres of inquiry separate. And that the Scriptures could be cheerfully trusted "to reveal the will of God, and then the creatures expressing his power," and that in these two books we might be "secured from all error." 3 So in the "New Atlantis" a divine miracle brings the Old and New Testaments to the people of the happy land Bensalem.

Not, indeed, that Bacon would have had religion thus relegated to a sphere by itself to get rid of it, as Hobbes wished to do. Bacon deprecated all merely intellectual curiosity that had no element of service of mankind in it, or that did not aim at the making "goodness" real in life." Knowledge was ever to be tested by its utility for mankind, and its function is to restore man's lost sovereignty over the world.

1 "Of the Interpretation of Nature," vol. III, p. 219, of Spedding's edition, London, $1857-1874$, to which all references are made unless otherwise noted.

2 "Interpretation of Nature," vol. III, p. 2 I 8; "Works."

3 "Interpretation of Nature," vol. III, p. 22 I.

4 "Interpretation of Nature," vol. III, p, 222; $f f$. p. 218 and "De Augmentis," book VII, chap. I. 
While this is true, however, Bacon's interest was primarily neither religious nor ethical, but intellectual. He was himself not a man of high moral tone. No apologist has been able to do more than teach us to condone and excuse his ingratitude to Essex and his faithlessness in office. His own letters abundantly reveal the self-seeking, ambitious, marvellously gifted and selfconscious time-server. Hence not only have we no systematic ethics, but in all Bacon's elaborate plans for advancing men's knowledge, religious and ethical advance have but little part.

The nearest approach to a systematic treatment of ethics is in the "Advancement of Learning" 1 and in the corresponding Latin sections of his treatise "De Dignitate et Augmentis Scientiarum." 2 He deals there with the "good," but not in the "heathen" sense of the highest good, but on the lower plane of man's utility. He divides ethics into two parts: "The Exemplar or Platform of Good, and the Regiment or Culture of the Mind; the one describing the nature of the good, the other prescribing rules how to subdue, apply, and accommodate the will of man thereunto." 3 He thinks the ancients and the church divines have handled, under the head of the Nature of Good, Positive and Simple, and under Virtue and Duty, the content of ethics well, but that the examination concerning the roots of good and evil has been neglected, and that they ought to have more "consulted with nature" and been less "prolix and profound." $\mathrm{He}$ thinks there is in everything a double nature of good, according as the purpose is within the object or is referred to the object's relation to the larger whole. The larger whole is the nobler purpose, which decides for Bacon the controversy between the advantages of the vita activa and the vita contemplativa, and against Aristotle he contends that the active life is the higher one. Only "God and the angels" have a right to be lookers on. And Bacon says that only the real

\footnotetext{
1 "Works," vol. III, pp. 4r9-444.

2 Book VII, chaps. I-3; cf. book V, chap. I, and book VI, chap. 3; "Works," vols. IV and V.

" "Advancement of Learning," book II; "Works," vol. III, p. 4rg.
} 
services the monastery rendered and not the contemplative life rommended it to the church. ${ }^{1}$ On this principle are to be decided all the ethical issues between Zeno and Socrates on the one hand, and the Cyrenaics and Epicureans on the other. The larger social good and not individual happiness is the moral end. Hence the moral man is not frightened from his social service by indignity and perturbations.

The private or particular good falls into two divisions of good, active and passive. Every creature is animated by the desire of self-preservation and of "dilating" or multipiying itself. And here again the active good is the higher. Passive good is conservative and perfective; of these, however, to perfect while conserving is the nobler ambition.

The real ethics of Bacon rest upon "the good of man which respecteth and beholdeth society, which we may term duty," and a man cannot understand "virtue without some relation to society, nor duty without an inward disposition." Duty may be either the common duty of every man, as a man or a member of the State, and the particular duty of every man in his profession, vocation, or place. This last division, Bacon says, can only be dealt with in special and particular treatment by experts, and the failings and temptations should, he thinks, be treated less cynically and more seriously.

Ethics should also deal with the culture of the mind, which never works independently of feelings and will. Man must prepare himself for the moral decisions and the moral strains of the active social life. Bacon, however, does not really get rid of authority in ethics by his complete separation of religion as a matter of revelation from the science of conduct based upon experience. He denies that theology can be founded upon the light of nature. ${ }^{2}$ In point of fact Bacon's social state was a monarchy of the type of Henry VIII or Elizabeth, in which the will of the king was practically supreme. He claimed that he

1 "Advancement of Learning," book II; "Works," vol. III, p. 422, and other passages.

" "Advancement of Learning," book II; "Works," vol. III, p. 478. 
had separated the science of "civic knowledge" from ethics," but in reality his treatments overlap as they were bound to do. Of the content of his ethical teaching it is difficult to speak, because it is so various in character. Much is taken from Seneca and Cicero, who seem to have profoundly influenced him. From time to time a lofty inwardness marks his thinking, but he often falls to a much lower level of merely shrewd worldly wisdom. In his "Meditationes Sacræ" he emphasizes the fact that "if evil overtake your enemy from elsewhere, and you in the inmost recesses of your heart are grieved and distressed, and feel no touch of joy, as thinking that the day of your revenge and redress has come; this I account to be the summit and exaltation of charity." He shakes himself loose from the prevalent theological disparagement of humanity, and claims that "the inclination of goodness is imprinted deeply in the nature of man; insomuch that if it issue not toward men, it will take unto other living creatures." 2 Man is on one side akin to the beasts and on the other related to God, and to deny God is to wrong man. In such an essay as that on superstition one may see the spirit which later issued in English empiricism in both ethics and religion. But nowhere does Bacon follow up his clews. He was, indeed, himself a fine example of the failure of speculation apart from experiment and facts, as the mere collection of facts is barren without speculative hypothesis of which facts must be the tests.

In spite of the lofty inwardness, of which we have spoken, and the social character of his fundamental ethics, the general impression is rather that of the noble paganism of the Roman Stoics and Cynics than of the sweet gentleness and yet stern severity of New Testament ethics. Bacon did little to develop his system, but it is at least doubtful whether had he done so

1 "Illa duas habet partes, easque notissimas et consensu receptas; Logicam et Ethicam: nisi quod Doctrinam Civilem, quæ vulgo ut pars ethical collocatur, jam ante emancipaverimus," "De Augmentis," liber V, cap. I; "Works," vol. I, p. 6ru.

2 Essay XIII; see also Essay XVI. 
we should have had any marked advance in a truly Christian morality.

Another English thinker is dominated from the beginning of his thought by the political situation and by the peculiar intellectual position the transformation of English life created. Thomas Hobbes ${ }^{1}$ was, however, quite far removed from Bacon, though influenced, of course, by him in a measure not now easy to determine.

It is hard to read the brilliant and clever work of Hobbes without a sense that cynicism and an overweening self-estimate to a very great degree lowers all his work, and gives it, even though the work of genius, a certain unreality and artificial character. He was so sure of his ground that he was careless about making sure of his facts; and his wonderful command of language made him, at times, the victim of his own cleverness. His work is a curious admixture of the old and the new in thought, and represents a more or less serious attempt to retain the old under new forms of expression.

For the actual ethics of the New Testament he had no comprehension, and the wonder is rather that he was listened to at all than that he was violently attacked.

Yet Hobbes has had great influence both direct and indirect, and there are so many points of contact between his thinking and later types of English empiricism that even Christian ethics must take account of him.

Like Bacon, Hobbes wished absolutely to separate religion

${ }^{1}$ Hobbes, Thomas (April 5, r588-December 4, r679), student at Magdalen Hall, Oxford, 1603, B.A. in 1608 (Feburary 5). His works are collected in eleven volumes of English and five of Latin writings by Sir William Molesworth (1839-1845). Those of special ethical interest are "Human Nature, or the Fundamental Elements of Policy" (1650), and "De Corpore Politico, or the Elements of Law, Moral and Politic" ( 1650 , republished in 1889 by Dr. Ferdinand Tönnies). His own translation of his "De Cive" (Paris, I642; Amsterdam, I647, as "Elementa Philosophiæ de Cive"), under the title "Philosophical Rudiments Concerning Government and Society" ( $\mathrm{r}_{5} \mathrm{I}$ ), and then especially his "Leviathan, or the Matter, Form and Power of a Commonwealth, Ecclesiastical and Civil" (1651, edited by A. R. Waller, Cambridge, 1904). An elaboration of his doctrine of the will appears in his debate with Bramhall (vol. V of his "English Works"). 
from philosophy. God was no object of speculative thought, and religion as an outward exercise was a State matter. Any one who was a loyal citizen accepted what the State established and that became his (outward) religion; to attempt any additions or alterations was superstition. Of course Hobbes thus really sheltered all kinds of private scepticisms under the guise of conformity. For Hobbes's own philosophy is quite destructive of the forty-nine articles.

His metaphysics and epistemology are secondary to his ethics and politics. His metaphysics is a mechanical realism, in the sense that all real substance has body and all knowledge is of effects produced by one body on another. Our knowledge is, however, of the effect upon us, thus giving a subjective character to all ultimate knowledge. Words are mere signs of arbitrary character for holding together things with no necessary or inherent common character (nominalist).

He came under the influence of Bacon, but his interest in mathematics and his conception of the subjective reconstruction of experience separates him from the stiff phenomenalism of of the "Novum Organum." There is therefore an element again of rationalism in Hobbes.

His ethics come together with his politics, and represent an attempt to rationalize Byzantianism. Ethics and government have grown out of the demand for the peace and safety of the individual. Unlike bees and ants, the natural state of man, who is selfish and pleasure-loving, is war. The only way, however, to escape the horrors of war is the voluntary subjection of all to a chosen instrument of government (hint of social contracttheory of Rousseau). There is no good or evil in itself, but what now the central authority declares to be for the good of all is good and what is bad is evil. The whole basis, therefore, of good or evil is the determination of the central power. This power may be an assembly, but is better a king. Once chosen, this central power can only function if made absolute. If not made absolute we will quarrel as we did as barbarians. This doctrine falls in with the absolutism of the religious 
party (Hooper, etc.). Men are absolutely determined by their sense of pain and pleasure, and when these things are in the future they represent desire and aversion. The State seeks by playing on desire and aversion, by rewards and punishments, to maintain the social bond, so that the higher values of life may be conserved for the individual.

This determinism was attacked by the religious world, but is in point of fact the kind of teaching made popular in the eighteenth century. Religion serves the State's purpose by heightening the sense of rewards and punishment, and so the State is really put by Hobbes in the place of God. There is no good in itself, but what maintains peace comes to be called good, and the really good man is the good citizen (hint of Bentham). All knowledge must have practical end, but especially ethics has as its end simply the experience of how we may best live together. The central State is therefore the necessary outcome of experience. And reason can show that it always must be the outcome.

Just as nominalism really was digging its own grave in the Middle Ages, so Hobbes's "Leviathan" was actually the reduction of Toryism to an absurdity. Under the cloak of an intense mediæval Byzantianism the reader sees, however, a really modern view of the world skilfully hiding itself. There is a half-concealed empiricism and a private rationalism which remind us of the political apologies of a Cicero.

More than to either Bacon or Hobbes, English ethics owes its character to the work of John Locke, ${ }^{1}$ whose contributions to the progress of human thought are hardly sufficiently recognized. To him we owe the revolution in education commonly accredited to Rousseau, and his defence of representative government has cogency yet. ${ }^{2}$

${ }^{1}$ Locke, John, born in August, I632, and died October, I704. He studied at Oxford, and afterward came deeply under the influence of Descartes. He shared the fortunes of Lord Shaftesbury, and so lived with him for lengthened periods on the Continent of Europe until the accession of William of Orange (I688). He was the apostle of constitutional liberalism. In I690 appeared his great essay, "Concerning Human Understanding."

${ }^{2}$ Cf. Windelband, "Geschichte der Neueren Philosophie," vol. I, pp. 273-274, $4^{\text {th }}$ ed., I907. 
His ethics are not worked out in any systematic way, yet he laid the foundation for modern ethical empiricism, although he himself never developed his theory even as far as did Hume. Yet his negative work is all important. ${ }^{1} \mathrm{He}$ in these chapters opened the way for the scepticism, so-called, of Hume.

Locke, in accordance with his fundamental postulate, denied that there were any innate practical ideas. All our knowledge comes from sensation and reflection. More particularly is this true in morals. That there are no innate moral ideas is proved by the actual practice of men and by the different courses of conduct which they defend. "Virtue is generally approved, not because innate, but because profitable." 2

"The true ground of morality, which can only be in the will and law of a God, who sees men in the dark, has in his hands rewards and punishments, and power enough to call to account the proudest offender. For God having, by an inseparable connection, joined virtue and public happiness together, and made the practice thereof necessary to the preservation of society, and visibly beneficial to all with whom the virtuous man has to do; it is no wonder that every one should not only allow, but recommend and magnify, those rules to others, from whose observance of them he is sure to reap advantage himself." 3 And the very fact that men cry up what they do not themselves practice shows "that they very little consider the Law-giver that prescribed these rules, nor the hell he has ordained for the punishment of those that transgress them." 4

"Conscience is nothing else but our own opinion or judgment of the moral rectitude or pravity of our own actions, ${ }^{5}$ and so some follow what others avoid.

Thus Locke regards a revealed law as a necessity, and thinks that "Moral laws are sent as a curb and a restraint to these exorbitant desires, which they cannot be but by rewards and

${ }^{1}$ Book I, chaps. 3 and 4 of the "Essay." See vol. I of the edition of 18 r2, pp. 33-76.

${ }^{2}$ Chap. $3, \S$ vi.

${ }^{3}$ Book I, chap. 3 , § vi.

I Ibid.

5 Book I, chap. 3 , \& viii. 
punishments that will overbalance the satisfaction any one shall propose to himself in the breach of the law," and "there is a great difference between an innate law and a law of nature," for "we may know the law of nature by the light of nature." 1

In the fifteenth section he gives a most complete and damaging criticism of Lord Herbert's doctrine of innate principles, as he set them forth in his chapter on "De Veritate." 2

Locke shows very easily that these things, however true, are not innate, and that many things seem to us innate which examination proves to be only impressions produced in various ways. "For such who are careful (as they call it) to principle children well (and few there be who have not a set of those principles for them which they believe in), instil into the unwary and as yet unprejudiced, understanding (for white paper receives any characters) these doctrines they would have them retain and profess." 3

It was Locke also who set English ethics distinctly on the ground of a common social advantage. Bacon had already drawn the distinction between the good of the individual and the good of the community, but Locke developed the conception of an ethical political commonwealth, with the majority ruling. In his treatise on "Toleration" "Locke defines a commonwealth as "a society of men constituted only for the procuring, the preserving, and the advancing their own civil interests," and these civil interests are "Life, liberty, health, and indolency of body," 5 which is the forerunner of the more modern "Life, liberty, and the pursuit of happiness," as well as the caring for

${ }^{1}$ Book I, chap. $3, \S$ xiii.

2 These "notes" of Lord Herbert's have played quite a part in English and Scotch thinking. He defines them as "Prioritas, Independentia, Universalitas Certitudo, Necessitas, i. e., faciunt ad hominis conservationem," and then gives the five points of Deism, i. e., "(I) Esse aliquod supremum numen; (2) Numen illud coli debere; (3) Virtutem cum pietate conjunctam optimam esse rationem cultus divini; (4) Resipiscendum esse à peccatis; (5) Dari præmium vel pœnam post hanc vitam transactam." $C f$. "De Veritate," 3 d ed., 1656, p. 79.

3 "Essay," book I, chap. $3, \S$ xxii.

"The letters on "Toleration" are in vol. VI, of the edition of 1812 .

$s$ "A Letter Concerning Toleration," vol. VI, p. ro, of edition of I8I 2. 
those property interests which commercial and feudal England has always valued so highly.

The ethics of Locke reflect also the extreme individualism that has always marked English thought. Beyond the protecting life and property the State has but little function, and the church should be a voluntary society within the State, for "the care of a man's soul belongs unto himself and is to be left unto himself." 1

Like Hobbes, he thought " the pravity of mankind being such that they had rather injuriously prey upon the fruits of other men's labors than take pains to provide for themselves," government becomes a necessity. Locke, however, has limits for his toleration. Men are not to be tolerated "who deny the being of God," but it is because such an one cannot be "bound by oath," and thus the foundation of society is shaken."

The thorough-going empiricism of Locke leads him to turn to historical experience for the data of ethical postulates, and so he rendered an untold service in making ethics an historical as well as a systematic study. On this account he regarded ethics as a science in which demonstration was as possible as in mathematics. ${ }^{3}$

Thus Locke furnished the basis for a thorough-going rationalism in ethics, and more than any one else did he prepare the way for the inevitable separation in Protestant thought between authoritative theology and empiric ethics. And even while proclaiming the traditional basis in a "revealed religion" he was actually on the side of a pronounced historic empiricism. Thus he differed distinctly from the men whom he greatly influenced, and who are generally but somewhat loosely called the English deists.

It is hard to find more than a general agreement amidst men as different as Clarke is from Lord Shaftesbury or Wollaston from Collins. But for all that there is a spirit that unites the English

\footnotetext{
1 "Letter on Toleration," vol. VI, of edition of r8I 2.

2 "Letter on Toleration," vol. VI, edition of 1812.

3 "Essay," book I, chap. 3, § xiii.
} 
deists. ${ }^{1}$ They all reacted in various ways against the interpretation of Bacon's empiricism, made fashionable by Hobbes. Already the Cambridge Platonists sought an "immutable morality," and in his preface to Ralph Cudworth's posthumous work on ethics the Bishop of Durham singles out Hobbes as the one against whom this whole reaction was aimed. ${ }^{2}$ It was clearly recognized that with the breaking up of a central ecclesiastical authority upon which to build a religious and moral structure another basis had to be found for these values.

The so-called Cambridge Platonists, among whom Cudworth and More ${ }^{3}$ stand out as representatives, seek in the permanent objective reality of ideas given in "reason" a basis for an immutable morality. In them, as in the whole deist movement of a later day, a source of endless confusion is the failure to ask themselves what was meant by "reason" or to hold fast to any clear theory of knowledge. With the Cambridge Platonists, as with Lord Herbert of Cherbury, ${ }^{4}$ there was a natural religion

${ }^{1}$ Besides the works of the men themselves, see: Leland, John: "A View of the Principal Deistical Writers," 2 vols, 4th ed., I 764 ; also Longmans, 1807; Lechler, Gotthard Victor: "Geschichte des englischen Deismus," Stuttgart and Tübingen, 1841; Stephen, Leslie: "History of English Thought in the Eighteenth Century," 2 vols., London, 1876; Tulloch, John: "Rational Theology and Christian Philosophy in England in the Seventeenth Century," 2 vols., Edinburgh, London, and New York, 1872.

${ }^{2}$ Cudworth, Ralph, $\mathrm{r} 6 \mathrm{r} 7-\mathrm{r} 688$. This treatise is published in the third volume of the edition of 1845 of Cudworth's "True Intellectual System of the Universe," and the preface by the Bishop of Durham is on p. 519 .

${ }^{3}$ More, Henry (1614-1687). A profuse writer whose work, "Enchiridion Ethicum præcipua Moralis Philosophiæ Rudimenta complectens . . . " (London, 1667, 1668, 1669, 1679, r695, nova editio, Amsterdam, I 7 I I, 4th London edition), is the one of interest to the student of ethics. Cf. Tulloch's (John) "Rational Theology and Christian Philosophy in England in the Seventeenth Century," 2 vols., Edinburgh, London, and New York, 1872, vol. II, chap. 5, pp. 303-409. The second volume is given up to the so-called Cambridge Platonists, of whom More was a leader.

4 Edward, Lord Herbert of Cherbury, born March 3, 1583 (1582 -3), died August 20, 1648, his autobiography edited and completed by Solomon Lazarus Lee, London, 1886. He was a statesman and courtier. His main work for the student of ethics is "De Veritate prout distinguitur à Revelatione, à Verisimili, a Possibili et a Falso," Paris, 1624, 1633, 1639, London (rst London edition), I645, 1656, r659. A French translation, Paris, 1636 . See also the tract, "De Religione 
and a moral content which was really "given" in human life. The main question was how was it given?

To this question the general answer was based upon the assumption that there was a content of morals accepted as true, and as all of them were steeped in pagan culture this content is largely the later Roman Stoicism with Platonic elements.

Lord Herbert of Cherbury was not a man of very high moral attainments in some ways. He was vain and pushing, with an overweening love for playing the part of court gallant. But he clearly saw that amidst the confusions of the Reformation some other basis for morals and religion must be found than the divided authorities of organized ecclesiasticisms.

The subsequent deist movement accepted almost as their platform Lord Herbert's definition of religion, ${ }^{1}$ and sought to build up a universal religion which should contain the essentials of all. In this universal religion morals and conduct were to be the best service rendered to God. ${ }^{2}$ We therefore should naturally expect a distinct contribution in ethics from the deist movement. But though they do devote a great deal of time to ethical discussion, two circumstances render their work on this field relatively unfruitful. First, they failed to properly examine the epistemological and psychological postulates with which all ethics must begin. Secondly, they failed to really appreciate the positive contribution the empiricism of Bacon and Hobbes was capable of making. They, in fact, only recognized the negative side of this movement in English thought.

Laici," in "De causis errorum: una cum tractatu De religione laici, et appendice ad sacerdotes," 3 parts, London, I645, and "De Religione Gentilium, errorumque apud eos causis," Amsterdam, I663, 2d ed., Amsterdam, I700; English translation, "The antient religion of the gentiles and causes of their errors considered . . . , " translated by W. Lewis, London, I705. An exceedingly appreciative monograph is by Rémusat (Charles François Marie de), "Lord Herbert de Cherbury sa Vie et ses Euvres, ou les Origines de la Philosophie du sens commun et de Théologie naturelle en Angleterre," Paris, 1874.

'See p. 449 for Locke's critique of it. $C f$., also, "Autobiography," Lee's edition, pp. 60-62.

${ }^{2}$ So Shaftesbury, "Characteristicks," vol. II, book I, I : I; Wollaston, "The Religion of Nature," sec. I, p. 8, 7th ed. 
Shaftesbury ${ }^{1}$ has an interesting attempt to find in harmony and adjustment a rational basis for ethics. He sees that "Mankind (is) alarmed by the freedom of some late pens," ${ }^{2}$ and attribbutes it to the general collapse of authority. He then seeks the nature of virtue as consisting "in a certain just disposition, or proportionate affection of a rational creature toward the moral objects of right and wrong." 3 But important as was his theistic argument, the ethics seems to have had no such influence as was exercised by Wollaston. ${ }^{4}$ He has an interesting discussion of moral good as essentially a correspondence with the facts of the universe. ${ }^{5}$ Truth is the good because it corresponds to God's nature, ${ }^{\circ}$ and all human acts are statements affirming or denying in various degrees God's eternal truth. " "Every intelligent, active, and free being should so behave himself as by no act to contradict truth, or that he should so treat everything as being what it is." 8 But Wollaston leaves an unresolved antinomy between the "ought" and happiness. He says plainly that "to make itself happy is a duty which every being, in proportion to its capacity, owes to itself, and which every intelligent being may be supposed to aim at in general," " but as to a correspondence between duty (truth) and happiness he can only say: "Now present pleasure is for the present indeed agreeable, but if it be not true and he who enjoys it must pay more for it than it is worth, it cannot be for his good or good for him. This, therefore, cannot be happiness." 10 And he has a robust faith that the practice of truth cannot make any being ultimately

${ }^{1}$ Anthony Ashley Cooper, third Earl of Shaftesbury ( $\left.1671-1713\right)$. "Characteristicks of Men, Manners, Opinions, Times," 3 vols., I711, I7 14, 1723, 1732; 6th ed., $1737-173^{8}$ (of edition 1870 , edited by Rev. W. M. Hatch, only one volume appeared). The student of ethics should turn to vol. II, treatise IV, "An Inquiry Concerning Virtue or Merit."

2 "Characteristicks," vol. II, book I, I : I.

" "Characteristicks," vol. II, book I, $3:$ I.

"Wollaston, William, born March 26, I660 (1659-60), died October 20, I724. "The Religion of Nature Delineated," privately printed in $1722 ; 7$ th ed., 1746.

${ }^{5}$ Sec. I, $4:$ I (p. 19 of 7 th ed.).

- Sec. I, $4: 3$.

${ }^{7}$ Sec. I, $2: 5$.

${ }^{8}$ Sec. I, II.

- Sec. II, 9.

${ }^{10} \mathrm{Sec}$. II, 7, and sec. II, II. 
unhappy, but his own doctrine of probabilism, "where certainty is not to be had," "reveals the fact that the correspondence between truth and happiness is not so easy to prove as his theory demands.

The deists were active-minded men, and faced real questions, but in the advancement of ethics their work was often more fruitful of doubt than productive of certainty.

Some did good critical work in showing as did Blount ${ }^{2}$ the untenable character of much prevalent scholastic apologetic, but Blount had nothing to put in its place, and he did his work lightly and offensively. And so far as this work was positive it did little more than reinstate an eclectic pagan morality as the substance of both religion and ethics. Thus, for instance, in the ethics of Tindal ${ }^{3}$ the primary postulate is that "natural religion" is perfect, and that in point of fact as "the perfection of any nature, whether human, angelical, or divine, consists in being governed by the law of its nature," 4 it was open to the pagan. world to live on the highest plane of morality. There is no room for historical development in Tindal's scheme, and the scheme itself is Stoic intellectualism in search of personal happiness. The way he uses history is to try to strip off from it the mistakes and errors of the past, in perfect confidence that the whole truth has always been present. God is unchangeable, man's nature remains the same, hence religion and morals must always have the same character and content. Christianity brought, according to Tindal, and with him the deists generally, no new morality, but a message of repentance from $\sin$ and of freedom from superstition. Christianity is thus a higher phase of natural religion. It is this negative work alone that has had such great and sweeping influence. Deism began the

${ }^{1}$ Sec. III, I6.

2 Blount, Charles, 1654-1693. Collected works in 1695.

3 Tindal, Matthew, born I653, died August 16, I733. Fellow of Oxford. He went from the Anglican church over to Romanism and then back again. His last and best-known work is "Christianity as Old as Creation, or the Gospel; a Republication of the Religion of Nature." London, I730, r73I; 4th ed. in 1733 . 4 "Christianity as Old as Creation," p. I4, $2 \mathrm{~d}$ ed. 
critical examination of the accepted content of Christianity and its morality, but it can hardly be said to have pushed its examination into the fundamental postulates with the thoroughness of Locke or Hume, nor yet to have really given any valuable reconstruction of ethics as a system of conduct. And in all of them there is a curious mingling of formalism and freedom, of dogmatism and rationalism. Herbert of Cherbury prayed for a sign from heaven as to whether he should publish his book "De Veritate," and a voice or sound answered him out of a clear sky. ${ }^{1}$ And Tindal is very insistent upon retaining the word Christian for a system which he shows long preceded Christ.

Such an examination as Toland gave to the canon, to show that it could not be made the sole foundation for morals, was too superficial to do more than raise serious questions, and Samuel Clarke and afterward Dr. Lardner, had the best of the argument even where, as critical opinion now knows, they were wrong.

The extremely modern note that rings throughout the English deists is rather suggestive of the coming freedom than an actual herald of it. And although it is not fair to undervalue many of their most useful protests, as that of Shaftesbury against what we would now call, with George Eliot, "otherworldliness," ${ }^{2}$ yet even these protests were mingled with the acceptance of so much inconsistent matter that they gave undue advantage to their critics. Shaftesbury, for instance, bases the acceptance of the Christian religion upon the enactment of the State exactly in the spirit of Hobbes, and while he himself professes his acceptance of the "holy mysteries of our religion even in the minutest particulars, notwithstanding their amazing

1 "Autobiography," Lee's edition, p. 249.

2 "Where infinite rewards are thus enforced (i.e., by fear of hell and hope of heaven) and the imagination strongly turned toward them, the other common and natural motives to goodness are apt to be neglected and lose much by disuse. . . . On this account all other affections to our friends, relations, or mankind are often lightly regarded, as being worldly, and of little moment in respect of the interests of our souls." "Characteristicks," vol. II, p. 68 of the 5th ed. 
depth," 1 the modern student cannot but feel that ecclesiastical intolerance was reaping its just reward of contemptuous outward conformity as the demoralizing price paid for an inner freedom of spirit. ${ }^{2}$

At the same time there was a churchly reaction on the basis of the practical acceptance, however, of rationalism against the empiricism of Bacon and Hobbes. Cumberland, ${ }^{3}$ the Bishop of Peterborough, boldly challenged Hobbes's theory of universal war as the natural state of mankind, and self-interest as the law of human nature. ${ }^{4}$ Rejecting the easy-going intuitional method of the Platonists, who solve the whole difficulty at once by supposing that there are innate ideas, ${ }^{5}$ Cumberland prefers the rationalism of Descartes, by whom he is deeply influenced. ${ }^{\circ}$ He seeks universal propositions from which all else can be deduced. This universal principle is benevolence, and in seeking the welfare of the greater whole the individual finds, or may find, his own individual happiness. ${ }^{7}$ Amidst much loose and pedantic reasoning Cumberland searches out some of the

1 "Characteristicks," vol. III, pp. 315-316.

${ }^{2}$ No history of English thought would be complete without a review of such men as Chillingworth, Jeremy Taylor, and Bishop Tillotson, with an estimate of their relationship to the rationalistic movement. But their contribution to ethics within Christianity as an organized system of thought is simply nothing. So completely had doctrinal and metaphysical questions overshadowed thought that even the sermons of the period neglect ethics in exact proportion as they are "orthodox."

${ }^{3}$ Cumberland, Richard, Lord Bishop of Peterborough, born July I5, I63I (or I632, according to Willis), died October 9, 17 r8. "De legibus naturæ disquisitio philosophica in qua earum forma, summa capita, ordo, promulgatio et obligatio è rerum natura investigantur; quinetiam elementa philosophiæ Hobbianæ, cum moralis tum civilis, considerantur et refutantur." London, r672: Dublin reprint, I720. Two English translations: "A treatise of the Laws of Nature. Made English from the Latin by John Maxwell . . . , London, I 727 ; "A philosophical Enquiry into the laws of Nature . . translated into English .. . with notes and an appendix by .. . John Towers," Dublin, 1750.

4 "The moral writer may very justly say that he has faithfully discharged the office of moralist if in the beginning of his book, if in settling his principles, he briefly tells you that all possible cases which can happen are comprehended under the most general, the most diffusive benevolence." Part I, I : 9, English translation of Towers, p. 26.

5 "Prolegomena," sec. V.

6 Part I, I : 9.

${ }^{7}$ Part I, I : 14 , and I, I : 16. 
weakest points in Hobbes's ethics, ${ }^{1}$ and he anticipates the later utilitarians in their analysis of the character and origin of moral good. This moral good may be discerned by right reason, ${ }^{2}$ and happiness is the reward attached by the will of God to the conduct of the individual in seeking the general good. ${ }^{3} \quad$ The work of Cumberland has been somewhat neglected and the confusions of his style do not make him easy reading. ${ }^{4}$

Substantially upon the same ground, and also influenced by Descartes is Samuel Clarke, ${ }^{5}$ who bases morality upon the general fitness of things, and like Cumberland and Descartes, he confuses himself with false analogies between the moral sphere and conceptual mathematics. ${ }^{\circ}$ His interests were metaphysical rather than ethical, and nowhere does he really systematize his ethics.

In fact the ecclesiastical reaction against the philosophic currents spent itself rather in dogmatic and apologetic work than in ethical defence. At the same time the issue was not wholly neglected. One of the acutest minds in English history, the famous author of the "Analogy," Bishop Butler, ${ }^{7}$ began a correspondence while he was yet a quite unknown young man with Clarke, in which, though he professed himself convinced, he raised the objections which seem now to the general modern mind overwhelming against Clarke's general ontology. $\mathrm{He}$ makes the remarkable criticism that "space and duration are

${ }^{1}$ As in I, $\mathrm{I}: 28$; III, $6: 2$.

${ }^{2}$ I, 2, \$ I to XXX (whole chapter).

${ }^{3}$ II, $5: 1-58$ (whole chapter).

- The author depended on Tower's translation, but since then has found the Dublin reprint of the Latin version much clearer, and the student is recommended especially to caput IX of the original Latin for the best summary of his teaching.

${ }^{5}$ Clarke, Dr. Samuel, $1675^{-1} 729$. Into the metaphysics we cannot go. In spite of his denial his whole reasoning is the most dogmatic a prioriism.

- $C f$., for instance, preface to his "Discourse Concerning the Unchangeable Obligations of Natural Religion," 8th ed., I732, pp. I33-146.

${ }^{7}$ Butler, Joseph, Bishop of Durham, $1692-175^{2}$. His ethics are contained in his famous sermons, often reprinted, and in an "Ethical Dissertation." The latest edition of his works is by Bernard, in two volumes, I900. There are many editions. 
very abstruse in their natures, and, I think, cannot properly be called things, but are considered rather as affections which belong, and in the order of our thoughts are antecedently necessary to the existence of all things." 1 This re-examination of the psychological basis of knowledge was the crying need of ethical reflection, and Butler's whole attitude was deeply psychological.

He himself entered, unfortunately, upon no re-examination of Locke, or we might have had an English Kant, but he contented himself with seeking in the facts of life such analogies as would justify the reasonable man in holding on to the Christian faith.

So also in his ethics he substantially accepts the premises of Locke, and anticipates Hume in his doctrine of good and evil rising out of pain-pleasure sensations, and so resolving morality ultimately into utility along the lines of Cumberland.

Man, Butler shows, is to be thought of as in a system "the whole nature of man, and all the variety of internal principles which belong to it." 2 And man is found in two relations-to himself; "the nature of man as respecting self, and tending to private good, his own preservation and happiness; and the nature of man as having respect to society, and tending to promote public good, the happiness of that society." 3 These ends coincide and mutually promote each other. There is a natural principle of benevolence in man which is in some degree to society what self-love is to the individual. Butler takes direct issue with Hobbes and denies that this can be resolved into love of power, etc.

These appetites and affections make for public good and are a mark of our Maker's care for the species.

There is also a principle in men which leads them to reflect on themselves. "This principle in man, by which he approves or disapproves his heart, temper, and actions, is conscience." This is the strict sense of the word. Conscience approves of our good conduct toward society, and thus shows "that we were made for society, and to promote the happiness of it, as that

${ }^{1}$ Second letter to Dr. Clarke.

${ }^{2}$ Sermon I.

- Sermon I. 
we were intended to take care of our own life and health for private good." 1

Butler takes a more hopeful view of human nature than the traditional theology of post-Reformation times. Man has no inherent "love of injustice, oppression, treachery, ingratitude; but only eager desires after such and such external goods." True, man may be without such natural affection for the social good, but he is also found without natural affection for himself. "But the nature of man is not to be judged of either of these, but what appears in the common world, in the bulk of mankind." ${ }^{2}$

The real difficulty is that men lack "cool and reasonable concern enough for themselves to consider wherein their chief happiness in the present life consists; or else, if they do consider it . . . reasonable concern for themselves or cool self-love is prevailed over by passion and appetite." This conscience is a "natural faculty" and "bears its own authority of being so." 3 "Self-love is in human nature a superior principle to passion," to act conformably to the economy of man's nature, "reasonable self-love must govern." "The natural supremacy of reflection or conscience being thus established," " we get some idea of human nature as a system. Butler assumes that the plain man knows his duty, his obligation to do it springs from the internal obligation. "Your obligation to obey this law is its being the law of your nature." s Yet "self-love then, though confined to the interests of the present world, does in general perfectly coincide with virtue, and leads us to one and the same course of life." ${ }^{\circ}$

So that at last Butler traces ethics to the public and private functions of the individual and to his self-love and desire for social peace. There is also an intellectual reflective element brought in. Conscience is really moral intelligence. It declares what is good and what is evil as well as lends sanctions to conduct. In the sermons on compassion, Butler teaches that it belongs to man's nature to rejoice with them that do rejoice, etc.,
${ }^{1}$ Sermon I.
${ }^{2}$ Sermon I.
${ }^{3}$ Sermon II.
Sermon III.
${ }^{5}$ Sermon III.
- Sermon III. 
and that a man must act up to his "nature," by which Butler means the ideal system from which alone we can judge of human conduct.

In all the men from Cumberland to Butler it is assumed that not only are there postulates of right moral reason common to all men in all ages, but also an ethical content that can easily be examined. They loosely identify this with the "ethics of revealed religion," as if there were not many "ethics" in revealed religion. Not even the work of one like Collins ${ }^{1}$ could call men back to real study of the actual Scriptures. All was still seen through the mists of $\grave{a}$ priori dogmatism or equally dogmatic indifference.

The movement of thought had seemingly been caught in a whirlpool without escape. The work of John Locke fell really upon barren ground among the deists. Only his negations and critical work had caught their attention and they vainly attempted to substitute an unexamined tradition half pagan and half scholastic for the faith in Christian morals that had once rested upon the church.

It remained for one to awake men both on the Continent and in England from their dogmatic slumbers, and by scepticism with regard to the whole accepted psychology of knowledge to call men to a larger basis for the ethical life.

This voice was that of David Hume, whose epistemology is substantially based upon that of Locke. The mind is thought of primarily as passive and receptive. Impressions give rise to

${ }^{1}$ Collins, Anthony, born June 21, 1676, died December 13, 1729. See particularly his "Scheme of Literal Prophecy Considered . . . ," printed anonymously, London, 1727 .

${ }^{2}$ Hume, David, born Edinburgh, April 26 (O. S.), 1711 , died August 25, 1776. He wrote a short sketch of his own life and Adam Smith completed it by an account of his death. Both are published in Green (T. H.) \& Grose's (T. H.) edition of his philosophical works, Edinburgh, 4 vols., $1875-1878$, in vol. III ( 1875 ) or vol. I of the "Essays." A complete edition of his philosophical works first appeared in 4 vols., Edinburgh, 1826. His life and correspondence are edited by John Hill Burton in 2 vols., Edinburgh, 1846, reprinted 1854 . Friedrich Jodl has described his philosophy in "Leben und Philosophie David Hume's" Halle, 1872. George von Giz̀ycki has elaborated his ethics, "Die Ethik David 


\section{ETHICS OF PHILOSOPHICAL PROTESTANTISM 46I}

"simple ideas," and complex ideas are worked up by reflection. The more or less "lively" character of these ideas determine their reality for us.

On this basis Hume begins his study of "man." All science will depend primarily on its correct estimate of man and human nature. We must examine the extent and force of the understanding, the nature of ideas, and the operations in reasoning. Knowledge can only rest upon the solid foundation of experience and observation. The ultimate essence of the mind is, like the ultimate essence of the external bodies which constitute the world, utterly unknown. It must therefore be equally impossible to form any notion of its powers and qualities otherwise than from careful and exact experiments. ${ }^{1}$ It is at this point that the fruitful scepticism of Hume made way for a more modern positivism.

Hume then discusses how the raw material given in sensation is worked up by the mind under the head of the relation of ideas, and thus formulates his famous contribution on the connection or association of ideas. ${ }^{2}$ The law of this association he formulated under resemblance, contiguity, and cause and effect. "These qualities," he says, "produce an association among ideas" and "upon the appearance of one idea naturally introduce another." All philosophical relations he thus groups under seven heads: Resemblance, Identity, Space and Time, Quantity or Number, Degree, Contrariety, Cause and Effect. ${ }^{3}$ Into his discussion of these principles we must not go, although they have important bearing upon his ethics. All our knowledge, including of course moral knowledge, springs from habit or custom founded upon observation and experience, and "all

Hume's in ihrer geschichtlichen Stellung," Breslau, 1878. Clear but somewhat shallow is Leslie Stephen's account in his "English Thought in the Eighteenth Century," vol. I (1876). The essay by Thomas H. Green that precedes his edition of the philosophical works is of great interest, but calls for critical examination at almost every page.

${ }^{1}$ Introduction to "Treatise on Human Nature," p. 308, vol. I, Green's edition.

2 "Treatise on Human Nature," book I, p. r, § IV.

8 "Treatise on Human Nature," book I, § V, and book III, § I. 
knowledge resolves itself into probability." 1 But we must think and know; hence by a "law of nature" we are saved from any undue scepticism." Hume was assured that "all probable reasoning is nothing but a species of sensation. 'Tis not solely in poetry and music we must follow our taste and sentiment, but likewise in philosophy. When I am convinced of any principle 'tis only an idea which strikes more strongly upon me. When I give the preference to one set of arguments above another, I do nothing but decide from my feeling concerning the superiority of their influence." 3

Hume begins his moral treatise by a discourse on the passions, which are impressions arising within the body, and are secondary or reflective impressions, "such as proceed from some of these original ones, either immediately or by the interposition of its idea." These passions he rather apologetically divides into "calm" and "violent," "direct" and "indirect." The whole book (II) is full of keen and shrewd psychology. But it is in the third book that morals are more especially dealt with. Morals are based upon perceptions, "to approve of one character, to condemn another, are only so many different perceptions." 4 But as perceptions may be ideas or impressions, we ask in which class do morals come? And Hume answers that reason is inert, and that therefore it is not in the region of ideas that morals must be sought, and they are not derived from reason, but our "passions, volitions, and actions are not susceptible of any such agreement or disagreement; being original facts and realities complete in themselves." 5 Thus "vice and virtue may be compared to sounds, colors, heat, and cold, which according to modern philosophy are not qualities in objects, but perceptions of the mind." " What we now know as a "judgment of value" thus goes back under a rather complicated terminology

1 "Treatise on Human Nature," book IV, § I.

2 "Treatise on Human Nature," book IV, § I.

3 "Treatise on Human Nature," book I, part 2, \$ VII. The whole section is very instructive-and modern!

" "Treatise on Human Nature," book III, I : I.

${ }^{5}$ Book III, part r, \& I.

${ }^{6}$ Book III, part 1, \& I. 
to Hume. These sentiments produced by impressions are either agreeable or disagreeable. "That arising from virtue is agreeable, that from vice is disagreeable." 1 Thus this pleasure is of a peculiar kind, each pleasure has its own character, and so the pleasure of virtue has its own character. Wine is not harmonious nor is music of a good flavor, though both give pleasure after their kind. ${ }^{2}$ This peculiar form of pleasure-pain sensation has its roots, not in an original quality nor primary constitution, nor yet in that ambiguous thing "Nature"; nor yet in self-love, which rather produces evil, nor in any "love of mankind," as that is not really existent as such, nor even directly in sympathy, but its origin is social, "in that justice creates force, ability, and security. And it arises primarily from property considerations, so that justice is a convention founded upon "a general sense of common interest." 3 Thus "'tis only from the selfishness and confined generosity of men, along with the scanty provision nature has made for his wants that justice derives its origin." 4 So justice is not founded on our ideas, but on our impressions, and these are not natural (i.e., innate), but arise from artifice and human conventions.

"Thus self-interest is the original motive to the establishment of justice; but a sympathy with public interest is the source of the moral approbation which attends that virtue." 5

Hume thinks that although politicians in order to govern men more easily "have endeavored to produce an esteem for justice and an abhorrence for injustice," but that at the same time certain writers on morals have gone too far in "efforts to extirpate all sense of virtue from among mankind." These discriminations rise "naturally" out of the situation. Property and justice rise together. Before property there was "no such thing as justice or injustice." " Hence Hume enters upon questions of legal casuistry in connection with property rights in attempting to define the ethics of property.

${ }^{1}$ Book III, I, § II. $\quad{ }^{2}$ Book I, part I, § III. $\quad$ s Book III, part 2, § II.

4 Book III, part 2, § II.

${ }^{5}$ Book III, 2 : II.

- Book III, 2 : II. 
So keeping of promises is not a "natural" but a conventional virtue, it is an invention "founded on the necessities and interests of society." 1 Men being naturally selfish and very limited in our kindness and affection, the keeping of promises is not based on this, but on the necessity for insuring a return for any favor I do. "Hence I learn to do a service to another without bearing him any real kindness." 2 Here, as elsewhere, "public interest, education, and the artifices of politicians" effect the same in all cases.

So the peace and security of society depend on keeping three laws, "that of stability of possession, of its transference by consent, and of the performance of promises." And "society is absolutely necessary for the well-being of men; and these are necessary to the support of society." 3

So this legal-ethical system is built up on public utility and "the propensities of the imagination." "

In Hume's discussion of the rise of government we have substantially Hobbes's theory that it arises out of the necessity on the part of all to maintain peace for the good of all.

In tracing the history of the other virtues and vices that do not depend upon the "artifice and contrivance" of men, the principle of sympathy is brought in. ${ }^{5}$ All virtue and vice depend upon our pleasure-pain sensations. Utility gives pleasure and the associations with utility tend to suggest pleasure (æsthetics). There are four sources of moral distinctions, "for we reap a pleasure from the view of a character which is naturally fitted to be useful to others or to the person himself, or which is agreeable to others or to the person himself."

There are, as any one may see, confusions in Hume's most acute discussion, nor are these cleared up in his later thinking. But Hume rendered immortal service in once and for all compelling ethics to leave its old scholastic authoritative basis and seek its basis in faith's view of the world as rational and good, while it confesses that this cannot be demonstrated; and to

${ }^{1}$ Book III, part $2, \S \mathrm{V}$.

Book III, 2 : VI. Book III, 2 : VI.

${ }^{2}$ Book III, part $2, \S \mathrm{V}$.

${ }^{5}$ Book III, 3 : I. 
seek its content in an examination of the actual experiences of men with social utility as the measure at hand for the empiric testing of special lines of conduct.

In all its strength and weakness the ethical system of Hume was most elaborately and clearly formulated by his great friend and fellow-student Adam Smith, ${ }^{1}$ who thereby laid the foundation for all empiric utilitarianism in its various shapes. It is a wonderfully shrewd analysis of the moral psychology of the existent humanity. Like Hume, Adam Smith does not dogmatize upon the metaphysics of the moral nature, but simply analyzes it. "Upon whatever," he says, "we suppose that our moral faculties are founded, whether upon a certain modification of reason, upon an original instinct called moral sense, or upon some other principle of our nature, it cannot be doubted that they were given us for the direction of our conduct in this life." 2

He comes to the conclusion that the basis of the moral life is sympathy, or fellow-feeling with the natures akin to ours. This is, however, not a resolution of morality into selfish feeling, for what we do is not to transfer his feeling to us, but our feeling to him. We feel his resentment against oppression or his joy at the success of an enterprise. When we see our fellow-man exult or resent, we put ourselves in his place (as far as we can do so), and now we approve or disapprove of his exultation or

\footnotetext{
${ }^{1}$ Smith, Adam, born June 5, 1723, died July 17, 1790. Famous for his creation of modern English political economy by his book, "An Inquiry Into the Nature and Causes of the Wealth of Nations," published March 9, 1776, after a delay of nine years; with a life of the author by J. R. McCulloch, r828; edited by E. G. Wakefield, 4 vols., 1835-r839; Edinburgh, 1846; reprinted (5th edition) 1863. Recent editions are those edited by James Edwin Thorold Rogers, Oxford, 1869, 2 vols., 2d edition, r880, by J. T. Nicholson, r884; and by E. Cannan, New York, Putnam, $\mathrm{r}_{904}$, in 2 vols. Previously he had published his "Theory of the Moral Sentiments" in r 759; 2d edition, 1759 ; 3 d edition, 1767 ; 6 th revised edition, 1790 ; a rath edition in r8og. The best life is by John Rae, London, Macmillan, r895, which is founded upon the sketch by Dugald Stewart, "Account of the Life and Writings of Adam Smith, LL.D., F.R.S." in Smith, Adam, "Essays on Philosophical Subjects," London, r795; also in Smith's "Works," 5 vols., London, 181r-18r 2.

2 "The Theory of the Moral Sentiments," III, $3: 3$.
} 
his resentment, according as the situation as we conceive it seems to us to demand exultation or resentment. Then by a third step we know our own conduct in the mirror of other people's conduct, and we judge ourselves as an "impartial spectator" might be supposed to judge us; thus we construct moral maxims by which we rule our life. These maxims are thus rational. "The general maxims of morality are formed like all other general maxims from experience and induction." 1 At the same time the first moral perceptions are not based upon reason but upon "sense and feeling." Nor is utility primary. "Originally, however, we approve of another man's judgment not as something useful, but as right." 2 In what is undoubtedly a critique of his friend Hume, ${ }^{3}$ he draws a clear and in the main correct line between utility as a test of moral conduct and as a source for moral feeling. The moral faculties "carry along with them the most evident badges of this (moral) authority" and "were set up within us to be the supreme arbiters of all our actions." Man is social in his nature. He gets his standards of taste from seeing and judging other men, then judging himself as he thinks others see him and judge him. We look at ourselves in the mirror of public opinion. Thus we adapt ourselves to life by gradual process. "It is thus that man who can subsist only in society, was fitted by nature to that situation for which he was made." 5

At the same time Adam Smith is, like all the empiric school even after Bentham, fundamentally individualistic. He recognizes no organic unity as underlying the social sameness. All things are adjusted in nature for the "support of the individual and the propagation of the species." "

One of the serious blemishes, apart from the false place given sympathy in the discussion, is the confusion in his treatment of justice. Justice is, according to Adam Smith, an exact science as the grammar is in speech exact, while moral rules are loose and appeal to the individual instinct. He then confounds
${ }^{1}$ VI, 3.
2I, $2: 2$.
sIV, $4: 2$.
${ }^{4}$ III, $3: 3$.
\&II, $3: 2$.
- II, 2 : 2 . 


\section{ETHICS OF PHILOSOPHICAL PROTESTANTISM 467}

justice with law in a way that again has been fruitful of many other confusions in English thinking.

The little sketch of the unfolding of ethics in the sixth book is still interesting and instructive. His criticism of Hutcheson, his old teacher, is both acute and instructive; and some of his criticism still has force against some modern ethics.

The main lack is Adam Smith's failure to consider the metaphysical elements involved, and to follow up Hume's theory of knowledge to its logical issue.

At the same time this was not wholly a misfortune. From Adam Smith an ethics stood forth to claim a place as a science as separate from dogmatic religion as philosophy is from theology. From this time on consciously or unconsciously theology recognized the fact that given, on the basis of a religious faith, the postulates of a Christian life, the contents of that life, so far as they are ethical, must be worked out empirically.

From Hume on there is no ecclesiastical ethics worth discussing. Protestantism was freed from the bonds of scholastic authoritarianism. The closed system was broken up by Hume's merciless critique, and a new freedom found. Theologians like frightened children have hardly yet dared to enter into the higher and nobler freedom of redemptive love. But from Hume on the history of Christian ethics is no longer confined "within organized Christianity." 


\section{CHAPTER VIII}

\section{THE CONTINENTAL REFORMATION AND ITS ETHICS}

I. The Ethics of Luther. (I) The Protestant Elements in Luther's Ethics. (2) The Scholastic Elements in Luther's Ethics. (3) The Practical Ethics of Luther-II. The Ethics of Melanchthon-III. The Anabaptist Movement and Its Ethics-IV. The Ethics of the Reformed Churches-V. The Ethics of John Calvin-VI. The Ethics of the Creeds-VII. The Epigones and Their Ethics-VIII. The New Protestant Casuistry-IX. The Ethics of Pietism-X. The Ethics of Post-Tridentine Roman Catholicism-XI. The Ethics of Philosophical Protestantism on the Continent.

\section{THE ETHICS OF LUTHER}

The systematic attempt at churchly reorganization was effectively carried through by two men, Martin Luther ${ }^{1}$ and John Calvin, although on different principles. They were not, indeed, alone, nor did they lack forerunners, like Wyclif and Wyclif's translator Huss. But neither Wyclif nor Zwingli left

${ }^{1}$ Luther, Martin, born November ro, 1483, at Eisleben, where he also died, February 18, 1546. The outline of his life is too familiar and accessible to warrant condensation here. Of the seven relatively complete editions of his works (Wittenberg, I539-1558; Jena, I555-1558; Altenburg, I66I-I664; Leipsic, I 729-1 740, Halle [Walsch], I 740-1 753; Erlangen-Frankfurt, 1826-1857 [Latin works and letters later as supplement, in all more than one hundred volumes]; Weimar, 1883 [and yet in progress, some thirty-eight quarto volumes having appeared]), the only ones of importance to us are the last three. (Our citations are all from the Erlangen-Frankfurt or Weimar editions, or from Enders's edition of the "Letters".) A useful cheap selection is the edition edited by Buchwald, Kawerau, Köstlin, Rade, and Schneider, in eight duodecimo volumes (with index separate by R. Sell, r899), 2d edition, Berlin, C. A. Schwetschke, 1898. A fairly good translation into English of some of his chief works ("A Short Catechism," "The Greater Catechism," "Address to the Christian Nobility," "Concerning Christian Liberty," "On the Babylonian Captivity of the Church," "The Ninety-five Theses) is "Primary Works, Translated into English by Henry Wace and C. A. Buchheim, with Theological and Historical Essays," London, Hodder \& Stoughton, 1896, 2d edition. Until the "Tabletalk" has been carefully re-edited, as it no doubt will be in the Weimar edition, it can only 
behind them organizations reflecting their special type of thought and feeling. It is doubtful whether, even had Zwingli lived, the Swiss reformation would have lasted had not Calvin joined it. It is also perfectly true that neither Luther nor Calvin fully realized the complete implications of their break with Rome. In various degrees they both moved within a closed system contained in the Bible, and handed down to the church for safe-keeping. ${ }^{1} \quad$ In this sense they were both as much scholastics as Anselm or Thomas Aquinas. It was only the claim to judge the church by the Bible rather than the Bible by the church that separated them from the scholastic period. And

be cited in support of positions otherwise clear, for much that passes as Luther's talk was no doubt utterly irresponsible gossip. The best "Life" is that of Julius Köstlin, "Martin Luther, sein Leben und seine Schriften," 2 vols., 3d edition, Leipsic, 1883 , $5^{\text {th }}$ edition, edited by G. Kawerau, Berlin, 1903; English translation of the first edition by E. P. Weir, London, I883, and another, London, Longmans, 1895. Another good "Life" from a different point of view is by Adolf Hausrath, "Luther's Leben," Berlin, 2 vols, r904-1905. Köstlin's "Luther's Theologie in ihrer geschichtlichen Entwickelung, und ihrem inneren Zusammenhange," etc., Stuttgart, $186_{3}$, is translated from the $2 d$ edition by C. E. Hay, Philadelphia, 2 vols., I897. Theodor Harnack's "Luther's Theologie mit besonderer Beziehung auf seine Versöhnungs und Erlösungslehre," 2 vols., Erlangen, 1862, 1886, gives a mass of valuable material for the student of ethics. For Luther's ethics, see Luthardt, Christoph Ernst: "Die Ethik Luthers in ihren Grundzügen," 2d edition, Leipsic, I875, and "Luther nach seiner ethischen Bedeutung," Vortrag, Leipsic, $188_{3}$; Lommatzsch, Siegfried Otto Nathanael: "Luther's Lehre vom ethisch-religiösen Standpunkte aus und mit besonderer Berücksichtigung seiner Lehre vom Gesetze dargestellt," Berlin, r879; Hering, Hermann: "Die Mystik Luthers im Zusammenhange seiner Theologie und in ihrem Verhältniss zur älteren Mystik," Leipsic, I879. From a hostile point of view, Denifle, Heinrich Suso, O.Pr.: "Luther und Lutherthum in der ersten Entwicklung quellenmässig dargestellt," Mainz, I904-1906, 3 vols. in 4. But see also Walther, Wilh. M.: "Für Luther wider Rom . . . ," Halle, I906, and Janssen, Johannes: "Geschichte des deutschen Volkes seit dem Ausgang des Mittelalters," Freiburg, 1876, seq., 8 vols., I $5^{\text {th }}$ to 18 th eds.; Freiburg i.B., 18971904; English translation by M. A. Mitchell and A. M. Christie, London and St. Louis, 14 vols., r900-rgog. Special literature will be noticed in the discussion.

${ }^{1}$ Luther in 1520 wrote: "Und das thun sie darumb, den die weyl sie wissen, und war ist, das die gemeyne christliche kirche (das ist alle christen sempthich in aller welt) nit yrren mag," Weimar edition, vol. VI, p. 6r5. Cf., also, "Adversus execrabilem Antichristi bullam," Weimar edition, vol. VI, p. 607 . Calvin speaks of truth as "thesaurum hunc apud ecclesiam deposuit," "Instit. Christ," book IV, $\mathbf{x}: \mathbf{I}$. 
more particularly upon the field of ethics did Luther shrink from being considered either revolutionary or an innovator. ${ }^{1}$

Both Luther and Calvin estimated highly the task to which scholasticism had addressed itself, namely, the systematic formulation and defence of revealed truth. And both regarded correct thinking as of more fundamental importance than conduct. $^{2}$ The reason is also plain. Correct conduct depends, in the view of scholasticism, on holding in all its fulness the conception of the world revealed by God once and for all, and handed down to a church for safe-keeping, proclamation, and explication.

The highest service Luther rendered was his placing, with magnificent inconsistency, the ethical-religious interest distinctly in the foreground, and that on the basis of his personal religious experience. Like Paul, Luther based his message upon a tremendous religious experience of catastrophic character. Like Paul, his quarrel with the organized religious life of his day was its ethical ineffectiveness. It is absurdly unhistorical to charge, as some have done, that Luther simply sought license. ${ }^{3}$ This was also charged against Paul by the organized religious life of his day. Luther put life before doctrine, and vital righteousness before formal correctness whenever the issue was really raised. They were supreme with him.

Nowhere is this more plainly seen than in his famous ninetyfive theses. Here the whole underlying thought is that the really repentant man does not seek to escape his punishment but his sin; and that the whole system of indulgences blurred the vision of sin. Luther's movement began in no revolt against Rome, but against local abuse, and thus Luther became the

1 Preface to the "Little Catechism," (enchiridion), I529.

2In 1522 Luther wrote: "Ich hab vorhynn gesagt, das eyn ander ding ist die Lere und das leben. Darumb sollt yhrs gar wol unterscheyden, denn Gott ist nicht pzo (so) viel gelegen am leben als an der Lere, darumb lest er die seynen oft strauchlen ym leben, wie wyr lesen. Aber was die lere angehet, da hatt er sie Keyn har dreyt fallen lassen. Deun eyn böses leben ist nyrgent pzo shedlich als böse lere," "Predigt am Johannistage 24ten Jnui, 1522," Weimar edition, vol. X, part 3, p. 20r. Cf. with this also Calvin's "Institutions," book IV, I : 12.

'So Denifle, "Luther and Lutherthum," pp. 90-97, 2d edition, vol. I, part I, and ultramontanism generally. 
leader in a revolt more far-reaching than he could realize or than some of his professed followers realize to-day. The world of his thought remained to the end colored by scholasticism, and his Protestantism only became pronounced when a practical issue forced him to face outworn formulæ and to deny them. Then in this denial he forced the issue and bravely maintained the authority and moral supremacy of the spiritual man.

To the end his own personal religious experience was shadowed over by the morbidness of a substantially dualistic and often despondent view of life. He was here at one with Augustine and Francis of Assisi and St. Bernhard. The sharp contrasts between the lights and the shadows grew deeper as time went on. Indeed in the whole Reformation movement one sees the conflict constantly emerging within the movement itself between the now muddy waters of a lifeless scholasticism and the clearer springs of a new fountain.

The Roman Catholic position was weakened by the same conflict. Humanism within had made her resistance weak. It was only when the newer elements had been absorbed or driven out that she presented a strong united front, in the counterreformation, to a still divided and immature Protestantism.

This divided world Luther reflected with extraordinary exactness in his life and his teachings. That was in part his tremendous power. Although Luther, unlike Calvin, never engaged in the actual task of reconstructing a new theocratic state, his ideal was such a state. He, however, called the German princes to this task. He regarded them as the God-sent instruments for doing that work. His mission was political as well as religious, and in this work there is in Luther none of that intellectual aloofness which marks Calvin.

He was a product of the social struggle and political readjustments born of a thousand new conditions, among which we have seen were the new commerce; the wider world (America discovered, I492); the triumph of imperialism (Charles V, Francis I); the flowering of the Germanic free city; the spread of new learning; the opening up of a world-wide system of 
roads; the fixing of European boundaries (the fall of Constantinople, I453, and the fall of Granada, I492); the reformation of the Roman communion within (Council of Constance, I4I4) and the establishment of the Inquisition; the rise of definite national tongues with national literatures-French, High German, Low German, English, Italian; the beginning of the struggle of the bourgeoisie with feudalism; the real democratization of learning by the printing-press; the invention of gunpowder; the founding of a new astronomy (Copernican); the practical use of the compass; in a word, the beginning of the new world, with a slowly growing consciousness of the value of organized experience and the futility of $\grave{a}$ priori speculation without the constant testing of every hypothesis by such organized experience.

It is perfectly vain to claim that Luther belonged wholly to our modern world. There are wonderfully radical notes in him, and he united great insight into the weaknesses of mediævalism with boldness and even daring in speech and thought. Yet he remained essentially conservative and even scholastic in temper and method. He never completely reacted from the cloister type of ethics, and in him reactionary forces have found strength and comfort ever since.

The supreme service Luther rendered was that as he actually. did put life before dogma, and the religious-ethical interest in the foreground instead of scholastic speculation, he once more made religion a vital factor in social reconstruction. He was not democratic in his thought or mood. He belonged rather to the forceful middle-class not yet come to full self-consciousness, but which was feeling its way to power, and was resisting on the one hand the pressure of the landed aristocracy and on the other the claims of the landless proletariat. Thus the free cities of North Germany accepted Luther and his form of the Reformation almost without any struggle, and Lubeck, Hamburg, Bremen, and most of the northern trading centres became the unwavering friends of the new movement. In part this came from the new ethical revolt against Roman rapacity and uncleanness (Tetzel and his indulgences), in part the new national 
feeling was beginning to stir men. And Luther in all his somewhat coarse strength was the very incarnation of this new Germanism. He voiced its eagerness for knowledge, for independence, for action, and self-development. Some of Luther's writings reached a circulation of four thousand in a few weeks, which meant thousands of hearers and readers, for the printed page went from hand to hand and was read to eager groups. He took the side of the Germanic home group against the ascetic monkish individualism. He incarnated the new longing for life as a good in itself and for self-expression as having its own peculiar value. He voiced with fierce directness the northern revolt against powerful oppression. We hear, surely, something familiar in such words as these: "Yes, we might well let the little thieves alone, if we could stop the great powerful archthieves, with whom the princes and rulers combine, and who daily plunder not a town or two, but all Germany. Yes, what would happen to the head and chief protector of all thieves, the papal power at Rome, with all that belongs to it, and which has robbed us of our material goods and keeps them until now? In fact it is the world's way that he who can steal and plunder openly goes safe and free, unpunished by any one, and expecting to be honored; but little secret thieves, though they may have only once done wrong, must bear the shame and penalty." 1 Thus he stood out as the greatest figure of an age in which many shone.

The difference between Roman Catholicism and the Teutonic religious movement which we call the Reformation was not even mainly about authority. All at that time moved, or thought they moved, in the atmosphere of authority. Nor was it even mainly between the authority of church versus the Bible. The reformers all acknowledged the authority of a church, and Rome might easily have compromised that quarrel. Nor was it on such abstractions as "justification by faith" or "transubstantiation." Here again the Council of Trent leaves little to be desired. The real difference was a different estimate of the really pious life. And Luther was the incarnation in actual

1 "Greater Catechism," the Seventh Commandment. 
feeling and conduct of the Reformation type. Rome could adjust herself to the semi-paganism of humanism (Erasmus), but Luther she could not away with. The ethical freedom of sonship with God, the moral supremacy of the spiritual man brooked in the last analysis no earthly over-lordship. It was not so much a matter of intellectual antithesis as of profound and far-reaching spiritual intuition that separated once and for all the really Protestant forces from Rome and the papacy.

The very excesses of the Reformation which have been glossed over far too much by Protestant historians were the almost inevitable outcome of the new liberty." For the "laity" in the Roman communion there are no adult years. All are "children of mother church," with prescribed reading and father-confessors to the end. As this authority broke down all manner of evils showed themselves. The records of Reformation society are exceedingly dark with violence, drunkenness, sexual excesses, and low forms of vice. It is impossible to give comparative estimates of any value, but the indications are that in the breaking up of feudalism the ethical standard to which it had contributed also gave way. This decay is not, of course, wholly the result of the Reformation freedom, because the Council of Constance witnesses abundantly to decay, or at least to the belief in decay, before the Reformation. It was one of the conditions of the times out of which the Reformation sprang, in part, no doubt, as reaction against it. It is not fair even to ascribe the horrors of the Anabaptist revolts or the Thirty Years War to religious bigotry. They were in large part the results of the economic clash between the new merchant class with its commercial morality and the old land-owning aristocracy with other ideals in their struggle still going on in Europe for the control of the productive forces of life.

The ethics of Luther have the divided character of the period.

${ }^{2}$ Luther never blinked the facts and perfectly understood the underlying reasons. Cf. his preface to the "Little Catechism." He himself was so disturbed by the dreadful disorders at Wittenberg that the last days of his life were seriously embittered, and he even threatened to leave his beloved university. 
Nor is it easy to do justice to their influence when they are regarded simply as systems of thought. Luther was emphatically a man of action who often justified his right instincts by wrong reasons. His life was a constant struggle between the shadows of a mind overcast by temperament, by training, and probably by improper diet in fasting when he should have been nourished and nourished when he should have been fasting. His ethics, like his theology, retain a mediæval character to the end.

In order to bring out the contrast in Luther, which lies on the surface, and which is neither a chronological matter nor yet a conscious accommodation, it may be well to treat of his ethics under the three heads: his Protestant ethics and his scholastic or Roman Catholic ethics and his practical ethics.

\section{THE PROTESTANT ELEMENTS IN LUTHER'S ETHICS}

I. Luther sounded the key-note of every real ethical advance in his defence of the moral supremacy of the spiritual man. He and Tyndal, alone of all the reformers, grasped firmly this supreme truth. He sets it forth best and most boldly in his wonderful treatise, "Von der Freiheit eines Christenmenschen." 1 "A Christian man is a free master over all things, and no man's subject (untertan). A Christian man is a useful servant (ein dienstbar knecht) of all things and every one's subject; ${ }^{2}$ this freedom he bases upon love. ${ }^{3}$ And for Luther at his best love is the dynamic for all good works. ${ }^{4}$ This power is the union of the Christian man's spiritual life with Christ in which union Christ becomes sin for us and we share his righteousness. ${ }^{5}$ Just as in Paul, so in Luther it is indeed possible to interpret this mystic union with Christ metaphysically, $i$. e., as an actual

1 Erlanger edition, vol. XXVII, p. I73.

${ }^{2}$ Erlanger edition, Vol. XXVII, p. 176.

3 "Lieb aber die ist dienstbar und unterthan dem, das sie lieb hat" (loc. cit.).

4 "Aus dem Allen folget, der Beschluss, dass ein Christen mensch lebt nit ihm selb, sondern in Christo und seinem Nähsten: in Christo durch den glauben; im Nähsten durch die Liebe" (loc. cit.).

5 "Hie hebt sich nu der fröhliche Wechsel und Streit," Erlanger edition, vol. XXVII, p. 183 . 
losing of our being in the being of Christ. At the same time the far simpler explanation is that both Paul and Luther were thinking along the line of their main interest, and treat of the union as really ethical. It is identity of life's purpose and aim that forms the basis of the union. The image of the bridegroom is not conclusive in either case, but it is perfectly evident that Luther's mind was intensely practical, ${ }^{1}$ and even the attraction that mysticism had for him was its ethical content rather than its metaphysical basis. ${ }^{2}$ Luther was the child of a tremendous spiritual reaction against the false and weary legalism of the monkish view of life. At every point one is compelled to recognize this reaction as the explanation of both good and evil in Luther's ethical system. He had actually found God as his Father in Christ Jesus, and from that on all that is best in his thinking grows out of this sense of new relationship to God. "We should fear love and trust God above all else." ${ }^{3}$ And all obedience is as child to father, who "entices us to trust him." 4 With Luther this was the actual power that made in him for righteousness. What the law and the church and the Pope could not do, this vision of God in Christ Jesus actually did for him. Hence he became a Protestant against all authority save as it made its appeal directly to his soul.

2. Faith is thus for Luther a liberating principle. It sets us free to know and do the truth. ${ }^{5}$ And although he is not always

1 "Die Theologia stehet im Brauch und Ubung nicht im Speculiren und Gottes Sachen nach denken nach der Vernunft. . . . In summa: ein igliche Kunst, beide im Haus- und Weltregiment, so nur mit Speculiren umbgehit und nicht ins Werk bracht wird, ist verlorn und taug nichts," Tischreden, Erlanger edition, vol. LIX, p. I82.

${ }^{2}$ Cf. "Vorreden zu dem Büchlein; Ein deutsch Theologia," Erlanger edition, vol. LXIII, p. $235 \mathrm{ff}$.

3 "Wir sollen Gott über alle Ding fürchten, lieben und vertrauen," "Der Kleine Kat.," Erlanger edition, vol. XXI, p. 10.

4 "Gott will uns damit locken, dass wir Gläuben sollen, er sie unser rechter Vater, und wir seine rechte Kinder; auf das wir getrost und mit aller Zuversicht ihn bitten sollen, wie die lieben Kinder ihren lieben Vater," Erlanger edition, vol. XXI, p. I4.

5 "Aber Glaube ist ein göttlich Werk in uns, das uns wandelt und neu gebiert aus Gott (John I : 13) und tödet den alten Adam, machet uns ganz ander 
true to this principle, yet he asserts it often enough to show that it was no accident. The spiritual man is lord of the Sabbath. "We are lords of the Sabbath, and we should insist that we are lords of the Sabbath and other days and places, and do not place particular holiness or divine service in them as do the Jews and papists." "The church is not a particular church, as if it were better than other places where one preaches God's word." 1

Our lordship is only limited by love, and the happy conveniences of life-order, etc. But the sum and substance of all preaching is the freedom of faith and love. "Love is our captain." ${ }^{2}$ This freedom he taught so that from time to time he has to defend himself against antinomianism, ${ }^{3}$ and on the other hand attacks Carlstadt for infringing liberty by "forbidding," as the Pope has infringed it by commanding."

3. Thus Luther has a firm basis for his ethics in the freedom of the loving life, and recognizes frankly that faith cannot be forced. ${ }^{5}$ It cannot even be forced by eternal pains and penalty. Luther rejects in so many words all hedonistic ethics, even with heaven and hell as the basis, if the works are done to gain heaven

Menschen, von Herzen, Muth, Sinn und allen Kräften, und bringet den heiligen Geist mit sich. O es ist ein lebendig, schäftig, thähig, mächtig Ding umb den glauben, dass ummöglich ist, dass er nicht ohn unterlass sollte Guts wirken," "Vorrede auf die Epistle S. Paul an die Römer" (1522), Erlanger edition, vol. LXIII, p. I24.

1 "Ein weihungs predigt über Luc. I4 : I-I I" (I544), Erlanger edition, vol. XVII, pp. 239-252.

${ }^{2} C f$. the eight "Fast Sermons," Weimar edition, X, 3, pp. I-64.

'Erlanger edition, vol. LV, p. II5; vol. LI, p. 4I5, and many passages.

4 "Aber es hat hierinnen mit dem Rottengeist eine andere Nasen, denn mit dem Papst, sie brechen beide die christliche Freiheit, und sind beide Widerchristisch; aber der Papst thuts durch Gebot, D. Carlstadt durch Verbot; der Papst heisst thun, D. Carlstadt heisst lassen; wie denn die christliche Freiheit durch die zweierlei gebrochen wird, wenn man gebeut, zwingt und dringt $\mathrm{zu}$ thun, das doch nicht Geboten noch erzwungen ist von Gott," "Wider die himmelischen Propheten" (1524-1525), Erlanger edition, vol. XXIX, p. I89.

s "Summa Summarum predigen will ichs, sagen will ichs, schreiben will ichs, aber zwingen und dringen mit Gewalt will ich niemand; denn der Glaube sei

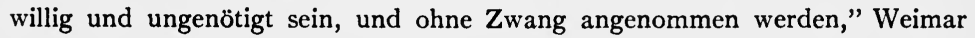
edition, vol. X, 3, p. I8 (Erlanger edition, vol. XXVIII, p. 219). 
or evade hell. ${ }^{1}$ All good works must spring from an inner principle. It cannot be said that he really built his ethics consciously in opposition to a refined eudæmonism ("God rewards with heaven, etc., etc.), but he prepared the way.

We serve God in serving our neighbor, and by the loving life make heaven on earth, and by the loveless life make earth a hell. ${ }^{2}$

4. Intensely "other-worldly" as Luther was in his main interest, he nevertheless felt keenly the wrongs done to Germany by Rome, and he did more than any man of his generation to kindle the fire of national enthusiasm and foster national selfrespect. Luther constantly denounced the rapacity of Rome, and urged the rulers of Germany to sweeping social reforms. He reveals not only a keen interest in the political and social struggle of his day, but also far-seeing vision as to its significance. Thus although in theory Luther remained entangled in the other-worldliness of the monastic conception of life, he in point of fact was the foremost herald of the new message, that is yet as old as the Old Testament prophets of the eighth century, and the prayer of Our Lord, that God's kingdom is to come to this earth and that here his perfect reign is to be made clear in the moral and political worlds.

5. Most especially useful was Luther's defence of a nonascetic wholesome type of ethics. Scholastic Romanism taught that the highest perfection was only open to the priest, monk, or nun. Luther insisted with anxious and repeated care upon the sanctity of the daily task. ${ }^{3}$ The housemaid was engaged in as sacred a task in properly cleaning a room as the preacher in the

1 "Predigt von den guten Werken" (1520), Erlanger edition, vol. XX, p. 218.

2 "Denn gleich wie du dir hie ein Paradies und Himmel machen könntest, wenn du deinem Nähesten dienetest (denn dasselbige heizt Gott im Himmel gedienet): also, wenn du deinem Nähesten nicht dienest, machest du dir selbst eine Hölle auf Erden; denn du dienest dem Teufel, der die Hölle gehöret." "Predigt" (1533), Erlanger edition, vol. V, p. 138.

${ }^{3}$ Erlanger edition, vol. II, pp. I33, I37, I39; vol. IV, 300, 343, 344; vol. V, pp. 57, 84, 87, 104, 137, 148, 160-162; vol. VII, p. I01; vol. X, pp. 160, 272, 233, 339 ; vol. XXI, pp. 60,80 , etc., etc. 
pulpit or the priest at the altar. The poor housemaid can say when cooking for her master and mistress that she is cooking for God in heaven.

This was to that day a new point of view and struck at the very roots of the Roman theory of a twofold standard of holiness, and in its logic swept away all real distinctions between civil and religious virtues. ${ }^{1}$

Quite consistently, therefore, Luther taught the priesthood of all believers. It was only a matter of order and opportunity that a clergy should exist at all. ${ }^{2}$ The distinct type of piety taught was throughout non-ascetic. Thus Luther not only himself married, but took strong and rational ground on the subject of celibacy and the married state. ${ }^{3}$ He became the incarnation of the wholesome Teutonic feeling for the family group as against the ascetic oriental intrusion, and he rightly passed over the fathers of church history and turned to the equally sane and rational traditions of the Old and New Testaments for his authority as over against the Hellenized traditions of early Christianity.

6. It cannot be said that Luther freed himself from sacramental magic and from mechanical views of grace. But he is nevertheless the real father of an ethical estimate of grace. The character of grace is the ethical imperative within man's soul. Luther at his best rises to wonderful heights when dealing with grace as the gift of ethical freedom from law that we may be free to righteousness. ${ }^{4}$ So that grace is strength for the vitally

${ }^{1}$ Luther is not self-consistent nor thorough-going even here. "Tres enim hierarchios ordinavit Deus contra diabolum, Scilicet oeconomiam, politicum, ecclesiam," Erlanger edition, vol. IV, 394, and of these house and state are "worldly" and "the church" is "spiritual."

${ }^{2}$ Erlanger edition, vol. XI, 304, 318, and many passages.

3 "Hochzeit predigt über Heb. I3 : 4" (first print, I53 I, and in other version, 1536), Erlanger edition, vol. XVIII, pp. 269-302; Tischreden, Erlanger edition, vol. LXI, pp. 164-304; two sermons, "Vom Ehestande" and "Vom Ehelichen Leben," Erlanger edition, vol. XX, pp. 45-89, and many other passages.

4 "Denn in dem Stand und Wesen, dadurch wir Christen werden, da hören auf unsere und aller menschen Werke; also auch alle Gesetze. Denn wo kein Werk ist, da kann auch kein Gesetz seyn, das das Werk fordere, und spreche: 
righteous life, and ethics are logically the test of indwelling grace. ${ }^{1}$ It is with this ethical character of grace that Luther's doctrine of determinism is linked. It is the religious necessity for surety against the ultimate victory of sin and death that makes all, or nearly all, great religious leaders determinists-Paul, Augustine, Luther, Calvin, Knox, and Cromwell. Exactly as to-day, socialism turns to economic determinism from religious rather than really scientific necessity, so religious reformers found in determinism a refuge from life's confessed uncertainties. Of course one may believe that it were better to rest the matter upon an ultimate faith in our estimate of God and the world than on metaphysical and economic speculations which are always subject to correction and revision on the one hand and abuse on the other. Yet the hunger of the human heart for even bad reasons for its fundamental faiths has also its message to us. It may seem a thousand pities that the work of the Reformation was rent by the sad jumble of metaphysics and faith involved in Luther's controversy with Erasmus. ${ }^{2}$ At the same time the habit of mind was such that it is hard to see how Luther could have taken any other position. And after all the modern scientist, socialist, or religious thinker is a determinist on exactly the same ground. They all need, that is to say, the hypothesis in the work they have in hand, and all or nearly all maintain their position with quite as bad reasoning as Luther.

7. It is thus not too much to say that Luther laid the foundation securely for a modern Christian ethics yet to be worked out in the living, thinking, and feeling of a really Christian community, in which the supremacy of the spiritual man will be no one-sided anarchistic individualism, but the finding of the highest individuality in a social world of mutual service. Luther also prepared the way for that modern psychological subjectiv-

Das sollst du thun, das sollst du lassen; sondern wir sind schlechts durch die Taufe und Christi Blut frei von alten Werken, aus lauter Gnade und Barmherzigkeit gerecht, und leben auch allein derselben vor Gott." "Zweit Predigt am dritten Sonntage nach Trinitatis." Erlanger edition, vol. XIII, p. 35.

${ }^{1}$ Erlanger edition, vol. XIII, $289 \mathrm{ff}$., and many passages.

2 "De servo arbitrio," I525, Erlanger edition, "Opera Lat.," vol. VII, p. I 3. 
ism formulated by Kant in which the ultimate ethical authority is found in the human soul. He also saw more or less clearly that this subjectivism becomes moral insanity if separated from the traditional historical community in which it can alone have its healthy growth. Church history became a necessity in a new sense on the basis of Luther's teaching, for the spiritual man must inform himself about the ethical experiences of the past in order that he may meet in his spiritual freedom the world he must subdue, and meet it with intelligence and wisdom. Thus also Luther stripped faith of its artificial character as a holding of opinions on the basis of external authority. Faith was for Luther, as for Paul, a dynamic for righteousness, an inward power and not an external opinion. Sacramental magic logically falls away, for union with the purpose of God is not spasmodic magic but a definite and permanent trend of the soul's life. Magic and ethics are sworn enemies, and in spite of all appearances to the contrary Luther is on the side of ethics.

And lastly, in spite of temporary depressions and profound despondency at times, Luther awoke Protestantism to a new and profounder joy in life than even humanism could inspire. His faith that God's will for mankind was ethical perfection, joy, peace, and love, and that God's will was the predestined outcome of life's struggle, nerved men for the new social organization which was yet to cost such untold sufferings and which stretches itself from the Thirty Years' War (I6I8-I648) on into our own day.

II. THE SCHOLASTIC AND ROMAN CATHOLIC ELEMENTS IN LUTHER'S ETHICS

I. It is a peculiarly ungrateful task to have to point out the weaknesses and failures in the work of the heroic figures who have fought in the forefront for an ethical life. More particularly ungrateful is it for the Protestant historian to have to acknowledge how imperfect was often the criticism of the Roman Catholic position. Both Luther and Calvin carried over into 
historic Protestantism many elements which have been a serious hindrance in our struggle with the principle of authority on which the papal claims rest. It is easy for us to see these things now. On the other hand we must ever remember that to some degree Luther's very usefulness depended upon his honestly sharing some of the narrowness and superstition of his generation. Luther was intensely human and intensely Teutonic. His genius summed up his age and gave, as it were, reality to its ideals. It was impossible for the really religious spirit of that day to wholly escape the bondage to the letter. Luther's position was, of course, wholly untenable. On the one hand he could freely reject whole books of the Bible on the strength of his own subjective impression, as when he called James "a strawy (strohern) book," ${ }^{1}$ and rejected Revelation because it did not seem to him to have the mind of Christ, ${ }^{2}$ and on the other hand he could stake the Reformation unity on his interpretation of "Hoc est meum corpus." Luther in reality supremely trusted the subjective impression, and felt that so far as we can hear God at all it must be in such final personal impressions. The next step, namely, that though we know these impressions are not infallible we yet must trust them as final, Luther did not, and in his age could not, take. He, with all the other reformers, sought refuge from the false infallibilities of the church in an equally false claim of infallibility for the letter of Scripture. It is vain for the modern theologian to gloss Luther's maintenance of the infallibility of the letter of Scripture. The case is all too clear. In $\mathrm{I}^{20}$ he thought the universal church could not err. $^{3}$ But as he was pushed further and further back he took at last refuge in the word of God. So far as the writer knows, the world infallibility (unfehlbarkeit, infallibilitatis) occurs neither in the Latin nor German works of Luther. But the idea

1 "Vorreden," Erlanger edition, vol. LXIII, p. I I5.

${ }^{2}$ Erlanger edition, vol. LXIII, p. I69.

3 "Und das thun sie darumb, denn dieweil sie wissen, und wahr ist, dass die gemeine christliche Kirche (das ist, alle christen sämptlich in aller Welt) nit irren mag, etc." "Wider die Bulle des Endchrists," Erlanger edition, vol. XXIV, p. 36 . 
is there in a thousand passages, where the word of God is identified with the text of Scripture as we have it. ${ }^{1}$ And again and again Luther warns against setting up reason against the letter of Scripture. ${ }^{2}$ He was ready at any time to struggle with what became rationalism. Nor did he clearly see the strength and the weakness of the Roman Catholic position. What may now be regarded as the assured gain of Protestant thinkingnamely, faith in human intellectual processes as essentially divine-would in all probability have been as much a stumblingblock to Luther as it is to that Protestantism still under the bann of Roman Catholic thinking. To have said to Luther, "Ye believe in God, believe also in the reality of an ethical humanity," would have startled and aroused him, no doubt, because he was still hampered by Augustinianism with its heathen estimate of the relationship between God and man.

2. In like manner Luther did not widely differ from his scholastic opponents in his conception of the church. In his theory he had but little quarrel with them. Luther defines it as a holy communion of saints, ${ }^{3}$ an ecclesia christiana with a twofold nature, an invisible spiritual Christianity, and also an outward natural Christianity, which, however, are related to one another as body and spirit, and must not be separated. Or, as the apostle says, an inner and an outer man." This church holds the keys, and has the power of spiritual bann in its proc-

${ }^{1}$ Cf. "Vorrede zum Alten Testament," Erlanger edition, vol. LXIII, pp.

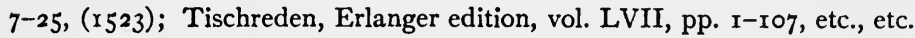

2 "Kirchenpostile über Matt. 20 : 20-23," Erlanger edition, vol. XV, pp. 419-427, and many passages.

${ }^{3}$ Cf. "Von den Conciliis und Kirchen," I 539, Erlanger edition, vol. XXV, pp. $219-388$. The whole tract is of the greatest importance, as both in time and purpose marking his maturest thought.

- "Drumb, und mehres Vorstands und der Kurz willen wollen wir die zuo Kirchen nennen mit unterscheidlichen Namen. Die erste, die naturlich, grundlich, wesentlich und wahrhaftig ist, wollen wir heissen ein geistliche, innerliche Christenheit. Die andere, die gemacht und äusserlich ist, wollen wir heissen ein leibliche äusserlich Christenheit: nit dass wir sie von einander scheiden wollen; sondern sogleich, als, wenn ich von einem Menschen rede, und ihn nach der Seelen ein geistlichen," etc. "Von dem Papstthum zu Rom," I520, Erlanger edition, vol. XXVII, p. IO2. 
lamation, ${ }^{1}$ although its limits are too sharply defined. ${ }^{2}$ This church is also a mysterium mystically linked with Christ and sharing his experiences. ${ }^{3}$ It is likened to an ark of safety amidst the destructions of life, ${ }^{4}$ in which are clean and unclean, but all outside get drowned (denn die andern die es nicht hören, sind nicht im Kasten, sondern ersaufen im Wasser). Hence it is enormously important to know which is the right church. For there is no forgiveness without, ${ }^{5}$ and we must distinguish between the true church and the devil's exact imitation of it. ${ }^{\cdot}$ Hence the notes of the true church are to be found in the preaching of the Word and the right administration of the sacraments. ${ }^{7}$ And when the question is raised about what is the preaching of the Word, the answer is again in terms of an intellectual system. And this teaching is of more importance than life, ${ }^{8}$ because it is at the root of life. The church is then to maintain the true tradition, and in her the Bible.(Schrift) and not reason is to control, ${ }^{9}$ and when the whole church has taught anything it is dangerous to reject it. ${ }^{10}$ So Luther is led to take over the truth of all the ages in establishing the true church so that in it all may find safety. ${ }^{11}$

With Luther himself the message for which the church stood was so much more than any ecclesiastical organization, and in the overwhelming confusion of the day the church as an organiza-

1 "Sermon am Tage St. Petri und Pauli," Erlanger edition, vol. XV, p. 395.

2 "Tischreden," Erlanger edition, vol. LIX, p. I32; cf., also, the collected sayings of Luther on the church in the same volume, pp. I3I-I80.

${ }^{3}$ Loc. cit., Erlanger edition, vol. XXV, 374 .

4 "Predigt über das Sechste Capitel des ersten Buch Moses," Erlanger edition, vol. XXXIII, p. 175.

5 "Von der Beichte," Erlanger edition, vol. XXVII, p. 351.

${ }^{6}$ Erlanger edition, vol. XXV, p. 380; vol. XXXI, p. 339, etc.

${ }^{7}$ Erlanger edition, vol. XXV, p. 362; vol. XXVII, p. ro8; vol. XL, p. 16r; vol. XLIV, p. 253; vol. XLV, p. I03; vol. LXII, p. 46, and many other passages.

8 "Die drei Symbola," I538, Erlanger edition, vol. XXIII, pp. 252-254; also loc. cit., Erlanger edition, vol. XXV, p. $24 \mathrm{I}$.

${ }^{9}$ Erlanger edition, vol. XVIII, p. I 7 .

${ }^{10}$ Erlanger edition, vol. LIV, p. 288.

${ }^{11} C$ f. most interesting passage in 1541 , "Wider Hans Wurst," Erlanger edition, vol. XXVI, pp. I-75. 
tion counted for so little, that the danger of a dead ecclesiasticism, precious as the symbol of various class privileges, and overburdened with all sorts of theological opinions, was hardly real. Yet just such an ecclesiasticism can, alas, find in Luther all that it needs to defend its position and to identify itself with the permanent and necessary guardianship of the truth. It is vain, moreover, to charge, as some have done, the work of establishing such a theory upon Melanchthon. The ecclesiasticism of Luther belongs to all stages of his thought, and is quite as profound and self-conscious as that of Melanchthon. At this point Luther is even more Roman Catholic and scholastic than Calvin. For in point of fact reformed theology has valued the church rather as the organ for discipline than as the organ for the discovery of truth. Augustine's acceptance of the church as the guarantee of truth has never been seriously taken as a point of departure in reformed theology, not even in the highest church Presbyterianism, as, for instance, in the theology of Breckinridge. And this for the very reason that reformed theology has so emphasized the Scriptures as the only source of truth. The church is only receptive of the truth, and not either its guarantor nor even its final interpreter. Luther's. theoretical ecclesiasticism conflicts with the teaching of the moral supremacy of the spiritual man. But Luther was most glorious in his inconsistency.

3. The world of Luther remained in an astonishing way the world of scholasticism with its all-pervading dualism. The devil plays a large part in Luther's thought and teaching. He struggles with our "guardian angels," who protect us, ${ }^{1}$ and who are ever on the watch to guard us from harm. ${ }^{2}$ The devil is the

1 "Erste Predigt von den Engeln," I 532, Erlanger edition, vol. VI, pp. 397-407.

2 "Denn es ist ein stetiger Kampf $z$ wischen Engeln und Teufeln. Der Teufel wollte gern alles Unglück anrichten; wie wir täglich sehen und erfahren, dass mancher ein Bein bricht auf ebener Erde; mancher fällt einen schweren'gefährlichen Fall die Treppen oder Steigen ab, dass er selbst nicht weiss, wie ihm geschehen ist. Solches und anders würde der Teufel wohl immerdar anrichten, wenn Gott durch die lieben Engel nicht wehrete," loc. cit., Erlanger edition, vol. I, p. 399. 
real present ruler of this world, and this world is his principality still, even though Christ has signally defeated him once. ${ }^{1}$ And hence, as to a sort of magic we must go to the sacrament. The coarse superstitions of his age Luther entirely shared. ${ }^{2}$ The most foolish old wives' tales he apparently accepted and in his "Tabletalk" seriously discussed, together with witchcraft, sorcery, etc. He makes the devil responsible for all plagues, sickness, accidents, etc., and the world is for him full of the weird terrors of the ignorant superstitious northland. No really self-consistent system of Christian ethics could long prosper in such an atmosphere. Nor did it in point of fact. Thus the sacraments are debased to magic against these evil powers, ${ }^{3}$ and throughout the whole of the post-Lutheran development the ethics are hampered by this dualism. The rude anthropomorphism of Luther contrasts unfavorably with the treatment of the angel and devil superstitions at the hands of reformed theologians. This may not be wholly due to conscious rejection of these superstitions by reformed teachers, for that was seldom done; it is due to the more speculative and less concrete forms in which reformed theology conveyed its teaching. Luther's great force with the people rested, perhaps, in some degree upon the fact that he shared with them the rude and almost pagan conception of the world inherited from the past.

4. Luther's doctrine of the relation of the Church to the State is full of inconsistency, and lacks even the elements of strength possessed by the relatively consistent scholastic view as developed by Thomas Aquinas and later by Calvin. In the passages referred to on pages $483-485$ we have the doctrine of the church

1 "Demnach sprich: wahrlich der Teufel ist noch ein Furst in der Welt, und ich bin ihm noch nicht entrunnen, so lange ich aber in sinnen Furstenthum bin, bin ich sein nicht sicher; darumb muss ich zum Sacrament gehen," etc. "Vermahnung zum Sacrament des Leibes und Blutes unsers Herrn," I530, Erlanger edition, vol. XXIII, Iو9.

${ }^{2} C f$. "Tischreden vom Teufel und seinen Werken," Erlanger edition, vol. LIX, pp. 289-348, and vol. 60, pp. I-75.

${ }^{3} \mathrm{Cf}$. Erlanger edition, vol. XXIII, p. 165; vol. XXII, p. 160, and many passages. 
as a spiritual force developed. But Luther has no really defensible view of the State. It has an existence apart from the kingdom of God, ${ }^{1}$ is heathenish ${ }^{2}$ and absurd. ${ }^{3}$ Yet it is not taken away by the Gospel but rather strengthened."

Moreover, it is God's arrangement for "secular" affairs, but should not meddle with "spiritual" affairs, ${ }^{5}$ for these two worlds (weltlich und christlich Reich) are not to be mingled. ${ }^{8}$ But Luther had no hesitation himself in telling prince, king, and kaiser in the name of God just what they should do in all manner of situations. In his very declaration to the Protestant princes of this freedom from ecclesiastical tyranny, he really would only change the nature of it, and it was no fault of Luther's that a new churchly organization did not undertake the reconstruction of Germany, much as Calvin undertook the reconstruction of Geneva. This was, in fact, impossible in Germany, and Luther bowed to the necessity of the case, but the result was a compromise in which the church became the mere handmaid of the State, and often her most subservient and ignoble tool.

It is hard to blame Luther for this. Not since Paul wrote Romans 13, with its eminently practical but easily misunderstood assumptions of the divine character of all governments, has the Christian world had any clear doctrine of the relation of the kingdom of God to the State. The scholastic identification of the church with the kingdom of God is the real cause of the trouble. The result is with Luther that the real church is for him a transcendental "other-worldly" quantity, which gives again even to the great human Luther a certain monkish flavor when dealing with the Christian life. The "other-worldliness" is thus reflected in his ethics to their great disadvantage.

5. The sombre mediæval despondency, with its world-flight and fundamental despair, is never wholly absent from any

1 "Auslegung des ror Psa.," 1534, Erlanger edition, vol. XXXIX, p. 328.

${ }^{2}$ Loc. cit., Erlanger edition, vol. XXXIX, p. 33 r.

${ }^{3}$ Loc. cit., Erlanger edition, vol. XXXIX, p. 329.

Erlanger edition, vol. XIV, p. 239; vol. XX, p. 28.

s Erlanger edition, vol. XXVII, p. 336.

- "Predigt am heiligen Christtage," I 532, Erlanger edition, vol. I, pp. 254-255. 
period of Luther's life, though it deepens toward the close. The world is a "vale of tears" 1 (Jammertal), and is intended by God to be only a preparation for his other world, as a carpenter builds a scaffold for the house. ${ }^{2}$

In sermons preached between $\mathrm{I}_{537}$ and $\mathrm{I}_{540}$ Luther looks forward to a speedy end to the world, ${ }^{3}$ and he takes a most gloomy view of the increasing drunkeness, gluttony, usury, extravagance, and excesses of the time. He constantly thinks in terms of two worlds or kingdoms wrestling with one another."

This "other-worldliness" did not prevent Luther from inculcating cheerfulness upon believers, and in his "Tabletalk" he expressly enjoins music and cheerfulness as good remedies against the devil. ${ }^{5}$

\section{THE PRACTICAL ETHICS OF LUTHER}

I. When we look at the practical reforming activities of Luther the reason at once appears why he takes so large a place in history. He was inferior to Melanchthon in knowledge of the scholastic system within which the intellectual life of both was cast. He was far less in touch with the really modern world at many points than was Erasmus. He had no such profound and exhaustive scholarship as Reuchlin. But no one of these made history as Luther made it. The identification of Church and State was a commonplace of human thought at

${ }^{1}$ Erlanger edition, vol. XLVI, p. 25.

2 "Diese Welt ist Gott nur eine Vorbereitung und Gerüste zu jener Welt. Gleich als ein reicher Bauherr muss viel Gerüsts haben zu einem Hause." "Tischreden," Erlanger edition, vol. LXII, p. 345 .

3 "Die Wel( $t)$ hat nun gestanden funf tausend funf hundert und etliche Yahr, nun soll im sechs tausend Yahre das Ende kommen, und wird dasselbige letzte tausende Yahr nicht erfullet werden," "Uber das 24 capital Matthäi," Erlanger edition, vol. XLV, p. Ig6.

4 "Das sind die zwei widerwärtige Reiche die raufen sich mit einander für und für um die Krone," Erlanger edition, vol. VIII, p. 216, and many passages.

5 "Der Teufel ist ein trauriger Geist und macht traurige Lente, darumb kann er Fröhlichkeit nicht leiden. Daher kömpts auch, dass er von der Musica aufs Weiteste fleuget; bleibt nicht wenn man singet, sonderlich geistliche Lieder," Erlanger edition, vol. LX, p. 60. 
that time. Luther's practical sense flung itself upon a farreaching reform of the State. Germany should be an independent power apart from Rome, and thus his letter to the Protestant princes became, together with his treatise on the Babylonian captivity, the Magna Charta of German liberty. ${ }^{1}$

Luther looked upon the State as ordained of God for certain purposes, and the Christian man had no right but that of passive resistance. So he deprecated force, and yet he also realized that the German princes had the right of self-defence. ${ }^{2}$ His attitude toward the peasants in 1525 was along the lines of his thought and influence. He saw in the twelve articles only a caricature of the teaching he himself would have died for. And in exactly the same spirit in which he refused co-operation with Zwingli he refused co-operation with Thomas Münzer. It is unhistoric to attempt to gloss the mistake in both instances. The Reformation was again and again betrayed by the same princes who so savagely put down the peasants. We must remember, however, that at the same time Luther as sternly demanded humanity and justice at the hands of the princes as he did submission on the part of the peasants. That was his point of view. It was the point of view of the rising middle-class with the stamp of the free city upon it.

2. In his view life was still in reality divided into religious and secular, and the State was still "Christian." He could not seemany do not yet see-that no social order has ever been really "Christian." Hence Luther's treatment of law as twofold or threefold is exceedingly confused and confusing. ${ }^{3}$ Here scholasticism is apparent in a most pronounced form. There are offences against "common morality" which are given over to the State. There is "essential" sin, $i$. e., original, which needs the "justicia" of regeneration, and there is actual transgression (quod est fructus originalis) which only faith can overcome.

${ }^{1}$ English readers will find the translation of Luther's primary works by Wace and Buchheim fairly well done. (London, 1896.)

${ }^{2}$ Erlanger edition, vol. LXV, pp. 83-86.

3 "Triplex est pecatum, cui triplex apponitur justicia," "Sermo de triplici Justicia," Weimar edition, vol. II, p. 59. 
This dealing with the State as "secular" and yet as "Christian" and from God is further confused by Luther's relegating the State and its government to reason, ${ }^{1}$ while the church is governed by the "word," conceived of as a something external to reason.

This separation rendered him at times despondent about the State. "Government changes and government reform," he says, "are two different things, as far apart as heaven and earth. To change is easy, to improve is uncertain and dangerous. Why? Because this does not rest on our will or power, but belongs alone in God's will and hand." ${ }^{2}$ Government is God's ordinance and the Christian man, who must not himself fight, must fight if commanded by God's servant the "secular" prince. ${ }^{3}$ And this prince may himself be a Christian, but in that case governs "not as a Christian but as a prince." " Thus Luther not only recognized, as all must, the prevailing double morality, but sanctions it in a way fatal to the highest ideals. In the advice that Luther gave to Philip of Hesse comes out plainly the practical effect of a theoretical defect in Luther's ethics. ${ }^{5} \mathrm{He}$, in point of fact, fell back into the double morality which the compromise between Church and State has always made necessary. ${ }^{\circ}$

3. On the other hand, it is absurd to charge Luther with theoretic looseness in regard to sexual purity. There clung to him some of the unfortunate casuistical weaknesses born of the

1 "Von weltlicher Obrigkeit," I 523, Erlanger edition, vol. XXII, p. I05.

2 "Ob Kriegsleute auch in seligem Stande sein Können," 1526, Erlanger edition, vol. XXII, pp. 244-290. The whole treatise is exceedingly suggestive.

${ }^{3} C f$., also, Erlanger edition, vol. XLII, xII; vol. III, 280; vol. LII, 298, and many passages.

4 "Ein Fürst kann woll ein Christen sein, aber als ein Christ muss er nicht regieren; und nach dem er regiert heisst er nicht ein Christ, sondern ein Furst." "Postelle," Erlanger edition, vol. XLIII, 2 I r.

${ }^{5}$ See "Die Doppelehe des Landgrafen Philipp von Hessen," Rockwell, W. W., Marburg, 1904; also Luther's "Lehre von der Ehe" Salfeld, Ernest, 1882, "Luther und die Ehe," Fuchs, G., Stuttgart, r89r.

- Where the head of the State is the head of the Church, and the church has no power to depose the chief ruler, it must either secure a saint for the secular prince or wink at the sins and follies high position makes exceedingly easy to the average man. 
unnatural relationship established by the Roman confessional. It is, however, as unfair to charge him with these as to assert that the notorious sexual laxness of special Roman Catholic communities is the fault of the confessional. ${ }^{1}$

4. With growing admiration one must study the fine Christian wisdom and almost unfailing common-sense of Luther as he addressed himself to the work of re-establishing the churches of Germany. He is in the line of apostolic succession with Paul, Augustine, and Wesley. He felt himself rightly to be a conserver of the historical past. He did not sympathize with the thoroughgoing radicalism of Carlstadt, and only pressed for reform where he thought some ethical or religious value endangered by the old custom.

In his letter to the Protestant princes he brings out plainly the ethical test of the true church, and we have already seen how he recognized the priesthood of all believers, so that even in the administration of the sacraments it is only a matter of order that some function and others do not. ${ }^{2}$ For all men he demanded the highest attainment in grace, and the church is the "holy community," and so far as it is not "holy" it is not a true church.

The most serious practical weakness in the ethical reconstruction as regards the church was the magical intrusion. The sacraments were too often thought of, not in the categories of ethics but of magic and externalism. Thus sacramental grace becomes a "treasure" which "the church possesses" and "distributes." So he adopts Augustine's "accedat verbum ad ele-

${ }^{1}$ Cf. Denifle, Heinrich, "Luther und Lutherthum," 2d ed., 1904, in two parts, which is an unfair and one-sided criticism of Luther. The mere misuse of italics (gesperrter Druck) enables the author again and again to utterly misrepresent Luther. The present writer has no brief in Luther's defence. Protestantism is for him far too much an ideal of the future to make him willing to stake his faith in it on the character of any man. But after careful examination of all that has been recklessly charged against Luther, the admiration for the man has steadily grown. He used frank, coarse language. $\mathrm{He}$ is never impure. He spoke slightingly of good works done to gain heaven, never of good works. His own life, by historic testimony Denifle himself quotes, was pure, simple, and of good report. Could Denifle say that of all the popes?

${ }^{2}$ Erlanger edition, vol. XI, pp. 304 and 318. 
mentum et fit sacramentum," and baptismal water becomes a "divine and holy thing," 1 And he says "the whole force, work, necessity, fruit and end of baptism is to confer salvation," or "faith clings to the water and believes that baptism confers life." For infant baptism he has no defence save the incorrect one that God commanded it. This high sacramentarianism sooner or later reacts to the disadvantage of the church thought of as a religious-ethical force. At the same time Luther himself guarded with insistent faithfulness the conception of the church as God's messenger of salvation to all men. The church was the proclaimer of God's truth and the educator of her own children.

5. Thus Luther's practical common-sense taught him the bad policy of expecting reformation by the sword and by force. At the same time he had no really consistent theory of the church, and based his right conclusions upon a false and fitfully held theory of non-resistance to princes. Seldom does Luther engage in weaker arguments than in his dealing with the peasant revolt, even though he had good reason for denouncing the folly of staking the Reformation upon the fanaticism of the Anabaptists and the revolting serfs and peasants. ${ }^{2}$

In his practical teaching he was here as elsewhere almost always right, although he made mistakes, and his sermons against the unfortunate peasants are no more to be defended than Gregory XIII's Te Deum for the massacre of St. Bartholmew, or Calvin's complicity in the death of Servetus. He also, with the other reformers, made a mistake in even seeming to give a dispensation to the Landgrave. That again was an intrusion of Roman Catholic casuistry upon the reformed thinking. No real Protestant is the lord over another man's conscience. He was also mistaken in his defence of the "not-luge" (lie of necessity), but he took it over from the legal morality of the past, and the church of Rome should be the last to throw stones at him in the

1 "Greater Catechism" upon baptism.

${ }^{2}$ Cf. "Sermons to the Peasants," in 1525 , and in 1522 his "Vermahnung an alle Christen." 
matter. It is as untrue to accuse Luther of defending impurity or untruth as it would be to assert that Rome defends murder. ${ }^{1}$

6. Equally coarse is the frequent assertion that Luther was drunken and a defender of excess. Again and again he denounces his own people for their drunkeness. It is " $\sin , " 2$ although a less vice than uncleanness. It makes the service of God impossible." A Christian "should be such a man as will keep his body temperate in eating and drinking, and will not spoil it by intemperate gluttony and excess, that he may be constant, sensible, and skilled in prayer." " No drunkard can be a Christian, and it leads to all other vices. Such was the constant teaching of Luther. ${ }^{5}$ That he took wine, as all then did, was not even an infringement of the rules of his order.

7. In the matter of personal truthfulness Luther's discussion compares favorably with the general treatment in scholastic ethics. The distinction common in casuistry between the mendacium perniciosum and the mendacium officiosum Luther accepts, ${ }^{\boldsymbol{B}}$ in order to shield some of the Old Testament characters, but he was himself too bold, fearless, and outspoken to have patience with lying. He pours out his contempt upon it, as the cause of half the sin of the world. ${ }^{7}$ No lie that injures any one can have any defence, although a lie to help may at times be permitted. But it is even here very dangerous, and grows like a snowball, ${ }^{8}$ and is to be classed with murder.

Luther discusses the doctrine of non-resistance, and most

${ }^{1}$ Besides works quoted, see Luther's teaching on marriage set forth in von Stumpf, "Martin Luther über die Ehe," Berlin, 1857 .

${ }^{2}$ Sermon on the ninth chapter of Genesis, Erlanger edition, vol. XXXIII, p. 215.

3 "Am zwanzigsten sonntage nach Trin," Erlanger edition, vol. IX, p. 33 I.

4 "Am Sonntage nach Himmelfahrt," Erlanger edition, vol. VIII, pp. 280286. The sermon is an excellent temperance tract.

"The lines "Wer nicht liebt Wein, Weib, Gesang" are not by Luther, but by Voss. He never said anything of the kind.

- Erlanger edition, vol. XXXV, p. I8.

7 "Am neunzehnten Sonntage nach Trin," Erlanger edition, vol. IX, p. 3133I4.

8 “Tischreden," Erlanger edition, vol. LVIII, p. 308. 
clearly, in a sermon upon Matt. $26: 56 .^{1}$ He who takes the sword will die by the sword. Yet resistance to evil-doing is proper, so long as it is without anger or hatred and along the given lines of legal remedy. Moreover, any one attacked by a murderer in the woods has a right to defend himself, but it is only in extreme cases, and all must be done under the general law of love to our neighbor. Nor must we ever forget how passive and unresisting Jesus was, even under illegal treatment. ${ }^{2}$ Luther felt so deeply that personal revenge was out of place that he urges the injured one to abstain from pressing his own suit. He should rather "ask and hinder" any one revenging him. Thus punishment would be carried out in a spirit of brotherly love. $^{3}$

Luther saw the evils plainly enough of the commercial middleclass spirit which was to so soon rule the progressive West. $\mathrm{He}$ denounces fiercely, although of course indiscriminately, greed, usury, and the commercial hardness of his day. ${ }^{4}$ He goes back to Aristotle and Roman law for his arguments against all interest, ${ }^{5}$ but fails to really put his finger on either the economical or the ethical weakness of the new development. Indeed that would have been too much to expect of him. ${ }^{6}$ He traces the revolt of the peasants to their ignorance of the Gospel and to the unwisdom of the land-owners. ${ }^{7}$ For Luther the revolting peasants were "breakers of the peace, forsworn, traitors, blasphemers against God," but he demanded of the triumphant land-owners that they should not press their advantage, and pled for mercy for those who gave way. His sympathies were wholly with his class, and the proletariat, he knew, were deceived by the un-

${ }^{1}$ Erlanger edition, vol. III, pp. 49-6o.

2 "Grosser Sermon vom Wucher," I 509, Erlanger edition, vol. XX, pp. 89-92.

Erlanger edition, vol. XX, p. 93.

Erlanger edition, Vol. XLV, p. $6 f f$.

s "An die Ffarrherrn, wider den Wucher zu predigen," I 540, Erlanger edition, vol. XXIII, p. $282-338$. The whole sermon is most interesting, with its bad political economy but clear insight into the evils of the commercial spirit.

- The classic passages will be found in his sermons against usury. C $f$. vol. XX, pp. 89-122 and 122-127; vol. XXIII, pp. 282-338; vol. XLV, pp. 158-160.

' Erlanger edition, vol. XXIV, p. 267 ; also vol. LXV, pp. I-46. 
doubtedly fanatical "prophets." On the whole Luther could hardly have been expected to act otherwise. Where would the sympathies of any white Southern minister of the Gospel have been in case of a temporarily successful rising of the slaves before ${ }^{2} 86_{5}$ in America? For Luther serfdom was as much a divine institution as slavery was for Southern Presbyterianism. ${ }^{1}$

The ethical process is a twofold one. On the one hand we extract from our experiences the general principles which must rule our conduct, and on the other in the application of those principles to conduct we correct and enlarge them. Luther awoke the world to a new and larger conception of the Christ life as springing from the Christ purpose. He saw that "good works do not make a good man," but that "a good man does good works." The full Christian obligation he laid upon all: "I will give myself as a sort of Christ to my neighbor as Christ has given himself to me, and will do nothing in this life except what I see will be needful, advantageous, and wholesome for my neighbor."

Nowhere, perhaps, does Luther sum up better his religious ethics than in the beautiful tract "Tessaradecus." 2 There are in it many touches of a distinctly Roman Catholic piety, but the general outline is above and beyond the narrow limits of sectarian dispute. The truth as it is in Christ Jesus is life's highest good. The goal is the vision of God, because that vision will separate us forever from sin. Death is, in so far, for the Christian man a good. Life has two kinds of hope, one negative, the termination of evil, the other positive, the attainment of the good. ${ }^{3}$ There is here a beautiful refinement in the treatment of heaven and hell in pleasing contrast to the ordinary thought of that day, even as reflected in Luther's other writings. Separation from sin is heaven, abandonment by God is hell. Hell is sin, heaven is love within us. God is our friend and communion with him and co-operation with him in his work is heaven. More than once

${ }^{2}$ Erlanger edition, vol. XXXVI, p. I75 ff., and many passages.

2 "Fourteen Sources of Comfort for the Weary and Heavy-laden." In Latin

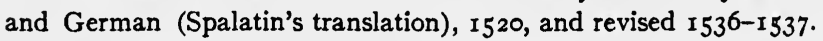

3 "Spes mali amovendi, et spes boni accessuri." 
Luther is reported in his "Tabletalk" as saying that the devil cheats men with the false syllogism: "You are a sinner. God is the sinner's enemy. God is your enemy." Luther denounces the assertion that God is the sinner's enemy. The power of the priest in all ages has been men's fear of God. Loving children do not need a priest between them and their Father. Thus Luther struck a deadly blow at the power of the priesthood.

But most especially did Luther teach men, as no one had taught them hitherto, that the daily task was sacred. This became the watchword of a new ethical life. He himself never quite shook off the shadows of priestly misrepresentation of God. In this Denifle is quite right. But the fault was not Luther's but the popular religion fostered by the hierarchy. He was often afflicted by physical depression. Yet in hymn and sermon, in work and life, the greatest of the reformers taught the newold lesson, rejoice in the Lord always, again I say rejoice!

\section{THE ETHICS OF MELANCHTHON.}

If Luther was the man of action, and the adviser of action on the part of those who had the political responsibility for the Reformation on their hands, no less was Melanchthon the formulator of the churchly system of thought which took the place of the discredited Roman Catholic theology. This may be deemed unfortunate. Certainly Melanchthon was dogmatic and reactionary in the outlines of his thought; at the same time it is unhistorical to contrast too strongly the two men. As we have seen, there was in Luther a scholastic and reactionary trend which only some immediate ethical or religious interest could make him override. ${ }^{1}$ It is often overlooked, however, that here

'In Ritschl's "Lehre von der Rechtfertigung und Versöhnung," and particularly in the third volume there is a running critique of Melanchthon's theology (pp. 7, 97, 107-108, 110, 136-137, 273, 370, etc.), 4th ed., 1895, which produces often the impression that Ritschl laid upon Melanchthon the blame of the reactionary character of post-Reformation theology. This was, certainly, the impression he also left upon his students of dogmatics, but how fairly he held the historical balance may be seen in his first volume, 3 d ed., I889, pp. 185-203. 
as elsewhere, the age determined to a large degree the limits of the intellectual revolution. The disorders of the time demanded constructive statesmanship. This was sadly lacking. Conservatism has always definite and material interests to give unity to its activity. It stands for the defence of vested privileges, of class, of property, of education, of Church, and of State. Reform and a really progressive idealism has little but promises of a better future; and the faith of even its most sturdy defender is sadly tried by the vagaries of the camp-followers, who range from dogmatic one-sidedness to fanatical, unhistorical radicalism all along the line.

Luther never sought to cut himself off from history. Even his denunciation of Aristotle is explicable on the line of his own intellectual development (nominalist). He was always at one with Melanchthon in seeking to maintain the intellectual unity of history. The immediate pressing need of some definite reconstruction of the intellectual basis of life called into play the great powers of thought and feeling possessed by the gentle and learned Melanchthon. ${ }^{1}$

${ }^{1}$ Melanchthon, Philipp, born February 16, 1497, died April 19, 1560, the son of Georg Schwarzerd, but he wrote his name later in Greek, and himself used from $153 \mathrm{I}$ on the shortened form Melanthon. The "complete edition" of Carl Gottlieb Bretschneider and Heinrich Ernst Bindseil in the "Corpus Reformatorum," vols. I-XXVIII, Halle, 1834-1860, has been supplemented by Bindseil, Hartfelder, and others, but the student of ethics will find his material mainly in vols. XI, XII, XVI, XXI, XXII, XXIII, and XXVIII. The "Loci" have been very carefully edited by Plitt-Kolde with most useful introductory matter ("Die Loci Communis Philipp Melanchthons in ihrer Urgestalt nach G. L. Plitt; in zweiter Auflage von neuem herausgegeben und erläutert von Theodor Kolde," Erlangen and Leipsic, r89o). The best life is by Karl Schmidt, "Philipp Melanchthon, Leben und ausgewählte Schriften," ("Väter der lutherischen Kirche" series, vol. III), Elberfeld, r86r, and James William Richard, "Philipp Melanchthon: The Protestant Preceptor of Germany," I 497-1560 ("Heroes of the Reformation" series), New York, 1898. His ethical work is especially treated by Christoph Ernst Luthardt, "Die Arbeiten Melanchthons im Gebiete der Moral," Leipsic, r884. See also "Theologische Studien und Kritiken," 1897, for estimates by Gustav Kawerau, "Melanchthon neben Luther," pp. 668-686, and Friedrich Loofs, "Melanchthon als Humanist und Reformator," pp. 64I-667; also Adolf Harnack, in "Revue Chrétienne," vol. XLIV, r897, "Philippe Mélanchthon," Discourse r6, February, 1897, University of Berlin, 
The outline of Melanchthon's ethics is set out in his "Philosophiæ Moralis Epitome," 1 which appeared in the first edition in ${ }_{1538}$, and under different wording remains substantially the basis of all his later thought. He defines moral philosophy as that part of the divine law which concerns itself with external action, ${ }^{2}$ and then goes on to distinguish between philosophy and the Gospel, any confusion of which produces "horrible errors." The Gospel is a revealed promise of God on account of Christ of the free forgiveness of $\sin$, of reconciliation and the gift of the Holy Spirit, and of life eternal. This could not be discovered by reason. Yet in the exact spirit of the scholastics he accepts reason as the blurred impress of the law of God upon the human soul. $^{3} \quad$ This revelation (ethical) is a remnant of the divine light, and the dignity of human nature consists in the fact that it is a glass in which the wisdom of God is reflected. Philosophia has a distinguished place therefore, although it is not on a level with the Gospel Evangelium. It deals with demonstrations from principles, and he rejects the Academy position that these principles are simply probable.

Thus Melanchthon sets before himself the task of scholasticism, namely, the rationalization of human conduct within a closed system. The law of nature, he teaches with the older Stoics, is the law of God. But moral philosophy concerns itself with civil custom, and at this point Melanchthon confuses ethics with statute law. Law is a school-master to bring us to Christ, he quotes from Paul, and as such has its rewards and penalties. It has also its assured principles, and the moral

translated by Rene Puaux, pp. I6I-177. The scholasticism of Melanchthon has been treated by W. Bornemann, "Melanchthon als Schulmann," Magdeburg, 1897. See also Franz Költzsch, "Melanchthons philosophische Ethik," Freiburg, I889, and § III in Christoph Ernst Luthardt's "Geschichte der Ethik seit der Reformation" (vol. II of his "Geschichte der christlichen Ethik"), Leipsic, I893, pp. 38-53.

1 Vol. XVI, "Corpus Reformatorum," pp. 20-163.

2 "Sed eruditissima definitio est hæc: Philosophia moralis est pars illa legis divinæ, quæ de externis actionibus præcipit."

3 "Nam lex divina hominum mentibus impressa est, sed in hac imbecillitate naturæ obscurata est," etc. 
extravagances of the race are due to ignorance of these. Thus Melanchthon again divides ethics into natural and supernatural, with the ultimate assumption that there can be no real conflict between them.

The uses of moral philosophy are educational, and it has the advantage of written law in so far that written law is concise, while philosophy can and should explicate the reasons for the conduct it commands.

It sets forth also the foundations of jurisprudence, for as Aristotle showed of old the best law is that which follows nature. Hence the lawyer should be a student of moral philosophy.

The theologian also must study it, for although the Gospel has a different place from law and philosophy, nevertheless the theologian must discourse about the dignity of civil affairs, of political laws, of magistrates and rulers, and the morals necessary in the civil State.

The main difference, however, between the laws of the magistrates and the conclusions of the philosophical dispute Melanchthon sees in the fact that the laws are bare, naked precepts without assigned cause or reason. Philosophy explicates the reasons for conduct.

Moral philosophy deals with ends and must ask what is the end of human life. The answer is to know God and to reveal his glory. ${ }^{1}$ In nature all things obey the law of their being, the sun hastens to its goal, but man has lost by original sin the power of obedience, and the goal must be reconstructed according to the law of God and a true and sound philosophy. The Stoics were right in seeing God in the notions of justice and social order. Following the Gospel, however, the end of human life is to know Christ the son of God, and to accept the gracious offering and to glorify God by obedience to it.

There then follows a criticism from this point of view of the "end" of human life as set forth by Aristotle, and of the Epicureans, whose doctrines he sets forth in syllogisms, which he then

1 "Ergo finis hominis est agnoscere Deum, et patefacere ejus gloriam." $C f$. "Westminster Cat.," Q. r. 
refutes, but without true appreciation of the real position of Epicurus. He defends the Stoic position that the only real good is virtue, and at the same time shows that there are inferior goods and that the dispute is about words.

If, then, as Aristotle has shown, virtuous action is the end of human life, moral philosophy must concern itself with the nature of virtue. He then follows Aristotle. Virtue is a habit, which inclines the will to obedience of right reason. ${ }^{1}$ At the same time Plato was right so far that in defining virtue as justice, he marks the fact that virtue is harmony in which all parts co-operate and the inferior obey the superior.

Melanchthon then seeks the causes of virtue both primary and secondary, and here again he stands upon the old scholastic position of a closed system revealed in nature and in revelation from which right reason deduces the principles of conduct. The secondary causes conducing to virtue are teaching (doctrina), the natural impulse, and discipline. Rites and ceremonies are often God's method of discipline. So far philosophic ethics goes, but the Christian adds the conception of the Gospel and the Holy Spirit aiding and impelling human nature; and when we see the weakness of philosophy in the midst of man's helplessness, then the more ardently do we embrace the Christian teaching which offers aid in this weakness. There then follows a bit of choice scholasticism in a distinction between "causa formalis" and "causa finalis."

Classic for the post-Reformation ethics is now Melanchthon's discussion of the freedom of the human will. ${ }^{2}$ He rejects the Stoic teaching of fate, and shows that both philosophy and Paul teach a degree of freedom for the human will in external and civil affairs. This he does in a series of arguments with "solutions" and in an acute and learned critique of (Roman) Stoicism. Then he takes up Aristotle, whose position as to the grades of action he accepts, ${ }^{3}$ and distinguishes between "common" and

1 "Virtus est habitus, qui inclinat voluntatem ad obediendum rectæ rationi."

2 “Estne voluntas humana libera?" “Corpus Reform.," vol. XVI, p. 42.

3 "Sunt igitur hi gradus actionum. Aliæ sunt $\dot{v} \sigma \epsilon \iota$ tales, aliæ $\delta 6 \xi q$, aliæ

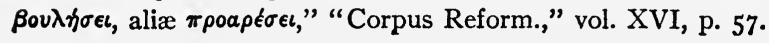


"heroic" virtues. Heroic virtues are only reached by the help of divine inspiration. This was the case in even classic times, and such are the virtues of the saints, who were sustained by the Holy Spirit, like Abraham, David, Paul, and others. Nor is this inconsistent with Aristotle's definition of virtue as a mean between extremes, when that definition is rightly interpreted. Nor does Plato, when properly understood, stand upon any other ground.

In the division of the virtues the Decalogue is Melanchthon's convenient guide. At this point there is no real advance upon the classic scholastic distinctions between duties to God, to man, and the evangelical virtues. The discussion of the virtues is also disappointing, falling far below Luther's estimate of the rounded Christian life of common tasks. Indeed as an ethical treatise it is below the level of Thomas Aquinas's work. ${ }^{1}$

It is not so much, however, his conclusions as his method that did harm to the development of a genuine Protestant ethics. Even humanism, although primarily so pagan in its ethical outlook, might have given rise within Protestantism to a genuine religious rationalism, with a unified and consistent ethical philosophy, but upon the vain and outworn distinctions of the mixed culture of scholasticism there was no chance to build securely. Thus into post-Reformation ethics Melanchthon reintroduced the authority of an external code, the quasi-authority of classic philosophy, the confusions of metaphysical discussions from the standing ground of $a$ prior $i$ dogmatism; and thus he lost himself, and post-Reformation Lutheranism followed him back into the wilderness of dreary scholastic unreality.

It would not be profitable here to take up in detail Melanchthon's acute and learned reviews of Aristotle and Cicero's ethics. He is not always self-consistent, nor has the writer been able to trace consistent chronological development in his ethical thought. He seems rather to have readily yielded to the force of particular writers with whom he was busy. In the second redaction of the "Epitome" in I550, under the heading "Ethical 1 "Pars Secunda Secundæ," of the "Summa." 
doctrinæ elementa," "1 there is, for instance, a marked increase in the influence of Cicero, perhaps as seen through Ambrose, and also greater scholastic refinement.

In the "Loci" and the ethics of his middle and later periods there is wavering and uncertainty, and after Luther's death, which came to him both as a shock and yet also as a relief from masterful pressure, ${ }^{2}$ the scholastic interest is ever in the foreground. He increasingly inclined to the impossible intellectual mediation which has been the bane of Protestantism. Perhaps this wavering character was the constitutional weakness of a scholar thrust into an unwelcome leadership in action. Perhaps Melanchthon recognized the fact that he had many intellectual bonds with the mediæval past. ${ }^{3}$

This especially reveals itself in a field from which this history has tried to keep aloof, namely, the dogmatic presuppositions of an authoritative ethical system. The relations, for instance, of grace to the renewed man and the place in the ethical life of the whole sacramental system become, for post-Reformation ethics, important questions. In the unio mystica of the redeemed man with Christ the questions arise, Is the mystical union with his manhood or with his will? Does the sacrament complete the process, or is it only a "seal" upon the completed event or an aid to its completion? etc., etc.? These and like school questions were again thrust upon the Reformation by the acceptance

1 “Corpus Reform.," vol. XVI, p. 165.

${ }^{2} C f$. the oft-quoted letter to Carlowitz: "Tuli etiam antea servitutem pæne

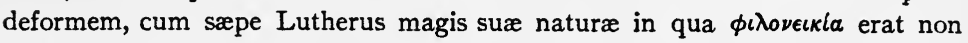
exigua, quam vel personæ suæ, vel utilitati communi serviret," "Corpus Reform.," vol. VI, p. 880 .

3In the "Schriften des Vereins für Reformations-geschichte," No. 73 (Igth year, I90I-I902), Dr. Gustav Kawerau has published a most interesting account of Melanchthon's relations to the Curia, "Die Versuche Melanchthon zur katholischen Kirche zurückzuführen (I9O2)." Here we see the purely humanistic and literary tastes of Melanchthon struggling with the religious and dogmatic interests, and although it may be unfair to press too far expressions of Melanchthon's used in politeness in his correspondence with Roman Catholics, or in temporary fits of disgust with the rawness of the new Protestantism, at the same time such expressions would have been perfectly impossible for such self conscious Protestants as Luther and Zwingli. 
of the scholastic Aristotelian philosophy as a quasi official interpretation of the evangelical ethics. ${ }^{1}$

In the "Loci" ( $3 \mathrm{~d}$ form $)^{2}$ the sections that have ethical interest are those dealing with sin and the law. ${ }^{3}$ Luther was still living, but the change in emphasis wrought by scholastic disputation is apparent. In both method and matter there is distinct reversion to the ethics of the schools and deep and fundamental confusion with regard to law and grace.

The sinner has freedom of the will for civil virtues and in regard to outward actions. He is free to commit or abstain from committing the grosser sins. And youth should be taught that God punishes in this life infractions of the outward morality. At the same time, against sin and death all are helpless without grace. This is given freely together with penitence and contrition. Then enters again the old scholastic distinctions between kinds of grace and the confusions grouped generally under the head of "synergism." The grace that redeems gives penitence and renewal, and then sustaining grace enables, by the continuous merits of Christ, the sinner to please God by the imperfectly sanctified works of the redeemed man. If a student of ethics may be allowed an opinion in dogmatics as between the ultimate position of the Council of Trent and Melanchthon's last edition of the "Loci," the dogmatical position of Trent is ethically clearer and less objectionable.

The practical outcome of Melanchthon's position would be a twofold ethical relation, a rather coarsely eudæmonistic ethics for the unredeemed in his civil relations, and a religious ethics for the redeemed, in which, however, the Decalogue is fundamental and the legal element is never overcome.

The threefold division of the law into moral, ceremonial, and

${ }^{1}$ Even down to Julius Müller, as one may see in his chapters upon "Hilfsätze aus der Dogmatik," in the ethical work published after his death by Julius Leopold Schultze ("Dr. Julius Müller als Ethiker und die Glaubensfrage mit Bezug auf das Apostolicum," etc., Bremen, r895).

2 "Corpus Reformatorum," vol. XXI, pp. 560-1 106.

3 "De causa peccati et de contingentia (III), De humanis viribus seu de libero arbitrio (IV), De peccato (V), De lege divina (VI)," pp. 643-73I. 
judicial or civil is not self-consistently carried out. ${ }^{1}$ Nor does Melanchthon grasp the subject of law as firmly as the older scholasticism, and at the same time he brings in the creeds and the church as equal authorities with the law in a way selfconscious Protestantism can never do. ${ }^{2}$ And although Melanchthon distinctly refused to identify faith with the acceptance of "history," ${ }^{3}$ in both his definition of faith as "acceptance of the Gospel that sin is forgiven" in "real fright and terror before the anger of God," as well as in his definition of law, there are weak and beggarly elements.

While making these criticisms and deploring the subsequent confusions into which Melanchthon led the ethics of Lutheranism, from which they did not emerge until Kant, it is at the same time true that Melanchthon saw the need of both intellectual formulation of ethics and greatly stimulated the interest in moral philosophy. Perhaps it is to him that German philosophy owes in large part its tremendously ethical interest, and the very confusions of Melanchthon compelled religious thought restlessly to seek a firmer ground upon which to stand.

Melanchthon's interest in humanism also prepared the way for that union of religious Protestantism with the intellectual awakening, which, in spite of all the protests of Roman Catholic imperialism within Protestant orthodoxy, so-called, has steadily compelled Protestantism to shake off the grave-clothes of scholasticism and to seek God in humble dependence upon the only means he has given us to find him.

1 The third commandment is a lex natura, and for all time and for all men. "De tertio præcepto," vol. XXI, p. 700, "Corpus Reformatorum."

2 "Und nach dem die Kirche zur Apostles Zeit die Hauptstücke christlicher Lehre in das symbolum Apostolorum gefasset hat, und ist hernach im Symbolum Niceno und Athanasii, der vorigen Symboli warhafftige Klerunge treulich gemacht worden, will ich im Anfang hie meine Ewige Bekentniss mit warhafftigem Hertzen setzen, das ich warhafftiglich alle Artikel in demselbigen symbolis gefasset, gleube, und als göttliche Warheit anneme, und mit Gottes Gnaden ewiglich also halten wil, und sage dabey das alle Engeln und Menschen dieselbigen Symbola mit warhafftigene glauben an zu nemen schuldig sind." “Loci German," “Corpus Reform.," vol. XXII, p. $5^{8 .}$

${ }^{3}$ Cf. "Examin. Ordinandorum," "Corpus Reform.," vol. XXIII, p. 50-51. 


\section{THE ANABAPTIST MOVEMENT AND ITS ETHICS}

No movement has been more misrepresented and learnedly misconstrued than the so-called Anabaptist movement. Those who are classed as Anabaptists have often no common bond at all. Münzer did not reject infant baptism. Hübmaier did not teach communism. Denck was a mystic with almost no interest in social reconstruction. Storch had almost no other interest than the proletarian uprising, than which nothing could have been more abhorrent to the learned and gentle Schwenckfeld. The prophets of Zwickau were premillenarians, but this no more organized the thought of many of them than it did Luther's thought. To represent the whole movement as a socialistic,

Literature.-Newman, Albert Henry: "A History of Anti-pedobaptism from the Rise of Pedobaptism to A. D. I609," Philadelphia, I897 (with exceeding good and full bibliography up to 1896, p. 395).-Vedder, Henry Clay: "Balthasar Hübmaier, the Leader of the Anabaptists" ("Heroes of the Reformation" series), New York, I905.-Arnold, Gottfried: "Unparteyische Kirchen und Ketzer-Historien vom Anfang des Neuen Testaments biss auf das Jahr Christi, r688," 3 vols., Schaffhausen, r688; later editions in 4 vols., with additional matter, published as late as I 740.-Beck, Joseph von: "Geschichtsbücher der Wiedertäufer in Esterreich-Ungarn in der Zeit von 1526 bis 1785 , gesammelt, erläutert und ergänzt," Vienna, I883.-Brenz, Johann: "Bedenken etlicher dass weltliche Obrigkeit der Wiedertäufer mit leiblicher Strafe zu wehren schuldig sei," I536.-Bax, Ernest Belford: "Rise and Fall of the Anabaptists" (Social Side of the Reformation in Germany), London, Swan Sonnenschein, r903.-Heath, Richard: "Anabaptism; From Its Rise at Zwickau to Its Fall at Münster, I $521-1536$," London, 1895.-Bullinger, Heinrich: "Von dem unverschamptē Fräfel, ergerlichem verwyrren, unnd unwarhafftem leeren, der selbsgesanndten Widertöuffern vier gespräch Bücher," Zürich, I53I; "Der Widerteuffern ursprung, fürgang, secten, wasen, fürnemē und gemeine jrer leer Artickel . . . mit widerlegung und antwort ....,"Zürich, 1560.-Burrage, Henry Sweetser: "A History of the Anabaptists of Switzerland," Philadelphia, American Baptist Publication Society, 1881; "The Anabaptists of the Sixteenth Century," in "American Society of Church History Papers," vol. III, New York I89r.-Erbkam, Heinrich Wilhelm: "Geschichte der protestantischen Sekten im Zeitalter der Reformation, Hamburg und Gotha," I848.-Loserth, Johann: "Balthasar Hübmaier und die Anfänge der Wiedertäufer in Mähren," Brünn, I893.-Keller, Ludwig: "Geschichte der Wiedertäufer und ihres Reichs zu Münster . . . nebst ungedruckten Urkunden," Münster, I880; "Ein Apostel der Wiedertäufer (Hans Denck)," Leipsic, I882.-Ritschl, Albrecht: "Geschichte des Pietismus," vol. I, Bonn, r88o, pp. 22-36. 
communistic proletarian uprising is as false as to deny with others that primitive communism had no proper place in their teachings. The literature is happily growing, for a really balanced and historically objective estimate of the movement is much needed.

The hypothesis of Ritschl that the movement is the outcome of the Tertiary order of the Franciscans cannot be maintained. Indeed, he wavered himself. At the same time it is true that many of the things that gave strength to the reforming orders found also expression in the Anabaptist movement. Nor was it in any degree a truly Protestant movement, if by Protestantism one means moral and religious autonomy. It was thoroughly under the Roman Catholic conception of external authority, only it was the authority of a book and a written law rather than a tradition and a pope.

Everything we find among the Anabaptists one also finds in the New Testament. It is simply a matter of emphasis. If to take the New Testament literally is Protestantism, then as over against Luther, Calvin, and Zwingli the Anabaptists were the real Protestants. They based their teaching upon Luke's estimate of poverty or upon the communism of Acts, or the freedom of the spirit in the Pauline sense, or upon the premillenarianism of the early church and the early Gospels. They took the Sermon on the Mount literally, and they rejected with more or less consistency all things not commanded by the Bible. They saw, generally, as the reformers did not see, that primitive Christianity was inherently opposed to the existing and non-Christian social order. They found, of course, no warrant in the New Testament for sacramental magic, because it is not there.

All this is not new in church history. From the time of Jovinian and Claudius of Turin, from the days of primitive British Christianity to the Waldensians and Lollards, the New Testament has always raised up men who took it seriously and tested by it at one point or another the traditional dogmatic Christianity. And as dogmatic Christianity is not, in fact, built upon the New Testament, it has never stood the test. The Anabaptist move- 
ment, however, has no real unity. Some rejected the Old Testament ${ }^{1}$ or believed it completely fulfilled in the New Testament. Some, like Thomas Münzer, held up the bloody pages of the Old Testament for imitation in the style of Calvin and John Knox.

What made the movement obnoxious was its prevailingly rude proletarian character. It is extreme to say, with Bax and Heath, ${ }^{2}$ that they were "socialists." They were mainly of the oppressed small-town trading class, in union with the discontented peasants, and led by educated and even learned teachers like Count Schwenckfeld von Ossig or the devout and temperate Hübmaier.

Indeed the revolt of Münster and the peasant wars were made the most of by the small nobility and the reform leaders to accomplish their own purpose of re-establishing their power on the basis of national and provincial churches as heirs of the rejected imperialism. The cold-hearted callousness of Zwingli in torturing his former friend Balthasar Hübmaier and forcing from him on pain of death a humiliating and false confession is of a piece with Calvin's attitude toward Servetus or Luther's to Carlstadt. ${ }^{3}$

There is nothing in the teachings of the Anabaptists that cannot be shown to at one time or another have had the support of the orthodox reformers. Mysticism mingled with Luther's teaching, legalism and bloody rebellion with that of Calvin and Knox. Zwingli was staggered by infant baptism, and did emasculate to the end the magic sacramentarianism of the Lord's Supper. It was a question of power, order, and submission to the new heirs of Catholic imperialism and not a question of "evangelical purity" or "dogmatic correctness" that separated the reformers from their persecuted and despised brethren.

It is of no use speculating upon the possible effects of another course of conduct. The triumph of Anabaptism would not

\footnotetext{
'Bullinger, "Der Wiedertaüfer Ursprung," IV, pp. I39-140.

${ }^{2}$ In the books cited in the "Bibliography," and in articles in the "Contemporary Review" from the pen of Heath.

${ }^{3}$ Cf. Jackson, S. M.: "Huldreich Zwingli," New York, 1891, pp. 243-265.
} 
have given us "evangelical Protestantism" any more than Puri. tanism did. Puritanism was as near to Anabaptism-with the exception of the detail of adult baptism, which is not of the essence of the movement at all-as it could be. Puritanism was the direct heir to Lollardism in England. Anabaptism was legal, under the authority of the letter of Scripture, and yet so excessively individualistic that agreement as to what Scripture taught was impossible. Save under the tyranny of strong leadership, all united political action was impossible. On that rock Anabaptism split and went to pieces. The favorite doctrine of the Holy Spirit guiding each individual to an infallible interpretation of the letter of the New Testament was not conducive to harmony, nor did it make submission to a common compromise easy.

True it is that the orthodox reformers also professed to take the letter of the Scriptures as their guide and also claimed the guidance of the Holy Spirit. But they neither took it so seriously as the Anabaptists, nor did they permit themselves to be led by Scripture too far away from the interpretations and ideals of the Protestant princes in Germany or the military Bourgoisie in Switzerland. They were, in fact, all unconsciously no doubt, yet completely and always the expression of the sober-minded, well-balanced national, rising middle-class. The Anabaptists represented the unorganized, and often vague and ill-ordered aspirations of discontent both religious and social.

It is vain, therefore, to take up Schwenckfeld, Thomas Münger, Balthasar Hübmaier, Carlstadt, and the others to search for their ethics. They had rude social ideals of a primitive Christian character. They took the New Testament very seriously and very literally, but they made no important contribution to systematic Christian ethics, save that as a persecuted minority some of them learned to believe in a real liberty of conscience as over against the power of the State. Thus Hübmaier demanded liberty of conscience in his well-known tract on the "Heretics and Their Burners." 1 But this was not the attitude 
of all. Indeed, the Anabaptists generally held that the church must be "pure" and that discipline even to the complete bann, shutting the unrepentant completely off from all intercourse, was a Christian duty. It is also claimed that Schwenckfeld was on the side of complete freedom of conscience, ${ }^{1}$ but the evidence is not given, and certainly Schwenckfeld believed in the bann.

Nor does liberty of conscience lie generally along the line of an outward authority, even when interpreted by an infallible spirit, for each one deems his particular spirit the infallible one, and the others are only "lying spirits." Hence the great fanaticism and the endless divisions and absurd and even dangerous positions taken up (bigamy, strange dresses, etc., etc.) by many of the Anabaptists. Nearly all the reformers talked at one time or another about Christian liberty. But that meant the liberty to accept the new evangelical doctrines. And all really approved heartily of persecution, including Zwingli, Bucer, and Luther. They themselves of course suffered most frightfully. No mercy was shown them by either Protestants or Roman antagonists; and, divided and distracted by the countless differences of opinion as to what the Spirit spoke or the Scriptures really taught, the Anabaptist movement lost ground steadily and directly. It failed to capture the Reformation, and it sank back into the humble but not unfruitful, though narrow, sectarian life in which it still survives wherever circumstances favor its survival. The great Baptist movement in England and America can hardly be called its direct outcome, for it is a child of the evangelical revival and has only superficial resemblance to the Anabaptist religious-social struggle.

\section{THE ETHICS OF THE REFORMED CHURCHES}

Luther's instinct that Zwingli was a man of another spirit was undoubtedly right. Whether the difference was so great that co-operation was impossible is another question. The

\footnotetext{
${ }^{1}$ Professor Hartranft, in "Corpus Schwenckfeldianorum," vol. I, p. xxii of introduction (very badly done).
} 
moment we enter upon the examination of the ethics of the reformed churches as distinguished from the Lutheran churches we enter into a quite different atmosphere.

The essential being of Protestantism cannot be sought in any theological formulæ. The later creeds of Protestantism are both too various in character and too unprotestant and scholastic in spirit to be regarded as really expressing the true inward character of the Reformation. Cult was, also, never a bond of unity but rather a cause of division. Neither in England nor on the Continent has Protestantism succeeded as yet in expressing herself in any satisfactory way in a cult. The later movements in Protestantism, Pietism in Germany and evangelicalism in England, sought to define Protestantism in terms of feeling, using that term broadly; but the analysis was incorrect, and so far as success was attained the church simply reverted to types of expression long familiar in the Roman communion.

The reformers themselves hardly clearly realized what separated them so widely from Rome. They were so much engaged in concrete struggles against visible evils that the inner quality of the revolt was hidden in large part from themselves. In point of fact Protestantism was a long step forward toward spiritual and intellectual autonomy. It was a rebellion against external authority in the spiritual realm; and a splendid attempt to relate the spiritual adult as a self-conscious member in the family of God to the great spiritual experiences of the past. The essence of Protestantism is not its elements of immediacy in experience of God (mysticism as generally defined, and the sentimental phases of evangelicalism), but personal access to him and experience of him in all life and all history.

As Protestantism, therefore, has come more and more to selfconsciousness it has become increasingly historical and critical. It has definitely widened its conceptions of God in history. It has slowly come to recognize the need for vast variety of experiences and the legitimacy of great varieties of interpretation of them. 
From this point of view it was a fortunate thing that Protestantism had many roots in the past and that from various directions leaders came to give form to her energies. Humanism had as such no quarrel with the Roman imperialism, although exceedingly critical of her ways. But humanism gave a Protestant leader who was more than a humanist ere he had done his work. Huldreich $\mathrm{Zwingli}{ }^{1}$ though primarily religious, remained

${ }^{1}$ Zwingli, Huldreich or Ulrich, the great reformer of German Switzerland, was born January I, $\mathrm{I}_{4} 84$, in Wildenhaus, in the Toggenburg Valley, about forty miles from Zürich. His parents were well-to-do and their connections good. He was almost raised in Protestantism. His patriotism carried him completely over. He died on the battle-field at Cappel, October I I, I53 I, where Zürich lost the day to Rome's Forest Cantons.

A critical edition of his works is in preparation, but will not be completed for some time to come. ("Huldreich Zwingli's sämtliche Werke unter Mitwirkung des Zwingli-Vereins in Zürich herausgegeben von Emil Egli und Georg Finsler" ["Corpus Reformatorum," vol. LXXXIX, etc.], Leipsic, Heinsius, 1908, seq.; third volume appearing in parts, I9ro.) The best edition (accessible) is that of Melchior Schuler and Johannes Schulthess, 8 vols., in II parts, with a supplement (186I), Zürich, 1829-r842. The best English biography is that of Samuel M. Jackson ("Huldreich Zwingli, the Reformer of German Switzerland, 1484I 53I" ["Heroes of the Reformation" series], New York, I90I); a somewhat smaller handy biography is that by Samuel Simpson ("Life of Ulrich Zwingli, the Swiss Patriot and Reformer," New York, I902). The best in German is that of Rudolph Staehelin, "Huldreich Zwingli, sein Leben und Wirken nach den Quellen dargestellt," Basel, 1895-1897, 2 vols. A good life, though older, is that in the series "Väter der Reformirten Kirche," by Raget Christoffel, "Huldreich Zwingli, Leben und ausgewählte Schriften," Elberfeld, I857, of which the first part, the "Leben," has been translated into English by J. Chochran, "Zwingli; or, the Rise of the Reformation in Switzerland," a life of the reformer, with some notices of his time and contemporaries, Edinburgh, $T$. and T. Clark, 1858 . Other literature is: Baur, August: "Zwingli's Theologie, ihr Werden und ihr System," Halle, I885, 1889, 2 vols. Sigwart, Christoph: "Ulrich Zwingli: der Character seiner Theologie mit besonderer Rücksicht auf Picus von Mirandula dargestellt," Stuttgart und Hamburg, I855. Zeller, Eduard: "Das theologische System Zwingli's in seinen Grundzügen dargestellt," in "Theologische Jahrbücher," edited by F. Chr. Baur and E. Zeller, Tübingen, vol. XII, I853, pp. 94-I44, 245-294, 445-560, and "Über den Ursprung und Character des Zwinglischen Lehrbegriffs, mit Beziehung auf die neueste Darstellung derselben" in "Theologische Jahrbücher," vol. XVI, I 857, pp. I-59. Schweizer, Alexander: "Die Entwickelung des Moralsystems in der Reformirten Kirche," in "Theologische Studien und Kritiken," I850, pp. 5-78, 288-327, 554-580; "Zwingli's Bedeutung neben Luther, Festrede," Zürich, January I, I884. Usteri, Johann Martin: "Initia Zwinglii: Beiträge zur 
under the influence of humanism even after the religious, ethical, and patriotic elements had gained the hegemony in his practical activity. The patriotic character of Zwingli's Protestantism has often been pointed out. But this was characteristic of all the early reformers. Wyclif stood out for England against the papal cosmopolitan imperialism. The appeal of Luther was to Germany against papal exploitation, and Zwingli was aroused by the abuses of conscription and indulgences to give new ethical and religious life to his nation.

Zwingli nowhere works out any systematic ethics, and the writings in which he most systematically unfolds his thought, like "De vera et falsa Religione," 1 reveal a penetrating and splendidly furnished, but not a philosophically organizing mind. His exegetical works reveal the earnestness of his ethical interest, and much ethical insight ${ }^{2}$ but not ethical system.

Zwingli's thought starts from his conception of God. ${ }^{3}$ With him the greatness and the power of God, his righteousness and justice, his creative power, and his constant preserving activity are the leading notes. ${ }^{4}$ It is not just to charge him with leaning toward philosophical pantheism except in so far as all reformed theology, under the distinct influence of Stoicism, exalts God as all in all, and emphasizes rather his power than his goodness. This power shines as well in the election of men to life as in creation. $^{5}$ At the same time Zwingli had a firm grasp of the fact that Jesus Christ had taught love as the final and only possible fulfilment of law. ${ }^{6}$ Following Paul in his argument in Romans, but still in somewhat too scholastic dress, he develops

Geschichte der Studien und der Geistesentwickelung Zwingli's. in der Zeit vor Beginn der reformatorischen Thätigkeit, nach bisher zum Teil unbekannten Quellen," in "Theologische Studien und Kritiken," I885, pp. 607-672, and I886, pp. 95-159. For other literature, see: Jackson's "Life," pp. xxi-xxvi, or Simpson's, pp. 280-29I.

${ }^{1}$ In vol. III, p. I45, opera omnia.

${ }^{2}$ His exegetical works are contained in vols. V, VI, parts I and 2, opera omnia.

3 "De vera et falsa Religione," vol. III, pp. I55-165, opera omnia.

"Cf. "Sermones in Psalmos" (German), vol. IV, particularly pp. 216-2rg.

5 "De vera et falsa Religione," vol. III, p. I78, opera omnia.

6 “De vera et falsa Religione," vol. III, pp. 205 ff, opera omnia. 
the conception of Christian freedom. Law is the eternal will of God, ${ }^{1}$ but this law is deeper than the civil or ceremonial laws that concern themselves with the external man, and which change; in the true sense law never changes. Love alone enables us to keep this law, whose substance is contained in the injunction to love God and one's neighbor. There is in Zwingli, as in reformed theology later, a general confusion introduced by the Stoic conception on the one hand of a "natural law," eternal and unchangeable, and on the other of "a supernatural law," as in the written word.

Zwingli laid great stress on the written word as the sole authority, but even here he is not always clear. In $I_{522}$ he could write: "For who would not joyfully accept what was decided by the concurrent opinion of all Christians," ${ }^{2}$ although he was constantly laying stress upon the inward witness of the Spirit as needful even for the acceptance of Scripture. Nor is he clear in regard to the authority of the Old and the New Testaments. $^{3} \quad$ At times he seems ready to reject the Old Testament, but in fact it often is the real basis of his thinking, and through it there enters into his ethics a certain legalism which still haunts all ethics within Protestantism. The Old Testament is, in point of fact, taken over even in its ceremonial phases. For baptism is the continuation of circumcision, and the Lord's Supper of the Passover. ${ }^{4}$

It is, indeed, a mistaken judgment that Zwingli was the most protestant of the reformers. He had a wider outlook in some respects than the others, due to his early humanistic training and the fact that he never was really Roman Catholic in his

1 "Lex nihil aliud est, quam æterna dei voluntas," vol. III, p. 203, opera omnia (Augustinian).

2 "Letter to Erasmus Fabricius," vol. III, pp. 7-16, opera omnia.

${ }^{3}$ Cf. " De delectu et libero ciborum esu," vol. I, p. 8.

"See for the first the argument in "In catabaptistarum strophas elenchus, "Opera," vol. III, pp. 357-437 (translated from the Latin into English by Henry Preble and George William Gilmore, pp. $123^{-258}$, in "Selected Works of Huldreich $\mathrm{Zwingli,} \mathrm{...} \mathrm{translated} \mathrm{for} \mathrm{the} \mathrm{first} \mathrm{time} \mathrm{from} \mathrm{the} \mathrm{originals} \mathrm{.} \mathrm{.} \mathrm{.} \mathrm{edited}$ by Samuel Macauley Jackson," New York, I90I), and for the second, see "Ein klare underrichtung vom Nachtmal Christi," "Opera," vol, II, p. $45^{8}$. 
deeper religious life. But for Zwingli human nature was as corrupt as for Luther or Calvin, only Zwingli and Calvin emphasized the will of God in such a way as to make the "election" possible for heathen. There was no "natural goodness" for Zwingli. All came by grace, but grace was the free gift of the sovereign secrecy of the divine will. Men were born diseased, although not "sinful" or "guilty" until the disease (morbus) asserted itself in activity. ${ }^{1}$

In Zwingli scholastic Aristotelianism is indeed largely displaced by the great ethical conceptions of Paul, but Augustine is still Paul's interpreter and Stoicism is still influential in his ethics. It is true that sacramental magic disappears more largely from Zwingli's thought than from some other reformed types. This is, however, because he pressed home, as even Calvin did not, the sovereign character of God's elective grace. In reformed theology there is really no room logically for sacramental magic.

Nor was Zwingli any more modern than Luther, Calvin, or Melanchthon in his treatment of opponents. With the Anabaptist radicals he was as cruel and severe as Luther with the peasants, Melanchthon with the "false prophets," or Calvin with Servetus; and for the same reason they seemed to him to discredit and endanger the whole reformatory movement. ${ }^{2}$ Even Luther seemed to Zwingli too violent and bitter. ${ }^{3}$

1 "Sic ergo diximus originalem contagionem morbum esse, non peccatum, quod peccatum cum culpa conjunctum est: culpa vero ex commisso vel admisso ejus nascitur qui facinus desegnavit." " De peccato originali declaratio ad urbanum Rhegium," vol. III, opera omnia, p. 629 (in year 1526).

${ }^{2}$ It is interesting to analyze the charges Zwingli makes against the Anabaptists. They were guilty of (I) going unbelted or girded with ropes to prophesy in the market-places and squares. (2) They boasted that they had all things in common, and threatened with God's anger those who did not. (3) They cried out, "Woe to Zürich." (4) They reviled the ministers of both Church and State. (5) They only went where the Gospel had already been preached and made confusion. (6) They had an unpaid ministry. (7) They proclaimed salvation by obedience to the law. (8) They had wives in common and deserted

${ }^{3}$ C $f$. the tone of the "Amica exegesis . . . ad Martinum Lutherum," vol. III, opera omnia, pp, 459 ff, especially pp. 462 and 561 . 
Zwingli was national in his thought and feeling. This colors his ethics and his theology. His ambition was an elected holy nation for the establishment of God's purpose. Plato's "Republic " exercised here undoubted influence, ${ }^{1}$ for the visible church is for Zwingli a mixed assembly. Only the invisible church is inerrant and holy. ${ }^{2}$

This visible church, therefore, is in parts, and is set apart in God's council for the manifestation of his will. If, therefore, the cantons were to rise to their opportunity they must exhibit their election by their works. Thus Zwingli's preaching took on a national ethical character. He attacked the sale of Swiss soldiers and the exploitation of the cantons by Rome. The cantons become practically for Zwingli the visible church, because State and Church (visible) cannot be separated. Nor does Zwingli think highly of any higher unity among the churches. He prefers a unity of spirit binding together national churches, ${ }^{3}$ and any outward unity has for him but little meaning. At this point Zwingli marks distinctly the national character of the whole Reformation movement.

His fierce attacks upon the Anabaptists were again largely national and political. The maintenance of civil authority was one of the functions of the visible church, and the purity of the visible church was one of the direct responsibilities of the civil government." Like a good many religious leaders, he had little objection to centralized authority in religion as long as he was their children. (9) That they were lazy and had only other people's goods in common. (IO) They forbade oaths and appeals to the magistrates. (II) They rejected the whole Old Testament. (I 2) Preached excommunication for all who fell into sin. (13) That men should not carry arms and weapons. (14) That excommunication should be the limit of churchly punishment. (15) That Christians had no citizenship here.

${ }^{1}$ Sigwart seems to overestimate the influence upon $\mathrm{Zwingli}$ of Picus von Mirandula and to ignore too much the direct influence of Plato. Cf. Sigwart, "Ulrich Zwingli," I 855.

2 Zwingli's doctrine of the church he sets forth clearly and at large in the "Antibolum," "Adversus Emserum," vol, III, opera omnia, pp. 125-135.

${ }^{3}$ Cf. Epist. CLIII, vol. VIII, p. 549, opera omnia.

"Cf. "Ein Kurze christenliche ynleitung," etc., vol. I, pp. 549-582, opera omnia. 
the authority. For, although Zwingli stoutly protested against interfering with the freedom of the congregation, in point of fact, the Swiss autocracy, which was supreme, was at Zwingli's own advice exceedingly tyrannical. ${ }^{1} \quad$ Zwingli, like Luther and Calvin, accepted the situation created by Constantine as the permanent relation between Church and State, and he and they were quite blind to the interminable confusion this ecclesiastical Byzantianism wrought and still produces.

On the other hand, Zwingli was an admirable leader. Warm, loving, and fearless, he appealed to many hearts to whom even Luther might not have found access. And although his work was to some extent swallowed up in the Calvinistic movement of a later day, it is an honorable fact in Swiss history that Zwingli was an outspoken and fearless Protestant quite as early as Luther. He maintained his peace with the Vatican longer than Luther could do, because at Rome he was not only feared, but he was confused with the humanists, ${ }^{2}$ with whom Rome ever felt itself in a certain sympathy, if only as a counterbalance in Rome's complicated policy to the monks and orders who gave the curia great trouble.

The outcome of the reformed position in ethics can, however, be better studied in Bucer and Calvin.

Butzer or Bucer ${ }^{3}$ was a remarkable figure as counsel for and helper of the early churches. He came first under the influence

${ }^{1}$ Cf. "Ratschlag von den Bildern und der Mess," vol. I, pp. $583 f f$., opera omnia.

${ }^{2} C f$. vol. I. p. 354 , and vol. VII, p. 178 ff.

${ }^{3}$ Butzer, Martin, born I49I, in Schlettstadt, Alsace, and died in Cambridge in 1551. He spent most of his life in Strasburg, and is connected in his way of thinking with the Swiss Reformation. In Baum's book, "Capito und Butzer, Strassburgs Reformatoren. Nach ihrem handschriftlichen Briefschatze, ihren gedruckten Schriften und anderen gleichzeitigen Quellen dargestellt" (Johann Wilhelm Baum), Elberfeld, r860 ("Väter der reformirten Kirche," vol. III), is a catalogue of Butzer's printed works (pp. 586-6ir). There is good reason for accepting him as the author of the wonderfully popular book, "Ain schener Dialog un gesprech zwischen aim Pfarrer vnd aim Schulthayss betreffend allen übel Stand der gaystlichen. Vnd dess handlüg der weltlichen," which went rapidly through thirteen editions; cf. "Archiv für Reformationsgeschichte," Nr. I3, IV, Jahrgang, Heft I (Igo6), Alfred Götze's article, pp. I-64. 
of Luther ( $\left.\mathrm{I}_{5} \mathrm{I} 8\right)$ and then under the influence of the Swiss reformers, and sought without much success to mediate between the two types of thinking. His ethics have only significance in that he sought to establish theoretically the right relation between Church and State. Undoubtedly his work at this point greatly influenced the English Reformation. His work, "De Regno Christi Jesu," in two books, addressed to the English king in 1557 , struggles with the question of the two swords. The two things, he finds, that are among all men are a divine cult and a civil government. ${ }^{1}$ He seeks then, somewhat vainly, to distribute the power and the responsibility. The attempt was worth making, but is not very successful. There is a constant dualism maintained between "The Kingdom of Christ" and "The Kingdom of the World"; both are from God, but as in all reformed thinking, in the last analysis the church is really supreme. $^{2}$ There is also the same terrible failure to grasp the real significance of the Old Testament. On the basis of excessive literalism and traditional interpretation there arose an ethics which was of the law rather than of the Gospel.

On the transformation of the bread and wine Bucer held rather with the Swiss, but he had very high notions about the significance of the partaking. His position is the high-church position of Calvin. And with Calvin he shares an almost slavish conception of the authority of Scripture. Like the English reformers, he was really more interested in the political than the dogmatic or ethical side of the Reformation. He was clearsighted enough to see into what failures and disasters a divided Protestantism must enter. He was not clear-sighted enough to recognize the fact that only on the foundation of a broad, comprehensive organization could the Reformation rest. He was as hard and bitter against the poor Anabaptists as any of the leaders, although he was willing to take Zwingli, Calvin, and Luther under one roof.

1 "Cultus divinus et civilis gubernatio," preface to the treatise, "De Regno Christi Jesu."

${ }^{2}$ Cf. p. 12 with its scene between Ambrose and Theodosius. 
The type of his thinking is allied to the Swiss reformers, because he uses the Bible in the same way, and with a mechanical literalism which at times makes it a very misleading book.

\section{THE ETHICS OF JOHN CALVIN}

The ethics of reformed theology received an almost classic formulation at the hands of Calvin. ${ }^{1}$ There is a certain lofty simplicity about the ethics that has made them exceedingly influential, although the ethics are generally lost sight of in the dogmatics.

On the ethical side Calvin introduced the reformed churches again to scholasticism with its closed system given on authority, and its rationalizing methods. He, like the scholastics, regarded the explication of the closed system of truth as of primary importance.

His ethics are contained in the "Institutions" 2 as well as in his commentaries upon the Ten Commandments and numerous tracts and sermons. The outline is clear and convincing.

${ }^{1}$ The literature is scant and unsatisfactory. The classic histories, i. e., C. F. Stäudlin, W. M. L. de Wette, W. Gass, C. E. Luthardt, Th. Ziegler, either make no contribution or confuse the subject by failing to grasp Calvin's central thought. There remain only: Lobstein, Paul: "Die Ethik Calvin's in ihren Grundzügen entworfen," Strasburg, 1877. Schweizer, Alexander: "Die Entwickelung des Moralsystems in der Reformirten Kirche," in "Theologische Studien und Kritiken," XXIII (I850), pp. 5-78, 288-327, 554-580. Kuyper, Abraham: "Calvinism: Six lectures (on the Stone Foundation) delivered (1898-1899) in the Theological Seminary at Princeton," 1899. A singularly worthless book of indiscriminate misjudgments. The Calvin celebration is bringing a great and welcome addition to the literature of Calvin, but so far his ethics seem neglected. Cf. the author's article in the "Hibbard Journal" for October, 1908, of which, by permission, large use has been made. Kampschulte, F. Wilhelm: "Calvin, seine Kirche und sein Staat in Genf.," Leipsic, I869, I899 (last vol. posthumous). Choicy, Eugène: "La théocratie à Genève au temps de Calvin," Geneva, 1897. Troeltsch, Ernst: "Der Calvinismus," in "Die Kultur der Gegenwart," teil I, abteilung IV, "Die christliche Religion," pp. 333-36I, Berlin and Leipsic, I906. Doumergue, E.: "Le Protestantisme au Moyen Age," Montauban, I889. Doumergue, E.: “Jean Calvin, les hommes et les choses de son temps," Lausanne, 1899, sq. (3 vols. appeared up to I905).

2 "Institutio Christianæ Religionis," books III and IV. 
It is throughout a theological ethics. The whole scheme is worked out on the basis of man's relation to an omnipotent and holy God. Man is utterly sinful and hostile to God, and practically, for Calvin, can sustain no ethical relation to him at all. Man is cut off from God as completely as a country at war with another is cut off from it. Ethics can therefore only be spoken of after regeneration. "The object of regeneration is to bring the life of believers into harmony with God." 1 Thus we are restored to the image of God and are made "ethically free." Only after regeneration do the Scriptures really fulfil their function of instilling and "implanting in our minds" the amor justitice "or love of righteousness" which we lost at the fall. Thus there must be restored to us the active ethical principle, and in the written word, but particularly the Ten Commandments, we have a norm ${ }^{2}$ which will prevent us going astray if we use it properly.

But the Scriptures are not the basis of the ethical life which is thus founded upon authority. That basis is the Scriptural church. For the Roman imperialism Calvin simply substitutes a Scriptural imperialism. The Biblical church is the ultimate and final authority over the really regenerate man. Hence the theory of the church is very important in Calvinism, and Calvin devotes a great deal of space to it. ${ }^{3}$ In the church God has sought to secure the effectual preaching of the Gospel by depositing this treasure with the church." Calvin's ethics are therefore based upon a church of divine right. ${ }^{5}$ God has appointed her teachers and given her the sacraments. God is Father and the church is mother. ${ }^{\circ}$ Beyond her pale there is not only ordinarily no salvation, but no really ethical life, for the forgiveness of sins is a "benefit so peculiar to the church that we cannot enjoy it unless we continue in the communion of the

1 "Scopus regenerationis," "Ins.," III, 6 : I.

2 "Norma præscripta," "Ins.," III, $6: 2$.

3 "Ins.," book IV, I, 2, 4, 8, 9, II-I4, and many passages in "Sermons," etc.

4 "Thesaurum hunc apud ecclesiam deposuit," "Ins.," IV, I : I.

s "De jure divino."

- "Ut, quibus ipse est pater, ecclesia etiam mater sit," "Ins.," IV, I : I. 
church." 1 To this church are committed the "keys," and the ministers of a true church are constantly not only shutting out the unrepentant, but continually opening the doors by "the preaching of the Gospel or the administration of the sacraments." 2

The Christian is bound by the creed (!) to believe "the church," for the word "in" is an interpolation, ${ }^{3}$ and in the bosom of this church we must abide at the peril of eternal death. It is this visible sacramental church that is our mother, "since there is no other means of entering into life unless she nourish us at her breast, and unless we remain under her care and pilotship until stripped of our flesh we become as angels. For our weakness does not allow us to leave school until as scholars we have done with life. Moreover, outside her bounds there is no hope of the forgiveness of sin nor any other salvation." 4

No really Protestant, $i$. e., autonomous ethics can flourish on this basis. The church officers controlling the sacraments and the preaching of the Gospel become the directors of men's consciences. "As anciently he did not confine himself merely to the law, but added priests as interpreters, . . . so in the present day he would have us not only be attentive to this reading but has appointed masters to give us aid. In this there is a double advantage, for on the one hand he by an admirable test proves our obedience when we listen to his ministers just as to him," etc., etc. ${ }^{5}$

This is exactly the substructure of the Roman Catholic ethics of authority. For having convinced ourselves that we are dealing with a true Biblical church, we are then to listen to its "priests" or ministers exactly as to God himself. This is a test of our obedience, and these "ministers" have the power of the keys to open and close to us the doors of forgiveness. This is simply Roman Catholicism without the name Roman.

\footnotetext{
1 "Ins.," IV, I : $22 . \quad 2$ "Ins.," IV, I : 22. 3 "Ins.," IV, I : 2.

1 "Adde quod extra ejus gremium nulla est speranda peccatorum remissio, nec alia salus," "Ins.," book IV, $1: 4$.

5 "Ins.," IV, $x: 5$.
} 
The interest of all high-church Calvinism in the sacraments is in obtaining a guarantee of a true and therefore authoritative church. Thus Calvin in ${ }^{1544}$, in an address to the Imperial Diet, sums up Christianity in practically four things: a knowledge of the way in which God must be duly worshipped; the knowledge of the source from which salvation is to be obtained; the right method of administering the grace-imparting sacraments; and the maintenance of a duly authorized ministry. To this ministry is committed the care and preservation of this sacred knowledge and the administration of the grace-imparting sacraments.

This church, therefore, of Calvin's thought is no longer the family circle gathered about Jesus the elder Brother in the presence of the Father. It is no democracy of believers banded together for the establishment of the kingdom, but a divine sacramental organization for the avowed purpose of ruling men's thoughts and conduct.

As ethics, therefore, is taught on the basis of the Ten Commandments by an authoritative church, it is all-important to know what is the true church. The notes as given by Calvin are quite clear. It is the whole body of mankind scattered over the world, who (I) profess to worship one God and Christ, (2) who by baptism are initiated into the faith, (3) who by partaking of the common table profess unity in doctrine and love, (4) who have agreement in the word of the Lord, and (5) lastly, who conserve the ministry for the preaching of this word. In this church there are hypocrites whom our ignorance of the heart must tolerate; but as we must believe the invisible church, so we must seek the communion of this visible one. ${ }^{1}$ In lieu of full certainty as to the election we must accept as true members of the church all who (I) confess the faith, (2) are regular in conduct, (3) who participate in the sacraments, and (4) unite in acknowledging with us the same God and Christ. ${ }^{2}$ Hence the form of the church is wherever we see the word of God sincerely preached and the sacraments duly administered. ${ }^{3}$ Where this
${ }^{1} \mathrm{IV}, \mathrm{I}: 7$.
${ }^{2}$ IV, I : 8 .
' IV, I : 9 . 
is the case, no one should separate himself from the church or question her authority. To impair her authority is to impugn the authority of God himself. No crime is more atrocious or sacrilegious than to break this bond. ${ }^{1}$ We must even put up with minute errors of doctrine, for "we must either have no church at all, or we must condone hallucinations in such things as one may be ignorant of without injury to the substance of faith. ${ }^{2}$ In conduct our tolerance must be even larger, for doctrine is even more important. ${ }^{3}$ In this church we have constant forgiveness of sin, and to impart this blessing Christ gave the keys of the church; $;^{4}$ these are committed to the presbyters and bishops, who dispense forgiveness to us in the preaching and the sacraments. ${ }^{5}$ This ministry has power as it is vested in the church in spiritual matters, and consists in doctrine, in jurisdiction, and making laws. The place of doctrine has two parts"the handing down of authoritative $\operatorname{dogma}{ }^{6}$ and the expounding of these dogmas.

The hard mechanical way in which men may come to the knowledge of ethical truth is, however, not confined to the layman. "Whatever authority or dignity the Holy Spirit confers in the Scriptures upon priests, prophets, apostles, or their successors, is given to them not as men, but to them as (members of) the ministry to which they are appointed, or, to put it more clearly, to the word, to whose ministry they are appointed. . . . For whenever they are called to office they are enjoined not to bring anything of their own, but to speak by the mouth of the Lord." 7 There can therefore be no "progressive revelation," nor any autonomous ethics nor any interpretation of personal experience. The "word" is a law. "Surely God here proclaims a law to all, and it is a law which does not permit any one to teach more than he has been ordered. ${ }^{8}$

\footnotetext{
IV, I : Io.

2 IV. I : I 2.

3 IV, I : I3.

IIV, I : 22.

s IV, I : 22.

" "Authoritatem dogmatum tradendorum et eorum applicationem," "Ins.," IV, $8: 8$.

7 "Ins.," IV, $8: 2$.

8 "Ins.," IV, $8: 3$.
} 
Even the relative freedom of Old Testament times is gone. The old prophets had new and important ethical revelations made to them, but now no new light can be expected, for, "contented with the perfection of Christ's doctrine, we may learn to frame no new doctrine for ourselves or admit any one devised by others." 1 Hence the Gospel is but a new and more final and more exacting law. The Messias has so spoken "as to leave nothing to be spoken by any others coming after him." 2

The law governs not only the church but also the State. Calvin reintroduces the lofty dream of Gregory the Great of a theocracy, with the two swords, and the magistrates as having "a commission from God and invested with a divine authority, and in fact representing the person of God, as whose viceregents they, as it were, act." 3 The form of government is relatively immaterial if all are equally obedient to the divine word as taught by the church. But, as one might suspect, Calvin leans to centralization and power. In the French of the "Institutes," he says: "One may reckon with three types of civil government: There is monarchy, which is the domination of one alone, whether he bear the name of king or duke or other title; aristocracy, which is the domination by princes and families of note who govern; and there is democracy, which is the domination of the people, in which each of the people has power."

These all have dangers, and Calvin inclines to aristocracy. "I, for my part, do not deny that the form surpassing all others is aristocracy, either pure or tempered by popular government." 5

1 "Ins.," IV, $8: 7$. 2 "Ins.," IV, $8: 7$.

3 "Ac omnino Dei personam sustinere cujus vices quodammodo agunt," "Ins.," IV, $20: 4$.

4 "On conte trois espèces de régime civil; c'est assavoir Monarchie, qui est la domination d'un seul, soit qu'on le nomme Roy ou Duc, ou autrement; Aristocratie, qui est une domination gouvernée par les principaux et gens d-apparence; et Démocratie, qui est une domination populaire, en laquelle chacun du peuple a puissance," "Ins," IV, $20: 8$.

3 "Nam si illi visum est, reges regnis præficere, liberis civitatibus senatores aut decuriones, quoscumque locis prefecerit in quibus degimus nostrum est is nos morigeros ac obedientes præstare" (IV, $20: 8)$. 
But the Lord has assigned the forms of government, and the wish to change the form is not only superfluous but pernicious. In whatever form he has appointed, our duty is to submit and obey. The church may not put to death, but the magistrate acts as God and puts to death. "It is not the part of the pious to afflict or hurt, but to avenge the injuries done to the pious is not to afflict or hurt. All is done in obedience to God." 1 We ought indeed to obey God rather than men, but in obeying our rulers we are obeying God and not man. ${ }^{2}$

Holiness plays a large part in Calvin's thought, just as it does in that of Thomas Aquinas and Ignatius Loyola, whose ethical systems are most nearly akin to that of Calvin. Holiness becomes a bond between us and God, "because it is greatly pertinent to his glory" that he should not be associated with iniquity and foulness. ${ }^{3}$ To arouse us to this new purity the Scriptures exhibit God the Father, who has reconciled us to himself in Christ, that in him we may have the image to which he would have us conformed. "Since Christ has purified us with his blood, and communicated this purification through baptism, it is not fitting that we should soil ourselves with new wrong-doing." We are engrafted into his body and should not stain it; we are temples of God and should not defile them; we are destined to immortality and should not live the corruptible life. ${ }^{4}$ Doctrine is not of the tongue but of the life. ${ }^{5}$ It must possess the whole soul and the innermost heart. To doctrine, in which our religion is contained, the first place must be given; but it must pass into conduct, and so transform us. ${ }^{\circ}$

Calvin does not insist upon perfection in this life, but on the life being directed toward perfection, and upon progress being daily made. ${ }^{7}$ The law of God contains the most perfect method of life, but the celestial Magistrate has been pleased to adopt a more accurate way of training us to this rule, which is by making us present our bodies a living sacrifice; hence we

\footnotetext{
'IV, $20:$ 10. 2 IV, $20: 32$ 3 "Ins.," III, $6: 2 . \quad$ "III. $6: 3$.

3 "Non enim linguæ est doctrina, sed vitæ," III, $6: 4$.

6 "Atque in mores transeat oportet," "Ins.," III, $6: 4$.

${ }^{7}$ III, $6: 5$.
} 
should not think, speak, design, or act without a view to his glory. Philosophy gave the first place to reason, but Christian philosophy bids her (reason) give place and yield complete submission to the Holy Spirit. ${ }^{1}$ We seek only God's will and act for his glory. Hence Scripture enjoins us to lay aside all excessive longing for wealth or power or human favor. We are to follow good for its own sake and not for the love of praise. Even the philosophers who most taught this were swallowed up by arrogance. ${ }^{2}$ We deny ourselves and renounce reason.

Thus the two obstacles to virtue are taken away in usungodliness (impietas) and worldly lust (mundance cupiditates)and our lives are reduced to sobriety, denoting chastity and temperance as the pure and frugal use of temporal goods and the patient endurance of want; righteousness (justitia), comprehending all the duties of equity in rendering to every one his due; and godliness (pietas), which connects us with God in true holiness. To aspire to these things Paul sets before us immortality, "because as once Christ appeared as our Redeemer, so on his final advent he will give full effect to the salvation he has obtained for us." 3

Our abnegation has a twofold aspect-first to fellow-men, and secondly and chiefly toward God. Only divine grace can pluck out the pest of contentiousness and self-love. ${ }^{4}$ We are only the stewards of any endowments God has given us, and we are to see, even in the most unworthy, the image of God, and show it honor and love, especially to those in whom that image has been restored in Christ. Is any one mean or unworthy, or has any one done us injury, we are to love in him the image of God. ${ }^{5}$ No arrogance should mark our service, for we are only paying a debt due from us. ${ }^{6}$ Toward God we must assume an attitude of absolute dependence upon his blessing, and endure all things as from him with tranquillity and thankfulness. ${ }^{7}$
III, $7:$ I.
2 III, $7: 2$.
III, $7: 3$

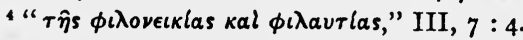
III, $7: 6$.
' III, $7: 7$.
7II, 7 : 10. 
The pious mind must aspire. We must take up the cross. "Those whom God has chosen and has honored by his fellowship (consortio)" must prepare for a hard, laborious, troubled life, ... it being the will of the Father to exercise them by making them endure the test. It was thus he began with his first-born, Christ, and thus he continues with all his children. It should, therefore, sweeten the cross to think that we share it with Christ, and that our sufferings are not only blessed to us, but bring many aids to the much furtherance of our salvation. ${ }^{1}$

The only reason Jesus had to bear the cross was to demonstrate his obedience to his Father. There are many reasons why we should bear it constantly. It teaches us humility and patience and obedience. So the cross reveals the virtues God himself bestows. ${ }^{2}$ Thus also it separates between sons and bastards. The sons are not condemned with the world, the bastards are hardened by the punishment. ${ }^{3}$ And to suffer for righteousness' sake is to increase our real joy; if driven from our homes, we have a higher place in the kingdom of God. ${ }^{4}$ The endurance is not, however, insensibility to pain or mere Stoic endurance, but the believer acquiesces in the spiritual consolation of God. ${ }^{5}$ So the difference between philosophy and Christianity is the attitude toward the will of God. Philosophy says: "Yield because you must." The believer says: "We yield because God's will is right." •

The end, therefore, is to reach a contempt for the present life, and to exercise ourselves in contemplation of the future, for there is no medium between the two: the world must either seem vile to us, or it will detain us as slaves by intemperate love

1 "Sed ad promovendam quoque nostram salutem multum afferunt adjuvamenti," III, $8:$ I.

${ }^{2}$ III, $8: 2-5$.

${ }^{3}$ III, $8: 8$.

4III, $8: 7$.

3 "In spirituali Dei consolatione acquiescit," III, $8: 8$.

- "Iam vero quia illud demum amabile nobis est, quod saluti ac bono esse nobis agnoscimus, hac etiam parte consolatur nos optimus pater, dum asserit, se eo ipso quod nos cruce affligit, saluti nostræ consulere" (III, 8: I I). "Which leads us to the thought, if afflictions are salutary, why should we not bear them in patience, for thus we are resting satisfied with our own good?" 
of it. It is, therefore, of the highest importance that we be convinced by experience of the miserable character of this life. ${ }^{1}$ At the same time we must not be led into ingratitude to God. The world, ever abounding in all kinds of wretchedness, is yet justly classed among the divine blessings which are not to be despised, and it contains foretastes of the heavenly felicity. ${ }^{2}$ Yet we are to ardently long for death and constantly meditate upon it. ${ }^{3}$ We are to use the world without abusing it, and fixed laws are out of place in so doing. The Scriptures lay down general rules, and we should keep within these limits. ${ }^{4}$ The natural quality of things indicates to us their use, but they must never hinder our progress to eternal life. ${ }^{5}$ Therefore, while the liberty of the Christian is not to be bound to external things, he is bound by the law-he must indulge as little as possible. ${ }^{6} \mathrm{He}$ must be patient and content, and treat all things as a trust confided to him. And every man's mode of life is a station assigned to him, and all is to be subject to the will of God.

Such in brief are the foundations upon which Calvin raises his ethics. Many phrases, like "liberty of conscience," "responsibility of the soul to God," are used, as countless passages demonstrate, exactly as any Roman Catholic schoolman would use them. The essential difference between Calvin and Trent consists not in the definition of the church, but in the historic answer to the question, Is the Roman church the true church? For Calvin the church was a sacramental organization with an authoritative ministry of the word, watching over the State in spiritual things, while the State did its behests in material things. The State only had authority in the word of God, and the church had the word of God as its priceless possession.

The glory of Protestant ethics as founded by Luther and developed by Kant is the autonomous, democratic, unpriestly character stamped upon it. All men should be kings and priests to God. The ministry according to Luther was purely functional. He did not carry out the logic of his assumption at all
${ }^{1}$ III, $9: 2$.
2 III, $9: 3$.
IIII, $9: 4$.
'III, IO : I.
III, I0: $2-3$.
'III, IO : 4 . 
times, yet in the main he was true to them. In the last analysis for Luther the soul must stand alone for truth and trust that it will not be forsaken. In the last analysis for Calvin the soul finds out which church has the sacrament and the word and submits wholly to it. The difference is world-wide. For true ethical development there is no more room in logical Calvinism than in logical Romanism. Ethics has been swallowed up in dogmatics and systematic theology. This is no accident. That is exactly where Calvin put ethics-inside dogmatics.

Reformed systems of ethics have, as a matter of fact, sprung up almost in defiance of theology. The vital principle of a real Protestant ethics is the logical and thorough-going acceptance of the relative character of all casuistical judgment. As the moral character of any judgment depends upon the motive, and only God can know the motive, we can only apply the objective test, and ask in utilitarian terms for the ultimate effect of any action; but for the agent the moral attitude and not the outcome is the determining element. For Roman Catholic scholasticism and for Calvin there is an absolute norm by which all actions can be truly and thoroughly tested, and Church and State must apply the tests. Even opinions and doctrines held by the individual are thus subject to an infallible review. It was therefore no hasty or ill-considered action for Calvin to hand Servetus over to the State for proper punishment. Calvin would have been false to his fundamental convictions had he acted otherwise. Rome was only wrong in shedding the blood of the martyrs because Rome was not a true church. Given a true church and her duty was to insist that the State protect pure doctrine. Calvin's ethics is thus based on an outward authority.

Over Calvin's ethics are flung the shadows of the twofold view of life that did so much damage to Christian thinking. For Jesus all life was under God's hand-the sparrow did not fall without his consent, and the hairs of our head are all numbered. For Luther at his best there is always the glorious assurance that life is good. That all life, all days, all places 
are sacred, if only we use them in the joyful service of God. So that the housemaid sweeping out a room was engaged, says Luther, in as sacred a task as the priest at the altar. For Calvin the world was primarily evil-human nature was in itself corrupt. The world must seem vile to us and we are to ardently long for death. ${ }^{1}$ All the mediæval morbidness that has so often corrupted Scotch piety has its legitimate roots in the essentially Roman Catholic scholasticism of Calvin. His conception is in essence dualistic, and the world is per se evil. Of course, Protestantism has largely overcome this taint of Manichæism, which historically Calvin got, in the writer's judgment, not from Paul, but from Augustine. At the same time the phrases in which the oriental intrusion historically asserted itself have never been banished from the Reformed creeds.

The most serious blunder of all was Calvin's acceptance of the Roman Catholic theory of the two swords. To mistake Calvin's theory of the State for democracy, and that in spite of his own statement, is so wildly far from the truth that we may assert on the contrary that all the services Calvinism has rendered democracy have been by indirection. Presbyterianism has, on the whole, been most true to Calvin's conception and has never been truly democratic. It is essentially aristocratic in organization and feeling. To a selected ministry (minister, elders, and deacons) are handed over all the spiritual interests of the church. To this ministry the congregations owe not cooperation, but obedience. That the tide of Protestant feeling in the Presbyterian church has happily been too strong for Calvinism and its logic should not blind us to the real state of the facts.

Calvin's ethics partake also of the legal character common to all the scholastic systems. He founds his ethics on an exposition of the law of the Old Testament. Luther plainly saw that ethics was an inner compulsion, and that the Christian man was free from all merely external law just so far as he was Christian. So in his dealing with the Ten Commandments in his catechisms

$$
{ }^{1} \text { IV, } 9: 4 \text {. }
$$


there is a world-wide difference between his method and that of Calvin. For Luther the law of Christian freedom delights to expand in the atmosphere of loving submission. For Calvin the Christian life is bounded by an almost pharisaic attempt to determine the exact letter of written law. His comments on Romans are often painful reading for any really clear-thinking Protestant. Submission to legal requirement would be Calvin's interpretation of the Protestant Magna Charta in Gal. $4: 3^{\mathrm{I}-}$ 5 : I2. For this submission is in true Roman Catholic spirit made an act of faith. For the Christian man rejoices in the legal enactment, but, crushed and humbled by his inability to meet the requirement, flees in his weakness to the mother church and the sacraments, as sealing ordinances for his assurance of forgiveness. In Calvin the sacraments are essential to the Christian ethical life. Baptism is the mortification of our corrupt nature, and without it there is ordinarily no ethical life possible. He simply puts it in the place of circumcision. One has only to read the Institutio, IV, I6, to see that to-day we as Protestants really hold with the Anabaptists at nearly all points as against Calvin, except in circles on the side of Roman Catholic scholasticism (high-church Presbyterianism, Lutheranism, and Anglicanism). In spite of Luther's most unfortunate realism in his interpretation of Hoc est meum corpus, he remains substantially unaffected in his ethics (though not wholly) by the element of sacramental magic. For Calvin the imparted grace of the sacrament is an ethical element of first importance. The superstitious regard of the older Scottish thought for the Lord's table is the direct outcome of what is an essential element in Calvin's teaching. For Calvin there was sacramental magic, and although it was by no muttered incantation that the elements became the bearers of special grace, yet by the clear spoken word they do. ${ }^{1}$

The Protestantism of to-day can hardly understand how large a part this sacramental element played in the Calvinistic system. Under the influence of a Protestant thought that has 
developed independently of the theological and ecclesiastical intrusions, the average Protestant has an æsthetic and ritual interest in the sacraments, but almost no ethical or metaphysical interest whatsoever. Very different was the case with Calvin. As every one may see in his fierce attacks upon Anabaptists, he clearly saw that his system was profoundly interested in the metaphysics and ethics involved.

The whole conception of the Christian life, as Calvin draws it, is Roman Catholic rather than Protestant. The essential feature of Luther's message was that in Christ we were free to live more and more unto righteousness, and that that freedom was joy and peace and a sense of security and sonship, and that all might have it who claimed it. Thus, again, Luther's unfortunate incursion into the realm of metaphysical speculation on the freedom of the will had a genuine ethical interest, and can be resolved into a relatively harmless though unfortunate psychological determinism. This is not the case with Calvin's doctrine of decree. It is part of the warp and woof of a system of thought whose dominant note is God as law-giver and not as redeeming Father. Hence no more for Calvin than for the Roman Catholic can there be logically, in spite of the doctrine of perseverance, any assurance of faith. The secret decree of God by which corruption is changed to incorruption can only be known in the final glory. Fear and trembling is the note of the Christian life and not joy and peace. Over Luther's faith flits the clouds of mediæval morbidness, as the scurrying clouds that follow on a storm well past. With Calvin we descend again into the twilight darkness of valleys the glad sunshine scarcely touches. The relatively gloomy, despondent type of piety which is connected with Calvin's memory is part of his fundamental thinking. It is the outcome of his essential conception of the Christian life.

Hence on ethical grounds we may say that Calvin was one of the last, though not one of the greatest, of the schoolmen. The ethical services of Calvinism have been indirect and in spite of his scholasticism. In breaking with the Roman sacra- 
mental system, Calvin happily failed in his attempt to establish an effective rival Protestant sacramental system; and in Calvin's tremendous and crushing attacks on the Roman hierarchy he made the establishment of a Protestant rival hierarchy impossible. We are still cursed by the attempts-made in the great name of Calvin - to establish again a Protestant priestly sacramentalist organization, with the power of the keys, interpreting again an infallible legal code.

The great service Calvin rendered the Reformation was the organizing of a movement strong enough to stand up against the Roman hierarchy, and yet utterly separated from it by the rejection of celibacy, five of the seven sacraments, the authority of the Pope, the whole monastic system, penance, purgatory, auricular confession, the mass, the sacred Latin tongue, bishops in the technical sense, and the magic of the real presence. $\mathrm{He}$ gave men a central conception of great power, as one sees in the history of Mahomet, where the same conceptions organized the religious thought and overthrew corrupted Christianity. The Puritan state became the fighting force of the Reformation. Perhaps the very fact that legal discipline and hard, unyielding authority took the place of leadership gave it its power and its success, but also led to its ultimate failure and defeat.

The crystalline clearness with which the trained political lawyer set forth his views leaves no excuse for the wide-spread misunderstanding of Calvin. The tremendous force of his argument must be felt by any one who goes carefully through his "Institutes," with his letters as a commentary. He organized the Reformation, gave it a fighting theology and a political creed. The Puritan state arose. It was another aristocratic, highly organized theocracy, and its great services should never be forgotten, when as more thorough-going Protestants we recognize its weaknesses and see that it took over the great conceptions of Calvin and treated them as final and ultimate, whereas they are in fact foreign to the spirit of Protestantism. 


\section{THE ETHICS OF THE CREEDS OF THE CONTINENTAL REFORMATION}

There is but little in any of the creeds that can be said to advance systematic ethics. Increasingly as time went on the creeds occupied themselves with dogmatic discussion and scholastic refinements. Even the discussion of justification by faith, whose immediate interest was ethical, lost itself, for instance, in the Formula of Concord, in unreal and scholastic abstractions. To an increasing degree the doctrines of sin, total depravity, free-will ceased to be matters of genuine personal experience, or rather the hypothetical explanation of such experience, and they became items in a system given on external authority. The Augsburg Confession falls back upon "God's will" as the reason of good works. The sacraments are exalted, and although the definition of the sacramental elements varied in the Lutheran and Reformed churches, the high-church doctrine prevailed in all of them. The Augsburg Confession regards baptism as necessary to salvation, ${ }^{1}$ and the Helvetic Confession and the Heidelberg Catechism both take high ground about salvation being only possible in the church, and baptism is a requisite for church membership. ${ }^{2}$ The reformed churches, indeed, rejected the thought of any change in the bread and wine, but though symbols, they are grace-imparting symbols. Thus a real sacramental magic found its way back into Protestantism. The ethical import of this is by no means small. It was one of the important factors in the hardening and legalizing process that began so soon.

The thought of the kingdom of God on earth previously to the general resurrection is categorically denied by the Augsburg Confession, ${ }^{3}$ and the dangerous but convenient distinction between "civil" and "spiritual" righteousness is asserted. The

1 "De Baptismo docent, quod sit necessarius ad salutem, quod que per Baptismum offeratur gratia Dei," art. IX.

2 "Second Helvetic Conf.," cap. XX; 3-5. Cf., also, "Damnamus Anabaptistas, qui negant baptizandos esse infantulos recens natos a fidelibus," etc., etc.

3 "We condemn others also, who now scatter Jewish opinions, that before the resurrection of the dead the godly shall occupy the kingdom of the world," art. XVII. 
writers of the confession claimed that they taught nothing hostile to "Scripture or the church, or the Roman church, so far as it was informed from the Scriptures." 1

At one point the Lutheran symbols are all plain and definite. The service of God is along the line of the ordinary avocation. Whatever a man does, in that he is to serve God, and true perfection is in attending to our calling and not in "beggary and vile apparel." 2 And even the Lord's day is a matter of Christian liberty, "that men might know that the observation neither of the Sabbath, nor of any other day, was of necessity." 3

The Formula of Concord is so swallowed up in dogmatics and speculative theology that the ethics is formal, conventional, and a simple iteration of positions common to all the churches.

Neither in the Lutheran nor the Reformed symbols is there any real development of a Protestant autonomous ethics, on the basis of the indwelling living spirit; and in the Reformed symbols the Ten Commandments are frankly accepted as the written norm of Christian conduct. The ethical vigor of Luther, Calvin, and the Council of Trent is sadly missing from the Reformed creeds. However much the student of dogmatics may delight in them, the student of ethics from his point of view will find them only a source of discouragement and perplexity. The ethics are in the background, and the Roman Catholic misconceptions of the relation of the Church to the State reflect themselves increasingly in the creeds. The Helvetic Confession in its XXVth article demands that the State shall punish and suppress heresy. The Gospel is a new "law," the ministry a new priesthood, and the church an ark of safety for the believer. There is therefore here little vantage-ground for advance to real Christian ethical freedom. ${ }^{5}$

${ }^{1}$ Nothing "quod discrepet a scriptis vel ab ecclesia Catholica, vel ab ecclesia Romana quatenus ex Scriptoribus nota est," art. XXII.

2 "Aug. Conf.," pars secunda (Apologie), Art. VI.

s "Aug. Conf.," pars secunda (Apologie), art, VII.

- For a different estimate, see Luthardt, "Geschichte der christ. Ethik," I893, pp. $53-58$ and $8 \mathrm{I}-84$.

s For literature, see Schaff's "Creeds of Christendom," vol. III; Uhlhorn, Johann Gerhard Wilhelm: "Exponuntur librorum symbolicorum, maxime eorum, qui in ecclesia Lutherana obtinuerunt, ethica argumenta," etc., Göttin- 


\section{THE EPIGONES OF THE SIXTEENTH AND SEVENTEENTH CENTURIES}

Both in England and in Germany the Reformation was followed by a period of great instability, which affected the entire European world. It was not wholly the result of the religious awakening nor yet of the rise of nationality, but was also conditioned by the economic changes that followed hard upon the struggle of the middle-class for recognition in the political life. The absorption of the energies of the Protestant churches in self-defense and in dogmatic and economic reorganization was such that the men who now began to lead seem pigmies in comparison to men like Luther, Bucer, Bullinger, Calvin, Bugenhagen, Zwingli, not to speak of such pronounced personalities as Carlstadt, Schwenckfeld, and Thomas Münzer.

The counter-reformation had the advantage that reaction always has. It defended existing vested interests; it appealed from the unknown and the untried to the familiar and timehonored; it was centralized and worked as a resolute unified body, whereas Protestantism was split, irresolute, and only half roused to self-consciousness. The counter-reformation used force, but that did not distinguish it from the reformers. It had, however, some great advantages in using force. It was consistently imperialist; Protestantism was not. It had a clearcut theory of the Church and State; Protestantism did not. It voiced the new religious life that awoke in the Roman Catholic church, and gave it new directness and power.

As over against the counter-reformation, Protestantism did not have men of great power within the ecclesiastical organization. The intellectual work was done for Protestantism in political science and philosophy sometimes by men actually hostile to the ecclesiastical organization.

The ethics are dominated by Melanchthon, whose Loci are gen, 1848; Troeltsch, Ernst: "Der Alt-Protestantismus (I-II) (16. und 17. Jahrhundert)," pp. 315-36I in "Die Kultur der Gegenwart," teil I, abt. 4, part I. 
the subject at once of elaborate commentary, ${ }^{1}$ without any real advance, and sometimes, as in the treatment of the Decalogue, with a distinct decline of vigor and vitality.

This decline is even more marked when Venatorius of $\mathrm{Nu}$ renburg ${ }^{2}$ attempts an independent ethics, and starting with Luther winds up with Cicero. The attempt to combine Stoicism with the evangelical teaching of Luther reveals the entire misconception both of paganism and Christianity that prevailed.

In fact for Venatorius apparently the pagan ideal is good enough, only it needs Christian faith to live up to it. Thus "faith" is a new Christian philosophy. And in the law and Gospels all is contained.

Melanchthon had done his work so well that again Aristotelian intellectualism and individualism occupy the centre of the stage, and the ethics of the New Testament are swamped in the cardinal virtues and Melanchthon's distinctions between virtues and duties. The whole treatment is so scholastic and so confused that the reader is set wondering where the Gospel really has any place.

Much more truly reformed and Christian seems to be the work of Weller, ${ }^{3}$ who deals at length, and in the sense of Luther, with the service of God in the round of daily duty, and especially

${ }^{1}$ Strigel, Victorinus: "Locorum theologicorum ... V.S. enchiridion ad methodum Locorum . . . P. Melanthonis . . . "Wittenberg, r59r; Chemnitius, Martinus: "Locorum theologicorum . . Francofurti, r604." Cf. Pelt, L.: Die christliche Ethik in der lutherischen Kirche vor Calixt und die Trennung von der Dogmatik durch denselben," in "Theologische Studien und Kritiken," XXI, 1848, pp. 27r-3rg.

${ }^{2}$ Venatorius, Thomas: "De virtute christiana libri tres, Norinbergæ [15]29." Cf. Luthardt, Chr. Ernst: "Geschichte der christlichen Ethik seit der Reformation," Leipsic, r893, pp. 89-90, who gives a good summary but a very poor critique of the work; also Schawarz, J. C. E.: “Thomas Venatorius und die ersten Anfänge der protestantischen Ethik im Zusammen hange mit der Entwickelung der Rechtfertigungslehre," in "Theologische Studien und Kritiken," XXIII, 1850, pp. 79-142.

${ }^{3}$ Weller, Hieronymus: "De officio ecclesiastico, politico et œconomico libellus pius et eruditus," Noribergæ, $\mathbf{r}_{552}$. The Latin the present writer has not seen. Justus Jonas produced a paraphrase of it. 
defends the taking up of office by Christians as over against the Anabaptists, who often attacked the holding of State office by the "regenerate." In fact the popular preached ethics was probably superior to that of the schools. The systematic treatise by Chytræus ${ }^{1}$ deserves attention from his attempt to adjust the claims of law and Gospel by postulating the Decalogue as the norm of the Christian life, because in it the final will of God is revealed; but God wants freedom and sonship of us, and not merely legal obedience, so Christ appears to enable us freely to accept and live up to the commandments. Virtue is doing the things commanded in the Decalogue, but they must be done from the heart, hence the need of regeneration, that the heart may move us to loving obedience. Thus the ethical life moves within a given closed system, and we have the old scholastic method in the fulness of its fruitage. Thus ethics are also lost in a theological description of regeneration.

The outcome of Melanchthon and Chytræus may be seen in the ethical scholasticism of Johann Gerhard, ${ }^{2}$ who, after treating of Scripture in the first volume as the perfect norm, develops a speculative system of theology akin to Thomas Aquinas, from whom it is hard to believe that he has not borrowed much material. In the fifth volume he enters upon a controversy with Bellarmine upon the subject of free-will, and all the confusions of Melanchthon are repeated. Ethical material is also contained in the sixth volume, where he deals with the relation of ceremonial law to the ethics of the new dispensation, ${ }^{3}$ with the character of the Gospel as given to us in Christ Jesus, and with penitence. It is illustrative of his method to turn to page 142 of this volume, where he asks the question, whether and in

${ }^{1}$ Chytræus, David (the elder): “Regulæ vitæ. Virtutum descriptiones methodicæ . . . recens recognitæ . . . ac exemplis . . . illustratæ," etc., Leipsic, I558; other editions, Wittenberg, 1570 and 1573.

${ }^{2}$ Gerhard, Johann: "Loci theologici, denus edidit variique generis observat ... ed. Jo. F. Cotta. 20 tom. et index generalis," Tübingen, r $762-1789$; "The Summe of Christian Doctrine written originally in Latine . . . and translated by R. Winterton," Cambridge, I640.

${ }^{3}$ In Tomo sexto, locus XIV, tracts II and III. 
what sense Christ may be called a new law-giver. ${ }^{1}$ The Council of Trent had anathematized all who said that Christ Jesus was not a law-giver, ${ }^{2}$ and after reading all the arguments in refutation of this position the reader is left wondering where exactly Gerhard disagrees with Trent, for in point of fact the Gospel is a new law, and Christ Jesus came to enable us to keep it. ${ }^{3}$ With vast scholastic learning we are led into all the legal casuistry of the Middle Ages, and even while maintaining in name the evangelical freedom, the substance is sacrificed to a new legalism. Even the machinery for the maintenance of this new spiritual tyranny is elaborately supplied. We have all the apparatus of reproof, minor excommunication and major excommunication, ${ }^{4}$ and with the State magistrate to enforce the spiritual decisions. ${ }^{5}$ It was not the fault of these new scholastics that a national spiritual imperialism did not take the place of the old international imperialism, with the Church and State as the two pillars. Although with patent inconsistency Gerhard denies that the State should put heretics to death.

Nor is the work of Calixtus ${ }^{7}$ one whit better. Here he deals with the regenerate as the subjects of a new ethics in exactly the same spirit. Even Luthardt has to admit the confused and scholastic character of this greatly overestimated work. Of really original work there is from the ethical point of view in neither Calixtus, Paul v. Eitzer, or Dürr any trace. The same old material borrowed at third hand from Aristotle is worked over in bad Latin, and then the vain attempt is made to distinguish between this product as philosophic on the one hand and as "theological" on the other.

${ }^{1}$ As throughout, this question is treated as controversial, with the Roman Catholics on one side and the Anabaptists on the other.

2 "Se quis dixerit, Christum Jesum a Deo hominibus datum esse, ut redemtoreum, cui fidant, non etiam ut legislatoreum cui obediant, anathema fit," Council Trid., VI, 2 r.

${ }^{3} \mathrm{Cf}$. vol. V, locus, XIII.

4 "De Ecclesia," tom. XI, cap. VI, §§ II and IV.

${ }^{3}$ Tom. XIII, locus XXV.

- Sine ecclesiastico ministerio commode quidem sed non pie, sine politica potestate pie quidem sed non commode vivi potest," locus XXV.

${ }^{7}$ Calixtus, Georg: "Epitome theologiæ moralis," Helmstadt, I634. 
The influence of renewed legal study and political theory shows itself in the second part of Buddeus's work, ${ }^{1}$ who deals with the difference between the divine and natural law. ${ }^{2}$ At the same time the discussion is hopelessly scholastic. Practical theology, he says, is the science which teaches regenerate men, following the leading of divine writings, how they shall live so that they shall grow in the divine image, and at death leaving all imperfections become participants in the eternal and highest felicity. ${ }^{3}$ The closed system within which we are supposed to move is the Bible. In reality it is only the traditional mediæval theology slightly tinged by the new colors of the Reformation. Life and the end of life are thought of in the peculiarly narrow and selfish individualism characteristic of the post-Reformation men. The thinking of Malebranche is somewhat reflected in places, and the psychological discussions of the period are taken into account. Regeneration does not change our faculties, but the affections, inclinations, and propensities are changed. ${ }^{4}$

A large part of the book is a polemic against the rationalism of this period, but it is really exceedingly unintelligent and has only authority to set up over against it. Learned and clear, then, as Buddeus undoubtedly is, the outcome is in the last degree unsatisfactory and cannot carry us out of the dogmatism and unreality of the ecclesiastical ethics of that day.

The same may be said of Danneus, ${ }^{5}$ who does not seem to the present writer to be so nearly the father of reformed ethics as Schweitzer seems to think. Certainly Melanchthon is the

\footnotetext{
${ }^{1}$ Buddeus, Johann Franz: "Institutiones Theologiæ Moralis variis observationibus illustratæ," Leipsic, I 7 I I and 1727 .

2 "Non enim ex ratione, quod Puffendorf fecit, sed ex revelatione, nostra probamus quod theologiæ proprium est, et si subinde, illustrationis caussa, rationis Scita in subsidium vocemus," preface, p. 3 .

3 "Proleg. de nat. et indole," $\$ \mathrm{~V}$, p. 6.

'Cap. I, \$ XXXVII, p. 36 .

'Dannæus (Daneau), Lambert, r530-r595. Cf. Alexander Schweizer: "Die Entwickelung des Moralsystems in der Reformirten Kirche," in "Theologische Studien und Kritiken," XXIII, r850, pp. 5-78, 288-327, 554-580. Luthardt, Chr. Ernst: "Geschichte der christlichen Ethik seit der Reformation," Leipsic, 1893, p. 99.
} 
organizing spirit in the "Ethica Christiana," 1 and although the legal studies of Dannæus give the ethics, as they give those of Calvin, a certain form, the underlying assumptions are just those of the Lutheran ethics which we have been considering. His interest in the theocracy is not greater than that of Buddeus, nor is the Bible any more of a closed system for him than for Gerhard or Calixtus. The Puritanism that so markedly dominated reformed ethics in Calvin and those who followed in his footsteps does indeed not characterize the Lutheran systems to the same degree. At the same time it is there, nor does it seem to the present writer historical to make it so exclusively an introduction from the Netherlands as Ritschl does. ${ }^{2}$

\section{THE NEW PROTESTANT CASUISTRY}

By casuistry one may mean the application of general principles to particular cases. But such a definition is so wide that it really ceases to mean what casuistry has historically meant. In a narrower sense it is the attempt in cases of conscience, where pleasure conflicts with duty, or seeming duty with seeming duty, to resolve the conflict on the basis of authoritative decisions. In this sense Roman Catholic morality had a final code in the decisions of the church. Where she had spoken the case was closed. It was inconceivable for faith that there should be any conflict between her decisions. An elaborate casuistry thus grew up out of the simple faith that through appointed officers the Christian could come into direct contact with a final and definite authority, and that all cases of conscience could be resolved in the confessional.

Protestantism by several stages broke with priest and bishop, with pope and even general council, but stopped at the pages of the New Testament. Here in the words of Scripture are laws which are the final rules of faith and practice. This law is binding on each conscience, hence it becomes eternally impor-

${ }^{1}$ Published in 1577 and appearing in many editions.

2 In his "History of Pietism." 
tant to know just what the law says. Roman Catholic exegesis could afford to be general and inexact. The symbolic meanings were many, and the letter was relatively unimportant. Could not mother church at any time give a final and definite interpretation of the letter, or an authoritative answer on the basis of the Scripture, that in fact superseded Scripture? Not so in Biblical Protestantism. Here only the most careful exegesis could elucidate the meaning of the text, and the text alone had authority. At the same time it was the business of the church to elucidate the text through her pastors and theological teachers. At this point the elucidation may again be the relatively simple and always necessary application of general principles to special cases, and on such a basis one can have no casuistry, properly speaking. All systematic instruction amounts to just that. Quite otherwise is it, however, when it becomes necessary to collect important decisions, and to balance them one against another to discover the authoritative voice in these decisions. The beginnings, but only the beginnings, of a casuistry appear when Luther and Melanchthon and the evangelical universities were summoned to give, not advice, but authoritative decisions binding upon the conscience.

All the credal statements were apologetic in character. They attempted to set forth and explain wherein they agreed with the past and wherein they differed with Rome. Neither in ethics nor in social theory did any of the creeds dream of a break with the historic past. And yet they expressed under old formulæ new life, new hopes, and called attention to new situations. New situations, however, demand a new ethics. The ethical confusion of the Reformation period has already had our attention. It is hard at the best of times for even a well-intentioned, ethically trained man to know what in complicated circumstances he ought to do. But the generations of the Reformation had been treated as children. The confessional, so far as it has significance, discourages autonomy and independent judgment. This timidity born of moral dependence is reflected in the period. The great leaders were overwhelmed 
with all sorts of moral questions. The doctrinal questions were answered in great fulness in creeds that at once began to take a place of authority. And corresponding to these there was no system of ethics that more nearly fulfilled the same function than that of Melanchthon. At the same time to collect the authorities and give categorical answers in the forms of the old casuistry became seemingly increasingly necessary as the Protestant movement gradually began to rest rather on authority than upon the great primary enthusiasms.

It is hardly casuistry that we find in Luther's letters and "Tabletalk." He, like his master, taught as one having authority, and not as the casuists. This advice only becomes casuistry when some one like Petzel gathers it together in the sayings of Melanchthon, ${ }^{1}$ and these decisions become quasi-authoritative, and men like Amesius and Baldwin begin to lecture upon them. ${ }^{2} \quad$ The first Thesaurus seems to have been that of Dede$k e n,{ }^{3}$ but from that on the literature began to multiply. Happily casuistry in this sense was out of place even where Protestantism had only come to half self-consciousness. The only real basis for casuistry must be a central authority. The wide range of the Biblical literature shut out any thoroughgoing use of it as such authority. We will only take up as an illustration the work of Osiander. ${ }^{4}$

He discusses at considerable length the meaning and function of conscience, but gives us only the old worn-out material. The most original note is where he discusses the "signs" of the kind of conscience a man has. These are found in physical character,

1 "Berathschlagungen und Bedenken," r6or.

${ }^{2}$ Amesius, G. (William Ames): "De conscientia et ejus jure vel casibus, libri quinque, . . . 1630," Ed. nova, Amsterd., 1634, 1654, Oxford, 1659. "Conscience, with the power and cases thereof. Divided into V. bookes . . T Translated out of Latine," etc., 3 parts, portr. (London, r639), and Baldwin (Balduinus), F.: "Casus Conscientiæ," 1621-1627.

${ }^{3}$ Dedeken, M.: "Thesaurus consiliorum decisionum," edited by Gerhard, $167 \mathrm{r}$, in 3 vols.

'Osiander, Johann Adam: “Theologiæ casualis, in qua quæstiones, dubia et cauus conscientiæ circa credenda et agenda enucleantur," Tübingen, I68o. 
and the list is careful and painstaking, but of course futile, ${ }^{1}$ for the psychology is really misleading.

Then follows a discussion of law as the norm of conscience. ${ }^{2}$ All the various types of law, natural law, the law of nations, ecclesiastical law, and human laws, etc., etc. The discussion is inconsequent for lack of really distinguishing between the types. Next follows a discussion on the examination of conscience, $^{3}$ which is interesting as dealing with the dispute about probabilism. Of course the "Gospel" is exalted as the sole source of truth, and Augustine quoted for this position." The cure of conscience forms the next theme. Since man's fall he has needed a remedy, and the satisfaction of Jesus' death is set forth. This is applied in the Gospel, baptism, and the Lord's Supper. The theology of the treatise is that of Melanchthon, and Calvin's doctrine of perseverance is rejected. ${ }^{5}$ From this on the book is theological, and along the lines of Melanchthon's Loci, with much scholastic material, as in the treatment of angels. ${ }^{6}$ The second part deals with the moral law and the Decalogue. ${ }^{7}$ Here the treatment becomes distinctly scholastic and casuistical. Very sharp and interesting are many of the discussions, but Scripture words and the interpretations of Scripture words and the decisions of the church fathers are the means of getting at authoritative answers to the various questions of conscience given. Nor is there actually any advance upon the material which was already common possession. More interesting, although again deeply disappointing, is the treatment of Christian liberty ${ }^{8}$ in the section dealing with incorruption. ${ }^{9}$ This liberty is freedom from bondage to sin, from the curse of the law, from the traditions of men and churchly rites, which are by their nature indifferent. When, however, this liberty is set forth more at length, distinct limitations are noted and the doctrine is guarded against the claims of the "Anabaptists, Libertines, Quakers, and such like." On the

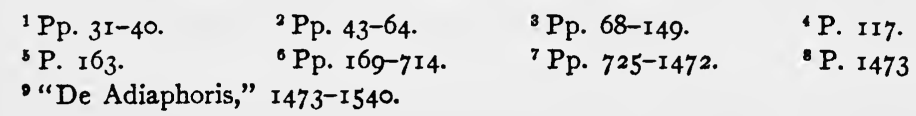


whole the position is that rather of Luther than of Melanchthon, although this is a question rather for dogmatics than ethics. The treatise closes with discussions of temptations, penitence, confession, and absolution.

It cannot be said that the Pars Secunda is really fruitful. Its method precludes the highest fruitfulness. It is, however, an honest attempt to deal with the situation and to gather authoritative decisions on ethical questions. That casuistry did not flourish is due to the fact that increasingly the genius of Protestantism and the new spirit of ethical autonomy and spiritual maturity makes itself felt in the church and in the nations in which Protestantism maintained itself.

\section{THE ETHICS OF PIETISM IN THE CONTINENTAL CHURCHES}

One function of all organization is the conservations/of values attained by hard struggle and which would be lost unless fixed in definite forms. The hardening of life into institutions and traditions is needful if the acquirements of the past are to be handed down to the succeeding generations. At the same time the process is attended by grave dangers. No formulation of a great vital movement is ever complete. How miserably the primitive church formulated the teachings of Jesus or of Paul!

Thus it happened that the Protestant formulation of the great awakening was exceedingly incomplete. In the first place important elements, such as were represented by the Anabaptist movement, were either ignored or trampled upon. That these despised Anabaptists had definite and most important contributions to make is beyond all doubt. That they were often wrong and that the bonds of an excessive literalism fettered them may be admitted. But Protestantism was a poorer, meaner thing because they were excluded from its active fellowship.

In the second place far too much stress was laid upon intellectual formulation, for which in fact the world was not ready. For this reason the creeds are heavy with a half-digested scholas- 
ticism, and are in bondage to a view of the world from which men were eagerly preparing to emancipate themselves.

It was also the misfortune of the Reformation that wars and political struggle both in England and on the Continent robbed her of energy and absorbed her strength. The cold, bare dogmatic Protestantism of the sixteenth and seventeenth centuries sends a chill down the back of the modern man. The forms of her piety seemed to have lost so much in the struggle to barely exist. Nearly all æsthetic values were gone. The ministry of feudal Romanism to the hunger of human life for color, for art expression in singing, acting, and painting was a real and very beautiful ministry. Nearly all of this seemed hopelessly swept away.

In the Middle Ages the burden of life's responsibility had been much lightened, whether wholesomely or not, by the willingness of mother church to take some of the most burdensome of these upon herself. The Reformation left every man alone, face to face with God, and the God of the Reformation was not always the forgiving Father of Our Lord Jesus Christ.

And perhaps the worst of the situation was that the inwardness of faith which had pervaded the teachings of Luther, Calvin, Bucer, Bullinger, Zwingli, and the others was all too often lost in post-Reformation times in formal intellectualism and ritual correctness. The pure word became intellectual orthodoxy and the right administration of the sacraments became sacramental magic.

Slowly there came, however, over the face of Protestantism a change. Albrecht Ritschl does not think very highly of the change, ${ }^{1}$ and in an exceedingly careful analysis of the movement has shown beyond much question the survival in it of types of thinking neither essentially Christian nor modern. When, however, he goes on to demonstrate that this type of thinking has its origin in the reformed theology and is a strange element in Lutheranism, ${ }^{2}$ it is harder to follow him. The Roman Catholic

1 Ritschl, Albrecht: "Geschichte des Pietismus," 3 vols., Bonn, I88o.

2 "Geschichte des Pietismus," vol. II, pp. 3-33. 
forms of piety never really disappeared from either Luther or reformed thought. The ascetic mysticism that marks certain phases of Roman Catholic piety survived in hymn and sermon and in the thought and feeling of both communions.

Whether Ritschl is right in tracing the actual spread of Pietism to the work of men like Gisbert Voet, Johann Coccejus, Jodocus van Lodenstyn, de Labadie, and others, the present writer does not know. The works of these men are obscure, and first-hand knowledge is difficult and demands theological expertness as a systematic theologian. The student of ethics will, therefore, soon find himself lost in the minutiae of dogmatic discussion. What, however, does at once appear when typical pietistic thought is examined from the ethical point of view is that the pietistic movement had a distinct and valuable contribution to the advancing spirit of Protestantism. This contribution is, nevertheless, not chiefly theological, but ethical and religious. The fact that controversy forced it into theological forms was unfortunate, for theological formulation was entirely contrary to its genius. No doubt Ritschl is right in his main contention that the theological formulation is reactionary. At the same time Ritschl's error is the resolving of Pietism into a theological movement. It became this, so far as it was this, only because of radical misunderstanding of its fundamental interest.

Just as in regard to the evangelical movement in England, ${ }^{1}$ which was so nearly related to Pietism, the awakening was only accidentally theological. It really affected various types of mind and thought. It was itself never consciously an attempt to engage in theological reformation. In the work of Spener, ${ }^{2}$

${ }^{1} C f$. author's "Social Significance of the Religious Movements of the Seventeenth and Eighteenth Centuries in England."

${ }^{2}$ Spener, Philip Jakob (1635-1705), was born in Rappoltstein, at the foot of the Volgesian Mountains, in Alsace. He was preacher in Strasburg and in Frankfurt-a.-M., as well as in Dresden and Berlin, where he died. His life and work has been best described by Grünberg (Paul) in three volumes (Göttingen, 1893-1906). In the third volume, pp. 205-388, is a wonderfully complete bibliography, in three parts: I. A complete list of Spener's own writings; 2. A systematic list of the literature referring to Spener; 3 . A chronological list of the literature of Spener. The only English work referred to of importance is by 
what most strikes us is the practical goal. He wanted to make the church life religious and ethical. He regarded himself as the interpreter again to the church of Luther, and he was to a great extent right. His catechism ${ }^{1}$ is in immediate connection with the main thought of Luther, namely, faith as an inner life enabling us to keep the commandments. He begins, to be sure, where reformed theology would also be likely to begin, namely, with the Bible. Yet on the other hand in his practical use of the Bible he shows great freedom and at times even critical vigor, and his attitude is not one of slavish literalism.

The ethics of Spener are distinctly a religious individualism. The relations of the regenerate man to his neighbor reveal the reality of his relations to God. The traditional orthodoxy sought the evidence for regeneration in "pure doctrine" and the proper use of the sacraments. For all practical purposes the church guaranteed to the believer the reality of his faith by setting forth this pure doctrine and by obedience to the sacramental institution. Against this Spener protested. And in

Richard, Marie E.: “Philip Jacob Spener and His Work," Philadelphia, I897, I54 pages. (This work contains also "Augustus Hermann Francke and His Work.") The English reader will find a short article on him in the "Encyclopædia Britannica." A real service might be rendered by an adaptation of Grünberg's work for English readers. Spener is best studied in his numerous sermons. $C f$., also, "Pia Desideria: oder hertzliches Verlangen, nach Göttefälliger Besserung der wahren Evangelischen Kirchen . . . ," Frankfurt-a.-M., I676, a good edition appeared in Leipsic, I84I, a revised edition with notes by F. W. P. L. Feldner, Dresden, I846: "Das geistliche Priesterthum aus göttlichen Wort kurtzlich beschrieben, und mit einstimmenden Zeugnissen gottseliger Lehrer bekräfftiget," etc., Frankfort, I677; and Herrn D. P. J. Spener's “. . . Letzte theologische Bedencken und andere brieffliche Antworten, welche von dem seel. autore, erst nach seinem Tode zu ediren, anbefohlen . . . nebst einer Vorrede," Hr. Baron C. H. von Canstein, etc., 3 Theile, Halle, I 7 II; a good little book is Spener's (Philip Jakob) "Hauptschriften, bearbeitet und eingeleitet von Paul Grüberg," in 220 pages, Gotha (Perthes), 1889 ("Bibliothek theologischer Klassiker," vol. XXI).

1 "Einfache Erklärung der christlichen Lehre nach der Ordnung des kleinen Katechismus Dr. Martin Luther's in Frage und Antwort verfasst," various editions. Third edition, edited by J. A. Detzer, Erlangen, 1846 , another in the same year at Berlin; the latter is the edition the present writer has used, being the one accessible to him. 
his protest he reasserted the inward character of faith, and seemed to his critics unchurchly and anti-ecclesiastical. Yet Spener was never a separatist, ${ }^{1}$ and when the "collegia" began to separate he ceased to organize these "collegia." 2 Yet they rested upon his own most highly prized teaching of the universal priesthood of believers, and they were a protest in the interests of Christian democracy against the usurpation of professional religious teachers.

In general his ethics are divided into "Duties to God." First, those virtues that have their seat in the heart, and secondly, the duties that spring from these virtues, and thirdly, our attitude to the means of grace. Then duties to the neighbor, in general and in particular social position. And then lastly, duties to one's self, in general and particular. This fulfilment of duties is evidence of regeneration.

It was not Spener's individual fault that he carried over a certain tone of world-flight into his thinking. Puritanism has its roots in the thinking of the earliest reformers, and the somewhat dualistic conception of life that underlies Protestantism, in many of its forms, was indeed Roman Catholic, but came over with Luther, Calvin, and nearly all the great reformers into the more modern world. It is interesting to note that Pietism was often a strong and effective protest against a priestly church in its intolerance and excessive claim to have authority. It took up the struggle against intellectualism and based itself on the claim of the priesthood of all believers. Religion, said Spener constantly, was not knowledge but practice, it was a habitus practicus. $^{3}$

It is interesting to note the things that his most vigorous critic, Valentin E. Loescher, charges. against Spener. He notes his indifference to the "doctrine," his undervaluation of the

${ }^{1} C f$. Grünberg's careful citation of passages, vol. III, p. 187.

2 The "Collegia pietatis," as the forerunners of the evangelical prayer meeting and the Methodist class meeting, are full of interest. "Pious," i. e., "reawakened," persons gathered together outside the regular church services for selfexamination, instruction, reading of the Bible, prayer, and singing.

3 "Des geistige Priestestum," and in many sermons. 
means of grace (of course the sacraments), the underestimate of orders, for only converted men are in true orders, that workrighteousness is mingled with faith. Of course he also took issue with his chiliasm, his mysticism, and his relative indifference to many things important to ecclesiasticism. Ritschl, indeed, does not regard Spener as a thorough-going pietist, at the same time Spener almost summed up the movement, and it is quite evident that the dogmatic weakness of Pietism blinded Ritschl to many of its religious and ethical values. With many weaknesses Pietism was yet a call to greater inwardness and to a less dogmatic and more practical Christian life. Systematic ethics can hardly be said to have made distinct advance. The foundation laid was too narrowly individual, the "religiosity" was too much modelled after the contemplative piety of Tauler and the "Teutsche Theologia." The development of its life was influenced, undoubtedly, by unwholesome traditions with regard to the undervaluation of this world and overestimate of what George Eliot cleverly called "other-worldliness." If the student of systematic ethics goes to Pietism or to the evangelical revival, which was its daughter, expecting to find advance toward ethical autonomy and a more scientific and systematic treatment of the great problems of a really Protestant ethics, he will be disappointed. The formal ethics are still too much in the bonds of a traditional and scholastic view of the world to constitute a basis even for advance. If, however, he on that account underestimates the social service of Pietism, it is because he has fallen into the mistake which Ritschl seems to have made, and deals with it too exclusively as an intellectual movement.

How little it was this is seen in the life and work of one who next to Spener may be said to have given Pietism its historic form, the great leader of Pietism, Francke. ${ }^{1}$ As a theological

${ }^{1}$ Francke, August Hermann ( $1663^{-1727}$ ). In 1692 (January 7 ) he came to Halle-a.-S. and there really gave Pietism a new direction as pastor and professor. His works are numerous: "Öffentliches Zeugniss vom Werk, Wort und Dienst Gottes," 3 vols., 1702, also Halle, 1739; "Segensvolle Fussstapfen des noch lebenden und waltenden, liebreichen und getreuen Gottes," I 709, also Halle, I769; "Epicedia," Halle, I727; "Idea studiosi theologiæ," Halle, I7 I2; "Mo- 
thinker he is even less effective than Spener, and Ritschl's judgment on this side of his life and thought seems all too just. At the same time this is not the whole of Francke's life and thought. $\mathrm{He}$ not only aimed at a measure of inwardness for the Christian life, which the scholastic orthodoxy sadly missed, but he found in Christian activity the proper test of the reality of that inwardness. Prayer was for Francke communion with a living God. It is hardly fair to Francke to find in his emphasis upon prayer anything like the mechanical magic which marks the lowest estate of Roman Catholic prayer. ${ }^{1}$ The reproach is, however, just that it was often an emphasis upon the individual relationship with God apart from relationship to him in the social activities of the church life. At the same time Francke never really underestimated the church. His missionary zeal was the dawning of a better day for German missionary activity. His orphan schools and students' homes were in direct contact with the church, and by his long and faithful pastorate he raised the whole conception of the privilege and calling of the ministry.

His theology abounds, no doubt, in remembrances of scholastic Roman theology, but so does all Protestant theology. We have done very little save clear away some of the more offensive intrusions. Where Francke advanced was in his conception of a dynamic faith revealing itself in personal piety and in social service. That the type of personal piety had many false lines in it, and that the social service was neither as intelligent nor as thorough-going as it might have been, is simply true of Francke and some of the rest of us.

His ethics were, however, still very individualistic, sometimes sentimental, and often moved too much in the heavy armor of theological formulæ, as those of regeneration and penitence,

nita pastoralia," Halle, I7I7; "Methodus studii theologici," Halle, I723; etc., etc. Kramer's (Gustav) "A. H. Francke, ein Lebensbild," in two volumes (Halle-a.-S., r880, r882), is the best biography, although not critical. Cf. also Marie E. Richard's "Augustus Hermann Francke and His Work under Spener . . ." See also Ritschl, Albrecht: "Geschichte des Pietismus," Bonn, I880, vol. II, pp. 249-294.

${ }^{1}$ As in Ritschl, vol. II, pp. $259 \mathrm{ff}$. 
without seriously facing the great ethical questioning of even his own day. While all this is true, the outcome of Francke's activity was of the greatest benefit to both the church and the nation, and his own services should never be underestimated because of the feeble caricatures of the pietistic epigonen.

The chief ethical weakness of the pietistic movement was its failure to formulate an ethical principle for the judgment of life's actual situations, and the consequent relegation to law and convention of some of the most important and educative of moral decisions. It is very easy to set up a law, "Thou shalt not do so and so"; it is far harder but also far more important to teach men to apply fundamental principles to the constantly changing and shifting circumstances of life. The ethics of Pietism shared with monasticism and Puritanism an element of world-flight. The world danced, therefore the Christian must not dance. The world played cards, therefore the Christian must not play cards. The world went to the theatre, therefore the Christian must not go to the theatre. The world amused itself with games and fêtes, therefore the Christian must play no games and attend no fêtes. The fatal compromises made with the world were so abhorrent to Pietism, it so rightly judged a lukewarm Christianity as more harmful than actual opposition, that it sought to cut the knot and get out of any danger even of compromise. The result was the hypocrisy, the sense of unreality, the pharisaism that haunts all legalism and all attempts at world-flight.

The men we have been considering did not leave the church. They did not even try to construct an imperium in imperio, but they gave the inevitable basis upon which such attempts should be made. Some sought in inner circles within the church to realize the dream of a purer type of Christian living for themselves at least, ${ }^{1}$ and free from the amusements and the temptations of the world.

'Johann Georg Walch: "Historische und theologische Einleitung in die Religionsstreitigkeiten der evangelisch-lutherischen Kirche, von der Reformation an bis auf jetzige Zeiten," 5 vols., Jena, I 733, especially vol. II, pp. 357-400. 
Others again found this hard or uncongenial, and pushed by the logic of the situation began to separate themselves from organized Christianity and to found brotherhoods for the cultivation of their life and the speedy furtherance of their central purpose. Such an attempt was made with the greatest success by Zinzendorf. ${ }^{1}$

He found the old Moravian church which had taken refuge on his estates the foundation for a brotherhood within the Lutheran church. The missionary purpose was his and their controlling and central ideal. The ethics of the movement exhibit the type of religious individualism made familiar in Spener, but the religious life represents even more strongly a reversal to mediæval piety. The person and physical sufferings of the Saviour are in the foreground, and mystic devotion and even ecstasy were cultivated. The missionary zeal and selfsacrificing devotion to social service (nursing, teaching, etc.) saved the situation, but the theology and ethics are not in any sense pronouncedly Protestant. The Scriptures are the external authority, with, however, that dash of subjectivism that has always made this type of Roman Catholic devotion difficult to manage even face to face with the imperial hierarchy (Tauler, Suso, etc.). As over against State Lutheranism it had a very hard time, and never has flourished save where it commanded the situation absolutely, as at Herrnhut.

\footnotetext{
${ }^{1}$ Zinzendorf, Count Nicholas Lewis ( $700-1760$ ), who gave the refugees from Moravia not only a home, but also a new organization. His works are numerous. Godfrey Clemens has collected some of his sermons: "Auszüge aus des seligen Ordinarii der Evangelischen Brüderkirche, sowol ungedrukten als gedrukten Reden über biblische Texte nach Ordnung der Bücher heiliger Schrift . . . etc.," ro vols., Barby, ${ }_{17} 63$, etc. His hymns are collected by A. Knapp: "Geistliche Gedichte, . . . gesammelt und gesichtet . . . mit einer Lebensskitze," etc., Stuttgart and Tübingen, 1845. Bengel (Johann Albrecht) has a critique of the movement: "Abriss der sogenannten Brüdergemeine, in welchem die Lehre und die ganze Sache geprüfet," Stuttgart, 1751, neuer unveränderter Abdruck, Berlin, 1858. The most quoted life is that of Spangenberg (August Gottlieb): "Leben des Herrn N. L. Grafen und Herrn von Zinzendorf und Pottendorf," Barby, $\mathrm{I} 773-1775,8$ parts (the pagination is continuous throughout). The Life of N. L. Count Zinzendorf . . t translated (in an abridged form) by S. Jackson, London, I838; a still briefer edition by J. Jackson, London, I844.
} 
Zinzendorf lived to see his movement floating on the tide of triumphant Pietism that swept over Germany. He had been banished from Saxony in the early days, but now was recalled and loaded with tokens of confidence and recognition. Pietism was never a proletariat movement in the strict sense in Germany. It never even had a large proletariat following such as Methodism won in England. It affected the smaller tradespeople and the urban population at a certain middle-class stage, and appealed strongly, like Whitefield's movement, to the aristocracy. Zinzendorf was himself brought up by his titled grandmother, and she had been one of Spener's personal friends and supporters. Neither in theology nor in ethics was there any original note or any great advance, save only as religious zeal enforced a measure of inwardness and broke down formalism and dogmatic correctness as a measure of life.

The pietist was taught to do a quite unwholesome amount of introspection, and the feelings were most unduly worked upon and emphasized. Fanaticism lay often close on the border line, and Puritanism was the outcome, with its almost inevitable deadness and mechanical religiosity. Hypocrisy is always an easier charge to make than to prove. But beyond question the pietistic movement produced in its later stages on the minds of many the impression of hypocrisy.

The separation of groups of pietists from the State church was made necessary by the foolish narrowness of State governments as in Würtemberg, ${ }^{1}$ and the usual results of such separations appeared. Fanaticism is the child of persecution and intolerance breeds narrowness and extravagance. These all appear in the history of the little sects and divisions that sprang up in the wake of the great pietistic revival. With them, however, the main stream of history can hardly reckon.

\footnotetext{
${ }^{1}$ Systematic ethics finds little new in the teachings of these groups. For an account of them, see Luthardt's "Geschichte der christlichen Ethik," vol. III, pp. 248-33I, of the edition (in one vol.), I893, but the details are too local to interest the English student.
} 


\section{THE ETHICS OF POST-TRIDENTINE ROMAN CATHOLICISM}

It is a false assumption often made by Protestants that the great awakening was wholly a break with Rome. The Council of Constance (I4I4) began a distinct reformation, which, however, seemingly defeated resulted in many most important changes in the Roman policy. The attitude of the University of Paris was significant. It made a steady demand for exactly the step which at first marked Luther's attitude. Already in I 409 Gerson $^{1}$ asked for a council, and he took the high ground of the supremacy of a council over the Pope. ${ }^{2}$ Gerson's mysticism was not metaphysical, but rather a religious and sentimental emotionalism. It included the "contemplation, ecstasy, rapture, melting, transformation, union, exultation, joy, joy to be in the spirit," etc., ${ }^{3}$ and is not exclusive of the discursive reason. Gerson was a nominalist, but sought to avoid the scepticism of nominalism far short of resting simply on authority. We have immediate knowledge of God, and the powers of the mind are discussed under the two heads of "cognitive and effective." 4 At the same time his ethics does not mark any advance upon mystical scholasticism of the type of Bonaventura, for example; and Dionysius and the Fourth Gospel are used uncritically.

${ }^{1}$ Gerson, Jean Charlier, born December I4, I365, died July I 2, I429. The founder, in a sense, of Gallicanism. Chief works (from our point of view) are: "Espistola de Reformatione Theologix" (1400); "De Monte Contemplationis"; "De Mystica theologia speculativa"; "De Mystica theologia practica." Editions of his works, Paris, I606 "Opera . . . auctiora et castigatiora, inque partes quatuor distributa . . Accessit vita Gersonis ...." edited by E. Reicher, in four parts). An edition by M. L. Ellies Du Pin, Antwerp, in 5 vols., I 706. The best monograph said to be that of Schwab (Johann Baptist): "Johannes Gerson. Eine Monographie," Würzburg, 1858. The writer has not seen it.

${ }^{2}$ Opera omnia, Antwerp edition, I 706, tom. II, pars 2, p. I6I.

3 "Consideratio prima de triplici Theologia," pars I, consid. 2, p. 366; vol. III, Antwerp edition.

4 "Expedit ad ipsius Theologiæ mysticæ cognitionem speculativam acquirendam, naturam animæ rationalis, et ejus potentias, tam cognitivas, quam affectivas cognoscere," "De mystica Theol.," pars 2, consid. 9 (p, 369, Antwerp edition). 
At one point, however, he rises to a high level. He asserts in true Neoplatonic sense the immediate vision. Intelligence is unified, and is capable of receiving light immediately from God in which and through which the first principles are known to be true. ${ }^{1}$ Then he brings this immediate knowledge in the "Theologia Practica" into direct relationship with morals. It is a pity that tradition blinded him to the ultimate logic of this position, and that thus he oscillates between reason and authority, between freedom and casuistry. He was, however, a thoroughgoing Catholic, and his persecution of Huss and maintenance of orthodoxy was the outcome of his real basis in authority. At the same time he was an exceedingly independent critic of the existent authority and one of the great forces making for actual living righteousness. Both the councils of Pisa and Constance were earnest and to some degree markedly successful attempts at reformation. It is noteworthy that Gerson undertook popular expositions of the Ten Commandments ${ }^{2}$ very much in the spirit of the later Lutheran exposition.

When, therefore, the great awakening came, Rome became again profoundly conscious of what was at stake. At first the insurrection in the north was treated with contempt. Then as the revolt spread it was forced home upon Rome that her imperial ambition was endangered, and she began the work of reconstruction. In this work Ignatius de Loyola ${ }^{3}$ (Don

1 "In qua et per quam principia prima cognoscuntur esse vera et certissima, termini es apprehensis," "De mystica Theologia," pars 2, consid. 10 (p. 371, Antwerp edition).

2 "Opusculum Tripertium, de præceptis Decalogi," Antwerp edition, tom. I, p. 426 .

${ }^{3}$ Ignatius Loyola, was born I49r, and his work bears the stamp of his Spanish birth and his military training. His religious experience was profound and real. He dedicated himself to the church before he knew of her danger through Protestantism, and only his experience at Venice seems to have awakened him to his real mission. For full literature, see Otto Zöckler's article, "Jesuitenorden," in Herzog-Hauck's "Realencyklopädie," vol. VIII, Leipsic, I900, pp. 742-784, and V. Frins's article, "Jesuiten," in Wetzer and Welte's "Kirchenlexikon,"

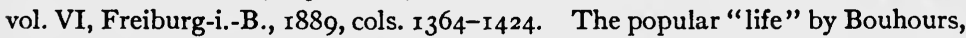
Dominique. "La vie de S. Ignace, Fondateur de la Compagnie de Jésus," Paris, r679, Nouvelle édition, "revue et corrigée," 2 vols., Avignon, 1821. An 


\section{Inigo Lopez de Recalde of Loyola) was a chief instrument.} In a most remarkable manner he reflected the nobler side of Roman Catholic ethics and faith. His own experience of excessive asceticism led him to rational views of its value, such views as modern and intelligent Roman Catholicism holds today. ${ }^{1}$ He became the father of modern missions and the foundation of a thorough-going view of life from the point of view of authority, absolute and final. ${ }^{2}$ Moreover, the Jesuitism which he founded drew firmly and consistently the only conclusion open to Roman Catholic reasoning from the premises, and

English translation "by a person of quality," London, I686. The 6th book is added by Butler (Alban) to his "Life," Dublin, 1841. The writer has not seen Genelli's "Das Leben des heiligen Ignatius von Loyola . . . Mit Benutzung der authentischen Acten, besonders seiner eigenen Briefe," Innsbruck I848; "The Life of St. Ignatius of Loyola . . . Translated from the German of Christoph Genelli by C. Sainte Foi; and Rendered from the French by T. Meyrick, London, 1871. Nicolini's (Giovanni Battista) "History of the Jesuits, Their Origin, Progress, Doctrine and Designs," London, 1854, in Bohn's "Illustrated Library," is intemperate in tone. Döllinger (Ignaz) and Reusch (F. H.): "Moralstreitigkeiten in der römisch-katholischen Kirche seit dem XVI. Jahrhundert mit Beiträgen zur Geschichte und Charakteristik des Jesuitenordens," Nördlingen, I889, 2 vols., mentioned later, is invaluable.

${ }^{1}$ Asceticism is an "exercise" to promote efficiency. "Since soul and body both come from the Creator you should take both into account, and for his sake not weaken the bodily nature, for if this is weakened the inner (spirit) cannot be effective." Quoted by Huber from Genelli, pp. 382 ff., of "Das Leben des hl. Ignatius von Loyola."

2 The literature is gathered in the two articles mentioned already, p. 555 (note). Luthardt (Chr. Ernst) has also a most valuable collection of bibliography in his "Geschichte der christlichen Ethik seit der Reformation," Leipsic, I893, pp. II 5-I5I. The writer has found most useful Huber's (Franz) "Der Jesuiten Orden nach seiner Verfassung und Doctrin, Wirksamkeit und Geschichte," Berlin, 1873 ( $c f$., also, his "Jesuitenmoral, aus den Quellen dargestellt," Bern, I870), and Gothein's (Eberhard) "Ignatius von Loyola und die Gegenreformation," Halle, I895. C $C f$., also, Blaise Pascal's "Les Provinciales" (many editions and translations, the writer has used the edition of M. Prosper Fangere, "Les Provinciales, D'après les manuscrits autographes les copies authentiques et les éditions originales," Paris, 1886, 1895, 2 vols.). But it is most important that some one of the Jesuits, like Gury or Escobar, be studied at first hand to avoid the caricature of their teachings easily made possible by even lengthy quotations. No better guide can be found for the material than Döllinger and Reusch's "Geschichte der Moralstreitigkeiten in der römisch-katholischen Kirche seit dem XVI. Jahrhundert," etc., Nördlingen, 1889, 2 vols. 
accepted the Pope as the final and living voice of the sacramental institutional church. They did exactly what the Puritan State also did, they took their authority seriously and tried to apply it to actual human life. It seems almost absurd to accuse Jesuitism of "lowering the ethical standards of the confessional" by their lax casuistry. They found every man of power and prominence with a "pocket chaplain," and they, in the real interests of morality, supplanted these by trained and experienced casuists.

The sympathy of Protestantism for Jansenism is really greatly misplaced. Pascal's ${ }^{1}$ wonderfully clever attacks upon the Jesuits should not blind us to the fact that from the Roman Catholic point of view Jesuitism was right and Jansenism was not only wrong, but dangerously and divisively wrong.

Probabilism is the only logical outcome of the authoritarian position. The Pope has only spoken infallibly upon a few main doctrines. His administrative authority is final, but not infallible. In the confessional the priest has not the advantage of access to infallibility. He has access only to authorities and not to authority. In the actual guidance of complex human life it is not only important but absolutely necessary that no single human authority bind the conscience save that of the one infallible voice where it has spoken, and that the confessor have a flexible rule that he can adapt to every personal need where he has only authorities. That such flexibility can be, nay, will be, abused is undoubted; but all such responsibility can be abused. The Jesuits were not the only father confessors to abuse this trust. But Jesuitism taught in season and out of season that it was a trust. The abuses that grew up pertain to all casuistry. It is the authoritarian system that is wrong and not the probabilism which grew logically out of it.

This probabilism consisted in weighing all the various authorities, and Jesuitism, perfectly correctly, contended that these authorities could not be weighed simply by being numbered,

\footnotetext{
${ }^{1}$ Pascal's ethics are intelligently discussed by Bornhausen, Karl: "Die Ethik Pascals," Giessen, r907.
} 
but that any one grave doctor's opinion might form a basis of judgment. That this opened the door to all sorts of extravagances Pascal has shown. But no one really gets from his pages a conception of the earnest and sincere though mistaken work the Jesuits were doing in trying to reorganize the confessional as a vital moral force. And the proof is that they did reinstate the confessional. The Jesuit order, like all orders, no doubt became corrupt, and its condemnation, and suspension, I773, was thoroughly well deserved, although it is also well to remember that it was the unspeakable House of the Bourbons that forced the issue upon Clement XIV and made it a condition of the return of the Papal States. ${ }^{1}$ Instead of being an instrument of imperial power, the Jesuits had cherished the ambition to wield the power, with the Pope as a puppet and with kings and nations as their real subjects. Imperial ambition has always been unscrupulous whether it has been ecclesiastical or political, and Jesuitism was no exception to the rule.

At the same time the casuistry which they defended must be the outcome of any legal ethics. The letter of the law is inequitable and unjust, and having been made to fit one set of conditions works intolerable hardship under any other conditions. To make the law really work, and to use "authority" without inhumanity, was, without question, the real goal of probabilism. Jesuitism had exactly the same questions before it with which Pharisaism had to deal, and dealt with them in much the same way and for the same reason-both had substituted the letter for the spirit. The Pharisee said "Corban" (it is devoted) to escape the rigor of rules for filial duty, and the Jesuit sought the way out of impossible positions made actual by legalism, and in trying to do so stumbled into more impossible positions.

Nevertheless, many Protestant critics have been unjust to the ethical discussions of Jesuitism. They occupy, for instance, no peculiar position on the question as to whether the end justifies the means; and for the simple reason that they, like ethical teachers in all ages, are divided on the subject. But this turns

${ }^{1}$ The calmest account and discussion of this affair, by Huber, pp. $529 f$. 
on the use of words. It is most certainly not "right" to do evil that good may come, but that raises the previous question what is "evil." Is it a "lie" in any real sense if a man saves his life by telling a man in a drunken fury an untruth? Is it "evil" in any real sense-to take Gury's illustration ${ }^{1}$ - when a man is unjustly held a prisoner, and whose escape is a social good, to use trickery to effect his escape? These are questions no abstract letter of the law can answer. And in the discussions with Jesuits carried on by Pascal and lesser writers since, the real attitude should have been a wholesale rejection of any and all merely external laws as binding upon the moral man.

Moreover, in these controversies most of the Protestant critics have permitted themselves to be led off really ethical ground. There are always two considerations in any action: First, the attitude of the agent; his morality is determined by his intent. Secondly, the social outcome of the action, which is inevitable apart from all intent, and may be "bad" or "good."

The Jesuits were often fanatic men of hard, rigid, and sometimes fierce morality. They were willing to die ad majorem Gloriam Dei. To call them "bad" men is ambiguous. So far as fanaticism, hardness, pride, bigotry mingle with our actions we are all "bad." But Melanchthon and Calvin in rejoicing over Servetus's death were mistaken, misled men and not "bad" men. Jesuits were often misleading guides and have a quite undeserved reputation for political cleverness, but they were not "bad" men, and their morality is not worse and not better than any legal morality, whether pharisaic or Puritan. They blundered most shamefully. Far from being really clever, they have been bad political advisers of the papacy. They lost the North American continent for France and Catholicism. They gave Protestant Germany the hegemony of Europe by forcing on the war of 1870 . They lost France to the papacy by stupid intrigues of no meaning, and are now in danger of destroying even the papacy by absurd insistence upon lost positions. But

${ }^{1}$ Gury: "Casus conscientiæ I de peccatis," c. I7 : 2, rv I8I :2, pp. 55 and 56, quoted by Huber, p, I 9 op. cit. 
these things have resulted rather from their single-minded devotion to the lost cause of the Pope's imperial supremacy than from any moral crookedness. Their tragic failure is only one more evidence of the futility of attempting to force the living present into the forms and modes of the dead past.

While this is all true, the Jesuits are not really responsible for the foundations upon which they tried to build. Casuistry begins always as soon as authority, final and definite, is proclaimed. Hence we find the beginnings of it even in St. Augustine, ${ }^{1}$ and we have already seen the necessary development of it in the books of penitence. The Jesuits really deserve great credit for their having by careful systematic elaboration reduced the whole thing to an absurdity. They found it, as father confessors of really good religious people, of the utmost importance to tell exactly a deadly from a venial sin. But only authority makes this plain. Now in the balancing of authority there are four main theories: I. Probabilismus, the less certain may be followed if a grave doctor can be cited on that side. 2. Aequi probabilismus, the less certain opinion may be followed if they seem equally well supported by authority. 3. Probabiliorismus, the less certain opinion may only be followed when a weight of authority makes it more probable. 4. Tutiorismus, $i$. e., the rigorous following of the best-supported authority, against which no probability can be urged. There are again here shades of difference. $^{2}$ It must be remembered that these discussions are to train father confessors.

So also the discussion of the degree and motive of penitence became for the Jesuit confessors a burning one. Attritio formidolosa or attritio servilis was repentance from fear of punishment, and casuistry had to decide how far such penitence had validity. It was agreed that the highest penitence was only contritio perfecta, which meant penitence because of love to God only. ${ }^{3}$

${ }^{1}$ As in his books, "De Mendacio" and "Contra Mendacium ad Consentium."

${ }^{2}$ Cf. Gury's "Compendium theologiæ Moralis," particularly the opening sections.

${ }^{3}$ Cf. Döllinger and Reusch, “Moralstreitigkeiten," pp. 68-94, edition I889. 
The Council of Trent dealt with this question, accepting attritio as sufficient if accompanied by resolve to forego the sin and to do penance, but added that the contritio was higher. ${ }^{1}$ Now here again the Jesuits as the confessors of half of the Catholic world were deeply interested and again out of practical grounds took the more flexible rule. This was not because they were "laxer" as father confessors than others had been, but because they had greater need of elasticity in working an impossible position. They were becoming the confessors of the European courts and princes, and these had never been noted for any strict morality. Exactly the same reasons that controlled Luther and Melanchthon in their unfortunate advice to the elector controlled the individual Jesuits, and they were compelled to defend flexibility to make the system of authority work. That it involved theoretic laxity was inevitable, and that sooner or later the evil effects of this would appear is beyond dispute.

But when we turn to Jansenism all that is found is a stricter legalism, an unflinching application of an external morality. It was a Puritan, though individualistic Puritan, movement. The men and women of Port Royal bowed to authority and to the Pope, and although persuaded that Augustine taught a doctrine of grace very different from the semi-pelagianism of historic Roman Catholicism, they were as much afraid of Protestantism as the Jesuits themselves. One must have deep personal sympathy with the sufferings of the faithful few at Port Royal, and the intrigues of the Jesuits ${ }^{2}$ are exceedingly contemptible. But even the convinced Protestant must carry away the impression that, as a matter of papal imperial policy, the Jesuits were right and Port Royal was wrong.

Liguori $^{3}$ is often confused with the Jesuits, and his rules and

${ }^{1}$ Cf. 4 cap. of 14 th Session, 1651 , and the discussion of it in Döllinger, "Moralstreitigkeiten," p. 7 r.

${ }^{2}$ The best account is in the book already mentioned, Joh. Huber, "Der Jesuiten Orden," pp. 438-495. He was of the school of Döllinger, so stands between extreme views on either side.

${ }^{3}$ Alfonso Maria de Liguori ( $1696-1787$ ) was the founder of the Redemptorists, who are often confused with the Jesuits. He was a most prolific writer, and the 
his main interests closely coincide with those of the Society of Jesus. He began as a probabilist but ended as an aequi probabilist. His casuistry is open to all the objections that can be urged against a legal formal system stretched to try and meet actual life. He was himself forever tormented by scruples and the fear of offending, and as in all such cases tries to justify all manner of really immoral ways of escape from the letter of law. His tricks with Equivocatio and Restrictio mentalis are certainly demoralizing. Yet here again they are the outcome of the system, and it is hard to escape Liguori's conclusions starting with his assumptions. The outcome is hideous, it always must be. It was so in Christ's time and always will be. It is the bankruptcy of an external morality on the basis of outward authority.

The Council of Trent made no advances in systematic ethics, but simply fixed the discipline. The papacy has always been practical and political in its aims rather than theoretical or systematic. It reformed the Catholic system and made it at once more simple and more highly authoritative and centralized. The young Jesuit movement already made its devotion felt, and the new religious vigor of the great awakening found expression in a revived Catholicism. But it made no great contribution to the systematizing of ethics. It indeed regulated the discipline and carefully defined indulgence and sought to guard against abuses, but beyond that it did not go.

Thus in theory and in its teachings the ethics of Thomas Aquinas are the authorized statement of the Roman position.

cult of Mary was his special message. His "Gloria di Maria" ("Glories of Mary," many editions and translations) and his "Moralia Theologia" are still powerful books of propaganda. The best life is by Carl Dilgskron, "Leben des heiligen Bischofs und Kirchenlehrers Alfonsus Maria de Liguori," 2 vols., Regensburg, 1887. There are many Italian editions of his works and a new French edition ("CEuvres completes du S. Alphonse Marie de Liguori. Traduites par les Peres L. Dujardin et Jules Jacques," Tournai, I855 ff.; nouv. édit., r895 ff.), and a German edition in 42 vols. ("Sämmtliche Werke von Alphonsus Maria von Liguori," Regensburg, I842-1847). An English edition by R. A. Coffin, of which, however, only six volumes appeared, London, I854-1868. 
Nor did any philosophic system up to the time of Kant seem to make any impression upon the revived and invigorated Roman Catholic imperialism.

\section{THE ETHICS OF PHILOSOPHICAL PROTESTANTISM ON THE CONTINENT}

The controversy between Arminius and the Calvinistic party was ethically singularly barren. Although in fact the heart of the question was the ethical character of God and his government, the dispute was carried on on scholastic lines, and dealt with the metaphysics and exegetical questions involved, without due consideration of the ethics. So that the protest of Arminius, like that of Socinus, with whom his opponents sought to identify him, never really gave ethics the help that discussion along more fruitful lines might have rendered. But one man came out from the Arminian ranks, or rather from the atmosphere which made Arminius possible, who did much to give ethics an independent place in human thinking.

Hugo Grotius ${ }^{1}$ is the real father of modern international ethics. But the basis of his international ethics is really pagan and not Christian. Not that he was not himself a most devout believer. On the contrary he, like Bacon, still attempted the

${ }^{2}$ Grotius (or de Groot), Hugo ( ${ }_{5} 8_{3}-1645$ ), was alike scholar and statesman. He was condemned by Prince Maurice of Orange to life-long imprisonment, but escaped after two years, and, fleeing to Paris, became later the Swedish ambassador to France. Many editions of his works, and translations of his great work, "De jure belli ac pacis," libri tres, Paris, I625; “The Illustrious Hugo Grotius of the Law of Warre and Peace; with Annotations, III Parts, and Memorials of the Author's Life and Death," translated by Clement Barksdale, 2 parts, London, 1654; "On the Rights of War and Peace: an Abridged Edition," translated by W. Whewell," 1853; "Drei Bücher über das Recht des Krieges und Friedens," in Kirchmann's "Philosphische Bibliothek," vols. XV and XVI, Berlin, I868 sq. This and his "De Veritate Religionis Christianæ," Paris, 1627; editio novissima, 1669, many English translations and editions; "Truth of the Christian Religion, Literally Translated by T. Sedger," London, $2 \mathrm{~d}$ ed., 1859, form our chief source for the ethics. His life has been written by Charles Butler ("The Life of Hugo Grotius; with . . . Minutes of the Civil, Ecclesiastical and Literary History of the Netherlands," London, 1826), and a large literature concerning the legal aspects of his work exists. 
impossible task of separating the fields of knowledge, and admitting the relative and progressive character of "secular" knowledge while still retaining the "absolute" character of knowledge that has been "revealed."

Thus Grotius has a threefold standard in ethics. There is first the law of nature, ${ }^{1}$ which is fixed and quite unchangeable from the beginning of time, ${ }^{2}$ and then following Aristotle there is the given law, ${ }^{3}$ and then besides these there is the law of custom and habit." God's law is twofold. There is a general law given at creation, again at the flood, and then by the revelation of Jesus Christ. There is also a special law given only to the Jews and only binding upon them. ${ }^{5}$ From these complicated premises Grotius strives to build up an ethics that should have international sweep and validity. But in point of fact the foundation has to be laid in natural law (jus naturale) and never rises higher than the old Stoic ethics in its Roman dress. As the student reads the complicated argument of Grotius, wearisome in a degree from being overburdened by quotation after quotation from relevant and irrelevant authors, one is at first surprised at the place and influence assigned to the work. It never really rises higher than Roman Stoicism at its best, and is often on lower planes, as in the defence of private war. ${ }^{\boldsymbol{\theta}}$ Then, however, there is forced upon us the historic significance of such an effort at a time when the old "imperium," whether ecclesiastical or military, had given way, and some basis had to be found for the existence side by side of independent national units. If ever the world sees a great federation of nations, as doubtless it will, men will look back upon Grotius as the historical student who first tried to construct an ethics for such a federation.

1 "Jus belli ac pacis," Prol. r.

2 "Jus belli ac pacis," lib. I, cap. I, X : r-7.

3 "Juris ita accepti optima partitio est, quæ apud Aristotelem exstat, ut fit aliud jus naturale, aliud voluntarium, quod ille legitimum vocat, legis vocabulo strictius posito: interdum et $\tau \dot{\partial} \dot{\epsilon} \nu \pi \ell \xi \epsilon l$, (sic) constitutum," "Jus belli ac pacis," lib. I, cap. I, IX : 2. 4 "Jus belli ac pacis," Prol. I.

5 "Jus belli ac pacis," lib. I, cap. I, XV : 2, and XVII : I-8.

o "Jus belli ac pacis," lib. I, cap. III, § II. 
There are ethical sections in his other best-known work, "De Veritate," ${ }^{1}$ in which Grotius attempts to define the relation of natural law to the Gospel and to revelation. And the outcome of his discussion is a real separation between "reason" and "revelation," and what Grotius did not really intend, an emphasis upon "reason" which makes all revelation superfluous.

The failure with Grotius as with all the seventeenth and eighteenth century men up to Kant is the unquestioned acceptance of a system of absolute truth on the basis of revelation, and of a world of perception apart from the mind perceiving. For Grotius the senses never really deceive the healthy mind, ${ }^{2}$ but there is an antinomy between "reason" and "revelation" which can only be solved by separating their spheres. And in this separation practically everything in which a healthy man is interested is relegated to the field of "reason," and religion is left to deal with questions of but very secondary importance. That such a rationalism should be religiously barren was no wonder, and not even the exceedingly religious cosmogonies of Descartes, Spinoza, or Leibnitz could give back again what religion thus lost.

The assumption by Descartes ${ }^{3}$ of a universal doubt, and then of a reconstruction on the basis of the assurance of personality

${ }^{1}$ Lib. II, $\S \S X I I-X V I I$, and lib. V, $\S$ VI-XIV.

2 "De Jure Belli ac Pacis," Prol. \& XXXIX.

${ }^{3}$ Descartes or Des Cartes, René (Renatus Cartesius), I596-r650. Born at La Haye, Touraine, and of old noble family. The best edition of his works is that of Victor Cousin ("Euvres . . . publieés par Victor Cousin," I I vols., Paris, $1824-1826$ ), and the Latin edition (" $R$. Des Cartes Opera philosophica, Editio secunda ab Auctore recognita," Amsterdam, I650). The best bibliography is that of the last edition of Ueberweg-Heinze, "Grundriss der Geschichte der Philosophie," theil $3, \S$ XIII. The life has often been written, but one of the most lively and sympathetic summaries is that of Kuno Fischer's "Descartes' Leben, Werke und Lehre (Geschichte der neueren Philosophie Band I), Heidelberg, 1897, vierte neubearbeitete Auflage," pp. 149-272. English translation of $3 \mathrm{~d}$ ed. by J. P. Gordy, London, 1887. Kuno Fischer has also admirably translated into German the chief philosophical works, " $R$. Descartes' Hauptschriften zur Grundlegung seiner Philosophie. Ins Deutsche übertragen und mit einem Vorwort versehen," Mannheim and Darmstadt, 1863. English translation by J. Veith ("The Method, Meditations, and Selections from the Principles 
of all life, is neither a real nor possible position. No theoretical doubt ever really more than temporarily shakes the actual basis of our conduct or judgments of conduct. And these judgments are not the result either of the rational process pure and simple, nor of a process of revelation apart from human psychological process and moral experience.

Thus Descartes' analysis of the foundation for ethical advance is a mixture of authority and rationalism, ${ }^{1}$ but his treatment is still really in the bonds of an unpsychological method. Mathematical processes have still something magically superior to the material given in the sense-perception, ${ }^{2}$ and the process of introspection gives us an assurance higher than that gained by observation, ${ }^{3}$ and in spite of Descartes' suspicion of the syllogistic reasoning of logic, ${ }^{4}$ and his rejection of it in the province of physical science for theology and ethics as well as metaphysics, it remains in essence his method. So that even his science never frees itself from a hampering theological metaphysics, ${ }^{5}$ and there is set up a dualism of mind and body which is really fatal to an examination of either, ${ }^{6}$ and this because a knowledge of the soul is more certain than any knowledge of the body. ${ }^{7}$ This knowledge Descartes would gain by introspection and reflection.

of Descartes. Translated from the original texts . . . ," Edinburgh and London, Blackwood, Irth ed., 1907), as well as by others, but generally only of extracts from the "Principles" with the "Discourse" and the "Meditations" in full. The ethics have been especially treated by Max Heinze ("Die Sittenlehre des Descartes," Vortrag (28 pp.), Leipsic, Hinrichs, 1872.

1 "La premiére étoit d'obéir aux lois et aux coutumes de mon pays, retenant constamment la religion en laquelle Dieu m'a fait la grâce d'étre instruit dès mon enfance," etc. "Discours de la Méthode," Cousin's edition, vol. I, p. I47 (1824).

2 "Discours de la Méthode," Cousin's edition, vol. I, p. I 28 (1824).

3 "Méditation seconde," Cousin's edition, vol. I, pp. 246-262 (I824).

" "Discours de la Méthode," Cousin's edition, vol. I, p. I40.

5 "Et ainsi je reconnois très clairement que la certitude et la vérité de tout science dépend de la seule connoissance du vrai Dieu," etc., "Méditation cinquiéme," Cousin's edition, vol. I, p. 321 (1824).

- "Les principes de la philosophie, Première partie," Cousin's edition, vol. II, p. 67 .

7 "Les principes de la philosophie, Première partie," Cousin's edition, vol. II, p. 69. 
The ethics of Descartes revolve about the question of the Highest Good. ${ }^{1}$ This divides itself into two great divisions. God is of course the absolute Highest Good, ${ }^{2}$ but there is a realm less than God in which man seeks his "good," and this is not that of the material things, nor of intellect, because these lie outside our immediate control, but man must seek his highest well-being in the will to virtue. ${ }^{3}$ And this will is free, or at least may be free, and rule over the sensuous elements. This control of the passions is the end of human life, therefore the life of virtue is not in becoming passionless, but in proper control of the passions and their right direction, so that we long for the things worth while. ${ }^{5}$ These things Descartes very beautifully expounds in his third part of the "Passions," separating the noble from the ignoble with great beauty and insight.

Descartes would have the ethical man seek indeed happiness, but a certain kind of happiness, namely, peace and contentment, "vivere beate," is "to have a spirit perfectly contented and satisfied," "and to do this knowledge and a measure of intelligence is necessary, so that every one is bound to cultivate knowledge and intelligence to the extent of his capacity. ${ }^{7}$ At the same time the seat of the ethical life is in the will and not in the intelligence, so that often when we stray we have peace in remembering that we willed to do the good. The relation between the "good will" or virtue and "peace" Descartes leaves almost as undecided as between soul and body. But in his letter to the Queen of Sweden ${ }^{8}$ he seems to assume a necessary relationship.

\footnotetext{
1 The correspondence must be largely relied upon, but besides the "Meditations" (rather religious and metaphysical than ethical, yet containing the foundation of his ethics), see also, "Les Passions de l'Ame," Cousin's edition, vol. IV, pp. 3-163.

${ }^{2}$ On peut considérer la bonté de chaque chose en elle-même, sans la rapporter à autrui, auquel sens il est évident que c'est Dieu qui est le souverain bien," etc., Cousin's edition, vol. X, p. 60.

3 “A la Reine de Suéde," Cousin's edition, vol. X, p. 62.

" "Les Passions de l'Ame," art. CXLVIII, Cousin's edition, vol. IV, p. I6r.

5 "Les Passions de l'Ame," art. CLX, Cousin's edition, vol. IV, p. I7 I.

" "Lettre à Mde. Elisabeth," Cousin's edition, vol. IX, p. 2 I I.

7 "Lettre à A. M," Cousin's edition, vol. VI, p. 3 ro. ${ }^{8} \mathrm{Op}$. cit.
} 
At bottom the ethics of Descartes are little more than Roman Stoicism, but with vagueness and irresolution introduced by traces of Christian feeling.

It remained, therefore, for Spinoza ${ }^{1}$ to work out the Cartesian dualism to a monistic system on the basis of the will. Already in Aristotle there is raised the problem of how the will is related in ethics to the intellect, and the answer is not clear, but as the will must be informed the intellect, as in all Greek ethics, has the place of prominence. This intellectualism is not overcome in Descartes, although distinctly disavowed, and yet the unresolved dualism which haunted the Cartesian system is as troublesome in ethics as it is in the metaphysics. Malebranche ${ }^{2}$ had pre-

\footnotetext{
${ }^{1}$ Spinoza (Despinoza, De Spinoza), Baruch (or Benedict) de ( $163^{2-1677)}$. Bibliography in full in Ueberweg-Heinze, "Grundriss der Geschichte der Philosophie, Dritter Theil $\$$ I 6 and I 7 ," and in Antonius van der Linde's "Benedictus Spinoza, Bibliografie," Gravenhage, I87 I (in Dutch), and "Zur Litteratur des Spinozismus in Zeitschrift für Philosophie," vol. XLV, 1864, pp. 30I-305. The best edition by van Vloten and Land ("Benedicti de Spinoza Opera quotquot reperta sunt. Recognoverunt J. van Vloten et J. P. N. Land. Editio altera," 3 vols., La Hague, 1895). The "Ethica" appears as a separate volume taken from this edition of 1895 . Excellent introduction to Spinoza is Kuno Fischer's "Spinozas Leben, Werke und Lehre," vol. II of his "Geschichte der neuern Philosphie"), Fünfte Auflage, Heidelberg, r 1909. His life is beautifully interwoven into a novel by Berthol Auerbach in his "Spinoza, ein Denkerleben," Neu bearbeitet, Mannheim, I854 (in Gesammelte Schriften, vols. X, XI, Stuttgart, Cotta, 1863,1864$)$. The early life in the tongue of the Netherlands by Jean Coler (Johann Köhler), Lutheran pastor at Amsterdam, is known in the French translation, "La Vie de Spinosa" ("The life of Benedict de Spinoza ... Drawn out of French," p. 92, London, I 706), but must be corrected from the studies of later students, especially van Vloten's. Very sympathetic, yet critical, is Kuno Fischer's sketch, pp. I $21-195$, in the volume already referred to.

${ }^{2}$ Malebranche, Nicolas (1638-1715), of the Congregation of the Oratoria in Paris, wrote, besides his famous "De la Recherche de la Vérité; où l'on traitte de la nature de l'Esprit de l'Homme, et de l'usage qu'il en doit faire pour éviter l'erreur dans les Sciences" (Paris, 1674-1678), which estranged him alike from the Jesuits and the Jansenists, a treatise on morality, "Traité de Morale, par l'auteur de la Recherche de la vérité" (2 parts, Rotterdam, I684); both of these appeared anonymously. The latter is found in the first volume (p. 400) in "Euvres complètes de Malebranche. Ouvrage publié par MM. de Genoude et Lourdoneix," 2 vols., Paris, I837. Here he proclaims man's unity with the reason of God, chap, I : I. This final divine substance is God, and God is reason (raison). The love of order is the fundamental virtue, chap. II : r.
} 
pared the way for a pantheistic monotheism on the basis of Descartes' metaphysics, and now Spinoza deliberately sought a resolution of the dualism upon the basis of intellectual love, whose seat is really in the will.

The one substance is God, who is, however, not personal and is under no constraint, but acts according to his own being. He is not the supreme cause of the universe, if by that is meant a separation between cause and effect, but is the immanent reason for all being existing as it is. ${ }^{1}$ God is the cosmical substance, and the cosmos is God. Everything, therefore, acts in strict conformity to its own nature. ${ }^{2}$ Substance has infinite variety in its attributes, but human intellect knows God under two aspects, that of thought and extension. These are as independent of each other as in Descartes' system, but find their union in God. That is to say, Spinoza is no materialist deriving thought from matter, nor is he an idealist like Malebranche or Berkeley in that he derives material from thought. So far as attributes have independent existence, both extension and thought represent the inner being of God, but they are not opposed to each other. We are only interested in Spinoza's elaborate metaphysics so far as they affect our problem, and it must be confessed that within the confines of Spinoza's pantheism there is no room for a really Christian ethics. All the relations under which Jesus thought of man and God are made impossible symbols in which to interpret Spinoza's world.

It has two divisions, one of union and the other of benevolence, chap. III : 8 , and this love of order or harmony is the basis for our unity with God in free and loving co-operation, chap. IV : Io-I9. And yet this freedom in any real sense is a gift of God's grace, chap. VII : $1-3$, and the means of grace are Jesus Christ and the sacraments of the church, chap. VIII : $1-4$, and motives to right-doing are the fear of hell and the desire for happiness, chap. VIII : $13-16$, and hence he develops a somewhat mystical version of Augustine's ethics with intrusions from Descartes in exceedingly beautiful French, but with skilful evasion of the principal problems and much real confusion of the issues.

1 "Deus est omnium rerum causa immanent, non vero transiens. Eth. I : Prop. 18 and in the demonstration Spinoza points out, "Deinde extra Deum nulla potest dari substantia, hoc est res quæ extra Deum in se fit."

2 "Ethica pars," IV, prop. 59. 
The modes under which we know matter are motion and rest, the modes of thought are intellect and will. These are infinite like the attributes and have neither beginning nor end. Spinoza is bound up with a determinism that carried over into the sphere of conduct is fatalism; from this Spinoza vainly tries to escape by intellectualism of a thorough-going character. ${ }^{1}$ Man can only be free through thought. Any affection (affectus) which is a passion ceases to be a passion so soon as we have a clear and distinct idea of it. $^{2}$ To understand the world is to mark its necessary inevitable character and to cease to be weak and fearful and indeed to realize that there is nothing either good or bad, but that things simply are. Religion is this sense of complete acquiescence in the nature of things, and it is hard to see how it differs much from the Stoic resignation of later Roman days. Nor is it easy to see why it should be a joyful resignation. The certainty that substance is infinite and imperishable will fill us with joy or sorrow according to our experience of its painful or pleasurable character. We may as philosophers surrender gracefully to the inevitable because it is "of the nature of things," but our opinion "of the nature of things" may then be either that of Leibnitz or Schopenhauer, and there can be no room in Spinoza's ethics for a duty to trust or believe, for the essence of his morality is to see things as they are. We may rejoice that the despised, poor, fear-haunted Jewish outcast rose to such heights of peace and faith, but one distrusts his analysis of the groundwork of that philosophic calm and gentle, loving, simple life as given in the Pars Quinta of his ethics.

Moreover, throughout the metaphysics and ethics of Spinoza runs the great fundamental fallacy that in the method of mathematics the human mind has access to a type of certainty more stable than that based upon phenomenal experience.

Upon this assumption there was built up a new philosophical scholasticism, which reached its climax in the school philosophy that dominated the thinking world up to Kant's critical examina-

1 "Ethica," pars IV, de servitute humana, and pars V, de libertate humana.

2 "Ethica," V, prop. 3, and demonstration. 
tion of it. This school philosophy was under the influence of Leibnitz $^{1}$ and Christian Wolff. Leibnitz was more interested in metaphysics and the metaphysical assumptions that precede ethics than in ethics itself. But Christian Wolff formulated the ethics on the basis of Leibnitz's metaphysics and gave to rationalist Protestantism an almost final ethical statement. Wolf ${ }^{2}$ and Leibnitz felt the influence of the tremendous services that mathematics was rendering to invention. It was not Bacon's method, but the application of mathematics as a conceptual short-hand to physics and to chemistry, enabling invention to

${ }^{1}$ Leibniz (or Leibnitz), Gottfried Wilhelm von ( $1646-1716$ ), was born in Leipsic, where he also began his studies. For full details of a most useful and interesting life, see Guhrauer's "Life" ("Gottfried Wilhelm, Freiherr von Leibnitz, Eine Biographie von Gottschalk Eduard Guhrauer, 2 Theile, Breslau, r842, mit Nachträge, I846"). He did much for higher education by the founding and conducting of the Berlin Academy, whose first president he was. His correspondence is preserved in the library at Hanover, not all of which has been published. The philosophical works are edited by Paul Janet. 2d ed., Paris, I900, and there is an older edition ("G. G. Leibnittii opera philosophica quæ exstant Latina Gallica Germanica omnia. Editio recognovit e temporum rationibus disposita, pluribus ineditis auxit, introductione critica atque indicibus instruxit J. E. Erdmann cum Leibnitii effigie," 2 vols., Berlin, I839, r840). The philosophical works have been translated by G. M. Duncan, New Haven, 189o. The Open Court Publishing Company in Chicago has published his important works, in 1902 ("Discourse on Metaphysics, Correspondence with Arnaud, and Monadology," with an introduction by Paul Janet, Member of the French Institute, translated from the original by George R. Montgomery). Very full bibliography in Ueberweg-Heinze: "Grundriss der Geschichte der Philosophie," Dritter Theil, §XXIII, and in Alfred Weber's "History of Philosophy," translated from the French by Frank Thilly, New York, Scribner, 1903; also in Kuno Fischer's third volume of his "Geschichte der neueren Philosophie," "Gottfreid Wilhelm Leibniz, Leben, Werke und Lehre," 4th ed., Heidelberg, rgo2.

${ }^{2}$ Wolff (Wolf), Christian, Freiherr von (I679-I 754), born in Halle as the son of an artisan. His works are most numerous, and his philosophy appears both in his exceedingly discursive Latin and in admirable German text-books (various editions, see Ueberweg-Heinze: "Grundriss der Geschichte der Philosophie," Dritter Theil, $\S$ XXVI). The student of ethics will find nearly all he needs in the "Ethica," five parts. The edition cited is "Philosophia moralis, sive Ethica, methodo scientifica pertractata," etc., Halæ Magdeburgicæ, r750I753. But a study of his German works is a good introduction to the terminology of Kant, who never shook off entirely the influence of Wolff upon his ethical thought. 
overcome the limitations of human senses, and extending almost indefinitely the potential reach of human observation that marks the era from Descartes to Kant. Both Leibnitz and Wolff were distinguished mathematicians, and the philosophy of the period may almost be called the period of almost pathetic faith in mathematics as the key to the absolute.

On the field of ethics Wolff is, however, as scholastic as Thomas Aquinas, only "reason" gives the content as well as its analysis. And by reason is meant the discursive analysis of the conceptional machinery. The quiet assumption made by Descartes, Leibnitz, and Wolff, as well as by the English deists, was that the traditional content of the religious-ethical life could all be taken somehow out of the discoursive reason by rational process. And however indefinite its limits, this content is for them still a closed system as much as the closed systems which Biblical Protestantism thought were given in the Scriptures and Roman Catholicism in the traditions of the church.

Wolff in the prolegomena to his ethics claims for philosophy, rightly handled, an absolute certainty. ${ }^{1}$ The end of ethics is man's happiness, ${ }^{2}$ and he foresaw the reach and scope of the future science. $^{3}$ But he only takes the theory of knowledge of Leibnitz and rationalizes the traditional ethical-religious content, and that in extremely wordy manner, though with great clearness and learning, and with a useful widening of the German terminology.

This brings us to the close of our study of systematic ethics within organized Christianity. From the Reformation on the stream widens. Authority is shifting. The ecclesiastical im-

\footnotetext{
- 1 "Ita in philosophia morali quoque demonstranda sunt omnia, ut certam habeamus, praxin," Proleg. to "Ethica," p. 3, edition 1750.

2 Proleg. to "Ethica," p. 5, edition I750.

${ }^{3} \mathrm{He}$ says in the Prolegomena that it presupposes ontology, psychology (empirical), natural theology, practical philosophy, universal and the law of nature and of nations, and even cosmology.

'Students of Kant in the English-speaking countries would do well to study some of Wolff's German works as a preparation for the understanding of Kant's complicated terminology.
} 
perialism built up so carefully on dogmatic unity has given way. Biblical Protestantism has utterly failed to find in the authority of so wonderfully diverse a literature as the Scriptures a sufficient basis for re-establishing intellectual unity. Nationalism and individualism swept away the weak barriers Protestant ecclesiasticism sought hurriedly to erect. The seventeenth and eighteenth centuries sought in "reason" a sufficient apology for the maintenance of the traditional religious-ethical life. The services that mathematics had rendered the cause of human progress made it the natural ally to which men turned. Two names are linked in our history as the destroyers of this false hope. Hume and Kant turned men's gaze in upon the nature of the whole conceptual machinery and compelled Protestantism to reckon at last with the limits of the human mind. From that hour the struggle for an absolute knowledge in theology as in ethics has been a losing battle.

At that hour, however, ethics began to really come to her own. Not now as an absolute content given on authority and within the limits of a closed system of human duty, but as a science of human conduct working like any other science on the material given in human experience and limited like all science by the capacity of the human mind. As physics is the study of the laws of force and matter, that we may adjust our life to our surroundings, and by knowledge of the laws of force and matter may master our surroundings, so the science of ethics is the study of the laws of human life and conduct that we may adjust our lives to our changing surroundings and become masters of those surroundings. This involves the creation and exploitation of ever new ethical ideals. The false assurance of an absolute in ethics has been a hinderance to the formation of new ideals. They have had to shelter themselves almost sneakingly under the cover of misinterpretations of the past. Thus almost every battle against slavery, feudalism, private war, the duel, persecution for faith's sake, for freedom and toleration has been waged in the face of an absolute ethics that claimed a completed and divinely given content sanctioned by a revealed authority. 
The new Protestantism from Hume and Kant placed at last faith in the room and stead of authority, and thus came back again to the divine ethical autonomy of Jesus, who promised a Holy Spirit guiding men step by step into all truth, but who himself felt that the only real basis was the experience of the loving individual heart working on and with the experience of all the ages. All authoritative absolutism, whether ecclesiastical or Scriptural or rationalist, has gone. Even those who think they still maintain it flee daily to the modern workshop and use the tools furnished by the modern study. In law and ethics, in theology and philosophy, the ghosts of the absolute still haunt us, but they are shadowy with the twilight of a rising day. And as that day breaks we enter with joy upon the study of the past. It is, indeed, no longer a storehouse of infallible revelations, but it is a history of a steadily unfolding revelation, of God to man, and of man to humanity. Augustine, Bernhard of Clairvaux, Francis of Assisi, Luther, Calvin, and Tyndal become voices of God to us speaking, not indeed in infallible tones as Paul and Aristotle were thought by the schoolmen to speak, but all the more clearly and wonderfully because they speak as divinely illumined men to men seeking divine guidance.

The history of ethics is not more and not less a weary struggle with human limitations than are the histories of astronomy and chemistry. They, too, had to shake off the chilling hands of an authoritative past, that in the very sense of their helplessness they might gain strength.

On no field of human activity is the realization of the limited and relative character of all our knowledge at first more painful and more depressing than upon the field of ethics. And yet a moment's thought should show us human life struggling at every moment with just that half-darkness. No matter how absolute and final the commandment, Thou shalt do no murder! may at first appear, the moment we ask, what is murder? all the doubt and uncertainty of a thousand differing voices besets us. Is capital punishment "murder"? Was Servetus "murdered"? Was the beheading of King Charles "murder"? Was Hamilton 
"murdered" by Burr? Is modern warfare wholesale "murder"? What is the good of an "absolute" authority that cannot answer these most pressing questions? No two churches, no two councils, no two ecclesiastical courts, no two popes would probably answer all these questions alike. What, then, is the good of an "absolute" authority that leaves a poor erring soul to take his choice between answers, one of which must be wrong, and with only the individual experience to guide him?

Christian faith replies that the process is more than the immediate product. Our mistakes and wanderings are our training for communion and fellowship with a Father of free as well as loving children. Only the truth can make us free, and that truth, in ethics as in all other sciences, can only be won by hard work on the materials of human experience. In that struggle for truth Christian faith gives us assurance that in spite of all mistakes, nay, because of them and through them we may yet enter the kingdom of God's loving fulfilled purpose. In this spirit we have tried to faithfully and as objectively as possible follow the struggles and splendid victories of God's army of chosen spiritual and ethical leaders. If our judgments have often been one-sided and wrong, as they like enough have been, it has been through no lack of respect for those who have done such yeoman's service in the discovery of truth. And even when the emphasis has often been, perhaps, rather on the failings than the successes, it has only been so because it is so largely from the failures of great men that we lesser ones learn to steer our smaller way aright. 


\section{CHAPTER IX}

\section{THE MERGING OF CHURCHLY WITH PHILOSOPH- ICAL ETHICS-A SUMMARY}

Note of Introduction.-I. Kant and Post-Kantian Thought; Fichte; Schelling; Hegel; Schleiermacher-II. Kant and Empiricism; Fechner; Lotze; Wundt-III. Rationalism in France; Voltaire Rousseau; The Encyclopædists; Cousin; Comte-IV. The English Reaction upon Hume; Price; Reid and Uncritical Intuitionalism; Coleridge; Green-V. English Utilitarianism; Bentham; Mills; Darwin; Spencer.

\section{INTRODUCTORY NOTE}

This chapter can only be a hasty summary of the history of ethics from Hume and Kant to the present time, for the history of ethics within Protestant organized Christianity so merges with philosophic ethics that there is no distinguishing line. It is impossible to write a history of Protestant ethics and omit Bentham and Herbert Spencer, but it is equally impossible to regard them as constituent elements of organized Christianity. Protestantism, in its denial of the ever-present authority of an ecclesiasticism to determine thought and conduct, failed happily to really establish any past authority as final in ethics. It would have been fatal to moral progress if it had succeeded in doing so. The faith of Christianity in all ages has been that a Holy Spirit is guiding us into all truth. Moreover, in Protestantism the distinction between the religious and the secular has broken down. It is a false antithesis. Ethical advance is always religious in the highest sense, and it is not in ecclesiastical Christianity alone that ethical advance has had its rise. In a really Protestant ethics dogmatism has no proper place. The science of Christian ethics is, like all other sciences, a science of experience with its advancing organization of thought. The 
destruction of dogmatic ethics on the basis of authority was complete with the work of Immanuel Kant, ${ }^{1}$ whose services on the ethical field are largely the examination and rejection of the last traces of dogmatic rationalism. The critical rationalism which he sought to substitute in ethics must, however, be seriously challenged. The weakest point of Kant's philosophy is his formal attempt at ethical reconstruction.

I. Kantianism is the reaction upon the dogmatism of such as Wolff and an attempt to again assert faith in its proper sphere. Kant himself was roused, as he explains, by the necessity laid upon him of meeting the doubts and the negations of Hume; he entered upon his critique of pure reason in order to get a basis for faith. His style is overladen by the terminology of dogmatic rationalism; his schemes of classification are artificial and by their elaboration defeat his own end. He never frees himself completely from the superstition that mathematical conceptualism has something superhuman in it and can be divorced from sense-perception. The influence at this point of Descartes, Leibnitz, and Spinoza, not to speak of Plato, is apparent. Moreover, some of his most fruitful conceptions are either not worked out at all, or they are implicitly contradicted by the formal outcome. At the same time he is the founder of the new Protestantism which looks out upon a world of science with a faith large enough to trust scientific analysis as by divine

\footnotetext{
${ }^{1}$ Immanuel Kant, born April 22, I724, died February 12, I804. His whole life was spent in Königsberg. The best life is still that by Schubert, F. W., in Schubert and Rosenkranz's edition of his works, although corrections in details are being constantly made, as in Arnoldt's (E.) "Excursen zur Kantforschung," 1894. The completest English life is that of Stuckenberg, J. H. W.: "The Life of Immanuel Kant," London, I882. The edition of his works undertaken by the Berlin Academy of Science is not yet finished. The ethical works are translated (unequally) by Abbott, Thomas Kingsmill, the 5th ed. in 1898. Max Müller has translated the "Critique of Pure Reason." An excellent popular introduction to Kant is Paulsen, Friederich: "Immanuel Kant, His Life and Doctrine," admirably translated by Creighton and Lefevre (I902), who have added the English works of chief importance to the bibliography. Schopenhauer's criticisms upon Kant are among the best in the literature, but the system of Schopenhauer forbids any serious development of his own ethical thought as a proper substitute.
} 
right in its own sphere, and at the same time to demand the recognition of a world of supersensuous values which scientific analysis can neither give nor take away.

The main interest for the student of ethics in the "Critique of Pure Reason" is its demonstration of the possibility of a concept of freedom not found in the phenomenal world. This freedom is the moral spontaneity needed for the world of moral activity. This freedom which analysis of our world of knowledge shows is possible, the ethical man asserts as a first necessity of his rationality. The moral man asserts as a postulate of his moral will, God, freedom, and immortality. ${ }^{1}$ He lives in a world that belongs essentially to supersensuous reality, as well as in a world of phenomenal appearances held together in the category of causality. The basis, therefore, of his moral world is intuition, but it is a critical intuitionalism made necessary by a metaphysical examination of the world of experience. ${ }^{2}$ Only that conduct is really moral which is dictated by respect for the categorical imperative of the law within each rational creature. All conduct that has pleasure or happiness as its motive may be legal and appropriate, but it is not moral. ${ }^{3}$ The end of moral conduct is perfection, and faith in its attainment makes the postulate of immortality a necessity. God is needed to unite worthiness and happiness, which cannot be identified in the world of our experience as the Epicureans and Stoics would from different stand-points do. "The characteristic of this moral law must be its universality. Hence Kant gives as a rule for conduct the possibility of willing that that conduct should be a universal law. ${ }^{5}$ It is at this point that Kant's greatest service to ethics

1 "Kritik der praktischen Vernunft (v. Kirchmann's edition, vol. II, pp. $3^{8} f$. and $\left.146-15^{8}\right)$, II : $2 ; \mathrm{V}, \mathrm{I}, \S 8$; IV and II : 2 ; III.

${ }^{2}$ Carried on in "Kritik der reinen Vernunft," and in "Grundlegung zur Metaphysik der Sitten," v. Kirchmann's edition, vols. I and III.

3 "Kritik der reinen praktischen Vernunft," I :3, v. Kirchmann's edition, vol. II, pp. 86-107.

4 "Grundlegung zur Metaphysik der Sitten," v. Kirchmann's edition, vol. III, pp. 67-73.

s "Der Analytik der praktischen Vernunft II," v. Kirchmann's edition, vol. II, pp. $83-84$. 
ends. His destructive criticism of dogmatic rationalism by revealing the complex character of "ratio," and his forceful attacks upon all types of eudæmonism and hedonism that claim to exhaust the content of our moral reactions, stand to this day. At the same time Kant is not true in his ethics to the analogy he sets up between the categories of the pure reason and those of the practical reason. He is still haunted by the ghost of the slain absolute, and vainly seeks to escape the relative character his critiques make inevitable for all knowledge whether in the fields of metaphysics or ethics. The will to do the moral thing is according to Kant the final essence of morality. He rightly rejects all final authority outside of ourselves as capable of giving content to the moral life; he fails to draw the inevitable conclusion that the content must ever be a relatively correct interpretation of human experience. The concept of "oughtness" is empty until experience gives it content; but experience without the concept "oughtness" could never produce the moral life but would move in the realm of mechanical causation. Even the Golden Rule, of which Kant's formula is but a modification, is an empty concept until intelligent interpretation of our own experience gives it content. We simply do not yet intelligently know what we want others to do to us. It is taking us centuries of ethical experience to find out.

Thus Kant does no proper justice to eudæmonism as a test of empiric morality. And this was because he failed to catch the genetic point of view already on the horizon. He for the same reason utterly failed to grasp either the meaning and dignity of the morality of the Old Testament or the gentle graciousness of the ethics of Jesus and Paul. His own actual ethical thinking was hard and cold, though lofty and imposing. His own mental world was a reaction, not only upon the dogmatic rationalism of the schools, but upon the Pietism of his early training. And yet he saved Protestant ethical thinking from being lost once more in a rationalistic scholasticism on the one hand, and from seeking its salvation from that fate in ascetic and mystic emotionalism on the other. 
The ethics of Fichte 1 reveal a strong emotional reaction from the world of Kant's interest on the basis of that side of his thinking in which the "thing-in-itself" was the important element. Kant disowned Fichte, just as Fichte disowned Kant; but it is none the less true that Kant left an unresolved discord between the noumenal and phenomenal. Fichte instinctively turned with his keen ethical interest to the noumenal, where Kant had placed ethics. And on the basis of the autonomous "I" in its relation to the "not-I," evolved a fantastic but most interesting rationalism. The meeting-place of the objective and the subjective is the "II' the intelligence, the Reason." ${ }^{2}$ The freedom of the "I" is the essential postulate not only for moral action, but for any action at all, and the outcome of the extensive dialectic of the whole first two parts ${ }^{3}$ is the simple Kantian formula, "Act always according to your best persuasion of your duty." The universality of the command links us with the unchanging intelligible world, whereas the wavering obedience to nature's impulses links us with the changes in time, ${ }^{4}$ in the world of time. The correctness of our persuasion must come from within, and the guarantee is not given in theoretical knowledge but as a "practical" (moral) judgment.

The rationalistic character of the ethics is seen in the three moral laws which Fichte formulates: "I. Negative: never subordinate your theoretical reason as such, but investigate (forsche) with absolute freedom without reference to anything but your knowledge (Erkenntniss). (Set no goal [Ziel] for yourself beforehand, for where should it come from?) 2. Positive: Cultivate (bilde) your capacity for knowledge as far as you can:

${ }^{1}$ Fichte, Johann Gottlieb, $1762-1814$. Collected works in eight volumes, by J. H. Fichte, Berlin, $1845-1846$. Those of special interest to the student of ethics are "Grundlage des Naturrechts nach Principien der Wissenschaftslehre," vol. III, pp. $1-385$; "Die Staatslehre, oder über das Verhältniss des Urstaates zum Vernunftreiche," vol. IV, pp. 396-600, and, particularly, "System der Sittenlehre nach den Principien der Wissenschaft," vol. IV, pp. I-365, and "Reden an die deutsche Nation," vol. VII, pp. 259-516.

2 "Die Ichheit, die Intelligenz, die Vernunft," "Works," vol. IV,.p. I.

${ }^{3}$ First and second "Hauptstück," "Works," vol. IV, I-I56.

4 "Works," vol. IV, p. I6g. 


\section{CHURCHLY AND PHILOSOPHICAL ETHICS 58I}

learn, think, investigate, as far as it is possible for you. 3 . Limiting: relate all your reflection, however, formaliter to your duty.-Investigate as a matter of duty and not from simple intellectual curiosity, or to simply occupy yourself.-Do. not think in order to discover this or that as your duty-for how could you before your own personal knowledge know your duty?-but in order to recognize what your duty is." 1

The extreme individualism that would naturally result from Fichte's ethical fundamental postulate he modifies by his interposed state, which plays a great part even in his ethics, ${ }^{2}$ but into which space forbids us to enter.

His practical ethics comes to light in his "Reden," or "Addresses to the German Nation," in which, amidst a good deal of confusion and much that is extravagant and fantastic, a high ideal is set forth, and produced great social and political effect. ${ }^{3}$

So also the church has a place in Fichte's ethics, as the place of union about simple symbols of a common purpose, ${ }^{4}$ but not in such a way as to form a tyranny over our own free thought as to what the symbol stands for.

The final sections of the third division ${ }^{5}$ of his system are given up to his discussion of duties, which is a rather disappointing treatment and has less originality than in the "Reden," more particularly as the social order is treated unconsciously as Stoic.

The ethics of Schelling present no material advance upon Fichte, as one might assume from his predominant interest. As in Spinoza, the metaphysico-cosmical swallows up the ethics.

A real advance was, however, made by $\mathrm{Hegel}^{6}{ }^{6}$ in his introduction of the historic genetic point of view. The ethics are not

1 "Das system der Sittenlehre," "Works," vol. IV, p. 2 I8.

2Besides his "Grundlage des Naturrechts," "Works," vol. III, I-385, see "Der geschlossene Handelsstaat," vol. III, pp. 389-513, and "Das System der Sittenlehre," "Works," vol. IV, pp. $23^{8} f f$.

${ }^{3}$ There are many editions. In the collected works in vol. VII, pp. 259-499.

"Among many passages, see "Das System der Sittenlehre," "Works," vol. IV, pp. $24 \mathrm{I}-245$.

5 "Works," vol. IV, pp. 254-365.

${ }^{6}$ Hegel, Georg Wilhelm Friedrich, 1770-1831. Collected works in nineteen volumes, by the "Hegel Verein," Berlin, $183_{2}$ ff. Most of the volumes have been 
fully developed, but the social character is marked, and is in many respects a development of and advance upon Kant's "Kingdom of Ends." The moral ideal unfolds itself in the family, the citizenship, and the State, and the philosophy of history is the explication of this unfolding. The conception of liberty as taught by Rousseau is now delineated under the familiar formulæ of thesis, antithesis, and synthesis. But the idealism is the unfolding of an objective absolute in very different terms from those of Fichte and Schelling. Nor does Hegel succeed in keeping morality and legality as far apart as the underlying Kantian thought demands. In fact morality consists largely in adjusting the relations of free personalities on the basis, it is true, of an unfolding of personal moral obligation.

The influence of Hegel has been remarkable, and no one having once come under the influence of his thought ever seems wholly to escape the forms in which he did his thinking. The social character of his ethics and theory of law has been profoundly influential. The State, as Hegel conceived it, being the phenomenal reality of the unfolding moral purpose, and hence the constantly increasing realization of God's will on earth.

In Protestantism Hegelianism gave rise to two great movements: the one the critical school now known as the BaurTübingen school, the ethics of which remain in the framework of Hegel's earlier thought; the other the reaction upon Hegel in the extremely influential ethics of Schleiermacher. ${ }^{1}$

The ethics of Schleiermacher have a twofold character. He separates philosophical from Christian ethics. On the philo-

since re-edited. Those of most interest to the student of ethics are vol. VIII, containing the "Grundlinie der Philosophie des Rechts," etc., and vol.IX, "Vorlesungen über die Philosophie der Geschichte," 2d ed., by Hegel's son. But to understand Hegel the student must master the extremely difficult vol. II, "Phænomenologie des Geistes." "The Philosophy of Right" is translated by Dyde, S. W. London, 1896. A "System der Sittlichkeit," published from the manuscripts after death, and without the author's revision, was published by Georg Mollat, 1893, but adds little light upon his ethical system.

'Schleiermacher, Friedrich Ernest Daniel, 1768-1834. Collected works in three divisions: I, "Zur Theologie"; II, "Predigten"; III, "Zur Philosophie und Vermischte Schriften," Berlin, 1835-1864. 


\section{CHURCHLY AND PHILOSOPHICAL ETHICS 583}

sophic side he attempts on the basis of Kant to escape the monastic determinism of Spinoza by postulating in the world of determined causality, moral beings acting as well as being acted upon. It is at this point that Hegel's thought merges with Spinoza. Every part of our world is both acting (tätig) and suffering action (leidend). As acting we feel ourselves free and are justified in this feeling. As suffering action we feel ourselves dependent. When we raise these primary experiences into the world of ultimate reality we have morality and religion. For religion is the sense of dependence and morality the sense of free activity. But this free activity is not emancipation from the chain of causation, but the development of each according to the law of its being. Man being a moral being with the sense of dependence must be alike moral and religious in order to reach full manhood. Sin is eventually traced to lack of (moral) intelligence. The "lower" forces are not mastered by the moral will and brought into harmony with the dominating aim. Sin is "ugly" and unæsthetic. This (moral) intelligence must be combined with "nature," and the process gives us "goods." The discussion of these "goods" or values forms the first part of his ethics. The absolute unity of reason and nature in a mastery of nature by reason is the highest good. And in this discussion the influence of Platonic intellectualism is apparent. In order to attain the highest we must have inward power, and this is virtue, whose discussion is the second point of view from which the whole field of ethics may be seen. These virtues may be divided according as reason (moral) is directed upon nature to attain harmony with it. But a third point of view from which again the whole ethical field may be viewed is that of "Duty," which represents the relation of the moral being in the variety of his actions to the end or goal of his moral purpose. This involves a relation to the moral law, and the various attitudes give us the various duties. Thus we have in ethics a Doctrine of Values, a Doctrine of Virtues, and a Doctrine of Duties. $^{1}$

\footnotetext{
${ }^{1}$ Güterlehre; Tugendlehre; Pflichtenlehre.
} 
Rather complicated divisions mark the application of Schleiermacher's ethics. He has two regions of marked social significance; these are our relations with one another in systematized contact (verkehr) and systematized thought and speech. But we have also morals growing out of our unfolding personalities, in property and in our personal feelings. All these are spheres of moral activity. They give rise respectively to law, to faith, to social activities, and to revelation, which must ever remain therefore individual. These find their appropriate expression in the State, the church, the social association, and the school. All have a common basis in the family in which personality and the "other personality" are brought into unity. On this basis also he tries to classify both the virtues and the duties, and inspirational and edifying as much of his treatment is, it is too much an artificial scheme to be really satisfactory.

Schleiermacher must be still classified in the field of ethics as a rationalist; he is indeed a critical rationalist, under the distinct influence of Kant, but the concept is after all the essence of the ethical reality, and the unfolding of the concept is the key to truth. The genealogy of his thought is to be traced through Spinoza to Plato; and his influence in the thought of the more recent men like Pfleiderer is always on the side of this somewhat barren even if most fascinating intellectualism. ${ }^{1}$

2. Kantianism had, however, another line of development. As Fichte and Hegel caught at the transcendental elements of his system, and by giving them the emphasis worked out philosophic structures which were most perilously near the very thing against which he felt himself born to protest, so the empiric elements of his thought called into being systems in which the transcendental was distinctly ignored, or dealt with as gentle and even useful but wholly unscientific dreaming and speculation. Such was the attitude of one of the most strik-

'This intellectualism appears also in the work of Schopenhauer and von Hartmann, whose ethics are based on "pity" defined in terms of Buddhism rather than Christianity, but which lie beyond our scope. 


\section{CHURCHLY AND PHILOSOPHICAL ETHICS 585}

ing and attractive figures in all German philosophy, Gustav Fechner. ${ }^{1}$

Fechner is patently dependent upon Kant in his theory of knowledge, and the use he makes of it is to separate sharply between the two worlds of our experience-that of empiric sensational experience and that of experience with the supersensual values. These two are equally valid experiences but give quite different types of assurance. We may, and indeed must, deal honestly with both, but we cannot at our peril confuse them. Most amusing is one of Fechner's skits in which he holds up to ridicule this confusion in "A comparative anatomy of the angels" (1825). We may seek, for instance, from the physical study of plants to determine the type of their phenomenal existence, but having determined the type only analogy with our own psychical life can give us any clew to its character. When Fechner, therefore, turns to transcendental metaphysics, he lets his beautiful fantasy and imagination have full sway. $\mathrm{He}$ is poet and mystic and seer by highest divine right, for here we are not bound by sensational empiricism, but by experience in the field of æsthetic, moral, and religious values. He has no organized ethics on this basis, but its constitution would not be a difficult task.

In many respects seeking the same aim is one of the greatest of post-Kantian thinkers, Lotze. ${ }^{2}$

On the basis of critical intuitionalism, Lotze seeeks to over-

${ }^{1}$ Fechner, Gustav Theodor, r801-r887. The writings of interest to us are especially: "Die Tagesansicht gegenüber der Nachtansicht," ı879; "Nanna oder über das Seelenleben des Pflanzen," 2d edition, 1899, and "Zendavesta oder über die Dinge des Himmels und des Jenseits," 2d edition, r9or, and "Das Büchlein vom Leben nach dem Tode," 4 th edition, 1900.

${ }^{2}$ Lotze, Rudolph Hermann ( $1817-1881$ ). His interest was religious and ethical throughout. The student of ethics will find the best statement in his "Mikrokosmus, Ideen zur Naturgeschichte und Geschichte der Menschheit," 3 vols., 5 th edition in 1896 , and particularly in book V, chap. 5 , and book VI, chaps. $x-5$ (both in vol. II). The English translation is in two volumes (1885). See also "Grundzüge der praktischen Philosophie," notes taken in his classroom and published, second edition, r884. Professor Rehnisch has collected the most complete list of Lotze's writings. They are published as an appendix to "Notes on Psychology," published in the same series, $1881-1884$. 
come the dualism which unquestionably remains in Kant. As in Schleiermacher and Fechner certain elements are taken over from the metaphysics of Spinoza, but the mechanical determinism of Spinoza is rejected and in Kantian terms. The ethical man has as a fundamental experience the sense of "ought." Against determinismus, "theoretically there is nothing to be said. The motive to the denial of such views lies in the wholly undemonstrable but strong and immediate conviction that they are false, and that the conception of an 'ought' and 'obligation,' which has no place in this view (deterministic), is on the contrary of the most sure and the most unquestioned validity." 1

But on the other hand Lotze subjects Kant's categorical imperative and his "naked sense of obligation," without reference to pleasure and pain, to a searching and destructive criticism. $\mathrm{He}$ shows that in truth such an abstract emotionless moral sense is impossible. All we can postulate is the capacity for a moral ideal; the working out of that moral ideal must be under the conditions of pleasure and pain. Then we are confronted by the task of determining the worth or value of different types of pleasure and pain, and these estimates of worth or value depend upon the constitution of the individual who estimates; and the estimates again take place under the complex conditions of varied human life in its inter-relations with other human lives and with nature. "Pleasure in itself is, then, that light in which existing reality first displays its own objective excellence and beauty." 2 Thus the content of all traditional morality grows out of experience and is not the unfolding of universal principles; and experiences are of pleasure and pain, of worth and worthlessness. Conscious principles of action are slowly formed, and their application to complex situations tests their validity and gives them ever greater hold over us as they justify themselves in experience. Thus in ever greater degree the intellect is called in to co-operate with the moral, volitional, and emotional elements in our nature to formulate moral concepts whose binding force upon our life is their appeal to our whole

1 "Grundzüge der praktischen Philosophie," 1884, p. 25.

${ }^{2}$ Mikrokosmus, book I, chap. 5 (the fourth section in the translation). 


\section{CHURCHLY AND PHILOSOPHICAL ETHICS 587}

nature, and their ever greater justification in the widening moral experience of the race.

In this way Lotze seeks to make room for the empirical elements in the totality of any given morality. His idealism is therefore also teleological, because the morality of an action is determined not only by the abstract sense of obligation as Kant defined it, but also by the degree of value or worth that the end possesses which the moral agent sets before himself.

In marked independency this line of thought reflects itself in the work of such recent men as Paulsen, Wundt, and Höffding; and it forms also the basis of the ethics of Albrecht Ritschl, whose dogmatic interest, however, prevented him from ever organizing his ethics in the same full way.

Thus the systematic ethics of modern Protestantism has broken the bounds of its ecclesiastical organization. In an everincreasing degree organized religious life must restrict itself to inspiring men to seek the highest ethical ideals and to give strength and consolation to them in the search, but refuses to dogmatically formulate the content of that ideal. Thus the formal concept of the kingdom of God must receive its content from the advancing political, social, and ethical experiences of the race, and these experiences must be interpreted into all manner of new social and ethical experiments. The family group that gave form and color to the ethical ideals of Jesus still maintains itself in the Christian consciousness as the profoundest basis for the ethical life; and in the exaltation of the moral autonomy of each member of the group as the aim of the group, both the high individualism of the New Testament, and the exalted social ideals of the Old Testament, on its highest levels, are resolved into a higher unity.

How completely modern empiric ethics has united itself with an ideal philosophy which may or may not be interpreted in a Christian sense is seen in the theory of ethics held by $W$ undt. $^{1}$

\footnotetext{
${ }^{1}$ Wundt, Wilhelm M., r832. The student of ethics should get first an introduction to his system either by reading his "Einleitung in die Philosophie," $4^{\text {th }}$ ed., I906, or his "System der Philosophie," 2d ed., 1889. His ethics he has
} 
The philosophic substructure is based upon the critical psychology of Kant, and the influence of Spinoza and Fechner are apparent. Like Fechner and Lotze, Wundt has flung himself upon the psycho-physical questions, but with a perfectly clear understanding of the limitations of this method. His ethics also are a severe and most instructive application of the historical method to the content of the ethical experience, but again with a clear perception of the fact that the original impulses are not explained in the fullest unfolding of their content. "How out of the construction of the nervous system moral perceptions (Anschauungen) should arise is and remains a mystery." 1 At the same time philosophy is given its full place in the inquiry concerning the rise and development of the categories of the understanding and the place of what Kant would call the "pure reason." With this a thorough-going, undogmatic Protestantism is gladly content. Under the inspiration of Luther a good Protestant takes his vitalizing faith into all life, and the legitimate processes of the laboratory and the historical study become God's guidance to his feet, even though he recognizes the relative character of all rational process and finds his ultimate finalities in the realm of the transcendent hope and faith.

3. The rationalism of France grew up within the limits of Roman Catholicism, but in varied degrees of open warfare with its authority. The results upon the ethical life and ethical thought cannot, from a Protestant point of view, be regarded as fortunate. True it is that the humanitarian idealism of Rousseau, and to a lesser degree Montesquieu and Voltaire, never wholly disappears. But values seem at times irrecoverably lost in the shipwreck of authority, and all such attempts at again rationalizing the authority, as those of Lamennais, met with little success. The church as a cultural institution remarkably given in his "Ethik," 2 vols., 3 d ed., I 903 (English translation of early edition). His "Vorlesungen über die Menschen und Tierseelen," 4th ed., I906, are also of deep interest. His pupil and friend, Dr. Rudolph Eisler, has condensed his philosophy into a small volume, "Die Philosophie und Psychologie W. Wundt," 1902.

1 “Ethik," p. 344 of edition 1886. 


\section{CHURCHLY AND PHILOSOPHICAL ETHICS 589}

reasserted herself, but she failed to really dominate the moral and intellectual situation. We have therefore hardly any excuse for touching French philosophical ethics in connection with organized Christianity, save the general one that Protestantism is a demand for spiritual maturity and adult autonomy, and that French thought has powerfully contributed to that end. Voltaire based his thought upon Newton and Locke, and far from being an "atheist" maintained not only the being of God, but that it was capable of rational proof by the cosmological and teleological arguments. His life-long struggle was with the dogmatic authority of the church. His ethics were substantially again those of the English rationalists, but his powerful and artistic interpretation make them still exceedingly attractive reading, although the English student of the Deist movement will find surprisingly little that is novel in Voltaire.

He interpreted English rationalism to the Continent, and his three years' residence in London had put him in touch with all that was best in English rationalism.

Nor will the student of ethics find much in Jean Jacques Rousseau which is essentially an advance upon Locke, who is far more systematic than Rousseau, but lacks the wonderful artistic glow that gives Rousseau his power and has led to such great overrating of the content of his thought. He, the supreme artist, raves at art, and he himself the most artificial product of the scientific education of his day, dreams of a return to barbarism as the ideal. Even Rousseau's democracy is a good deal like the china shepherd and shepherdesses to which the fashion he set gave rise-it is a democracy without real human needs moving in wig and high-heeled shoes.

His influence for good, however, was enormous. Education, art, literature, statecraft, as well as the great popular movement that culminated in the blessings of the French Revolution, owed great debts to him. To him also, as well as to Voltaire, the encyclopædists were much indebted. And one has only to look back at the great encyclopædia of Diderot and d'Alembert to realize what a giant's task he inspired these men to. 
If the physiocrats owed their fundamental philosophy to English philosophy, they repaid the debt in the way they influenced and fructified in their turn the thought of Adam Smith. The ethics of all these men is based on a crass materialism only at times softened and modified by an almost equally crass pantheism. But when it is remembered against what intrenched dogmatism they were fighting, much can and must be forgiven them.

Nor will the student of ethics find much of original interest in Victor Cousin, whose philosophy lies between Hume and Hegel and whose ethical interest was swallowed up in the metaphysical. Some idea of his exceedingly interesting thought may be gained from his admirable work on Abelard, which has been already noted, but his strength was rather in brilliant critical insight than in profound constructive development.

Protestantism, using the term in the broad sense indicated above, has felt deeply the impact of a writer now more talked about than actually read. The student of John Stuart Mill will always turn to find out the secret of the great influence exercised upon that cool intellect by Auguste Comte, ${ }^{1}$ whose "religion" has rather discredited his philosophy. Comte traces three stages in man's history, called respectively: (I) The theological (2) the metaphysical, and (3) the positive. This evolution is deeply ethical and culminates in the science of sociology. The emotional nature should be supreme, but the intellect is no longer the slave of the heart but should be its servant. The ethical man is the man who subordinates the lower to the higher, and who therefore makes his passions and lower life subject under love to his reason. Society will be moral when science reigns supreme in the organization of human life, and the motive to

\footnotetext{
${ }^{1}$ Comte, Auguste (1798-1859). His ethics are embraced in his "Système de politique positive, ou traité de sociologie instituant la religion de l'humanité," 4 vols., Paris, $1851-1854$. English translation $1875-1877$. Cf., also, Harriet Martineau's "The Positive Philosophy of Auguste Comte Freely Translated and Condensed," London, I87 I. See, also, Comte's own "Catechisme Positiviste, ou Sommaire Exposition de la Religion universelle," Paris, 1852, 3d ed., I89o (also English translation).
} 
well-doing will be a deeply religious life centring in a cult about ideal humanity. This will always be progressive, for Comte considers Leibnitz's optimism shallow and based on a false theology. Even the heavenly bodies do not work perfectly, and improvements could easily be suggested upon the "laws of nature." We have no reason for believing either that moral perfection is within our reach, but the highest rationality is the highest morality and to that we should progressively move. For Comte regards it as the great error of all science, but particularly of history and sociology, that the fields of inquiry have been regarded statically. Comte denounces the undue praise of antiquity. According to him, the mediæval is better than the classic period and modernism an advance upon both. Nor is sufficient attention paid to the fact that both observer and thing observed are in a constant state of change. One cannot but notice the Hegelian forms of thought in the discussion of history, although the men had almost nothing in common, and the present writer knows of no interchange of thought. Moral advance is a constant synthesis of the elements of advance, and action and reaction follow one another. Comte is a pure phenomenalist. We know nothing but laws of activity, and all this knowledge is relative. This is as true in the field of ethics as in any other field. He has no satisfactory discussion of the subordination of the individual to the group, but always assumes it. He sees in the working class and in women the receptive elements in society for the new religion.

This last stage of Comte's thought suggests the disordered mind, so extravagant are its pretensions and so fanciful its provisions. He suffered mentally in younger years and was confined in an asylum; perhaps sorrow and overwork strained his mental faculties. Whether this be so or not, his influence on English thought has not been on the side of religion. Mill and Spencer are unquestionably deeply influenced by Comte, ${ }^{1}$ and we owe much to him for his social ethics and the remarkably modern classification of the sciences, in which, however, one fatal omis-

'Herbert Spencer's disavowal to the contrary notwithstanding. 
sion removes it from the most modern world, for Comte never realized what Kant had made necessary upon the fields of both speculative and experimental psychology.

4. Dissent in England had its intellectual lights and shadows. On the one hand it separated thoughtful men from the intelligence and culture of Oxford and Cambridge to a degree alike bad for them and for the historic universities. On the other hand it needed strength of mind and individuality to maintain the separation, and it bred a detachment of mind most useful for launching out into new fields. A man like Joseph Priestley (I733-I804) stands out as an intellectual worker of the first class, but with defects born of his relative isolation. He was a follower of Hartley in his insistence upon psychology being made a branch of physiology, while still asserting the independence of metaphysics and the immortal character of the soul. For the student of ethics he is mainly interesting only in controversy with another great dissenter, Richard Price. ${ }^{1}$ Both had learnt scientific method not from Bacon, but from Newton, and both were intensely interested in metaphysics. Indeed the battle was now hot between the immaterialism of Berkeley (I684-I753) and the materialism in various shades held by men influenced deeply by Hartley and Priestley. Price follows Plato's distinction between sense and understanding, ${ }^{2}$ and then treats duration and space and reality, etc., as necessary elements of the understanding. Power and causation are also ideas the understanding brings with it. Experience has only a secondary place in our knowledge. "Experience and observation are only of use when we are ignorant of the nature of the object and cannot in a more perfect . . . way determine ... the uses of

\footnotetext{
${ }^{1}$ Price, Richard (1723-179I). For the student of ethics his main works are "A Review of the Principal Questions in Morality," I757, and later editions. "Four Dissertations," I 767 , of which only the first, "On Providence," has ethical interest, save as side lights on his philosophy are found in the third on immorality for virtuous men. And then his correspondence with Dr. Priestley on materialism and necessity (London, I778). $C f$., also, Priestley's sermon on Price's death, I79r.

${ }^{2}$ He refers especially to Plato's "Theætetus," p. 22, note, edition 1787.
} 
particular objects." 1 Hence Price is an intuitionalist, but he comes remarkably near the later critical intuitionalism, but just misses the point through failure in psychological analysis. Morality is eternal and immutable. Right and wrong denote what actions are, and they are this by nature and necessity. Man has certain ideas that baffle further analysis. "Virtue is essentially a proper object of favor, vice of discouragement." These "ideas arise in us immediately," and there is no possible resolution of them into rational consideration of public utility and inutility.

Good and evil are not even matters God's will can determine. They are independent of him in the same sense that his own existence and attributes cannot be changed by him. Knowledge rests upon "feeling," which can give no reason: upon "intuition," which is "the mind's survey of its own ideas, and relations between them," and "argumentation or deduction." 2

The morality of an action depends upon the will of the actor to conform to the law of absolute right. "Virtue is a law" and is "an unalterable and indispensable law," and almost in anticipation of Kant he says, "the repeal, suspension, or even relaxation of it, once for a moment, cannot be conceived without contradiction. ${ }^{3}$ When therefore he discusses the subject-matter of virtue he turns away from Butler's rule of general benevolence. His treatment is based like Kant's upon duties. These we owe first to God. Subjection and homage we owe him, but these cannot be possibly paid to him from motives of "general benevolence." We render him no service in our worship nor should we worship him to secure our own felicity. We worship, Price claims, as an "instance of immediate duty intuitively perceived." Not even in duty to self is self-love a sufficient guide. We must act from sense of obligation to ourselves. So also beneficence is a "duty to others." Price then discusses what he seems to

\footnotetext{
1 "Morals," p. 34, edition I 787

${ }^{2}$ For discussion, see "Review of Principal Questions in Morals" pp. 158-167, edition 1787 .

3 "Review of Principal Questions in Morals," p. I78
} 
regard as the intuitive virtues, and at this point appeals as Reid does later to "common-sense." The discussion is most valuable but inconclusive. The exalted tone, and often extremely acute reasoning cannot hide the fact that the place for empiric ethical experience is not properly defined and that the analysis of "intuition" is imperfect. ${ }^{1}$

The strongest reaction upon Hume was that of the uncritical intuitional school of which Reid $^{2}$ was the principal leader.

Reid's influence has been very great although really exceedingly baleful. For in point of fact his attitude is a dogmatic acceptance of the "material reality" of the external world which exists as perceived without reference to the perceiving mind. Hence he is fundamentally an agnostic whenever serious questions are asked about the character of either the external world or the perceiving mind, or the relations between the two.

His morality is really slipshod. Moral truths, he says, "may be divided into two classes, to wit, such as are self-evident to every man whose understanding and moral faculty are ripe, and such as are deduced by reasoning from those that are selfevident. If the first be not discerned without reasoning, the last never can be so by any reasoning." 3 "Some first principles must be immediately discerned," and the "evidence of these fundamental principles of morals, and of others that might be named, appears then to me to be intuitive rather than demonstrative." Reid places five main moral intuitions as the basis

\footnotetext{
1 Price took the side of the struggling colonists in America during the war for independence; he also regarded the National Assembly of France as the first note of man's ultimate song of complete freedom, and in practical matters may be regarded as the father of exact actuary work in insurance. $C f$. Priestely's sermon on his death in $\mathrm{r} 79 \mathrm{r}$.
}

' Reid, Thomas, D. D., 1710-1796. His works have been edited by Dugald Stewart, Edinburgh, 1804, and re-edited by Sir William Hamilton, 1827. An American reprint of Dugald Stewart's edition in $1813-1814$ in four volumes. His chief contribution is "An Inquiry into the Human Mind on the Principles of Common Sense," London, I764. His ethics are contained in the "Essays on the Active Powers of Man" ( 1788 ) in the collected works by Sir William Hamilton, and the $4^{\text {th }}$ volume of the American edition

3 Essay VII, chap. 2 ("Essays on the Intellectual Powers of Man"). 


\section{CHURCHLY AND PHILOSOPHICAL ETHICS 595}

of what then becomes a rationalistic system, namely, the obligation to consult one's own present and future happiness; to be faithful to engagements; to obey one's maker; to injure no man; to do to others what we approve in other men, and vice versa. In point of fact he admits the relative character of all moral conduct, for "prudence" must apply these first principles, and prudence can "very rarely use demonstrative reasoning, but must rest in what appears most probable." Throughout Reid argues from what must be "necessary" as "the knowledge that is necessary to all must be attainable by all." 1 In"spite of much good sense and even acute reasoning, Reid never really meets the main question, and his morality is not a real advance upon the systems of rationalism which he opposes.

Nor can it be said that Dugald Stewart in his "Outlines of Moral Philosophy" makes any great addition. He adopts the moral sense of Hutcheson, but his analysis is sadly lacking in coherence and clearness.

Sir William Hamilton follows in the way and in spite of great learning and a most attractive method of presentation he leaves the reader with a sense of his utter failure to grasp the real question at issue, and Hume remains really unanswered.

Coleridge (I772-I834) brought to England the inspirations of critical idealism, but only as they had been worked out more particularly by Schelling, and his work is too scattered and unsystematic to be called a serious contribution to organized ethics. The chief representative upon English soil of idealism was Green (Thomas H., I836-I882), who in his introduction to the philosophical works of Hume and his "Prolegomena to Ethics" (2d ed., I884), applied the critical method learned from Kant, but more especially from Kant as read by the light or darkness of Hegel. It cannot be claimed that Green's ethics are a closely interrelated whole. Many questions are left seeking an answer, and the impression left is often of searching and destructive questioning than of any great success in constructive rearrangement. The powerful and beautiful mind is,

1 Essay V, chaps. I and 2. 
however, still inspiring men by his bold challenge to further psychological analysis as a basis for ethical reconstruction.

5. English utilitarianism has had a long and honorable history, but it has been mainly outside of or even in avowed indifference or antagonism to organized Christianity. ${ }^{1}$

There are exceptions. It may be really said to arise within Christianity, for it can be traced in its beginnings to Bishop Cumberland (I632-I7I9) and appears in Butler, where the social type of utilitarianism is found. But its classic formulation was carried through by Bentham. ${ }^{2}$

The principle that all legislation should seek the greatest happiness of the greatest number is also the foundation of the moral life. Bentham is an extreme individualist. For his thought society is really an aggregate of disparate units. $\mathrm{He}$ misses altogether the organic connection of the group life, so that both his legal and ethical contributions have an air of unreality about them. He tries also to group under pain and pleasure psychological reactions in which we must recognize both quantitative and qualitative differences so great that to transpose them is impossible or to measure them with a common standard is impossible.

John Stuart Mill, ${ }^{3}$ whose great influence is well deserved intellectually, began with Bentham's single criterion for moral differentiation but soon had to recognize a "higher" and "lower" pleasure and pain, and at length to really abandon morality as a science and treat it as an art. Then under the influence of Comte he abandoned the extreme individualism of Bentham, but too late to ever wholly reorganize his thought

\footnotetext{
${ }^{1}$ For full bibliography and history, see Ernest Albee's "History of English Utilitarianism," I902.

${ }^{2}$ Bentham, Jeremy, I748-1832. Complete works edited by Sir John Bowring, in II vols. The student of ethics needs to know his "Deontology" (edited by Bowring, in 2 vols., 1834) and his "Introduction to the Principles of Morals and Legislation," many editions.

${ }^{3}$ Mill, John S., I806-1873. His "Logic" represents his formal philosophy. Book VI treats of "The Logic of the Moral Sciences." In his later writings Mill defends positions that represent a distinct departure from his early thought.
} 
on this basis. Indeed the whole character of English empiric utilitarianism was to receive a great change in the introduction of systematic organic evolution into modern thinking by Charles Darwin ${ }^{1}$ and Herbert Spencer.

The derivation of morality from feelings needed to preserve the species, and their development by a process of natural selection, appealed most powerfully to many foremost minds. In Herbert Spencer's philosophy ethics is treated as a part of the process from the homogeneous and undifferentiated to the heterogeneous and differentiated, and its laws are discussed in his social statics. But perhaps the most attractive statement is in John Fiske's "Outlines of Cosmic Philosophy." 2

The fullest statement of Darwin's thesis is by Sutherland. ${ }^{3}$ Into an examination of the evolutionary utilitarianism space forbids us to go. The social basis is recognized and to some degree a scale of values is accepted. It can only be pointed out that the life of moral faith has as yet never been fully rationalized, and that what evolutionary utilitarianism always does is to give us an account of the unfolding of that which in point of fact is always assumed as inherent in the situation. Given the occasional occurrence of a moral variation amidst unmoral sensations, and evolution can do all the rest; but how to account for a moral variation amid non-moral changes is as baffling as ever. Nor does evolutionary utilitarianism give us any key to the scale of values by which we measure life's complex experiences and give to the moral feelings an unquestioned hegemony, and compels us to say with Darwin: "It is the most noble of all the attributes of man." Why should we call that which is simply the most useful factor in the preservation of the species the most noble?

Once the life of moral faith has appealed to us as the most noble, then indeed content may be given that life through an

\footnotetext{
'Darwin, Charles, 1809-1882. "Descent of Man," part I, chap. 3, deals with his explanation of the rise of the moral sense.

${ }^{2}$ Vol. II, part 2, chap. 22, p. 324 , edition 1874 .

${ }^{3}$ Sutherland, Alexander: "The Origin and Growth of the Moral Instinct," 2 vols., 1898.
} 


\section{8}

HISTORY OF CHRISTIAN ETHICS

examination of our empiric experiences with social and individual utility is a guide. So ethics becomes not only an historic but an experimental science, with its examination of empiric experience as an essential element. We must under the imperative of a sense of "oughtness" or obligation seek our ideal, but the content of our ideal can never be given $\grave{a}$ priori, but only as the result of historical and experimental science. For the sense of moral obligation we may claim categorical finality, for the content of moral experience a relative approach to truth is all that is open to the finite mind.

With this hasty survey our examination of the rise of a modern Christian ethics from the systems of the past must close. May the survey enable us to enter more freely and more intelligently into the ethical plan of Our Father, the God of Our Lord Jesus Christ. 


\section{INDEX}

Aaron, Moses and, 4r.

Abba, $5^{6}$.

Abelard, Peter, $334 f f$.

Absolute, the, in ethics, 573; Kant and the, 579.

Acedia, 248.

Action, prophets of, 36 .

Africa, Council of, 244.

Agobard of Lyons, 289 ff.; superstition and, 290.

Albertus Magnus, 309 ff.; and mvstic thought, 357 .

Alcuin, $274 f f$., 283.

d'Alembert, $5^{8} 9$.

Alexander the Great, 19.

Almsgiving, in Hermas, 111 ; in the Didache, 120.

Ambrose, 23, 204 ff., 232.

Amesius, 542.

Amos, 34 .

Anabaptists, 433; ethics of, 505; Franciscans and, 506; proletariat character of, 507; liberty of conscience and, 509; Baptists of England and, 509 .

Anablatha, 233.

Anglo-Catholicism, ethics of, $410 f f$.

Anselm, 9; ethics of, $302 f f$; satisfaction theory, 305 .

Anskar, Bishop of, $293 f f$.

Anthony, St., 196.

Aquinas, Thomas, 309, 316; ethics of, $319 \mathrm{ff}$; Church and State in, 328; service and, 329; aristocratic temper of, 329; attitude toward war, 330; property and, 332.

Arabic, scholarship and literature, 307.

Areopagite, Dionysius the, 275 .

Arianism, 197, 203, 232, 244.

Aristotle, influence of, 11, 19; Aquinas and, $318 \mathrm{ff}$.
Arminians, Calvinism and, 563 .

Asceticism, Jesus' attitude toward, 64 ; meaning of, 199, 20r; monastery and, 215 .

Assisi, Francis of, 357 .

Athanasius, monasticism and, $193 \mathrm{ff}$; literature of, 193; St. Anthony and, 194; service of, 202.

Athens, population of, 19 .

Attritio, contritio and, $560 \mathrm{ff}$.

Aufklärung, 369.

Augsburg Confession, 533 .

Augustine, $236 \mathrm{ff}$; the church and, 238; morals of, 239; confessions of, 239; Pelagius and, 240; psychology of, 240; fides implicita and, 24I; love and, 242.

Authority, infallible, uselessness of, 254 .

Babylon, cosmogony, 44, 108.

Bacon, Francis, $440 \mathrm{ff}$; conduct to Essex, 442.

Ban, communal, ror.

Baptism, in "Recognitions," I4I; in Erigena, 299.

Baptist, John the, 36 .

Barclay, Robert, 433.

Bardesanes, 138 .

Barnabas, letter of, II3.

Basil, life and literature of, $209 f f$; cœnobium and, 2 IO.

Basilides, 135 .

Baur-Tübingen, 97, 127 .

Bede, the venerable, $267 \mathrm{ff}$., 272.

Bentham, Jeremy, 596.

Bernard of Clairvaux, $35^{8} \mathrm{ff}$; attack on Abelard, 359.

Berno of Clugny, 355 .

Bestmann, 7.

Blount, Charles, 454.

Bœthius, 333. 
Bonaventura, $357,360 \mathrm{ff}$; mysticism of, $36 \mathrm{r}$.

Bonifacius, Winfred, 272.

Breckinridge, theology of, 485 .

Browne, Robert, 402, $426 \mathrm{ff}$.

Bucer, Martin, ethics of, $5^{16} f f$.

Buddeus, Johann F., 539; Malebranche and, 539 .

Busher, Leonard, 433.

Butler, Bishop, 457 .

Byzantianism, 287.

Cainites, 133 .

Calixtus, Georg, $183,538 f f$.

Calvin, John, 469; ethics of, $518 \mathrm{ff}$; theory of church, 519; sacraments and, $52 \mathrm{I}$; notes of true church, $52 \mathrm{I}$; theories of State and, 523; significance of the cross, 526; Servetus and, 528; services of, 532; Puritan State and, 532; canon law, 301.

Canons of Basil, 213; law, 213 ff:; of Nice, 230; of Elviræ, 230, 250.

Carlstadt, 49r.

Carlovingian books, 287 .

Carpocrates, 138 .

Cartwright, Harrison and, 428.

Cartwright, Thomas, ethics of, 398 ; literature, 398 .

Cassianus, Johannes, $245 \mathrm{ff}$; fasting and, 250; Cicero and, 250.

Cassiodorus, 23I, $272 \mathrm{ff}$.

Casuistry, the new Protestant, $540 \mathrm{ff}$; definition of, 540 .

Cathari, 356.

Celibacy, r99.ff; democracy and, 276.

Celsus, 159 .

Cenobium, origin of, $215,248$.

Chævemon, Abbot, 245.

Charlemagne, 275; hierarchy and, $285 . f$.

Charles the Bald, 293; tolerance and, 300.

Chillingworth, 456.

Christianity, linked with Jesus, 3 .

Chrysostom, slavery and, 183, 209, 23.2; life of, 207; service of, 208.

Church, Old Catholic or Bishop's, 9, 22 I $f f$; Christian beginnings of, ro; functions of, 106; basis of, for Paul, Io6.

Churches, the building of, 232.
Chytræus, D., 537.

Cicero, his empire of thought, 20; ethics of, 30; Ambrose and, 205.

Cistercians, 356 .

City, the free, 368 .

City of God, Augustine's, 242.

Clarke, Samuel, 457.

Claudius, Bishop, $288 \mathrm{ff}$.

Clement of Alexandria, 148.

Clement XIV and the Jesuits, $55^{8}$.

Clement, letter of, II 5 .

Clementine literature, pseudo, 139.

Coleridge, 595 .

Collegia, piestistic, 548 .

Collins, Anthony, 460 .

Commandments, the ten, 37 .

Communism, churchly, 182, 220.

Community, the holy, 39 .

Comte, Auguste, $590 \mathrm{ff}$.

Concord, formula of, 533 .

Constance, Council of, 366,554 .

Constantine, interest in church, 222; protection of church, 224, 234.

Constantinople, capture of, 286.

Councils, ethics of, $251 \mathrm{f}$.

Counter-reformation, 535 .

Cranmer, 393.

Creeds, ethics of, $533 \mathrm{ff}$.

Criticism, literary or higher, 42.

Crusades, literature of, 366 ; effect upon Roman imperialism, 367 ; and commercial Judaism, 367 .

Cudworth, Ralph, 45I.

Cult, the oriental, 25; fourth Gospel and, 89.

Cumberland, Bishop, 456.

Cumont, 27.

Cyprian, 172.

Dahn, Felix, 270.

Dalman, 57.

Damascus, John of, 259.

Daniel, 46.

Dannæus, L., 539.

Dante, 369, 380.

Darwin, Charles, 597 .

Decalogue, I7r.

Decretals, the Isidorian, 300 .

Dedeken, M., 542.

Deists, the English, 450 .

Denck, 505 .

Denifle, H. and Luther, 49I (note). 
Descartes, René, 565 ff:; Queen of Sweden and, $5^{6} 7$.

Deuteronomists, school of, 33; ethics of, $4 \mathrm{I}$.

Diderot, 589 .

Dionysius, pseudo, the Areopagite, $275 \mathrm{f}$.; so-called liturgia of, 344 .

Dionysus, cult of, 25 .

Doceticism, fourth Gospel and, 88.

Doctrine, sound, 99.

Donatists, 21 2, 238.

Droysen, Hellenism and, 20.

Duns Scotus, 9, $33^{8} f f$.

Ebionites, the, $\mathbf{2 7}$.

Ecclesia, 51, 60.

Eckhart, Meister, 363 .

Ehrenfeuchter, 8.

Elvira, canons of, 182, 230.

Encyclopædists (French), 589.

Ephraem, his hymns, 232.

Epictetus, 23.

Epicureanism, Christian feeling and,2I.

Epigones of sixteenth and seventeenth centuries, 535 .

Epiphanius, 135, 233.

Erigena, Johannes Scotus, 296 ff.

Essenes, 36, I 28, 200.

Eusebius, $222 \mathrm{ff}$.

Evangelicalism in England, 546.

Experience, Christian, 6.

Fasting, 64; in Hermas, 112.

Fechner, Gustav, $585 f$.

Feudalism, church and, 26I; rise and nature of, 277 .

Feuerlein, 8.

Fichte, J. G., 580.

Fides implicita, 24I, 308.

Fiske, John, 597.

Fitz-Ralph, Archbishop, 378 .

Flora, Ptolemæus to, I35.

Fourth Gospel, 5 I.

Fox, George, 433, 435 .

France, post-Protestant, 588 .

Francis, St., 340.

Francke, A. H., 549.

Free city, relation to crusades, 368 ; relation to feudalism, 368 .

Galatia, church of, 73 .

Gass, ethics of, 7 .
Gehenna, 176.

Gerhard, Johann, 537.

Germanic tribes, 270 ff.

Gerson, J. C., 554.

Gnosticism, fourth Gospel and, 88, 129, 132,134 .

God, kingdom of, 57 ; reign of, 58 ; Jesus' attitude toward, 66; confidence in, 68; Paul and, $7 \mathrm{I}$; Clement and, 151 .

Gottschalk, $292 f$.

Greece, cosmopolitanism of, 20.

Green, Thomas H., 595.

Gregory, Nazianzen, 195 .

Gregory of Nyssa, 226.

Gregory, Pope I, 260, 263 ff.; music of, 266; Gregory VII, 306.

Groot, Gerhard, 363 .

Grotius, Hugo, ethics of, 563 .

Guyot, Yves, 279.

Guzman, Dominic de, 357 .

Hamilton, Sir William, 595.

Hammurabi, code of, 38 .

Harnack, 131, 135, 156, 164 .

Hartmann von, 584 .

Hatch, 24, I 79 .

Hebrews, ethics of, 93.

Hegel, G. W. F., 58r.

Heidelberg Catechism, 533 .

Hellenism, Paul and, ro; Christianity and, $\mathrm{I}$.

Helvidius, 229.

Helvetic Confession, 533.

Henry VIII, and the English church, 4IO; Lollardism and, 4Ir.

Herbert, Lord of Cherbury, 449; works of, 45I ff., 455 .

Hermas, 107, II0; and baptism, II2.

Heron, story of, 246.

Herrnhut, $55^{2}$.

Hierarchy, Paul's relation to, 86; Roman, and authority, 284.

High places, 42.

Hippolytus, r31, r33.

Historia Lausiaca, 226.

Hobbes, Thomas, $445 \mathrm{ff}$.

Hoeffding, 587 .

Hooker, Richard, 4r 4 ff.

Hooper, Bishop, ethics of, 393.

Horace, 230.

Horus, 201. 
Hosea, 35 .

Hübmaier, Balthasar, 433, 505.

Hugo of St. Victor, 349.

Humanists, the, $369 \mathrm{ff}$.

Hume, David, 448, 460 ff.: property and justice, 463 .

Hymns, churchly, 232.

\section{Iconoclasts, 255, 258.}

Ignatius, letters of, 167 .

Illumination, the, 368 ; effect upon native literature, 369 .

Image worship, 233 .

Imperialism, Roman, 108.

Independency, ethics of, 424 .

Individualism, Christianity and, 22; Congregationalism and, 425; literature of, 425 .

Innocent III, $350 f f$; and slavery, 353; and marriage relation, 354 .

Inspiration of Scriptures, 103.

Irenæus, 127, 133; life of, 169.

Isaiah, 45 .

Isidor, 135 .

Isidorian decretals, 300 .

Isis cult, $190,192$.

Jahwe, prophetic picture of, 36 .

James, 95 .

Jansenism, 557 .

Jerome, 218; his "lives," 227; life of, $227 f f$; heresy and, 228; marriage and, 228.

Jesuitism, 556; political failures of, 559.

Jesus, relation to Christianity, 3; ideals of, 4; misconception of, 5; God in Christ, 6; as central figure in history, 48; historical character of, 48 (note); ethics of, 49; Jewish character of, 50; literary style of, 53; deification of, 178 .

Jews, Agobard against the, 290.

Job, 45, 6r.

Jodl, ethics of, 8.

John, fourth Gospel, 87 ; ethics of, 87 ff:; Jewish character of, 92 (note).

Josephus, II, 44, 47, 125 .

Josiah, 4 I.

Jovinianus, 229, 236.

Judaism, unorganized character of, II ; not exclusive, 40, 43; Hellenized,
43; Jesus' relation to, 67; Paul's relation to, 72; Gnostic, 257; influence of on Christianity of M. A., 290.

Julian of Eclana, 239, 24I, 244 .

Julian the apostate, I9I, 203.

Jülicher, 66.

Justinian, pseudo, tracts, 148 .

Justin Martyr, I44.

Kant, Immanuel, 9, 577; works and literature, $577 \mathrm{ff}$.

Kiss, the holy, $4 \mathrm{I} 7$.

Knox, John, ethics of, $404 f f$; literature, 404; Knox and the bann, 406; and Mrs. Bowes, 408.

Köstlin, 8.

Laodicea, canons of, 256.

Lapsi, 207.

Lateran council, 356.

Latifundia, effects of, 277 .

Laud, Archbishop, 420 ff.; attitude toward Scotland, 423.

Law, canon, 30r.

Leibnitz, G. W., 571 .

Leo, Pope, 252; Leo IX, 257, Leo I, 260.

Leviticus, laws of, 39 .

Libri pœnitentiales, 296.

Lignori, A. M., 56r.

Locke, John, 447 ff., 449.

Loescher, V. and Spener, 548.

Logos, 46; Johannine literature and, 91 .

Lollards, ethics of, $3^{86}$; literature of, 386.

Lombard, Peter, $308 \mathrm{ff}$.

Lotz, Rudolph H., $5^{85}$.

Louis the Pious, 292.

Loyola, Ignatius de, 555 .

Luke, universalism of, 56 ; proletariat character of, 100 .

Luthardt, $7,8$.

Luther, Martin, ethics of, $468 f f$; world of, 47I; free cities and, 472 ; Protestant elements in, $475 \mathrm{ff}$; scholastic elements in, 48r; infallibility and, 482; church and, 482; doctrine of the State, 486 ; practical ethics of, 488; attitude to peasants, 489; Philip of Hesse and, 490; intemperance and, 493. 
Mackintosh, 9.

Magic, the church and, 302.

Magna Mater, 190, 192.

Mahometanism, eastern church and, 280; limits of, 286.

Malebranche, Nicholas, 568 .

Manicheans, Augustine and, 238.

Marcion, 135, 136, 137, 162.

Marcus Aurelius, 144.

Marheinecke, 7 .

Mark, chronology of, 60 .

Marsiglio of Padua, 379.

Martineau, 8.

Martyrdom, church and, 183, 200, 223.

Mater Dolorosa, 201.

Matthew, Gospel of, roo.

Maurice, F. D., 7.

Maximus the Confessor, 259, 348.

McGiffert, 139 .

Mechthild of Magdeburg, 363 .

Meiners, C., 8.

Melanchthon, 250; ecclesiasticism and, 485; ethics of, $496 \mathrm{ff}$.; Ritschl and, 496; life of, 497 (note); free will and, 500 .

Meritum, 200, $24 \mathrm{I}$.

Mill, John Stuart, 591, 596.

Milton, John, $435 f f$.

Missionary, the movement and monastery, 269.

Mithras, cult of, 26; church and, 190.

Molesme, Robert of, 356 .

Monastery, the hermit and, 200; asceticism and, 215; ideals of, 216 ; literature of, 216; its learning, 229; missions and, $269 \mathrm{ff}$; in the tenth century, 355 .

Monotheism, ethical and metaphysical, 15 .

Montanists, r6r.

Morality, relation to ethics, 5; supreme importance of, 62.

Moralium, Gregory I and the, 265.

More, Henry, 45I.

Moses, 37, 41.

Mount, sermon on, 58,59 ; temptation on the, 68.

Münzer, Thomas, 505 .

Musonius, 149.

Mysticism, Erigena and, 299 ff.; scholastic, $34 \mathrm{I} f f$; definition of, 342 ; types of, 342; literature of, 343; Bonaventura and, 36r; German mysticism, 362 .

Neander, 7.

Neoplatonism, 28.

Neopythagoreanism, 29.

Newman, Cardinal, 418.

New Testament, Jewish in thought, ro.

Nicæa, its orthodoxy, 203, 204; theme of, 193 ; council of $(787), 255$, 257.

Nietzsche, Fr., challenge of, 6 .

Nominalism, 34r.

Novatians, 206.

Ockham, William, $340 \mathrm{ff}$; and Pope John XXII, 381 .

Oldcastle, $3_{87}$.

Old Testament, relation to Christianity, Io; preparation in, 32 .

Ophites, r3r.

Optatus, 201.

Organum, the, of Aristotle, 307.

Origen, 155 .

Orthodoxy, Johannine Gospel and, 90.

Osiander, J. A., 542.

Pachomius, Athanasius and, r98; monastery and, 215.

Palladius, 226.

Papacy, militant, and its ethics, $25^{8} \mathrm{ff}$.; infallibility of, $34 \mathrm{I}$.

Paradisus Animæ, 310, 313.

Parousia, 126.

Pascal, 557.

Paul, inward authority of, 3 ; mission of, 10 ; relation to Jesus, $5 \mathrm{I}$; ethics of, $69 . \mathrm{ff}$; letters of, 72; doctrine of flesh and spirit, 77; letter to Rome, 74; letters to Corinth, 79; kingdom of God and, 80; letter to Thessalonians, 8r; letters of captivity, 8r; slavery, 83 ; Plato and, 84 ; sense of infallibility, 98 ; and marriage, I79.

Paulsen, 587.

Paulus, life of, 218.

Peacock and Wycliff, 386 .

Pelagius, Augustine and, 240, 244. 
Penance, types of, 212.

Penitence, books of, 196 .

Pentecost, Nicæa and, 223.

Peratæ, I33.

Peter, Apocalypse of, I8r.

Petzel, casuistry of, 542 .

Philo, I I, 44, 46, 47, I25, I 28.

Phocas, Gregory I and, 263.

Photius, 257, 261.

Piers Ploughman, 387 .

Pietism, ethics of, $544 f f$; Ritschl upon, 545 .

Plato, influence of, II; cult and, I3; immortality and, 13 ; "idea" and, 14; despondency and, 15; monasticism and, 16.

Platonists, the so-called Cambridge, $45 \mathrm{I}$.

Pliny, 179, 232.

Plymouth brethren, 430 .

Polycarp letter of, 123.

Port Royal, 56r.

Post-Tridentine Catholicism and its ethics, 554.

Prayer, Lord's in the Didache, I2r; Tertullian and, r64; Cyprian and, I 76.

Price, Richard, 592.

Priestly development, 37, 40.

Priestley, Joseph, 592.

Probabilism, 557; grades of, 560 .

Propheticism, ethics of, 34 .

Protestantism, ethics of philosophical, 438, $563 \mathrm{ff}$.

Ptolemæus, I35.

Purgatory, 193.

Puritanism, Tertullian and, r66; ethics of, $396 f$. ; interests of English, 397.

Pythagoras, 233.

Quakers, 435 .

Queen of heaven, 256.

Rabbinism, 52.

"Recognitions," I40.

Redemption, vision of, 46 .

Reformation, the English, $365 f f:$ joy of, 372; immediate effects of, 373 ; practical character of, 375 ; divisions of, 377; continental, and its ethics, $468 f f$; morals of, 474 .
Reformed church, ethics of, 509 .

Reid, Thomas, 594.

Relativity, essential, of Protestantism, 6.

Relics, 233, 255; Bonifacius and, 273.

Renan, on Mithras, 27.

Revelation to John, 95, 96.

Reward, Jesus' attitude toward, 65.

Richelieu, Cardinal, 368.

Righteousness, character of, 63 ; Paul's conception of, 70, 73; christology of, 70.

Ritschl, Otto, 5 .

Rohde, 2 I.

Roman, the church cosmopolitanism of, 293; relation of feudalism, 368 .

Rome, military organization of, 116 , II 7 contribution to church, 30; church of, 189 .

Roscelin, Abelard and, 335; Nominalism of, 340.

Rousseau, J. J., 589.

Sacrifice, Hebrews and, 94 .

Satan, 44.

Satyrus, brother of Ambrose, 206.

Schelling, 58r.

Schleiermacher, F. E. D., $5^{82}$.

Scholasticism, ethics of, 282 ff.; definition of, 282 and 295; history and, 332.

Schopenhauer, 584 .

Schultz, H., 55 .

Schwenkfeld, 505 .

Second temple, prophets of, 36 .

Seneca, 96, 173 .

Serapion, story of, 246.

Serapis, monks of, $217,218$.

Serfdom, rise of, 277 .

Servant, suffering, 59 .

Sethians, I33.

Sexual fanaticism, 235 .

Shaftesbury, Anthony, Earl of, $453 f f$.

Shirley, Canon, judgment of Wyclif, 385.

Sidgwick, 8.

Simon, 142.

Sins, venial and deadly, 246.

Slavery, Jesus' attitude toward, 65 ; Essenes and, 136; church and, 182, 276, 277; church fathers and, 278 ; Southern Presbyterianism and, 495. 
Smith, Adam, $465 f f$; critique of Hutcheson, 467, 590; physiocrats and, 590 .

Social Democrats (German), I85, 2 II.

Socrates, demon of, 12; the history of, 225 .

Song of songs, 229.

Sophocles, Edipus of, 235 .

Sozomen, 222, 225.

Spencer, Herbert, 591 .

Spener, P. J., 546 ff.; ethics of, 547.

Spinoza, Baruch, 53, $568 f f$.

Stäudlin, 7 .

Stewart, Dugald, 595 .

Stoicism, composition of, 20; two-fold character of, 23; and redemption, 25; character of, $7 \mathrm{I}$.

Suso, Heinrich, 363 .

Sutherland, Alexander, 597.

Syllogism, Aquinas and, 322.

Synagogue, brotherhood of, 40.

Synoptic, the question of, 52 .

Tauler, Johannes, 363 .

Taylor, Jeremy, $437,456$.

Teaching of twelve apostles, II8; "two ways" relation to, IIg.

Temple, the second, 45 .

Tertullian, 133, I60; slavery and, r83; and Mithra cult, r9r.

Teutsche theologie, 364 .

Thelemic, 54 .

Theodoret, 225, 23I.

Thessalonians I and II, 72.

Thomas, see Aquinas, 3 I6.

Tillotson, Bishop, 456 .

Timothy, 72, 99.

Tindal, Matthew, 454.

Titus, 72.

Torah, 39; Paul and, 72.

Trades-unions, 185 .

Travers, Walter, 400, 413.

Trent, Council of, 332, 503 .

Tyndale, William, ethics of, $388 f f$; literature, 388 .

Tyre, Eusebius's discourse at, 231.

Unity, 102, 106.
Valens, I 23.

Valentine, Emperor, 230.

Valentinus, 133 .

Vallombrosian order, 355 .

Values, doctrine of, 583 .

Venatorius, Thomas, 536 .

Victorinus, $343 f f$.

Vigilantius, 236, 255 .

Vincentius of Lerins, 245.

Virgil, 230.

Virginity, 198, 199, 205.

Virtues, Aquinas's classification of, 325.

Voltaire, $5^{89}$.

Vulgate, Jerome's, 230.

Waldensian church, Claudius and, 289.

Waldo, Peter, 357.

Ward, Osborne, 28.

Weller, H., 536 .

Wellhausen, estimate of Jesus' place, 4.

Wendland, 149 .

Wendt, 66.

de Wette, 7 .

Weiss, J., 5 .

White, Andrew D., 438.

Whitgift, John, 42 I.

Wilamowitz, Moellendorf Hellenism, 24.

Williams, Roger, $233 f f$.

Wisdom, the literature, 33 ; its method, 46; Jesus and, 52.

Wolff, Christian, 57 r.

Wollaston, William, $453 f f$.

Wundt, 8.

Wundt, W. M., $5^{87}$.

Wuttke, 7 .

Wyclif, ethics of, $378 \mathrm{ff}$; literature, 378 , 379; and German Anglican alliance, 385 .

Zeno, 233.

Ziegler, 4, 7.

Zinzendorf, Count, 552; life and works, $55^{2}$.

Zwickau, prophets of, 505 .

Zwingli, H., 469; ethics of, $5 \mathrm{II}$; life and works, 5 II (note); Protestantism of, 513 ; national character of, 515; Vatican and, 516. 





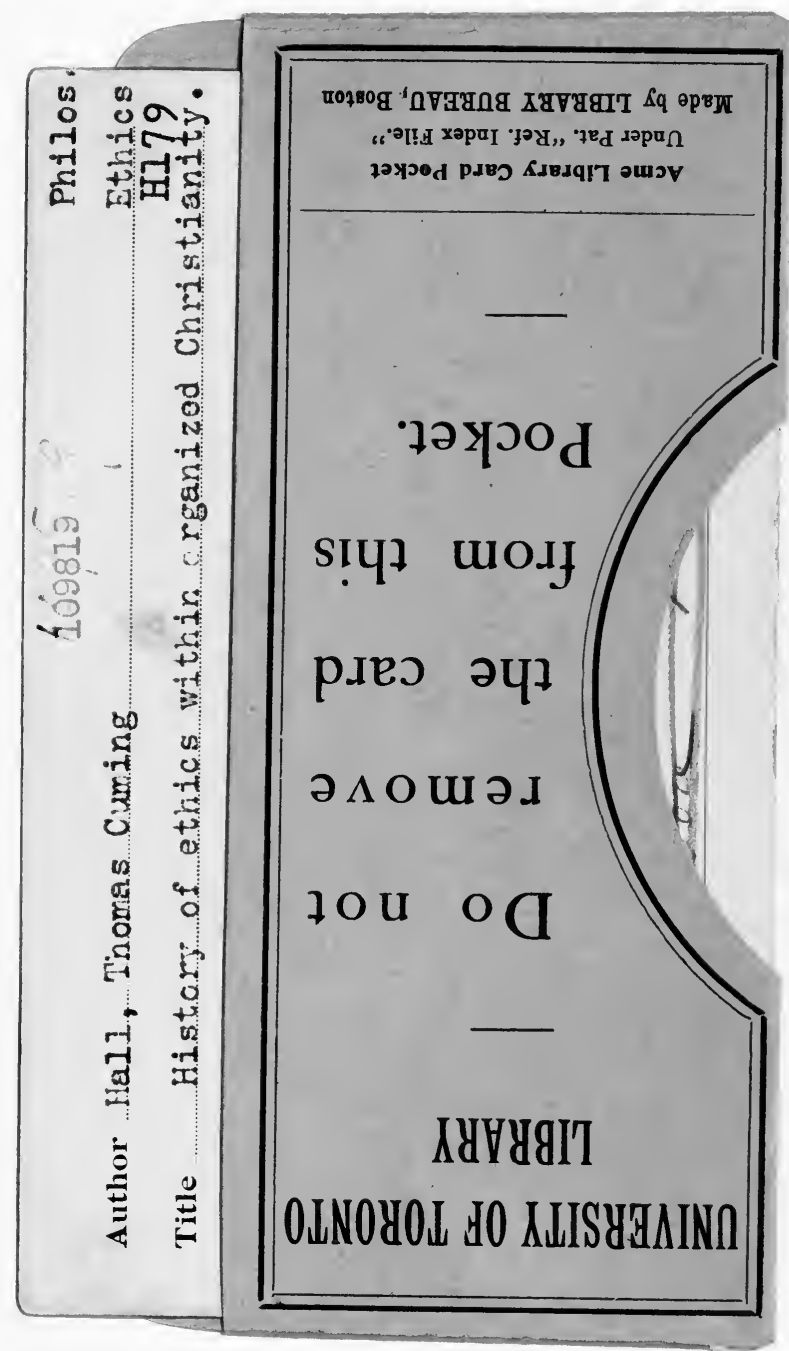


